UNIVERSIDADE DE SÃO PAULO

FACULDADE DE FILOSOFIA, LETRAS E CIÊNCIAS HUMANAS

SÓCRATES OLIVEIRA MENEZES

O TRABALHO NAS FISSURAS DA CRÍTICA GEOGRÁFICA

(Versão Corrigida)

São Paulo 


\title{
O TRABALHO NAS FISSURAS DA CRÍTICA GEOGRÁFICA
}

\author{
(Versão Corrigida)
}

Tese apresentada ao Programa de Pós-Graduação em Geografia Humana da Faculdade de Filosofia, Letras e Ciências Humanas da Universidade de São Paulo para obtenção do título de Doutor em Geografia.

Área de concentração: Geografia.

Orientador: Prof. Dr. Manoel Fernandes Sousa Neto. Co-orientador ${ }^{\mathrm{a}}: \quad \operatorname{Prof}^{\mathrm{a}} \quad \operatorname{Dr}^{\mathrm{a}}$ Alexandrina Luz Conceição.

São Paulo 
MENEZES, S. O. O Trabalho nas Fissuras da Crítica Geográfica. 2015. 420 f. Tese (Doutorado em Geografia) - Faculdade de Filosofia, Letras e Ciências Humanas, Universidade de São Paulo, São Paulo, 2016.

Tese apresentada ao Programa de Pós-Graduação em Geografia Humana da Faculdade de Filosofia, Letras e Ciências Humanas da Universidade de São Paulo para obtenção do título de Doutor em Geografia.

Aprovado em:

Banca Examinadora

Prof. Dr. Instituição:

Julgamento: Assinatura:

Prof. Dr. Instituição:

Julgamento: Assinatura:

Prof. Dr. Instituição:

Julgamento: Assinatura:

Prof. Dr. Instituição:

Julgamento: Assinatura:

Prof. Dr. Instituição:

Julgamento: Assinatura:

Prof. Dr. Instituição:

Julgamento: Assinatura: 
Curioso que seja primavera. Nem tanto pelas flores, mas pelas rosas. De uma rosa em especial, da nossa Rosa, Aquela que, na beleza do seu jardim, Ainda hoje a alegrar a Rua São Pedro, N. 303,

Na pequena Macaúbas

Era a mais bonita.

E se ainda hoje o solitário Tota, seu escudeiro de sempre,

Rega e zela pelas cores de sua lembrança, Admitamos com tristeza a ausência do seu perfume.

E nos deixastes, D. Rosa,

Quando o estudo que hora concluo Estava ainda no meio de sua franca jornada.

A história do trabalho humano,

Que aqui conto com frieza e seriedade científica,

Não poderia ter outra referência:

Filha de imigrantes, Rosa herda a penúria do fardo histórico,

O mesmo que determinará seu destino,

Como o de suas filhas, como o de seus netos e bisneto. Contudo é bom saber que podemos lembrar de sua beleza,

Hilária até quando rígida.

Ríamos por celebrar sua existência.

Lembramos com carinho da união em torno da Rosa,

Tal como choramos sua partida,

Mas ficaremos com seu exemplo.

Mesmo porque outras primaveras virão, Ainda que rosas e flores,

Como fardo histórico,

Continuem a nos deixar.

À Rosalina Ribeiro de Oliveira, mulher, trabalhadora.

A quem carinhosamente chamávamos de vó Rosa

$\mathrm{E}$ a quem dedico o desfecho desse importante momento

De minha trajetória.

(São Paulo, 02 de outubro de 2015) 


\section{AGRADECIMENTOS}

Agradeço a Manoel Fernandes, amigo e orientador, por ter apoiado, acreditado e incentivado aquelas que nos idos de 2011 não passavam de ideias soltas e confusas. Agradeço pelo companheirismo, conversas, ensinamentos, cervejas e risadas.

À Alexandrina Luz. Mais que co-orientadora, amiga, companheira. Continuo redescobrindo a certeza do socialismo em ti, tal como a fundamentação sobre os enormes desafios que temos diante de nós.

A Henri Sócrates. Um agradecimento que é também um pedido de desculpas: pela ausência, pela distância. Um dia entenderá que os homens só se propõem a problemas que dispõem resolver. $\mathrm{E}$ o que temos a resolver, juntos, é o próprio mundo na sua história. Me disponho a contribuir em tentar resolve-lo por ti, mas também por outros, por todos outros. Vejo em ti essa representatividade que nos reimpõe a necessidade e o vigor de lutar pelo futuro.

Aos colegas do Grupo de Estudos do Capital - GECA (Denis, Gilmar, Carlão, Ana, Paulo, Marcel, Bábara, Hugo, Erivaldo, Jucier, Larissa e Rildo). Vocês foram fundamentais. Das melhores coisas que levo de São Paulo, essas amizades certamente são das mais saborosas.

A João Diógenes, colega, amigo, parceiro de tantos debates, farras e "muros", aqueles que já pulamos e tantos outros que ainda haveremos de pular. Não apenas pela prestatividade de anfitrião em minhas voltas a Vitória da Conquista, nem à inabalável crença de que tudo daria certo e à confiança no trabalho que ora concluo, mas sobretudo pela sensibilidade e generosidade de tanto ter ensinado o sentido das questões reais humanas.

A Arakin e a Lina, pelo apoio e amizade em me receber em sua casa nos momentos de itinerança.

A Rogério, meu amigo que longa data "para onde quer que eu vá". Pela presença, pelas discussões, conhecimento, da ontologia à política; pelo nosso vascão, por isso, pelas alegrias e tristezas. Pelos bares, botecos e rauzitos da Augusta.

Universidade Estadual do Sudoeste da Bahia (UESB), por ter me apoiado, não pela concessão do direito de afastamento que possibilitou dedicação exclusiva à pesquisa, mas pela prestatividade com que, na figura dos seus trabalhadores, logrou os encaminhamentos institucionais.

Aos meus colegas do departamento de Geografia da UESB, na figura de seu diretor, Jânio Diniz, tal como nas figuras das coordenadoras da Área Teoria e Método em Geografia 
(Suzane e Fernanda), e também pelos seus secretários (em especial José), pelo incentivo, apoio e confiança.

À Coordenação de Aperfeiçoamento de Pessoal do Ensino Superior (CAPES) pela bolsa de estudos.

À Faculdade de Filosofia, Letras e Ciências Humanas, FFLCH - USP. É sempre incrivelmente prazeroso viver seu cotidiano: de encontros, amizades, conhecimento e, sobretudo, crítica.

Ao Programa de Pós-Graduação em Geografia Humana (USP), nas figuras de suas coordenadoras Rita Ariza e Marta Inez, sempre gentis e cordiais diante da burocracia que nos separa. Um agradecimento também especial aos secretários e secretárias da Pós-Graduação, em especial ao já amigo Firmino, sempre prestativos diante de nossas constantes demandas.

Ao Laboratório de Geografia Política (GEOPO), na figura de sua bela secretária Clenes Louzeiro. Amiga que sempre esteve a incentivar e participar de nossa trajetória.

À Neide e a Golimpé. Casal dez! Pessoas que chamo de mãe e pai. Também aos meus irmãos, Geisa e Peu. Continuo sabendo que vocês não entendem muito bem o sentido de minha trajetória, mas também continuo a crer na confiança que emana de vocês.

Aos amigos do Tô Nem Tchum, amigos de vida. Ainda presentes, um pouco mais velhos; um tanto mais barrigudos, mas ainda unidos.

A Joniel, amigo de longa data, laços que somente se fortaleceram nos momentos de idas e vindas da Bahia e que, assim, muito contribuiu para a leveza do cotidiano tornado saborosamente mais engraçado, até mesmo diante piadas sem graça.Aos amigos d'A Panelinha, por contribuir em tornar os dias mais engraçados.

Aos amigos da Maurolândia, por tornar o cotidiano mais alegre e animado.

A Carioca, amigo "véi” de São Paulo, do Rio Pequeno. Pelas várias cervejas, longos papos sobre a vida e por ter proporcionado as condições de exceção do cotidiano universitário.

A Dui, amigo de infância. As lembranças do Macatuba's Bar, tal como de seus fiéis seguidores, Maelson, Mauri (vulgo "Vate"), Jorjão, Pernambuco, e até Romeu, estão cristalizadas nas presentes páginas.

A Jô Carvalho, pela amizade, cachaçadas, porres e tradução do resumo. 
"Enquanto houver espaço, corpo e tempo e algum modo de dizer não, eu canto".

Belchior, "Divina Comédia Humana" 


\section{RESUMO}

MENEZES, S. O. O Trabalho nas Fissuras da Crítica Geográfica. 2015. 418 f. Tese (Doutorado em Geografia) - Faculdade de Filosofia, Letras e Ciências Humanas, Universidade de São Paulo, São Paulo, 2015.

O objetivo da presente pesquisa é analisar as formas com que o trabalho, tomado como categoria da análise social, foi inserido na crítica do movimento de renovação da Geografia no Brasil. Tal movimento se inicia na década de 1970, mas se mantém vivo em suas principais perspectivas ainda atuantes. Buscou-se identificar no processo de incorporação do trabalho seu papel na mediação entre a crítica social e a crítica geográfica que se montava, primeiro como denúncia capitalista, depois como consolidação epistemológica. A tese é que, na urdidura da crítica tensionada pelo movimento de renovação (que se pretendera como Geografia Crítica), o trabalho se estabeleceu como importante elemento de transição para a abertura crítica da análise geográfica, mas que, em seu processo de afirmação teórico-epistemológico, não o fora tomado em sua totalidade contraditória e dialética, significando, simultaneamente, sua própria negação. É, por isso, um estudo sobre a afirmação/negação do trabalho na gênese da crítica da Geografia em seu movimento de renovação a partir de suas principais perspectivas teóricas. Considerouse, para tanto, as proposições teóricas que, de forma direta ou indireta, central ou apenas tangencial, adotaram o trabalho como objeto, tema ou perspectiva política para suas formulações. Essas perspectivas são aqui denominadas como geografias do trabalho. Dentre os objetivos específicos que comporão a argumentativa da presente tese, aponta-se: $\left(1^{\circ}\right)$ o papel fundamental da teoria do valor para a formulação de uma crítica que se volta contra o desenvolvimento e a expansão capitalista. Observou-se como o trabalho fora tomado como cristalização valor para subsidiar uma leitura que, pelo espaço, procurava desvendar os mecanismos de dominação e exploração do capital a partir de sua instrumentalização no território. Nota-se nesse momento, uma forte vinculação à interpretação concreticista confundida como leitura propriamente geográfica; $\left(2^{\circ}\right)$ a montagem de uma leitura geográfica que se pretendia ontológica teve no trabalho uma de suas principais referências. Mas se notou que as formulações, muitas delas por sistemas de montagem ou de fusão teórica, não foram pautadas pela autocrítica, o que levou a um discurso ontológico remoto e, consequentemente, confundido com a gnosiologia e com a própria epistemologia geográfica, dada a manutenção da interpretação concreticista que se conservara; $\left(3^{\circ}\right)$ a natureza da crítica geográfica e sua expressão teórica. Neste último ponto da análise se observou como o problema da contradição foi interpretado e inserido na crítica geográfica; constatou-se, em última análise, sua ausência. Tomando o trabalho como referência, constatou-se ainda que a dialética envolvida em sua formulação tendeu a ser mais um instrumento de conciliação teórica do que uma crítica social. Concluiu-se que, tomando a argumentativa da tese que se pretendeu partir do trabalho como referencial para análise da crítica geográfica, esta apresenta fissuras no interior de suas próprias formulações, fissuras essas que tendem a se desenvolver como autocontradição, deixando ainda incompleta sua efetividade como crítica social emancipatória.

Palavras-chave: Trabalho. Geografia e Trabalho. Geografias do Trabalho. Geografia Crítica. Movimento de Renovação Crítico. 


\begin{abstract}
MENEZES, S. O. Labor in the Gaps of Geographical Criticism. 2015. 418 f. Tese (Doutorado em Geografia) - Faculdade de Filosofia, Letras e Ciências Humanas, Universidade de São Paulo, São Paulo, 2015.

The aim of the present research is analyzing the ways labor, as a category of social analysis, was inserted in the criticism of renewal movement of Geography in Brasil. Such movement has its beginning in the 1970s, but it remains alive in its most active perspective. It was sought to identify, in the process of insertion of labor, its role in mediation between social and geographic criticism which has been coming up; first as a capitalist denunciation, afterwards as epistemological consolidation. The theory is that, in the warp intended by the renewal movement, labor settled as an important element of transition to the critical opening for the geographic analysis, but, in its process of theoretical-epistemological affirmation, it was not considered in its conflicting and dialectical entirety, meaning, simultaneously, its own negation. That is why it is a study concerning the affirmation/negation of labor in the genesis of criticism in Geography in its renewal movement from its main theoretical perspectives. For this purpose, the theoretical proposals which, directly or indirectly, centrally or simply tangentially, have adopted labor as object, core or political perspective for its formulation were considered. Those perspectives are denominated as labor geographies. Among the specific aims which compose the argumentation in this thesis, it is remarkable to mention: $\left(1^{\text {st }}\right)$ the essencial role of value theory to the formulation of a critique against development and capitalism expansion. It was observed how labor was taken as value crystallization to subsidize a view that, by space, intended to reveal mechanisms of domination and exploitation of capital from its territory instrumentalization. At this moment, a strong linking to a concreticist interpretation, misunderstood as a properly geographical reading is remarkable; $\left(2^{\text {nd }}\right)$ the construction of a geographical reading supposed to be ontological had one of its main references in labor. But it was noticed the formulations, many of them through assembly or theoretical fusion systems, were not guided by self-criticism, which led to a remote ontological discourse and, consequently, mistaken as the gnosiology and geographical epistemiology itself, considering the remaining of concreticist interpretation. $\left(3^{\text {rd }}\right)$ the nature of geographical criticism and its theoretical expression. At this latter point of analysis, it was able to observe how the issue of contradiction was interpreted and inserted in the geographical criticism. Its absence was, after all, concluded. In addition, taking labor as reference, it was observed that the dialectics involved in its formulation tended to be more like an instrument of theoretical conciliation than for a social critique. It could be concluded that, considering the argumentation in the thesis, intended to be from labor as a reference to the analysis of geographical criticism, the present thesis presents some fissures in its own formulations, those ones which tend to develop as a selfcontradiction, leaving its effectiveness as an emancipatory social critique still incomplete.
\end{abstract}

Keywords: Labor. Geography and Labor. Labor Geographies. Critical Geography. Critical Renewal Movement. 


\section{SUMÁRIO}

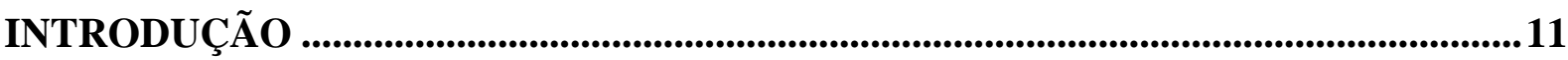

PARTE I - O TRABALHO NAS FISSURAS DA SOLUÇÃO TEORICAEPISTEMOLÓGICA E ONTOLÓGICA …...........................................................................28

CAPÍTULO 1 - DA CRÍTICA AO CAPITALISMO À VALORIZAÇÃO DO ESPAÇO:

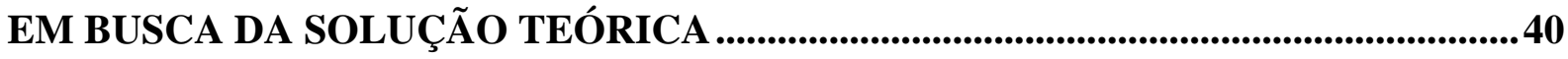

1.1 - Milton Santos e a crítica da diferença espacial como dominação capitalista .............. 43

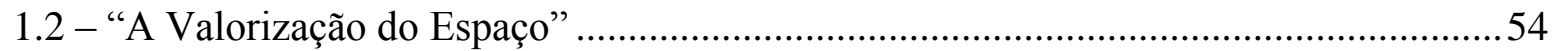

1.3 - Valor-Trabalho, contradição e crise: inversões nos limites da solução teórica 68

CAPÍtUlO 2 - A NECESSIDAdE EPISTEMOLÓGICA: CRÍTICA DA CRISE À

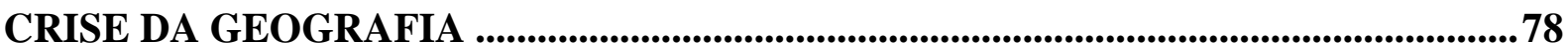

2.1 - O meio "técnico-científico-informacional”: entre o "colapso da modernização" e a "crise estrutural"

2.2 - Técnica: a autossustentação, a autorreferenciação e o sistema filosófico fechado.... 102

CAPÍtUlo 3 - A SOLUÇÃO ONTOLÓGICA E OS LIMITES PARA A

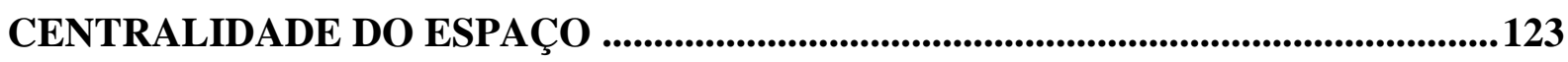

3.1 - Das "linhas de fuga" à crítica do "amálgama originário" ...................................... 127

3.2 - Estatuto ontológico versus teoria da transição....................................................... 135

3.3 - "Corpo" versus "carcaça”: entre a substantivação e a dissecação .............................. 160

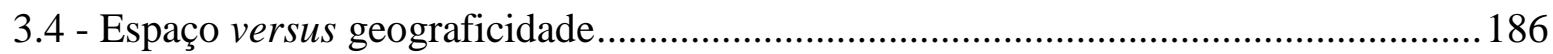

3.5 - As possibilidades da crítica na ontologia do espaço ................................................202

3.6 - Das "linhas de fuga" aos "refúgios" de uma crítica não efetiva ...............................210

PARTE II - O TRABALHO NAS FISSURAS DA CRÍTICA GEOGRÁFICA: ENTRE

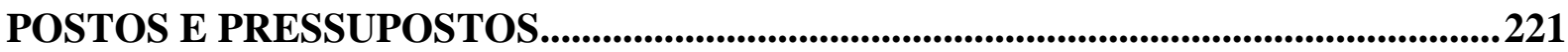


CAPÍTULO 4 - A EXPOSIÇÃO DO EXPLÍCITO: AS PRETENSÕES DA CRÍTICA E O PAPEL DA CONTRADIÇÃO .......................................................................................236

4.1 -As "unicidades" e a tendência de mistificação ...............................................................246

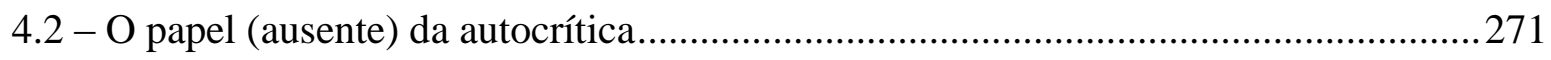

4.3 - A suficiência do "salto epistemológico" .................................................................28

CAPÍtUlO 5 - A ORIGEM E A GÊNESE CONTRADITÓRIA DA CRÍTICA: DISPUTAS E CONFLITOS ......................................................................................................291

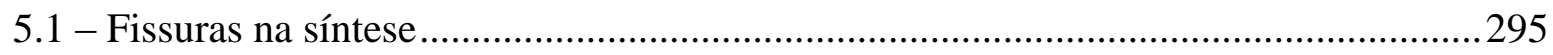

5.2 - Os fundamentos da crítica herdada .......................................................................... 304

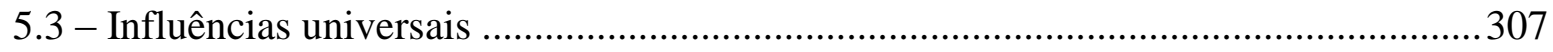

CAPÍTULO 6 - A EXPOSIÇÃO DO IMPLÍCITO: O TRABALHO ENTRE AS VIAS DA CRÍTICA SOCIAL E DA CRÍTICA GEOGRÁFICA ....................................................311

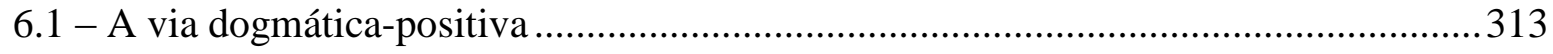

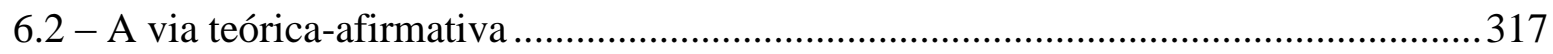

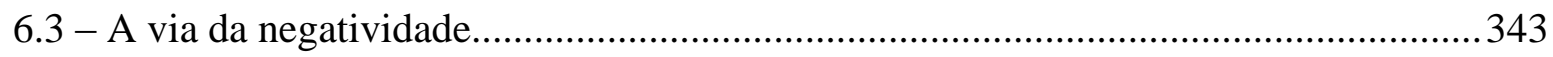

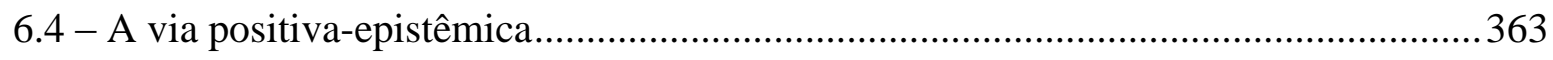

CONCLUSÃO

REFERÊNCIAS _.............................................................................................................409 


\section{INTRODUÇÃO}

O objetivo do presente estudo é analisar o trabalho, categoria central para a análise da sociedade moderna, e as formas com que foi inserido na crítica geográfica, especificamente no movimento de renovação empreendido por geógrafos brasileiros desde a década de 1970 até os dias atuais. Mas não só: é, sobremodo, a fundamentação da tese de que no processo de inserção do trabalho, como fundamento da afirmação da crítica social geográfica, há na internalidade do seu movimento teórico a negação de sua própria dialética. Ou seja, que sobre trabalho não se buscou o entendimento em seu movimento contraditoriamente crítico, o que tendeu a levar, por um lado, a redução de seu conceito à unilaterialidade concreta (imediata ou ontológica), e, por outro, às possibilidades de sua negação diante da concorrência epistemológica posta em relação à categoria a ser centralizada: o espaço. A perda da totalidade da dialética do trabalho não apenas o tornou vulnerável às reduções sintéticas e conciliatórias que possibilitaram forjar as principais perspectivas teóricas, tão importante para a positivação da nova epistemologia pretendida, como também fundamentou a composição de uma crítica geográfica estruturalmente marcada por fissuras que expõe suas comtradições internas.

A internalidade do movimento teórico da Geografia no Barsil, da qual pretende-se aqui entender a inserção contraditória do trabalho, refere-se à internalidade de suas determinações teóricas e remete a duas considerações: (1) que diante do crescimento dos estudos sobre o movimento da renovação crítica da Geografia, como pode ser observado pelo crescente número de teses e dissertações sobre a temática ${ }^{1}$, mas também pelas dezenas de artigos e ensaios sobre esse momento histórico que ainda é atual (ou que ainda admite a "coetaneidade") ${ }^{2}$, constata-se uma efetividade histórica que põe as proposições teóricas do movimento crítico em reconhecida legitimidade e, sobremodo, representatividade, conforme tais perspectivas passam a se reproduzirem por meio das pesquisas em Geografia. É notório a quantidade de pesquisas que tem como fundamento, por exemplo, a perspectiva da valorização do espaço (originária de Antônio Carlos Robert Moraes e Wanderlei Messias da Costa), mais ainda aquelas que se

\footnotetext{
${ }^{1}$ Em destaque os trabalhos de SCARIM, Paulo César, Coetâneos da Crítica: Contribuição ao Estudo do Movimento de Renovação da Geografia Brasileira, São Paulo, Universidade de São Paulo (Dissertação de Mestrado), 2000, e o de SILVA, Ana Cristina da, O Pensamento Geográfico Brasileiro na Travessia do Século XX para o XXI: O Território na Trama das Significações Imaginárias (tese de doutorado), Presidente Prudente, Universidade Estadual Paulista, 2010.

${ }^{2}$ Como lembra Scarim, a necessidade de se distinguir a "coetaneidade" de contemporaneidade, sendo aqueles "que vivenciam uma mesma perspectiva em relação ao mundo, independente da idade e da época, sendo identificados a partir de um evento comum a estas pessoas" (SCARIM, 2000; p. 06).
} 
referenciam no conceito de meio técnico-científico-informacional (de Milton Santos); (2) conferida a legitimidade histórica, sobretudo pela solidez científica intrínseca, as perspectivas teóricas formuladas nos meandros da efervescência crítica iniciada da década de 1970 pode agora se pôr como objeto da própria crítica geográfica, no sentido de ser possível desenvolver o exercício autocrítico sobre elas. Isso pode, inclusive, levar a identificação dos limites internos da própria teoria quando, por exemplo, se constata que a mesma autocrítica, aqui pretendida inicialmente apenas como exercício dialético, foi um elemento não identificado na pesquisa sobre o processo de elaboração da crítica social geográfica, sobretudo na internalidade de sua formulação teórica. Como se constatou, em grande medida isso se deu pala própria necessidade propositiva com que os geógrafos passariam a compor suas propostas. Tem-se assim uma crítica isenta da simultaneidade autocrítica, o que seria um primeiro limite interno do exercício teórico pretendido e, consequentemente, das perspectivas teóricas que dele sucedem.

Essas duas considerações, da efetividade histórica e da possibilidade de estudo das teorias geográficas como objeto da (auto)crítica, situam a objetividade da presente pesquisa: trata-se de um estudo sobre a gênese da crítica, não apenas de sua origem.

E ainda que, inevitavelmente, a dimensão histórica necessariamente se situe como ferramenta imprescindível para o posicionamento correto da análise, considerou-se central penetrar em suas nuances, influências e referências para se buscar, sobretudo, suas fissuras. Por isso não se trata apenas de buscar uma "interpretação", ou fazer uma "avaliação" da teorização que se pretende crítica (de posicionar visões concorrentes e fazer uma "crítica externa", por exemplo, do marxismo contra a Geografia), mas das possibilidades de identificação de seus limites internos para que a crítica social-geográfica, dotada de objetividade autocrítica, possa ela mesma buscar, pelo exercício autorreflexivo, o reconhecimento de sua condição como teoria aberta e referenciada no real, este regido por profundas contradições que marcaram o contexto de sua efervescência política cujo marco foi por muitos considerado 1978.

Uma tensão então se impõe entre as propositivas teóricas que emergem do movimento de renovação e a realidade socioeconômica cada vez mais criticamente estabelecida, pois a mesma crise que marca o contexto de final da década de 1960 e início da de 1970 haveria de ser, a um só tempo, a condição histórica-objetiva para a existência da chamada Geografia Crítica e também objeto de suas soluções teóricas (ao menos num primeiro momento). Por um lado, o movimento de renovação buscando estabelecer suas bases para o desenvolvimento da teoria especificamente geográfica; por outro, contradições cada vez mais radicais questionando a efetividade e estabilidade dessas bases que pretendem referenciar o próprio desenvolvimento teórico-geográfico. Da referida tensão se abre um problema de ordem prática para o exercício 
teórico: a realidade, posta como criticamente contraditória, não está disposta a se "resolver" pelas soluções teóricas ou epistemológicas. Não podendo ser o real apreendido em sua totalidade por sistema fechado e autorreferenciado de ideias (ou em uma "epistemologia" limitada a um campo disciplinar), a contradição que o substancia só pode ser admitida como objeto, e também como limite da análise geográfica-crítica. Esta seria, aliás, a condição do método dialético buscado: admitir a contradição para não se autocontradizer (FAUSTO, 1983) 3 .

Porém, como será visto, os problemas advindos da tensão entre o real criticamente posto e a positivação da crítica geográfica não foram efetivamente equacionados pela admissão do contraditório, mas por uma intensificação ainda maior no sentido de explicar as coisas como elas se afirmam, não como elas se negam. ${ }^{4}$ Neste sentido, é sintomático que Milton Santos, no contexto de efervescência de 1978 e diante da crítica ao "empiricismo abstrato", não avançaria

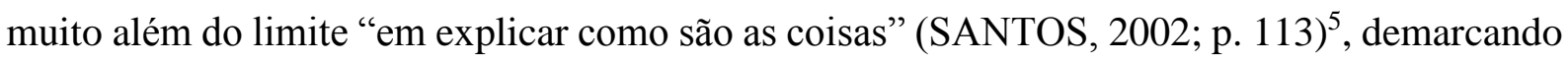
assim até os tempos mais atuais o caráter positivo (explicativo) da crítica, não apenas a sua, mas de grande parte de geógrafos contemporâneos.

Um grande desenvolvimento da "leitura" geográfica se observa, em parte porque a própria realidade criticamente contraditória conclama a crítica geográfica, mas sobretudo porque tais leituras em sua maioria explicativas precisariam cada vez mais de novos fundamentos (e até de sistemas filosóficos) especificamente geográficos para a autossustentação teórica. Nota-se nesse momento (em destaque a década de 1980, em que os efeitos da crise pareceriam mais permanentes que os previstos) um grande debate metodológico em Geografia ${ }^{6}$. Contraditório ao avanço das explicativas e das metodologias, em que a crise social já se convertera em crise da disciplina, a busca de sua solução passa por uma tendência de internalização disciplinar muito forte. A direção que se aponta e em que se avança é no sentido de um movimento teórico autorreferenciado no qual apenas uma "interdisciplinaridade" formal se tornaria possível, até porque o método que permitiria sua

\footnotetext{
${ }^{3}$ Ruy Fausto, sobre a importância da contradição na teoria que se pretende crítica: "assumimos a contradição para não nos contradizermos” (FAUSTO, Ruy, Marx: Lógica e Política, São Paulo, Brasiliense, 1983, p. 33).

${ }^{4}$ Ainda como referência, Ruy Fausto, para quem a dialética, como método efetivamente crítico, deve garantir a contradição como objetivo fundamental, mesmo diante dos seus compromissos afirmativos com a epistemologia (FAUSTO, 1983).

5 "Para os positivistas modernos, que baniram toda preocupação histórica, as coisas têm valor definitivo 'das coisas em si'; de resto, o processo de sua formação não tem interesse. Eles estão mais preocupados em demonstrar do que em explicar como são as coisas" (SANTOS, Milton, Por uma Geografia Nova, São Paulo, ED. USP, 2002). ${ }^{6}$ É na década de 1980 que se nota como as atenções se voltam para a questão do "método geográfico". De Milton Santos, por exemplo, é publicado o Manual de Geografia Urbana (de 1981), Espaço e Método (de 1985) e Metamorfose do Espaço Habitado (de 1988). Mas também é nesta década que Costa e Moraes publicam o importante A Valorização do Espaço (de 1984), além de Armando Correa da Silva, De Quem é o Pedaço (de 1986).
} 
abertura para o real em movimento contraditório tenderia a ser substituído pela epistemologia que se pretende também propriamente geográfica.

Por isso que a tomada do ponto de vista do trabalho se faz aqui fundamental. Primeiro porque o trabalho não poderia ser "internalizado" na epistemologia da Geografia que o tinha como categoria "não-geográfica". Isso já o coloca como contraponto ao movimento de autorreferenciação. Segundo porque o trabalho se põe eminentemente como uma categoria da crítica social, aberta, voltada para a contradição histórica (e não disciplinar). Terceiro porque ao mesmo tempo em que esboça uma "visão de mundo crítica" notoriamente admitida pela renovação geográfica - qual seja, aquelas fundamentadas nos objetivos de última instância humanos-emancipatórios - prescinde um "método" (auto)crítico do mundo moderno, este que é sobredeterminado pela impessoalidade, pelo não-concreto-imediato, pelo movimento crítico e autocriticamente universal de força abstratas (a troca, o valor, sociedade civil, Estado, etc.); ou, nas palavras de Lefebvre, "como um esboço mais ou menos adiantado de crítica e de autocrítica, numa tentativa de conhecimento" (1969; p. 04). ${ }^{7}$

É exatamente no conjunto dessas condições críticas e autocríticas que a dialética do trabalho ganha importância conceitual, porque é emancipatória, mas especificamente moderna: supõe a superação das mesmas condições que permitem sua existência. Essa contradição, longe de ser uma autocontradição destituinte, é o que move a presente pesquisa no sentido de admitir sua autocrítica: "tomar o ponto de vista do trabalho dotado criticamente" (MÉSZÁROS, 2008) Para isso, a contradição precisa ser admitida, não negada aprioristicamente, pelo simples motivo de que ela continua a ser o motor da história moderna. O trabalho, como categoria da modernidade, devém da própria dialética moderna entre a positividade das coisas como elas se afirmam e realizam o mundo em sua forma de ser (como é o real em sua concretude mais imediata) e a negatividade com as quais elas se contradizem, como é a natureza abstrata das leis das determinações universais deste mesmo real em seu movimento desrealizante, este que também compõe a forma de ser do mundo moderno.

Diante da totalidade que envolve o trabalho em seu movimento dialético, é salutar observar como que, na generalidade do movimento de renovação crítica da Geografia, a dimensão concreta e imediata do trabalho - seja como contraponto do capital para objetividade da empiria pretendida (ou ainda como ponto de vista contra-hegemônico), seja como atividade finalística para a objetividade ontológica -, em suma, sua concreticidade fora "preferida" diante da providencialidade com que ela se encaixava no temário tradicional da Geografia. Em

\footnotetext{
${ }^{7}$ LEFEBVRE, Henri, Introdução à modernidade, São Paulo, Paz e Terra, 1969.

${ }^{8}$ MÉSZÁROS, István, Filosofia, Ideologia e Ciência Social, São Paulo, Boitempo, 2008.
} 
contrapartida, é igualmente importante observar como a dimensão de seu método, que, como dito, envolve a própria dialética moderna, fora posta apenas como um "dado", não como objeto de um debate a ser aprofundado. De fato, os grandes debates metodológicos da década de 1980 se voltariam muito mais para uma saída da crise da disciplina geográfica (o que, em parte, explica a grande quantidade das "soluções" teóricas-epistemológicas do contexto) do que da crise social real que necessitava de um enfoque dialético apurado, inclusive como forma de subsidiar a própria reflexão geográfica. Como resultado, o movimento da quebra do equilíbrio dialético que torna possível inserir o trabalho como temática, ou como visão contrahegemônica, é o mesmo que permite negá-lo como método crítico e dialético.

A objetividade imediata do trabalho se preserva como referência temática e ontológica para os propósitos afirmativos da teoria. Isso ocorre no mesmo processo em que os níveis de radicalidade das contradições de suas determinações abstratas e negativas (mercadoria, valor, trabalho abstrato) se apresentam extremamente desenvolvidas no plano real, sobretudo diante da crise que estoura no início da década de 1970 (falências, "desindustrialização", desemprego estrutural). Em uma vertente, como objetividade imediata, o trabalho tende a se inserir como elemento da crítica geográfica, dada sua própria referência teórica com o legado da crítica social, mas agora reduzido a sua dimensão concreticista; em outra, como abstratividade do tempo histórico (do capital, da mercadoria e do valor, por exemplo), tende a ser deslocado da centralidade da análise histórico-social sob o argumento, quase sempre reformado, de "não se tratar de Geografia", mas de "economia política" ou de "marxismo". Ou seja, da dialética do trabalho que envolve sua dimensão concreta, como atividade orientada a um fim, e sua dimensão abstrata, como tempo abstrato do valor da sociabilidade possível da mercadoria, a tendência adotada no movimento de renovação crítica foi a de unilateralizar a dimensão concreta na medida em que, em contrapartida, deslocava o "abstrato" como um dado "nãogeográfico".

A quebra da dialética do trabalho e a unilateralidade concreticista da Geografia foi admitida como necessária perante os objetivos de (re)unificação disciplinar. Isso ocorre sem o reconhecimento de em que tal movimento deveria conter sua própria arbitrariedade. Tal condição afetaria, inevitavelmente, o equilíbrio dialético da totalidade que envolve o trabalho. O que não seria admitido é que a dimensão do trabalho que passa a ser "não-geográfico", equivale àquela mesma dimensão que se buscava para o espaço: sua dialética social fundamentada na abstração do tempo. O que se nega do trabalho é aquilo que se busca para o espaço. A não admissão desse paradoxo já é o indício de que o trabalho concorreria com o 
espaço diante da estruturação epistemológica que se pretendia nova, o que justificava seu deslocamento.

Diante da necessidade de positivação do espaço, a partir da negativa da dialética do trabalho, a identificação da crise real como crise disciplinar fora admitida sem qualquer constrangimento autocrítico 9 . O pressuposto de que o desenvolvimento da teoria geográfica baseada em sua epistemologia própria, seu método próprio e seu objeto próprio - pudesse nutrir o geógrafo de potencial explicativo e ativo perante o real, que é contraditório e crítico, tendeu a secularizar a herança estruturalista. Esta que, por vezes identificada, não haveria de ser efetivamente negada em sua integralidade: a forma da teoria estruturalista tendeu a ser confundida com a necessidade em si da estruturação teórica. No entanto, o que a identificação do estruturalismo permitiu barrar foi, em certa medida, o desenvolvimento de um viés positivista, travestido de culturalista, dentro da própria perspectiva crítica (como o empirismo lógico que tendeu ao retorno diante da observável expansão do descritivismo limitado à escala do lugar) ${ }^{10}$. Mas não foi capaz de tomar outra direção que não fosse aquela, quase sempre, direcionada a um sistema teórico e filosófico fechado e autorreferenciado ${ }^{11}$.

$\mathrm{Na}$ verdade, a ausência da autocritica que permitiu prosseguir o projeto epistemológico da "Geografia Crítica" não fora acidental. Pelo contrário. Ela ajudou a impulsionar importantes setores propositivos do desenvolvimento teórico, em grande medida forjados por um exercício teórico que se orientava por sistemas de montagem, ou de fusões teóricas. A dialética, nesses termos, ao mesmo tempo em que permite se dispensar do rigor entre o real crítico e a crítica das abstrações própria do trabalho, ficaria também "liberada" e "disponível” como instrumento que, além de possibilitar, legitima conciliações teóricas que agora, e somente por esses meios, tornam-se possíveis. Diante dessa dialética suposta, não apenas se torna aceitável o

\footnotetext{
${ }^{9} \mathrm{O}$ contexto da crise vem servindo à fundamentação do discurso da crise da Geografia desde os tempos mais inspiradores da renovação crítica, como, por exemplo, em ANDRADE, Manuel Correia de, O pensamento Geográfico e a realidade Brasileira, São Paulo, Boletim Paulista de Geografia, n 54, 1977; ou em GONÇALVES, Carlos Walter Porto, “A Geografia Está em Crise. Viva a Geografia!”, In: Boletim Paulista de Geografia ( $\mathrm{n}^{\circ}$ 55), São Paulo, AGB, 1978. Até em contexto mais recente, o discurso da crise é retomado como identificação da crise da Geografia para a manutenção da busca infinitesimal da solução teórica, como em DINIZ FILHO, Luiz Lopes, "Certa Má Herança Marxista: Elementos para Repensar a Geografia Crítica". In: KOSEL, Salete \& MENDONÇA, Francisco (org), Elementos da Geografia Contemporânea, Curitiba, Ed. UFPR, 2002. ${ }^{10}$ Como advertiria, em 2002, A. F. A. Carlos: "Assiste-se, hoje, a reabilitação do empirismo, da descrição do lugar, o retorno do individuo para abolir o pensamento crítico e a reabilitação da evidência positivista e, com isso, em alguns casos, o retorno ao senso comum. O retorno à descrição do lugar, muitas vezes, sem a preocupação com o conteúdo esvazia a potência do debate teórico dos anos 70/80." (CARLOS, Ana Fani Alessandri, A Geografia Brasileira, Hoje: algumas reflexões, São Paulo, Terra Livre, ano 18, v.1, n. 18, 2002; p. 166).

${ }^{11}$ Como assim insinuaria Milton Santos nos inspiradores tempos de 1978: "Acreditamos que uma teoria que não gera sua própria epistemologia, é inútil porque não é operacional, do mesmo modo que uma epistemologia que não seja baseada numa teoria é maléfica, porque oferece instrumentos de análise que desconhecem ou deformam a realidade" (SANTOS, 2002; p. 24).
} 
relacionamento não crítico entre, por exemplo, o existencialismo heideggeriano e o conceito de trabalho lukacsiano para as proposições do debate ontológico em Milton Santos, ou entre Durkheim, Weber e Marx para aliançar a-criticamente categorias como objeto técnico, racionalidade e trabalho, como também tende a se tornar inaceitável o "retorno" de um debate profícuo que envolve categorias como valor, mercadoria, capital, dada a aparente anacronia provinda do próprio reducionismo a que se aprisiona a dialética, sobretudo em sua dimensão positiva.

A crítica social que surge por meio de uma dialética aprisionada tende a se desaguar em perspectivas teóricas estruturadas em sistemas fechados e autorreferenciados, como dito. Entretanto, em decorrência, tende também a se cristalizar, seja pela sua institucionalização, seja em sua própria necessidade epistemológica isenta de autocrítica. A cristalização da crítica social em sua própria necessidade de positivação epistemológica e institucional não apenas representa uma contradição em si nos termos, como sobremaneira também força o movimento a uma bifurcação no seio de sua "militância". A unidade teoria e prática (prática essa não restrita à imediaticidade da participação política engajada, mas na forma específica de apreensão do real-objetivo), outrora garantida como necessidade do próprio desenvolvimento teórico, tende assim a se quebrar em uma "militância epistemológica" referenciada na própria Geografia (por isso, autorreferenciada) e em uma militância política referenciada na imediaticidade de um politicismo ${ }^{12}$ desprovido de teoria. O resultado é o próprio "fim" da crítica, como tentado por Vesentini, a título de exemplo, no questionamento sobre sua validade histórica da crítica do movimento de renovação: “já não teria ele cumprido o seu papel?” (2009; p. 121) ${ }^{13}$. No entanto, é preciso considerar que tal interpretação nada mais representa do que a manifestação da forma de entender a própria crítica autorreferenciada (posta como "adjetivo") no movimento da conhecida "Geografia Crítica", ou da "Geocrítica".

Como saldo desse movimento tendencial de quebra dialética no interior da crítica, temse a perda da realidade objetiva, regida por profundas e radicais contradições, como a referência da análise. A crítica tende a se refugiar na própria institucionalidade ${ }^{14}$, ou na epistemologia dela

\footnotetext{
${ }^{12} \mathrm{O}$ politicismo aqui tem referência na argumentativa levantada por José Chasin a respeito do desenvolvimento intelectual de Marx no momento de seu rompimento com o idealismo hegeliano, em que se dá a inversão do método dialético e sua fundamentação materialista propriamente marxiana. Este momento é marcado quando a "política" (ou as considerações sobre o Estado), ao contrário do pensamento de Hegel, passa a ser entendido como negatividade (CHASIN, José, "Marx: A Determinação Ontonegativa da Politicidade”, In: Espaço de Interlocução em Ciências humanas, Verinotio - Revista On-Line de Filosofia e Ciências Humanas. N. 15, ano VIII, ago. 2012). ${ }^{13}$ VESENTINI, José William, Ensaios de geografia crítica: história, epistemologia e (geo)política, São Paulo, Plêiade, 2009.

${ }^{14}$ É interessante observar, por exemplo, a forte tendência da formalização de "grupos" e "núcleos" de estudos e pesquisas. Só no quadriênio de 2010 e 2014 foram criados 203 grupos de pesquisa credenciados no Conselho Nacional de Pesquisa (CNPq). Essa quantidade é um pouco menor que a quantidade de grupos criados em todo
} 
derivada, mas agora como "aplicação" de seus pressupostos e, assim, destituídos da autocrítica necessária. Não de outra forma se observa como, sintomaticamente, as contribuições de Milton Santos tendem a ser envolvidas nesse processo de cristalização de sua crítica, por exemplo, no sentido que passa a ser atribuído ao conceito de "meio técnico-científico-informacional", passando a ser utilizado apenas como demarcação empírica temporal e contextual (como forma de "garantia" na demarcação do "geográfico" e do "crítico") de objetos pesquisados que envolvem apenas os setores avançados da produção capitalista, sobretudo nas análises acerca da "agricultura científica". O conceito cristalizado passa ser a garantia da própria criticidade, pelo simples meio de sua mera utilização, ainda que muitas dessas análises não consiga superar os limites do descritivismo daquilo que é pretendido à análise.

Embora tais condições que envolvem a reprodução cristalizada do conceito de meio técnico-científico-informacional tenham, em parte, relação à forma não muito clara com que o próprio Milton Santos aborda o problema da contradição no interior das determinações objetivas do conceito em detrimento do real, o nível de sua reprodução usual e comum no seio das análises geográficas se constitui como um outro problema ainda mais grave que muito diz sobre o estado atual da crítica pretendida. No caso das determinações internas do conceito em Milton Santos, ou da não-contradição como elemento constituinte em sua formulação, isso ocorre, por exemplo, no próprio processo de centralização da técnica que, ao tomar sua condição "hegemônica" como referência, resultante da "unicidade" histórica inédita, permite focar apenas nos níveis de sua "intensidade" ou de seu desenvolvimento ${ }^{15}$. Se essa é uma condição necessária para a centralidade do próprio conceito, paradoxalmente essa condição não permite desenvolver suas contradições internas, que são reais. Ou seja, não permite entender como se dá a hegemonização da técnica como negação de si mesma no seu próprio processo de constituição material e objetiva. Isso tende a excluir da sua análise, por exemplo, a importante esfera produtiva que envolvem os 2,4 bilhões de pessoas no mundo que usam apenas as mãos como "instrumento" de trabalho para lavrarem terras ${ }^{16}$, estes mesmos que estão inseridos na

período anterior catalogado pelo CNPq (1993 a 2010), que foi de 232. (Conselho Nacional de Pesquisa. Diretório dos Grupos de Pesquisa no Brasil (grupos por área). Disponível em: http://lattes.cnpq.br/web/dgp/por-area>. Acessado em: 10 jul. 2015). É importante observar também que grande parcela desses grupos, antes divididos em grandes áreas da Geografia, passam a ser agora divididos conforme suas temáticas, o que insinua uma fragmentação ainda maior no seio do campo de conhecimento. Mas é necessário reconhecer que esses dados precisam de um estudo mais profundo com relação às tendências que surgem e apontam o caminho seguido pela Geografia brasileira.

15 "Mas as técnicas atuais se difundiram universalmente, ainda que com diferente intensidade e seus efeitos se fazem sentir, direta ou indiretamente, sobre a totalidade dos espaços. Esse, aliás, é um dos caracteres distintivos da técnica atual" (SANTOS, Milton, A Natureza do Espaço, São Paulo, Ed. USP, 2008; p.193).

16 "Do total de 6,2 bilhões da população mundial, 3,2 bilhões vivem no campo, dos quais 70\% são miseráveis. Ainda conforme a ONU, destes, 2 bilhões e 400 milhões de pessoas lavram a terra com as próprias mãos, 600 
simultaneidade contraditória da "globalização", e não apenas como "excluídos" ou "segregados".

Também é importante colocar que, do ponto de vista da referenciação que se segue na utilização banal da técnica ou do meio técnico-científico-informacional, tal tendência de uso cristalizado dos conceitos que se pretende críticos apenas reproduzem aquelas mesmas condições em que o conceito de trabalho passou a ser majoritariamente reduzido (destituído de sua dialética, logo dogmatizado como "certa má herança marxista"17) e, consequentemente, destituível da analítica geográfica por assim ser considerado não apenas como "nãogeográfico", mas agora também como anacrônico e não-crítico.

Se a condição com que a forma positiva e afirmativa em que os conceitos passam a ser apreendidos no movimento de renovação da Geografia se contradiz com a necessidade de sua autocrítica, isso se dá apenas de forma tendencial. Aliás, o significado literal da palavra tendência (amplamente utilizada no corpo do presente texto), como movimento lógico, mas que admite seu próprio movimento contrário, também como contratendência, deve ser tomado como advertência para se entender a demonstração da cristalização da crítica em sua formação epistemológica e institucional.

Ou seja, quando se afirma, por exemplo, que entre a posição de Milton Santos e o uso corrente e banal do seu conceito há um processo de cristalização epistemológica, isso deve ser tomado não como um dado absoluto. Sem dúvida, há um movimento tendencial de reducionismo que contribui para a perda da potencialidade crítica contida no conceito miltoniano. Mas tão importante quanto a identificação de sua cristalização em sua reprodução no "chão da universidade" são as possibilidades em que o próprio conceito na sua concepção originária se permite a tal processo. A tendência do reducionismo até o limite da sua cristalização a-crítica é em si um dado e suas possibilidades de verificação devem ser buscados também na forma com que o conceito é montado.

As fissuras contidas na lógica interna dos conceitos, as mesmas que possibilitam sua cristalização na externalidade crítica, são as referências de busca aqui pretendidas, na especificidade do debate em torno do trabalho. Assim se faz importante porque são a partir delas que será possível penetrar nos sistemas teóricos que se pretendem sólidos, e muitos deles

milhões com tração animal e 60 milhões com máquinas" (THOMAZ JR, Antônio, "Geografia e trabalho no século XXI: os limites para a compreensão da classe trabalhadora no Brasil”, OKARA: Geografia em debate, v.1, n.2, p. 79-97, 2007; p. 92).

17 Referência ao texto citado acima (em nota de rodapé), de Luiz Lopes Diniz filho, no qual a destituição da dialética que envolve o estudo de Marx, e do marxismo em geral, se mostra representativamente reduzido às tradicionais reproduções dogmatizadas. Ou seja, uma crítica ao dogmatismo por uma via também dogmática, esta supostamente geográfica. 
fechados, para que se possa antecipar as próprias condições de sua implosão, ou como exercício ilimitado de sua autocrítica que permitirá entender os limites da própria crítica. Em última análise, admitir sobre elas todas as contradições possíveis, para assim "não nos contradizermos"

É dessa forma que o processo destituinte da totalidade do trabalho (a partir da não observação de sua dialética própria) no momento de sua inserção nos sistemas teóricosconceituais do movimento de renovação da Geografia deverá ser entendido: como uma tendência que, apesar de ainda viva e pulsante, já admite certa efetividade. E assim deve ser por dois motivos: primeiro porque, embora latente a disputa no seio da teoria, sobretudo perante os objetivos de centralização epistemológica do espaço ou da técnica, o trabalho permanece inserido na crítica geográfica, mesmo que apenas formalmente ${ }^{18}$. Por isso não seria correto afirmar um processo de negação absoluta do trabalho, mas como tal negação se dá em sua própria afirmação; ou seja, por meio da perda do rigor que envolve sua dialética e de sua consequente arbitrariedade concreticista. Segundo porque, em consequência, todas essas tendências apontadas acima, que em suma compõem os objetivos da presente pesquisa, só poderão ser observadas e demonstradas em seu nível mais fiel, ou seja, perante aquelas perspectivas teóricas que admitem o trabalho como categoria fulcral em sua composição. Isso explica o porquê das geografias do trabalho: como aquelas perspectivas que, de forma direta ou indireta, buscaram no trabalho sua via de composição e afirmação, seja como categoria que permite se integrar ao rol discursivo da crítica social desenvolvida também por outros campos do conhecimento (como "temática" ou "visão de mundo"), seja como categoria da construção teórica que permite a perspectiva geográfica o "acesso" ao profundo desenvolvimento da dialética envolvida em seu acúmulo histórico e teórico (de Hegel, Marx e Adorno a Lukács).

Todavia, como conceber as "geografias do trabalho" na imensidão da própria Geografia brasileira em seu movimento de renovação? Como observaria Ana Fani Alessandri Carlos, em importante texto do ano de 2002 intitulado "A Geografia Brasileira, Hoje. Algumas Reflexões" (citado anteriormente, em nota de rodapé), é necessário admitir a "impossibilidade de dar conta de tudo que se produz no Brasil” (2002; p. 162) em Geografia. Soma-se a isso, ainda segundo a autora, o grande processo de fragmentação disciplinar e da realidade observada, o que dificulta ainda mais o posicionamento de uma análise que se pretende abrangente, mas objetiva. Podese mesmo afirmar que tais condições se agravaram ainda mais até o presente. O que repõe os mesmos riscos observados pela autora no início dos anos 2000: "pode nos levar a falar de tudo

\footnotetext{
${ }^{18}$ Estudos, ainda que monográficos, começam a aparecer sobre a relação entre técnica e trabalho, como pode ser lido no texto LEAL, Victor Andrade Silva, Trabalho versus Técnica na Produção Histórica do Capitalismo, (monografia de graduação), Vitória da Conquista, Universidade Estadual do Sudoeste da Bahia, 2014.
} 
e mergulhar no nada, ao mesmo tempo"19. Isso ajuda a identificar a grandiosa complexidade do problema. Mas indica também uma saída objetiva que a crítica do trabalho à Geografia pode e será aqui direcionada, pelas "geografias do trabalho" porque estas representam a própria forma com que as principais perspectivas teóricas da renovação da Geografia no Brasil interpretaram a mesma categoria da qual agora se pretende colocar em contraposição: trabalho versus trabalho. Um enquanto categoria da crítica social genérica, outro enquanto categoria de inserção da crítica geográfica: crítica da dialética do trabalho x crítica das geografias do trabalho.

Neste sentido é importante observar que, diferente da Geografia Regional, da Geografia Urbana, da Geografia Agrária, Geografia Política, etc., o que aqui se chama de "geografias do trabalho" não se refere a uma "área" de efetividade institucional, mas apenas como perspectiva de análise. Perspectiva esta escusa dentro da própria forma com que se põe as demais perspectivas atuais. Basta observar, por exemplo, que no texto supracitado, dentre as perspectivas atuais identificadas por Carlos - quais sejam, no campo da Geografia Humana, a questão da globalização e a razão técnica em Milton Santos, a monopolização e territorização do capital no campo em Ariovaldo Umbelino de Oliveira, a desterritorialização em Rogério Haesbaert, a Amazônia e a integração do regional na globalização em Berta Becker, além do cotidiano e da reprodução no espaço urbano como a perspectiva da própria autora - não se encontra aquela derivada do legado de Armando Corrêa da Silva, intimamente ligada à questão ontológica e ao trabalho. Legado este amplamente retomado e reproduzido atualmente por Ruy Moreira (1994, 2007, 2008), a partir da perspectiva da desterritorialização do trabalho e a condição de regulação e controle do trabalho pelo espaço (condição específica do trabalho na modernidade), e, indiretamente, por Antônio Thomaz Junior (2002, 2009), a partir do problema da plasticidade do trabalho e a posição da classe trabalhadora no processo de subsunção ao capital, pela sua fragmentação também territorial, nos tempos da reestruturação produtiva e da crise estrutural. Estas duas últimas conservam em seu interior a perspectiva ontológica originariamente levantada por Silva desde a década de 1970, apesar de apresentarem suas especificidades também originais e de importância substancial aos problemas que envolvem a análise e a pesquisa atual em Geografia.

As perspectivas de Moreira e Thomaz Jr. estão entre aquelas mais admitidamente vinculadas às "geografias do trabalho". Herdeiro direto do legado de Silva, Moreira considera a geografia do trabalho "com letra minúscula, não como uma corrente nova na Geografia"

${ }^{19}$ CARLOS, 2002; p. 162. 
2001; p. 42) ${ }^{20}$, como aquela que se volta para o tema do trabalho, a partir do ponto de vista do trabalho, dos trabalhadores, enfim, que se volta para o mundo do trabalho. É assim um conjunto temático que, a partir da Geografia, pode ser considerado em dois planos. Um primeiro, mais genérico, que em última palavra irá entremear a escala do debate ontológico, está relacionado às questões que envolvem o metabolismo homem-meio, "genericamente apresentados hoje como questões ambientais, questões de ralação da técnica com o espaço, com o território" ${ }^{21}$. A segunda escala reúne um grande conjunto de temáticas mais específicas, de presença mais forte na sociologia, economia e antropologia, mas que recentemente foram incorporados ao temário geográfico. A variação temática nesta segunda escala pode assim se dar desde temas como organização e domínio fordista, produção flexível e acumulação toyotista, enfim, “aspectos que vão dar em configurações do tipo do chão de fábrica aquele tipo de configuração espacial interna da fábrica, do taylorismo, do fordismo"22, até um outro conjunto de temáticas que extrapolam o "chão da fábrica" e se direcionam a "um espaço arrumado a montante e a jusante pela fábrica e em função de ser, então, uma cidade fordista, uma região fordista, um espaço nacional fordista, um espaço mundial fordista, neofordista, hoje toyotista, etc."23

Em Thomaz Jr. a Geografia do Trabalho (em letras maiúsculas) ganha um aspecto mais disciplinar ("como as demais disciplinas ou ramos do conhecimento científico") ${ }^{24}$. O trabalho é admitido de forma a se aproximar mais da sua condição de objeto ("não existe diferença em relação ao objeto, é na ação do sujeito que as atenções se voltam" ${ }^{25}$, ao passo que o peso institucional se evidencia pela importante rede nacional de debate e pesquisa em torno do já consolidado Centro de Estudos de Geografia do Trabalho $\left(\right.$ CEGET) ${ }^{26}$. Aqui se observa a sintomática condição entre o contexto geral da cristalização institucional da crítica geográfica e a possibilidade de seu avanço rumo a práxis emancipatória, como pretendida por Thomaz Jr.: "uma geografia do trabalho fundada na compreensão histórica do trabalho e, consequentemente, na estrutura espacial que o regula, possa nos permitir dialogar com a comunidade interessada [...], sobre os rumos do mundo do trabalho no âmbito da luta emancipatória” (2002; p. 09).

\footnotetext{
20 MOREIRA, Ruy, "Trabalho e Movimentos Sociais no Brasil: um diálogo possível no âmbito da luta emancipatória?", In: II Jornada sobre o Trabalho. Caderno de Textos - Centro de Estudos de Geografia do Trabalho (CEGeT), Presidente Prudente, CEGeT, 2001.

${ }^{21}$ MOREIRA, 2001; p. 42.

${ }^{22}$ Id., Ibid.

${ }^{23}$ Ibid., p. 43.

${ }^{24}$ THOMAZ Junior, Antônio, "Por Uma Geografia do trabalho”, Revista Pegada Eletrônica (Geografia), Vol. 3 (edição especial), Presidente Prudente, CEGET, 2002; p. 17.

${ }^{25}$ Ibid., p. 01.

${ }^{26}$ O CEGET é atualmente o mais importante Centro de pesquisa em Geografia do Trabalho. Se integram em sua rede nacional pesquisadores de São Paulo, Paraíba, Goiás, Paraná, Rio de Janeiro, Distrito Federal, Mato Grosso do Sul, Tocantins, Piauí, Rio Grande do Sul, Acre, Amazonas.
} 
Mas as geografias do trabalho, das quais as perspectivas de Moreira e Thomaz Jr. podem ser consideradas as mais diretamente representativas, sobretudo porque admitem o trabalho como tema ou objeto da análise geográfica, não serão as únicas aqui consideradas. Interessa também aquelas perspectivas envolvidas com renovação crítica da qual o trabalho permitiu, ainda que em um dado momento da análise, "acessar" um rol mais amplo e interdisciplinar da crítica social. Isso significa admitir geografias do trabalho a partir do reconhecimento de que sua legitimidade está na análise em si, não apenas na referência direta (institucional ou não) do trabalho como categoria de análise.

Por exemplo, significa considerar que há uma geografia do trabalho no texto "Geografia Crítica: A Valorização do Espaço", de Antônio Carlos Robert Moraes e Wanderley Messias da Costa, importante livro para o contexto das proposições teóricas no início da década de 1980. Não há como não o pôr, diante dos objetivos da presente pesquisa, como objeto importante para a presente análise. Isso não apenas pelo que representou esse livro como referência para muitos pesquisadores que ainda hoje buscam nele alguma substanciação, nem só também pela sua fundamentação teórica amplamente situada no debate da economia política sobre a mais-valia e a valorização do capital. Mas acima de tudo importa a forma como foi depois tomado aprioristicamente, cristalizado, o que permitiu a redução sua poderosa crítica interna como uma análise já dada, e por muitos até superada, sem nem sequer poder ter havido qualquer movimento autocrítico mais amplo em torno dele.

A forma de tornar relevante também a negação do trabalho passa a ser um dado importante. Além da afirmação do trabalho nas perspectivas aqui abordadas, importa sobremaneira a forma como sua negação se deu, seja em torno da proposição teórica em si, seja em torno de sua representação como referencial abandonado. Aliás, é interessante notar que para entender o movimento autocontraditório da crítica geográfica a partir do trabalho, como aqui objetivado, importa mais o movimento dialético entre afirmação e negação do trabalho do que necessariamente a mera identificação de sua adoção para a fundamentação teórica.

Neste sentido, é bastante representativo a perspectiva de Milton Santos porque o movimento de afirmação/negação do trabalho no interior de sua geografia do trabalho, embora sutil porque jamais abertamente admitido, pode muito dizer sobre a natureza da crítica desse autor que foi o principal expoente do movimento de renovação. Assim, a título de exemplo, é geografia do trabalho quando o mesmo esboça seus objetivos no inspirador "Por Uma Geografia Nova", de 1979: "a tese sustentada é de que, ao se tornar produtor, isto é, um utilizador consciente dos instrumentos de trabalho, o homem se torna ao mesmo tempo um ser social e um criador de espaço" (SANTOS, 2002; p. 21). Tal como continua a ser geografia do 
trabalho quando o mesmo Milton Santos, já em "A Natureza do Espaço" (de 1996), momento em que toma o posicionamento da ontologia da técnica, a põe como centralidade na relação homem e meio deslocando, for fim de sua trajetória teórica, o trabalho de sua referência no metabolismo fundamental sociedade/natureza - como antes adotado a partir do referencial eminentemente marxista. Se o trabalho está presente afirmativamente na perspectiva embrionária de 1979, ou se continua presente diante da negativa em suas últimas formulações de 1996, é o movimento de um em detrimento do outro, no interior da obra de Santos, que deve aqui interessar. $\mathrm{O}$ deslocamento do trabalho em favor da técnica diz muito mais para o entendimento da crítica do que as formas em si em que o trabalho, ou a técnica, estão conceituadas em seus momentos específicos. O objetivo é entender a natureza da crítica, tal como seus objetivos emancipatórios de última instância, daí o porquê de buscar entende-la em seu próprio desenvolvimento.

Seja como objeto, seja como temática, seja como categoria auxiliar, seja como negativa para as formulações que se pretendem críticas, o relevante sobre o trabalho em seu movimento dialético e autocrítico (e como categoria carregada de referencial crítico já desenvolvido) é que ele pode expor as fissuras no interior das perspectivas teóricas, que se abrem como resultante do movimento de sua afirmação e negação. Tais fissuras, até então não objetivamente identificadas no interior da crítica geográfica, permitem entender as contradições internas das próprias geografias do trabalho, o que demarca o papel da autocrítica para o desenvolvimento da própria crítica geográfica a partir da identificação de seus limites.

A objetivação da crítica do trabalho (em seu movimento dialético e autocrítico) à crítica das geografias do trabalho (em seu movimento de cristalização epistêmica e institucional) é, a um só tempo, a demarcação dos limites da presente pesquisa e sua abertura para a incerteza do contraditório. Isso significa que a presente análise se processa em dois movimentos simultâneos: se "retrai" diante da necessária viabilidade com que a análise precisa se objetivar, para efeito de sua inteligibilidade, especificamente do trabalho (da crítica social genérica) contra o trabalho (da crítica geográfica), ao mesmo tempo em que deve se "generalizar" para as possibilidades com que às perspectivas teóricas analisadas das geografias do trabalho vão sendo incorporadas suas autocríticas. Este é, aliás, o objetivo prático da presente pesquisa: por meio das fissuras identificadas, abrir os sistemas sólidos e fechados no sentido de mostrar suas contradições internas e, por vezes, generalizadas no movimento de renovação como um todo. Essa "abertura" é exatamente a dimensão "positiva" da presente pesquisa: "como um esboço mais ou menos adiantado de crítica e de autocrítica, numa tentativa de conhecimento", como nos termos de Lefebvre sobre a modernidade e citados anteriormente. 
Demonstrada a complexidade com que os objetivos se entrelaçam na composição da tese central sobre a quebra da dialética do trabalho para o avanço contraditório da crítica geográfica, a exposição da sequência argumentativa no corpo do presente texto apresenta, assim, uma divisão bastante nítida. Uma primeira parte, intitulada "O Trabalho nas Fissuras da Solução Teórica-Epistemológica e Ontológica", volta-se para o debate interno das principais perspectivas que se dispuseram no movimento de renovação da crítica e está dividida em três capítulos, que distribuem o debate em três grandes áreas: teoria, epistemologia e ontologia. $\mathrm{O}$ objetivo é demonstrar o desenvolvimento interno das proposições críticas referenciadas no trabalho, basicamente na crítica do capitalismo, sua fundamentação na teoria do valor e a busca da estruturação ontológica. Mas também é analisado os conflitos em que cada uma delas estabeleceram com a própria necessidade de suas exposições relativamente prematuras, posta pela urgência da renovação: a formulação teórica como solução para vazio teórico que passou a ser estabelecido diante do criticismo contra a tradição regional francesa e neopositivista; a epistemologia como necessidade de oferecimento de uma estruturação discursiva que se pretendia coerente; e a ontologia como estatuto de legitimação do objeto (o espaço) ou do enfoque geográfico.

Tomando como ponto de partida o trabalho e sua inserção em cada uma dessas grandes áreas da renovação da crítica, tornou-se nítida a tensão entre a definição da natureza da análise que se pretendia nova e o resguardo dessa mesma tradição, isso pela própria garantia de se conservar a legitimidade da disciplina. $\mathrm{O}$ trabalho, diante da perspectiva que se adotou da teoria do valor, por exemplo, tendeu a subsidiar a leitura sobre o processo de "fixação" de homens e capitais. Isso acabou por reforçar o distanciando de suas dimensões mais abstratas e vinculadas à própria valorização do capital (ao mesmo tempo em que se pretendia partir delas).

O componente técnico do capital orgânico passa a interessar mais a leitura geográfica porque, como pareceria óbvio, a técnica carregava em si os elementos providenciais de assimilação à leitura geográfica. A centralização da técnica permitiu um grande avanço diante da necessidade de solucionar os problemas teóricos, epistemológicos e ontológicos. Contudo, como se verá, não foi observado que tão relevante quanto o componente técnico era a composição-valor do capital orgânico, do qual contém os elementos explicativos do processo de desvalorização tanto do capital como da própria técnica posta como valorização em seu processo de fixação. Um problema então tendeu a se estabelecer (embora não admitido), pois a dimensão "deslocada" da valorização, diante das necessidades e soluções disciplinares, seria exatamente aquela mais vinculada às crises socioeconômicas reais que, sintomaticamente, 
explodem no mesmo contexto (final da década de 1970 e início da década de 1980) em que a crítica geográfica parecia encontrar o caminho de sua estabilização teórico-propositivo.

A dimensão deslocada da valorização do espaço pela técnica seria exatamente a dimensão do trabalho, agora envolvido no processo avançado da valorização capitalista em sua fase de acumulação flexível (HARVEY, 1993) ${ }^{27}$. Mas não só: é também a dimensão deslocada da radical desvalorização destrutiva e da crise estrutural do capital (MÉSZÁROS, 2011) ${ }^{28}$, ou do sistema produtor de mercadoria (KURZ, 1992) $)^{29}$, conforme se avança o mesmo desenvolvimento técnico. Uma contradição entre técnica e trabalho se instaura e, como não reconhecida nem efetivamente abordada, se desenvolve dentro do próprio exercício teórico.

O deslocamento do trabalho se confunde com a necessidade de sua tomada negativa (reestruturação produtiva, neoliberalismo e os avanços contra a classe trabalhadora, superexploração da mais-valia, etc.), tomada essa que se tornaria fundamental para a explicação do tempo presente, que é crítico. A técnica passa a representar assim a estabilidade oposta ao mundo crítico e fundamentalmente intstável percebido do ponto de vista do trabalho. Por outro lado, deslocado da centralidade analítica do tempo histórico crítico em prol das soluções e necessidades das garantias disciplinares, o trabalho, não podendo ser excluído absolutamente, passa a se refugiar nos cômodos residuais mais remotos da ontologia geográfica, ao tempo em que essa mesma ontologia passa a significar cada vez mais a garantia do estatuto científico e filosófico da disciplina.

O processo de deslocamento do trabalho em sua própria inserção na teorização geográfica revela um movimento contraditório na composição de sua crítica, essa que também se expressa discursivamente. A forma com que a crítica geográfica se constitui, se desenvolve e se expressa será analisada na segunda parte do presente texto: “O Trabalho nas Fissuras da Crítica Geográfica: Entre Postos e Pressupostos”. Também está composta por três capítulos que, na sequência argumentativa, aborda o debate, tomando, primeiramente (capítulo 4), o problema da contradição e como fora ela abordada por uma crítica que, em última análise, se apresentava desprovida da autocrítica. A análise sobre a natureza da crítica geográfica que se monta sobre as condições abordadas ao longo da primeira parte do texto volta-se então para a natureza da dialética envolvida composição; busca-se nelas suas heranças, tal como percebe-se

\footnotetext{
${ }^{27}$ HARVEY, David, Condição pós-moderna: uma pesquisa sobre a origem da mudança cultural, São Paulo, Edições Loyola, 1993.

${ }^{28}$ MÉSZÁROS, István, Para além do Capital: rumo a uma teoria da transição, São Paulo, Boitempo, 2011.

${ }^{29}$ KURZ, Robert, O Colapso da Modernização: Da Derrocada do Socialismo de Caserna à Crise da Economia Mundial, Rio de Janeiro, Paz e Terra, 1992.
} 
sua vocação de se situar relativamente isolada, porque necessária de autorreconhecimento por autossustentação, deve se constituir como propriamente geográfica. Forja-se uma unidade.

No capítulo 5 (“A origem e gênese contraditória da crítica: disputas e conflitos”), diante da unidade pretendida busca-se as fissuras que permitem penetrar em sua internalidade no sentido de expor suas contradições. Tal busca pelas fissuras se dá a partir dos conflitos não admitidos diante do enquadramento normativo posto como necessário para a consolidação da unidade da Geografia Crítica: sobredeterminação ou não diante da necessidade epistemológica; crítica geográfica versus Geografia Critica; crítica política versus crítica epistemológica; crítica social versus crítica institucional; crítica genérica versus crítica especificamente geográfica.

No sexto e último capítulo (“A exposição do implícito: o trabalho entre as vias da crítica social e da crítica geográfica") o debate em torno da crítica volta, objetivamente, a reencontrar o trabalho. Tal reencontro se dá por meio da síntese proposta em torno "vias" por onde se fundem, mas também se confrontam, a crítica geográfica e a crítica social. Busca-se nesse momento da análise demonstrar como o trabalho esteve afirmado/negado em todas as "vias" de conformação da crítica geográfica. Mas também pretende-se demonstrar que em todas elas, a partir do exercício autocrítico, é possível compreender as contradições internas ainda latentes e abertas para uma crítica que, reconhecidos seus limites, vislumbra a possibilidade de se abrir para o universo indeterminado da contradição, como é o movimento histórico. Uma crítica voltada para os objetos reais críticos, como se impõe a condição crítica histórica dada, e em prol dos reais objetivos emancipatórios de última instância. 
PARTE I - O TRABALHO NAS FISSURAS DA SOLUÇÃO TEORICAEPISTEMOLÓGICA E ONTOLÓGICA 
[A interdisciplinaridade possível pelo "lado real"]

Quando em julho de 2015, por meio de uma carta, o mais recente "rock star"30, Thomas Piketty, em conjunto com um punhado de outros renomados economistas ${ }^{31}$, se lançou como possível intercessor nas negociações entre a cúpula de credores capitaneados pela Alemanha e o governo da Grécia (com sua “economia esmagada" 32 pelas políticas de austeridade, que desde 2010 são exigidas como garantias), acreditava-se que haveria de ter um futuro a ser decidido ou intercedido pela chanceler alemã Ângela Merkel. Diante do desastroso quadro de crise e do colapso econômico em que se envolveu a economia grega e a zona do euro como um todo, parecia-se estar em momento decisivo: "a história irá lembrar de você pelas suas ações essa semana"33, como assim advertiram os economistas à Merkel.

Desde a crise de 2008, quando o Banco Central Americano (FED) se viu obrigado a retirar do mercado, ou dar fôlego, à bolha da liquidez composta por ativos "des(a)creditados", por meio da compra de títulos na ordem total de 3,5 bilhões de dólares - o que representa a "maior emissão monetária na história de cinco séculos do sistema capitalista mundial", como lembra Tomasz Konicz $^{34}$-, por meio do programa de resgate econômico que se estenderia até 2013 (a partir de onde se daria a diminuição no apoio financeiro), as tentativas de prolongar o adiamento dos efeitos destrutivos da crise tem se mostrado cada vez mais limitadas no espaço e no tempo. Uma das mais importantes companhias de regulação da informação financeira do mercado internacional, a Bloomberg, chegou a afirmar que tal programa de resgate histórico do sistema do capital (a partir de sua esfera financeira), ou termina cedo demais, "dada a fraqueza econômica global", ou termina muito tarde, "perante os sinais de formação de bolhas em muitos mercados" 35 .

\footnotetext{
${ }^{30}$ Assim se refere The Guardian ao livro O Capital no Século XXI, como está inscrito em notas-propaganda na capa de fundo da edição consultada: PIKETTY, Thomaz, O capital no Século XXI, Rio de Janeiro, Intrínseca, 2014.

${ }^{31}$ Figuras engajadas no mundo institucional público, acadêmico e corporativo, como de Heiner Flassbeck (exSecretário de Estado no Ministério Federal das Finanças alemão), Jeffrey D. Sachs (Universidade de Columbia), Dani Rodrik (Fundação Ford e Escola Harvard Kennedy), Simon Wren-Lewis (Universidade de Oxford).

${ }^{32}$ Parte do conteúdo da referida carta extraída de: Carta Maior (Economia). "A Austeridade Falhou: uma carta aberta de Thomas Piketty a Angela Merkel", São Paulo, 09 de julho de 2015. Disponível em: <http://cartamaior.com.br/?/Editoria/Economia/A-austeridade-falhou-uma-carta-aberta-de-Thomas-Piketty-aAngela-Merkel/7/33945>. Acesso em: 20 jul. 2015.

${ }^{33}$ Id., Ibid..

${ }^{34}$ KONICZ, Thomasz, "Mais uma Vez se Põe a Questão: quando estoura a grande bolha de Liquidez em que está preso o sistema financeiro mundial?" 2015. Disponível em: 〈http://obeco.no.sapo.pt/tomasz_konicz5.htm>. Acesso em: 18 jul. 2015.

${ }^{35}$ Id., Ibid.
} 
A conjuntura da qual se monta o quadro da dívida grega em seus "impagáveis $175 \%$ do PIB" e o "necessário" programa de austeridade que levou a Grécia a um quadro em que " $40 \%$ das crianças vivem na pobreza, a mortalidade infantil sobe aceleradamente e o desemprego dos jovens chega perto de 50\%”, como lembrado por Piketty e seus colegas na referida carta, não deixa de ser a condição real desse quadro contraditório e insolúvel. A crise grega, tal como o aperto exigido pela Troyka (Fundo Monetário Internacional, Banco Europeu e Comissão Europeia), que coloca em xeque a solidez econômica, mas sobretudo a subcondição humanitária da "zona do euro", passa a significar a forma como se velam mecanismos contraditórios de valorização do capital (financeiro) por meio da massificação da miséria.

O ordenamento da dívida a partir de Luxemburgo, por meio de outros capitais privados (institucionalizados na forma de empresas financeiras privadas) e a suposta transferência para o governo grego, este sob a condição mais “favorável” por estar imerso na emergência da crise - logo “disponível” como receptáculo providencial desses novos "títulos podres", insolúveis pelo próprio mercado a partir do reconhecimento dos limites ou da incapacidade do FED ou outros bancos centrais, sobretudo o europeu, em prolongar ainda mais o colapso - tende a demonstrar como a própria crise se converte na possibilidade de redirecionar para os governos a mesmas condições da qual são vítimas, mas agora como forma de "ajuda financeira". Em outras palavras, é a demonstração de como a condição de crise nacional passa a se tornar importante meio de relocação das condições específicas da crise mundial (sobretudo como depósito de títulos insolventes) como forma de salvamento delas próprias.

Por isso que, em última instância, não haveria nada que pudesse ser feito pela chanceler alemã. A referência de Piketty ao exemplo mesmo da Alemanha que, ao final da Segunda Guerra Mundial e diante de um quadro de destruição da capacidade produtiva que gerou uma dívida perto dos $200 \%$ do PIB, fora beneficiada com o perdão de governos (inclusive o da Grécia) que fez decair tal dívida a $20 \%$ e com generosos 30 anos de prazo para sua quitação, soou apenas como balbucio de um passado esquecido. Primeiro porque a complexificação com que se imbricou diferentes naturezas do capital (sobretudo público-privado) no atual estágio de financeirização gerou um quadro de autonomização dela própria, dada sua "hipertrofia" (CHESNAIS, 1996) ${ }^{36}$ incontrolável, que em nada pode ser comparada à relativa autonomia dos governos em relação aos mercados nos anos que sucederam a guerra; segundo, e mais contundente, os trinta anos dos quais a Alemanha se beneficiou como prazo para o pagamento de sua dívida significa uma eternidade para os padrões atuais da valorização. A própria volatilidade da hipertrofia financeira promovida pela concorrência

\footnotetext{
${ }^{36}$ CHESNAIS, François, A Mundialização do Capital, São Paulo, Xamã, 1996.
} 
mundializada exige uma intensificação da lucratividade que faz com que o capital experimente o tempo dentro de uma nova lógica em que não seja mais possível ser concebido 30 anos, quiçá um futuro.

Ainda que seja questionada a forma como foi montada a dívida grega, o que ela tende a refletir com certa exatidão é a forma em si de constituição da esfera financeira e sua condição rentista (e destrutiva) do capital. A origem do mercado financeiro, do qual remonta outro quadro crítico mundial por onde se inaugura uma crise de caráter estrutural do final da década de 1970, significava, tal como agora, a possibilidade de deslocamento do travamento do processo de valorização do capital para o futuro. A crise que exigia condições concorrenciais cada vez mais mundializadas requeria, para os capitais, fontes de investimento a serem pagas pela própria força produtiva do presente, mas sobre um futuro adiantado. Um desenvolvimento do capital orgânico se observa com o avanço técnico e tecnológico nas décadas seguintes, tal como se tem o decréscimo relativo do trabalho vivo na produção. A "hipertrofia" financeira se fortalece em sua "autonomização" porque seria a única esfera do capital capaz de deslocar para o futuro os custos de investimentos correntes necessários. Mas isso não sem contradições.

O pagamento pelo adiantamento se dá na forma de acréscimo (por meio de juros), diferença essa a ser retirada do próprio resultado da produção corrente - por sua vez, relativamente mais alijada de sua dimensão real da valorização: o capital variável, como analisado originalmente por Marx. Em ritmo exponencial, uma dívida impagável assim se constitui condenando gerações de forças e recursos de trabalho a se adiantarem em um presente cada vez mais crítico, conforme esse futuro passa a ser atualidade na medida em que suas dívidas começam a se autovalorizarem em mercados próprios de "derivativos", por exemplo, que tendem a antecipação dos mesmos lucros futuros. O futuro é, assim, consumido pelo presente, como bem observa Robert Kurz em “ $O$ Consumo do Futuro": "a crise da dívida global é o resultado da tentativa desesperada de, através do 'consumo do futuro' insuflado por receitas em dinheiro que nunca mais virão, manter dentro

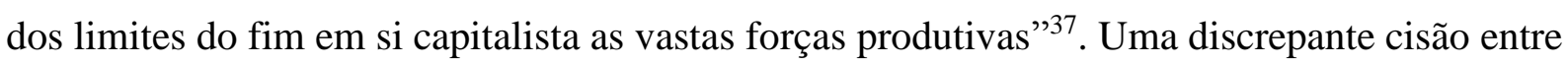
o mercado que se constitui em mecanismos financeiros aparentemente próprios de valorização tende a se efetivar diante da produção real do valor: valor-trabalho.

Ao tempo (em 2011), já observava Kurz que "o limiar da dor já foi alcançado e não apenas na Grécia. Porém a consciência social ainda não aprendeu a utilizar com uma lógica diferente os recursos 'inutilizados" $" 38$ que condicionam criticamente a própria perspectiva de

${ }^{37}$ KURZ, Robert, “O Consumo do Futuro", 2011. Disponível em: 〈http://o-beco.planetaclix.pt/rkurz380.htm>. Acessado em: 19 jul. 2015.

${ }^{38}$ Id., Ibid. 
futuro do qual, ingenuamente, Piketty e seus colegas economistas acreditam estar no improvável malabarismo humanitário de Merkel.

Todavia, o que chama atenção na tomada de atitude de Piketty e seus outros colegas filantropos é a ressurgência da economia política no quadro prático da vida econômica e política de um contexto em que o próprio Fundo Monetário Internacional passou a considerar como “impróprio para cardíacos"39.

É fato notável que o sucesso de seu mais recente e aclamado livro, “O Capital no Século $X X I^{\prime \prime}$, que se tornara best seller (o que indica ao menos a amplitude de seu conhecimento para além dos círculos restritos da economia), tem em grade medida seus créditos à tomada do seu tema central: a questão da desigualdade. Contudo é notável também como Piketty representa e dá segmento à sequência de uma linha mais "crítica", ao menos denunciativa, que se apresenta firmemente desde a concessão do Prêmio Nobel de economia de 2008 (ou seja, quando ainda se observava a tenebrosa perspectiva duradoura da crise creditada à falência do banco de investimento Lehman Brothers) a uma figura não tão apologética como Paul Krugman ${ }^{40}$ : crítico assaz dos padrões de liquidez irracional do qual o sistema financeiro atua e intermedia a dinâmica econômica dos países, além de denunciar a natureza dos pacotes de austeridades impostos a eles, como no caso grego.

Entre Krugman (e sua análise sobre a crise de 2008 em um revelador livro intitulado " $A$ Crise de 2008 e a Economia da Depressão"41) e Piketty (e seu "O Capital do Século XXI") pode ser observado uma tendência: a das análises não apenas estarem se voltando para os problemas reais da crise econômica e suas consequências humanitárias, mas, inversamente, como a condição evidente dela mesma começa a pautar, inevitavelmente, o próprio debate econômico. Isso promove o resgate das linhas de contornos mais universais e críticos sobre a própria crise. A crise resgata a crítica.

No caso de Krugman é importante observar como a crise, especificamente a financeira, passa a compor um quadro de análise voltada para o "lado real"; ou, especificamente, como as crises que surgem como “crises bancárias" escondem nelas mesmas um potencial paralisante

39 "O conhecido site de notícias norte-americano Business Insider advertiu, perante a leitura do Global Financial Stability Report do Fundo Monetário Internacional (FMI) publicado em meados de Abril, que este relatório sobre o estado dos mercados financeiros mundiais "não era próprio para cardíacos"” (Tomasz Konicz, 2015).

40 Paul Krugman chegou a elogiar o livro de Piketty, como assim pode ler lido em sua capa de fundo da edição consultada: "Piketty transformou nosso discurso econômico; jamais voltaremos a falar sobre renda e desigualdade da mesma maneira".

41 Assim é o título traduzido para o português pela editora Campus (2009) do original The Return of Deprresion Econômics and the Crisis of 2008, que contém um sentido invertido; afinal, o que veio primeiro, a "economia da depressão" ou a "crise de 2008"? Isso mudaria o significado da "depressão" como mero resultado da crise em específica (2008) ou dela enquanto condição da mesma crise (KRUGMAN, Paul (org.), A Crise de 2008 e a Economia da Depressão, Rio de Janeiro, Campus, 2009). 
do próprio mercado financeiro, e do capitalismo hodierno como um todo. Tais crises, revela Krugman, nascem do próprio boom financeiro ${ }^{42}$, como a que por um tempo relativamente longo (segunda metade da década de 1990 até 2007) sustentou a demanda efetiva da economia (fundamentada no crédito) ao mesmo tempo que velou a realidade sobre a "desigualdade" e a consequente criação de bolhas, como aquela que estourara na forma de "falência do crédito imobiliário" em 2008. Esses elementos constitutivos da crise (e não apenas a de 2008), por sua vez não observado nem explicado por Piketty, revelam que, mesmo em condições em que as políticas econômicas nacionais se apresentam equilibradas, ainda assim poderiam sofrer o que Krugman denomina como "ataques especulativos autorrealizáveis" (KRUGMAN, 2009). Desde a crise do final dos anos 1990, que transformou Tigres Asiáticos em gatinhos acanhados (MÉSZÁROS, 2011), essas condições pareciam ressurgir como questionamento da aparente normatividade do livre mercado.

Esses "ataques autorrealizáveis", ainda segundo Krugman, são racionais e provém de "erros" do próprio mercado os quais, assim, ocasionam uma "crise cambial" nas nações de economias estáveis. Elas podem ser geograficamente caracterizadas, como é o caso em que se assenta a atual crise europeia diante da querela Alemanha-Grécia, que é denominada por Krugman como "crise de segunda ordem".

Mas também as crises financeiras podem ser de primeira ordem e terceira ordem e assim são por estarem estabelecidas sobre uma determinada base geográfica: as de primeira ordem são aquelas ocorridas em economias sem sólidos fundamentos político-econômico que, na perspectiva de sua estabilização pela manutenção da paridade cambial, causam, em decorrência, um desequilíbrio entre a moeda e a realidade econômica nacional. São por isso crises provindas da forma de governança e apresentam como solução a sobrevalorização cambial e a consequente desvalorização relativa de sua produção. São crises que se apresentam geograficamente específicas e "até pouco tempo, ou talvez até agora”, próprias de países sem sólidos fundamentos na política econômica, como os da América Latina (KRUGMAN, 2009; p. 31).

A crise financeira de terceira ordem, conforme Krugman, é aquela que, como a de segunda ondem, se apresenta sob economias de relativo equilíbrio da política econômica e envolvem condições técnicas-informativas que compõem sua geografia. São por isso também de natureza "autorrealizáveis" e estão vinculadas ao desequilíbrio da estrutura informativa com que os agentes se medeiam. São provocadas por "problemas de informações assimétricas,

\footnotetext{
${ }^{42}$ Segundo Krugman, nos momentos de boom de crédito a probabilidade de crises bancárias se eleva de 50 a $75 \%$. Deste total, $20 \%$ se tornam crises financeiras.
} 
seleção adversa ou moral hazard" (BRITO; HOLLAND, 2010; p. 180) ${ }^{43}$, que ocasionam mudanças bruscas no comportamento dos agentes diante do mercado. Quem “erra”, nessa terceira ordem, são os agentes econômicos e pode ser observada no caso da crise asiática.

Krugman consegue assim elaborar uma teoria geral da crise financeira por meio de um quadro geral geográfico onde ela se realiza. E o "geográfico", neste caso, não é gratuito: é o próprio "lado real" do qual o economista se volta como foco objetivo analítico para retirar dela suas diferenças e universalidades. Ganhador do Nobel de 2008 por ter se adiantado e explicado dentro de suas condições específicas a crise financeira do mesmo ano, Krugman se constitui como referência importante na área de distribuição industrial, aspectos de espacialização produtiva e localização comercial (temas esses muitos debatidos pela Geografia, sobretudo a chamada Geografia Econômica). Do ponto de vista da economia, a título de exemplo, Krugman escreveu (em parceria com Masahisa Fujita e Antony J. Venables) o sintomático The Spatial Economy (1999) [Economia Espacial] ${ }^{44}$. A aproximação com a análise geográfica se confirma ainda em outros livros como Geography and Trade (1991) [Geografia e Comércio], EMU and The Regions (1995) [EMU e as Regiões], Development, Geography, and Economic Theory (1995) [Desenvolvimento, Geografia e Teoria Econômica].

A notória aproximação com o debate geográfico acumulado, sobretudo na década de 1990, não apenas permitiu Krugman entender a crise financeira em seu movimento global ante suas específicas formas de se concretizar em sistemas econômicos irregulares (equilibrados ou não) e assim compor uma geografia da crise financeira a partir de seu movimento econômico, mas é notório que permitiu também, ao observar a simultaneidade com que essas diferenças se expressam no espaço, avançar, no plano do "lado real", sobre os questionamentos que envolvem o tempo de início e duração dessas crises financeiras de diferentes ordens. O que, por conseguinte, recoloca a objetividade sobre as possibilidades de intervenção no plano da política econômica sobre quais novos parâmetros teóricos e concretos deverão ser estabelecidos, novas formas de pensar e agir no mundo perigosamente crítico pós-2008: “A economia mundial se revelou um lugar muito mais perigoso do que supunha no passado" (KRUGMAN, 2009; p. 191)

No entanto, as condições de posição geográfica que permitem Krugman levantar questões de tal relevância (que o possibilitou entender, pela simultaneidade espacial, a "autorrealização" das crises financeiras, mesmo em ambiente econômico equilibrado) e que o

\footnotetext{
43 BRITO, Igor Arantes; HOLLAND, Márcio, "Resenha: A crise de 2008 e a economia da depressão" (Paul Krugman, Rio de Janeiro, Campus, 2009) Rio de Janeiro, Campus, Revista de Economia Politica, 2010.

${ }^{44}$ O The Spatial Economy foi traduzido e publicado no Brasil pela editora Futura (São Paulo, 2002) com o título Economia Espacial.
} 
substancia teoricamente em prol de um posicionamento crítico e firme contra o neoliberalismo e a financeirização desregulamentada, tal qual os consequentes planos de austeridade, não foram o suficiente para que pudesse reconhecer, na própria dinâmica do capital financeiro denunciada, a expressão de suas contradições internas e insolúveis. O apelo à liberação de dinheiro público como medida para a remediação de crises cada vez mais caras e a consequente regulamentação das atividades bancárias ligadas ao mercado de ativos em um sistema fiscal estatal mais rígido que permita o acompanhamento, prevenção e detecção das condições de crise financeira, todas esses posicionamentos propositivos têm aproximado Krugman muito mais para uma via "neokeynesiana" do que propriamente para uma via original e efetivamente sustentável de longo prazo: "Figuras influentes deveriam ter promulgado uma regra simples: qualquer coisa que faça o que os bancos fazem, qualquer coisa que precise ser socorrida nas crises da mesma maneira como os bancos, deve ser regulada como os bancos" (KRUGMAN, 2009; p. 171). Afinal, como lembraria o próprio autor, a crise bancária entre 2007 e 2008 é a crise de não bancos.

Mas a solução "keneysiana" das proposições de Krugman é, em outros termos, de mesma natureza das proposições de Piketty, que, além da necessidade de regulamentação, defende o economista francês uma taxação "progressiva sobre a renda" e um "imposto mundial sobre o capital". Em outras palavras, como descreve Piketty em suas "lições para o futuro", "é necessário primeiro expandir a questão sobre o imposto do capital [...] para um contexto muito mais amplo: do papel do poder público na produção e na distribuição das riquezas e na construção de um Estado social adaptado ao século XXI” (PIKETTY; 2014; p. 459).

Assim como Krugman, ao não observar fundamentos contraditórios que tornam inconciliáveis os interesses do capital em sua mais franca "autorrealização" e qualquer forma de "regulamentação" minimamente social, ainda mais a partir de um "Estado social", Piketty não apenas subestima com profunda ingenuidade o poder destrutivo de tais contradições irremediáveis a um futuro que ele acredita poder existir apenas nessas mesmas bases contraditórias, mas ainda uma inabilidade incrível em retirar da crise corrente (desde 2008) qualquer perspectiva não trágica e não duradoura, como ingenuamente destaca: “A crise atual, felizmente, foi bem menos cataclisma [em relação à de 1929]. Daí ela ter sido chamada de 'Grande Recessão"'45.

Se é verdade que Krugman e Piketty chegam à mesma conclusão sobre a necessidade de "regulamentação" a partir da avaliação de que, ao contrário do ocorrido em 1929, em que os

${ }^{45}$ PIKETY, 2014, p. 460. 
mercados se dissolveram pela falta de "liquidez" provinda dos cofres públicos, a crise de 2008 não fora assim tão grave porque "governos e bancos centrais dos países ricos dessa vez não deixaram o sistema financeiro ruir e aceitaram criar a liquidez necessária para evitar a falência bancária" (PIKETTY, 2014; p. 460), poder-se-ia questionar quão inseguros serão os desdobramentos e surtos de colapsos financeiros que seguirão à crise de 2008, essa mesma que já consumira a "maior emissão monetária na história de cinco séculos do sistema capitalista mundial", como lembrado Konicz e citado anteriormente? Além dos questionamentos que também se desdobram sobre quais os limites reais de concessão e pagamento, do ponto de vista do capital, dessa dívida na ordem de 3,5 bilhões de dólares.

É claro que o sentido da regulamentação fiscal proposta por Krugman tem o objetivo de prevenir "erros" (de governos, mercados e agentes financeiros) que geram as crises “autorrealizáveis", porém ficou claro também que as próprias formas não prevenidas das crises financeiras atuais assim foram "não-previstas" exatamente pela sua capacidade adaptativa perante os novos contextos diversos. Piketty, embora nem chegue perto de tais explicativas, ao constatar (e em grande medida provar) apenas que o desenvolvimento do capitalismo leva à criação de "oligarquias antidemocráticas", como interpreta David Harvey ${ }^{46}$, chega à conclusão óbvia, mas não claramente aplicável, sobre a necessidade de "inventar novos instrumentos que retornem ao controle de um capitalismo financeiro que enlouqueceu" (PIKETTY, 2014; p. 462). Não pode assim ver que as condições que "enlouqueceu" tal capitalismo não são nada mais que evidências da inexistência das suas possibilidades de "controle".

Para Harvey, a impossibilidade de Piketty entender a natureza contraditória (e autonomamente contraditória, como é também, em última análise, o significado do caráter “autorrealizável” das crises analisadas por Krugman) do capital está na própria condição de não ter ele estudado o capital em si, mas sim o fenômeno da desigualdade decorrente do capitalismo. De fato, admite Harvey, o trabalho empírico desenvolvido por Piketty (“e estamos em dívida com ele e seus colegas por isso" ${ }^{47}$ ), com mais de três séculos condensados em dados, demonstra de uma vez por todas a natureza necessariamente desigual com que o capitalismo havia "prosperado". No entanto, apesar da constatação de difícil refutação que concede à história do capitalismo sua natureza socialmente desigual demonstrada pelo mesmo autor que requer apenas respostas corretivas, o que destaca Harvey é que, em última palavra, isso nada

\footnotetext{
${ }^{46}$ HARVEY, David, "Reflexões sobre 'o Capital', de Thomas Piketty", São Paulo, Blog da Boitempo, 2014. Disponível em: <http://blogdaboitempo.com.br/2014/05/24/harvey-reflexoes-sobre-o-capital-de-thomaspiketty/>. Acessado em: 01 maio 2015.

${ }^{47}$ Id., Ibid.
} 
mais é do que o reflexivo efeito da contradição estrutural capital versus trabalho, como desenvolvido por Marx em seu livro "O Capital”, ainda no século XIX.

Observa Harvey que Piketty consegue chegar, no máximo, em uma "regularidade estatística"48 da desigualdade, não na sua explicação. Harvey então propõe uma interpretação que seria fundamentalmente crítica inserindo nela a relação da dominação do trabalho diante do capital.

A queda constante da participação da renda nacional, desde os anos de 1970, é decorrente do poder político e econômico na medida em que o capital mobilizava tecnologia, desemprego, deslocalização de empresas e políticas anti-trabalho (HARVEY, 2015).

O período pós-Segunda Guerra, de crescimento e valorização da renda do trabalho, conhecido como "os trinta anos gloriosos" (CHESNAIS, 1996; p. 14) e regido pela política do "Welfare State", período esse lembrado por Piketty para demonstrar a possibilidades de "retorno do Estado" (dentro de outros padrões por ele observado), constituiu o momentoresposta da crise da década de 1930 exatamente pelo estímulo ao crescimento da demanda efetiva promovida na esfera do trabalho: valorização do emprego e do salário.

Contudo, continua Harvey, "ali pelo final dos anos 1960, ficou claro para vários capitalistas que eles precisavam fazer alguma coisa a respeito do excessivo poder do trabalho" que colocava em risco a necessidade de extração de mais-valor diante de um cenário em que a concorrência mundializada exigia produtividade. "Por isso, Keynes foi excluído do panteão dos economistas respeitáveis, o pensamento de Milton Friedman deslocou-se para o lado da oferta". E por isso também o fenômeno da reestruturação produtiva, iniciada no final da década de 1970 e efetivada na década de 1990; fenômeno este fundamentado na desregulamentação trabalhista, privatizações para abertura de novas esferas de investimento para o capital privado, financeirização para refugiar capitais "desprodutivizados" ao mesmo tempo que se revalorizavam no financiamento para novos investimentos, além da socialmente desastrosa política neoliberal.

Continua Harvey: "mas então a roda deu uma volta completa, e a pergunta mais importante tornou-se: e a demanda?”. Como já assinalado, na ótica da percepção de Krugman a inefetividade da demanda estava encoberta pela fictícia capacidade de compra concedida por meio da abertura de créditos (sem a devida regulamentação, como corrigiria Krugman). Ao

\footnotetext{
${ }^{48}$ HARVEY, 2015.
} 
mesmo tempo, e por isso também, tal disponibilidade desregulada de crédito iria constituir a chamada "bolha imobiliária americana", que estouraria em 2008. A não observância de Piketty sob essas condições específicas da demanda (que são condições em que o trabalho estava inserido), para Harvey, só assim se deu porque seu conceito de capital está definido como o "estoque de todos os ativos em mãos de particulares, empresas e governos que podem ser negociados no mercado - não importa se estão sendo usados ou não". O trabalho não constitui categoria da análise de Piketty porque seu conceito de capital não o admite em seu interior. Nega-se assim o movimento, logo, e por consequência, a contradição: capital aparece como "coisa" com potencial de valorização, não como processo de valorização. E nisso está toda a diferença entre os "Capitais"; o de Piketty e o de Marx.

Observa-se, assim, que o momento da crítica do "lado real" (que se "populariza" e se posiciona diante da condição da crise, que, por sua vez, passa a pautar a análise da "nova" economia política) tem em si um déficit de reconhecimento acerca dos limites de suas próprias possibilidades propositivas. Elas estão baseadas na crença em um futuro sob as mesmas bases desgastadas e incorrigivelmente postas: de um passado estruturalmente desigual (Piketty), passível de crises "autorrealizáveis" (Krugman) e cada vez mais destrutivas. Mas é inegável que se monta nessas mesmas condições de crise estrutural e crítica não-estrutural as possibilidades para sua interpretação e tomada de posição efetiva e originalmente nova.

Ainda que seja necessário reconhecer que entre Krugman e Piketty não há a transposição de uma "crítica oficial" de uma "economia oficial", por isso limitadas às condições internas e dadas do capitalismo financeiro, é importante observar o significado e o sentido de seus avanços. Krugman fornece a possibilidade de uma teoria da crise financeira a partir de uma "interdisciplinaridade" geográfica, que possibilita chegar na dimensão da simultaneidade espacial das crises, embora não consiga desenvolvê-la com efetividade crítica necessária, se prendendo a uma concreticidade da localização. Piketty, por seu turno, chega na comprovação da natureza contraditória e desigual do capitalismo, fornece o que seria talvez a melhor base empírica para tal comprovação, mas não aprofunda nos fundamentos da natureza da desigualdade, que estariam na contradição capital x trabalho. A avaliação de Harvey permite pontuar, a partir de uma crítica negativa, a possibilidade de identificação do sentido da metacrítica: uma crítica estrutural e, em última instância, emancipatória, nos termos já estabelecido por Marx.

Na tríade apresentada entre a crise financeira, a necessária abertura para a crítica e a sua possibilidade emancipatória, o que se pode concluir, no máximo, é uma avaliação bem modesta: a de que se tem diante do quadro apresentado uma crítica limitada, uma possibilidade geográfica 
de desenvolvimento analítico voltada ao mundo real-concreto e uma categoria negada, o trabalho. A partir daí se abre uma perspectiva que somente pode ser resolvida em seu "meio" mais apropriado: a dialética. Isso não significa uma somatória de elementos conciliáveis entre economia, geografia e marxismo, mas a busca das contradições que especificamente se dão diante de um quadro real como condição necessária da síntese teórica. Numa última palavra, tornar o "lado real" da crise financeira dos economistas a condição efetiva de uma ciência positiva real, voltada aos problemas dos homens reais (MARX, 2007) ${ }^{49}$

${ }^{49}$ Como, ao seu tempo, e contra a especulação hegeliana, afirmava Marx: “Ali onde termina a especulação, na vida real, começa também, portanto, a ciência real, positiva, a exposição da atividade prática, do processo prático de desenvolvimento dos homens" (MARX, K.; Engels, F, Ideologia Alemã, São Paulo, Boitempo. 2007). 


\section{CAPÍTULO 1 - DA CRÍTICA AO CAPITALISMO À VALORIZAÇÃO DO ESPAÇO: EM BUSCA DA SOLUÇÃO TEÓRICA}

Se "O Capital" de Thomas Piketty, inevitavelmente, remete ao "O Capital", de Marx, isso não se dá de forma gratuita. Não apenas porque aparece para a mídia pop como o providencial substituto da Crítica da Economia Política elaborada pelo filósofo alemão - como exageradamente se refere o The Guardian: "Maior que Marx. Nenhum outro trabalho sobre economia chegou tão perto de ganhar a condição de ícone pop" ${ }^{50}$-, mas sobretudo porque ela aparece para o discurso econômico oficial e limitado às condições internas da reprodução capitalista como uma crítica assimilável, não incômoda, que provavelmente será incorporada à lógica do esquecimento, como todo movimento pop (ao menos assim esperam os liberais mais conservadores).

Ainda assim, por mais ingênua que seja as propostas de Piketty em resguardar o capital por meio de sua regulação e taxação progressiva da renda, ou de um imposto global sobre ele (ideias consideradas "boas" por aqueles mesmos que as consideram "impossíveis"), tais soluções não efetivamente estruturais não deixaram de ser suficientemente sérias a ponto de se permitirem possíveis as acusações de "marxista" ou "socialista" direcionadas contra elas ${ }^{51}$. Tal relação nada tem de fundamento e nada mais indica do que a condição do estado crítico, incorrigível e estrutural da crise atual: qualquer referência a alguma forma de restrição das condições de livre acumulação soa "desastrosa" demais para todo o sistema econômico. É certo que a ausência "do ponto de vista do trabalho dotado criticamente" (MÉSZÁROS, 2008) ${ }^{52}$, nestes termos de apresentação teórica, se dá por condições políticas (de se resguardar das acusações de "comunista"), mas também, e sobretudo, porque as contradições não haveriam de serem expostas como forma de garantia da própria aceitabilidade, ou viabilidade, das proposições, por mais que reconhecidamente utópicas sejam estas. A não consistência da crítica, como demonstrado por Harvey (2014), se dá assim pela própria ausência de uma teoria do valor fundamentada na contradição capital x trabalho.

\footnotetext{
${ }^{50}$ Como pode ser lido em capa de fundo do livro de Piketty referenciado acima.

${ }^{51}$ Chega até a ser incrivelmente tosco o nível de rebaixamento com que setores declarados da direita estabelecem tal relação: "um francês best-seller marxista com nova roupagem que seduz incautos pela proposta de taxação confiscatória dos mais ricos, por pura inveja" (CONSTANTINO, Rodrigo, "A esquerda Ainda não Entendeu o Conceito de Escassez", Veja: Blogs e Colunas. Disponível em: <http://veja.abril.com.br/blog/rodrigoconstantino/tags/thomas-piketty/>. Acesso em: 03 jun. 2015).

${ }^{52}$ MÉSZÁROS, Filosofia, Ideologia e Ciência Social, 2008.
} 
Essa é também a fragilidade de Krugman que, sem o fundamento da relação estrutural com que o capital financeiro passa a significar uma grande "gelatina homogênea" sem valor, dado a tendência decrescente da participação do trabalho no processo de valorização, impossibilita-o de uma teoria e uma crítica também estrutural, apesar de suas importantes contribuições e elucidações sobre os mecanismos da crise financeira diante uma geografia econômica mundial. Contudo essas contribuições de natureza geográfica remetem também a uma inevitável referência.

O desenvolvimento da análise de Krugman desde, por exemplo, "Economia espacial" até "A Crise de 2008 e a Economia da Depressão" remonta um traçado analítico bastante conhecido pelos geógrafos: uma análise sobre a distribuição espacial da economia e suas desigualdades em sistemas comparáveis (Pierre George e sua "Geografia Econômica") ${ }^{54}$ e a composição de uma crítica quando as "coisas experimentam uma mudança praticamente revolucionária" 55 diante dos tortuosos tempos que se monta a partir da crise de 1970. Não seria demais apontar que diante dos limites provenientes de uma abordagem sobre a crise, marcada pela ausência da teoria do valor-trabalho, se soma à leitura espacial de Krugman os limites de uma interpretação geográfica desprovida do embasamento crítico sobre as contradições fundamentais em que se estabelecem, por exemplo, a base da política econômica dos países situados na periferia do processo da globalização, como profundamente analisado por Milton Santos. Essa observação é fundamental porque estabelece um parâmetro para o debate entre a crítica social, a economia e a Geografia.

Desde textos inspiradores, como aqueles de Milton Santos reunidos na coletânea igualmente intitulada "Economia Espacial" (originária de 1979), até suas formulações mais profundas sobre a globalização, é notória a observação do geógrafo sobre o desenvolvimento da complexidade que se monta diante do mesmo mundo da financeirização observado por Krugman. Também é bastante significativo que o economista, de forma a-crítica, tenha formulado a tipologia da terceira geração para crises que se dão sob "condições técnicasinformativas", concedendo sua causalidade aos "erros" dos agentes econômicos, sem se aprofundar nos significados da própria condição hegemônica e do uso político da técnica, como aqueles apontados por Milton Santos em "A Natureza do Espaço".

\footnotetext{
${ }^{53}$ Referência à explicativa de Marx sobre o trabalho abstrato encontrada ao longo do capítulo "A Mercadoria", sobretudo no subtópico "O Duplo Caráter do Trabalho representado na mercadoria" (MARX, Karl, O Capital: Crítica da Economia Política, São Paulo, Abril Cultural, 1983 (v.1, t. 1). Em se tratando do mercado financeiro de Krugman, a mercadoria em questão é o dinheiro.

${ }^{54}$ Cf. GEORGE, Pierre, Geografia Econômica, Rio de Janeiro; Fundo de Cultura; 1970.

${ }^{55}$ Alusão ao inspirador contexto de 1978, de publicação do "Por Uma Geografia Nova", de Milton Santos (2002; p. 18).
} 
A leitura não crítica sobre o espaço tendeu a ossificar as estruturas econômicas e técnicas de Krugman. Mas, em contrapartida, é igualmente interessante observar como que Santos não conseguiria aprofundar sua leitura sobre o fenômeno técnico em ambientes (históricos e espaciais) marcados por crises, como aqueles ambientes conturbados observados por Krugman. A "fragmentação", como processo indissociado da globalização, não seria tomado, na concepção de Santos, como contradição propriamente da crise que já nas décadas seguintes (1980 e 1990), pela sua permanência, toma sua feição estrutural. As observações de Santos ofereceriam um grande potencial da explicação geográfica de um mundo que se interage de forma fragmentária, que reforça os poderes das grandes corporações e que agrava as condições de desigualdade espacial, mas não como expressão da crise que mobiliza profundas contradições socioeconômicas de sua época. Por isso também não chegaria nas causas internas das crises "autorrealizáveis", da incontrolabilidade potencialmente destrutiva da financeirização e de um processo de mundialização integrada pela política econômica seletiva, como observado por Krugman. Este que também ficaria apenas no plano das expressões, enquanto mantinha resguardada a mesma base destas contradições críticas.

É interessante notar esta complementariedade negativa entre a leitura econômica e geográfica. O sentido em que se põe as duas críticas revela dois problemas que podem aqui ser isolados na perspectiva de identificar suas fissuras. O primeiro deles diz respeito ausência da teoria do valor-trabalho como fundamentação de suas explicativas e que, por conseguinte, não dispõe às análises da possibilidade de se aprofundarem no nível da contradição entre o processo de valorização capitalista e (des)valorização do capital; seja como fundamento para o entendimento da "autorrealização" da crise financeira como um fenômeno altamente vinculado a forma de produção do valor, e não apenas em sua circulação na esfera financeira, seja como fundamento para apreensão de como o "fenômeno técnico" é fruto e condição não só dos limites capitalistas, mas sobremodo dos limites da valorização do capital.

O segundo problema diz respeito aos objetivos da crítica e suas vinculações com a necessidade de estruturação teórica. No caso de Krugman, determinado a explicar e oferecer soluções práticas no plano da política econômica, se abstém o economista do rigor disciplinar de seu campo específico na evidente tentativa de se abrir para o real ("tentei evitar que essa dissertação se transformasse em exposição teórica [...]. O que o mundo mais precisa neste momento é da ação esclarecida"). ${ }^{56}$ Já no caso de Santos, o objetivo "em explicar como são as

${ }^{56}$ KRUGMAN, 2009; p. 06. 
coisas" ${ }^{\prime 57}$ está conciliado ao oferecimento de um referencial que se pretende eminentemente geográfico. Isso continuaria a reaparecer como necessidade imanente da própria crítica geográfica na perspectiva de solucionar suas próprias crises de fragmentação.

Estes dois problemas identificados, da ausência da teoria do valor-trabalho em teorias que pretendem explicar condições sócio-econômicas no presente estágio avançado da modernidade, e os conflitos dessas proposições teóricas no seu respectivo campo disciplinar, pode apontar um caminho de análise favorável à observação de como se deu o desenvolvimento da crítica geográfica e sua mediação com o trabalho diante do mundo que se monta após 1970. O caso de Milton Santos, na especificidade da Geografia, pode indicar importantes elementos que contribuam para o entendimento da natureza de uma crítica que, ao se pretender chegar no nível da produção do espaço, tentaria a mais fecunda vinculação com a teoria do valor-trabalho, mas que estabeleceria uma problematização conflitante em relação a suposta forma específica da análise geográfica

1.1 - Milton Santos e a crítica da diferença espacial como dominação capitalista

Milton Santos foi um dos primeiros Geógrafos brasileiros a identificar na teoria do valor-trabalho o potencial e as possibilidades de desenvolvimento de uma teoria crítica-social para a Geografia. Como em outras disciplinas em que tal vinculação já teria se desenvolvido de forma a avançar no posicionamento sobre as questões políticas, econômicas e históricas, parecia chegado o momento de se tentar uma teoria espacial do valor. É bastante representativo que Milton Santos tenha se disposto, nos idos de 1975 (quando a geografia francesa já havia amadurecido a perspectiva da chamada Geografia Ativa e os geógrafos brasileiros ensaiavam com seriedade a Geografia Crítica), dedicar à coletânea "Economia Espacial" um capítulo intitulado "Espaço e Dominação: Uma Abordagem Marxista". Mais importante ainda que a representatividade contida no título/subtítulo é o seu conteúdo.

O objetivo de Milton Santos no presente texto é demonstrar como se desenvolvem, a partir das diferentes configurações com que capital e trabalho se entrelaçam, as transformações e as diferenças entre os espaços a partir da incorporação de "valores". Esses valores são representados pela criação de uma infraestrutura no espaço que condiciona seu desenvolvimento, ao mesmo tempo em que promove sua diferenciação em relação a outros espaços. As diferenças são por isso de valores em sua montagem instrumental. Mas não só: elas

\footnotetext{
${ }^{57}$ Referência ao caráter positivo-explicativo da explicativa de Santos exposta desde o contexto de Por Uma Geografia Nova (2002; p. 113).
} 
desempenham importante papel no processo até então entendido como "dominação espacial”, processo esse que precisava ser desmistificado.

A análise em Santos leva a assertiva de não se tratar propriamente de uma "dominação espacial", mas de uma dominação do capital por meio da instrumentalização do espaço (modernização do aparelho burocrático e construção de infraestrutura). Santos promove uma alteração objetiva focando a relação agora no capital, não da dominação do espaço em si. A dominação do capital permite entender como se combinam formas de produção voltadas para a geração de excedentes apropriados de forma capitalista (mais-valia e lucro) e formas de distribuição que retroalimentam o próprio capital (“o excedente retorna para as empresas mais pujantes, sob forma de consumo ou sob forma de poupança, por meio dos canais institucionais ou não institucionais") $)^{58}$.

Ainda sobre o presente texto de Santos, é importante observar como se deu a organização da argumentação. Para demonstrar de que modo os espaços se diferenciam pela forma como se concentram e interagem capital e trabalho, Santos argumenta que no processo de inserção dos capitais em sua dinâmica e busca da produtividade, como exigência da concorrência do mercado, sempre se é imposto um aumento nos níveis de exploração do trabalho como forma de elevar as taxas de mais-valia. Isso muda o significado da “diversificação" para uma "especialização" capitalista propriamente dita que tende a se universalizar em escala espacial cada vez mais ampla podendo assim "tanto falar em uma alienação regional como em uma alienação do homem-produtor" ${ }^{\text {59. }}$.

Conforme Santos, a "diferenciação", desmistificada e posta como atributo desigual da especialização capitalista e provocada pelos níveis de interação capital-trabalho no espaço, se expressa em formas desiguais de capacidade de exploração da mais-valia, como expressão universal da divisão social do trabalho. Estão aplicados nessa máxima, não apenas a dialética em que o capital orgânico se monta na simultaneidade desigual capital-trabalho (no sentido da exploração relativa e absoluta do trabalho), mas também as "leis gerais" da determinação substantiva do capital em tornar as atividades produtivas em si (também a produção do espaço) em atividades produtivas de capital.

Isso leva, ainda segundo Santos, a segunda questão objetivada, a "dominação espacial", a um nível qualitativamente diferente daqueles descritos pelas teorias até então desenvolvidas em torno do ordenamento e da hierarquia espacial como aquelas análises que demonstram a

\footnotetext{
${ }^{58}$ SANTOS, Milton, Economia Espacial: críticas e alternativas, São Paulo, EDUSP, 2011a.

${ }^{59}$ Id., Ibid.
} 
suposta sobreposição de espaços sobre outros espaços: da cidade em relação ao campo, das metrópoles sobre as cidades médias, dos países desenvolvidos sobre países subdesenvolvidos.

A dialética até aqui expressada tende a se equivaler ao mesmo movimento dialético do desenvolvimento do capital orgânico apresentada por Marx, mas em sua forma espacial, o que explicaria sua distribuição específica. Essa dialética, para Santos, estaria na própria forma com que se relacionam capitais de distintas naturezas no espaço: os grandes capitais atraindo infraestruturas e equipamentos técnicos, tal como estimulando uma rede produtiva de escoamento; e os capitais dependentes, pequenos e médios, sendo atraídos ou mesmo produzindo os equipamentos técnicos no território. Como destaca Santos, "a dialética essencial se situa entre as formas complexas e as formas elementares de uso do capital, ou dito de outra forma, entre atividades com alto coeficiente de capital e atividades com alto coeficiente de mãode-obra" (SANTOS, 2011a; p. 150).

A dialética fundamental, inspirada na teoria do valor e tornada possível pela inserção da dimensão do ponto de vista do trabalho diante da lógica "dominante" dos grandes capitais, daria as condições suficientes para a constituição de uma "lei espacial do valor?", questionaria Santos. A possibilidade de elaborar uma teoria que concedesse os instrumentos necessários para a constituição da lei espacial do valor estaria fundamentada no entendimento central de que "valor é uma forma; ele esconde processos" ${ }^{60}$. Essa forma determinada de processo só se dá pelo reconhecimento de ser ele uma relação de diferentes valores que devem admitir, como possibilidade de intercâmbio social, uma "substância" comum, o trabalho (MARX). Assim então se pode estabelecer a lei na medida em que cada lugar é a expressão específica de sua forma historicamente determinada em relacionar forças produtivas e relações de produção, logo, de relacionar diferentes lugares e sua consequente forma de distribuição: “ $\mathrm{O}$ 'valor' do capital é também função de sua localização, se bem que o capital possa, por sua vez, modificar o valor do lugar" 61 . É por meio de tal "lei" que Santos busca explicar os fenômenos das "favelas" da "periferia do polo" e da "marginalidade", este último como substituto para a suposta "rígida classificação marxista" 62 de classes sociais.

Entendendo a dinâmica do espaço a partir de determinada "lei", avança Santos sobre as questões reais de ordem objetivamente social: a questão da "segregação" espacial pelo fenômeno da "periferia no polo" e expressa pelas "favelas". Questões estas que se desdobram em outras mais amplas, mas que sempre admitem um processo comum e estrutural de

\footnotetext{
${ }^{60}$ SANTOS, 2011a, p. 155.

${ }^{61}$ Id., Ibid.

${ }^{62}$ Ibid., p. 154.
} 
desigualdade, porque pertence à natureza do capitalismo impossibilitar a redistribuição do "excedente" produzido socialmente ("no sistema capitalista o excedente toma a forma de lucro, é por isso que ele não pode ser redistribuído" $)^{63}$.

Com relação ao espaço, apesar de ser ele o pano de fundo da desigualdade, a resolução desta não seria possível a partir dele. Ainda segundo Santos, o que "permanece fundamental" é a necessidade de ser invertido o processo da apropriação do excedente, mas a partir do Estado, este como único ente social capaz de inverter a distribuição desigual da riqueza. O Estado aparece, dessa forma, como o objetivo final da crítica, tanto em relação a suas finalidades políticas e sociais, como em relação à sua analítica teórica; o Estado como ente político e social para o projeto emancipatório, e o Estado-Nação como escala objetiva da análise.

A dialética de Santos chega assim na escala do território nacional porque assim se tem as melhores condições de se observar, a partir de suas concreções, a dinâmica do capitalismo no espaço. É, no entanto, nesse momento da tentativa de reposição analítica no plano do concreto que podem ser identificados possíveis "desencontros" entre a "dialética espacial" proposta por Santos e a "dialética do trabalho" proposta por Marx. Identificar essa fissura na síntese teórica (dificilmente admitida, quando não estão elas justificadas pelo fato de se tratar de "especificidade da Geografia") se faz importante porque pode contribuir com o exercício da autocrítica e, consequentemente, da teoria a partir do seu entendimento efetivo.

O ponto de vista da praticidade posta no nível da empiria, como forma de leitura que se apresenta propriamente geográfica em Santos, apresenta um problema no entendimento das abstrações. A empiria que permitiria a leitura concreta do capital em suas formas de existências específicas, até o nível das "empresas agrícolas", por exemplo, oculta um plano de mediação que contém uma contradição fundamental no que concerne a dinâmica dialética da teoria do valor. Assim, dirá Milton Santos, em citação importante:

O espaço agrícola está, assim, marcado por desigualdades gritantes: num extremo as explorações agroindustriais, muitas vezes dependentes do mercado mundial e apoiadas direta e indiretamente nos capitais internacionais; noutro extremo, as pequenas explorações que funcionam a base do trabalho humano e de um capital variável fraco obtido frequentemente por empréstimos usurários (SANTOS, 2011a; p. 143).

A demarcação desses "dois extremos” que, resumidamente, separam capitais orgânicos desenvolvidos e capitais orgânicos pouco desenvolvidos, posta como a relação entre "grandes

${ }^{63}$ SANTOS, 2011a, p. 157. 
capitais" ("agroindústrias") e "pequenos capitais" ("pequenas explorações agrícolas"), se apresentam em envolvimento dialético que admite apenas "uma gama de explorações que combinam, de modo múltiplo, frações de capital e trabalho"64, mas não uma contradição. $\mathrm{Ou}$ seja, permite avançar nas formas concretas das "combinações" e "multiplicidade" de relações entre os entes materializados e personificados do capital, todavia não na sua estrutura contraditória interna.

Por um lado, o entendimento do desenvolvimento orgânico do capital, como interpretado por Marx, permite apreender como que na mediação mais elementar entre capital e trabalho, a partir do descenso relativo do trabalho vivo envolvido na produção da riqueza, se reproduzirem as determinações mais gerais da lei da acumulação capitalista, no sentido de desvelar a tendência geral da queda das taxas de lucro e da desvalorização geral da produção no próprio desenvolvimento capitalista. Por outro lado, na interpretação de Santos, diante de tal condição fundamental importa apenas a dimensão externa da relação, momento em que a contradição em desenvolvimento se estabiliza e o movimento interno se cristaliza para sua evidenciação espacial.

Nestes termos, o movimento da contradição interna capital $x$ trabalho se paralisa para que a diferenciação espacial, diante da concorrência do mercado, seja apreendida a partir do poder das grandes empresas em sucumbir as pequenas empresas que, assim, desaparecerem, como pode ser entendido na própria exposição de Santos: "quanto mais desenvolvidas as forças produtivas de um país, mais as pequenas explorações agrícolas tenderão a desaparecer, a menos que seja posta em marcha uma política de acordo internacional, com apoio do Estado" "65. Não se torna possível observar, nessa forma externalizada e paralisada em que a dialética está submetida, que o movimento de desenvolvimento interno da organicidade do capital continua, e em estágios cada vez mais críticos, a desenvolver suas contradições internas (desvalorização e queda das taxas de lucro) nas próprias grandes empresas "vitoriosas" do mercado.

Na medida em que, pelo foco de Santos, a mais-valia só aparece na forma externalizada do lucro, não se pode observar também uma outra contradição fundamental: que tal tendência de desaparecimento de capitais com baixo desenvolvimento orgânico (como as "pequenas produções agrícolas") não é um dado absoluto, mas sempre relativo. Se, por um lado, a concorrência capitalista tende a ativar seu corolário mais contraditório expresso no monopólio (das grandes empresas), por outro, o próprio capital social total (reunião de capitais individuais compondo a organicidade do capital em si) tende a reestabelecer a taxa de extração de mais-

\footnotetext{
${ }^{64}$ SANTOS, 2011a; p. 143.

${ }^{65}$ Id., Ibid.
} 
valia - decaída pelo desenvolvimento capitalista fundamentado na maquinaria moderna - por meio da utilização dessas mesmas atividades mais vinculadas a extração da mais-valia absoluta, supostamente em extinção, que exigem alto envolvimento de trabalho vivo. Ou seja, ao tempo que os grandes capitais tendem a ganhar a concorrência dos pequenos, contraditoriamente estimulam a existência e a reprodução deles próprios pelo simples motivo de que assim equilibram a taxa geral de extração do sobretrabalho, como não observado por Santos. Marx havia apontado para isso no famoso prefácio da terceira edição de "O Capital", quando compara o desenvolvimento do capitalismo inglês e o alemão: “Além das misérias modernas, oprime-nos toda uma série de misérias herdadas, decorrentes do fato de continuarem vegetando modos de produção arcaicos e ultrapassados, com seu séquito de relações sociais e políticas anacrônicas" (1983; p. 12).

No seu contexto específico, os objetivos de Marx estão apontando para o "futuro" do próprio desenvolvimento capitalista a partir de sua lógica interna expansionista. Mas somente depois é que seria possível notar o quanto as "relações sociais anacrônicas" seriam tão fundamentais para a manutenção do próprio capitalismo, como expressão de sua própria lógica interna apontada por Marx. Estes seriam estes os objetivos de Rosa de Luxemburg, no seu famoso “Acumulação do Capital”, demonstrar como que relações não capitalistas de produção estão intimamente ligadas ao modo de produção capitalista, no sentido de sua interação contraditória para a valorização do capital. Em desdobramento da tese de Luxemburg, seria por este viés que se fundamenta a importante teoria do "Ajuste Espacial", de David Harvey. Seria também por esse foco que estabelece Mészáros a esclarecedora diferenciação conceitual entre capital e capitalismo, a partir da releitura do desenvolvimento crítico do capitalismo no século XX, tal como a partir da observação sobre a manutenção da produção de capital nos assim chamados países "pós-capitalistas” da extinta União Soviética.

Os estudos de Roza Luxemburg contribuem, por exemplo, com o entendimento de como o campesinato não apenas resiste, mas se reproduz estruturalmente no desenvolvimento histórico do capitalismo. Os estudos de Harvey ajudam a entender a dinâmica contemporânea do imperialismo a partir da exportação de capitais para países periféricos. A análise de Mészáros se tornou a mais poderosa ferramenta para se entender como que o capital, em sua fase destrutiva hodierna, passa a se reproduzir cada vez mais pela reativação de relações até a pouco tempo tidas como "em vias de superação" (como a superexploração e o trabalho escravo, por exemplo). O importante a ser considerado em todas essas contribuições é a necessidade de se atentar para o caráter contraditório inerente ao desenvolvimento capitalista: de se afirmar em suas próprias negações. 
A não observação em Santos desse elemento contraditório disposto no interior da própria teoria do valor, e em específico a questão do movimento contraditório inerente à dinâmica do capital orgânico (como amplamente utilizado na tentativa de criação da "lei espacial do valor"), se justifica pela forma de conceber à concretude propriamente geográfica sua pressuposta materialidade empírica que, assim, acaba insinuando a ocultação dos problemas de ordem abstratas, meio por onde a contradição se expressa. Por isso que o espaço em Santos, identificado como instrumentalização empírica, só assim pode ser concebido se for admitido em seu interior certa dose de unilateralidade, ou quebra do equilíbrio dialético, em favor do concreticismo sobredeterminado à abstração.

Não de outra forma é por esse viés que Santos, ao falar dos “capitais necessários para o empreendimento agrícola"66, estabelece uma divisão de capitais em duas naturezas: "capital fixo dormente", isto é, aquele que compõe o conjunto da infraestrutura necessária a produção, e o "capital vivo", ou seja, aquele que congrega ao mesmo tempo o capital constante (meios de produção) e o capital variável (trabalho). Aqui se observa não apenas a forma de privilegiar unilateralmente as condições de fisicalidade que podem ser percebidas no espaço, mas sobretudo a impossibilidade de se entender efetivamente a relação orgânica e potencialmente crítica com que, a partir da diminuição relativa do capital vivo em relação ao capital variável, o processo de desvalorização se instaura no interior do próprio processo de valorização do capital. Ou, visto de outra forma, a não observação de como que "capital dormente" (ou mesmo a composição técnica do espaço), assim tomado, não permite o entendimento dele próprio como uma "gelatina homogênea" em franco processo de "desvalorização", na medida em que, cada vez mais, menos trabalho vivo tende se incorporar a ele.

Ao colocar a empiria nestes termos, a análise de Santos toma, por exemplo, como referência de caraterização da urbanização o movimento decorrente da instrumentalização do espaço ("expansão do aparelho bancário, parabancário, comercial e administrativo") ${ }^{67}$. Isso leva a assertiva de ser a cidade, como espaço de complexificação das atividades econômicas, os "pontos do espaço" mais propícios à produção do "excedente" ("quanto maior a complexidade das atividades, mais o excedente se produz localmente") ${ }^{68}$. No entanto, a cidade em si e por si mesma não reuniria as condições de garantia que o excedente produzido seja distribuído socialmente. Mas isso se daria, ainda segundo Santos, pela natureza internacional das empresas. O problema passa a ser então o de distribuição do excedente (não mais o do modo em si de

\footnotetext{
${ }^{66}$ SANTOS, 2011a, p. 140.

${ }^{67}$ Ibid, p. 144.

${ }^{68}$ Ibid, p. 152.
} 
produção do capital) que, na forma capitalista, sempre retroage para as "grandes empresas que, desta forma, obtêm de volta a maior parte do excedente novo e ampliado por um efeitomultiplicação proveniente de sua própria estrutura"69. Sempre voltando para suas cidades e países de origem.

Milton Santos desvenda, em parte, a natureza universal "abstrata" do capitalismo a partir de sua expressão fenomênica: grandes empresas internacionais extratoras de excedentes mediados pelo espaço. Contudo, não desvenda a natureza específica do capital como processo social de produção e apropriação de um tipo específico de "excedente" qualitativamente diferente de qualquer outro tipo de "excedente"; ou seja, de processo em si desigual em sua internalidade mais íntima. Não apenas como modo de produção de lucros de capitais individuais, mas como processo mesmo de produção do capital. Ou mais que isso: processo especificamente moderno da produção em si. Tende assim a resolver um problema da crítica teórica do capitalismo ("Não se trata, então, de um problema de relocação do capital, como pretendia a doutrina oficial do planejamento regional" ${ }^{70}$, mas, ao mesmo tempo, resguardar a natureza contraditória do capital (“A eliminação daquilo que é chamado de dominação espacial não é concebível sem a utilização do capital acumulado, isto é, do excedente gerado coletivamente") ${ }^{71}$.

A forma de se chegar a um plano prático-real para efeito de entendimento das desigualdades sociais e espaciais a partir do empírico (como algo que aparece propriamente geográfico) pela teoria do valor, leva Santos ao entendimento das categorias abstratas confundidas com sua expressão material: capital como excedente, dinheiro; capitais como empresas, firmas; trabalho como força de trabalho, mão-de-obra. Isso não apenas significa a redução dessas mesmas categorias à sua dimensão instrumental, mas impede a mobilização de uma dialética que permita entender, por exemplo, como que a própria instrumentalização e infraestruturação (como formas de materialização identificadas como capital) significam formas de imobilização do capital (custos) que tendem a deslocar para o futuro sua própria valorização (rendimentos), enquanto o consumo do seu valor de uso se dá imediatamente.

Nestes termos apontados por Santos, o valor de troca e valor de uso tendem a se desencontrar, conforme se intensificam as condições de concorrência no mercado que se mundializa. Mas não só. Como produto das mesmas condições gerais da produtividade, sempre reposta em níveis mais intensos por meio da consequente redução relativa do trabalho vivo nele

\footnotetext{
${ }^{69}$ SANTOS, 2011a, p. 153.

${ }^{70}$ Ibid., p. 157.

${ }^{71}$ Id., Ibid.
} 
cristalizado, o espaço passa a admitir no seu processo de empiricização instrumental cada vez mais a negação de seu próprio valor, como assim se expressa a tendência geral de todo capital fixo, ou constante, diante de sua relação com o capital variável no desenvolvimento capitalista.

É claro que a tendência geral da desvalorização "espacial” do capital deve admitir suas contratendências, por exemplo, ao deslocar para a esfera financeira ou para o Estado tais investimentos de longa reposição da valorização, como observado por Santos: "uma parte, cada dia mais substancial, do orçamento [do Estado] para o desenvolvimento vai para infraestruturas indispensáveis à atividade das firmas modernas"72. No entanto, elas apenas indicam as origens das diferentes formas de capitais, mas não a gênese em si do capital. Se privada, financeira, ou estatal, sua natureza contraditória é intocada, tal como sua dinâmica de (des)valorização. Por isso as contratendências muito mais reforçam do que negam a constituição de um mundo cada vez mais abarrotado de capitais mortos e irressuscitáveis, "coisas sem valor”, e muitas delas sem sentido: por exemplo, como observado na cidade de São Paulo em 2010, onde para cada família sem teto haviam dois imóveis desocupados/vagos ${ }^{73}$.

O deslocamento das contradições do capital para o espaço, como apontaria Harvey na argumentação sobre o ajuste espacial (apesar não serem apontados seus limites), é também um deslocamento dessas contradições para o tempo, precisamente para o "futuro", como não observado pelos economistas Pikety e Krugman diante da chamada crise imobiliária americana citada anteriormente. Mas também são elas insolúveis, porque não se trata somente da forma de como o trabalho se materializa no espaço, porém a forma de como ele se estabelece como contradição do próprio valor, que faz com que "casas" (oferta social) e "sem tetos" (demanda social) não se encontrem, ou que na tentativa de reencontro se criem "crises imobiliárias" e “crises financeiras" de escala global.

Essa dupla dimensão do trabalho sob a ótica da teoria do valor se combina, ainda que também se contradiga. Por um lado, o trabalho, como categoria da concreticidade, é a "substância" social comum que faz com que seja possível o "intercâmbio social” de tudo que possa significar "valores de uso", mas é também o movimento de se tornar, no processo histórico, seu imanente negativo e abstrato, o "valor de troca", o capital. É, por um lado, a

\footnotetext{
72 SANTOS, 2011a, p. 153.

73 São 290.317 imóveis desocupados/vagos para uma quantidade de 130.000 famílias sem teto. Os dados de imóveis são relativos ao senso IBGE de 2010 (Instituto Brasileiro de Geografia e Estatística. Total de Domicílios em São $\quad$ Paulo: $\quad$ Senso $\quad$ IBGE, $2010 . \quad$ Disponível em: <http://www.ibge.gov.br/home/estatistica/populacao/censo2010/tabelas_pdf/total_domicilios_sao_paulo.pdf〉. Acessado em: 22 jun. 2015). Já os dados sobre a quantidade de famílias sem residência são da Secretaria Municipal de Habitação do Município de São Paulo (Secretaria Municipal de Habitação de São Paulo). "Conselheiros entregam Plano de Habitação de São Paulo ao Prefeito Gilberto Kassab”. 29 de setembro de 2010. Disponível em <http://www.prefeitura.sp.gov.br/cidade/secretarias/habitacao/noticias/?p=21864>. Acessado em: 22 jun. 2015.
} 
substância do valor que se cristaliza nos resultados da produção material/empírica humana, mas também seu "método" de abstração, de se apreender o movimento íntimo, interno, de como que esses mesmos produtos se tornam antítese de si mesmos, como se tornam mercadorias, "gelatinas homogêneas de trabalho", destinada a auto(des)valorização (MARX, 1983; p. 52).

A dupla dimensão que compõe a dialética do trabalho, que é uma síntese de uma contradição, é fundamental para a teoria do valor. Se, como no exemplo de Milton Santos, a inserção do trabalho como categoria que permitiria o desenvolvimento da análise resolve um problema teórico, no momento em que permite uma empiria e uma concreticidade crítica para além da praticidade propositiva das teorias do planejamento e localização produtiva, sua dimensão metodológica, onde se move e potencializa a dialética, não é igualmente incorporada com o rigor necessário, o que faz toda a diferença. Por exemplo, Santos se refere aos espaços agrícolas como aqueles em que "a intensificação de capital vivo (criação de novas atividades) sempre é capaz de forçar a criação de infraestruturas"74; este mesmo "capital vivo" como a relação já constituída entre capital constante e capital variável em uma "firma", como já visto. O trabalho não aparece, nem nessa passagem nem em outras, como categoria de processo contraditório, mas como "elemento" dado da produção que, igualmente empiricizável, compõe a estrutura do "espaço agrícola" ao lado do "capital dormente"; logo como externalidade, disponível à existência.

Por essas vias, a positivação material no espaço condiciona, por exemplo, a forma de entender a clássica relação campo-cidade que passa a ter como referência geográfica não mais apenas o complexo de mediações que se deriva da divisão social do trabalho como elaborado por Marx e Engels, mas as formas com que elas dispõem os "serviços" ("nos países desenvolvidos, não se trata mais de uma questão de uma diferença gritante entre campo e cidade, porque o acesso aos serviços é possível a todos") ${ }^{75}$. Aliás, a não observação com o rigor da dialética interna dos processos tende a inverter inclusive o entendimento da posição de Marx e Engels sobre o assunto, em que Santos se utiliza da seguinte passagem dos autores: "O antagonismo entre cidade e campo começa com a transição da barbárie..." para demonstrar a necessidade de superar as "dicotomias" inerentes à análise entre campo e cidade. No entanto, o "antagonismo" de origem supostamente atribuída a Marx e Engels parece ser nada mais que um problema de tradução da palavra "Gengensatz" que, para além de "antagonismo", admite como

\footnotetext{
${ }^{74}$ SANTOS, 2011a, p. 142.

${ }^{75}$ Ibid., p. 147.
} 
significado palavras mais condizentes com a dialética desenvolvida no contexto da escrita dos autores de "Ideologia Alemã": "oposição", "contraposição", "antítese"76.

Nessas condições por onde se insere o trabalho, como categoria social e da teoria do valor, tende ele a perder sua condição dialética no processo de produção porque é posto junto com os demais "capitais" como instrumento participativo da estruturação do espaço, não como processo em si. Dessa forma, se põe apenas como elemento de sua positivação para uma pretensão teórica explicativa. Da mesma forma que o trabalho é chamado para mediar uma crítica que relaciona as formulações teóricas da Geografia com a teoria do valor, ele próprio se ausencia diante do não reconhecimento de sua dimensão negativa no processo interno, que concederia a devida abertura dialética para a contradição. O trabalho se ausenta em sua própria presença positiva nessas condições em que sua dialética se incompleta pela retirada de sua dimensão negativa.

Isso explica, em parte, o porquê de Milton Santos se reter na questão da "desigualdade" (não na contradição em si) que se expressam nos "marginais" (não no "proletário"). Destituído de sua condição abstrata, o trabalho perde também o sujeito de sua personificação universal e equivalente. Voltada para a concreticidade material, que aparece como "não rígido" em Santos, o sentido das classes ganha a conotação devidamente condizente com o posicionamento do sujeito, não mais diante da contradição em si capital x trabalho, mas na empiria do espaço. Mas é por isso também que Milton Santos não rompe com a dimensão do Estado para a solução da "desigualdade", tal como quatro décadas depois, e por outras bases conceituais, a "nova" economia política de Piketty e Krugman também não romperá. E por isso também que a dimensão do Estado-Nação só pode aparecer para Santos nos dois momentos combinantes já revelados, seja na sua dimensão de escala de análise devidamente empiricizável (“a análise espacial deve ter como ponto de partida o capital global existente na formação socioeconômica por excelência - o Estado-Nação") ${ }^{77}$, seja na dimensão da solução prática da desigualdade pela distribuição do "excedente" que supostamente perderia sua condição de capital depois de apropriado pelo Estado (“Se o Estado não é capaz de o fazer ele permanecerá [...] tributário das grandes empresas quanto a organização do espaço, incapaz de impor uma alternativa à estrutura econômica e de devolver à sociedade o resultado de seu trabalho coletivo" ${ }^{78}$.

\footnotetext{
76 "Gegensatzs: contraste, oposição, antítese, oposta, antônimo; (unvereinbarkeit) antagonismo [...]" (Dicionário Editora, Dicionário Alemão-Português, Porto Editora, Porto, Porto Editora, 2000; p. 348). Por exemplo, na edição MARX, K.; Engels, F, Ideologia Alemã, São Paulo, Boitempo, 2007; p. 52, tal passagem está traduzida da seguinte forma: "A oposição entre cidade e campo começa com a passagem da barbárie à civilização [...]".

${ }^{77}$ SANTOS, 2011a; p. 150.

${ }^{78}$ Ibid., p. 158.
} 
Ainda assim, um plano de natureza crítica distingue radicalmente Milton Santos e os novos e "populares" economistas da desigualdade capitalista e da crise financeira. A perspectiva de Santos, sobretudo a apresentada até aqui, que reconstitui o momento de transição de uma crítica denunciativa para uma crítica teórica-efetiva própria dos meados da década de 1970, apresentava um fundamento básico de constituição de um projeto teórico que faria toda a diferença: o de transformar o mundo em direção à emancipação humana.

\section{2 - "A Valorização do Espaço"}

A perspectiva da valorização do espaço desenvolvida por Antônio C. R. Moraes e Wanderley M. Costa e publicada em 1984 (“Geografia Crítica: A Valorização do Espaço”) foi, na sequência e em paralelo ao desenvolvimento teórico de Milton Santos, uma das mais importante e influentes propostas de interpretação do espaço no movimento da renovação crítica. Tal como Santos, os autores de "A Valorização" compartilhavam a importância da natureza crítica contida no método desenvolvido por Marx, sobretudo a partir da sua perspectiva emancipatória: “[...] só a perspectiva de transformar o mundo fornece a possibilidade de compreendê-lo" (COSTA; MORAES, 1984; p. 35) ${ }^{79}$. Por isso, o "método" Marx deveria significar os meios para tais objetivos: "interessa-nos da obra de Marx, fundamentalmente, de um lado, o seu método revolucionário, e, do outro, as teorias que mais se aproximam da discussão de um temário geográfico" ${ }^{" 80}$.

As questões levantadas acima a partir de ótica de Santos tendiam, na análise sobre a valorização do espaço, ganhar outra dimensão. Isso porque pretendiam os autores "entrar na teoria do valor", em sua lógica interna, que permitiria entender os processos em si da produção do espaço à luz do movimento universalizante do capital em autovalorização: "Milton Santos não está, porém, diretamente preocupado com o processo em si da produção do espaço, o que implicaria entrar na teoria do valor" (COSTA; MORAES; p. 125). Estava aí reconhecida a necessidade de ir para além do espaço como estruturação instrumental.

Se em Milton Santos os problemas da "dialética do trabalho" representavam um limite diante de sua solução teórica, no que concerne sua relação entre trabalho e geografia ainda sob o contexto da segunda metade da década de 1970, a perspectiva da valorização objetivava partir, inversamente, do trabalho em sua dialética contraditória com o capital; como substância

\footnotetext{
${ }^{79}$ COSTA, W. M. da; MORAES, A. C. R, Geografia Crítica: A Valorização do Espaço, São Paulo, HUCITEC, 1984.

${ }^{80}$ Ibid., p. 117.
} 
da centralidade do valor, mas sobretudo da mais-valia na sociedade capitalista. Portanto, seguem os autores uma minuciosa interpretação da "Teorias da Mais-Valia" (de Marx) no sentido de revelar os mecanismos econômicos da valorização em que o espaço se insere no respectivo modo de produção.

Mas é também, como admitido, a busca de um método interpretativo, como solução teórica para a "crise da Geografia” que, segundo os autores a sua época, "já se arrasta por mais de duas décadas" $"$. A valorização do espaço significaria ao mesmo tempo a positivação do espaço na teoria geográfica e sua mediação com a teoria do valor. Esse duplo objetivo com a "valorização" é bastante perceptível na própria forma de composição do livro em duas partes bem distintas, mas ainda complementares: a primeira sobre a crítica da Geografia e a justificativa sobre a opção por uma "teoria marxista da Geografia" ("neste trabalho, assumimos claramente [...] a formulação de uma teoria marxista que dê conta das questões colocadas pelo temário geográfico") ${ }^{82}$; a segunda sobre a relação entre valor, formas de valorização e espaço. A divisão do livro nessas duas partes que se pretendem complementárias, e na sequência observada, é, em si, um dado importante, pois já se encontra presumido que o debate sobre o "método" apareça antes do debate do "valor", o que faz com que o primeiro não seja explicitamente o resultado do segundo (sendo, por isso mesmo, observado algumas contraposições entre elas). As consequências se efetivam, como será observado, na forma de pôr as questões que envolvem a dialética e a abstração necessária para ser possível desenvolvêla, sobretudo diante das relações colocadas como "contradições" entre espaço e valorização.

Se tal redirecionamento da autocrítica em relação a Milton Santos, por exemplo, permitiria avançar a interpretação do espaço para além da externalidade que imobiliza categorias como trabalho e capital em formas instrumentais de corporificação material no território, o sentido rumo às "abstrações do valor" também não deixaria de ser um problema perante o "temário" tradicional da Geografia em "A Valorização do Espaço". Isso porque, em última análise, deveriam estar as categorias modernas em sua dimensão "fixa”" no espaço, ou no território.

Como estabelece Costa e Moraes, a aproximação entre marxismo e temário geográfico, embora tenha em comum "a forma mais elementar do intercâmbio material" 83 homem-natureza, se estabelece pela observação de que o ato geográfico da valorização do espaço se dá com a "fixação do homem no território" o que representa, para além de uma mera relação homem-

\footnotetext{
${ }^{81}$ COSTA; MORAES, 1984, p. 09.

${ }^{82}$ Ibid., p. 38.

${ }^{83}$ Ibid., p. 74.
} 
meio, uma "verdadeira" apropriação do espaço. Ela não apenas coincide com a mudança do processo de produção do trabalho qualitativamente distintas das formas primitivas, mas é a própria condição, ou “meio", para sua realização: “A fixação numa dada porção do território [...] manifesta, muito mais, mudanças qualitativas ao nível das relações de trabalho [...]. A natureza [..] aparece agora não apenas como objeto de trabalho, mas como meio de trabalho" 84 .

Era preciso colocar o homem, natureza e espaço em seu nível conceitual de abstração econômica para além da "naturalização" desses mesmos territórios que, quando se desenvolvem a partir da produção de seus excedentes (valor de uso mais que necessidade), desenvolvem também sua "estrutura produtiva" cada vez mais determinada pelas trocas, como intercâmbio de seus valores de uso. O desenvolvimento do território é, em paralelo com o desenvolvimento das sociedades economicamente constituídas, a dimensão empírica do processo social: "As formas de existência na cidade [representam] um amplo processo de desnaturalização da sociedade, pois suas formas de sociabilidade em muito se diferem daquelas vigentes nas antigas comunidades tribais ou mesmo camponesas" "85. A "fixação", o território, não mais entendido como processos naturais, seria a dimensão positiva da valorização e estava a ela relacionada como sua própria identidade material, concreta e, por isso, geográfica.

Mas entender o processo de "desnaturalização" em prol da apreensão das determinações abstratas universais do valor aparece como principal problema teórico a ser resolvido: “o significado real da urbanização contemporânea [por exemplo] transcende em muito aquilo que nos é oferecido pela observação do seu empírico" ${ }^{86}$. Reconhece-se a necessidade de se chegar ao movimento próprio e interno do "concreto", movimento este que o explica, o justifica e o condiciona.

O mergulho na "Teorias da Mais-Valia" permite aos geógrafos em um primeiro momento atentar a tal reconhecimento: da crítica de Marx à escola mercantilista observam os autores os limites de se entender o valor a partir da circulação, mas como que por meio dela o valor se dá como relação entre desiguais (valores de usos específicos e diferentes) a partir da possibilidade da troca de uma substância permutável, por isso comum: o valor-trabalho ("É a primeira formulação explícita da categoria valor enquanto valor-trabalho") ${ }^{87}$. Apreende os geógrafos que o valor é sempre um dado relativo, uma abstração do elemento comum valor-

\footnotetext{
${ }^{84}$ COSTA; MORAES, 1984, p. 77.

${ }^{85}$ Ibid., p. 86.

${ }^{86}$ Ibid., p. 91.

${ }^{87}$ Ibid., p. 96.
} 
trabalho, que pela troca desigual geram o lucro. $\mathrm{O}$ valor não estaria assim limitado à esfera da circulação.

Da crítica de Marx aos fisiocratas, observam os geógrafos a tentativa de, no contexto de desenvolvimento industrial, chegar-se, enfim, à esfera da produção ("Por isso, [Marx] os considera os "verdadeiros fundadores da moderna economia"") ${ }^{88}$. Observam dessa crítica a "inflexão" da concepção do valor em sua forma "natural", como se houvessem "leis naturais", exatamente pela forma com que empiricamente tentam os fisiocratas determinar os mecanismos absolutos da produção ("interessa-lhes, antes de tudo, a análise empírica dos elementos constitutivos do funcionamento econômico, a verdadeira fisiologia da economia") ${ }^{89}$. E retiram dessa crítica os limites de condicionar a valorização com o setor produtivo supostamente mais vinculado à "natureza", ou seja, de considerar apenas a agricultura como atividade realmente produtiva: "Para eles [fisiocratas], na atividade manufatureira, por exemplo, ocorre apenas uma transferência ao produto do valor das matérias primas e do trabalho" ${ }^{90}$. Observam os geógrafos: tal como ao capital, ao trabalho não se deve admitir apenas sua dimensão concreta da produção, mas também sua dimensão abstrata.

Da crítica de Marx à Adam Smith e David Ricardo, observam os geógrafos a efetividade do reconhecimento da abstração do trabalho; ou seja, é o trabalho em si, como tempo, destituído de suas formas específicas de concreção, que contém a origem do valor, logo da mais-valia, independentemente de sua esfera produtiva. No caso específico de Smith, observase como que a mais-valia aparece "naturalizada" na própria relação econômica em que, dividido o valor em salário e lucro, cabe ao capitalista sua parte "deduzida" do trabalho alheio ("O lucro para Adam Smith é apenas uma dedução natural do produto do trabalho" $)^{91}$. A forma de “justificação" burguesa da mais-valia em Smith impedia-o, segundo a interpretação de Marx feita pelos geógrafos, a objetivação da própria mais-valia como categoria objetiva da economia capitalista relegando ela à imanência das formas concretas de sua expressão.

Da crítica de Marx à Ricardo observam os geógrafos uma mudança qualitativa na interpretação do trabalho e sua relação com o capital: o trabalho como tempo de trabalho e este, por sua vez, como princípio da produção capitalista (“Ao contrário de seus predecessores, [D. Ricardo revoluciona] ao defender a ideia de que o "ponto de partida" e o fundamento do valor na produção burguesa é o tempo de trabalho”). Aqui, diante da radicalidade da abstração

\footnotetext{
${ }^{88}$ COSTA; MORAES, 1984, p. 97.

${ }^{89}$ Id., Ibid.

${ }^{90}$ Ibid., p. 98

${ }^{91}$ Ibid., p. 100.
} 
identificada, na relação trabalho e valor tende a se reforçar a relatividade do valor e assim o seu caráter socialmente universal; na medida em que o valor é apenas aquilo que o é para um outro valor, ou seja, tempo de trabalho. Aqui também tende a se radicalizar a mais-valia (tempo de trabalho em si, destituído de suas formas concretas e específicas) como o princípio universal do capitalismo; como medida comum da produção em si. Como visto pelos geógrafos, o que Ricardo não observaria nessas tendências, além do desenvolvimento histórico delas, é que elas se intercruzam de forma contraditória. Isso só será possível a partir da análise de Marx, que, diferente dos economistas políticos e ao colocar a mais-valia como objeto da análise, percebe a tendência crítica e destrutiva inerente à natureza contraditória do capital.

O que, em suma, apreendem os autores de "A Valorização do Espaço" perante a "revisão" da economia política e sua relação com o "temário geográfico" é: (1) a desnaturalização das coisas, objetos, produtos ou relações no seu processo de valorização; (2) a abordagem sobre a superfície da terra e seus elementos naturais constituintes que, relativizados enquanto valor, dão outros significados ao "valor do lugar"; e (3) a questão da renda da terra, seus pressupostos como propriedade privada e suas consequências para os processos de povoamento e colonização. Sobre os “ensinamentos” de Marx diante da crítica da economia política, observam os geógrafos: (1) a forma como Marx demonstra o sentido da crítica para uma nova crítica, ou a forma de assim se fazer a partir da "dialética da superação: negação com assimilação"92; e (2) a capacidade de totalização da leitura, não apenas restrita à economia política, mas a integrando em seu sistema filosófico.

Sobre a teoria do valor de Marx, interpretam os geógrafos: (1) valor (e o capital) é uma categoria social e o trabalho nele cristalizado é sua substância material e é definido pela sua produtividade social média, não individual; (2) valor de uso e valor de troca representam a "forma dupla" do valor, mas pode ser dividida para a caracterização histórica ("a história humana até o advento do capitalismo é marcada basicamente pela produção dos valores de uso") $)^{93}$; (3) o trabalho, como substância comum do valor que permite a realização da troca, tem o seu próprio valor, que é definido pela "força média de trabalho social" e se expressa em força de trabalho (trabalho vivo) e em meios de produção (trabalho morto); (4) a mais-valia é uma "categoria específica"94 e é sempre movida por uma relação contraditória que envolve produtividade e a diminuição do valor adicionado (pela diminuição relativa do trabalho vivo) à

\footnotetext{
${ }^{92}$ COSTA; MORAES, 1984, p. 109.

${ }^{93}$ Ibid., p. 110.

${ }^{94}$ Ibid., p. 113.
} 
massa produzida. O lucro é a manifestação da apropriação da mais-valia (embora seja ela mesma a apropriação em si).

[Valor do espaço e valor no espaço: a natureza da contradição entre produção e circulação]

Tendo em mãos todas essas referências, iniciam os autores sua "teoria sobre a valorização do espaço". O primeiro ponto se dá na observação sobre a renda da terra, da qual identificam uma relação objetiva como o "temário" já explorado pela Geografia. Para Costa e Moraes as incursões sobre a natureza da renda diferencial da terra iniciadas por Ricardo e a renda diferencial II desenvolvidas por Marx em muito contribui para a análise do papel da distância e da produtividade (fertilidade) do solo, tal como seus investimentos em capital. O que recoloca o debate sobre a apropriação do território, localização produtiva e sua relatividade no espaço, além da questão sobre o povoamento, em um nível teórico mais condizente com as condições reais por onde se efetivam.

Essas condições reais de efetivação da "produção do espaço" ou a "valorização do espaço" é o que estabelece seu "corte ontológico", que é a objetivação da própria "valorização" como especificidade do real e de onde derivam particularidades concretas ("corte ontológico, ou seja, da sua identidade no próprio real [...]. Como foi afirmado, afirmar que a contradição capita-trabalho 'explica' a organização do espaço no modo de produção capitalista, por exemplo, não contribui muito") ${ }^{95}$. Soluciona, em parte, a forma de pôr o objeto na sua composição teórica, no caso a valorização do espaço, como concreticidade carregada de universalidade na forma em si de sua existência a partir de seu modo de produção ("Em qualquer época e em qualquer lugar, a sociedade, em sua própria existência, valoriza espaço. $\mathrm{O}$ modo de produção entra aí, portanto, não como panaceia teórica, mas como mediação particularizadora") ${ }^{96}$. No meio dessa definição ontológica, o trabalho entra como categoria central, pois qualquer forma de apropriação/produção do espaço já é uma relação valor-espaço. Isso leva a distinção fundamental entre valor no espaço e valor do espaço.

A distinção entre valor do espaço e valor no espaço servirá para melhor posicionar os processos que se põem dentre a dimensão ontológica das formas específicas de materialidade (ontologia) e os meios universais de onde se percebe a própria espacialidade geral dos modos de produção, ou da espacialidade enquanto atributo (não ontológico). Entre eles, valor do espaço e valor no espaço, uma unidade dialética. O valor do espaço se refere ao espaço como

\footnotetext{
${ }^{95}$ COSTA; MORAES, 1984, p. 122.

${ }^{96}$ Id., Ibid.
} 
condição da própria existência material, natural ou humana, um valor de uso, "um valor intrínseco, não necessariamente produto do trabalho humano, uma "riqueza natural",97. Mas que pode ser "receptáculo" do processo de acumulação de trabalhos cristalizados, mortos, que passam a compor novas pré-condições de existências do espaço. Natural, ou historicamente acumulado, se expressa por isso de forma desigual no tempo, mais complexo quanto mais se relacionam o natural e o humano. É por isso uma condição prévia; uma pré-condição para a acumulação ao mesmo tempo em que se mantém como condição, mas, para efeito do que aparece como solução para a "Geografia em crise" ("uma preocupação clássica da Geografia" $)^{98}$, a dimensão do valor do espaço deve admitir a parcela por onde se destaca as condições especificamente naturais, onde a finalidade do trabalho não intervém, mas que não deixam de ser um "limite historicamente relativizado", por isso equivalente à "primeira e segunda natureza",99.

A outra parcela do valor do espaço corresponde à acumulação material provinda do trabalho, resultado histórico do trabalho acumulado que estrutura instrumentalmente o espaço por meio de sua fisicalidade no solo, ou como "produções materiais que se agregam ao solo"100, e que servem à continuidade do processo na sua "inércia dinâmica" (como assim se referem os autores aos termos de Milton Santos). Todavia, para além de resultado do processo de produção do espaço, deve admitir também um processo interno na medida em que é fruto da sociedade e do tempo próprio de sua produção. A “inércia dinâmica” também é contabilizada como valor porque engendraria processos mais ou menos intensos de valorização. Como exemplo, destacam os autores a questão da renda do solo, agrário ou urbano, como um valor que se "cobra" não apenas pelo uso, mas pelo trabalho pretérito que historicamente está nele acumulado. É por isso e também um valor concreto, do lugar, que se apresenta para a produção: "A terra aqui é uma realidade natural e material que se define como receptáculo do trabalho humano historicamente acumulado" $"$.

Já o valor no espaço se define para além da materialidade em que o espaço concreto permite a acumulação de trabalho; por conseguinte, sua metamorfose em valor de troca é a abstração fundamental da existência concreta, por isso um atributo do ser, não um ser; por isso também não admite uma dimensão ontológica. É um atributo da existência. Contêm nele suas relações sociais, e por onde elas se tornam possíveis. É a própria espacialidade, uma

\footnotetext{
${ }^{97}$ Ibid., p. 124.

${ }^{98}$ COSTA; MORAES, 1984, p. 124.

${ }^{99}$ Ibid., p. 125.

${ }^{100}$ Id., Ibid.

${ }^{101}$ Ibid., 127
} 
"abstração": "A espacialidade, então, não pertence à esfera deste ou daquele lugar concreto, mas é uma característica imanente de qualquer processo, seja ele social ou natural”. Até onde o valor no espaço se refere a um "dado apriorístico" os autores não revelam, mas avançam na demonstração de sua validade a partir da circulação: “Aqui, não é a 'terra' ou espaço 'concreto' agregando-se ao valor final ou interferindo na produção, mas uma virtude da circulação e uma 'imanência' do espaço real (a distância) participando de um processo social específico" ${ }^{102}$. Algo que precede o capital, o capitalismo, e o próprio modo de produção, mas aos modos de produção permitem sua substanciação: "O valor no espaço é a própria espacialidade contida nos modos de produção"103.

A dialética entre valor no espaço e valor do espaço presume-se a própria dialética entre produção (inércia dinâmica) e circulação (atributos absolutos), tal como deve presumir suas contradições. Mas apenas se "presume", dado que, segundo os geógrafos, o espaço em valorização se porta como objeto especial, diferente de outros objetos. É produto do trabalho, é "condição da existência humana", mas é também, sobretudo, "um absoluto no próprio sentido da física, que dois corpos não ocupam o mesmo lugar"104.

O valor no espaço sempre está "disposto" às formas de concreticidade do valor do espaço; como "atributo". No máximo desafia a superação de si próprio, mas a ele não se contradiz: "não diretamente contabilizado como tal, [o valor no espaço] aparecerá para qualquer processo de trabalho como custo geral da produção, expresso em quantidade de trabalho e capital"105. A "unidade contraditória" que é anunciada como o motor da dialética da valorização do espaço apresenta-se mais como "articulação" do que propriamente como contradição: "Por determinar a produtividade do trabalho, o valor do espaço articula-se com o valor no espaço"106. No entanto, a exemplo da forma específica do capitalismo, se o valor no espaço se dá perante suas dimensões de "distância e magnitude", por onde a estruturação territorial do capital produz o valor do espaço, sempre na busca de sua superação, deve-se admitir que entre eles estabelece um processo contraditório no momento em que o próprio sentido da distância e magnitude se relativizam a ponto de tornarem opostos. Por exemplo, na seguinte passagem: "em especial na industrialização avançada, o aumento da escala é também uma ampliação do espaço diretamente afeto à produção e à circulação" ${ }^{\text {"107 }}$, a contradição está no fato de que o aumento da

\footnotetext{
102 COSTA; MORAES, 1984, P., 129.

103 Ibid., p. 130.

104 Ibid., p. 132.

105 Ibid., p. 135.

106 Id., Ibid.

107 Ibid., p. 130.
} 
escala da produção não é somente a "ampliação do espaço", mas também e relativamente sua compressão, como demonstrado posteriormente por Harvey (1993) ${ }^{108}$.

Se, como entendido na revisão da economia política, o valor (abstrato) só pode se estabelecer perante sua relação com outros valores (concretos), sua determinação é sempre relativa, e socialmente relativa; logo, o absoluto do valor no espaço sendo a síntese contraditória da relatividade concreta: "é necessário que o valor, em contraste com os coloridos corpos do mundo das mercadorias, evolua para essa forma reificada sem sentido próprio, mas também simplesmente social" (MARX; 1983; p. 91-92). É, por isso, seu inverso negativo, não de forma imanente, mas na mediação da própria concreção (se assim quiser ser preservada a condição histórica da dialética marxiana).

Como dito, o "valor no espaço diz respeito ao próprio espaço no processo de circulação" (COSTA; MORAES, 1984, p. 131). Logo, em determinação de relatividade com outros espaços (concretos), as condições concretas de determinação dos espaços são provindas da circulação (abstração), isso é correto. No entanto, a determinação mesma do valor no espaço, como todo valor, deve admitir em sua "externalidade", que seria o valor do espaço, a função de sua denominação contraditória de determinante, como diria Marx: “A denominação de uma coisa é totalmente extrínseca à sua natureza" (1983; p. 91). Mas também, e em decorrência, a mudança quantitativa de volume e intensidade de trabalho acumulado nos espaços concretos, ou dos valores dos espaços, devem levar a requalificação de sua natureza abstrata, como ainda dirá Marx: “Aqui, como nas ciências naturais, comprova-se com exatidão a lei descoberta por Hegel, em sua Lógica, de que modificações meramente quantitativas em certo ponto se transformam em diferenças qualitativas" ${ }^{109}$. O aporte concedido pelo valor do espaço em sua estruturação empírica banal não está apenas oferecendo condições de existência e percepção do valor no espaço, mas indo tendencialmente ao seu encontro negativo, como contrários; tal como valor de uso e valor de troca se contradizem em sua unidade dialética demonstrada pela teoria do valor.

Seguem, no entanto, Costa e Moraes a natureza de sua dialética entre o valor do espaço e valor no espaço no processo de valorização elencado à condição "especial” do espaço para deslocar dele sua relação com o trabalho, tal como suas contradições de valor, no interior do próprio desenvolvimento da mediação espaço-trabalho em sua teoria. Sendo o espaço um objeto especial de valorização (condição geral da existência humana, dotado de qualidades intrínsecas, atributos ou virtualidades, dotado de finitude, logo relativamente raro e de reprodução extensiva

\footnotetext{
${ }^{108}$ O livro de Harvey aparece em 1989, no final da mesma década de A Valorização (HARVEY, 1993). ${ }^{109}$ MARX, 1983, p. 243.
} 
limitada, detém a singularidade, além de ser depositário da história), essa se daria de forma diferente da valorização do capital. Apesar dos apelos de advertência de que "não se deve, contudo, inferir daí que a qualificação desse processo advenha das inerências do espaço" ${ }^{110}$, sua "qualificação" social não está clara a partir, por exemplo, de afirmações como que o consumo do espaço "não implica sua destruição [...]. O que ocorre é o consumo destrutivos de certos atributos desse espaço" $" 111$.

Com relação à teoria do valor, Marx havia observado que todo consumo é produtivo e, de fato, não há "destruição"112. Isso significa que, primeiro, a "indestrutibilidade" do espaço em valorização não é um atributo "especial” seu, mas do próprio consumo. Segundo, se o que se destrói são "certos atributos do espaço", deve-se admitir que, novamente, a intensidade e a magnitude quantitativa do processo destrutivo de seus "atributos" podem mover mudanças qualitativas da própria natureza da produção do espaço, esse que se põe uma vez como “indestrutível”. É claro que o espaço, na qualidade de atributo e abstração, condição da existência humana, tal como "trabalho", não se "destrói”, se apenas for considerado como categoria absoluta. Mas em processo de valorização, logo histórica e social, o próprio significado de sua absolutização se relativiza por meio de suas contradições internas, como o processo de trabalho se contradiz consigo mesmo na forma de processo de valorização. Não por outros motivos, Milton Santos, em "A Natureza do Espaço", momento posterior ao de Costa e Moraes, havia percebido a necessidade de requalificar a valorização do espaço, especialmente diante das possibilidades e riscos de sua absolutização. Ao falar sobre a eficácia mercantil atribuída aos lugares, pondera: "Essa eficácia mercantil não é um dado absoluto, mas se refere a um determinado produto e não a um produto qualquer. Seria uma outra forma de considerar a valorização do espaço, já assinalado por A. C. Moraes \& W. Costa (1984)” (SANTOS, 2008; p. 248$)^{113}$.

Nesse sentido, como categoria histórica, a condição "destrutiva" do trabalho, tal como do espaço, nada mais representa do que um processo contraditório interno em movimento, porque assume a natureza do capital, seu corolário negativo. Em Marx, mesmo observando suas advertências sobre a necessidade de se pensar a condição produtiva do consumo, em outro momento advertirá, diante da dinâmica tendencial do próprio valor-capital, que "as forças

\footnotetext{
${ }^{110}$ COSTA; MORAES, 1984, p. 133.

111 Ibid., p. 133.

112 “O trabalho gasta seus elementos materiais, seu objeto e seu meio, os devora e é, portanto, processo de consumo. Esse consumo produtivo distingue-se do consumo individual por consumir, o último, os produtos como meios de subsistência do indivíduo vivo, o primeiro, porém, como meios de subsistência do trabalho, da força de trabalho ativa do indivíduo" (MARX, 1983; p.153).

${ }^{113}$ SANTOS, A Natureza do Espaço, 2008.
} 
produtivas disponíveis já não mais favorecem o desenvolvimento das relações burguesas de propriedade; ao contrário, tornam-se poderosas demais para essas relações, que passam a entravá-las; e quando superam esses entraves, trazem desordem para a sociedade" (MARX, 1987; p. 60). ${ }^{114}$

As condições de ativação da etapa lógica do desenvolvimento das forças produtivas a que Marx se refere só assim foram percebidas porque em sua dialética a contradição das próprias categorias que se estabelecem na valorização tendem à radicalidade insolúvel. Cada vez mais intensas e estruturais essas contradições, conforme se acumulam no tempo e no espaço, se desenvolvem até a inversão qualitativa da natureza "produtiva" para "destrutiva" dos meios de produção. Ou seja, um sistema dialético demonstrando que, na sua própria valorização, se tem um processo de “desvalorização estrutural” do próprio valor. Uma contradição lógica estrutural, irremediável, e que se expressa no fenômeno da crise, conforme as tendências e as contratendências da desvalorização se interagem historicamente. $\mathrm{O}$ fato de os geógrafos da valorização, tal como Milton Santos, não oferecerem as condições para uma teorização das crises, não apenas evidencia, por conseguinte, os limitados objetivos afirmativos/instrumentais para com a proposição teórica, mas também, e em consequência, evidencia os limites da natureza de uma dialética estruturalmente sem contradições efetivas/negativas, como será analisado mais adiante.

Por hora, basta apenas demonstrar como o trabalho, diante da "dialética da valorização", se expressa como categoria espacial. Segundo Costa e Moraes, a valorização do espaço admite um movimento interno que se expressa na especificidade da "perenização" e da "transitoriedade do valor". Elas estariam dialeticamente relacionadas conforme a "concepção de trabalho dos autores"115. Para os geógrafos, o processo de valorização pode estar fundamentado em atividades extrativas de elementos naturais, da parcela do valor do espaço significada pela riqueza natural. Essas atividades, e a mineração é o maior exemplo, podem estruturar um aparato produtivo que se complexifica ou não. Uma atividade transitória, mesmo considerando uma eventual longa duração de tempo em que esteja em funcionamento, se caracteriza quando a produção não "espelha" seus interesses no espaço, mas tão somente no(s) elemento(s) a serem extraídos. Por outro lado, ela pode se perenizar, conforme consiga ela "extravasar a simples necessidade imediata da produção" ${ }^{116}$, complexificando as relações e tornando constante o processo de acúmulo de trabalho no espaço.

\footnotetext{
${ }^{114}$ MARX, Karl, Cartas Filosóficas e o Manifesto Comunista de 1948, São Paulo, Editora Moraes, 1987. ${ }_{115}$ COSTA; MORAES, 1984, p. 142.

116 Ibid., p. 143.
} 
Para os autores, essas duas formas demonstram como a valorização nem sempre corresponde positivamente. A faceta negativa seria determinada pelo "nítido processo de drenagem de recursos e de mercadorias, bens que servirão à acumulação alhures e que, dessa forma, incorporar-se-ão a outros espaços" ${ }^{" 117}$. Aqui, novamente, o caráter de externalidade insuperado da visão geográfica. A “drenagem”, que se dá na esfera da circulação das mercadorias (não propriamente do valor, embora eles possam coincidir), para outros espaços configuram-se assim, "como se vê, dadas certas condições, [...] possíveis formas predatórias de valorização. A dilapidação do patrimônio natural sem a correspondente incorporação de trabalho (valor) ao espaço, ilustra bem esse processo"118. Por conseguinte, a positividade estaria na incorporação de trabalho, valor, ao espaço. Nessas condições, se revelam a natureza da “concepção de trabalho": não apenas ele aparece "positivado" como o contraponto das "formas predatórias" da apropriação da natureza, mas ainda desprovido de seu caráter processual e potencialmente autocontraditório e autocrítico para uma teoria que se pretende crítica e marxista. Afinal, o trabalho cristalizado e "espelhado" no espaço em si, da forma como observado positivamente, não indica se advém de uma relação escravocrata ou do "sangue de crianças pequenas" $" 119$.

Aqui não é tomado o ponto de vista do trabalho dotado criticamente.

Se, como observado, a perenização "refere-se a uma escala ampliada de valor do espaço" e a transitoriedade "ao consumo destrutivo do valor", em ambos os casos a concepção de trabalho remonta a sua forma cristalizada da economia política clássica. Ela não avança na dialética marxiana porque - como na relação entre valor no espaço e valor do espaço, e agora entre perenidade e transitoriedade - o trabalho está situado em um sistema fechado de interpretação autoreferenciado no espaço, onde não se permite abrir para a contradição que possibilitaria ir no movimento em si de sua valorização mediada pelo trabalho, como intentado.

Isso remete a um problema de ordem prática da teoria, qual seja: a incapacidade de enxergar na valorização sua própria e mais fecunda contradição, a desvalorização. Como identificado pelos próprios autores, diferente dos economistas políticos, a teoria de Marx havia objetivado a mais-valia como categoria própria da análise no sentido de observar seu movimento em si como princípio de todo movimento da acumulação. No interior deste

\footnotetext{
117 COSTA; MORAES, 1984, p. 143.

118 Ibid., p. 143-144.

${ }^{119}$ Como assim se refere Marx à denúncia de parcela de industriais e seus pretextos contrários às leis trabalhistas de 1844: "O pretexto revelou-se, numa investigação posterior, como pura mentira, o que entretanto não os impediu de, com o sangue de crianças pequenas, que para a execução de seu trabalho precisavam ser colocadas em cima de cadeiras, fiarem seda 10 horas diariamente. (MARX, 1983; p. 232)
} 
movimento estabelece Marx a tendência geral da acumulação capitalista, qual seja: o desenvolvimento das relações de produção e das forças produtivas sempre no sentido de crescimento relativo do valor do capital constante em detrimento do valor do capital variável. A consequência contraditória desse processo é a diminuição relativa do próprio trabalho vivo, que é comandado pelo capital variável, em relação ao trabalho morto, este comandado pelo capital constante. Como o trabalho é a fonte da mais-valia, ocorre que sempre no aumento da massa de valor da riqueza produzida deve conter uma diminuição relativa de valor adicionado a ela. Ou seja, no avanço em direção a sua própria valorização, dado o aumento da produtividade condicionada pela concorrência capitalista, ocorre, de forma imediata, sua própria desvalorização relativa: um volume de valor de uso crescente em relação ao valor geral. Temse uma superacumulação. Essa contradição se desenvolve até o limite das crises que, por sua natureza histórica específica, são sempre crises de superprodução.

Costa e Moraes, no que concerne à valorização capitalista do espaço, partem da leitura histórica do capitalismo para entender sua dinâmica. Destaca-se, em tal leitura, não apenas a linearidade com que a história do capital é apresentada como a superação das barreiras territoriais e de suas próprias contradições econômicas que explodem no século XX (duas guerras mundiais e a crise de 1929), mas sobretudo o papel da técnica nesse processo que culmina no "desenvolvimento do trabalho e o agigantamento das empresas [como] resultado e condição da pesquisa aplicada em meios de produção" ${ }^{120}$. Essas seriam as pré-condições para a "subversão do "velho capitalismo""121.

O método da leitura histórica, concatenada com o método próprio de interpretação universal do valor "no" e "do" espaço, ao apresentar os elementos de positividade que desloca as contradições do capitalismo para sua condição não-estrutural, permite, então, chegar a uma fase nova do capitalismo. Essa fase seria marcada por uma complexificação da estrutura produtiva que corresponde a mudanças na estrutura de classes: "basta observar a pequena proporção do proletariado (industrial e agrícola) no conjunto dos assalariados de uma sociedade socialista avançada" "122. Isso se daria pelo desenvolvimento dos meios de produção que, diante do avanço da "revolução técno-científica", tende a promover um intenso processo de desvalorização pela redução do trabalho vivo na produção, como observado por Marx. A saída apresentada seria exatamente sua expansão territorial em busca de novos "proletários", o que expressa a relevância do valor no espaço. Este se expressaria de forma "contraditória”, pois “o

\footnotetext{
${ }^{120}$ COSTA; MORAES, 1984, p. 154.

${ }^{121}$ Id., Ibid.

122 Ibid., p. 156.
} 
capital contemporâneo necessita revalorizar-se, ampliando a quantidade de trabalho vivo que apropria, mas desastrosamente necessita ao mesmo tempo aumentar a produtividade à custa do capital constante (trabalho morto)". ${ }^{123}$ A radicalidade dessa contradição, assumem os geógrafos, "num certo sentido" acaba por subverter as próprias bases explicativas da origem da mais-valia e no significado do valor para a sociabilidade capitalista "contemporânea": ("quando impõe aos marxistas a necessidade de considerar tanto a origem da mais-valia, quanto as novas formas de sociabilidade presentes na socialização capitalista do valor") ${ }^{124}$.

De forma cuidadosa, expõem os autores suas "afinidades eletivas"125 que concedem validade teórica ao debate da "pulverização do valor" como forma de centralizar a dimensão do capital que se "fixa" no espaço: "o crescimento desmensurado do capital constante impossibilita a aferição do quantum de mais valia presente em cada mercadoria"126. Fundamentam, dessa forma, na negativa das mesmas abstrações que permitem entender dimensão interna e contraditória do valor pelo movimento do trabalho na própria descentralização do trabalho. O concreto se empiriciza de forma a validar o próprio critério da análise ("a mais-valia continua sendo a origem do valor? Não há dúvida, porém é cada vez mais difícil sua identificação empírica") ${ }^{127}$, tal como ao trabalho se concede sua dimensão positiva como o processo em si. O espaço, novamente como em Milton Santos, tende a ser concebido como externalidade no influxo da validade do valor como movimento interno do seu processo. A própria economia política se "quebra" em sua dialética ausente, restando, apenas, processos de "sociabilidade", não tanto econômicos, mas cada vez mais "políticos": "perde sua evidência empírica e assume formas intangíveis no circuito global da economia, estando, assim, mais afeito às determinações especificamente políticas" ${ }^{128}$. Uma quebra dialética que permitiu, anos depois, a economia política se converter em política econômica nas mãos dos "novos" economistas da regulação bancária-financeira e da taxação do capital.

\footnotetext{
${ }^{123}$ COSTA; MORAES, 1984, p. 156.

${ }^{124}$ Ibid., p. 157.

${ }^{125}$ Como assim se fundamenta Alexandrina Luz Conceição, em referência ao romance de Goethe, diante das formas de como são estabelecidos os referenciais para a defesa argumentativa das teses, em especial sobre as influências do pensamento que chega ao Brasil na primeira metade do século XIX e interpretado por Tobias Barreto. Chama atenção que tais influências não se estabelecem de forma pura, mas estão elas carregadas de significado ideológico e político. CONCEIÇÂO, Alexandrina Luz, Às margens do Beberibe e do Capibaribe: a crítica de Tobias Barreto nos meandros da geografia (tese de doutorado), São Paulo, Universidade de São Paulo, 2001.

${ }^{126}$ COSTA; MORAES, 1984; p. 158.

${ }^{127}$ Id., Ibid.

${ }^{128}$ Id., Ibid.
} 
1.3 - Valor-Trabalho, contradição e crise: inversões nos limites da solução teórica

A crítica "marxista" de Milton Santos ao capitalismo, tal como a teorização da "valorização" do espaço de Costa e Moraes, não representam "todas" as tentativas de soluções teóricas que se apresentam diante da "crise da geografia". Nem mesmo todas variantes daquelas outras que assim tentaram, de alguma forma, se efetivar tomando o trabalho e o valor como categoria de mediação para sua crítica, mas certamente representam as principais matrizes. Desde a "abertura" da esfera editorial, em especial o Boletim Paulista de Geografia a partir de 1976 - em que já se sinalizava "proposições de modificações também em seu conteúdo" (VIANA, 1976, p. 05) ${ }^{129}$, um importante editorial tido por Armando C. da Silva como fundamental para a retomada “do debate intelectual” $(1984 ; \text { p. } 74)^{130}-$, a perspectiva da crítica do capitalismo já havia se instaurado. Neste número específico dessa importante revista, destacaria Silva em seu igualmente importante texto de avaliação do movimento de renovação (de 1976 a 1983), a publicação da análise do Grupo de Trabalho da Área de Geografia Econômica e Humana da AGB realizada em 1973 sobre um texto de Bernard Kayser: "Le Nouveau Système de Relations Ville-Campagnes". Dentre as temáticas discutidas no referido Grupo de Trabalho, destaca-se a questão do capitalismo e suas formas de expressão no espaço.

Ao tempo, já estava em fase avançada o reconhecimento da autocrítica geográfica, ao menos diante daquelas vinculadas aos referenciais de um passado oscilante entre a ingenuidade da Geografia tradicional e o caráter ideológico da chamada "Nova Geografia". Assim seria até 1980, momento no qual asseverava Roberto Lobato Corrêa: "Se a geografia tradicional pode ser acusada de ter sido ingênua e alienada dos problemas reais que afetam a sociedade, à 'nova geografia' esta acusação é mais cabível, acrescentando-se ainda que além de alienada é alienante" ${ }^{131}$. Era, por isso, também o momento em que a crise da geografia se reconhecia diante do quadro crítico em que a leitura geográfica no Brasil não mais refletia sobre as condições de sua realidade: questão agrária, questão urbana, ditadura militar, etc. Como dissertaria Manuel Corrêa de Andrade em outro importante texto do referido momento, e não gratuitamente intitulado "O pensamento Geográfico e a Realidade Brasileira": "O compromisso com o crescimento econômico não racionalizado, com o chamado progresso,

\footnotetext{
${ }^{129}$ VIANA, Myrna T. Rego, “Editorial”, In: Boletim Paulista de Gerografia, São Paulo, N51, junho de 1976.

${ }^{130}$ SILVA, Armando Corrêa da, “A Renovação Geográfica no Brasil - 1976/1983 (As Geografias Crítica e Radical em Uma Perspectiva Teórica)”, São Paulo, Boletim Paulista de Geografia, nº 60, 1984.

${ }^{131}$ CORRÊA. Roberto Lobato, "Geografia Brasileira: Crise e Renovação”, In: MOREIRA, Ruy (org), Geografia:

Teoria e Crítica - Os Saberes Posto em Questão, Rio de Janeiro, Vozes, 1982.
} 
provocou a formação de escolas, nas várias ciências sociais, que procuravam abstrair as consequências negativas deste crescimento" (1977; p. 13) ${ }^{132}$. Neste quadro crítico duplo e autoidentificado entre o real e o teórico é que se monta, por exemplo, o projeto da busca do espaço enquanto “ser”, em Armando Corrêa da Silva. Este que, desde de 1973, já ensaiava uma ontologia geográfica tendo, não por coincidência, no "valor" seu fundamento argumentativo para tratar a questão da crise e fragmentação da ciência geográfica. O texto em questão é sintomaticamente intitulado "Ciência e Valor em Geografia"133 e representaria o início da “jornada ontológica” de Silva que duraria toda sua vida intelectual (como especificamente será debatido no capítulo “3 - A Solução Ontológica e os Limites para a Centralidade do Espaço”).

Dessa forma, as perspectivas de Milton Santos e a de Costa e Moraes mostradas acima representavam a sintonia mais avançada do quadro auto-identificado da crise geográfica e da crise capitalista porque apresentavam, ainda que de forma não completamente amadurecida, um projeto de efetivação teórica vinculada na perspectiva do valor, mediada pelo trabalho. Essa evidência mostra que tais propostas não eram somente herdeiras dos movimentos contestatórios que agitaram a Europa a partir de 1969, nem dos movimentos étnicos raciais que incendiavam os guetos americanos, mas significava ainda uma perspectiva de originalidade sobredeterminada pelos objetivos de última instância da emancipação humana, como visto. Assim, no que concerne às formas de inserção do trabalho na crítica geográfica, estas apresentadas, aos seus respectivos momentos, seriam as mais importantes. Importantes não apenas porque apontam como que a predisposição crítica que se avolumava desde finais da década de 1960 encontrava por meio delas possibilidades de vazão e fundamento, mas no que elas significariam depois, como possibilidade de desenvolvimento do exercício teórico que se pretendia propriamente geográfico.

Mesmo considerando os caminhos específicos outros tomados posteriormente pelas perspectivas de Santos e a de Costa e Moraes apresentadas e desenvolvidas no contexto da segunda metade da década de 1970 e início da de 1980, do pondo de vista estritamente teórico, são igualmente muito representativas, porque já estavam nelas congregadas aspectos que possibilitavam a garantia de uma desmistificação do espaço como sujeito autônomo (como a crítica de Milton Santos à teoria da localização produtiva), da revelação da natureza da dominação espacial que por ele se expressa (como dominação do capital: Milton Santos), de

\footnotetext{
132 ANDRADE, O pensamento Geográfico e a realidade Brasileira, 1977.

${ }^{133} \mathrm{O}$ texto em questão foi publicado originalmente em Métodos e Questão, $\mathrm{n}^{\circ}$ 4, Instituto de Geografia, São Paulo, como revela Silva em nota de rodapé (1988; p. 87), mas foi reeditado para compor a coletânea O Espaço Fora do Lugar em 1978 (SILVA, Armando Corrêa da, O Espaço Fora do Lugar, São Paulo, Hucitec, 1998).
} 
entender as desigualdades espaciais como sociais (distribuição dos excedentes: Milton Santos), tal como estabelecer uma teoria do valor que permitiria também chegar no nível da produção do espaço (Costa e Moraes) e derivar dela, desde uma ontologia (universalidades), até uma perspectiva de estudo da formação territorial (particularidades).

No entanto, as mesmas condições que possibilitariam tal avanço eram aquelas mesmas que condicionavam seus limites. Como visto, seja diante da "Valorização do espaço", seja da revelação do "domínio do espaço", o processo do trabalho tendeu a se deslocar da centralidade da análise na medida em que era, ao mesmo tempo, inserido em suas explicativas. O que, inclusive, limitava seu foco de análise diante dos contextos cada vez mais críticos que se montariam a partir do momento em que as perspectivas teóricas eram formuladas. $\mathrm{O}$ deslocamento do trabalho de sua centralidade contraditória e crítica significava, dentre outros, um germe teórico estrutural que tendia a deslocar o geógrafo da posição privilegiada de observação e análise efetivamente crítica, conforme a crise do capital começava a apontar suas tendências desde o final da década de 1970.

A forma sutil com que a contradição entre afirmação e negação do trabalho fora estabelecida de um modo geral no movimento de renovação crítica estaria fundamentada no não desenvolvimento criterioso das contradições que envolve a natureza dos movimentos dialéticos admitidos: universalidade $\mathrm{x}$ particularidade; concreto $\mathrm{x}$ abstrato; trabalho concreto $\mathrm{x}$ trabalho abstrato; trabalho vivo x trabalho morto; capital constante x capital variável, etc.. A importância de se entender este movimento de afirmação/negação do trabalho nessas referidas perspectivas teóricas se faz importante porque, de um modo geral, estão nelas estruturalmente estabelecidas as condições de sua efetividade. Essas condições, por onde se expressa a autocontradição do trabalho (em que haveria de ser desenvolvido sua dialética), tenderão a ser, por sua vez, assimiladas na maioria das perspectivas teóricas que se formulariam posteriormente, com suas consequências para a efetividade da crítica pretendida, como tentará ser demonstrado ao longo de todo presente texto.

[Universalidade e efetividade histórica do valor e as inversões do método]

A forma histórica do valor, em que as contradições da valorização se expressam em sua própria desvalorização, encontra no sistema do capital especificidades próprias, se assim for possível falar em valor em "outros modos de produção", como quer Costa e Moraes. Ainda assim, de acordo com o pensamento de Marx, amplamente tomado como referência pelos geógrafos até aqui citados, para quem as formas históricas mais avançadas "permitem 
compreender organizações e as relações de produção de todas as formas de sociedades desaparecidas" (2011; p. 58) ${ }^{134}$, a especificidade da relação valor-capital (no capitalismo moderno) contém em si o desenvolvimento histórico de categorias tidas como "universais", o que tornaria possível a compressão do "valor" em sua "específica" universalidade espacial (universalidade espacial especificamente capitalista). Isso não seria difícil de se reconhecer, dada a própria vinculação admitida entre geografia e economia política moderna, como tentada por Costa e Moraes. Mas também não deixaria de ser problemático, tal como geradora de embaraços não reconhecidos, quando se tenta assimilar à leitura histórica das categorias "modernizadas", como trabalho e valor, a tradição concreticista da Geografia, que vez ou outra acaba recaindo na linearidade da historiografia remota do processo de "fixação" do homem no território, como ponto de partida da valorização do espaço (na história de todos os tempos).

A concepção geral que permite ao valor se inserir nos esforços de efetivação teórica da "valorização do espaço", por exemplo, e a busca dos elementos passíveis da "fixação" no espaço, como "capital dormente", assim se dá por um viés que não é apenas condizente com o "temário geográfico", mas a ele já está sobredeterminado. Não é simplesmente uma "descoberta", mas sobretudo uma tentativa providencial de aplicabilidade, como assim se fortalecem as suspeitas dada a forma com que a discussão metodológica se encontraria previamente estabelecida em relação a discussão sobre o valor. Tal como a economia política criticada por Marx, nada mais providencial do que fundamentar a proposição teórica com uma historiografia que permita a evidenciação eterno-presente do objeto que se queira positivar, ou como advertiria Marx: "Não como um resultado histórico, mas como ponto de partida da história" (2011; p. 40). Tal como também nada mais providencial do que referenciar tal fundamento historiográfico da "fixação do homem" como valorização do espaço a partir da renda da terra, e suas consequências para sistemas agrícolas antigos ("a questão da renda [da terra] também tangencia o temário geográfico. A fertilidade absoluta do solo, por exemplo, e o seu papel na composição do valor é problema constante na exposição dos autores [economistas políticos clássicos e geógrafos clássicos]") ${ }^{135}$.

Por tais referenciais, torna-se incrivelmente cabível a crítica de Marx (2011, p. 59) à forma específica tentada pelos geógrafos: "Nada parece mais natural, por exemplo, do que começar pela renda da terra, pela propriedade da terra, visto que está ligado à terra, fonte de toda riqueza da existência". O que, necessariamente, leva "à primeira forma de produção de

${ }^{134}$ MARX, Karl, Grundrisse: Manuscritos Econômicos de 1857 - 1858, São Paulo, Boitempo; Rio de Janeiro: Ed. UFRJ, 2011.

${ }^{135}$ COSTA; MORAES; 1984, p. 108. 
todas as sociedades mais ou menos estabilizadas - a agricultura". No entanto, advertiria categoricamente Marx: "Mas, nada seria mais falso". Correndo o risco de cometer o mesmo equívoco da aplicabilidade da crítica marxiana direcionada a um outro contexto teórico, se pudesse manter a referência de Marx como forma de demonstração dos limites internos da crítica geográfica, a observação de suas advertências em relação à economia política de sua época tende a recolocar a condição "especial" do espaço de modo inverso, ou seja, na sua própria especificidade histórica, e a isso lhe conceder sua condição de universalidade.

A valorização capitalista do espaço já contempla, em nível de complexidade desigual e mais desenvolvida, as relações entre categorias fundamentais: trabalho, natureza, espaço. É uma questão de método buscar entende-las na sua própria abstratividade histórica (como se deixassem de existir, porque concretizadas na dimensão do tempo, parecem não serem mais universais). E é por isso que ele, o método, deve partir de sua condição histórica dada, da valorização especificamente capitalista, porque é onde as categorias da própria condição histórica objetivada estão mais desenvolvidas. A universalidade pretendida pela Geografia não está na história universal, mas na universalidade histórica desenvolvida no presente. O método, previamente estabelecido, só pode expor o que se pretende como pressuposto de perspectivas limitadas à explicação, não a apreensão. Isso não apenas levanta a questão sobre a forma de como Costa e Moraes - ao definir primeiro o "método marxista" para depois explicar a "valorização capitalista do espaço do espaço" (explicitamente observável na forma da divisão do livro) - possa ter invertido o método, mas sobretudo a forma de como se generaliza tal procedimento no movimento da renovação crítica onde a reflexão sobre o método (sobretudo a dialética) esteve, em última interpretação, confundida com as soluções teóricas.

[A história sem crises e a inversão trabalho x técnica]

Não observando tais condições, que são reflexões sobre a própria dialética, o entendimento histórico tende a se desenvolver com unilateralidade providencial a favor do espaço como centralidade disciplinar. Tal movimento se confirma com a perda da referência do trabalho, este também reduzido a sua providencialidade disciplinar, em detrimento da necessidade de se inserir em seu lugar a técnica. Não por coincidência, a história da valorização capitalista centrada na técnica, como esboçada por Costa e Moraes, não apresenta elementos das contradições estruturais do capital. Isso se observa na ausência das crises capitalistas em sua leitura sobre o século XX, como se o capitalismo tivesse triunfado harmonicamente em sua história, de modo que agora passa a ser contada como a história da superação pela técnica a 
partir do recrudescimento do trabalho, como observado. Do ponto de vista dos objetivos autoafirmativos necessários à Geografia em crise, a técnica é providencial, porque espelha a sucessividade histórica sem crise, enquanto o ponto de vista do trabalho aponta seus limites, fissuras, contradições, colapsos e crises estruturais.

A inversão se confirma na própria forma de supor que a técnica passa a controlar o trabalho. Nesse momento, já está consolidada a concepção do trabalho como "atividade". Mas também a concepção de que o próprio desenvolvimento da técnica se autonomiza, como se ela não fosse fruto de condições históricas da relação capital x trabalho, sobretudo mediado por crises. É desta forma que a leitura sobre a "revolução técnica-cientifica" passa a ser abordada: “seu pressuposto é o domínio das formas monopolistas nas relações capitalistas" (COSTA; MORAES, 1984; p. 154). Não se observa, ainda que não deixasse de ser a revolução técnocientífica uma forma de controle do capital sobre o trabalho, fora ela sobretudo respostas estruturais, igualmente críticas, para a crise estrutural no sistema do capital que se processou a partir do final da década de 1970, como se observará adiante.

[Tendência da "desvalorização" invertida como o próprio fim do valor]

A inversão entre trabalho e técnica só se torna possível porque a dialética que envolve processo de trabalho e processo de valorização se quebra na própria análise geográfica. De um lado, o trabalho se refugia na esfera do "processo de trabalho" (Marx), conservando-se como elemento ontológico, mas resgatado somente quando se necessita da evidenciação gnosiológica da eterna-presença do espaço, este confundido como ontologia. De outro, a técnica se expressa como a própria forma da valorização, que passa a centralizar no processo de valorização em si. Assim, refugiado na remoticidade que se pretende ontológica, o trabalho tende a se esvair do próprio processo de valorização. Uma consequência fundamental diante do refúgio do trabalho para além da valorização: a tendência geral da acumulação de capital, nos termos desenvolvidos por Marx, tende a perder sentido histórico a partir do momento em que a lógica do desenvolvimento do capital orgânico (amplamente citada pelos geógrafos) não significa mais possibilidades de explicação condizente com a realidade.

Marx desenvolve "a lei geral da acumulação capitalista" para demonstrar uma contradição fundamental e limitante do próprio capital: de que o processo de avanço da acumulação do capital por meio de sua valorização detinha em seu próprio movimento um processo de "desvalorização". Embora a lei em si tivesse sido apreendida pelos geógrafos até aqui analisados, o entendimento de seu desenvolvimento lógico tende a escapar diante da 
imposição da demonstração empírica que se pretende necessariamente geográfica. Como explica Marx, a composição do capital orgânico sintetiza uma relação entre a "composição técnica" e a "composição-valor" do capital global: a primeira correspondendo "a massa de meios de produção utilizados de um lado, e, por outro lado, o montante de trabalho exigido para seu emprego"136, a segunda correspondendo "a proporção em que se reparte em capital constante ou valor dos meios de produção e capital variável ou valor da força de trabalho"137.

Embora estejam necessariamente relacionados, composição-valor e composição técnica do capital não são a mesma coisa e refletem processos distintos. As suas formas confundidas, como se faz crer na interpretação dos geógrafos ("esse trabalho morto aparece na composição orgânica do capital como uma parcela do capital constante. Neste sentido, o próprio espaço físico necessário à produção é contabilizado como valor do espaço, valor previamente acumulado" ${ }^{138}$, subverte a lógica central da lei da acumulação desenvolvida por Marx. A tendência geral com que o desenvolvimento do sistema do capital promove o crescimento exponencial dos meios de produção, tal como seus resultados empiricamente observáveis na abundância de mercadorias no mundo, em relação à massa de trabalho observável pela "pequena proporção do proletariado", como identificara Costa e Moraes, reflete apenas a composição técnica em que se divide a proporção entre a materialidade do trabalho vivo e do trabalho morto. No entanto, essa dimensão material, instrumental, do trabalho indica "de modo apenas aproximado"139 sua relação com a composição-valor. Assim, a forma com que o trabalho-vivo se relaciona com a composição técnica não é necessariamente igual à forma como que ele se relaciona com a composição-valor. E mais: em relação ao trabalho, a diferença da proporção técnica que se apresenta na paisagem é sempre maior que a diferença de valor a ela relativa. Ou, nas palavras do próprio Marx: “O crescimento da diferença entre capital constante e capital variável é [...] muito menor do que a diferença entre a massa dos meios de produção em que o capital constante é convertido e a massa da força de trabalho em que se converte o capital variável" ${ }^{\prime 140}$. Ou seja, tendencialmente há sempre mais desenvolvimento da composição técnica (massa empiricizável de técnica e trabalho) do que de seu valor efetivo correspondente (capital constante e capital variável).

Isso significa que a observação empírica dos geógrafos acerca da disposição absoluta do trabalho morto, "fixo" ou "dormente", que tornaria "muito complicado 'medir' a quantidade

\footnotetext{
${ }^{136}$ MARX, 1983; p. 187, v. 1, t. 2.

137 Id., Ibid.

${ }^{138}$ COSTA; MORAES, 1984; p. 126.

${ }^{139}$ MARX, 1983; p. 194.

${ }^{140}$ Ibid., p. 195.
} 
total de valores criados" (COSTA; MORAES; 1984; p. 158), por essa via explicativa, não pode fundamentar com exatidão cientificamente necessária o abandono da teoria do valor em prol da teoria da "pulverização do valor". A forma de como se expressa empiricamente a composição técnica do valor não está exatamente identificada com a forma de expressão da composiçãovalor do capital. Isso porque a externalidade técnica "empiricizável” deve conter a dimensão do fetiche da própria técnica ordenada pelo capital, porque ela é ainda mercadoria; por isso a constante necessidade de confrontá-la com a dimensão de seu valor-trabalho.

A não observação da importância de se manter o confronto dialético entre técnica e valor, como expressões diferenciadas e até contraditórias (mas jamais separáveis) na internalidade do capital, é o que permite a referida aproximação com as teses da "pulverização do valor". Mas tal aproximação revela ao menos uma inversão: que o processo da radical contradição entre a valorização por meio da tendência de elevação da produtividade do trabalho e a desvalorização por meio da redução relativa do trabalho vivo contido na materialidade do mundo não apenas não foi incorporada à leitura geográfica, como confundida e subvertida com o próprio fim do valor e, consequentemente, do trabalho. Ou seja, a observância da contradição valor versus trabalho, ao passo de aprofundar-se em seu desenvolvimento, fora ela mesma negada em prol da universalização unilateral da composição técnica do valor, em prol da própria técnica, como medida empírica providencial para a análise geográfica.

A forma como essas questões jamais chegaria a se estabelecer como um "debate geográfico", dada a aparência de sua solução, ou pela negação em si mesma por se tratar supostamente de tema não-geográfico, não apenas explica, em parte, o porquê do abandono relativo dos próprios autores de "A Valorização" diante de tais questões, mas também evidencia o sentido "internalista" com que o movimento da renovação crítica tenderia a propor suas perspectivas teóricas. A própria questão da valorização do espaço não será retomada de forma contundente, nem por seus autores formuladores, nem por outros geógrafos interessados com a temática. Ela se estabelecerá como questão "dada", de "horizonte teórico genérico", inclusive em trabalhos seguintes de Antônio C. R. Moraes, por exemplo, em Ideologias Geográficas e Geografia Histórica do Brasil. Este último apontando a tendência mais prolongada do autor, a problemática da "colonização".

[Os limites internos estruturais da dialética concilatória]

A negação do valor dentro da própria teoria da valorização, tal como a negação do trabalho dentro do próprio esforço teórico de sua inserção, não apenas reforça as limitações de 
uma perspectiva geográfica que, ao tentar manter sua tradição concreticista por meio de seu "temário", limita suas possibilidades de desenvolvimento analítico, mas também explica por meio de sua própria estruturação teórica como que tendeu a chegar a determinadas conclusões limitadas as condições internas e históricas do objeto negado (o capital); em especial o entendimento da relação entre a produção do espaço e os sujeitos sociais.

Se, por meio das "afinidades eletivas", concluem os geógrafos da Valorização que "o valor, seria, assim, cada vez mais uma relação social", e que desta forma "perde sua evidência empírica" para se tornar cada vez mais "afeito às determinações especificamente políticas", como citado anteriormente, é porque a dimensão da produção, intentada como objetivo imediato para sair do plano das aparências, fora novamente perdida. Para isso, deve se admitir os limites da visão concreticista que se pretende “especificamente geográfica”. Primeiro porque a produção acaba se reduzindo ao seu conceito estritamente econômico; tal qual também se observa a redução do econômico como não-geográfico. Segundo porque a produção econômica da qual se referem os geógrafos, seja a partir da economia política clássica, seja a partir da crítica de Marx, nunca deixaram elas de representarem "relações sociais" e "políticas", por mais mistificadoras que elas se apresentassem em suas interpretações pela economia burguesa. Terceiro porque, tanto a "distribuição" em Milton Santos, como a "circulação" em Costa e Moraes estão envolvidas com a produção apenas por uma dialética enunciativa. O critério empírico e a dialética enunciativa seriam condições estruturais e necessárias para conciliar a “geografia nova” pretendida à dimensão identificada como propriamente geográfica.

Isso indicará porque Milton Santos, no plano da distribuição de capitais e pessoas, irá identificar apenas a distribuição do excedente como o problema a ser resolvido dentro da escala limitada e empírica do Estado-Nação. Mas também ajudará e entender o porquê de Santos não avançar na identificação dos sujeitos da personificação estrutural da contradição capital x trabalho, pois sua dimensão de profundidade (tanto nesse como nos momentos futuros do autor) chegaria apenas na expressão fenomênica dos "marginais", ou dos "pobres".

Por outros meios, é como também chegam Costa e Moraes, que não haveriam de entender a composição das classes como categoria de análise, além de concreta, também lógica, tão estrutural como a relação capital x trabalho no capitalismo. E por isso tomar unilateralmente a empiria da "pequena porção do proletariado" para confundir o próprio proletário com o operário $^{141}$. Contudo, para efeitos autocríticos, é também importante por meio desse viés buscar

\footnotetext{
${ }^{141}$ A questão do "sujeito" aparecerá em momento seguinte no livro de Antônio Carlos Robert Moraes, Ideologias
} Geográficas. Mas aqui apresentam-se reforçadas a referência empírica, desde a questão da "fixação" do valor ao 
o entendimento do porquê os geógrafos de "A Valorização", ao tentarem sair da externalidade do plano da distribuição miltoniana, chegaram apenas no plano expressão fenomênica e empírica do consumo e da circulação, quebrando assim sua dialética com a produção. Soltas e passíveis a autodeterminação, acabam elas se confundindo. Da circulação, observara Costa e Moraes, por exemplo, não mais dimensão da valorização (processo de metamorfose da formavalor), mas apenas a dimensão da circularidade da massa técnica, ou da "fixação do valor ao solo", sendo "consumida" no lugar: "A circularidade dos investimentos capitalistas centrada na reprodução do capital determina um processo ininterrupto de fixação do valor ao solo, não mais aquele tipo 'extensivo' no passado, mas aquele associado a uma aglomeração intensiva no lugar" (COSTA; MORAES; 1984; p. 171).

Tal qual Milton Santos, a perspectiva da valorização do espaço não conseguiria romper efetivamente com a "resistência de toda ordem" 142 da tradição concretista da Geografia, apesar de suas observações contrárias, e chegar, de fato, "no movimento interno da produção do valor do espaço"143. Isso pode ser constatado nas "contradições" elencadas a que chegam seus autores como parte conclusiva dessa importante contribuição recente para o pensamento geográfico: contradição, em última instância, decorrente da concentração e centralização do capital. Problema genérico do qual restaria a análise geográfica ir no sentido de suas especificidades ainda mais empíricas da formação territorial ou da formação socioespacial, como efetivamente fora realizado por Moraes.

solo, como também a relatividade do sujeito perante as representações espaciais e "culturais". Confirma e se reforça a perda da centralidade do trabalho, também na sua dimensão de classe.

${ }^{142}$ COSTA; MORAES, 1984; p. 70.

143 Ibid., p. 125. 


\section{CAPÍtULO 2 - A NECESSIDADE EPISTEMOLÓGICA: CRÍTICA DA CRISE À CRISE DA GEOGRAFIA}

Sobre o suposto "triunfo" com que o sistema do capital teria atravessado o século XX, observa István Mészáros em um livro sintomaticamente intitulado "Século XXI: Socialismo ou Barbárie": "se no século XXI ocorrer realmente o triunfalismo do 'século americano' do capital, não haverá no futuro outros séculos para a humanidade, muito menos um milênio (2003, p. 16) ${ }^{1}$. Lembra Mészáros que, para além do triunfalismo com que o capital superou as "barreiras territoriais" e economicamente "autocontraditórias", seja pela política, seja pela técnica, não pode ser ela contada sem o saldo desastroso de duas guerras mundiais, duas crises profundas (1929; 1971-1973). Também não pode ser contada sem apontar as revoluções contestatórias que, por mais integralizáveis que fossem a longo prazo, não podem ser desconsideradas como contraponto da lógica hegemônica capitalista, como aquelas que ocorreram da Rússia, China, Vietnã a Cuba. Esse "passado", agora contado de forma derrotista como evidência do triunfo histórico e técnico do capitalismo, representa mais do que história em si, mas as próprias manifestações destrutivas - e potencialmente destrutivas do ponto de vista da humanidade - das contradições mais íntimas e latentes do sistema de produção universal, não apenas do capitalismo, mas do capital em si.

As observações de Mészáros, diferente das dos geógrafos, se estabelecem por meio de uma avaliação do que foi a história do capitalismo no século XX por meio de suas contradições mais fundamentais. No plano em que chegam os geógrafos, qual seja, o plano das mediações a partir do Estado (ou como limite escala material da análise miltoniana, ou como da formação territorial de Costa e Moraes, enfoques esses jamais abandonados pelos respectivos autores), corresponde o ponto de partida de Mészáros por onde se observaria suas contradições internas: por um lado, a tendência material da "integração global" se chocando destrutivamente com os interesses antagônicos da "multiplicidade Estados" e seus respectivos interesses imperialistas, até o ponto do imperialismo americano; por outro, a evidenciação definitiva da incapacidade de constituição de um "Estado do sistema do capital como tal” pelas próprias contradições perante os interesses do mesmo capital: "Essa continua sendo a mais grave das complicações, apesar de toda a conversa sobre a 'globalização","2 .

\footnotetext{
${ }^{1}$ MÉSZÁROS, István, Século XXI: socialismo ou barbárie? São Paulo, Boitempo, 2003.

${ }^{2}$ Ibid., p. 12.
} 
O ponto necessariamente de chegada da análise histórica de Mészáros e, consequentemente, o ponto de partida para sua análise teórica, seria a do "movimento interno da produção do valor", do qual partiram os geógrafos anos antes para nunca mais retornarem. Pois, como destaca o próprio Mészáros, continua sendo fundamental "enfrentar a necessidade sistêmica do capital subjugar globalmente o trabalho"3, se os objetivos de última instância permanecerem, de fato, a emancipação humana, como amplamente divulgado no movimento da renovação da geografia brasileira entre os anos 1960-80.

A contraposição de Mészáros em relação ao que tendeu a crítica geográfica não é banal. A diferença entre tais perspectivas aponta caminhos inversos. E nessa diferença podem estar contidas condições teóricas e metodológicas que expliquem o porquê do filósofo partir de uma realidade crítica do capitalismo, estabelecendo a mais fundamental crítica estrutural do capital pela crítica do trabalho e encontrando na reafirmação dos objetivos socialistas e emancipatórios a solução estrutural para as contradições observadas, ao passo que os geógrafos partem, igualmente, de uma observação sob condições de crise capitalista, anunciam seus propósitos revolucionários e socialistas pela adoção da "metodologia marxista" (COSTA; MORAES, 1984; p. 35) e chegam, com o risco das generalizações, a proposições que apenas pretendem um posicionamento mais central na "orientação" dos processos da "modernização": Ou, "uma geografia que oriente a instalação da modernidade que queremos para o país" (MORAES; 2011; p. 143$)^{4}$.

Um primeiro ponto a ser destacado é que, como visto, a leitura sobre as crises capitalistas como motivação, ou "impulso", para o desenvolvimento técnico, não como expressões das contradições estruturais do capital, já colocaria em disputa a teoria do valortrabalho, que necessariamente caminharia para uma crítica negativa, ao menos em relação a suas contradições, e a perspectiva de posicionar, ou positivar, a técnica, ou espaço, com centralidade para a epistemologia que se pretendia "nova". Se não é de todo correto afirmar antecipadamente, tal disputa não seria de todo injustificado. Pois, de fato, a teoria do valortrabalho começa a ser questionada no mesmo momento, e pelos mesmos autores, que se pretende a sua inserção nas perspectivas teóricas emergentes. Isso ocorre não apenas em Costa e Moraes, como observado, mas também em Armando C. da Silva: "Não acredito que maisvalia seja atualmente apenas uma referência teórica. Mas sua consideração econômica

\footnotetext{
${ }^{3}$ MÉSZÁROS, 2003, p. 13.

${ }^{4}$ MORAES, Antônio Carlos Robert, Geografia Histórica do Brasil: capitalismo, território e periferia, São Paulo, Annablume, 2011.
} 
(principalmente a de anglo funcionalista) não se tornou mais suficiente para explicar toda complexidade existente [...]" (1993; p. 07) ${ }^{5}$.

Segundo ponto a ser destacado sobre a inversão do sentido teórico-crítico, que é também decorrente do primeiro, é aquele referente aos motivos que fizeram os geógrafos abandonarem as questões e a problemática da crise social e se voltarem para a crise da Geografia. A incapacidade decorrente de reconhecer a natureza socioeconômica das crises, sequer como possibilidade de análise, quiçá como contradição capital x trabalho, tendeu a levar o exercício teórico a uma internalização das proposições para dentro dos próprios limites disciplinares da Geografia, como necessidade autossustentada. Tal movimento pode ser evidenciado no não relacionamento efetivo da crise social (que se apresentaria apenas de forma enunciativa) nas observações, como citado acima, em "Geografia Brasileira: Crise e Renovação" e "O pensamento Geográfico e a realidade Brasileira", de Corrêa e de Andrade, respectivamente.

Constata-se, assim, que a crise que se apresentava desde a década de 1960-70, tal como o caráter denunciativo de sua crítica, fora internalizada até o ponto de ser confundida com a própria crise da geografia, ou a "crise de fragmentação" que seria o fundamento justificador da primeira à última proposta ontológica e unificadora de Armando Corrêa da Silva ${ }^{6}$, como foi igualmente a preocupação de Milton Santos ao perceber que, até nos idos do contexto de " $A$ Natureza do Espaço", de 1996, haveria "tantas geografias quanto geógrafos” (2008, p. 18).

É nesse sentido que, ao se referir ao projeto de crítica da Geografia, justificaria Ruy Moreira a necessidade da epistemologia: “A longa síntese da formação e desenvolvimento do pensamento geográfico pareceu-nos necessária ao que se pode chamar de 'a crítica epistemológica'. Isto é, um mergulho em seus fundamentos e na sua estrutura” (1994; p. 55) ${ }^{7}$.

O "mergulho" do qual se refere Moreira está relacionado à análise sobre a história do pensamento Geográfico, necessária para o projeto de constituição de uma Geografia crítica. Tratava-se, pois, da demarcação de três posicionamentos: (1) da autocrítica, ou da prestação de contras com o caráter descritivo e empiricista do regionalismo e com caráter ideológico do tecnicismo; (2) da necessidade de teorização crítica a partir de uma "estrutura" epistemológica propriamente geográfica, como assim também reconhecia, ao seu tempo, Costa e Moraes: “O

\footnotetext{
${ }^{5}$ SILVA, Armando Corrêa da, “A Geografia e a Teoria do Valor”, In: Informa AGB, São Paulo, n. 48, junho der 1993.

${ }^{6}$ Afirmativa em referência ao debate no plano ontológico pretendido em O Espaço fora do Lugar, de 1978, De quem é o pedaço, de 1986, e Geografia e Lugar Social, de 1991.

${ }^{7}$ MOREIRA, Ruy, O Que é Geografia, São Paulo, Brasiliense, 1994b. Tal obra, lançada em 1980, sucede o lançamento de Por uma Geografia Nova, de Milton Santos, e O Espaço Fora do Lugar, de Armando Corrêa da Silva (ambos de 1978), e precede dentre outros importantes textos de autocrítica e síntese da crítica geográfica: Geografia: Pequena História Crítica (de 1981), de Antônio C. R. Moraes, e Geografia Crítica: A Valorização do Espaço, de Antônio C. R. Moraes e Wanderley M. da Costa (1984).
} 
perigo atual é ter a crítica de um saber em ultrapassagem - uma autofagia da crise. Urge pesquisar novos caminhos, com audácia e seriedade teórica. [...] Enfim, cabe ao presente construir uma nova Geografia" (1984; p. 20). (3) No entanto, a Geografia nova significava também, e necessariamente, formas de conceber criticamente a sociedade, ou "formas de introduzir a contradição" 8 como instrumento da análise para a crítica social pretendida em seu movimento de inserção na Geografia. Era, por isso, nesse primeiro momento, um movimento que se fundamentaria no tripé entre a autocritica geográfica, a sutura de uma epistemologia nova e uma crítica social.

"A crítica epistemológica", ressaltada por Moreira, corresponde exatamente ao momento da autocrítica em direção ao "salto" da qual o movimento de renovação da Geografia no Brasil sintetizou a proposta da "Geografia Nova”, ou da chamada "Geografia Crítica" (agora com letras garrafais, como assim se exigia diferenciar em referência as vinculações institucionais que se seguia). Igualmente, a proposição de Costa e Moraes, que definiria o movimento como "unidade ética" (1996; p. 113) - e para quem o movimento deveria encontrar não apenas uma Geografia crítica, mas a "Geografia marxista" -, a necessidade de resolver o problema da "crise da geografia" passava pela necessidade de "circunscrevê-lo prioritariamente ao debate teórico-metodológico; a via pela qual a política se relaciona com a ciência" $"$. A unidade entre a autocrítica e a epistemologia nova parecia óbvia, pela dialética necessária que envolve o trabalho acadêmico-científico, mas ela (a unidade) não somente era o reflexo da necessidade advinda de uma crítica social como também parecia se estabelecer como instrumento de superação da própria crise que ameaçava - por "autofagia", como destaca Costa e Moraes - o próprio movimento crítico da renovação geográfica.

Por isso, a inserção da "contradição", da qual o trabalho exerceu mediação fundamental para o entendimento do "domínio espacial" ou da "valorização do espaço", dizia respeito não somente às perspectivas de uma nova sociedade, mas passou cada vez mais a significar garantias da Geografia Nova. Do ponto de vista do movimento crítico, pode-se sintetizar o movimento de renovação em duas frentes de luta: a autocrítica, ou uma "militância epistemológica", e as possibilidades afirmativas de uma crítica social, ou uma militância política; ou seja, esta como uma crítica social (de cunho político) e aquela como uma crítica geográfica (de cunho epistemológico). A afirmação de um novo sistema conceitual

\footnotetext{
${ }^{8}$ MOREIRA, 1984, p. 51.

${ }^{9}$ COSTA, W. M. da; MORAES, A. C. R, “A Geografia e o Processo de Valorização do Espaço”, In: Novos Rumos da Geografia Brasileira, São Paulo, UCITEC, 1996.

${ }^{10}$ Ibid., p. 115.
} 
eminentemente geográfico (sistema epistemológico) seria, nesse sentido, a mediação entre autocrítica ("interna") e a perspectiva de transformação social ("externa").

A unidade entre ambas - a "crítica interna" e a "crítica externa" - deveria pressupor a constituição de uma totalidade teórica que possibilitasse um exercício teórico fundamentado na mediação dialética entre as categorias e conceitos, no sentido de mantê-las unidas num processo autoprodutivo, complementativo e conciliatório. Isso deveria permitir o desvelamento das contradições sociais, como aquelas que as crises revelam. Mas a necessidade de sua busca pela “província do saber” geográfico, como dirá Milton Santos $\left(2008\right.$, p. 114) ${ }^{11}$, passou a ser um limite não reconhecido, nem posto em foco autocrítico. Isso logo se tornaria propriamente uma contradição, que também não seria reconhecida.

A “internalização", na forma de estruturação epistêmica, passou a ser justificada pelo reconhecimento de necessidades cada vez mais autojustificadas e autossutentadas, sobretudo a partir da positivação do objeto; ou pela carência na discussão em torno do objeto da geografia, como dirá o mesmo Milton Santos desde "Por Uma Geografia Nova": "o esforço de conceituação era feito, sobretudo, de fora do objeto da ciência e não de dentro" (2002; p. 19) ${ }^{12}$. Apesar dos anúncios afirmativos sobre a necessidade da manutenção da práxis diante da tarefa epistemológica ("esta tarefa pressupõe o encontro de conceitos, tirados da realidade, fertilizados reciprocamente por sua associação obrigatória") ${ }^{13}$, a "internalização", que deveria ter na "externalidade" da "realidade global" (SANTOS, 2008; p. 14) seus preceitos de última instância, continha nela mesma a inversão não admitida entre uma crítica necessária da crise e a necessidade de uma epistemologia crítica. Uma contradição em si nos termos não admitida, nem assimilada como parte essencial da crítica necessária, desde os alardes mais inspiradores do projeto unitário de Lacoste ${ }^{14}$ até as formulações mais maduras de Milton Santos sobre a Técnica e o Tempo, em "Natureza do Espaço": "A partir de tais premissas, este livro deseja ser uma contribuição geográfica à produção de uma teoria social crítica" (SANTOS, 2008; p. 23).

A história do movimento de renovação é, como se aponta acima, lida como a disputa por uma "Geografia Nova", por uma "sociedade nova", ou, nas inspiradoras palavras de Armando Corrêa da Silva, "é preciso tentar a aventura de conquistar o espaço novo" (1996; p.

\footnotetext{
11 “Cabe, sem dúvida, ao geógrafo propor uma visão totalizante do mundo, mas é indispensável que o faça a partir de sua própria província do saber, isto é, de um aspecto da realidade global. (SANTOS, 2008; p. 114).

${ }^{12}$ Advertia Milton Santos sobre a necessidade de "objetivar" o objeto da geografia, esforço antes negligenciado (SANTOS, Por uma Geografia Nova, 2002).

${ }^{13}$ Ibid., 2002; p. 19.

14 "É preciso uma outra Geografia que seja uma teoria dos conjuntos espaciais e uma práxis da articulação dos diferentes níveis de análise" (LACOSTE, Yves, A Geografia - Isso Serve, em Primeiro Lugar, para fazer a Guerra, Campinas, Papirus, 1988; p. 192).
} 
$15)^{15}$, em sua totalidade epistêmica e histórica. No entanto, a pretendida unidade passava cada vez mais a resguardar nela própria também a disputa entre elas porque, como crítica, não se constituiria ela mesma de forma autocrítica, o que inviabilizou a identificação dos seus limites ${ }^{16}$. A auto-identificação da crise com a crítica geográfica, embora tenha impulsionado num primeiro momento o desenvolvimento teórico, sobretudo aquele fundamentado em objetivos socialmente emancipatórios, logo deveria conceder a ela seu caráter especificamente disciplinar, especificamente geográfico. Não de outra forma, conclamará Milton Santos, ainda em 1978, no livro que inspirou gerações inteiras da crítica geográfica que fervia no contexto do movimento de renovação: "Se algumas disciplinas se aperceberam dessas mudanças qualitativas e as incorporaram ao seu acervo, algumas outras o fizeram apenas parcialmente. [...] A geografia se encontra nesta situação" (2002; p. 18).

À crítica social dos geógrafos logo se sobrepõe a necessidade epistemológica da Geografia. Uma epistemologia que, já em franco processo de deslocamento do valor e do trabalho de sua centralidade, porque tido como "não especificamente geográfico", teria que admitir "mudanças qualitativas" quando radicalizavam contradições no âmbito da sociabilidade do sistema do capital, ou como prefere Kurz, da "modernização". Assim, não é acidental os resultados antitéticos em que chegam o geógrafo e os críticos da crise diante da análise do mesmo contexto. Se, por um lado, "descobre" o geógrafo o "meio técnico-científicoinformacional" (Milton Santos), uma condição da relação tempo-espaço em que se estabelece a produção da sociabilidade contemporânea, por outro lado argumenta o filósofo sobre a "ativação dos limites absolutos do capital” (István Mészáros) ou sobre a "crise do sistema mundial produtor de mercadorias" (Robert Kurz).

2.1 - O meio "técnico-científico-informacional": entre o "colapso da modernização" e a "crise estrutural"

O conceito de "meio técnico-científico-informacional" ganha sua feição integral, na obra de Milton Santos, em “Técnica, Espaço, Tempo”, publicada no ano de 1994, coletânea que reúne textos da década de 1980. Em especial os textos "O Período Técnico-Científico e os

\footnotetext{
${ }^{15}$ SILVA. Armando Corrêa da, "Contribuição à Crítica da Crise da Geografia”, In: Novos Rumos da Geografia Brasileira, São Paulo, UCITEC, 1996.

${ }^{16}$ Por exemplo, a Valorização do Espaço, livro de importância peculiar para o movimento de renovação, não teve uma análise séria e crítica da comunidade de geógrafos. Quando não apologéticas, as críticas se restringiram ao caráter limitado dos autores diante dos processos de abstrações do valor, como foi a análise vinda de economistas. Cf., ALVES, José Manoel P, "Resenha: Geografia Crítica: a valorização do espaço", (Antônio Carlos Robert Moraes; Wanderley Messias da Costa, São Paulo, Hucitec, 1984), São Cristóvão, Geonordeste, ano 2, n. 1, 1985
} 
Estudos Geográficos" e "Meio Técnico-Científico-Informacional e a Urbanização do Brasill", de 1986 e 1989, respectivamente, já contém os elementos fundamentais que seriam desenvolvidos em "Natureza do Espaço" (1996), seu livro considerado por muitos como o mais importante. Mas também apareceria como parte fundamental, conceito do substrato materialgeográfico da formação territorial brasileira, também em livro que, junto com Maria Laura Silveira, Milton Santos esboçaria sua mais importante tentativa de aplicabilidade de sua teoria ao contexto nacional. No entanto, os elementos essenciais de conceituação do "meio técnicocientífico-informacional" já estariam estabelecidos desde em um momento mais recuado do autor, em 1981, em um texto intitulado "Espaço e Capital e o Meio Técnico-Científico", texto esse que iria compor a coletânea Espaço e Método, publicado em 1985.

Esse retorno à origem conceitual em Milton Santos é importante porque indica como que, no desenvolvimento, aos elementos de essencialidade vão sendo incorporando e somando estruturalmente os elementos contextuais, conforme se desenvolvem as mudanças no processo de produção social que se observa desde o final da década de 1970 até a segunda metade da década de 1990. Importa ainda que, na estruturação dessas mudanças do capitalismo do final do século XX, o trabalho vai, no desenvolvimento conceitual de Santos, rompendo sua barreira da "substância universal" e se deslocando da centralidade da acumulação capitalista até sua efetiva substituição pela "informação", ou "intencionalidade", no interior da "técnica", esta que passa a ordenar o próprio processo produtivo e o mercado "globalizado". Importa ainda como esse movimento é apresentado e analisado sem que se constate nenhuma contradição estrutural que o relacionasse à crise que se daria desde então, ou como "colapso da modernização", conforme observado por Kurz, ou como “crise estrutural”, conforme observado por Mészáros ${ }^{17}$.

O contexto em que se montam as formulações iniciais de Milton Santos sobre as vinculações "unicizadas" entre técnica e ciência é aquele que marca o processo de transição do fordismo para a acumulação flexível (HARVEY, 1993). Mas não foram mudanças simples. Embora Milton Santos, no texto de 1981, se referencie ao "meio técnico-científico" para demonstrar as mudanças qualitativas que desde a Segunda Guerra Mundial demarcam a produção do espaço provocadas pelo desenvolvimento técnico, as transformações operadas no contexto da crise de 1970 seriam suficientemente significativas para o autor enfatizar esse período como o marco efetivo das transformações mais importantes, como assim reconhecia

\footnotetext{
${ }^{17}$ Kurz e Mészáros publicam o conteúdo de suas formulações sobre a crise estrutural, respectivamente, em 1991 (ano de publicação de O Colapso da Modernização) e em 1994 (ano de publicação de Para Além do Capital). Contemporâneos de Milton Santos falam, por isso, do mesmo contexto.
} 
em 1996: “começa praticamente após a segunda guerra mundial, e sua afirmação, incluindo os países do terceiro mundo, vai realmente dar-se nos anos 70" (SANTOS, 2008, p. 238).

A lógica de acumulação que havia demarcado o período conhecido como os anos dourados do capital no século XX por meio de um longo período positivo para a cumulação embora houvesse experimentado crises e instabilidades, sobretudo de dimensão política (mas também econômica) com o processo da liberação das colônias inglesas, por exemplo - havia chegado ao seu esgotamento. O crescimento e a relativa estabilidade que marca o período entre 1945 e 1971 era caracterizado pelo tripé: regulação taylorista demarcando a forma racional, hierarquizada e regulada do trabalho nas fábricas; produção fordista, como a lógica industrial voltada para a alta produtividade por meio do sistema mecanizado; e o keynesianismo, como lógica em que o mercado e a economia em si, por meio do Estado, tendia a ser regulada. Do ponto de vista do trabalho, significava, em termos gerais, relativa estabilidade no âmbito do emprego, como lógica assimilável da acumulação do capital diante do contexto favorável com que o mercado se expandia progressivamente, sobretudo diante da necessidade de reconstrução dos estragos da guerra. Do ponto de vista da técnica, significava o acompanhamento do processo expansivo da acumulação e a vinculação da ciência definitivamente à produção, conforme as determinações que a produtividade fordista-taylorista exigia dos capitais individuais, estes relacionados em um mercado cada vez mais mundializado.

Do ponto de vista da relação entre técnica e trabalho, a exaustão desse processo se dá exatamente no limite em que encontram a necessidade da produtividade em um mercado cada vez mais mundializado. As necessidades dos capitais individuais em se garantirem competitivos exigiriam aumentos de produtividade que, do ponto de vista do capital social total, representava o abarrotamento do mercado em um volume cada vez mais crescente em relação ao crescimento de sua própria capacidade de absorção da demanda efetiva, essa sempre em descenso relativo. A realização do valor-trabalho tende a se contradizer com sua própria produtividade técnica: uma contradição insolúvel e interna da própria lógica do valor. A iminência da crise, que no final é uma crise de superprodução, se confirma quando os capitais, imóveis diante da superacumulação, tendiam a encontrar novas esferas de valorização, o que gerou, em 1971, a quebra do tratado de Breton Woods e a consequente liberação da esfera financeira para investimentos, mas também para especulação. Soma-se a este quadro de evidências o episódio da conhecida "crise do petróleo", em 1973, que significou o aumento dos custos gerais de produção, e consequentemente da superprodução já encalhada, dado a elevação do preço de sua principal fonte energética. 
Como coloca Ricardo Antunes (2002) ${ }^{18}$, a crise se intensifica e se confirma com relativo decréscimo das taxas de lucro porque o trabalho se encontrava relativamente valorizado (organizado em fortes sindicatos) e a taxa de mais-valia não acompanhava as necessidades da produção; havia a queda relativa do consumo dado a superprodução e ao desemprego crescente; crescimento parasitário da esfera financeira; tendência de monopolização do mercado em crescente processo de mundialização; falência do Estado do Bem-Estar Social pelas constante crises fiscais e o consequente crescimento exponencial da dívida pública; além da privatização, desregulamentação e flexibilização da produção.

Essas condições da crise, que também são consequências, irão afetar profundamente, sobretudo, os centros da produção capitalista avançados, como também o chamado bloco soviético. As medidas exigidas diante do processo da "reestruturação produtiva" provocarão transformações estruturais não apenas na economia capitalista, mas como um todo na economia de mercado, que praticamente já incluiria o mundo em sua integralidade. Milton Santos, ainda no texto de 1981, observaria as novas condições com que o novo padrão técnico elevaria a produtividade do trabalho, com o que chama de "expansão do trabalho intelectual" em um contexto de "circulação de capital à escala mundial, que atribuiu à circulação (movimento das coisas, valores, ideias) um papel fundamental" (SANTOS, 2014; p. 54) ${ }^{19}$. Entretanto não interpreta que tais condições em que a técnica se positiva diante de uma condição "qualitativamente nova" não é apenas uma consequência das transformações ocorridas na década anterior, mas sobretudo uma resposta às condições da crise do capital e a ela limitada.

Se, como reconhece Santos nos idos de 1981, “dentro de cada país há tendência a uma especialização cada vez maior das áreas produtivas [e] isso está ligado à necessidade de maior rentabilidade do capital" ${ }^{20}$, é certo que, no programa avançado da reestruturação produtiva, a acumulação flexível tem no "meio" universalizado da "tecnosfera" e da "psicosfera" (da qual Milton Santos comporá a nova unidade dos "sistemas de objetos" e "sistemas de ações", agora em "A Natureza do Espaço") ${ }^{21}$ as três frentes de ação que assim podem ser colocadas: as condições de intensificação da produtividade do trabalho e o consequente e radical desenvolvimento do capital orgânico pelo crescimento exponencial do capital constante em detrimento do variável; as condições de uma estrutura global de circulação do valor, de mercadorias e informações dado o desenvolvimento do componente técnico do capital

\footnotetext{
${ }^{18}$ ANTUNES. Ricardo, Os Sentidos do Trabalho: Ensaios Sobre Afirmação e Negação do Trabalho (6 ${ }^{\mathrm{a}}$ ed.), São Paulo, Boitempo, 2002.

${ }^{19}$ SANTOS, Milton, Espaço e Método, São Paulo, ED. USP, 2014.

${ }^{20}$ Ibid., p. 55.

21 “A tecnosfera é o mundo dos objetos, a psicosfera é a esfera da ação” (SANTOS, 2008; p. 257).
} 
orgânico; além da "abertura" dos territórios, por vias do discurso neoliberal, para os projetos da modernização tecnificada e desregulamentada, sobretudo na agricultura e no espaço urbano. Isso faz com que a reestruturação produtiva e o meio técnico-científico informacional sejam dimensões diferentes do mesmo processo.

No entanto, as mesmas condições do novo "meio" que aparece relativamente estável em Santos (como um novo período da humanidade) são as mesmas que intensificam as condições críticas da sociabilidade em questão. Os elementos que compõem o meio técnicocientífico-informacional, longe de serem meros resultados de transição do fordismo para a acumulação flexível, tal qual longe de serem estáveis, são resultados da crise da sociabilidade pautada no próprio valor, ou na sociedade "do sistema produtor de mercadorias" (KURZ, 1992) $)^{22}$. Ou seja, elas não estrão somente para afirmar o valor por meio das novas formas de circulação e produção, mas também para agravar o quadro de sua destituição. Para que seja possível colocar o "meio técnico-científico-informacional" como condicionante do processo de produção, circulação distribuição e consumo, do processo produtivo em si, a partir da carga técnica e informacional "identificadas na realidade empírica" (SANTOS, 2008; p. 257), o que torna a expansão do "capital fixo" ou "capital morto" um elemento ainda mais central nos projetos da modernização seria preciso, igualmente, considerar ao crescimento da incapacidade dela própria continuar a ser mero possibilitador da valorização. Pois passam elas a significar também o próprio limite do capital; as próprias condições da expansão agindo como seu limitante. Isso nada mais reflete do que a radicalização da contradição capital x trabalho.

Se, como observara Harvey (2005a), o capital pode deslocar suas contradições, sobretudo no que concerne a superacumulação, para a construção infraestrutural por meio de sua imobilização em capitais constantes, fixos e fixados, ainda assim suas contradições estariam apenas sendo remediadas, conforme elas também se acumulam no espaço e no tempo a níveis cada vez mais irremediáveis, e em um futuro cada vez mais próximo. Isso decorre pelas próprias condições de produtividade com que os "meios" engendram no processo da produção em si, mas também da produção de si próprio.

O próprio Marx já havia identificado esse processo de desvalorização dos “meios" de valorização: "Se, em consequência de uma nova invenção, se reproduz maquinaria da mesma espécie com menos dispêndio de trabalho, a antiga maquinaria é mais ou menos desvalorizada e transfere, por isso, relativamente menos valor ao produto" (1983; p. 172). Destaca ainda o autor que, no caso específico do capital constante, as variações de valor tendem ser ainda mais

\footnotetext{
${ }^{22}$ KURZ, O Colapso da Modernização, 1992.
} 
drásticas, pois podem incidir nelas "leis da especulação" que agregam a um determinado capital constante um valor maior que o resultado do seu processo de produção stricto sensu. Ou seja, o capital constante pode valer mais que o quantum de trabalho nele cristalizado, pois sua qualidade de permanência, no caso do "capital fixo fixado", permite agregar valores futuros do "tempo médio socialmente necessário" diferenciados que ele possa vir a ter, "como um efeito retroativo sobre a mercadoria antiga, que sempre vale como exemplo isolado de sua espécie"23.

Isso promoveria um aparente desligamento do valor em relação a seu processo de produção, além de aparecer como valorização autônoma na esfera da circulação ou independente do trabalho: "Mas também aqui a mudança de valor origina-se fora do processo de produção, em que a máquina funciona como meio de produção”. Nada mais enganador, mas também nada mais persuasivo e providencial para a mudança de referência do valor: do trabalho para a técnica. O limite é que, tanto a máquina como o conjunto dos "meios" de produção, ou a própria composição técnica do trabalho que compõe a estruturação existencialmente específica do "meio técnico-científico-informacional", por exemplo, não pode transferir os valores adquiridos pelas "leis da especulação", mas tão somente seu valor-trabalho cristalizado: "Nesse processo nunca cede mais valor do que possui, independentemente dele" ${ }^{24}$. Por isso seu valor é sempre menor do que sua "forma" expressa; e tanto quanto menor quanto maior sua magnitude empírica. A contradição entre trabalho e técnica, como não objetivada pelos geógrafos, assim se torna mais nítida.

O valor é escuso, e isso também foi advertido por Marx, porque a "objetividade fantasmagórica" com que o trabalho, na sua qualidade abstrata, se apresenta na concreção da mercadoria é de forma indiferenciada. O fato de o valor não se apresentar em sua empiria, como queira Costa e Moraes, é imanente à própria mercadoria e só pode ser apreendida a partir do momento em que, ou se dirige a análise para o "movimento interno da produção", ou se confunde a empiria com "metafisicalidade" escusa própria da mercadoria. Pode-se dizer que os geógrafos fizeram esse caminho: da "produção" à "confusão" (embora não exatamente "confusa", mas "com-fusão"; em referência às "fusões" operadas no interior da teoria, ou "unicizações", especialmente em Santos, em que categorias importantes da explicativa moderna, como relações de trabalho, forças produtivas e mais-valia, se confundem até sua dissolução em relação às subcategorias da técnica, como será analisado à frente).

Se, como observa Milton Santos, a "modernização do território", que se daria condicionada ao "meio técnico-científico-informacional", seria expressa pela densidade e

\footnotetext{
${ }^{23}$ MARX, 1983; p. 172.

${ }^{24}$ Id., Ibid..
} 
organização dos "capitais dormentes" orientado pelas "firmas monopolistas" (SANTOS, 2008; p. 11), seria necessário, por outro lado, observar como que esse processo se dá como expressão da falência de si próprio. Robert Kurz (1992), na argumentativa sobre o "Colapso da Modernização", havia indicado como que o mesmo processo observado por Santos (e para além de formas mais "brandas" com que as contradições da modernização são postas como "seletividade" ou "guerra dos lugares"), a vinculação científica à técnica "gerada cegamente pelo capitalismo criou, assim, no nível substancial-material, potências que já não são compatíveis com as formas básicas da produção capitalista, continuando-se não obstante a encaixá-las forçosamente nessas formas" "25. O resultado iminente, como também analisado por Marx e indicado anteriormente, é a tendência de alteração na natureza das forças produtivas em forças destrutivas, ou, nas palavras de Kurz: “A consequência é a transformação das forças produtivas em potenciais destrutivos, que provocam catástrofes ecológicas e sócio econômicas"26

A condição da "crise", de fato, não seria reconhecida por Milton Santos, seja como desdobramento teórico, seja como explicativa, seja como a própria forma de existir do "meio técnico-científico-informacional”. Embora possam ser lidos em “A Natureza do Espaço" suas observações sobre a "crise ambiental" - que será encarada como uma "constatação", “externalidade", ou "resultado", do poder anárquico de como os objetos técnicos, na busca pela mais-valia, se envolvem pela competitividade -, ou na entrevista publicada em 2000 com o título de "Território e Sociedade", em que a crise se apresenta apenas como possibilidade ("um acidente, digamos assim, mas de consequências irreversíveis, que seria equivalente a um efeito dominó...." $)^{27}$, não chegará ela a ser posicionada como elemento de importância analítica. Isso revela o aspecto positivo, "explicativo" e "orientador" de "A Natureza do Espaço", pois põe a dialética muito mais como referencia de contradições que aparecem apenas como "advertências" para a orientação da análise geográfica, de "como explicar o espaço", do que propriamente como condição interna e fundamental de sua proposição ou de seu entendimento $^{28}$.

\footnotetext{
${ }^{25}$ KURZ, 1992; p.227.

${ }^{26}$ Id., Ibid..

${ }^{27}$ SANTOS, Milton, Território e sociedade: entrevista com Milton Santos, (Entrevistadores: Odete Seabra, Mônica de Carvalho e José Corrêa Leite), São Paulo, Perseu Abramo, 2000; p. 16.

${ }^{28}$ Uma autocrítica começa a ser montada em torno do conceito e suas visculações positivista: "Milton Santos nos dá somente alguns apontamentos nesta direção sem avançar muito numa relação inextrincável e ontológica entre acumulação de capital e meio técnico-científico-informacional. Exatamente por isto sua interpretação do fenômeno pára, com frequência, nos limites da descrição, da constatação do novo, sem, entretanto, conseguir penetrar no âmbito dos elementos explicativos do fenômeno" (SANTOS, Lucas Maia dos. A constituição do meio técnicocientífico em Goiás: relações de trabalho e luta de classes no setor sucro-energético (tese de doutorado). Goiania: Universidade Federal de Goiás, 2014; p 27).
} 
Do "colapso" às alternativas positivas de manutenção da modernização capitalista pela natureza própria das possibilidades que parecem se abrir diante do "meio técnicocientífico-informacional", é possível identificar em Santos como sua fundamentação se processa, na decorrente destituição do valor e do trabalho, como categoria central na análise. Como observado, desde as primeiras vinculações das perspectivas da teoria geográfica miltoniana com o problema do valor, esse foi, paradoxalmente, mediado por um movimento de afirmação e negação. Chega-se a necessidade da epistemologia exatamente como forma de desenvolvimento das soluções teóricas, até então limitadas a "adaptações" da lógica do valor ao "temário" geográfico.

Se em "Espaço e Método", em específico o capítulo "Espaço e Capital: O meio Técnico-Científico" (originalmente de 1981), já é anunciado um quadro em que o trabalho se encontraria "unificado" diante da condição técnica, ainda nesse momento a unificação não representa nada mais além do que a relação imbricada em que o processo de trabalho já está intimamente ligado à ciência e à tecnologia. É, por isso, apenas a delimitação de uma condição produtiva em que os espaços, inseridos no processo da especialização seletiva, vão compondose por meios em que os instrumentos de trabalho promovem a fixidez e a fluidez em níveis cada vez mais "numerosos e densos" (“À medida que a economia se torna espacialmente seletiva dentro de cada país, e complementar entre países, os instrumentos de trabalho são cada vez maiores e mais os fixos e os fluxos correspondentes são forçosamente mais numerosos e densos") ${ }^{29}$. Ainda nesse momento as observações de Santos apenas sugerem um nível pouco justificado de inversão da lógica entre técnica e trabalho: "pelo fato de aumentar o capital fixo significar reduzir a quantidade de trabalho necessário, isso também significa que a produção necessita, em maior número, de insumos científicos" 30 .

As contradições entre trabalho e capital (fixo) não poderiam ser observadas por Santos, nem nos primeiros, nem nos últimos momentos, dado que a própria dialética não se encontra desenvolvida, afinal o "fato de aumentar o capital fixo" e a consequente "redução da quantidade de trabalho" não seria decorrente de outra necessidade senão do próprio imperativo de produzir "mais-trabalho". Isso porque não é o capital fixo em si que reduz a "quantidade de trabalho", como também o "aumento" de capital fixo não se dá por si mesmo, como expressão da condição "progressista" da humanidade. Ou, ainda, a "redução da quantidade de trabalho" não é um dado muito seguro, pois ela pode significar seu contrário; ou seja, seu próprio crescimento, caso seja abstraída seu envolvimento no desenvolvimento do capital orgânico, ou como dado absoluto.

\footnotetext{
${ }^{29}$ SANTOS, 2014; p. 55-56.

${ }^{30}$ Ibid., p. 57.
} 
Aliás, como a tendência na presente análise de Santos é de se voltar para as formas de cristalização do trabalho (instrumentos de trabalho ou capital fixo fixado), pode-se mesmo afirmar que há, nesse caso, um aumento absoluto de trabalho para a estruturação do "meio técnico-científico". Essa dialética entre "redução" de trabalho em seu próprio "crescimento" não poderia ser apreendida por Santos porque, na eminência de observar a centralidade da esfera da circulação (dimensão que se pretende propriamente geográfica), não a vê como parte constituinte da própria produção do valor; ou seja, não a observa por meio da lei do valor. Em última análise, a circulação, antes de ser o "meio" da estrutura técnica condicionante para o movimento de fixos e fluxos, é sobretudo por onde o valor se "metamorfoseia" entre uso e troca; muda de formas (empíricas) sem mudar de natureza (contradição entre troca e uso), e por onde essas formas e os objetos ganham sentido histórico. Assim, nem capital, nem meio, nem trabalho são apenas "condições", mas sobretudo "relações".

Essas questões jamais seriam colocadas de forma séria por Santos, porque questionaria o próprio exercício de centralização da técnica; e geradora de embaraços, levantaria a condição concorrente entre trabalho e técnica, um problema de difícil solução, do ponto de vista de uma dialética que se pretende apenas conciliatória.

[Os problemas da empiricização da universalidade]

Ainda assim, as "unificações", apesar de sua dialética ainda precária, é um primeiro movimento para demonstrar como tanto trabalho como capital se constituem uma unidade indiferenciável com o processo da globalização e estão cada vez mais dependentes de suas expressões empíricas (“banco", "firma”, "agentes hegemônicos”, etc.). Essa seria a protoforma do que Santos desenvolverá em "Técnica, Espaço, Tempo", que corresponde à fase de maturação do conceito do meio técnico-cientifico, face às mudanças que se acumulariam até a segunda metade da década de 1980. Nesse momento, a "unificação" ganha a efetividade da "unicização" e as relações com-fundidas ganham aspectos mais observáveis a partir do que Santos denominará como "empiricização da universalidade", isso em um tópico sintomaticamente intitulado "Unicidade Técnica e da Mais-Valia” (2013; p. 118-119) ${ }^{31}$.

Nestas condições em que se apresentam desenvolvidas, e agora unicizadas, a técnica, mais-valia, trabalho e capital, observa-se a forma, sutil e sofisticada, com que Santos inverte efetivamente o sentido das abstrações determinantes da produtividade deslocando para a

\footnotetext{
${ }^{31}$ SANTOS, Milton, Técnica, Espaço, Tempo: Globalização e Meio Técnico-Científico-Informacional, São Paulo, Ed. USP, 2013.
} 
empiria sua centralidade. Se, como o capital, por exemplo, é "uma coisa só" no mundo inteiro, o que irá definir sua natureza específica (como capital agrícola, industrial, etc.) passa a ser determinada pelas tomadas de decisões dos "agentes hegemônicos" materializados nos "bancos" e "firmas". Como dirá Santos, o "uso do território não é o mesmo para diversas firmas [...]. Cada firma usa seu território segundo sua força. Criam-se deste modo, circuitos produtivos e circuitos de cooperação como forma de regular o processo produtivo e assegurar a realização do capital" (2013; p. 121).

A autonomia autoproditiva e autocontraditória do capital se encontra confundida com os interesses no território, agora dominado pelas "firmas". Sua condição internamente contraditória (capital x trabalho) desaparece, restando apenas as formas de sua aplicabilidade no espaço. Assim, os próprios capitais individuais (ou as firmas) parecem incorporar a natureza supostamente não contraditória do valor-capital, tal como de sua relação com o capital social total não emana nenhum conflito. Isso só se torna possível na medida em que, na "empiricização da universalidade" tende ela a se unilateralizar como a própria abstração em si.

Disso observa a impossibilidade de colocar duas contradições como foco de entendimento da relação entre capital e território.

Primeira, do ponto de vista da circulação e da lei do valor-trabalho: os capitais individuais, ou as "firmas", se relacionam de forma competitiva no mercado. Os limites da competição não estão previamente definidos e a variação entre a "cooperação" (como coloca Santos, um termo aparentemente vindo das influências durkheiminianas) e a "cooperação destrutiva" são estabelecidos pelas próprias condições da circulação, cada vez mais intensificada pelo meio técnico-científico-informacional. Ocorre que cada capital individual, ou cada "firma", procura lucrar mais aumentando sua produtividade como forma de produzir mais por menos. No entanto, cada capital individual, cada "firma", deverá, junto às demais, se encontrar no mercado para compor o capital social total, ou o "capital universal", que pressiona ainda mais a tensão do preço contra o valor. Esse encontro faz aumentar continuamente a produtividade, ao mesmo tempo que abarrota o mercado de produção. Esse círculo vicioso tende a desvalorizar a própria produção na medida em que, ao sobrecarregar o mercado, precisa encontrar o consumo (ou demanda efetiva) em uma intensidade também crescente, enquanto, por outro lado, mais massa de trabalho é dispensada em relação à mudança da produtividade geral. O que se tem é que, enquanto para o capital individual, ou para as "firmas", o "meio técnico-científico" auxilia positivamente na busca do lucro (que é a real condição do controle do território), por outro lado, na dimensão do capital social total, esse efeito é inverso, ao ponto de promover sua desvalorização diante de um mercado cada vez mais superabastecido, 
conforme os níveis de produtividade e oferta geral, possibilitados pelo próprio "meio-técnicocientífico", se elevam. Essa condição negativa que o "meio técnico-científico" ajuda a promover é estrutural e corresponde a incontrolabilidade do processo de acumulação do capital. A lei do valor está, por isso, radicalmente em movimento contrário às possibilidades geográficas de "controle" da "firma" para com seu "círculo de produção e cooperação", porque a "cooperação" é também destrutiva. Além disso, essa contradição requalifica o sentido da "seletividade" territorial já que o "meio técnico-científico" passa a ser não mais apenas a expressão da capacidade de investimento das "firmas" que nele se inserem, mas a expressão de sua autodestruição, tanto em relação ao território, como em relação ao "meio", como em relação às “firmas" e, sobretudo, como em relação à produção em si.

Segunda contradição, do ponto de vista da produção e ainda a partir da lei do valor: a "empiricização da universalidade" só assim pode se admitir quando a composição-valor do capital orgânico estiver com-fundida com a composição técnica, e a ela sobredeterminada. Aqui se reproduz aquela tendência já observada em Costa e Moraes, mas em nível diferente de sofisticação. Dirá Santos quanto às mudanças na composição orgânica do capital promovidas pela vinculação entre ciência, tecnologia e informação: "mudanças importantes, de um lado, na composição técnica do território e, de outro, na composição orgânica do território, graças à cibernética, às biotecnologias, e às químicas, à informática e à eletrônica" 32 . Sem observar tais mudanças do ponto de vista do trabalho, assevera: "O trabalho se torna cada vez mais científico" ${ }^{\prime 3}$. Insinuando uma identificação invertida entre o sujeito (trabalho) e seu predicativo (científico), continua: "e se dá, também, em paralelo a uma informatização do território" 34 . O que aqui aparece como fenômeno em "paralelo" (determinante/determinado), "a informatização do território" por meio de seus “objetos geográficos", alguns parágrafos à frente já se torna a própria condição do trabalho: "o homem vai superpondo a natureza, verdadeiras próteses, de maneira a permitir que se criem as condições de trabalho próprias de cada época" 35 . "Próteses" essas que, finalmente, passam a orientar o próprio processo de trabalho, este que, não sendo mais dotado de autonomia ontológica, se encontra, a essa altura, reduzido a sua forma concreta: “esta nova necessidade de regulação, de controle estrito, mesmo que à distância dos processos da produção, mas também da distribuição e de tudo mais que envolva o processo de trabalho [...]"36.

\footnotetext{
${ }^{32}$ SANTOS; 2013; p. 133.

${ }^{33}$ Id., Ibid.

${ }^{34}$ Id., Ibid.

${ }^{35}$ Ibid., p. 134.

${ }^{36}$ Ibid., p. 138.
} 
Ocorre que, diante de tal inversão, não se observa que a própria estruturação espacial é ela ainda resultado do processo de trabalho e valorização, este que também condiciona sua existência como "prótese" da produção específica do valor, e às suas "leis" estão submetidas. Por isso que a "empiricização da universalidade" é igualmente a universalização radical do valor-trabalho. Mas não só: a universalização radical do valor-trabalho só pode assim se estabelecer quando a radicalização de sua composição-valor se contradizer com sua composição técnica. Afinal, como observa Santos, se cada vez mais a estruturação técnica se faz central para a realização do capital é porque, internamente, seu processo de valorização se definha como incapacidade de se realizar como valor, daí sua necessidade de se deslocar para a empiria.

Marx havia percebido os problemas em se separar a universalidade determinante da empiricidade, esta como momento preponderante daquela, e a observação da empiricidade desta universalidade quando, ao seu tempo, se dirigia ao "leitor alemão" a respeito das condições do desenvolvimento capitalista inglês analisadas pelo autor e ainda não presenciadas pelos germânicos. Ao seu tempo, resignava-se Marx às possibilidades de apenas "gritar" aos alemães: "De ti fabula Marratur!"37. Despois desta conhecida frase de Marx, a "empiria" experimentou as mais profundas e poderosas expressões universais das leis contraditórias do valor, como não observado pelos geógrafos: imperialismos, depressão de 1930, duas guerras mundiais e, por fim, a crise estrutural. A “unicização" que se pretende nova, como conjunto que fundamenta a "empiricização da universalidade", só assim pode se estabelecer quando desconsiderada a já relativamente antiga universalidade determinante do valor que, de forma incontrolável, expancionista e totalizadora (MÉSZÁROS, 2011) envolve e complexifica a dinâmica da produção da riqueza e da sociabilidade diante de sua dinâmica contraditória.

Mas admitir essas contradições seria admitir o próprio limite do "meio técnicocientífico". Significaria que, além de ir de encontro aos objetivos positivos para com a teoria, parecia não contribuir com a análise explicativa do fenômeno técnico e da globalização. Então, como vencer a teimosa contradição advinda da lei do valor que insiste em incidir sobre a necessidade epistemológica? Mudando a natureza e a substância da "lei".

A esta altura, em "Técnica, Espaço, Tempo", Santos já havia aproximado à “informação" do conteúdo dos objetos e da técnica, mas seria em "A Natureza do Espaço", de 1996, que ela, tal como a "intencionalidade" e a "razão", iria substituir a contradição entre valor de troca e valor de uso, além da dialética do trabalho, no interior dos "objetos":

\footnotetext{
37 "De ti fala a fábula". (Ver nota de editor: MARX, 1983; p. 12).
} 
Neste período, os objetos técnicos tendem a ser ao mesmo tempo técnicos e informacionais, já que, graças à extrema intencionalidade de sua produção e de sua localização, eles já surgem como informação; e, na verdade, a energia principal de seu funcionamento é também a informação [...]. Estamos diante de algo novo, a que estamos chamando de meio técnico-científicoinformacional (SANTOS, 2008; p. 238).

Por isso, não é mera coincidência, ou fatalidade, que a teoria do valor ou a dialética contraditória do trabalho tenha desaparecido da substância do espaço e da técnica na última fase de maturação do pensamento de Milton Santos. Embora o rompimento não tenha sido formal, dado a manutenção do caráter conciliatório da dialética empregada, o que faz com que capital e trabalho apareçam apenas de forma instrumentalizada (como investimentos, relações de trabalho, ou cristalizações ontológicas e remotas), é possível identificar sua ausência na forma com que as mesmas contradições apresentadas acima continuam a incidir em sua teorização.

[Os desafios positivos da teoria diante das negativas críticas: da modernização colapsada ao sociometabolismo destrutivo]

Se, como observado, as mais referenciadas soluções teóricas pareciam partir do "movimento interno da produção do valor" (COSTA \& MORAES) até as "fusões" que permitissem a composição de uma leitura que fosse "a cara geográfica da globalização" 38 , é no próprio reconhecimento de sua necessidade epistemológica que também se observa sua autojustificação. Por "fusões" entende-se o movimento interno da teoria que permite Santos promover as "unicidades", por exemplo, da mais-valia e da técnica, desde o contexto de “Técnica, Espaço, Tempo", e, por autojustificação, a forma de apresentar as unicidades como a própria forma de pôr a "geografia completamente nova", mas ainda marcada por um nível de abstração sempre retroagindo para a empiria. As fusões autojustificadas, como no caso específico da mais-valia e da técnica, seriam assim explicadas nessa importante passagem: "a impulsão que recebem esses conjuntos técnicos atuais (ou suas frações) é única, vinda de uma só fonte, a mais-valia tornada mundial ou mundializada, por intermédio das firmas e dos bancos internacionais" (SANTOS, 2013; p. 118). A importância dessa frase se dá pela forma de como ela sintetiza a singularidade da formulação teórica de Santos e que o seguirá até sua feição final em "A Natureza do Espaço".

\footnotetext{
${ }^{38}$ Como assim se refere Santos ao dizer que "o meio técnico-científico-informacional é a cara geográfica da globalização" (2008; p. 239).
} 
Primeiro: unicizada como mais-valia "mundializada" somente no momento atual, significa que a relação capital x trabalho não continha antes do novo período técnico seu caráter de abstrato universal determinante (ou a própria mais-valia), como ao seu tempo objetivou Marx. Segundo: que sua abstração universal só se torna possível por meio da técnica, também universalizada na forma de conjuntos técnicos. Terceiro: que a técnica universalizada do qual permite a universalização da mais-valia se dá por meio de sua dimensão empírica (bancos e firmas). Essas condições, como visto, seria “empiricização da universalidade".

Diante deste quadro, podem ser observados problemas de quatro ordens que vão seguir a composição do meio "técnico-científico-informacional". Primeiro: a "empiricização da universalidade", a partir da unicidade, não permite colocar em contraposição a mais-valia e a técnica: elas se apresentam em relação combinativa e autoafirmativa. A “crise", da forma como coloca Kurz, não pode ser percebida porque não se admite a contradição como motor da relação entre as categorias. Segundo: a mais-valia tornada "universal" somente pelas condições do meio técnico-científico atual inverte a natureza de sua abstração, não mais pela relação capital $\mathrm{x}$ trabalho, mas pelas possibilidades empíricas da técnica. Terceiro: a mais-valia universalizada tende, mediada pelos "agentes hegemônicos" que controlam e racionalizam a técnica, a se “emancipar" da produção, conforme a esfera da circulação se agiganta com o aumento da importância dos capitais fixos. Quarto: o processo de abstrações dessas condições, já destituído das possibilidades de apreensão da contradição interna da valorização, tende a unilateralizar a relação-capital por meio de sua composição técnica.

Todos esses desdobramentos, em suma, significam, antes de tudo, a sequência do deslocamento do trabalho em seu movimento contraditório da valorização. Kurz também observa o processo com que o capitalismo agiganta as forças produtivas e suas possibilidades de exploração do trabalho, mas por isso mesmo entende que, longe de significar qualquer possibilidade de sua continuação, aponta como "incapacidade" da "exploração", dada a insustentabilidade da massa de mais-valia diante da riqueza geral produzida: "o capitalismo tornou-se 'incapaz de explorar' [...], e isso em virtude da intensificação permanente da força produtiva" (KURZ, 1992; p. 226). Para Kurz, essas são exatamente as condições que levam à crise e ao "colapso" do sistema produtor de mercadorias".

Para Santos, o mesmo processo em que os limites da valorização não são percebidos se abre às possibilidades de positivação e autorreferenciação do espaço: se contempla a necessidade da epistemologia com sua solução teórica. Por isso chegam em resultados não apenas diferentes, mas antitéticos: Santos em uma teoria positiva que visa explicar a globalização a partir de como a técnica, agora substanciada pela informação e intencionalidade, 
ordena o espaço a partir de sua composição no território; Kurz como evidenciação de que as estruturas produtivas da sociedade do "trabalho abstrato" se destrói por dentro de suas próprias contradições, o que permite apontar "a extensão do perigo que brota nessa situação histórica" (KURZ, 1992; p. 227).

A forma como a proposição de Santos tende a solucionar os problemas epistemológicos se abre, por outro lado, para os problemas de última instância da emancipação, da superação. Diante da impossibilidade de aprender as contradições "internas da produção", o "meio técnico-científico-informacional" se estabelece, dado seu caráter positivo, como um espaço carregado de possibilidades e alternativas, inclusive para a manutenção do processo acumulativo do capital. Ele não permite apontar criticamente seus limites, que sempre se expressam na forma de barbárie. Por isso, naturalmente, se depara com a questão crucial: estaria a teoria geográfica cumprindo seu papel de crítica social, ou apenas se propondo a analisar as formas de existência “como elas se afirmam, e não como elas se negam" ${ }^{39}$ ? Exatamente na introdução do capítulo de "Para Além do Capital"40 dedicado à crise estrutural, colocará Mészáros a questão de outra forma: “A primeira questão que devemos considerar diz respeito à possibilidade de uma abordagem radicalmente diferente do desenvolvimento das potencialidades produtivas humanas, em resposta a uma necessidade genuína" (MÉSZÁROS, 2011; p. 605.).

Mészáros, para quem urge a necessidade de elaboração de uma "teoria da transição para além do capital", não se trata somente de entender, ou mesmo explicar, os "meios" pelos quais se condiciona a prática social "subordinada aos imperativos alienados da produção-docapital sempre-em-expansão" 41 , mas sobretudo a forma como ela se contrapõe às necessidades reais humanas. Por isso, tal questão se desdobraria em, primeiro, reconhecer a "disjunção" entre a produção da riqueza e a riqueza da produção perante suas necessidades humanas-sociais (produção x consumo), e, segundo, a demonstração de como a forma positiva de encarar o modo da "produção da riqueza" em eterna expansão, ou ainda eterna contradição, por mais destrutiva que seja, como se não houvesse "nenhuma alternativa", teria como resguardo a "falsa teorização da relação entre produção, ciência e tecnologia, concebida e caracteristicamente distorcida do ponto de vista do capital que ela eterniza"42.

\footnotetext{
${ }^{39}$ Referência a Ruy Fausto, como posto na introdução (FAUSTO, Marx: Lógica e Política, 1983).

${ }^{40}$ MÉSZÁROS, Para além do Capital, 2011.

${ }^{41}$ Ibid., p. 605.

${ }^{42}$ Id., Ibid.
} 
Do primeiro, da "disjunção" entre produção da riqueza e necessidade humana, devém a analítica da disjunção estrutural em que valor de troca se contrapõe ao valor de uso, e como aquele se sobredetermina diante deste como princípio da produção para, em seu máximo desenvolvimento (moderno), se expressar de forma, por fim, "explosiva, que transforma suas potencialidades positivas em realidades destrutivas" ${ }^{\text {"43 }}$. Ainda que não esteja em pauta a solução apriorística e imediata a inversão mecânica do processo (“opor valor de uso ao domínio capitalista do valor de troca em expansão está muito longe de ser capaz de oferecer as condições suficientes da transformação socialista bem-sucedida") ${ }^{44}$, como experimentou insuficientemente a União Soviética, trata-se sim de colocá-lo positivamente como princípio de um "sociometabolismo" historicamente concorrente e oposto à universalidade dominante do valor de troca. Do segundo, da formulação teórica como viabilidade concreta diante da contradição radical no interior do "sociometabolismo do capital", sobretudo no reconhecimento de sua fase destrutiva, é inevitável que esteja ela pautada de forma a "desafiar os próprios horizontes da 'riqueza' autorreprodutiva do capital, no interior dos quais não pode haver solução para tais problemas"; caso não queira ela "se contradizer", ou ainda caso estejam intocadas, do ponto de vista das pretensões da teoria geográfica, o entendimento de que somente a "perspectiva de transformar o mundo fornece a possibilidade de compreendê-lo", como exposto por Costa e Moraes.

Implicaria, assim, colocar diante da nova fase de acumulação condicionada pelo "meio técnico-científico-informacional", como a base das novas formas de reprodução sóciometabólica do capital, seus próprios desafios de, no mesmo processo de apreensão, demonstrar seus limites. Isso significa que o "meio" altamente produtivo da técnica tem, em sua forma atual qualitativamente distinta das outras do passado, sua própria essência qualitativa da produção quantitativa. Ou seja, o que há de novo na natureza técnica não muda a natureza imperativa da exigência quantitativa da produção, pois em última análise a condição qualitativamente nova esboçada pelo "meio técnico-científico-informacional" deve continuar a se expressar no aumento da própria produtividade como fim em sim mesmo. Tem-se, assim, não apenas uma inversão de qual determina ou condiciona o quê, mas propriamente uma contradição entre técnica e sua produtividade, pois seu caráter quantitativo, dada a permanente necessidade de aumento da produtividade, tende a limitar suas próprias mudanças qualitativas, pois a ela está também condicionada. Mas, novamente, se mudanças quantitativas podem engendrar mudanças qualitativas, o que poderia haver de realmente "novo"?

\footnotetext{
${ }^{43}$ Ibid., p. 614.

${ }^{44}$ Ibid., p. 609.
} 
Mészáros fala em ativação dos limites absolutos do capital, dada a própria incapacidade com que seu sistema metabólico permite, agora, pelas mesmas condições da mundialização observadas por Santos, contornar, controlar, ou deslocar suas contradições, seja no tempo, seja no espaço. A crise se mundializa porque as contradições estruturais, antes universalizada apenas na lógica interna do capital, se universaliza também em sua própria mundialização: “o final da ascendência histórica do capital em nossa época - [pois] seu domínio agora se estende aos bolsões mais distantes e anteriormente isolados do planeta - ativou os limites absolutos desse sistema de controle sociometabólico" (MÉSZÁROS, 2011; p. 219). As contradições internas potencialmente explosivas do capital se tornam agora efetivamente destrutivas em sua "globalização". Essas contradições insolúveis, do ponto de vista do capital, teriam suas expressões a partir de quatro conjuntos de questões que se relacionam e se independem.

Primeiro: o movimento de monopolização e a consequente limitação do mercado, dado o próprio desenvolvimento dos níveis de produtividade com que os capitais passam a concorrer entre si. Uma contradição estrutural entre o capital individual e o capital social total que desnuda, inclusive, a relação que se estabelece entre os grandes monopólios "muiltinacionais", pseudo-autônomos no mercado mundial, quando na realidade estão cada vez mais ancorados nas "garantias públicas" dos Estados-Nação que se rivalizam no jogo imperialista.

Segundo: a incapacidade da própria "globalização" significar apenas condicionamento de um novo padrão do meio técnico em que seja possível tornar a "mais-valia universalizada". Nem também que suas contradições devam ser apenas "consequências", como "seletividade" dos lugares ou desastre ambiental. Essas mesmas contradições "externalizadas" são frutos de condições intimamente ligadas à estrutura incontrolável e expansionista do capital que, depois de rompida todas as barreiras de produtividade e expansão, volta-se contra a produção em si, não só por meio da ativação dos mecanismos de redução dos valor de uso geral de sua própria produção, mas também na reinvenção de relações de produção odiosas, como o trabalho escravo e o terrorismo da máquina de guerra do "complexo militar-industrial” (MÉSZÁROS, 2011; p. $685)$.

Terceiro: a fragmentação que acompanha o processo da globalização, como apontado por Santos, e que sob a pena de Mészáros ganha a dimensão efetivamente destrutiva do capital, é também um processo de destituição das suas condições de controle. A relação do "macrocosmo" estrutural capital x trabalho, que sempre incidiu como reflexão ou determinação dialética - como momento preponderante - das relações mais intimas do "microcosmo" (indivíduo, família, relações interpessoais, etc.), encontrava possibilidades de deslocamento de 
suas contradições para esferas supostamente específicas e independentes da sociabilidade (como a política, como visto, apontado por Costa e Moraes, mas também por Santos). Isso permitia estabelecer com bastante exatidão os limites com que as "conquistas" políticas individuais e coletivas (e Mészáros utiliza como exemplo as questões da "liberação das mulheres", "ganhos sindicais", em detrimento da "igualdade substantiva") pudessem ser assimiladas dentro dos meandros não desafiadores da ordem estrutural do capital. Mas mesmo elas, a mais perceptível e aparente das relações de suposta indeterminabilidade, ou relativa independência, passaram a se expressar como "concessões" caras demais diante das condições críticas. O limite absoluto é que essas esferas "autônomas" não representam mais possibilidades para resguardo das contradições. O não reconhecimento de tais limites, a crença de que as contradições radicais possam ser absorvidas por "remediações" internas do próprio sistema, pela política ou pela expansão espacial, só pode assim se estabelecer por meio de arbitrariedades ou unilateralidades, quase sempre autorrenferenciadas e autossustentadas, quase sempre ingênuas.

Quarto: certamente, um dos pontos centrais para a articulação dos três conjuntos anteriores de questões aqui levantadas reside na contradição em que a massa de trabalho passa a ser incorporada na magnitude produtiva criada para produzir e realizar exponencialmente a mais-valia. O fenômeno do "desemprego estrutural" tem ocultado sua real condição interna das mediações do sistema metabólico do capital; esconde nela a esmagadora sobreposição do capital constante em relação ao trabalho vivo, relativa e absolutamente. Tal como cada vez mais os índices de emprego acumulam insucessos de crescimento, sempre remediados por algum malabarismo estatístico ou políticas efêmeras de governos, é ainda a forma como se acumula uma massa precarizada de trabalhadores que, sem perspectiva e em clima de apatia derrotista, nada mais refletem do que ativação desse último limite absoluto do capital: a impossibilidade de continuar a expandir "vitoriosamente" o processo de extração da mais-valia, ainda que isso não deixe de significar motivos mais que suficientes para o aumento ainda mais dramático da exploração do trabalho, relativa e absoluta.

Para Mészáros, esses quatro conjuntos de condições que apontam a ativação dos limites absolutos só podem assim significar mediante o desenvolvimento histórico do capital a partir da mundialização que pressupõe a simultaneidade e a interdependência entre eles. Significa, em última palavra, a impossibilidade da "lei do valor" encontrar possibilidades de desenvolvimento nos limites estreitados do próprio sociometabolismo do capital; o que faz dela, da "lei do valor", não apenas a condição da crise, mas o meio de torna-la inteligível: "a fase progressista da ascendência histórica do capital chega ao encerramento precisamente porque o 
sistema global do capital atinge os limites absolutos além dos quais a lei do valor não pode ser acomodada aos seus limites estruturais” (MÉSZÁROS, 2011; p. 226)

Em Milton Santos a novidade diante deste quadro de alterações da natureza quantitativa e qualitativa da produção se expressa de forma curiosa em relação à Mészáros, pois é possível identificar os mesmos processos percebidos, embora esteja a crítica colocada de modo invertido. A inversão se dá exatamente, no caso de Santos, pela perspectiva de manutenção do caráter positivo do "meio técnico científico-informacional" ao colocá-lo como “condição" que, inclusive, passa a "orientar" a própria modernização. Isso implica não apenas no não reconhecimento das contradições estruturais internas da produção que se expressam como crise, mas sobretudo em necessariamente colocar essas contradições como "resultados", "consequências" que, dado os interesses dos "agentes hegemônicos", subverte a técnica para atingir seus próprios “interesses”.

No caso dos limites da mundialização apontados por Mészáros, observa Santos (a partir de sua observação sobre a "globalização") o mesmo processo; desmistifica a "fábula" da globalização, percebe os capitais se concentrando em corporações, mas retira dela a "empiricização da universalidade" por supor que os níveis de controle e dominação estariam na dimensão mais concreta da instrumentalização técnica do território.

Já foi dito anteriormente que a relação do capital como abstrato universal (capital social total) e como especificidade concreta (capitais individuais) é mediada por profundas contradições e que, tomar apenas sua dimensão concreta e material (dos "interesses das firmas", das "ações dos agentes hegemônicos") permite apenas a parcialidade conveniente ao território, mas também permite a quebra dialética entre o "fenômeno da técnica" e suas vinculações contraditórias com as "leis gerais do valor".

Embora a justificativa geográfica para tomar a unilateralidade da "empiricização da universalidade" contribua profundamente para explicar, a partir do espaço e do seu "temário geográfico", a "globalização", ela impede, por outro lado, o desenvolvimento das abstrações enquanto analítica interna dos processos. Por isso fala Santos em "mais-valia universalizada", como algo próprio do "meio técnico-científico-informacional”, como se a mais-valia em si não fosse uma universalização própria da relação estrutural entre capital e trabalho. Santos, dessa forma, como antes, não consegue sair do nível do capitalismo, enquanto a questão fulcral e decisiva, tanto teórica como metodologicamente, se encontra no nível do capital.

Assim reduzido à sua própria concreticidade, que faz a complexidade do capital global ser expressa pelos interesses de "firmas" diante do território, as abstrações universais tendem a serem advindas da própria empiria. Isso faz com que os limites da reprodução do capital em 
crise, longe de serem destrutivos pela sua natureza interna e contraditória, sejam reconsiderados, pois tratar-se-ia de seu "uso político" no território. Tal como em Costa e Moraes, o campo da política é retomado com certa independência em relação à "lei econômica do movimento da sociedade moderna", onde parece apenas tratar-se de se "apropriar" da técnica. Por isso que, nesse nível de identificação concreticista, as classes, sobretudo o proletariado, não podem ser expressão da lógica da contradição abstrata do valor, restando apenas suas personificações mais imediatas diante da empiria.

2.2 - Técnica: a autossustentação, a autorreferenciação e o sistema filosófico fechado

A técnica se torna a mais poderosa referência para a análise do espaço, tal como a mais poderosa referência epistemológica para a análise geográfica. Isso ocorre, no caso de Milton Santos, em "A Natureza do Espaço", momento de maturidade do pensamento do autor e onde se encontra efetivado todo movimento de transição para um pensamento especificamente geográfico. Mas, em paralelo, também o movimento de deslocamento do trabalho e toda dialética contraditória interna da produção que o envolve no seu processo de valorização. Tanto é assim que a primeira frase do primeiro capítulo poderia ser dedicada a Marx, em referência a uma das passagens mais conhecidas de "O Capital", caso pudesse ser lido "trabalho" onde se encontra escrito "técnica": "É por demais sabido que a principal forma de relação entre o homem e a natureza, ou melhor, entre o homem e o meio, é dada pela técnica" (SANTOS, 2008; p. 29).

Na relação dialética entre trabalho e técnica, pode-se mesmo até constatar que houve uma inflexão, diante dos objetivos claros de centralização deste último na "empiricização da universalidade" condicionada pelo "meio técnico-científico-informacional". Por exemplo, quando Santos se propõe ao projeto de desenvolvimento conceitual do "processo de produção do espaço", como idealizado no inspirador "Por Uma Geografia Nova", de 1978, assim afirmava: "A tese sustentada é de que, ao se tornar produtor, isto é, um utilizador consciente dos instrumentos de trabalho, o homem se torna ao mesmo tempo um ser social e um criador de espaço" (2002; p. 21). Aqui se constata forte aproximação com as teses da ontologia do trabalho em Lukács, mas também com os compromissos de desenvolvimento da dialética no interior da empreita epistemológica. Neste momento mais recuado da maturação teórica, é possível observar, não por coincidência, uma maior aproximação de Santos com o enfrentamento das contradições estruturais. "Capitalismo", "modos de produção", 
"contradições", "formação social" são categorias que fluem com mais intensidade e liberdade diante do contexto combativo de 1978.

Mesmo em relação ao contexto de início da década de 1990, em que o movimento teórico começava a incorporar a inflexão da crítica social, contexto de publicação de "Técnica, Espaço, Tempo", referenciado anteriormente, a circunscrição conceitual ainda tinha determinada carga de influência da economia política: "um instrumento de trabalho [...], em virtude de suas características técnicas, pode alcançar apenas determinado desempenho [...], a idade dos instrumentos tem implicações com o resto da economia [...], e com emprego, e assim por diante [...]" (SANTOS, 2013; p. 58)

Mesmo considerando que já estivesse aí sendo montada a estruturação teórica, a partir da técnica, que pudesse operar as inversões na lógica da universalidade entre o abstrato e o concreto - por exemplo, a totalidade incontrolável do capital sintetizado nas ações e interesses das "firmas" ("na verdade a força da firma vem, hoje, muito mais da sua capacidade de modificar, no momento hábil, regras do jogo econômico em sua própria área de atividade e em função de seus interesses emergentes" $)^{45}$-, é notória a conservação de relações que envolvem valor-técnica-trabalho, ainda que para ponderar uma busca por "explicativas", e não a busca efetiva da contradição ("essa noção [de combinação entre idade tecnológica e idade organizacional] pode ser concretizada com a ajuda dos conceitos de composição técnica e composição orgânica do capital") ${ }^{46}$.

Já em "A Natureza do Espaço", o relativo equilíbrio dialético tende a se romper inclusive para se tornar possível aqueles objetivos tidos também como importantes, para que a "geografia possa aspirar ao seu reconhecimento como uma filosofia das técnicas" $" 47$. Agora, o "conhecimento empírico", como imanente geográfico e tornado a própria abstração determinante universalizado, tende a aparecer de forma autodeterminada, autojustificada e autorreferenciada pela técnica: "O conhecimento empírico como simultaneidade dos eventos e o entendimento de sua significação interdependente - base para a empiricização da universalidade (Santos, 1984) - são um fator determinante da realização histórica” (SANTOS, 2008; p. 204). Afinal, seria por meio dela que "os atores hegemônicos" teriam agora condições de exercer o domínio de seus interesses no próprio exercício da escolha dos "melhores lugares para sua atuação e, em consequência, a localização dos demais atores é condenada a ser

\footnotetext{
${ }^{45}$ SANTOS, 2013; p. 59.

${ }^{46}$ Ibid., p. 60.

${ }^{47}$ Id., Ibid..
} 
residual"48. Completa-se, por meio da unilateralidade técnica, não apenas as possibilidades daquilo que mais tarde Antônio Carlos Robert Moraes haveria de reconhecer como a "soberba" geográfica $^{49}$, mas também uma evidência autocontraditória de que assim seria possível manter os compromissos interdisciplinares da "metadisciplina" pretendida.

Ainda que, em primeira análise, os problemas autocontraditórios da "metadisciplina" estejam atrelados a uma incapacidade de abandono do ideal estruturalista da lógica disciplinar (como será analisado no tópico "6.4 - A via positiva-epistêmica"), as pretensões de colocar o espaço e a técnica como "um fator determinante da realização histórica" (não mais um dentre outros) exigiriam um gigantesco exercício teórico-epistemológico para sua justificação. E não foram poucos os esforços. Mas, mesmo diante de seus resultados positivos com a conquista de condições explicativas das coisas como elas se afirmam (não como elas se negam) diante da "globalização", os problemas que envolvem a crítica geográfica e seus limites, dado o processo de internalização da própria teoria que tende a fazer com que ela se reconheça somente nela mesma, continuariam a se expressar deslocadas de um debate crítico com o pensamento crítico universal. Isso se observa não apenas em relação à crítica dos economistas que, diante da obviedade da crise, propõe a regulação, o controle e a taxação do capital no século XXI, como observado em Piketty e Krugman, mas também em relação à crítica radical que vê a condição atual não apenas diante das possibilidades destrutivas, mas sobretudo diante de uma crise estrutural, como em Kurz e Mészáros.

[Os limites reconhecidos da autossustentação]

Um ponto central a se observar diante do movimento de renovação como um todo é que a crítica da disciplina positivista, como aquela contra a New Geography, não avançou muito mais além do que a solução por uma disciplina estruturalista. Aliás, a própria análise sobre a "globalização" teria ainda este efeito "positivo", a de possibilitar efetivamente a constituição da "metadisciplina", como assim admite Santos em uma de suas últimas entrevistas: "Dir-se-ia mesmo que só na globalização as inter-relações entre disciplinas cabalmente possíveis e a

\footnotetext{
${ }^{48}$ SANTOS, 2008; p. 204.

${ }^{49}$ Assim será posto na apresentação do seu livro Geografia Histórica do Brasil, na edição de 2009: "Também não se assume a soberba de coloca-la como um corolário do saber gerado por todas as disciplinas com as quais ela dialoga" (MORAES, Antônio Carlos Robert, Geografia Histórica do Brasil: cinco ensaios, uma proposta e uma crítica, São Paulo, Annablume, 2009; p. 09).
} 
interdisciplinaridade se afirmam plenamente. A metadisciplina é, também, um resultado da globalização" ${ }^{50}$.

Os compromissos disciplinares, identificados positivamente com a necessidade epistemológica, não puderam ser postos de forma autocrítica porque se constituíram também como um dos objetivos da renovação: renovar a disciplina. Embora convenha nesse momento apenas relacionar essa condição à natureza da propositiva teórica que se monta sob tais circunstâncias, é preciso pôr apenas que a identificação dos compromissos disciplinares e sua positivação teórica-epistemológica tenderam a se moldar numa simbiose autojustificada: o caráter positivo das categorias (e suas condições unilateralmente "explicativas") em sintonia com a necessidade disciplinar. Ou seja, uma justificando a outra (necessidade e solução). Porém, mesmo que sobre esse manejo, da simbiose autojustificada, tenha-se tentado supor qualquer "dialética", mais cedo ou mais tarde, tais suposições tenderiam a se mostrar frágeis demais, pois logo se revelaria a ausência da contradição entre a crítica e a forma interna da lógica disciplinar.

Mesmo sem expor explicitamente os limites diante desse movimento tautológico por meio do qual muitos geógrafos justificavam suas perspectivas teóricas pela unilateralidade da “especificidade da disciplina geográfica", uma tautologia que só reproduz o ideário positivista de ciência e a distância dos objetos reais da realidade concreta e social, Milton Santos será um dos poucos que reconhecerá que o caminho da autossustentação da Geografia, a partir dela mesma, seria nada mais que uma volta sobre si mesmo (“A essa indagação, com frequência a resposta é buscada numa interminável discussão a respeito do que é a geografia. Tal pergunta tem recebido respostas as mais disparatadas, raramente permitindo ir além de formulações tautológicas") ${ }^{51}$. Mas, ao mesmo tempo, a própria forma de não expor a natureza íntima de tal problema já indicava que o caminho a ser seguido por Santos não haveria de ser radicalmente outro, senão o de conciliar, em nível mais elevado, a própria proposição teórica a uma nova base epistemológica disciplinar que, se não fosse autojustificada e autossustentada, deveria ser ampla o suficiente para o estabelecimento do "diálogo" com "outras" disciplinas: "A metadisciplina é a filosofia particular de cada disciplina que lhe permite conversar com as outras" $" 52$.

Não é, por isso, de todo surpreendente que até as últimas formulações de Santos, na defesa da "metadisciplina", não haveria de ter outra referência senão a de Althusser: "Eu

\footnotetext{
${ }^{50}$ SANTOS, 2000; p. 50.

${ }^{51}$ SANTOS, 2008; p. 18.

52 SANTOS, 2000; p. 50.
} 
chamaria de metadisciplina a vontade de filosofar nas disciplinas particulares. Era o que Althusser chamava de filosofia espontânea dos sábios o que eu chamo de epistemologia, embora os epistemólogos de carteira não gostem desta dominação" ${ }^{\text {53 }}$. O problema é que se conserva no ideário disciplinar de Santos o mesmo Althusser que, conhecido nos círculos estruturalistas e um dos mais originais propositores da quebra da unidade do pensamento econômico-político e filosófico marxiano, levaria ninguém menos que Caio Prado Júnior a qualificar de "aberrante" e "insólita a maneira com que vê a questão central da filosofia que é a do problema do conhecimento" (PRADO JR, 1971; p. 73)..$^{54}$

A técnica, por tais referenciais, não era apenas providencial, mas necessária para os objetivos da referenciação teórica que se pretendia inteira novidade: uma categoria que, embora analisada por geógrafos como Max Sorre, ainda não havia sido explorada em seu sentido "filosófico" na Geografia, tal como o espaço já havia sido pela metafísica e o trabalho pelo marxismo. Não seria por outros motivos que o primeiro subtópico do primeiro capítulo de " $A$ Natureza do Espaço" fosse dedicado à constatação da "negligência com as técnicas". Se, como visto, a teoria do valor, em sua mediação a partir do trabalho, teve que ser deslocada do interior do exercício epistemológico por ter se tornado não "especificamente geográfico", ou por trazer com ela uma problemática contraditória e dialética que extrapolam as fronteiras da disciplina, a técnica apresentava a forma de identificar um "vazio teórico" (como assim se referia Lefebvre às "descobertas" do movimento estruturalista na década de 1960) ${ }^{55}$, mas sobretudo e também à forma de reinventar algo efetivamente novo a partir dela ${ }^{56}$.

Isso se torna um tanto mais evidente quando, na perspectiva de centralização da técnica, argumenta Santos sua qualidade de congregar, no campo da empiria tradicionalmente geográfica e dotada de "coerência interna e externa", sua capacidade de reunir "categorias internas e externas" ${ }^{\circ 7}$. A técnica, seria assim, a possibilitadora, diante do vazio teórico constatado, de urdir as pretensões geográficas num "tríplice aspecto", como nas palavras de

\footnotetext{
53 Id., Ibid.

54 PRADO JR, Caio, O Estruturalismo de Levi-Strauss; O Marxismo de Louis Althusser, São Paulo, Brasiliense, 1971.

55 A relação entre as influências estruturalistas para a teoria geográfica e a crítica de Lefebvre serão analisadas também no tópico "6.4 - A via positiva-epistêmica". Por hora, basta apenas lembrar que sob o a produção de um] "vazio teórico", seria assim que, segundo Lefebvre, os estruturalistas passariam a moldar suas "novidades" teóricas: LEFEBVRE, Henri, Sociologia de Marx, Rio de Janeiro, Editora Forense, 1968.

${ }^{56}$ Em várias passagens em Milton Santos podem ser percebidos a disposição desse "vazio teórico", como, por exemplo, neste momento: "O período atual, cheio de promessas é, ainda, incompleto. Em sua listagem dos paradigmas tecnoeconômicos vigentes desde a revolução industrial, Fu-chen Lo (1991) deixa o espaço vazio para as novas inovações relativas à informação e à comunicação, onde parecem residir os principais elementos do mundo novo a cuja formação estamos assistindo" (SANTOS, 2008; p. 174).

${ }^{57}$ Ibid., p. 23.
} 
Santos: "como reveladora da produção histórica da realidade; como inspiradora de um método unitário (afastando dualismos e ambiguidades), e, finalmente, como garantia da conquista do futuro" ${ }^{58}$. Desde que "sejamos guiados, em nosso método, pelo fenômeno técnico visto filosoficamente, isto é, como um todo" ${ }^{59}$. Essas citações correspondem à introdução de " $A$ Natureza do Espaço" e indicam que, ao seu tempo, à Geografia já estão dispostos um "método" e uma "filosofia" própria.

[Do vazio teórico produzido à autorreferenciação]

Se, como mostrado, não seria com surpresa que deveria ser observada as vinculações de Santos com o estruturalismo, por outro lado, é com surpresa que se observa como que essas vinculações não foram identificadas de forma efetivamente crítica, mas apenas denunciativa, a partir do que se convencionou acusar o autor de "ecletismo". O próprio Milton Santos haveria de situar a "ignorância" contida em tal (auto)crítica: "As acusações de ecletismo, que muitas vezes escutamos de um lado ou de outro, são, muitas vezes, formas larvadas de dogmatismo e até mesmo de ignorância" (SANTOS, 1996; p. 133) ${ }^{60}$. Ou seja, o não reconhecimento da necessidade de uma (auto)crítica no sentido de desvelar como que a suposição do "vazio teórico" acabou por também servir, de forma autojustificada, aos objetivos com a crítica social; uma autocontradição não admitida no interior da unidade entre a "contribuição geográfica" e a “teoria social crítica" pretendida por Santos (2008; p. 23). A autocrítica seria necessária porque, em última análise, identificados os problemas limitantes da tautologia que seria a autossutentação da teoria da Geografia pela Geografia, não mais pela geografia da realidade, a busca dos referenciais a partir da categoria pela qual se pretendia elaborar um "método" e uma "filosofia" efetivamente "nossa" seria, ao mesmo tempo, mediado por um exercício autorreferenciado na técnica. Assim, mantendo-se o nível da denúncia de ecletismo, ou mesmo de "estruturalista", a autocrítica não poderia reconhecer os problemas internos de um sistema que se pretende filosófico, sobretudo dos problemas da autorreferenciação que esse sistema não haveria de superar, pois a autorreferenciação passaria, mais cedo ou mais tarde, a concorrer com própria referência do real.

\footnotetext{
${ }^{58}$ Id., Ibid.

${ }^{59}$ Id., Ibid.

${ }^{60}$ SANTOS, Milton, “Alguns Problemas Atuais da Contribuição Marxista”, In: Novos Rumos da Geografia Brasileira, São Paulo, Hucitec, 1996.
} 
Mesmo que a autorreferenciação em um "método" e em uma "filosofia" propriamente geográfica fosse positivamente apropriado para a solução teórica da necessidade epistemológica, a natureza de sua solução apenas deslocaria para um outro nível de profundidade e sofisticação as mesmas limitações e autocontradições teóricas das proposições autossustentadas. Essas limitações e contradições internas da autorreferenciação podem ser observadas em quatro níveis de análise sobre a conceituação técnica em Santos: a natureza da substância da técnica, a sustentação material, a sustentação histórica e a sustentação ontológica.

- A natureza da substância da técnica:

$\mathrm{Na}$ acusação superficial de "ecletismo", ou mesmo de estruturalismo, há um sentido lógico. Milton Santos iria responder a tais acusações se fundamentando na própria realidade que parecia mais "complicada": "Quando as realidades do mundo se complicam e novas disciplinas científicas se estabelecem para tentar explicar os contornos até então inexistente da história, recusar a utilização de tais ensinamentos é estupidez pura e simples" (SANTOS, 1993; p. 133). Mas esse era também o subterfúgio para insinuar certa "liberação" do rigor críticodialético com relação ao rigor teórico ${ }^{61}$. Afinal, de que forma poderia ser concebido uma unidade não contraditória entre Marx e Durkheim para a concepção materialista do "objeto geográfico"? Como pode ser lido em Santos em importante citação:

Em sua famosa definição dos fatos sociais, cuja existência se impõe à sociedade, e, independentemente deles, aos indivíduos, Emile Durkheim (1895, 1962, pp. 12 -13) distinguia entre meio de ação e meio de existência. Nessa definição ele inclui os "meios de ação fixos", um caso particular dos "meios de existência", isto é, "meios de ação cristalizados". Essa cristalização dos meios de ação segundo Durkheim pode ser considerada como equivalente ao "trabalho morto" da terminologia de Marx e seria mais bem representada, em nossos dias, pelo conjunto de objetos culturais que, ao lado ou no lugar dos objetos "naturais", cuja significação modificam, formam o que podemos chamar de configuração espacial, configuração territorial ou configuração geográfica, da qual a paisagem é um aspecto ou uma fração (SANTOS, 2008; p. 74-75).

\footnotetext{
${ }^{61}$ Milton Santos havia mesmo acusado aqueles que seguiam a fundamentação autojustificada da Geografia nela própria dizendo que "deste modo, à pergunta 'o que é Geografia', e a pretexto de liberdade, a resposta acaba por constituir um exercício de fuga” (SANTOS, 2008; p. 18).
} 
Não bastaria somente lembrar que sob nenhuma outra forma seria possível equivaler o conceito de "trabalho morto" em Marx a "meios de ação cristalizados" de Durkheim ${ }^{62}$; que sob nenhuma outra forma seria igualmente possível conciliar a energia contraditória que move o trabalho cristalizado no conceito marxiano e a "ação" proveniente dos meios "fixados" da definição durkheimiana, a não ser quando está pressuposto, diante do "vazio teórico", a liberação do rigor dialético em prol do rigor epistemológico. Afinal, só mesmo diante de um "vazio teórico", ou de uma referência desprovida da totalidade específica que compõe a teoria de Marx, ou a de Durkheim, é que seria possível conceber "trabalho morto" desprovido de "trabalho vivo", ou equivalente à abstratividade durkheimiana dos "meios de ação". Não apenas porque, como já demonstrado, o "fixo fixado" em Marx não teria nenhum sentido, nenhum "valor", a ser considerado se não fosse ele gelatina homogênea de trabalho. Por isso, ele não devém “ação", é a própria ação; movimento de seus valores (de uso e de troca) se chocando em sua própria materialidade que faz dela mercadoria, como tudo que se é produzido diante da lógica do valor-trabalho. No entanto, Santos, ao supor certa equivalência, já supõe certa substituição do que seria de fato a substância da técnica por ele centralizada, pois a ação cristalizada durkheimiana "seria mais bem representada, em nossos dias, pelo conjunto de objetos culturais que, ao lado ou no lugar dos objetos "naturais",63.

É dessa forma, inicialmente, que à técnica se concede a sua nova substância: a "ação". Esta que, na mediação com as técnicas específicas, também condiciona "ação" humana. Nesta substituição está contido o próprio deslocamento do trabalho (de sua substância incontrolável, expansionista e contraditória entre valor de uso e valor de troca) em prol de algo ainda não necessariamente contraditório. A “ação” não supõe a contradição, e ao supor a não-contradição pode ela, a técnica, como originária e também orientadora de ações, se positivar como universal abstrato determinante; ser mais que mercadoria, ser mais que histórica e especificamente definida pelo valor, podendo, assim, não estar condicionada às suas "leis". Mas essa positivação não viria de outra forma senão da unilateralidade de se pôr em ausência a negatividade, representada pelo valor de troca. Desta forma, não seria gratuita a citação em que, também de forma unilateral, Santos considera de Marx e Engels, sobre a dialética do trabalho, apenas a dimensão do "processo de trabalho" (e não também o "processo de valorização"): “Trata-se,

\footnotetext{
${ }^{62}$ De fato, as vinculações às referências de Durkheim não seriam pouco importantes: "De todos os sociólogos e filósofos citados no livro, é Durkheim aquele que revela uma clara noção do que, à sua época, era considerado pelos geógrafos como sendo o espaço, noção que, aliás, ele, Durkheim, buscava aperfeiçoar. Incompreendido pelos geógrafos, na época dos seus escritos, Durkheim ainda está esperando que e suas ideias a respeito do espaço sejam retomadas e devidamente aperfeiçoadas" (SANTOS, 2008; p. 85-86).

${ }^{63}$ SANTOS, 2008; p. 75.
} 
aliás, de uma das ideias de base ou Marx e Engels. Quando, através do trabalho, o homem exerce ação sobre a natureza, isto é, sobre o meio, ele muda a si mesmo, sua natureza íntima, ao mesmo tempo em que modifica a natureza externa" (SANTOS, 2008; p. 78).

A técnica passa a ser, por isso também, relativa à externalidade, porque não contém nela, diante de sua primeira substanciação, qualquer dialética em seu interior: é produto da ação e dos interesses, além de condicionar essas mesmas ações que devem se concretizar na empiria. É sempre uma relação do exterior-interior-exterior ao próprio objeto, e por onde unicamente uma certa dialética pode existir. Por isso a importância da circulação, da concreção e da empiria. Não seria produto da produção; mas tão somente para assim ser um abstrato de universalidade ainda mais genérico: a técnica orienta a produção. Passa, por isso, a ser mais do que produto do trabalho humano, além de algo que precede e sucede o próprio valor-capital. Essa condição não é propriamente uma absolutização, mas é a própria autorreferenciação, e é necessária para sua abstração, e por isso não deve admitir suas contradições.

Configurados como sistema, os objetos se movem também por uma abstração específica para além da teleologia abstrata e contraditória do trabalho sobredeterminado no valor. Entre os sistemas de objeto e os sistemas de ações, sua "intencionalidade", que, por sua vez, determina a natureza da "energia" da mediação. Devidamente equivalente à generalidade abstrata positiva das "ações", seria por isso a "intencionalidade" e a "energia" que, dependente das "normas", orientarão as ações condicionadas pelo meio técnico "desde a fase inicial das

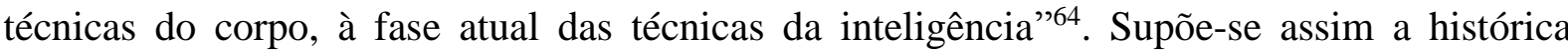
universalidade. A autodeterminação das técnicas, agora também comprovada historicamente, é equivalente à sua autonomia teórica que, na composição abstrata da técnica, vai, dessa forma, sintonizando suas subcategorias que irão paulatinamente concorrer e encerrar o movimento contraditório do valor que não mais pode atingir o interior da própria técnica.

Chega-se, então, pela sucessão de fases, à forma histórica da técnica condicionada pela novidade do "meio técnico-científico-informacional": a informação, como dimensão da ação, se torna componente da substância da técnica. Os sistemas de informações vão requalificando os históricos sistemas técnicos no contínuo "desencantamento do espaço geográfico" até o momento em que, "tendente a ser completamente racionalizado, [e sujeita] a regras preestabelecidas que incluem sua própria substância"65. Até chegar na informatividade, a "razão" substantiva a técnica: assim é que, sob o signo da modernidade, teriam como substância historicamente específica a ação mediada pela "racionalidade instrumental". Do abstrativismo

\footnotetext{
${ }^{64}$ SANTOS, 2008; p. 79.

${ }^{65}$ Ibid., p. 303.
} 
da "ação" durkheimiana, a técnica encontra a "razão", como nas palavras de Santos: "As ações são cada vez mais precisas e, também, mais cegas, porque obedientes a um projeto alheio. Em virtude do papel dos objetos técnicos, a ação é cada vez mais racional, mas a sua razão é, frequentemente, uma razão técnica" ${ }^{\text {"66 }}$. Uma razão especificamente moderna, conforme assim se observa a inserção da referência de Max Weber no desenvolvimento das formulações de Santos: "O meio técnico-científico representaria, na evolução histórica do espaço geográfico, o atingimento do nível de cálculo considerado por Weber, como necessário para impor um direito capitalista 'sobre o qual se pode contar como sobre uma máquina",67.

Ainda segundo Santos, Weber havia indicado a tendência de que o capitalismo perderia os limites da racionalidade, embora não houvesse propriamente a "irracionalidade". Para Santos esse momento é o que ocorre diante do "meio técnico-científico-informacional", um período limite em que se observa a expressão da tendência apontada por Weber, mas que seria também o momento cheio de "possibilidades" de se pensar a construção de "um novo sentido", por meio das "contra-racionalidades que a análise geográfica revela nos comportamentos atuais do campo e da cidade" $" 68$.

Aqui, novamente, uma vinculação tornada possível somente quando se submete o rigor crítico da teoria ao rigor epistemológico necessário para se constituir um sistema autorreferenciado. A racionalidade técnica de Weber não se refere ao abstrativismo da técnica (como nos termos de Durkheim), mas está, em sua integridade teórica, demarcada pela modernidade. Kurz, citado anteriormente, quando fala sobre modernização se baseia na formulação weberiana para demonstrar a demarcação das condições do trabalho especificamente moderno (“[...] esse ethos protestante do homem abstrato de trabalho dentro de uma sociedade transformada numa máquina de trabalho, declarada por Marx Weber como característica constitutiva ideológica do capitalismo [...])" "69 e como que, dentro desses limites, os sujeitos modernos, diante da fetichização da mercadoria, já estariam limitados também diante das formas de se pensar nas possibilidades de superação de sua própria condição, seja no "antes", seja ou "depois" da modernidade. Não seria de outra forma que Kurz procuraria explicar os limites da Revolução de Outubro: “os portadores desses desenvolvimentos já eram homens modernos, constituídos de forma capitalista, e suas controvérsias já estavam marcadas

\footnotetext{
${ }^{66}$ Ibid., p. 81.

${ }^{67}$ SANTOS, 2008, p. 303.

${ }^{68}$ Ibid., 310.

${ }^{69}$ KURZ, 1993; p. 22.
} 
pelas contradições do sistema produtor de mercadorias, mas essas contradições permaneciam insuperáveis" $" 70$.

Para Kurz, baseado na circularidade weberiana e diante do poder de fetichização da mercadoria, a possibilidade de superação das condições dadas pela modernização, sobretudo a partir dos sujeitos modernizados, tenderiam a se desaguar naquelas mesmas limitadas especulações sobre o futuro que Marx havia denunciado a utopia do movimento socialista de sua época.

Dessa forma, voltando ao caso das "contra-racionalidades" de Santos, como possibilidade de se pensar e experimentar o "novo", seria uma autocontradição sua referência weberiana se não tivesse o esforço epistemológico voltado para si mesmo. Isso porque a “contra-racionalidade" admitida, diante da lógica de universalização do fetichismo da própria razão técnica, não poderia supor sua autossuperação porque seu conceito estaria cristalizado como a própria "razão" capitalista em si: referência primeira e última. Tal circularidade weberiana não haveria de ser percebida por Santos porque, como demonstrado, a contradição interna do movimento que define a técnica foi esvaída. Nem mesmo as possibilidades de inserir o entendimento sobre os limites de uma possível "irracionalidade", como ativação de um limite absoluto (MÉSZÁROS) da própria razão técnica, poderia, nesses termos, ser considerados como uma contradição interna da própria dinâmica da técnica, diante da necessidade de sua positivação.

A questão não é simplesmente a arquitetura que permite conciliar autores como Marx, Durkheim e Weber, pois ela seria apenas a "forma" da epistemologia. Mas o que, em seu conteúdo, sobra-se diante de sua notável inconciliabilidade (se observada a importância e a necessidade de se manter a integridade das respectivas teorias). Somente diante da suposição de uma inteiramente nova "filosofia das técnicas" é que se pode presumir a incorporação conceitual de tais referências, mas, por outro lado, deve-se admitir como sustentação única sua autorreferenciação. Por isso que, depois de dado o primeiro passo a partir da alteração da substância da categoria tornada central (a técnica), agora liberta dos referenciais que parecia aprisioná-la, à sustentação deveria ser somada um complexo argumentativo vindo também de outros campos.

- Sustentação material

${ }^{70}$ Ibid., p. 51. 
Já foi demonstrado acima que, em Milton Santos, o posicionamento da centralidade da técnica em sua forma abstrata-filosófica não poderia ser efetivado sem a fundamentação do "meio técnico-científico" até sua variante "informacional”. Já foi visto também que Santos, na eminência da explicativa do que se apresentaria como o "novo" diante da globalização, haveria de promover as "fusões" até as diluições de categorias que, até então, pareciam importantes para a crítica da modernidade. Foi visto ainda que o saldo deste movimento significou o deslocamento da teoria do valor-trabalho (e suas contradições inerentes) do interior do seu exercício teórico fazendo com que fosse ela cristalizada no polo desenvolvido das relações produtivas capitalistas. Isso, por sua vez, tornaria inteligível a diferença entre o capitalismo por ele observado e as relações de produção do capital, como por ele não observado. E que esse conjunto de fusões seria a composição do próprio "vazio teórico" com que a filosofia da técnica deveria agora ser montada.

Assim, como sustentar a materialidade da técnica diante do não historicamente referenciável "meio técnico-científico-informacional" (ao menos em relação às principais referências disponíveis)? Construindo seu próprio "modo de produção técnico-científico".

Essas condições apontadas acima, que podem ser sintetizadas na "unicidade técnica", na "empiricização da universalidade" e na "mais-valia universalizada" (como "motor" do movimento), articuladas em relação indissociável, se pretendem como absolutamente novas de tal forma que poderia, mesmo em "A Natureza do Espaço", ser proposto, em substituição ao modo de produção capitalista, o "modo de produção técnico-científico". O que não ocorre. Mas ocorrerá mais tarde em um texto específico, de 1998, sintomaticamente intitulado: "Modo de Produção Técnico Científico e a Diferenciação Espacial"71.

Neste texto, em que a argumentativa é praticamente a mesma em relação ao famoso livro de 1996, nota-se como o procedimento se repete, no sentido de estabelecer o debate em cima de um "vazio teórico" em torno do "modo de produção": "Estabelecido por Marx e Engels, como ponto nodal de sua teoria da história, o termo 'modo de produção' não recebeu uma verdadeira definição dos seus fundadores" ${ }^{, 72}$. Assim é feito, apesar de na sequência expor o entendimento conceitual a partir de Marx: "Segundo Marx, a noção de modo de produção é central porque, a cada etapa de evolução da sociedade, os homens participam de um processo

${ }^{71}$ SANTOS, Milton, "Modo de Produção Técnico Científico e a Diferenciação Espacial", Revista TERRITÓRIO, ano IV, nº 6, jan./jun. 1999.

${ }^{72}$ Ibid., p. 05. 
unitário, que inclui formas materiais de produção, relações dos homens entre si e com as coisas $[\ldots]^{1,73}$.

Independente de quão confusa seria a avaliação de Santos se teria Marx definido ou não o conceito de "modo de produção", o que é necessário considerar para o debate é que Santos não havia de fato entendido a natureza do sistema filosófico de Marx (que seria um sistema necessariamente aberto pelas próprias condições com que a dialética deveria transitar entre o rigor científico e o rigor crítico do real), exatamente porque o seu sistema filosófico estaria em sentido contrário, dada as condições com que, por exemplo, o "modo de produção" deveria também compor a autorreferenciação específica para a "técnica".

Embora nesse ponto não há muito o que insistir, dado que a fundamentação em si já estaria pronta em "A Natureza do Espaço", longamente aqui já debatido, o interessante é notar o momento exato em que o modo de produção capitalista, diante de sua universalização empiricizada no globo ("A marcha do capitalismo marca um alargamento e aprofundamento dessa lógica, incluindo cada vez um número maior de sociedades e territórios. O modo de produção tende a ser único") ${ }^{74}$, tal como o reconhecimento de ele não se tratar de um conceito inviável, inclusive para a geografia atual do mundo ("Mas também é certo que, em nenhuma outra época, um modo de produção teve uma difusão tão generalizada [...]. Esse modo de produção global é um dado explicativo maior da realidade geográfica atual") ${ }^{75}$, e diante dessas afirmativas, como se torna especificamente modo de produção técnico-científico: depois como um derivativo ("Se o novo modo de produção é global, ele somente o é por ser, também, um modo de produção técnico-científico") ${ }^{76}$, antes como a própria referência ("Tais conteúdos de técnica, de ciência e de informação constituem a nova variável motora que permite reconhecer um novo sistema temporal, com a organização de um novo espaço") ${ }^{77}$.

- Sustentação histórica:

A abstratividade necessária à técnica a ser concebida como sistema filosófico do qual a Geografia deveria se referenciar (“o que faz falta, aliás, seria uma metadisciplina da geografia, que se inspire na técnica” $)^{78}$, necessitaria também de sua própria história. Se já foi demonstrado

\footnotetext{
${ }^{73}$ Ibid., p. 06.

${ }^{74}$ SANTOS, 1999, P. 06.

${ }^{75}$ Ibid., p. 07.

${ }^{76}$ Ibid., p. 08.

${ }^{77}$ Id., Ibid.

${ }^{78}$ SANTOS, 2008; p. 47.
} 
como ela se comportaria, do pondo de vista teórico-instrumental ("o recurso à técnica deve permitir identificar e classificar os elementos que constroem tais atividades") ${ }^{79}$, era preciso observar seu desenvolvimento em sua história autorreferenciada: “Através dos objetos, a técnica é história no momento de sua criação e no de sua instalação e revela o encontro em cada lugar das condições históricas [...]"80.

De fato, Santos já havia elaborado a história da técnica antes mesmo de sua referência autopositiva esboçada em "A Natureza do Espaço", nos famosos períodos técnicos: "meio natural", "meio técnico" e "meio técnico científico-informacional". Não seria demais lembrar dos "cinco períodos" (comércio em grande escala, manufatureiro, revolução industrial, industrial e técnico-científico) propostos desde a década de 1970 e publicado na coletânea "Espaço e Método". Mas é naquele último momento que seus propósitos se voltam para a necessidade de sustentação da "filosofia das técnicas", uma história que não haveria de mudar seu conteúdo de empiricidade e, por isso também, superar a linearidade reducionista da leitura historicista.

Não seria gratuita a observação de que, na sequência da argumentação sobre a necessidade epistemológica da historicização (“a epistemologia da geografia deve levar isso em conta. A técnica nos ajuda a historicizar, isto é, a considerar o espaço como fenômeno histórico e geografizar, isto é, produzir uma geografia como ciência histórica") ${ }^{81}$, volta-se Santos para a argumentativa sobre "as técnicas e a empiricização do tempo" como a própria forma de fundamentar historicamente a emergência da novidade que seria a "empiricização da universalidade", como visto, mas agora no nível da própria "concretização da metafísica" conduzida pela técnica informacional: ("Máquinas chamadas inteligentes e pensamento calculante são, juntos, testemunhas dessa transcendência da técnica que conduz a uma verdadeira concretização da metafísica, com a produção das realidades artificiais e das imagens de síntese") ${ }^{82}$.

- Sustentação ontológica

Milton Santos, apesar de ter admitido os limites das periodizações como forma de reconhecimento de um "tempo espacial" ("também assim o problema não se resolve, porque as

\footnotetext{
${ }^{79}$ Ibid.; p. 48.

${ }^{80}$ Id., Ibid.

${ }^{81}$ SANTOS, 2008, p. 49.

${ }^{82}$ Ibid., p. 187.
} 
periodizações no dão, sem dúvida, um tempo, mas apenas um tempo externo a cada subespaço $)^{83}$ não haveria de retirar de sua arguição as fases de evolução do espaço no tempo. Isso porque era importante, dado que desta forma seria preservado a evidência histórica de estar a técnica, desde a remoticidade humana, ligada à relação homem e meio para a constituição do espaço: "sempre existiu, sempre existirá!". Mas também era providencial para as pretensões de manutenção e equalização com tradição geográfica de se preservar o foco na concreticidade da empiria até, por fim, se chegar nos limites da "concretização da metafísica": "Assim empiricizamos o tempo, tornando-o material, e deste modo assimilamos ao espaço, que não existe sem materialidade" 84

No entanto, seria necessário chegar ao "tempo interno" do espaço do qual a técnica “entra aqui como um traço de união, historicamente e epistemologicamente", entre o próprio tempo e o espaço. Como visto, seja porque o valor-trabalho já havia sido deslocado de sua internalidade, seja porque o caráter negativo da própria produção do espaço havia sido deslocado de sua internalidade, a fonte das abstrações universais da dimensão interna não haveria de ter outra referência senão a própria empiria: "As técnicas participam na produção da percepção do espaço, e também do tempo, tanto por sua existência física, que marca as sensações diante da velocidade, como pelo seu imaginário. Esse imaginário tem forte relação empírica" (SANTOS, 2008; p. 55).

A ontologia surge como forma de sustentação dessas abstrações que, advinda da empiria, deveriam ser universalizadas, mesmo que depois deveriam elas retornar à concreticidade. Como já estavam esgotadas outras formas de sustentação da apreensão interna do espaço, ou por serem elas "metafísicas" demais, ou por serem elas "econômicas" demais, o "esforço interpretativo de dentro" $" 85$ do espaço, a partir da filosofia das técnicas, ganhava assim sua dimensão ontológica. Isso ao passo que o espaço perde definitivamente sua condição de resultado da contradição entre processo de trabalho e processo de valorização. A forma específica da ontologia do espaço na feição miltoniana, que só seria possível de ser realizada em "A Natureza do Espaço", em que toda fundamentação da "empiricização da universalidade" já estava desenvolvida, não teria outra função senão a referenciação da própria relação técnicaespaço vista de forma geográfica.

Tal sustentação ontológica para a epistemologia geográfica ganha terreno, não por coincidência, no mesmo momento em que, por função do avanço neoliberal e da fragmentação

\footnotetext{
${ }^{83}$ Ibid., p. 52.

${ }^{84}$ Ibid., p. 54.

${ }^{85}$ SANTOS, 2008; p. 19.
} 
flexível na década de 1990, se tem um avanço significativo contra os movimentos sociais e contestatórios no plano político-concreto. À sustentação ontológica se torna inerente o reforço do caráter de internalização da crítica geográfica no âmbito e nos limites da epistemologia. Embora muito pouco se tenha dito sobre essa relação, entre a função ontológica para a internalização da crítica geográfica dada exatamente no contexto de criminalização neoliberal contra os movimento sociais, ela acaba por refletir a própria impossibilidade de à ontologia ser concedida sua abertura efetivamente dialética para o real, porque ela já foi concebida dentro de um sistema autorreferenciado entre espaço (ser), técnica (categoria) e Geografia (epistemologia); todos estes, por sua vez, autorreferenciados na dimensão da empiricização propriamente geográfica do concreto ou do abstrato. Essa relação do espaço com a ontologia tenderá a ser generalizada no movimento da renovação como um todo, sobretudo diante ao contexto de crise que se monta a partir da década de 1980, como será debatido no próximo capítulo que é dedicado exclusivamente à questão ontológica.

[O sistema fechado da "filosofia das técnicas"]

A filosofia das técnicas proposta por Milton Santos, diante da sua imanente autorreferenciação, não poderia ser outra coisa senão um sistema fechado. É importante observar isso a partir das formulações do mesmo autor que a pretendia como sistema aberto: “[....] para apreendermos a constituição atual do espaço e surpreendermos a emergência de conceitos, cujo sistema é aberto, e cuja a dialética, nas condições atuais do mundo, repousa na forma hegemônica e nas demais formas de racionalidade". Disso se observa uma condição contraditória: ao mesmo tempo em que os objetivos epistemológicos que concedesse à disciplina geográfica seu "enfoque abrangente" que a permitisse "participar em um debate filosófico e interdisciplinar" ${ }^{" 86}$, assim só foi possível pela construção de condições com que o exercício teórico só poderia encontrar suas soluções diante da própria Geografia. Isso parece óbvio, num primeiro momento, mas o que se esconde diante da obviedade é que estão aí absolutizadas suas limitadas condições disciplinares de apenas mostrar as coisas como elas se afirmam, não como elas se negam. O saldo do sistema fechado é a incapacidade de desenvolver uma leitura que busque objetivar as contradições reais, ao menos até suas últimas instâncias humanas-emancipatórias.

\footnotetext{
${ }^{86}$ SANTOS, 2008, p. 47.
} 
Em Milton Santos, os limites da não-contradição podem ser observados diante de várias perspectivas, inclusive aqui já apontadas: de ver uma história como possibilidades do desenvolvimento técnico, mas sem o saldo das crises; de observar a racionalidade técnica e ver as "contra-racionalidades" como expressões de sistemas técnicos não complexificados, mas não como "irracionalidade" destrutiva da própria técnica ${ }^{87}$; de ver o mercado, a concorrência e não observar que a cooperação e a solidariedade possível é a da mercadoria; de olhar para o movimento da universalização da competividade, a busca pela "mais-valia universalizada", mas ver somente suas personificações imediatas nas "firmas" e nas multinacionais; de olhar para a desigualdade e enxergar "agentes hegemônicos", em detrimento dos marginalizados, pobres, e excluídos da globalização, mas não vê a contradição de classe, o proletariado; de observar a técnica, enxergar o trabalho morto, mas não observar o movimento do trabalho vivo, nem por isso o trabalhador como sujeito da produção; de ver a produção, sob tais condições, e não enxergar seu conteúdo destrutivo imanente e contraditório.

Por isso que o desafio "em separar da realidade total um campo particular, susceptível de mostrar-se autônomo e que, ao mesmo tempo, permaneça integrado nessa realidade total" $" 88$ só pode ser admitido quando esta mesma realidade é vista apenas unilateralmente, e a busca da totalidade se reduza a somatória das "províncias do saber", como "aspecto da realidade global”, não como um todo em movimento contraditório em si mesmo que se abre para o real.

Assim, a técnica autorreferenciada tende a se absolutizar, como determinante universal, diante de sua suposta autonomia. Não seriam poucas as admissões de suas expressões pelo próprio Santos, a ponto de ser até mesmo colocada como questão-afirmativa diante dela: "Estaremos diante de um determinismo de tipo novo, um neodeterminismo do espaço artificial?". Mas somente desta forma é que seria elevada a última instância sua condição de abstratividade, pois além de se expressar como "coordenadas que orientam as novas ações" 89 , passaria ela também, como visto, a ser "determinante da realização da história", diante das possibilidades que parecem se abrir sob suas mesmas condições que produzem seletividade e desigualdade: bastaria sua apropriação política.

A unilateralidade com que a "filosofia das técnicas" deve necessariamente se expressar é uma outra forma de considerar a parcialidade com que as teorias que compuseram seu sistema de fusão foram apropriados. Não basta somente lembrar como que Santos foi seccionando

87 “O que muitos consideram, adjetivamente, como 'irracionalidade' e, dialeticamente, como 'contraracionalidade', constitui, na verdade, e substancialmente, outras formas de racionalidade, racionalidades paralelas, divergentes e convergentes ao mesmo tempo" (SANTOS; 2008; p.309).

${ }^{88}$ SANTOS, 2008, p. 20.

${ }^{89}$ Ibid., p. 203. 
teorias e porções de teorias a serem incorporadas ou excluídas, por sistema de montagem epistemológico onde, diante do vazio teórico por fim produzido, não mais seria resguardada sua totalidade integral, como assim foi na argumentação sobre "a necessidade de um enfoque abrangente" em "A Natureza do Espaço", mas também foi na montagem providencial entre Durkheim, Weber e Marx. A contradição é que a autonomia histórica e relativa da técnica desaguou em sua própria autorreferenciação absolutizante que, por fim, nada mais reproduz que o seu próprio fetiche.

Pensar em contradições sociais por meio de um sistema de pensamento filosófico autorreferenciado não apenas é uma autocontradição do pensamento, mas o meio de se conservar as mesmas contradições sociais objetivadas pelo pensamento. Por isso que Milton Santos não pode avançar muito diante dos objetivos emancipatórios com a teoria, sempre na esquiva negativa de resguardá-la diante de suas vinculações de militância, como aliás também assim se estabelece sua referência na negatividade weberiana, reproduzida por Kurz e profundamente criticada por Mészáros.

Para Mészáros, a teoria que se pretende absolutamente negativa, ou ela se contempla com a reprodução das coisas como elas se afirmam, ou estão alinhadas ao discurso da barbárie de que "não há alternativa". Embora o debate entre as posições de Mészáros e Kurz (e por consequência o posicionamento de herança frankfurtiana) serão mais dispostos no tópico "6.3 - A via da negatividade", por ora basta apenas mencionar a busca do referencial marxiano diante dos problemas em se conceber o sistema autorreferenciado da técnica. Isso porque o sentido do desenvolvimento intelectual-conceitual de Santos em torno da técnica (da ciência para a filosofia) é curiosamente inverso em relação ao do trabalho em Marx (da filosofia para a ciência), como será lembrado por Mészáros: "não é surpreendente que o ônus de produzir uma estrutura geral de orientação radicalmente definida [...] tornou impossível para Marx completar qualquer um de seus trabalhos mais importantes" $" 90$.

A abertura de Marx, da filosofia para a economia política, embora tivesse mesmo como objetivo a realização da "filosofia do homem", se deu em reconhecimento que o sistema hegeliano (dominante em sua época) era também autorreferenciado na sua mesma filosofia e que, por isso, seria preciso "buscar a ideia na própria realidade" 91 , para além de seu caráter especulativo mítico. Um segundo ponto, ainda conforme Mészáros, "se refere ao fato de que a constituição de uma forma adequada da teoria deve ser concebida como parte essencial da

\footnotetext{
${ }^{90}$ MÉSZÁROS, 2008; p. 100.

${ }^{91}$ Ibid., p. 99.
} 
unidade entre teoria e prática" ${ }^{92}$. Para isso, uma crítica negativa seria necessária diante de suas próprias referências, por mais que elas continuassem a compor seu corpo argumentativo, a exemplo de Aristóteles, Hegel, Smith e Ricardo.

Tais considerações sobre a natureza de um sistema interpretativo eminentemente aberto para o real em contradição não apenas demonstra, ainda segundo Mészáros, como o sistema filosófico de Marx atingiria tal efetividade, mas explica ainda como Santos, ou qualquer outro geógrafo diante dos compromissos epistemológicos autorreferenciados, não poderia retirar de Marx qualquer "definição" conceitual, nem sobre "modos de produção" (como visto), nem sobre qualquer outra categoria que se pretende circunscrita nos limites disciplinares apenas. Por isso que, diante dos referenciais que se pretendem "abertos", a técnica, tal como o trabalho, não pode abstrair-se de suas contradições internas sob o risco de acabar se absolutizando, sobretudo como elemento ontologizado, no desenvolvimento de sua própria autorreferenciação.

Dessa forma, diante da obviedade da crise estrutural, desconsiderada pela ótica da epistemologia geográfica positivada e autorreferenciada, é que a técnica, tal como o trabalho, sob as determinações do capital em seus processos de acumulação mais recente, se constitui em elementos da destrutibilidade, não apenas da produção, mas da própria sociabilidade. Por isso que a tomada teórica sobre essas categorias não pode ser "positiva", mas eminentemente negativa e crítica. Porque elas expressam uma contradição estrutural: estão ela unidas em uma dialética, não apenas autoprodutiva, mas profundamente autodestrutiva. Mészáros é enfático ao demonstrar como que essa condição se torna possível diante da ativação dos limites absolutos do capital no que concerne especificamente à relação trabalho e técnica: é que seu desenvolvimento, como não se dispõe mais como barreira a ser superada pela expansão do capital (como observado por Santos), a própria valorização destrutiva tende a se voltar contra a técnica exatamente porque ela não possibilita mais "meios" de expansão. Assim ocorre no processo que Mészáros denomina como "taxa de utilização decrescente".

Ao tempo de Marx, da técnica só se observaria suas condições de produtividade ou barreira para a produtividade. Essas condições, como demonstradas por Santos, são qualitativamente diferentes, pois não limitam mais suas necessidades quantitativas de produção em permanente expansão. Ocorre que o tempo máximo de trabalho, vinculado com a técnica, para a produção corresponde, inversamente, ao tempo mínimo para o capital. O desenvolvimento do valor cristalizado na mercadoria está em razão invertida com seu tempo de

\footnotetext{
92 Id., Ibid.
} 
trabalho. A produtividade decorrente da utilização decrescente do tempo de trabalho se expressa em um aumento quantitativo de valores de uso dispostos ao consumo. Se uma mesma quantidade de trabalho, ou uma quantidade decrescente, tende a se cristalizar em cada vez mais valor de uso, ocorre que, necessária e relativamente, há sempre uma "taxa de utilização decrescente" na própria produção geral: "A taxa de utilização decrescente está, em certo sentido, diretamente implícita nos avanços realizados pela própria produtividade" ${ }^{93}$. Sua existência independe de condições de exceção de crise, por exemplo; embora nos momentos de crise ela tenda a se expressar por formas mais irracionalmente destrutivas. No entanto, ela está presente também diante das condições normais do sistema do valor.

Considerando a relação entre capital e trabalho mediado pela técnica, está implícito na natureza produtiva desta sua condição de atuar sobre a produção em geral (inclusive de si própria) segundo essas mesmas leis da "taxa de utilização decrescente" do seu valor de uso como forma de realização necessariamente expansiva do valor de troca. Mészáros destaca que a contradição interna é que o crescimento da taxa de utilização decrescente caminhou positivamente com o desenvolvimento técnico capitalista, ainda que essa positividade estivesse condicionada aos limites negativos da própria relação-capital. Entretanto, “como resultado da absurda reversão" 94 promovida pelas condições de alto desenvolvimento técnico a taxa de utilização decrescente se promove como possibilidade de não apenas se expressar na extensividade quantitativa das mercadorias, mas agora na intensidade qualitativamente destrutiva: “em favor dos produtos de 'consumo' rápido e da destrutiva dissipação de recursos, o 'capitalismo avançado' impõe à humanidade o mais perverso tipo de existência que produz para o consumo imediato" $" 95$.

Dada as condições com que, inclusive pelo "meio técnico-científico-informacional", a incontrolabilidade e a totalização do capital tende a universalizar suas relações "hegemônicas", as relações destrutivas da taxa de utilização decrescente tendem a se universalizar igualmente em relação às suas próprias dimensões produtivas aqui consideradas: técnica e trabalho. Do ponto de vista do trabalho não se expressa somente com o irremediável desemprego estrutural, mas na tendência de utilização de suas formas extremamente contraditórias como, por exemplo, a "peonagem", ou mais conhecido como trabalho escravo moderno. Do ponto de vista da técnica, que a esta altura já está fetichizada como "orientadora da produção" por meio de sua

\footnotetext{
${ }^{93}$ MÉSZÁROS, 2011, p. 639.

${ }^{94}$ MÉSZÁROS, 2011; p. 642.

${ }^{95}$ Id., Ibid.
} 
suposta racionalidade autonomizada, se constata o radical de desligamento de sua finalidade humana na radical tendência de separação entre produção e consumo.

Por isso que, insistirá Mészáros, não se trata de simples reapropriação dos "controles", nem da subversão da "razão" que substancia a técnica, muito menos de sua apropriação política, pois a técnica, da forma específica de sua existência histórica (e não haveria outra técnica a ser considerada), é fruto da estrutural divisão social do trabalho da qual fora ela projetada a reproduzir e intensificar. Longe de representar ela possibilidades para a realização da história, deve ela mesma ser transformada historicamente em sua natureza íntima, como denunciava Mészáros a ideologia, ou "utopia", da tecnificação socialista soviética, em que nada de muito diferente poderia se esperar se não for, de fato, "reestruturada e profundamente democratizada de um modo totalmente inimaginável nas condições de sociedade de mercado capitalista. Nenhuma boa vontade política pode substituir isso" ${ }^{96}$. 


\section{CAPÍtUlO 3 - A SOLUÇÃO ONTOLÓGICA E OS LIMITES PARA A CENTRALIDADE DO ESPAÇO}

Dentre as geografias do trabalho que surgem do movimento da renovação crítica, a primeira a indicar um debate ontológico foi a proposta de Armando Corrêa da Silva. No ano de $1975^{97}$, quando o movimento ainda ensaiava sua postura crítica, revelava Silva seu propósito: "Conversando com um professor de filosofia indagou-se dele sobre a possibilidade de uma ontologia do espaço geográfico. Respondeu que era possível e que seria um trabalho científico e cultural" (SILVA, 1998; p. 09). Na verdade, segundo o próprio autor, tais preocupações já vinham sendo nutridas desde a publicação do texto intitulado "Ciência e Valor em Geografia", no ano de 1972, como referenciado no início do capítulo anterior. Nesse texto mais antigo, expõe Silva suas preocupações metodológicas frente um contexto de fragmentação, pelo desenvolvimento técnico-científico, e de crise da unidade geográfica. Para tais questões, propõe o autor que os problemas decorrentes da insuficiência das respostas dos geógrafos requeriam uma leitura "globalizadora do problema, o que implica, sem dúvida, na consideração do problema do valor, como ponto de partida" (SILVA, 1988; p. 89).

A preocupação central de Silva com o método é também uma preocupação com a definição da própria Geografia ("a ciência define-se por um método") 98 ; ao tempo em que a preocupação com o "valor" é também em relação ao "humano"; da mesma Geografia que se pretende humana (“Ora, considerar o homem é também considerar o valor”) 99 . A mediação entre as preocupações científicas-metodológicas e "humanas" para com a Geografia se encontrariam, pouco mais tarde, na maturação do pensamento de Silva, na busca pela totalidade ontológica dentro do debate geográfico. No entanto, esclarece Silva no texto de 1975 que não se trataria de uma busca "metafísica", dado os riscos de se perder numa filosofia sem fim, pois sendo o espaço seu objeto deveria ser assim ele posto em centralidade objetiva da busca epistemológica contra as possibilidades de fragmentação científica.

Observa-se nesse momento da proposta metodológica (e ontológica) de Silva duas inversões em relação ao texto anterior de 1972: o objeto em detrimento do método, ciência em detrimento da filosofia. O que parecia ser óbvio, dada as vinculações científicas do autor, é que a escolha do objeto cientificamente bem definido estava condizente com sua proposta de

\footnotetext{
97 O texto "Espaço Geográfico Como Totalidade", do qual Silva indaga as possibilidades de uma ontologia do espaço geográfico, foi originalmente publicado na Revista Geográfica, n ${ }^{\circ}$ 82, IPGH, México, em junho de 1975, como assim pode ser observado em de rodapé (SILVA, 1998; p. 09) em sua publicação de 1978.

${ }^{98}$ Ibid., p. 94.

${ }^{99}$ Ibid., p. 97.
} 
Geografia frente ao contexto de fragmentação e crise social. O que não estava explicitamente óbvio eram os desafios teóricos, dado que o debate ontológico não poderia ser feito sem a metafísica, menos ainda sem a retomada de um profundo debate sobre o método (a dialética) que, também na filosofia, ainda havia muito a que se desenvolver. Mesmo considerando somente o âmbito restrito da ontologia, ainda era bastante incipiente tal debate no Brasil entre os professores de filosofia, ainda mais entre os geógrafos.

A solução ontológica, motivada pela imanência da fragmentação e crise científica, e pela "conversa com o professor de filosofia", parecia encontrar seu hiato no momento em que, de forma não admitida, metafísica e ciência, método e objeto, passariam a concorrer diante dos desafios teóricos cada vez mais vinculados à necessidade de apresentação das propostas epistêmicas. O atraso reconhecido da Geografia diante do debate das ciências sociais, e a consequente "ânsia pela atualização acadêmica" ${ }^{100}$, se compuseram como os elementos centrais de um movimento contraditório em que, ao mesmo tempo, acelerava e promovia as epistemologias novas, como a de Silva, mas retardavam, por outro lado, as possibilidades de uma crítica inteiramente nova e fundada em uma dialética madura e efetivamente aberta para as contradições do real.

Ainda tomando como exemplo a proposta de Silva, é notório como que a ontologia foi inserida com a objetivação imediata de relacionar à tradição geográfica as categorias novas que surgiam como perspectivas da crítica social, por sua vez muito influenciada pela perspectiva estruturalista, até sua via mais positivista da racionalidade matemática do planejamento. No caso embrionário de Silva, no texto intitulado "O Espaço Geográfico Como Totalidade", é tentada a relação entre o "desenvolvimento desigual" e a integração dos fatores "genéticos" de formação do espaço, ou como suas diferenças e desigualdades se dão desde o entrelaçamento dos fatores físicos na formação ontológica das paisagens naturais; ou ainda como os "fatores econômicos, sociais, políticos e culturais" 101 formam a paisagem cultural. Para Silva, as diferentes paisagens comporiam o próprio "meio geográfico" em sua relação unitária: "O meio natural e o meio cultural formam o meio geográfico. Este modifica-se no decorrer do tempo à medida que se desenvolvem a história natural e a história humana" (1988; p. 10). A “estrutura”, então, se sucederia à análise da "formação" e assim procederia pela "localização dos fenômenos" que, relacionando o físico e o cultural, tornaria o "habitat" a categoria possível

\footnotetext{
${ }^{100}$ Assim se referirá Antônio Carlos Robert Moraes a um contexto bem mais adiantado da crítica geográfica (2005). O objetivo em estabelecer este paralelo é incutir que o imediatismo não apenas predominou nas formulações epistemológicas originárias da renovação crítica, mas a ela continuou a seguir no seu desenvolvimento (MORAES, 2011; p. 135).

${ }^{101}$ Ibid., p. 10.
} 
para se entender o "sítio", este como a unidade onde se abrigariam os grupos humanos ("Este é o lugar que abriga efetivamente um grupo humano") ${ }^{102}$. A "situação" seria, em decorrência da escolha do "sítio", a relação entre "elementos" ou "unidades" do meio geográfico. Tira-se daí um "espaço de relações" que deverão ser classificados em "relações horizontais", "verticais", "internas" e "externas". A análise dessas relações deveria fornecer a "hierarquia" entre elas. Admite Silva, no entanto, que tal procedimento da análise da "estrutura do espaço" já havia sido concebido nas obras de Humboldt e Ritter, mas consideraria não haver ainda um “estudo sistemático sobre o assunto" (SILVA, 1988; p. 12).

À estrutura espacial, ainda segundo Silva, deveria ser somada suas "características". Estas, também já consideradas pelos clássicos, deveriam agora revelar, como indicado pela “teoria da difusão espacial” (de GOULD, 1969), se as estruturas dispõem seus fenômenos em “dispersos, concentrados, contínuos ou descontínuos na superfície do Globo"103. Pela forma de como se apresentam a disposição desses fenômenos seria possível identificar os "vazios", físicos e culturais. Às "estruturas", devidamente caracterizadas, deveriam ser incorporadas a análise sobre seus "processos e funções" no sentido de perceber seu movimento de "polarização". A análise dos processos e funções, segundo Silva, poderia ser melhorada "pelo seu tratamento matemático aplicado à Geografia"104. As "transformações", fenômeno novo no tempo das observações de Silva, seria observado pelo trabalho no planejamento dos "processos" e "funções". Isso tudo, na síntese entre "formação", "estrutura”, "processos e funções" e "transformações", representaria o "significado" do estudo completo do espaço para a consciência humana ${ }^{105}$.

É notório o esforço de Silva em tornar inteligível a fusão de tantas categorias de origens teóricas distintas, algumas delas até antagônicas. Mas tal esforço e o relativo sucesso diante dos seus resultados ocultava um grave problema metodológico. O ser do espaço é assim afirmado como síntese necessária à composição da uma saída epistemológica para o problema que aparentemente deveria ser resolvido pela ontologia, e não apenas uma mera relação com a filosofia ${ }^{106}$. Por outro lado, tal esforço de síntese (ou de fusão de teorias) se distancia do esforço

\footnotetext{
102 MORAES, 2011, p. 11.

${ }^{103}$ Ibid., p. 12.

${ }^{104}$ Ibid., p. 14.

105 Ibid., p. 15.

106 Não é de todo suficiente a explicativa de que as "motivações ontológicas" se deram pelo simples desejo em "dialogar com a filosofia", como assim é assimilado pelas interpretações mais desatentas sobre tal processo: "Por que o tema da ontologia ganharia tamanha envergadura no contexto da geografia brasileira? Certamente devido à importância que ela tinha entre os filósofos brasileiros como Ruy Fausto e Arthur Giannotti. A crítica ao estruturalismo e as leituras althusserianas de Marx os encaminhou para o tema" (PEDROSA, Breno Viotto, "A Geografia Crítica Brasileira e o Debate sobre a Ontologia do Espaço: uma Aproximação”, Revista Geografares, $\mathrm{n}^{\circ} 11$, p.139-168, Junho, 2012. ISSN 2175 -370; p. 143).
} 
crítico em reconhecer nessas distintas perspectivas as contradições entre si. Naturalmente este não poderia ser o caminho epistemológico de Silva, pois poderia significar um paradoxo no próprio esforço de síntese. Mas, por outra perspectiva, a não admissão da contradição pode significar uma limitação para os mesmos objetivos de síntese, ou de fusão teórica, que se dá como saída epistemológica para o problema da fragmentação disciplinar, além de uma questão fundamental sobre os termos em si do exercício teórico que pode indicar fissuras em sua composição: como considerar a formulação uma teoria ontológica eminentemente geográfica (e sua própria epistemologia) se sua própria composição se faz por fusão de outras teorias que, por vezes, nem expressam relações com a "especificidade geográfica"?

Como então tratar esse problema entre a saída ontológica como substantivação da crítica epistemológica, mas ao mesmo tempo não conferir a ela, a crítica, a contradição como elemento central do método que a sustenta? Em outros termos, como se apresenta o problema entre a crítica ontológica e a urdidura de uma epistemologia objetivamente crítica que, de antemão, não admitiu suas próprias contradições internas? Em desdobramento, como garantir à epistemologia geográfica sua condição efetivamente crítica, fundamentada em um discurso ontológico do espaço, apesar de não ser assimilado em sua dialética interna o movimento da contradição como objetivo da análise científica? Assim, como garantir que a ontologia do espaço não signifique sua própria absolutização? E como entender a história (ou o tempo) com o espaço absolutizado? Como chegar nas contradições "sócio-espaciais" se, internamente, na sua composição epistemológica, o rigor autocrítico não for o procedimento determinante para sua confecção?

Admitir ao menos a possibilidade de que, no exercício epistemológico em torno do discurso ontológico do espaço, possa haver problemas de resolução metodológica como as apontadas acima, significa se atentar para um grave problema na sua constituição teórica. Se tais problemas - não exclusivos ao exercício de Silva - forem de fato reais, poderia indicar uma série de inversões metodológicas operadas pelas propostas epistemológicas que tendiam a revelar seus limites e, em consequência, os limites de sua própria teoria. Por exemplo: que a ontologia tendeu a significar uma "saída epistemológica", não um fundamento metodológico crítico do ser social; que o ser espaço, dessa forma, tendeu a se absolutizar contra a própria história; e que o debate sobre o método tendeu a se confundir com a própria epistemologia geográfica, e a ela se reduzir e limitar. Confirmada tais suspeitas, ao menos na forma de tendência (como é pretendido demonstrar aqui), significaria compreender como na busca pela ontologia do espaço há uma questão de método não resolvida, ocultada pela "ânsia” das 
"soluções epistemológicas", que tendeu a conferir à crítica social geográfica sua própria anticrítica.

3.1 - Das "linhas de fuga" à crítica do "amálgama originário"

Voltando à proposta embrionária do professor Armando Corrêa da Silva, que a um só golpe esboça uma fundamentação do espaço a partir de uma síntese de fusão entre a tradição geográfica (ou seus "fatores genéticos" das paisagens físicas e culturais desde Humboldt e Ritter), os fundamentos tipicamente estruturalistas da "forma", "função", "estrutura", e sua consequente "aplicabilidade matemática" eminentemente positivista, a ontologia tende a aparecer aqui não apenas destituída de qualquer possibilidade crítica dada a forma afirmativa com que a "estrutura epistemológica" deveria ser aplicada, tudo isso possibilitado pelo casamento "ontológico" entre estruturalismo e positivismo, mas também pode ser identificado nela a busca pelo fundamento gnosioepistêmico, que acompanharia boa parte das tentativas de ontologização do espaço pelo movimento da renovação crítica. Tal fundamento tem como objetivo subsidiar a interpretação ontológica, não partir do rigor da autocrítica dialética que por meio dela seria possibilitado, como observa José Chasin $(2009)^{107}$, mas sim por meio da evidenciação da eterno-presença do objeto perante a história (sempre existiu, logo ontológico!). Chasin havia identificado esse "fundamento" na especificidade das "interpretações" com que o epistemologismo passou a incorporar as análises de Marx, o que levou a uma ontologização do trabalho, e a consequente precarização da dialética, a seu nível mais absoluto, sobretudo a partir do "marxismo soviético".

Ainda sobre Armando C. da Silva, para o acompanhamento de seu pensamento na sequência do presente debate é preciso considerar que sua perspectiva ontológica se desenvolveria ao longo do percurso do seu trabalho acadêmico para além da aplicabilidade positivista presente nas tentativas embrionárias até aqui observadas ${ }^{108}$.

Até chegar em sua "linha de fuga" para a superação da fragmentação do "real em pedaços", disciplinar e histórico, a partir de mais uma tentativa de unidade ontológica que objetivaria "o território possível” para uma Geografia fragmentada pela própria prática intelectual-epistêmica (que havia se reapresentado no final da década de 1980), foi traçado um

\footnotetext{
${ }^{107}$ CHASIN, José, Marx: Estatuto ontológico e Resolução Metodológica, São Paulo, Boitempo, 2009.

${ }^{108}$ Chagaria mesmo a afirmar Silva que a referida coletânea, O Espaço Fora do Lugar, seria um "trabalho ainda com a influência do período anterior" (SILVA, 1984; p 06).
} 
caminho bastante representativo para se entender as formas de inserção na Geografia das perspectivas ontológicas.

O que encontra Silva em sua "linha de fuga", no texto e na coletânea, ambas emblematicamente intitulada "De Quem é o Pedaço" - livro "não sistemático"109 publicado em 1986 com um viés mais fenomenológico diante das novas condições "do fazer em pedaços" do pensamento que, assim, deverão se (re)montar, reproduzir, no fazer pensar ${ }^{110}$-, representaria a nova tentativa, ainda como solução epistemológica, de uma proposta de totalidade que "fugisse" da tendência fragmentária da crise geográfica no sentido de resolver os problemas derivados de Gramsci acerca do papel dos intelectuais: "Como os intelectuais se relacionam por sua condição de intelectuais, o problema que se coloca é o dos intelectuais e dos outros" ${ }^{\prime 11}$.

Objetiva, assim, Silva, no plano da uma composição de síntese e de uma totalidade interpretativa, o resgate ontológico das questões levantadas por Harvey sobre o espaço ("O que é o espaço?"; "como que as práticas humanas distintivas criam e fazem usos distintos de concepções do espaço?" ${ }^{112}$ ), e o papel do intelectual em buscar suas soluções. Dentro do universo fragmentado "em pedaços" dos "subespaços na construção ontológica", propõe Silva sua própria superação, a partir do "pensar como montagem", pelo encontro das perspectivas de Lukács e o "território possível do ser social” (também presente em Hegel), este como procedimento de identificação do estatuto ontológico, como meio de "separar o verdadeiro do falso para estabelecer integridade do pensamento" ${ }^{113}$, como a possibilidade de superação do real; de Marx considera Silva o "território possível da história", como forma de desvelamento das ideologias para a afirmação da existência humana; e em Ratzel é reconhecido o "território possível da Geografia", a partir da relação imbricada entre solo, sociedade e Estado. Em síntese, afirma Silva, o território possível como ser: "Então, o território, enquanto ser, duração e extensão, deve pôr-se em movimento" (1986; p. 161)

Entre a proposta embrionária de 1975 e a proposta de 1986, o avanço da ontologia de Silva é notável, sobretudo pelo abandono, em certa medida, dos vieses estruturalista e positivista. Mas ainda é possível observar como que se é conservado a forma de "fusão" com que a síntese é montada sem que seja posto os problemas de se conciliar Marx e Ratzel, por exemplo, num mesmo corpo teórico. Se o recurso ontológico se mostra possível em uma síntese

\footnotetext{
109 "O tema substantivo deste livro pretende ser uma contribuição não sistemática sobre a noção contemporânea de território" (SILVA, Armando Corrêa da, De Quem é o Pedaço: Espaço e Cultura, São Paulo, Hucitec, 1986; p. 09).

110 Ibid., p. 09.

111 Ibid., p. 168.

112 Ibid., p. 160.

113 Ibid., p. 160-161.
} 
de fusão entre o estruturalismo e o positivismo, como na proposta embrionária de Silva, tal como na fusão entre Marx e Ratzel exposto na sua propositiva em "De quem é o pedaço", é porque está evidenciada uma ontologia voltada para uma "resolução epistêmica", não uma solução prática, o que é também metodológica, para se pensar o espaço como ser. Afinal, como poderia conceber sem constrangimento teórico o fato de a ontologia "servir" diante de propostas teóricas tão distintas como aquela estruturalista-positivista da década de 1970 e as de maturidade mais vinculada a um idealismo acadêmico?

[A Ontologia do "Professor de Geografia" versus A Ontologia do "Professor de Filosofia"]

José Chasin, ao observar como a teoria marxiana havia decaído perante as ânsias de suas resoluções epistêmicas, identifica no marxismo um movimento análogo. Para Chasin, no momento em que Marx passa a ser interpretado como "síntese de fusão" entre a filosofia alemã, a economia política inglesa e o socialismo francês, tendo como justificativa a necessidade de identificação epistêmica do pensamento de Marx, isso passa a ser o pressuposto da própria quebra de sua unidade dialética. O filósofo Chasin chamará isso de "amálgama originário" e defenderá a tese de que a unidade do pensamento de Marx não está na síntese de fusão deste “amalgama tríplice” (CHASIN, 2009; p. 29) ${ }^{114}$, mas na constituição de um pensamento próprio e originalmente genético: "Obviedade patente, a lida constante e decisiva de Marx - em torno dos ramos de ponta da produção teórica de sua época - não implica a química da retenção e ligadura das melhores porções dos mesmos no tamanho da própria obra"115. Todavia, considerando o pensamento de Marx a partir da síntese de fusão amalgamática, a dialética que comporia seu fundamento não haveria de encontrar outra forma de apreensão que não fosse aquela conciliatória, destituída de qualquer necessidade de análise mais profunda: “[...] nunca pensada e resolvida, mas que vai restando, ao longe, na qualidade de cômodo suposto residual, cuja crítica parece que convém sempre deixar de lado, porque trabalhosa, e talvez, indutora de embaraço" (CHASIN, 2009; p. 30).

Mas qual a relação da crítica de Chasin à forma amalgamática com que a teoria marxiana passa a ser interpretada, tal qual a sintese de fusão com que a ontologia geográfica é

\footnotetext{
114 "Desde muito cedo, sempre que carecia apresentar e esclarecer o ideário marxiano, este tendeu a ser exposto como um amálgama de origem tríplice. Até frase esparsas de Marx [...] e muito especialmente asserções que sustentam que 'devemos reconhecer que o proletariado alemão é o teórico do proletariado europeu, como o proletariado inglês é seu economista e o francês seu político', talvez tenha arrimado ressonâncias precipitadas à falta de conhecimento de causa" (CHASIN, 2009; p. 29).

${ }^{115}$ Ibid., p. 39.
} 
experimenta, em seus primeiros esboços no esforço de Armando C. da Silva? Dois problemas não observados: que a dialética ou se instaura como unidade originária para a fundamentação da teoria, sobretudo a ontológica, ou será passível de sua própria fragmentação e decomposição em movimento antidialético; e que a busca epistemológica pode transformar a ontologia em mero recurso de legitimidade científica, não necessariamente crítica, tendendo a operar por absolutizações do objeto ontologicamente pretendido.

Nesse sentido, observa-se que, tanto pela tradição positivista posta na proposição embrionária, como pelo viés fenomenológico (no sentido hegeliano) presente em sua solução para o "real em pedaços" de 1986, a perspectiva de Silva encontra na crítica do "filósofo" seus limites, pois ela contém seu próprio "amálgama originário" e os consequentes problemas decorrentes dele. Isso significa, como coloca José Chasin, um entendimento da crítica submissa à uma "resolução epistêmica" oscilante entre opostos radicais de uma análise "estrutural" ou uma "análise imanente" (2009; p. 25), como pode ser observado entre as duas propostas ontológicas de Silva. Tal analogia não é gratuita, pois somente sem as devidas mediações dialéticas entre ofilosófico-metafísico, o histórico-político e o material-econômico, é que pode encontrar Silva a possibilidade de constituir seu próprio "amálgama tríplice” especificamente geográfico composto, por sua vez, entre Marx, o marxismo lukacsiano e a geografia de Ratzel.

Da análise "estrutural” que caracteriza a proposição embrionária de Silva, supõe-se uma crítica desprovida de dialética, um materialismo levado às últimas instâncias (um Marx sem Hegel) para a composição de uma "Geografia aplicada". Da "análise imanente” que caracteriza sua proposta em "De Quem é o Pedaço" o problema se apresenta de modo inverso. Pois está suposto a suficiência idealista do "intelectual" que, manobrando a razão, como aplicador da lógica (um Hegel sem Marx), pudesse substanciar a partir das abstrações no seio da própria teoria (seja a partir do espaço, seja a partir das "possibilidades do território") os fundamentos da própria transformação do "real em pedaços".

Outro ponto importante e crítico do "amálgama originário" e conciliatório proposto por Silva em sua proposição ontológica em “De Quem É O Pedaço" foi o de não se ter aprofundado, como exercício autocrítico em sua tomada hegeliana, acerca das questões metodológicas que envolvem o debate sobre a ontologia de Lukács. Conforme Chasin, a necessidade de estudo da dialética interna da ontologia do filósofo húngaro se faz importante não somente pelos avanços no reconhecimento da ontologia no pensamento marxiano, "mas [também porque havia ele se embaraçado] no entendimento do método de Marx [...] exatamente por se exceder na vinculação de Marx a Hegel, apesar de certos cuidados e a interposição de restrições apropriadas" (2009, p. 30-31). Não por coincidência esse é o ponto contributivo da teoria de Lukács para a síntese 
ontológica de Silva, como irá admitir: "Em Lukács, um dos territórios possíveis é o território do ser social em Hegel” (1986; p. 160).

Sem tais cuidados em observar o "excesso" lukacsiano das "vinculações de Marx a Hegel", como demonstrado por Chasin, Silva não poderia ainda se atentar para um outro problema da ontologia de Lukács denunciado por ninguém menos que seu o principal assistente. Mészáros, apesar de toda tentativa de justificação e explicitação dos motivos históricos que levaram os posicionamentos políticos teóricos do seu mestre, não deixará de admitir que apresentaria Lukács um "discurso ontológico remoto"116. Silva não haveria de observar tais problemas no escopo das influências da ontologia de Lukács, não apenas porque tal empreitada analítica parecia estar além dos objetivos afirmativos da epistemologia geográfica, providencialmente conciliáveis com a tradição concreticista e gnosiológica da disciplina, mas sobretudo porque a própria forma de composição do amálgama originário, por síntese de fusão, não deveria admitir a contradição entre suas fontes. A não-contradição era, assim, importante porque possibilitava o engate positivo-afirmativo de uma ontologia "epistemologizada", ao mesmo tempo que "liberava" a dialética de seu rigor metodológico (negativo) para tornar viável as conciliações entre perspectivas conflitantes e até antagônicas, como, por exemplo, as de Lukács e Ratzel. A influência "filosófica" se incorpora, dessa forma, como a garantia de legitimidade de sua "linha de fuga" ao lhe conferir o devido estatuto ontológico; não mais como garantidor de uma teoria crítica, como assim fora para Lukács, mas como legitimador de uma teoria científica especificamente geográfica.

No entanto, o que Silva tende a proceder com o remotismo hegeliano, contido no método ontológico de Lukács, é inserir o "território possível” da história de Marx na perspectiva do território ratzeliano, mas tal vinculação não seria possível sem a própria retirada do papel das mediações (dialética-contradição) entre o "universal" e o "histórico" do próprio Marx. Isso, porém, teria uma justificativa, pois somente destituindo a dialética de tal fundamento é que se tornaria possível qualquer conciliação também entre Ratzel e Marx, autores entre os quais há muito mais contradições do que qualquer possibilidade de composição unitária, quando se observa o fundamental: a totalidade que envolve a composição teórica de ambos. A condição do "amálgama originário", como identificado por Chasin (geneticamente) diante das pretensões

\footnotetext{
116 Assim admite Mészáros sobre os limites da perspectiva metodológica da ontologia de Lukács: "discurso ontológico remoto, sem indicar as necessárias mediações materiais e institucionais que pudessem superar, pelo trabalho crítico estratégico, as dificuldades e contradições identificadas do presente" (MÉSZÁROS, Para além do Capital, 2011; p. 501). Tal debate será mais aprofundado no tópico "3.2 - Estatuto Ontológico versus Teoria da Transição".
} 
“epistemologistas" de parte da crítica marxista, não apenas encontra aqui sua variante geográfica, mas ainda se reforça na perspectiva ontológica da "linha de fuga" de Silva.

A forma "amalgamática" de compor "linhas de fugas" epistemológicas, como aquelas elaboradas por Silva, é, no entanto, observada de modo geral em todo movimento embrionário da crítica ontológica da renovação geográfica. A ontologia será assim concebida como "amálgama originário", pois a ela será dada a função de ser, ao mesmo tempo, instrumento legitimador das propostas epistemológicas ao tender a lhes conferir o estatuto metodológico, e ainda aquele "cômodo suposto residual", como levantado por Chasin (2009; p. 30), onde serão depositados, ou refugiados, aqueles incômodos elementos da crítica social genérica deslocadas das pretensões da crítica científica e especificamente geográfica; ou aquelas outras categorias que, como o trabalho e a contradição, aparecem como abstratas demais, cuja crítica espacial parece relegar "porque trabalhosa e, talvez, indutora de embaraço", deveriam ser situada como categorias não-geográficas.

Questiona-se, então: seria válida ou mesmo possível estabelecer tal linha crítica à Silva a partir de Chasin? Seria forçoso remeter a crítica de Chasin à "aglutinação eclética" "117 proposta por Silva, a respeito dos meios com que os epistemologistas "envolvem cumulativamente a ciência em geral"118. Seria exagerada tentar entender a crítica do "amalgama originário", tal como a crítica contra o "epistemologismo", à tentativa de Silva em reunir, em uma solução ontológica para a fragmentação e crise da ciência geográfica, as teorias de Lukács, Marx e Ratzel? Seria igualmente injusta a crítica do "filósofo" se dirigir ao geógrafo, quando aquele acusa de "unilateralidade" a tentativa de constituição da "identidade do método" fundamentada numa "fusão" arbitrária de diferentes perspectivas teóricas ${ }^{119}$, diante dos objetivos do geógrafo em propor ao trabalho intelectual a busca de uma relação complementária para compor sua própria totalidade? Seria ainda inviável simplesmente transpor, mecanicamente, a crítica da filosofia em torno das pretensões cientificistas da dialética, feita pelo marxismo, à forma como a crítica geográfica havia pensado sua práxis, ou a forma como o geógrafo "aplicaria sua teoria"?

De fato, a crítica do "amalgama originário" elaborada pelo "filósofo" não seria adequada aos esforços de ontologização do espaço em "suas linhas de fuga", se não estivessem elas compartilhando e dialogando diante de um mesmo contexto da teoria crítica no Brasil e, sobretudo, se não fosse ele, José Chasin, aquele "professor de filosofia" com que Armando

\footnotetext{
117 CHASIN, 2009, p. 32.

118 Id., Ibid.,

${ }^{119}$ Ibid., p. 34.
} 
Corrêa da Silva havia se consultado ${ }^{120}$, ainda na década de 1970 , sobre as possibilidades de uma ontologia do espaço $^{121}$. O mesmo professor Chasin que, por meio dos cursos sobre o estudo marxista, especificamente sobre Lukács, haveria de influenciar outro importante autor que contribuiu para o debate ontológico, Antônio Carlos Robert Moraes, como assim revela Paulo César Scarim:

As leituras que [Moraes] desenvolveu nos grupos de estudos marxistas buscou trazer para a Geografia, resultando em textos na década de 1970, como, em um curso de um ano sobre a obra de Georg Lukács, com o professor José Chasin, cujo resultado é o texto da Revista Temas de Ciências Humanas, publicado em 79, que se chama "Valor, Espaço e a Questão do Método", que já possui as ideias básicas que depois, juntamente com Wanderley Messias da Costa, desenvolve no livro "A Valorização do Espaço", publicado em [19]84. (2000; p. 187). ${ }^{122}$

Tal relação entre a crítica do "amálgama originário" levantada por Chasin (na especificidade do marxismo) e as tentativas de ontologização geográfica não é, dessa forma, gratuita. Geógrafos e filósofos conversaram e a não observação dessas questões críticas sobre o "rigor ontológico" é uma evidencia de como a pretendida "autonomização" do método, da teoria e da epistemologia propriamente geográfica significou também seu isolamento, com sérios prejuízos para a constituição de "uma" teoria crítica social efetiva. Estabelecer a relação entre "filosofia" e "Geografia" (na especificidade de Chasin, Silva e Moraes) pode oferecer ainda elementos para o entendimento de como, por mais "interdisciplinar" que fossem seus esforços e sua "ânsia pela atualização", contraditoriamente, o desenvolvimento da teoria crítica geográfica não acompanhou o desenvolvimento da crítica social (no caso do Brasil), tendendo a se refugiar naquelas questões tidas como "especificamente geográficas" ${ }^{123}$. Ou seja, a "nova" teoria crítica geográfica se refugiando em sua própria tradição.

A recusa da "metafisica", sob o perigo "de ver sua esfera de ação estender-se muito ao infinito", como dirá Milton Santos (2002; p. 146) acerca da necessidade de definição dos limites da ciência, não passaria despercebida, sobretudo em relação à forma de composição de uma

\footnotetext{
${ }^{120}$ As observações do colega e professor Gilmar Santos, sobre a necessidade de estudar José Chasin para o debate da ontologia geográfica são fundamentais como contribuição para a leitura aqui apresentada.

${ }^{121}$ Como indicará Silva em nota de rodapé "Trata-se do professor Chasin, ex-professor da Escola de Sociologia e Política de São Paulo" (SILVA1988; p. 09).

${ }^{122}$ SCARIM, Coetâneos da Crítica, 2000.

${ }^{123}$ As negativas filosóficas, pela "dificuldade" de se adentrar em campo do conhecimento alheio, irão continuar a justificar, até tempos mais recentes, a separação nítida e o não desenvolvimento pleno do debate entre ontologia e Geografia: "Cabe ressaltar a dificuldade de transitar pelo assunto, pois o termo e as discussões da ontologia são da filosofia. Portanto temos um intercruzamento entre um tema científico e filosófico" (PEDROSA, Revista Geografares, 2012; p. 143).
} 
dialética precária (FAUSTO, 1983), fundamentada em conciliações e complementariedades, pelo dever de estar ela submissa à necessidade imperiosa de positivação a partir da epistemologia.

Do ponto de vista histórico do desenvolvimento da teoria e das "leituras" e "interpretações" ${ }^{124}$ sobre a crítica dialética no Brasil, que passam a se aprofundar na década de 1980, e em relação a qual os geógrafos estabelecerão uma complicada mediação de afirmação e negação imanente, o percurso de Chasin é paralelo com o percurso de Silva. É curioso observar que entre o geógrafo e o filósofo, em um primeiro momento, há uma identificação em relação à "saída ontológica" para suas questões teórica e metodológica. Mas depois, em um segundo momento, esses caminhos se bifurcam: para o filósofo tratava-se de mergulhar nos fundamentos filosóficos da crítica ontológica ${ }^{125}$, sobretudo na "interpretação" de Marx, para assim se chegar aos significados negativos do método: "a rigor, não há uma questão de método no pensamento marxiano" (2009; p. 90) ${ }^{126}$, assina Chasin como forma de garantia e rigor autocrítico da análise que se põe com o necessário rigor científico. Para o geógrafo, tratava-se de aprofundar na leitura ontológica até o ponto do reconhecimento do estatuto metodológico e conferir ao espaço os mecanismos de seu entendimento e afirmação: "A linha de fuga conduz ao centro, que é centro recorrente, começo de encontro do movimento do território" (SILVA, 1986; p. 162). Assim são até um terceiro momento, em que os caminhos seguem em contramão, pois para o geógrafo a ontologia se interioriza como estatuto metodológico do espaço enquanto ser, para o reconhecimento das coisas como elas se afirmam espacialmente, enquanto que para o filósofo seria a ontologia "a não-certeza inicial como ponto de partida da certeza e do elucidamento do real em suas conexões íntimas" (VAISMAN e ALVES: 2009; p. 15) ${ }^{127}$ no sentido de desenvolvimento da crítica à sua última instância emancipatória.

\footnotetext{
${ }^{124}$ Estabelecerá Chasin o rigor crítico de diferenciação entre "leitura" e "interpretação", considerando esta última com a forma de "fazer provar" o que se "leu". (2009; p. 25).

${ }^{125} \mathrm{O}$ livro aqui referenciado surge originalmente como texto de posfácio do livro de Francisco Soares Teixeira, intitulado Pensando com Marx, e publicado em 1995. As colocações da proposta ontológica de Silva já se apresentam nos contornos maduros de seu desenvolvimento desde, pelo menos, 1986, ano de publicação de De Quem é o Pedaço.

${ }^{126}$ Isso em nada tem a ver com uma postura "anti-científica" que possa ser atribuída a Marx ou a Chasin. "Ao contrário. É um clarão que alerta para a peculiaridade do tratamento marxiano desses temas [científicos], de modo que a ausência de equacionamento convencional do assunto é apenas o sinal negativo da completa conversão e resolução positivas que a matéria encontra na reflexão marxiana, ainda que só trata ocasionalmente e esparsamente, tanto que a mesma não foi reservado um único texto exclusivo e sistemático que delineasse os contorno de sua fisionomia" (CHASIN, 2009; p. 89)

${ }^{127}$ VAISMAN, Ester. ALVES, Antônio José Lopes. “Apresentação”, In CHASIN, Marx: Estatuto ontológico e Resolução Metodológica, 2009.
} 
3.2 - Estatuto ontológico versus teoria da transição

O "amálgama" da proposição ontológica de Armando Corrêa da Silva não estaria completo se não fosse considerado o seu livro composto integralmente como exposição de uma "síntese" que seria, ao mesmo tempo, uma resposta e uma proposta de totalidade (ou subtotalidade) para o problema da fragmentação da disciplina geográfica que se apresenta no final da década de 1980 - um momento mais tenso quanto as garantias da unidade crítica dada a efetivação concreta do colapso da experiência soviética e das novas investidas pós-modernas contra a "dialética" e a teoria crítica-social. "Geografia e Lugar Social”, livro publicado no ano de 1989, representa uma alternativa perante os dois movimentos contextualmente percebidos por Silva - aqueles que entendem a fragmentação como totalidade e aquelas que admitem o fracionamento disciplinar - e teria como objetivo, na fala do autor, "[...] construir uma síntese das primeiras, em que se admite a divisão do conhecimento mas se tenta articulá-la como subtotalidade" (SILVA, 1991; p. 08) ${ }^{128}$.

Também nesse livro se observa um elemento comum aos outros textos de Silva: a condição positiva de síntese do pensamento como forma de solução dos mesmos problemas da “crise" e da "fragmentação" disciplinar. Aliás, o discurso da crise, importado desde as décadas de 1950 e 1960, não apenas seguirá a mesma linha de justificação da necessidade epistemológica (como observado no capítulo "2 - A Necessidade Epistemológica: crítica da crise à crise da Geografia") até os tempos mais atuais da renovação crítica, mas também e paradoxalmente, como se percebe em Silva, diante dessa mesma "crise" e da mesma "fragmentação", a natureza da crítica geográfica irá buscar soluções igualmente "internalistas" pela retomada das proposições epistemológicas que oscilará desde uma via "aplicada" e manualística, suas formas fenomenológicas mais próximas possíveis das soluções lógicas e idealistas dos "intelectuais", até por uma crítica do trabalho ingenuamente deslocada dos problemas socioeconômicos reais (como se observará a partir da proposta de Silva em “Geografia e Lugar Social"). Todas elas, conservando aquela mesma "aglutinação eclética" denunciada por Chasin, estruturalmente corporificada em um sistema "pretenso de fusão" e supostamente salvaguardada "pelos poderes mágicos do sacro nome da dialética" (2009; p. 31 32); uma dialética sem contradição e por isso mesmo aberta para as mais diversas formas de guinadas ontológicas onde à todas elas se tornarão possíveis afirmações epistemológicas supostamente críticas.

${ }^{128}$ SILVA, Armando Corrêa da, Geografia e Lugar Social, São Paulo, Contexto, 1991. 
No entanto, em "Geografia e Lugar Social”, diferente das duas propostas anteriores, o exercício ontológico adquire como elemento "auxiliar" a categoria trabalho na composição de estatuto científico, não somente como forma de mediação humana com a "força natural" para a composição do espaço (“[...] o espaço terrestre é posto como dado de força natural e a força de trabalho, que é como o apreende a observação geossocial") ${ }^{129}$, mas também como o processo que resultaria na lógica da formação do ser espaço ("formações naturais e sociais supõe o trabalho e, por isso, relações de produção" $)^{130}$. A inserção do trabalho representaria o elo com o que havia de mais desenvolvido na crítica social, eminentemente marxista, que seria a crítica ontológica como estatuto metodológico do conhecimento a partir do debate posto por Lukács e a crítica do valor a partir do debate econômico-político.

Na especificidade da proposta de Silva em "Geografia e Lugar Social”, a formação social seria a síntese entre o "modo de produção social, assim como o modo de produção natural"131, que, por sua vez, permitiria sua "apreensão" do real em suas duas dimensões: natural e social. Isso permitiria ainda supor a formação social como lugar que possibilitaria a identificação das mediações econômicas da "população" e o natural: lugar de trabalho, lugar de consumo, lugar de passagem. Entre formação social e meios de produção identifica Silva uma contradição, pois a formação social, enquanto passageira, "movimento", seria um momento do modo de produção.

Mas o espaço como ser, no que concerne a sua composição como totalidade, concorda Silva com Moraes à afirmativa de que deve a ele ser considerado sua condição ontológica inorgânica-orgânica, como a natureza em si, "sem a impulsão finalística", mas "em termos lógicos e históricos, admitimos que é nesta realidade que se forma o ser social, forma mais elevada da materialidade"132. Para os geógrafos, a natureza pré-historicizada, como dimensão ontológica concreta engendrada por uma história natural, que, assim, apropriada e transformada depois pelo trabalho, seria base geográfica, ou sua dimensão do "reino absoluto da causalidade" 133 , para a própria formação da concretude do espaço e do ser social, "forma mais elevada da materialidade" 134 . Tais condições conduziriam a "ação transformadora" entre o social e o natural a partir do ato teleológico, direcionado a um fim, que imbricariam homem e

\footnotetext{
${ }^{129}$ SILVA, 1991, p. 09.

${ }^{130}$ Ibid., p. 108.

131 Ibid., p. 107.

132 Ibid., p. 108.

133 Id., Ibid.

${ }^{134}$ Ibid., p. 109.
} 
natureza na totalidade do espaço ontológico ("Desde logo, homem e natureza já estão colocados em relação na perspectiva da ontologia do espaço") ${ }^{135}$.

A proposta de Moraes é a mais direta aproximação entre o exercício ontológico geográfico com a perspectiva de Lukács. Moraes irá admitir abertamente tal relação em um importante texto de 1979, intitulado "Em Busca da Ontologia do Espaço" (texto esse não muito estudado, em parte também pelo distanciamento posterior do próprio autor em relação ao debate ontológico, a Lukács e ao marxismo em geral). Na oportunidade, dirá Moraes: "Tentemos remeter à problemática do espaço a proposta lukacsiana. Assim, iniciar a busca ontológica do espaço. Desde logo devemos admitir 'o espaço enquanto natureza em si'” (MORAES, 1982; p. $71)^{136}$. Espaço e trabalho, diante desta perspectiva encontra sua mais substantiva conciliação. O que, não de outra forma, também contribuía para a solução de um problema "geográfico", pois se o espaço compartilha com a natureza a qualidade/condição de objeto intermediado pelo trabalho para a constituição do ser social, no constante processo de sua subjetivação a partir do ato teleológico eminentemente humano, para a Geografia se trata de: "Apropriar-se do espaço concreto implica na elaboração de categorias lógica sobre o espaço" ${ }^{137}$. Mas não só. Significaria também a solução de um "nó górdio da reflexão geográfica: a oposição entre a definição lógica e a definição empírica"138. Moraes acreditaria que a dicotomia geográfica entre o racionalismo (tradicional de herança kantiana) e o empirismo (herdada da tradição francesa) pudesse ser resolvida pela saída ontológica lukacsiana, na medida em que ela se propõe vislumbrar a mediatização do processo histórico, da natureza em movimento, apropriada e, assim, se tornando espaço em desenvolvimento contínuo ("Posto nestes termos, o natural vai ser visto como potencialidade substantiva na apropriação humana") ${ }^{139}$. Solução essa que continua a revelar a forte vinculação com os compromissos conciliatórios e disciplinares.

Restabelecida a unidade do objeto, por isso superada as limitações deterministas e possibilistas da tradição geográfica, adianta Moraes a análise para o entendimento deste objeto (espaço) em sua mediação histórica da apropriação. A dimensão da crítica do valor, como "valorização do espaço", ganha assim também sua importância ontológica na medida em que representa o "processo de histórico-concreto" (ou "marcos territoriais") do ato teleológico entre

\footnotetext{
${ }^{135}$ SILVA, 1991, p. 109.

${ }^{136}$ MORAES, Antônio Carlos Robert, "Em Busca da Ontologia do Espaço", In: MOREIRA, Ruy (org), Geografia: Teoria e Crítica - Os Saberes Posto em Questão, Rio de Janeiro, Vozes, 1982. (O referido texto de Moraes teve sua publicação original no primeiro volume da revista Território Livre, da União Paulista dos Estudantes de Geografia).

${ }^{137}$ Id,. Ibid.

${ }^{138}$ Ibid., p. 72.

${ }^{139}$ Id., Ibid.
} 
homem e natureza, do qual seria regido pela lógica do seu respectivo "modo de produção". À dimensão da natureza em si estaria contido o "valor do espaço", como possibilidade ou "potencialidade substantiva", para o processo de trabalho; à dimensão do trabalho, por sua vez, como efetivação da substantivação concreta do potencial adormecido na natureza, estaria contido o "valor no espaço", como já abordado amplamente no capítulo "1.2 - "A Valorização do Espaço"".

Essas duas formas de como se apresentam o valor, ou a "valorização do espaço" em síntese, têm uma relação admitida com a teoria do valor de Marx (ou as teses sobre a maisvalia $)^{140}$, mas também em relação ao que foi desenvolvido em “O Capital” sobre o processo do trabalho e processo de valorização. Já o estatuto ontológico da relação, por sua vez, é fortemente relacionado à influência lukacsiana, sobretudo na afirmação do "reino absoluto da causalidade" orgânica, ou da natureza em si como base geográfica da "substantivação potencial" para o desenvolvimento do ser social, como pode ser identificado a símile no próprio Lukács: "Como o ser social surgiu da natureza orgânica, ele forçosamente preserva as características ontológicas constantes da sua origem” (2013; p. 201) ${ }^{141}$.

Diante do debate levantado por Moraes, procede Armando Corrêa da Silva sua síntese ontológica do espaço afirmando a "Formação Espacial" como resultado de sua reprodução até a conformação do espaço produzido, e somando à sua linha argumentativa as contribuições de Moreira: “Além disso, 'a Formação Espacial é a própria formação Econômica-Espacial, especializada, contendo sua estrutura e leis de movimento, e nela estando contida."' (SILVA, 1991; p. 109). Para a "garantia" de que a Formação Espacial não tenha vida efêmera, e por extensão a própria sociedade humana, o elemento "orgânico da produção" deve ser afirmado como o pressuposto de uma "estrutura de produção duradoura e definitiva" (MOREIRA, 2007; p. 68) ${ }^{142}$. Estaria assim estabelecido o "continum" 143 entre formação espacial e formação social pela própria existência da produção em si, que colocaria esses dois elementos da "formação econômico-social geral" em relação, por meio de uma dialética autoprodutiva entre ambas, “numa relação de correspondência necessária, já que é dela [da formação espacial] o resultado e condição de reprodução [da formação econômico-social] ${ }^{144 "}$.

\footnotetext{
140 “A compreensão do processo de valorização do espaço e a construção de uma teoria a respeito, exige um recurso e o esclarecimento de uma categoria central do pensamento marxista que é o valor. Marx realiza a reconstituição crítica dessa categoria [...]. Os resultados desse seu trabalho estão expostos, em particular, na sua obra Teorias da Mais-Valia" (COSTA; MORAES, 1984; p. 93). Conderir tópico "1.2 - 'A Valorização do Espaço"”.

${ }^{141}$ LUKÁCS, Gyögy, Para uma Ontologia do Ser Social, 2, São Paulo, Boitempo, 2013.

${ }^{142}$ MOREIRA, Ruy, Pensar e Ser em Geografia: ensaios de história, epistemologia e ontologia do espaço geográfico, São Paulo, Contexto, 2007.

${ }^{143}$ SILVA, 1991, p. 69.

144 Id., Ibid.
} 
Nesse ponto argumentativo, o "amalgama" de Silva não apenas aglutina as proposições ontológicas de Moreira às de Moraes, como também incorpora sua dialética conciliatória por um sistema de fusão que se pretende maduro e desenvolvido. Mas encontra, ela mesma, seus paradoxos inevitáveis. Pois a autocomplementação, posta como dialética, entre formação espacial e formação econômico-social, estaria na contramão de um problema levantado pelo próprio Silva anteriormente, qual seja: "Ela [a formação natural-social] contém uma determinação de origem: seu ser é posto como contradição de momentos do movimento. Por isso a formação possui um tempo de existência que está dado no modo de produção" (1991; p. 108). Silva, no entanto, não indica se a "dialética conciliatória" de Moreira é uma solução à sua contradição observada ou apenas uma outra forma de entender a relação, nem se os problemas abstratos do "modo de produção" estariam suficientemente resolvidos, conforme acreditaria Moraes, de modo que, solucionadas as dicotomias tradicionais da geografia pela ontologização do espaço, dever-se-ia agora, os geógrafos, voltarem para o "processo de concreção [para] dar conta de formações territoriais concretas" (MORAES, 1982; 79).

Irresoluta a contradição levantada pelo próprio exercício teórico, segue Silva a pista da “concreção" deixada por Moraes e Moreira: o caminho da "formação social". Para isso busca uma definição do conceito de formação social contido em Hidess e Hirst, este como "níveis de teorização" que vão desde as relações de trabalho e produção econômica em si da riqueza, suas relações de classe, as relações políticas com o Estado e seu aparato político, cultura e ideologia, condições para suas transformações e seus vínculos com outras formações sociais. Assim o procede para em seguida incorporar, segundo as formulações de Thiollent, a sua relação com o "modo de produção" ("É possível dizer, numa primeira aproximação, que o conceito de MP [modo de produção] é mais 'lógico analítico' que o conceito de FES [formação econômicasocial], o qual é mais "histórico-sintético"”) e a "estrutura de produção" ("A Estrutura Econômica (ES) é um conceito intermediário entre MP e FES") ${ }^{145}$. Até chegar nas contribuições de Castells, de quem Silva observa a impossibilidade de tratar o espaço na sua forma genérica e abstrata, restando somente, para sua apropriação analítica concreticista, "a necessidade do corte da estrutura social em termos científicos [...], portanto, em termos de formação social, portanto em termos de articulação de modos de produção" ${ }^{146}$, passaria toda a costura amalgamática, na tentativa de uma coerência interna, pela seguinte ordem: de Luporini a base empírica para identificação dos "traços comuns" para a elaboração de modelos das formações sociais; de Sereni a "polêmica" que, desde Marx, abre ao conceito de formação social as

\footnotetext{
${ }^{145}$ SILVA, 1991; p. 111.

${ }^{146}$ Ibid., p. 117.
} 
possibilidades de existência de outras formações sociais mais específicas e inerentes a elas que fogem das próprias determinações capitalistas. Tal polêmica será estendida por Galissot na afirmação de que no interior da formação capitalista haveria o "desenvolvimento de forças produtivas que é desigual e contraditória" 147 e que, por isso, não poderiam ser explicadas pelos conceitos de modos de produção e formação social a partir de seu determinante abstrato ("A formação econômica é, pois, a invariante sócio-econômica de um modo de produção [...]”). De Dhoquois à elucidação de que a formação social não pode se referir à diferença posta na história efetiva e real, dado que o modo de produção, para Marx, não poderia ser outra coisa senão um "abstrato real", por isso não empiricizável no âmbito da análise, questiona Silva se o problema não seria de ordem semântica entre "forma" e "formação", mas encontra em Texier o argumento de que, em Marx, ambas remetem à noção de "estrutura", de leis de desenvolvimento geral característico do modo de produção. Retornaria então Silva ao debate interno do marxismo e, por Labica, expõe o debate proposto por Lenin sobre a "formação econômica social, como um conjunto de relações de produção"148 para, assim, chegar na concordância, como Lenin, de que este seria o conceito "preferível", em detrimento de "modo de produção"; como forma de resignação científica possibilitada pelo "concreto" em detrimento dos riscos de generalizações do "abstrato".

O objetivo de Silva diante de todo esse emaranhado de influências, praticamente o mesmo debate já elaborado por Milton Santos em 1977 149 , seria o de fundamentar a via categorial (Formação Social) para, em última instância, conceder ao espaço seu devido estatuto ontológico; ou seja, como resultado de uma busca argumentativa no seio da teoria social crítica: "uma síntese de fusão" propriamente dita. No entanto, deveria tal debate chegar na especificidade da Geografia. Neste momento é que, enfim, a linha argumentativa de Silva reencontra Milton Santos.

[O significado da preferência pela "formação social" e os problemas não admitidos da concreção]

Milton Santos, por vias não ontológicas, teria sido um dos primeiros a se interessar pela questão da formação, como meio de superar as limitações das interpretações geográficas então

\footnotetext{
${ }^{147}$ SILVA, 1991, p. 114.

148 Ibid., p. 116.

${ }^{149}$ Inclusive os referenciais em Silva são, em sua maioria, os mesmos levantados por Santos, variando as edições e posições dos autores em obras de síntese. Dentre eles: Sereni, 1974-76; Texier, 1973-76; Luporini, 1966-76; Labica 1971-76; Castells, 1971-77; Althusser, 1965.
} 
reduzidas à questão da forma ("pode-se dizer que a Geografia se interessou mais pela forma das coisas do que pela sua formação") ${ }^{150}$. Isso permitiria à Geografia perceber o próprio movimento da sociedade que se cristaliza na forma, ao tempo em que concedesse a ela seu papel "de servir como fundamento de compreensão da realidade espacial e permitir a sua transformação a serviço do homem" ${ }^{151}$. Por isso deveria ela proceder pela categoria Formação Social, pois seria a partir dela que se efetivaria uma teoria espacial que desse conta da "evolução diferencial das sociedades"152. A possibilidade que se levanta seria a de se apropriar da totalidade espacial a partir de suas nuances, similaridades e particularidades (essas como o todo cindido) por onde a Geografia deveria atuar. Aqui, a perspectiva do "estatuto ontológico" deveria encontrar, tanto na proposta do espaço como ser em Silva, Moraes e Moreira, a categoria elementar defendida por Santos: a "formação social e espacial" ("trata-se de fato de uma categoria de Formação Econômica, Social e Espacial mais do que uma simples Formação Econômica e Social (F. E. S.) tal qual foi interpretada até hoje”) ${ }^{153}$. Dessa grande junção, teria o exercício teórico as possibilidades de uma via revolucionária, de uma "teoria da transição" para a conquista do "espaço do homem". Nesta perspectiva de Silva, mas também de Santos, Moraes e Moreira, como observado, duas influências são fundamentais, Marx e Lukács: o primeiro enquanto perspectiva histórica de formação da "nova forma histórica", ou da nova forma do espaço humano; o segundo como mediações ônticas entre o universal e o particular e específico.

Mas, do ponto de vista do desenvolvimento e maturação da crítica, quais questões haveriam de ser colocadas entre uma ontologia lukacsiana e uma teoria da superação histórica marxiana? Ou como abordar um debate dessa natureza autocrítica entre essas duas referências de peso para o debate ontológico? Aqui se complica a análise proposta dos geógrafos. Os esforços de conciliação, por mais sofisticado que tenderam a ser em equacionar as arestas de perspectivas teóricas tão distintas, como por exemplo as de Marx e Ratzel em "De Quem é o Pedaço", como a "adaptação abandonada" de Moraes da ontologia do trabalho lukacsiana para uma ontologia do espaço, isso sem nenhum constrangimento, demonstra suas fragilidades quando se busca a contradição entre elas. Esse é um problema de método não observado pela perspectiva de positivação epistêmica que, embora legitimamente justificado diante da necessidade dos tempos de crise e fragmentação que se persistiam (inclusive como justificativa

\footnotetext{
${ }^{150}$ SANTOS, Milton, "Espaço e Sociedade: e formação da sociedade como teoria e como método", In: Boletim Paulista de Geografia, № 54, São Paulo, AGB, 1977; p. 81.

${ }^{151}$ Id., Ibid.

152 Id., Ibid.

${ }^{153}$ Ibid., p. 82.
} 
para a necessidade da solução epistemológica) nas décadas de 1970-80, não se adentaram para os riscos de, ao selecionar tais conceitos e categorias, dispô-las de modo "arremessadas à pretensa fusão", como advertiria Chasin $(2009$; p. 32). A unidade teórica e metodológica pretendida por Santos ("formação da sociedade como teoria e como método"), sob tais condições, tenderia ao próprio exercício epistemológico seu convertimento no mero exercício metodológico-prático (no sentido aplicativo do termo) ao "real concreto".

Aliás, a referência tanto na ontologia lukacsiana como na formação social marxista representou, desde o início, não muito além que a tentativa de adequação e adaptação da teoria do valor e da crítica do trabalho à tradição geográfica no sentido de instituir o pretenso "papel das formas" (e até mesmo da paisagem) na produção da história. O que, por sua vez, nunca deixou de ter como evidência um entendimento do concreto como o físico realizado historicamente, por mais que a ele fosse adicionado sua condição de movimento, conteúdo, ou ação; como "inerte movido". ${ }^{154}$

O que se pressupõe daí, antes de uma superação da forma-física como herança de um tradicionalismo geográfico socialmente inerte é, ao contrário, sua própria reafirmação onde a ela se soma seu suposto conteúdo histórico (o tempo ou a "finalidade"), uma somatória legitimada por uma dialética enunciativa, propositivamente conciliatória, entre fixos e móveis. Milton Santos, que a essa altura e diante das proposições afirmativas de Armando Corrêa da Silva, ainda não havia enveredado pela legitimação ontológica do espaço, observaria antes em sua “obra seminal” ("Por Uma Geografia Nova”, no capítulo sobre "As Noções de Totalidade, de Formações Social e a Renovação da Geografia"), na sequência da argumentação entre sociedade e suas formas (“A sociedade não se pode tornar objetiva sem as formas geográficas”), que sobre a "função" dos "objetos" e da própria "paisagem" seriam eles mesmos os “orientadores" da evolução da sociedade: "Por outro lado, os objetos que constituem a paisagem orientam, depois, a evolução da própria sociedade, fato que não tem sido suficientemente nem sistematicamente indicado" (SANTOS, 2002; p. 244).

Isso implicaria à Geografia introduzir em sua análise o debate da economia política, como antes havia indicado Lefebvre sobre o estudo do espaço, como revela o próprio Santos: "H. Lefebvre alude à economia política, cujo discurso parece haver-se esgotado. Mas essa ideia também se aplica a Geografia, quando esta se recusa a estudar o real, a considerar a sociedade na sua inteireza e no seu movimento histórico" (2002; p. 238). No entanto, as condições específicas da disciplina deveriam ser consideradas ("esse conjunto de premissas [sobre a

${ }^{154}$ Essa discussão será retomada de forma mais ampla no tópico "4.1 - Relendo as pretensões: o papel da contradição".) 
formação social] ajuda a entrever todo o problema do espaço como um conjunto de recursos a palavra inglês seja a mais adequada - fixos e móveis e, ao mesmo tempo, como instância social" ${ }^{155}$ ), porque assim estaria assegurada um afastamento perante os riscos de fragmentação da análise (“A utilização dessa categoria [formação social] apresenta um múltiplo interesse: ela não nos deixa cair nos enfoques 'especialistas', ela nos ajuda a fugir das posições metodológicas que fragmentam a realidade [...]"), para a consequente legitimação de sua crítica social fundamentada em uma totalidade pressuposta ("[...] e destarte conduz a uma análise do espaço segundo uma problemática que privilegia a totalidade social") $)^{156}$.

A "insistência" do geógrafo na formação social (como no caso de Milton Santos) teria, ainda como justificativa, o fato de ser ela mais condizente com o entendimento do "concreto" como "especificidade" (mais próxima à "leitura geográfica"), em detrimento da abstração decorrente do "modo de produção" ("[...] as formações sociais não existem senão pelos seus aspectos concretos, entre os quais os modos de produção concretos que as constituem e que possibilitam chegar a compreender a especificidade de cada sociedade [...]") ${ }^{157}$. Além disso, permitiria também a aproximação daquelas temáticas já envolvidas pelo enlace geográfico, aquelas fundamentadas na forma "diferencial" de existência das sociedades ("Essa categoria concerne à evolução diferencial das sociedades - em seu próprio quadro e em relação às forças externas das quais frequentemente lhe vem um impulso motor") ${ }^{158}$. Isso possibilitaria ao geógrafo, como assimilaria Armando Corrêa da Silva sobre as formulações de Milton Santos, sistematizar uma teoria para o espaço que fosse, ao mesmo tempo, fundamentada nas contribuições da crítica social do trabalho ("acima de tudo, a base fundamental da explicação vem da produção, isto é, do trabalho do homem para transformar, seguindo leis historicamente determinadas, o espaço com o qual o grupo se confronta") ${ }^{159}$, seu estatuto ontológicognosiológico em torno de uma "espaciologia" (“[...] isto é, aquilo que, no dizer de Benedetto Groce (1968, p. 85) deve pertencer à categoria de ciências meta-históricas 'uma classificação de coisas distintas pelo espaço à qual se chamou de meta-história") ${ }^{160}$, além de conceder à Geografia seu devido estatuto teórico válido e cientificamente legitimado ("Daí porque insistimos - a noção de formação social como categoria da realidade e como categoria analítica

\footnotetext{
155 SANTOS, 2002, p. 238.

156 Ibid., p. 238.

157 Ibid., p. 245.

158 Ibid., p. 246.

${ }^{159}$ Id., Ibid.

160 Ibid., p. 241.
} 
parece constituir o meio mais adequado para ajudar na formulação de uma teoria espacial válida") ${ }^{161}$.

Por isso que estes três objetivos para a configuração da crítica geográfica - trabalho, ontologia e estatuto metodológico -, aliados ao aspecto de constituição de uma teoria fundamentada em uma "dialética entre o universal, particular e singular" (CHASIN, 2009; p. 139) própria da formação social, não poderiam encontrar, senão nitidamente na influência lukacsiana, sua base de sustentação. Mas aí, como observaria Chasin em relação ao próprio Lukács, a retirada do campo de análise o papel das "abstrações", propriamente marxiana ("Não há nos estudos lukacsianos a respeito de Marx qualquer alusão à teoria das abstrações") ${ }^{162}$, não poderia se dar sem profundos prejuízos para a compreensão desse mesmo real-concreto, como objetivado pela crítica geográfica.

Especificamente no debate sobre Lukács, reconhece Chasin os objetivos de posicionar uma leitura fundamentada na dialética universal-particular, no todo e nas suas partes, com atenção especial ao particular e singular, como citaria Chasin no próprio Lukács:

[...] o problema da particularidade é um dos mais negligenciados, tanto do ponto de vista lógico, como do ponto de vista estético"'. O escrito é confirmado no capítulo 12 da Estética, o único do qual a questão volta a ser tratada, resumidamente, do ponto de vista lógico (CHASIN, 2009; p. 140).

Observa Chasin, ainda que "os textos de Lukács relativos à dialética entre universal, particular e singular, a parcela dos materiais que aqui importa, pertence à fase mais recuada dos esforços lukacsianos por "uma obra estética essencialmente sistemática""163, a referência e a dialética efetiva entre o universal abstrato e o universal específico, ou o problema de uma teoria da abstração em Marx, não se tornaria tema de suas análises na fase mais madura em "Para uma Ontologia do Ser Social"164. Ainda sobre a "fase mais recuada da estética", e sobre a questão da abstração em Marx, destacaria Chasin a respeito da produção de Lukács: "Em verdade foi a única vez em que tratou da questão, já que mais de uma década e meia depois, no capítulo sobre Marx, integrante da parte histórica da Ontologia, sintomaticamente não reservou tratamento específico ao tema" (2009; p. 141).

\footnotetext{
161 Ibid., p. 246.

162 CHASIN, 2009; p. 139.

${ }^{163}$ Ibid., p. 140-141.

164 Ibid., p. 140.
} 
Segundo Chasin, há na proposição do filósofo húngaro, na clara tentativa de constituição de uma teoria "gnosiológica" fundamentada na crítica inversa das abstrações apriorísticas kantianas, tal como uma negativa frente às vinculações idealistas da dialética hegeliana, uma perspectiva que visa chegar nas concreções históricas: do universal ao particular e singular, tal como objetivaria Antônio C. R. Moraes, mas sobretudo Armando C. da Silva em sua passagem de 1989 (“Geografia e Lugar Social”): “A formação é e contém a forma e o processo. A expressão elementar da Geografia, enquanto objetivada como espaço terrestre" (1991, p. 107).

Retomando às preferências de Lukács em relação ao "específico e singular", analisa Chasin que o húngaro operou uma interpretação ontológica de Marx que se desdobra em uma série de problemas metodológicos em torno da dialética ${ }^{165}$. Tais problemas têm relativa importância na medida em que se identificam com a preferência da ontologia geográfica em se refugiar nas concreções propriamente derivadas das formações sociais em detrimento (ou apenas formalmente relacionadas) ao modo de produção, como admitido por Silva, Moraes, Moreira e Santos.

Tal questão gravita em torno do uso da ontologia para a suposição de um teoria que, propositivamente operada na direção do abstrato para o concreto, do "universal para o específico e singular”, recai, necessariamente, na própria abstração (e totalização) de um concreto específico, anulando, assim, perspectivas sólidas e equilibradas de manutenção dos vínculos dialéticos com a totalidade da relação entre o universal (agora posto como abstrato genérico e metafísico) e o particular (agora posto como a própria realidade concreta e “cientificizável”).

Em Lukács, observa Chasin que tal forma de entender a dialética incorpora à sua leitura científica o preceito sempre de se buscar a mediação do "em-si" (posta como "abstração", a lógica contraditória em si) para o "para-nós" (o concreto tornado "inteligível”, historicamente específico). Tem-se, assim, ainda conforme a análise de Chasin, o entendimento das "abstrações" apenas como um "fundamento geral” para o exercício epistemológico ("fique registro de que [como assinala Lukács] 'o propósito desses detalhes e dessas generalizações concretas, a questão epistemológica tão decisiva no estudo do em-si [abstrato], não constituirá mais do que um fundamento geral"”) ${ }^{166}$; e que somente a partir do "concreto", este tomado

\footnotetext{
${ }^{165}$ Aqui deve ser admitido que qualquer tentativa de sintetização da crítica de Chasin à ontologia de Lukács não deverá condizer com os esforços, tal como rigor analítico, contido no capítulo "Da Teoria das Abstrações à Crítica de Lukács" presente no livro aqui citado (Marx: Estatuto Ontológico e Resolução Metodológica).

${ }^{166}$ CHASIN, 2009, p. 207.
} 
como a própria "totalidade" em si, é que se torna inteligível a realidade apropriada pela ciência. É assim que demonstra Chasin, ainda por meio de uma citação do próprio Lukács: "Também segue disso que - do ponto de vista rigorosamente epistemológico - a única que pode ser considerada contrapnto concreto do em-si é a totalidade do para-nós conduzido à síntese"167.

Não só Moraes, mas sobretudo Milton Santos havia percebido tal predisposição concreticista em Lukács, providencial para as tentativas de "adaptações" geográficas do marxismo, que, ao propor a categoria Formação Social para a análise do espaço, assim se fundamentava no filósofo: “Aproxima-se nisso de Lukács $(1970)^{168}$, para quem o estatuto histórico das sociedades opõe a primazia do econômico à da totalidade" (SANTOS, 1977; p. 83). E, para ratificar a "oposição" (que mesmo em Lukács jamais poderia significar "separação") e a tomada em direção à um concreto histórico e específico, se fundamenta no exemplo de Lenin a negativa em relação à abstração da "sociedade em geral", como assim confirmará Santos: "Não é à 'sociedade em geral' que o conceito de F. E. S. [formação econômica da sociedade] se refere, mas a uma sociedade dada, como Lenin (1867) fez a respeito do capitalismo na Rússia" ${ }^{169}$. Isso irá, por sua vez, vincular às próprias formulações miltonianas, originárias e de maturidade, uma concepção materialista fortemente empiricizada do concreto, tal como (e por isso também) a escala do Estado-Nação como recorte/escala de sua análise geográfica (ou os limites de sua totalidade).

Isso, por sua vez, tem muito significado para as pretensões ontológicas da Geografia que, no âmago do seu "amálgama originário", o posicionamento da Formação Social como categoria crítica possibilitadora da mediação entre teoria do valor e a crítica do trabalho (regidas por mediações em si abstratas, no caso de Marx) na composição de uma teoria do espaço enquanto ser (nunca desvinculada de suas tradições epistemológicas "concreticistas") haveria de ser extremamente problemática no âmbito da sustentação dialética.

O uso da Formação Social como a busca pelo concreto e vinculada à pretensão de unidade epistemológica especificamente geográfica ("como teoria e como método"), como proposto por Santos, tal qual a sistematização ontológica por "pretensa fusão" de teorias, como proposto por Silva, foram, como visto acima, formuladas e justificadas pela sua própria ausência; ou ainda pela urgência de respostas diante do contexto de fragmentação disciplinar e crise social. A suposta "solução epistemológica" da crise, de velhas dicotomias e da

\footnotetext{
${ }^{167}$ Id., Ibid..

${ }^{168}$ Tal referência está contida no livro História e Consciência de Classe, lançada em 1923, precede a um período muito longo o lançamento do Por uma Ontologia do Ser Social, obra conhecida somente depois da morte do autor, em 1972.

${ }^{169}$ Id., Ibid.
} 
fragmentação geográfica, que apresentaria como base a via ontológica e a formação social como categoria de mediação espacial para a crítica social tendia a deslocar, ou mesmo ocultar, a forma como as mediações categoriais (universal x particular, concreto $\mathrm{x}$ abstrato, forma $\mathrm{x}$ substância) estavam cada vez mais fundamentadas em uma dialética sem contradições, complementária e conciliatória.

Onde entre elas deveriam existir uma mediação rigorosamente lógica de uma dialética efetiva, há apenas o anúncio de manutenção de uma dialética formal, como o próprio resguardo prévio diante de qualquer acusação de dicotomia, como parece proceder Santos ao afirmar que "as noções de totalidade e de estrutura, de universal e de particular, deverão ser unificadas em um mesmo movimento conjunto [...]” (2002, p. 240), mas somente para na página seguinte refutar o próprio "equilíbrio" dialético: "Mas a ideia de Formação Social não deve ser confundida com a noção de sociedade global, tão repetidamente utilizada. Ela permite, igualmente, ir mais longe do que a noção, aliás tão vizinha, de estrutura social” (2002; p. 241).

Ainda que quantas vezes forem possíveis refugiar a lógica interna e contraditória do "modo de produção" em quaisquer outros termos equivalentes, ou de "vizinhança", como "sociedade global” ou "estrutura social”, a opção por categorias mais assimiláveis à tradição geográfica representa, por isso e contraditoriamente, muito mais do que uma preferência providencial à especificidade geográfica. Tal justificativa, ao mesmo tempo em que restringia a interpretação geográfica por meio de uma dialética precária, formal e conciliatória entre abstrato e concreto, significava a retirada daquelas outras categorias, "mais abstratas", próprias do modo de produção (especificamente o trabalho), que passariam a concorrer na formulação epistêmica caso fossem admitidas internamente em sua estruturação teórica-metodológica.

A linha de fuga pelo "concreto", efetivada na opção pela formação social, não significa somente a manutenção da tradição da leitura geográfica, mas uma opção política de constituir sua crítica que passa agora, depois de formada as bases da "solução epistêmica", a depender somente dos geógrafos a desenvolvê-la: "cabe iniciar o processo da concreção", para lembrar novamente o postulado de Moraes. Isso porque, desde as formulações embrionárias miltonianas e ontológicas de Silva, a dialética por onde se forja a solução epistemológica, fundamentada na ontologia, já nasce cindida no seu interior apresentando, não por outra forma, a condição empírica em si como entendimento do concreto geográfico, preservada e legitimada como própria abstração em si possível da análise geográfica. Algo mais além disso, mais "abstrato", não deveria ser, assim, considerado geográfico. A autorreferenciação encontra, assim, sua fundamentação ontológica. 
[A disputa pela centralidade ontológica: a técnica em cena]

É notório como que essas bases específicas de entendimento da dialética (conciliatória, formal e concreticista) se confundiram com a própria forma possível de se fazer Geografia, e a ela conceder seu devido estatuto ontológico. Para citar o exemplo mais significativo, assim pode ser observado como que a busca pelo "empírico", escondido num suposto conceito ampliado sobre o concreto, sustentaria não apenas as formulações embrionárias e nãoontológicas da crítica de Milton Santos, mas também sua proposta ontológica do espaço, agora mediado pela técnica, em pleno contexto de maturidade teórica do autor: "se quisermos unificar tempo e espaço, se pretendermos mutuamente includentes, o tempo deve ser também empiricizado" (2008; p. 54). O "empiricizado" significaria, nas palavras do autor: "essa realização [que] se dá sobre uma base material: o espaço e seu uso; o tempo e seu uso; a materialidade e suas diversas formas; as ações e suas diversas feições" ${ }^{\prime 10}$.

Mas, o que esse "também empiricizado" significa? Quais seriam as outras formas de "também" conceber o espaço para se admitir sua unificação com o tempo? Ou melhor, quais seriam essas outras formas não-geográficas de se conceber a relação de unificação? E, consequentemente, quais seriam os caminhos a não serem seguidos? Neste aspecto, se revela o caráter metodológico-propositivo-instrumental (manualístico, em outras palavras) do livro " $A$ Natureza do Espaço". Para isso, Santos faz toda uma retrospectiva crítica, e até autocrítica para demonstrar, como observado, a forma precária, meramente formal e enunciativa, com que a dialética havia sido tratada, "uma certa frouxidão conceitual"171, no ato de pôr a relação tempo e espaço. Assim, questiona Santos diante da crítica contra os geógrafos feita por economistas (Mrril, 1965 e Ulmann, 1973) sobre sua incapacidade diante do "explicito reconhecimento do tempo": "[Seria] o estudo da modernização e da difusão das inovações, a delimitação dos períodos históricos segundo as escalas geográficas, ou simplesmente, o enunciado da inseparabilidade do tempo e do espaço?" ${ }^{\text {172 }}$. Diante da postura meramente enunciativa da dialética entre tempo e espaço com que os geógrafos haviam tratado a questão, reconhece Santos:

\footnotetext{
${ }^{170}$ SANTOS, 2008, p. 54.

${ }^{171}$ Ibid., p. 50.

172 Id., Ibid.
} 
O tratamento da questão do tempo nos estudos geográficos não é mais um tabu, mas testemunha, ainda, uma certa frouxidão conceitual [...]. Como ir além do discurso que prega a necessidade de tratar paralelamente o tempo e o espaço, do discurso de crítica dos outros especialistas que menosprezam esse enfoque, e do próprio discurso de autocrítica de uma Geografia igualmente faltosa? (2008; p. 50).

A provocação de Santos é reveladora, pois, a um só tempo, observa a precariedade da dialética e encontra como justificativa não um problema interno da suposta "autocrítica geográfica", mas em algo "externo" à teoria em si, no certo desinteresse, no "menosprezo" dos geógrafos diante da questão. Santos assim aponta, então, três caminhos a não serem seguidos: a relação espaço-tempo por uma "geografia histórica", ou uma "história geográfica" ("enfrentamos aqui o difícil problema de discernir, através de uma geografia retrospectiva, o que, num dado ponto do passado, era, então o presente") ${ }^{173}$; a relação espaço-tempo pela teoria da relatividade proposta pela física (“É mesmo certo ou - totalmente incerto - que possamos mecanicamente transcrever esse raciocínio para uma disciplina histórica como a geografia") ${ }^{174}$; e a Geografia Histórica baseada em periodizações (“[...] as periodizações não nos dão, sem dúvida, um tempo, mas apenas um tempo externo a cada subespaço. Falta resolver a questão do tempo inteiro") ${ }^{175}$.

A busca pelo tempo em si, ou pelo "tempo inteiro", poderia significar a retomada dos debates "mais abstratos" como forma de "equilibrar a dialética" da totalidade do espaço. O que não ocorre. Ao invés disso, recorre novamente Santos à empiria como forma precavida de não "estender-se muito ao infinito". A solução epistemológica é novamente apresentada. Para isso, busca então o autor a mediação que concederia ao tempo sua forma empírica, especificamente geográfica, e encontra na técnica sua via de efetivação: “A técnica entra aqui com um traço de união, historicamente e epistemologicamente" (SANTOS, 2008; p. 54). E, assim, encontra Santos a via de epistemologização baseada no estatuto ontológico do espaço, conservando nele, igualmente como antes em Silva, Moraes e Moreira, sua relação com o trabalho: "É por intermédio das técnicas que o homem, no trabalho, realiza essa união entre espaço e tempo" 176 . Mas assim o faz somente para depois se afastar de sua condição "abstrata" (do trabalho como categoria inerente à "metafísica do valor") e, assim, passar a considerar somente sua forma

\footnotetext{
173 SANTOS, 2008, p. 51.

174 Id., Ibid.

${ }^{175}$ Ibid., p. 52.

176 Id., Ibid.
} 
fisicalizada, cristalizada e instrumentalizada como forma de justificar a opção pela "concreção" em detrimento ao "modo de produção". Isso possibilitaria, enfim, reafirmar o exercício epistemológico eminentemente geográfico que passaria agora a gravitar em torno da técnica como categoria ontológica em si: “Através do processo de produção, o 'espaço' torna o 'tempo' concreto. Assim, a noção de trabalho e a de instrumento de trabalho são muito importantes na explicação geográfica, tanto ou mais do que no estudo dos modos de produção" ${ }^{177}$.

Aqui, um ponto importante de continuidade de descontinuidade: ponto de continuidade se nota pela, além da "solução epistêmica", manutenção do entendimento sobre o "concreto" que se preserva como o posto afirmativo do físico, existência geográfica enquanto materialidade empírica "orientadora da história"; o ponto de descontinuidade é em relação à categoria da centralidade ontológica na teoria crítica que, desde Lukács, estaria fundamentada no trabalho. Em Santos, sua proposta ontológica representa uma ruptura com as influências da ontologia lukacsiana: o trabalho aparece como categoria "auxiliar" para a afirmação da materialidade do espaço ontológico. Assim também pode-se supor a saída explicativa que responda o porquê da "ontologia tardia" de Milton não ter se tornado possível antes da "redescoberta" da técnica, pois ter-se-ia que admitir o trabalho e todos seus desdobramentos "metafísicos" não especificamente geográficos.

O deslocamento do trabalho da centralidade ontológica para seu posto de "categoria de auxílio" da materialidade do espaço, em detrimento da técnica, representa a mais poderosa "solução epistêmica" para as mediações entre tempo e espaço oferecida à renovação crítica. Por outro lado, do ponto de vista da crítica social efetiva, ela tem outras importantes implicações no que se refere à manutenção da unidade entre o estatuto ontológico conquistado como "solução epistemológica" e a sustentação de uma teoria socialmente emancipatória e revolucionária, ou uma "teoria da transição", como acordado nos primórdios da renovação crítica.

Mesmo considerando que as influências de Lukács para o "renascimento do marxismo" tenham se convertido nas mais sólidas e eficientes "soluções epistemológicas" para as "ciências fragmentadas" no contexto de permanente crise e desenvolvimento técnico, como a Geografia - que ainda admitirá rajadas estruturalistas incompreensivelmente não questionadas e, por isso, jamais plenamente superadas -; e mesmo que seu exercício ontológico tenha se tornado o mais atual instrumentário metodológico quase que estritamente voltado para a legitimidade epistemológica, são inegáveis os compromissos do filósofo húngaro com a

${ }^{177}$ SANTOS, 2008, p. 56. 
perspectiva do "salto" histórico, para a "verdadeira história humana" que, desde o início, sempre estavam unidas em um só esforço. Uma ancora crítica do século XX que aponta para aqueles que se distanciaram da perspectiva lukacsiana, a perspectiva de uma guinada conservadora, como se observa na crítica geográfica ao admitir, e assimilar ainda sem nenhum constrangimento autocrítico, suas novas referências (sobretudo a weberiana e a heideggeriana) como forma de "melhorar o encorpamento" de sua teoria-ontologia.

\section{[Ontologia Epistêmica versus Transição Histórica]}

A crítica geográfica chega ao seu ponto de maturidade (mesmo considerando, mais enfaticamente apenas e por ora, os exemplos de Silva e Santos), seja por "fusão de síntese", como no caso de Armando Corrêa da Silva, seja por "ontologização pela técnica", como no caso de Santos, com um inegável distanciamento entre teoria proposta e seus compromissos efetivamente emancipatórios, identificáveis e objetiváveis.

No caso de Milton Santos, em que as categorias de superação do real deveriam agora gravitar em torno de sua posição com as técnicas, seu movimento de universalização no espaço concreto e material, objetivo e individual, do lugar como o mundo ("cada lugar é, a sua maneira, o mundo") ${ }^{178}$, contraditoriamente se sustenta por categorias ainda mais abstratas e generalizáveis, inclusive em relação às "formações sociais" mais remotas e longínquas no tempo presente globalizado. Por um lado, uma ontologia resguardada pela remoticidade histórica das categorias do suposto "mundo vivido" ("os objetos, as ações, a técnica, o tempo") ${ }^{179}$, e por outro sua "atualização" mais conservadora e não menos remota em torno das questões sobre a "racionalidade", da lógica e da política, no sentido mais avançado da "razão" e da "ação simbólica" orientada, como assim se inserem as influências weberianas ${ }^{180}$, redescobertas por Habermas e assimiladas por Santos ("É largamente conhecida a tipologia da ação social proposta por Weber, segundo a qual se podem distinguir uma atividade racional visando a um fim prático e uma atividade comunicacional, mediada por símbolos") ${ }^{181}$.

No traçado da maturidade do pensamento de Milton Santos, desde a proposição do concreto a partir da formação social reconhecidamente de influência marxista, até sua chegada à razão técnica reconhecidamente de influência weberiana e heideggeriana, não se observa

\footnotetext{
${ }^{178}$ SANTOS; 2008; p. 314.

179 Idem; p. 315.

${ }^{180}$ A questão sobre as influências weberianas no desenvolvimento teórico de Milton Santos será mais amplamente tratada nos tópicos "7.1 - Formas de inserção da contradição" e "6.3 - A via da negatividade"

${ }^{181}$ SANTOS, 2008; p. 315.
} 
apenas o distanciamento de um discurso objetivamente emancipatório, mas a ocultação de sua crítica social na sofisticação teórica e epistemológica que se pretende propriamente geográfica. Tal discurso tende a exilar sua crítica social do próprio exercício teórico que, assim conformado, só poderá garantir sua legitimidade refugiando a geografia em sua própria epistemologia. Não gratuita é a atenção dos geógrafos que, por vias da ontologização ou não, insistem nas recorrentes questões sobre a "epistemologia propriamente geográfica", a "teoria propriamente geográfica" e o "método propriamente geográfico".

O que não pode ser revelado mediante a necessidade de autossuficiência disciplinar, ou da formação "metadisciplinar" como propõe Santos (sem que seja apontado a superação em si dos mesmos mecanismos de aprisionamento disciplinar de ideal estruturalista-positivista) é que as condições de elaboração de uma teoria da transição emancipatória se tornam cada vez mais impossibilitadas. Tem-se assim uma tendência curiosa, ainda que por meio de uma generalização prévia: quanto mais madura parece estar a teoria e a epistemologia do espaço, mais politicamente conservadora tende ela a ser (o que nada mais revela senão um problema metodológico de composição da natureza de sua própria teoria).

As condições possibilitadoras de uma teoria da transição emancipatória, cada vez mais inviabilizadas diante da própria maturação teórica conservadora, tendem, assim, a serem deslocadas para outros terrenos como a "política", "ação popular" e "ação do Estado e governos”. Assim, ressalta Milton Santos sobre a relação entre a materialidade técnica e a política: "Se há as condições materiais para realizar as possibilidades sonhadas, então o otimismo não seria quanto aos materiais à nossa disposição, mas muito mais em relação à possibilidade da política, de uma outra política" (2000; p. 65-66).

Não por coincidência, esse é o movimento inverso do desenvolvimento teórico da ontologia do trabalho de influência lukacsiana, que sai do weberianismo, passa pela ontologia marxista até chegar nas condições em dispor de uma teoria da transição. Como observa István Mészáros sobre o mestre Lukács, o tempo das incursões no debate crítico em "História e Consciência de Classe", de 1923, em que "o peso da influência weberiana é particularmente revelador neste contexto" (2011; p. 407) seria bem diferente da natureza da crítica de suas últimas obras ("Nas últimas obras de Lukács temos um tratamento incomparavelmente mais realista destes problemas ['racionalidade' e 'divisão do trabalho'] do que no famoso volume de transição de 1923)"182. Ainda que, como também concorda Mészáros, os problemas da ontologia de Lukács em sua obra de maturidade estarem imersas em uma crítica limitada pelas

${ }^{182}$ MÉSZÁROS, 2011; p. 405. 
posições do próprio autor, no sentido de não de se alongarem muito diante da "experiência socialista" por ele mesmo defendida ("é por isso que ele continuou o falso paradoxo de que 'a pior forma de socialismo é qualitativamente melhor do que o melhor capitalismo"”) ${ }^{183}$, Lukács continua a significar, inclusive para o próprio Mészáros, uma das mais fundamentais influências para se pensar e reafirmar uma teoria da transição socialista eminentemente emancipatória.

Para isso, recorre Mészáros à crítica frente ao próprio mestre húngaro no sentido de identificar suas questões limitantes (“o discurso ontológico abstrato de Lukács [...] postulam a viabilidade da 'ética como a única mediação possível' entre o passado e o futuro remoto") ${ }^{184} \mathrm{e}$, a partir dele, repor as perspectivas do movimento socialista frente o "“realismo' estreito e à burocratização" como perspectiva transformadora, com força histórica e propositiva “[...] devendo [a ele] ser concebida uma teoria que seja capaz de afirmar e reafirmar sua validade diante de quaisquer derrotas e despontamentos que o futuro real ainda tenha guardado para o sitiado movimento socialista" ${ }^{185}$, como, aliás, a crítica geográfica que se torna hegemônica (ou o que se tornou o leque inautêntico e relativista da "Geografia Crítica") não conseguiria sustentar, dada suas vinculações insuperáveis do ponto de vista de suas necessidades epistemológicas e afirmativas.

Mesmo com todas as limitações teóricas e políticas próprias do seu tempo e de sua consciência, continuaria a representar Lukács o ponto origem do "renascimento do marxismo" que por vias críticas e autocríticas deveria continuar a restabelecer a alternativa socialista como contraponto das mediações contraditórias do capital, como destaca Mészáros: “Apesar de o Próprio Lukács não ter podido submeter à ordem social pós-revolucionária [socialismo soviético] à necessidade crítica radical, permanece uma parte válida e legítima do seu discurso [...]", que seria, ainda segundo Mészáros, a rejeição "com consistência intelectual e paixão, a perspectiva do pessimismo que se autodesarma" ${ }^{" 186}$.

Do ponto de vista da proposição ontológica de Lukács, não seria demais lembrar que o filósofo havia conferido a ela um esforço que, ao invés de uma mera fuga teóricaepistemológica, representou a fundamentação de uma Ética, propriamente circunscrita em uma teoria crítica (“"as obras em que penso reunir os principais resultados de minha evolução filosófica, da minha ética e da minha estética': a Ontologia seria assim a introdução da

\footnotetext{
183 Ibid., p. 503.

${ }^{184}$ MÉSZÁROS, 2011. p. 508.

185 Ibid., p. 394.

186 Ibid., p. 512.
} 
Ética" ${ }^{187}$. Mas representou também a extensão da teoria crítica para um campo de conhecimento explorado majoritariamente pelas tendências mistificadoras e absolutizantes que variariam desde as neopositivistas até as neo-kantianas. Foi, por isso e também, uma postura crítica frente a "remissão" e o "irracionalismo" de Heidegger (“[...] terreno para uma crítica radical ao neopositivismo - mesmo que a crítica se dirija às concepções tradicional-idealistas e irracionais da ontologia contemporânea [de Heidegger]") ${ }^{188}$; e a retomada crítica da ontologia de Hartmann, para então chegar no reconhecimento da ontologia em Marx ("Lukács detém-se sobre a contribuição de Hartmann [...], avança para a análise e a problematização da ontologia hegeliana e só então resgata o que designa por princípios ontológicos fundamentais de Marx") ${ }^{189}$

Para Mészáros, o ponto central da crítica ontológica de Lukács - e nisso se permite à teoria avançar sobre contradição entre o absoluto posto ontologicamente e a transição histórica - é a fundamentação de no trabalho estar contido, em sua "essência ontológica, um claro caráter de transição" (LUKÁCS, 2013; p. 44), o que haveria de abrir uma série de possibilidades, inclusive a partir do resgate de Marx, de pôr o problema da "transição" para além do capital como exercício vivo de busca contínua diante do estágio atual das contradições socioeconômicas quase sempre explicadas por teorias de cunho pessimista e derrotista. Mas seria necessário ir além da condição remota com que a ontologia lukacsiana havia estacionado pelas condições políticas do seu tempo, tal qual seus aprisionismos epistemológicos e metodológicos de segunda ordem, e propor uma crítica efetivamente radical às formas de reprodução do capital (capitalistas e pós-capitalistas), além de inseri-la em um discurso afirmativo e propositivo. Como declara Mészáros:

O discurso ontológico de Lukács sobre o 'bom trabalho' como 'categoria fundamental da vida dos trabalhadores', desde o ancestral primitivo que afiava com consciência-da-qualidade o machado de pedra até a 'subjetividade adequadamente livre dos seres humanos livres na sociedade comunista', simplesmente evita a questão das materialidades, em vez de empreender a crítica radical vitalmente necessária das formas estabelecidas de mediação socioeconômica e política ${ }^{190}$.

187 PAULO NETO, José. “Apresentação”, In: LUKÁCS, Gyögy, Para uma Ontologia do Ser Social, 1, São Paulo, Boitempo, 2012; p. 12.

${ }^{188}$ MÉSZÁROS, 2011, p. 16-17.

${ }^{189}$ Ibid., p. 17

${ }^{190}$ Ibid., p. 507 
Mészáros irá admitir que o recurso “à proposição, constantemente repetida [por Lukács], de que 'apenas a ética pode superar o idealismo entre o particularismo dos indivíduos e seu caráter genérico’ etc."191, algo aliás muito próximo dos últimos postulados miltonianos (estes, por sua vez, resguardados na "razão" e apropriação política da técnica ontologicamente concebida e universalmente materializada no lugar), seriam insuficientes perante as "graves contradições e aos explosivos antagonismos materiais e políticos-ideológicos 'do socialismo realmente existente", no caso de Lukács, e do capitalismo "técnico-científico-informacional" existente, no caso de Santos.

Mészáros, diferente de Santos, Silva, Moraes e Moreira, não apenas irá reafirmar a necessidade de uma teoria da transição socialista, como também a substanciará como teoria geral das contradições mais atuais e destrutivas do sistema metabólico do capital, refirmando, por sua vez, o trabalho e sua condição ontológica no constructo de sua epistemologia.

A primeira orientação em Mészáros para se pensar em uma teoria segundo tais objetivos concretos é reafirmar sobre a relação capital-trabalho, contraditoriamente, sua condição de determinante universal abstrato; por isso, adotar o ponto de vista do trabalho dotado criticamente. Mészáros observa, como já disposto anteriormente, que a via concreticista da qual Lukács havia substanciado sua busca epistemológica desde "História e Consciência de Classe" até "Ontologia do Ser Social”, via essa também largamente conservada pela crítica geográfica, só poderia recair em postulados genéricos e não efetivamente objetiváveis; inviáveis enquanto a projeção de uma estratégia de superação real que, por sua vez, oscilariam entre a convocação dos "postulados morais imperativos" da classe trabalhadora, até a defesa da articulação política limitada e mediada pelo Estado-Nação (como objetivará, em última instância, Milton Santos), ou como no caso de Lukács, a insuperável defesa do "socialismo em um só país". Mesmo considerando que, no caso de Lukács, "em seu último trabalho, os mesmos postulados morais imperativos se apresentam sem qualquer corporificação histórica concreta"192, o papel dedicado à "ética" da ação disciplinar socialista ainda está contraposto ao papel das mediações materiais que ordenam a lógica interna do universal abstrato ("Lukács postula que os indivíduos, em resposta aos desafios particulares que são chamados a enfrentar em suas vidas cotidianas, tomarão consciência das responsabilidades decorrentes do 'seu pertencimento à espécie e as abraçarão positivamente"”) $)^{193}$.

\footnotetext{
${ }^{191}$ Ibid., p. 501.

192 MÉSZÁROS, 2011; p. 877.

${ }^{193}$ Ibid., p. 879.
} 
Haja vista que um projeto dessa envergadura não haveria de ter apenas como desafio a demonstração concreta das contradições abstratas já amplamente reveladas por Marx, seria notório o desafio de encarar com segurança teórica as desconfianças que naturalmente emergiriam diante de um quadro histórico pós-fim da "experiência comunista". Além de enfrentar o ceticismo dos que contraditoriamente propuseram o fim das categorias da crítica social já desenvolvida (modo de produção, trabalho, proletário, socialismo, etc.) sem nada de substancialmente alternativo pôr em seu lugar, Mészáros admite as dificuldades perante tal pretensão, sobretudo porque se encontraria diante da possibilidade de reduzir a teoria a seus enlaces de exteriorização e concreticização, limitadas ao tempo histórico empírico e quase sempre fetichista do capital, exatamente como havia denunciado Marx ao seu tempo contra as “especulações sobre o futuro" (“A [...] nova forma histórica não poderia ocupar nenhuma parte no projeto teórico de Marx: de fato, ele menosprezou aqueles que se engajaram em tais 'especulações sobre o futuro"”) ${ }^{194}$. A referência afirmativa para uma teoria da transição também não deveria partir de Lenin (já citado pelos geógrafos como justificativa de sua "opção" pela formação social em detrimento do modo de produção), já que suas formulações, segundo Mészáros, estavam confundidas com a necessidade estratégica e histórica de revelar as possibilidades revolucionárias no "elo mais débil da cadeia" global ("Nem para Lenin, o problema da transição foi relevante antes da Revolução de Outubro, uma vez que estava engajado na elaboração de uma estratégia para 'quebrar o elo mais débil da cadeia [...]"') ${ }^{195}$.

Diante de tais dificuldades, a possibilidade de constituição de uma teoria da transição estava destinada, de modo geral, a um "beco sem saída". Desde a Revolução de Outubro teria ela aparecido, como lembra Mészáros, como necessidade imanente da própria condição cíclica das crises capitalistas, condições essas que apareciam fragmentárias, parciais e pontuais espacialmente, como aquelas que possibilitaram a própria Revolução Russa. Além das condições históricas soma-se às restrições estruturais de conformação de uma teoria da transição "as determinações históricas essencialmente defensivas a que as forças combatentes socialistas do período estavam sujeitas, na sua confrontação desigual com o capital" (MÉSZÁROS, 2011; p. 1069), sobretudo no período que se segue à experiência soviética (não apenas ao engate histórico stalinista, mas à resignação conformativa da social-democracia europeia, o "isolamento" cubano e a integração chinesa ao mercado). O que resta diante deste quadro que aponta o "beco sem saída" para a efetividade de uma teoria da transição foi que, quase sempre, o caminho de retorno conduziam-na a duas alternativas que, também do ponto

${ }^{194}$ MÉSZÁROS, 2011, p. 1068.

195 Id., Ibid. 
de vista do destino histórico da crítica geográfica, podem ser relacionadas: por um lado, a internalização de uma crítica puramente epistemológica, concreticista e não menos remota e limitada, como que aquelas de Lukács haveriam de ser confinadas sobretudo pelos seus seguidores; e, por outro lado, a resignação fatalista e fragmentária da crítica que nada mais aponta do que várias variantes de "negações abstratas” (MÉSZÁROS, 2011; p. 1068).

“Hoje, a situação é qualitativamente diferente”, afirma o mesmo Mészáros (2011; p. 1069). Diante das mesmas condições das que observam Milton Santos sobre o mundo hodierno, da "globalização" como universalização fragmentária do capitalismo, observa Mészáros a condição totalitária, incontrolável e expansionista do "sociometabolismo do capital". Contudo onde o geógrafo vê uma "materialização do metafísico", observa o filósofo a radicalidade daquelas mesmas contradições abstratas desveladas por Marx na forma de uma crise estrutural do capital, sobretudo na "quebra" desastrosa da relação entre "produção e consumo". Esse mundo é também observado pela Geografia, especialmente por Milton Santos, que a ele denominará como "meio técnico-científico-informacional", no âmbito de sua vinculação racionais e normativas entre técnica e científica, e que apresenta sua crise apenas como potencialidade, ainda assim "acidental" (SANTOS, 2000; 17).

No entanto, Mészáros aponta que a partir da concreticidade histórica atual, tão requerida pela Geografia, no próprio tempo empírico atual, fundamentada em eventos sintomáticos como a Guerra do Vietnã e a demonstração do "colapso da forma mais abrangente agressiva do intervencionismo americano", os movimentos contestatórios no centro capitalista, sobretudo o maio de 1968 na França, mas também das lutas étnico-raciais no Estados Unidos (eventos esses de profunda importância para a renovação da crítica geográfica mundial, mas também a brasileira) que demonstraram "clamorosamente no coração do capitalismo 'avançado' a doença da sociedade, a fragilidade e o vazio de suas ruidosamente anunciadas realizações"; tal como o colapso da "saída" para as contradições estruturais do sistema soviético constatado pela "repressão às tentativas de reforma na Tcheco-Eslováquia e Polônia, sublinhando o crescimento das contradições nas sociedades do "socialismo real, como parte integrante da crise estrutural geral” (MÉSZÁROS, 1069 - 1070), todas elas tinham como significado o aprofundamento de contradições históricas do capital que não podiam ser mais deslocadas no tempo ou no espaço: os limites do deslocamento externo a partir do colapso do imperialismo militar-territorial, os limites dos deslocamentos internos nos países avançados que passaram também a apresentar suas contradições mais intensas, a integração e a demonstração de que a crise do "socialismo real" não seria relativo ao modelo soviético, mas à economia de capital como um todo. 
Mészáros irá até mesmo listar uma série de muitos outros eventos e suas repercussões econômicas, políticas e territoriais decorrentes das limitações absolutas dessas três categorias mais fundamentais das estratégias reprodutivas do capital acima apresentadas. Em síntese, basta mencionar os traços gerais: o fim dos regimes coloniais africanos e o fim das "tutelas" americanas na Europa e América Latina ("O fim do regime colonial em Angola e Moçambique [...]; o colapso do regime tutelado pelos EUA administrado pelos coronéis na [...] a desintegração do governo vitalício de Somoza - bancado pelos EUA na Nicarágua...”), as crise internas e incontroláveis no centro da produção capitalista mundial ("a correspondente erupção de grandes distúrbios sociais sobre as ruinas do welfare state [...], o fracasso das estratégias neocolonialistas do pós guerra [...], dentre elas a crescente crise econômica dos EUA [...], a volta do 'desemprego estrutural' [...]") e a integração total da "crise socialista" à "crise capitalista" (“o colapso da revolução Chinesa [...]; a indescritível tragédia do Camboja; ocupação soviética do Afeganistão e o consequente confronto armado [...]; o reescalonamento da dívida dos países do leste europeu [...]”).

O "pano de fundo" que se apresenta na concreticidade da crise estrutural a partir dos diferentes e variados eventos que, em suma, estarão interligados a uma forma genérica de dominação sociometabólica será, para Mészáros, o ponto de partida para a identificação de seus elementos mais abstratos. O que pode ser observado, diante do processo de "fragmentação geográfica", é apontar, para as ciências sociais críticas como um todo, a necessidade do resguardo de sua própria crítica em um plano mais abstrato e efetivo da própria crítica. Isso levaria Mészáros, para continuar com o exemplo, a apontar três suportes teórico de fundamentação para uma teoria da transição:

Primeiro: a identificação das categorias de sustentação reprodutiva do sistema sociometabólico do capital: capital, Estado, trabalho. Considerando a organicidade em que elas se entrelaçam (o capital como abstrato determinante que principia a substância e a existência das coisas; o Estado como a força política orgânica que agencia e medeia a relação capital-trabalho, em franca prevalência para o primeiro; e o trabalho como condição do processo de produção histórica do mais-valor e a condição ontológica, e por isso contraditória, de sua própria superação, dada as possibilidades também orgânica de sobredeterminação perante as "mediações de primeira ordem") seria o seu conjunto, reafirmado em franca organicidade e totalidade, como forma de se evitar a "identificação equivocada do alvo apropriado da transformação socialista [...], como é dolorosamente conhecida a história passada" (MÉSZÁROS, 2011; p. 1064). 
Segundo: isso levaria à consideração, como destaca Mészáros sobre Marx, de entender essa organicidade como um sistema de "mediação de segunda ordem" em que não deve ser confundido o sistema do "capital" com o sistema "capitalista". Conforme pontua Mészáros: “Marx chamou seu trabalho 'CAPITAL', e não 'CAPITALISMO', na verdade por uma boa razão [...]”. Ainda fundamentado em Marx, continua Mészáros: “Capital' é uma categoria histórica dinâmica e a força social a ela correspondente aparece - na forma de capital 'monetário', 'mercantil', etc. - vários séculos antes de a formação social do CAPITALISMO enquanto tal emergir e se consolidar" ${ }^{\prime 196}$.

Terceiro: isso indica que a substância alienada do trabalho efetivada na forma de capital se diferencia de suas formas especificamente históricas podendo ela existir antes e até mesmo depois do "capitalismo". Mészáros alerta que tal diferenciação, como já apontado por Marx (“como insiste Marx, 'a produção de mercadorias, necessariamente, transforma-se em produção capitalista de mercadorias, num momento dado") ${ }^{197}$, é fundamental do ponto de vista das objetivações práticas da crítica histórica e da prática emancipatória, pois ao mesmo tempo em que ela identifica a natureza contraditória e estrutural não superada pela experiência do “socialismo real”, aponta a dimensão objetiva da crítica transitória: a emancipação do trabalho.

Com relação à crítica geográfica, pode ser indicado a partir deste último ponto dois elementos fundamentais para o entendimento de como ela tendeu a contrapor sua estruturação epistemológica e suas possibilidades de conformação de uma teoria da transição: a relação entre abstração versus materialidade no entendimento sobre a história e sobre a ontologia.

É reconhecidamente aceito a necessidade de, na especificidade da formulação da crítica geográfica, o recurso à concreticidade e da empiria como "linha de fuga" para sua própria crítica histórica. Tal recurso, como visto, aplicado não apenas na perspectiva da ontologia de Armando Corrêa da Silva, mas também em Milton Santos, Ruy Moreira e Antônio C. R. Moraes, passa a se confundir com a forma em si de se fazer Geografia, inclusive sendo dele possível forjar suas próprias "abstrações". Uma questão então se coloca: quais a limitações de tal recurso no momento em que o "equilíbrio dialético" entre abstrato e concreto se quebra, já que, do ponto de vista da tradição geográfica, é "preferível” uma análise mais concreticista? Em desdobramento: como salvaguardar o rigor dialético (que deveria estar localizado no processo em si de mediação entre concreto e abstrato no sentido de revelar suas contradições),

${ }_{196}^{196}$ MÉSZÁROS, 2011, p. 1064.

197 Id., Ibid. 
mesmo considerando os esforços em "dialetizar" a "forma", o "físico", ou o "território", conferindo a eles atributos de movimento? Essas questões ajudam a revelar, em certa medida, os objetivos para uma ontologia propriamente geográfica sobre os significados do "estatuto ontológico" para uma disciplina em crise de fragmentação, como autorreconhecido por Armando Corrêa da Silva. Mas, do ponto de vista de sua constituição em si, a ontologia seria um processo de substantivação do objeto geograficamente corporificado em sua empiria concreticista (ser espaço determinado por sua essência material), ou seria a forma de pôr a contradição entre o universal comum (ser como abstração) e sua determinação diferenciada (ser como ente em sua apresentação histórica)?

\section{3 - “Corpo" versus "carcaça": entre a substantivação e a dissecação ${ }^{\mathbf{1 9 8}}$}

É notório como a análise sobre a separação do "corpo" (em sua constituição material) e a representação abstrata do espaço regeu o debate ontológico. A questão passa a girar em torno de saber como reestabelecer ao espaço sua substância corpórea, especificamente geográfica, mas carregada de possibilidades explicativas para além da simplificação da descrição regionalista ou do clássico determinismo geográfico ${ }^{199}$. Em suma, era preciso entender o "corpo" espacial, sua essência material e universal, para além de sua determinação fetichizada, como carcaça do tempo para o valor de troca, como especificidade do capital, carregada de determinações alienantes com relação a sua forma e conteúdo.

Milton Santos, por exemplo, que na urdidura também "amalgamática" de sua ontologia da técnica encontraria Jacques Maritain, concordaria com o filósofo que "o tempo verdadeiro [...] sendo baseado no movimento, é, como o espaço, inseparável da matéria corpórea". Assim, a título de solução epistemológica, assevera sobre o corpo do tempo: “o espaço tem, sempre, um componente de materialidade donde lhe vem uma parte de sua concretude e empiricidade"; essa matéria, empiricizada, seria, assim, a solução da dialética propriamente geográfica da relação espaço-tempo: "Se queremos unificar tempo e espaço, se pretendemos que possam ser mutuamente includentes, o tempo deve ser, também, empiricizado" (SANTOS, 2008; p. 5354).

A solução epistemológica proposta por Santos avança no sentido de ir além da dicotomia, mas apenas para enunciar a unidade que, sem apontar as mediações de como o

\footnotetext{
${ }^{198}$ O presente tópico é resultado do importante debate estabelecido com o professor e colega Marcel Di Angelis. 199 "Sem minimizar a importância das condições naturais, são as condições artificialmente criadas que sobressaem, enquanto expressão dos processos técnicos e dos suportes geográficos da informação. Estaremos diante de um determinismo de tipo novo, um neodeterminismo do espaço artificial?” (SANTOS, 2008; p. 248).
} 
empírico é também, na simultaneidade, a própria não-realização do tempo, nessa união de contrários, supõe apenas uma unidade formal: objetos e ações. Aos objetos estariam a condição material dada e possível, do ponto de vista de efetividade humana a partir da técnica; e às ações o que daria conteúdo aos objetos; sua informação, razão, ação, etc.

A busca pela substância do objeto geográfico, seja em Silva pelo "território possível da verdade" lukacsiana em seus remotos complexos orgânicos-inorgânicos, seja em Santos a partir das mais atualizadas categorias da "razão", "ação", ou "informação", conserva, em relação à forma, uma mediação de "exterioridade" material em que a única "dialética" possível entre elas é a da conciliação ou complementariedade - por isso, formal e enunciativa.

Resguardando, desse modo, o concreto e material como o próprio empírico, a especificidade da substância do corpo do espaço geográfico se aproxima mais da crítica feuerbachiana do que propriamente à dialética marxiana, como não fora admitido. É certo que Milton Santos haveria de se atentar para os riscos apriorísticos das absolutizações feuerbachianas perante o círculo vicioso da contradição que envolve a produção da natureza ("[...] já não são mais a natureza natural, mas a natureza historicizada. E não há precedência a buscar entre natura naturans e natura naturata. Cada qual, ao seu tempo, dá origem e explica a outra" ${ }^{200}$, mas é certo também que a vinculação da ontologia do espaço a partir da "empiricização do tempo pela técnica", e sua consequente materialização objetiva concreticista, em muito se aproxima daquela crítica de Feuerbach dirigida à própria metafisica lógica e conceitual de Hegel: "Um tal efeito material - por conseguinte, uma simples expressão do poder sensível - é, acima de tudo, a criação ou a produção de um mundo real, material" (FEUERBACH, 2008; p. 17) 201 .

É notório como tal passagem de Feuerbach em muito se aproxima daquela famosa consideração de Santos sobre a revelação do "corpo" do espaço no "ser humano":

O mundo da fluidez, a vertigem da velocidade, a frequência dos deslocamentos e a banalidade do movimento e das alusões a lugares e a coisas distantes, revelam, por contraste, no ser humano, o corpo como uma certeza materialmente sensível, diante de um universo difícil de apreender (SANTOS, 2008; p. 313-314).

Mas também é notório como se revelam aquelas categorias que, como denunciadas por Marx em sua crítica contra Feuerbach, saltam-se para além da própria história em que estão

\footnotetext{
200 SANTOS, 2008; p. 119.

${ }^{201}$ FEUERBACH, Ludwig, Princípios da Filosofia do Futuro, Covilha, Luso Sofia Press, 2008.
} 
conformadas. Isso permite, por conseguinte, tanto Feuerbach, como Milton Santos, poderem falar em "homem" e "ser humano", tal como também em uma técnica ontológica que se desenvolve, senão "neutra” ou independente da economia política, ao menos “disponível” como externalidade para a apropriação socializada: "Só por sua presença, os objetos técnicos não têm outro significado senão o paisagístico. Mas eles aí estão também em disponibilidade, à espera de um conteúdo social" (SANTOS, 2008; p. 105). O mais curioso nessa passagem de Milton Santos é que, na sequência, o autor cita Marx para demonstrar que, em relação à técnica, procede a mesma relação com a qual o filósofo alemão considerou a diferença entre tecnologia e economia política: "Marx já dizia que 'a economia política não é tecnologia' [...]. Se o homem, por seu trabalho [...] não transmite vida à coisa, essa vida da qual somente ele é detentor, o objeto permanecerá sempre como tecnologia, e não como economia" (SANTOS, 2008; p. 105). Mas aí está uma oportunidade crucial para entender a diferença, e a provável inconciliação, entre a proposição ontológica de Marx e a de Milton Santos em sua busca ontológica. Na verdade, em última instância, elas se encontram invertidas, tal como a teoria marxiana se encontra invertida em relação à de Feuerbach.

Marx encontra em Feuerbach, no momento em que se "viu em apuros" diante dos problemas de "interesses materiais" ${ }^{202}$, a saída mais avançada para o desafio de enfrentar a "Filosofia do Direito", de Hegel, como assim consideraria: "Quanto menos ruidosa, tanto mais segura, profunda, extensa e duradoura é a eficácia dos escritos feuerbachianos, os únicos nos quais - desde a Fenomenologia e a Lógica, de Hegel - se encerra uma efetiva revolução teórica" (MARX, 2004; p. 20) $)^{203}$. A leitura de Feuerbach tinha permitido a Marx avançar na crítica do caráter especulativo e logicista da filosofia hegeliana (idealismo) e avançar na fundamentação do pensamento científico baseado na positividade e objetividade para, enfim, estabelecer a “determinação ontológica mais geral que subjaz ao perfilhamento, igualmente ontológico, do homem em sua autoefetividade material” (CHASIN, 2009; p. 56-57). Isso significaria o reconhecimento desse mesmo positivo, da sociabilidade dada, como condição inicial da apropriação inteligível e crítica (em oposição ao procedimento abstrativista, logicista e especulativa propriamente "hegeliano da negação da negação") ${ }^{204}$. A conclusão de Marx acerca

\footnotetext{
${ }^{202}$ Como assim caracteriza o próprio Marx o momento exato em que percebe a necessidade de desenvolver a crítica histórica pela economia política, tal como revela na introdução da Crítica da Economia Política: "Minha especialidade era a jurisprudência, a qual exercia contudo como disciplina secundária ao lado de Filosofia e História. Nos anos de 1842/43, como redator do Gazeta Renana (Rheinische Zeitung) vi-me pela primeira vez em apuros por ter que tomar parte na discussão sobre os chamados interesses materiais” (MARX, Karl, Para a Crítica da Economia Política, São Paulo, Abril Cultural, 1982; p. 24).

${ }^{203}$ MARX, Karl, Manuscritos Econômico-Filosóficos, São Paulo, Boitempo, 2004.

${ }^{204}$ CHASIN, 2009; p. 56.
} 
dos problemas da Fenomenologia e da Lógica hegeliana, descobertas nos "Manuscritos Econômicos-Filosóficos", não haveria de ser outro senão a inauguração de uma crítica dialética "materialista" que passou a conter até o fim da produção intelectual marxiana uma nova esfera ontológica, que seria mais tarde revelada por Lukács: uma ontologia baseada na realidade concreta e, por isso, fundamentada e uma ontologia do trabalho. Por outro lado, era preciso reconhecer e dimensionar a natureza da "crítica materialista" para além do concreticismo vulgar que a filosofia feuerbachiana tendia a levar. A delimitação do nível ontológico da crítica material era, por isso, também uma autocrítica e o consequente rompimento com a filosofia de Feuerbach.

Marx tinha que reconhecer que o materialismo de Feuerbach tendia à própria mistificação do mundo sensível denunciado: "Mesmo os objetos mais simples da 'certeza sensível' são dados a Feuerbach apenas por meio do desenvolvimento social, da indústria e do intercâmbio comercial" (MARX, 2007; p. 30-31) ${ }^{205}$. E caso se torne possível estender a crítica marxiana à técnica miltoniana, ontologizada pela sua expressão empiricizada, pode-se aqui utilizar aquela famosa passagem da "cereja" ("a cereja [...] foi transplantada para a nossa região pelo comercio, há apenas alguns séculos e, portanto, foi dada à 'certeza sensível de Feuerbach apenas mediante essa ação de uma sociedade determinada numa determinada época') ${ }^{206}$ para identificar os problemas derivativos de como entender que a técnica, produzida pelo capital, esteja aí, "disposta”, à espera de um conteúdo social, sendo que ela nunca deixou de ser, na sua integridade e na referida sociedade dada, outra coisa senão essa mediação entre o trabalho e a condição do mais-valor.

No caso de Milton Santos, a evidência de que tal composição ontológica só se tornaria efetivável diante da "liberação dialética" para este tipo de cisão efetiva entre a técnica e sua "economia política" historicamente específica (do capital e como capital) é reveladora, embora escuso no interior mais íntimo de sua sofisticação teórica. Todavia, é exatamente na passagem de Marx, usada por Santos (citada acima) para fundamentar a "disponibilidade" da técnica "à espera de um conteúdo social", em detrimento de sua determinação especificamente histórica da "economia política" do capital ("Mas a Economia Política não é tecnologia" - no "Grundrisse"), é que pode ser notada a diferença fundamental entre a substância ontológica de Marx e a de Santos. Na sequência da referida passagem citada por Santos, continuará Marx em seu próprio texto: "Finalmente, a produção também não é somente produção particular. Ao contrário, é sempre um certo corpo social, um sujeito social em atividade em uma totalidade

\footnotetext{
${ }^{205}$ MARX; ENGELS, Ideologia Alemã, 2007.

${ }^{206}$ Ibid., p. 31.
} 
maior ou menor de ramos de produção" (2011; p. 41) ${ }^{207}$. O "corpo social”, definido mais adiante por Marx em sua obra, não está se referindo apenas à forma meramente histórica de expressão do objeto posto inteligivelmente. Nem se refere a sua forma de expressão enquanto ente. Mas como totalidade em si, como a forma constituinte do ser; ou seja, do ser social, logo histórico.

Lukács será o primeiro a levantar o problema central dessa postura no campo específico da ontologia, que é substancialmente também histórica: o universal ôntico se contradizendo consigo mesmo na sua efetividade histórica. E a resolução por ele buscada em Marx não haveria de ser outra senão a admissão dessa contradição na constituição em si do ser, como forma de elevação da unidade dialética entre o ser e o ente a sua última instância.

Conforme analisa Lukács, ainda sobre os escritos embrionários do autor:

Marx coloca já aqui [em sua tese doutoral], portanto, um problema que mais tarde, quando ele se tornar economista e materialista, terá grande importância em sua obra: a função prático-social de determinadas formas de consciência, independente do fato de elas, no plano ontológico geral, serem falsas ou verdadeiras (LUKÁCS, 2012; p. 284)

A determinabilidade do ser se constituindo como tal na sua lógica histórica, se contradizendo assim com sua forma universal, significa, a um só golpe, o rompimento e a superação não apenas do idealismo hegeliano, mas da própria "abstração" universalistamaterialista feuerbachiana: "Na medida em que Feuerbach é materialista, nele não se encontra na história, e na medida em que ele não se encontra na história, e na medida em que ele toma em consideração tal história ele não é materialista" (MARX; 2007; p. 32). Daí que, retornando o problema levantado a partir da colocação de Santos, se a técnica ontologicamente concebida haveria de estar "disposta a espera do conteúdo social", só poderia encontrar nos dispostos marxianos sua mais fundamental crítica, análoga à desferida contra Feuerbach, na medida em que não poderia ser ela cindida de sua "economia política" própria das determinações históricas do trabalho, este também em contradição histórica na sua forma-valor, como forma abstratadeterminante do tempo histórico do capital, como carcaça do tempo $^{208}$.

Milton Santos, entretanto, parece se antever a tal problema e, no âmago da substituição daquilo que parecia não ser efetivamente "geográfico" ("economia política" fundada na

\footnotetext{
${ }^{207}$ MARX, Grumdrisse: Manuscritos Econômicos de 1857-1858, 2011.

${ }^{208}$ Mészáros, recorrentemente, usará essa expressão extraída de Marx para designar a concreticidade alienante do tempo pela efetividade da contradição entre qualidade e quantidade: "Tempo é tudo, o homem é nada; no máximo ele é apenas a carcaça do tempo. A qualidade já não mais importa. A quantidade sozinha decide tudo, hora por hora, dia por dia (Marx, The Poverty of Philosophy, pp. 126-7.” (MÉSZÁROS, 2011; p. 415).
} 
“dialética do trabalho"), elabora uma interessante saída teórica-ontológica para a mediação entre a "ação" (histórica) e o "objeto" (ontológico). A "intencionalidade" (em "A Natureza do Espaço", cap. 3) significará a resolução de três problemas no processo de centralização da técnica, além de salvaguardar suas possibilidades de condição "autônoma", cindida da sua específica "economia política", no momento em que ela passa a aparecer como "potencialidade" para o uso humano.

Primeiro: a mudança de referencial teórico. Da "economia política" para a "filosofia da técnica", como observado desde o texto "Técnica, Espaço, Tempo" até sua proposição ontológica $^{209}$ : assim, de forma amalgamática, costura Santos o argumento filosófico para fundamentar a "intencionalidade" na "reconstrução da teoria do conhecimento", agora com forte influência da fenomenologia, no sentido de constituir uma linha própria de pensamento (“A própria consciência, diz Husserl, é intencional [...], ou como lembra W.A. Luijipen (1996, p. 31), o intelecto é tanto uma inteligência ativa como uma passiva" $)^{210}$;

Segundo: a mudança de referencial histórico. Da especificidade histórica e objetivável do capital para uma abstração gnosiológica conveniente à tradição geográfica: também de forma amalgamática urde Santos o argumento filosófico "propriamente espacial” da intencionalidade como mediação fundante entre o homem e o mundo ("Ao propor o que chama de "fato primitivo’ de uma filosofia existencialista, Luijpen (1966, p. 889) denomina de encontro essa 'implicação mútua do sujeito e do mundo', essa 'reunião do homem e do objeto'”) ${ }^{211}$, ou da intencionalidade como substância do objeto até a efetiva "objetivação do sujeito" ("O filósofo italiano C. Diano (1994, p. 90) talvez vá ainda mais longe ao lembrar que 'no ato teórico sujeito e objeto constituem uma unidade, mas o sujeito aparece como objeto"').

Terceiro: a mudança do referencial ontológico. Da admissão da contradição como procedimento lógico-inteligível do objeto para sua substantivação essencialista teóricaepistemológica: por fim, e ainda de forma amalgamática, sintetiza Santos a natureza da intencionalidade no objeto, agora "geograficizável”, na "empiricidade" do real, com categorias e conceitos próprios ("Segundo ele [C. Diano], pode-se pretender que sujeito e objeto criam-

\footnotetext{
${ }^{209}$ É interessante lembrar que a forma de entender a técnica como uma dimensão para além da economia política está especificamente posta no debate ontológico em A Natureza do Espaço. É importante notar seu contraste com aquela noção desenvolvida no texto "Técnica, espaço e Tempo", publicado em livro de título homônimo, em que a relação entre técnica e economia política ainda estão, no pensamento de Santos, bastante imbricados (SANTOS, 2013).

${ }^{210}$ SANTOS, 2008; p. 90.

${ }^{211}$ Ibid., p. 90.
} 
se mutuamente, eles se substancializam um à custa do outro na 'empiricidade', onde, sob a ação da forma, revelam-se no evento") ${ }^{212}$.

Em relação à Marx, observa-se em Santos um processo inverso de amadurecimento na constituição ontológica. Como já citado, não foi acidental o reconhecimento de Marx de que somente pela economia política é que os problemas de "interesses materiais" pudessem ser revelados na sua gênese interna, contraditória e real. Isso o permitiu, além de compor uma esfera ontológica inteiramente nova, afastar-se do idealismo (mas não da filosofia mesma) para a constituição de sua dialética sobre a realidade concreta, não meramente material (Feuerbach). Milton Santos, inversamente, vai buscar na síntese de fusão filosófica (por vias fenomenológicas, mas não só) o fundamento de uma materialidade empiricizável para a substantivação de uma leitura científica propriamente geográfica fundamentada na técnica ontologizada e substantivada pela "intencionalidade", ou "razão" no que concerne sua forma moderna. No entanto, a título de exemplo, é interessante relembrar ainda a crítica de Marx contra a universalização empírica hegeliana, e seu consequente "resultado místico", numa passagem assustadoramente extensível à empiria e a racionalidade técnica miltoniana, apesar dos riscos de anacronia: "A realidade empírica é tomada tal como ela é; ela é, também, enunciada como racional; porém ela não é racional devido a sua própria razão, mas sim porque o fato empírico, em sua existência empírica, possui um outro significado diferente dele mesmo" $(\text { MARX, 2013; p. 37) })^{213}$

Embora as questões como "reificação do sujeito", problemas sobre a alienação no processo produtivo, unidade sujeito-objeto em processos de coisificação, etc. sejam questões comuns nas perspectivas ontológicas de Santos e Marx, elas são essencialmente, e em última palavra, diferentes. Não só porque estão elas invertidas no processo de desenvolvimento e maturação teórica, mas sobretudo porque se constituíram para atender finalidades diferentes.

Em Marx, a ontologia - embora nunca efetivamente admitido a necessidade de sua definição teórico-metodológica, dada a natureza com que a teoria deveria se confrontar com real-concreto, não como ela deveria se apresentar perante o debate científico-disciplinar - se efetiva como recurso de inteligibilidade na forma de pôr o objeto diante do próprio desafio de seu entendimento. Mas não do entendimento puramente em si, de suas mediações mais íntimas e contraditórias como a fenomenologia hegeliana procede.

Embora a dialética hegeliana tenha sido importante meio de "dissecação" do objeto até o limite de suas contradições conceituais mais intimas, Marx eleva tal procedimento às

${ }^{213}$ MARX, Karl, Crítica da Filosofia do Direito de Hegel, São Paulo, Boitempo, 2013. 
últimas instâncias até a revelação de sua própria insuficiência conceitual de onde, então, só restará a necessidade de "voltar", fazer o caminho inverso, para o desvelamento da "lógica da coisa" 214 em sua forma real-concreta, dimensão originária de onde o objeto fora intelectivamente apropriado. (“[...] do concreto idealizado passaríamos a abstrações cada vez mais tênues até atingirmos determinações mais simples. Chegados a este ponto, teríamos que voltar a fazer a viagem de modo inverso" $)^{215}$. Se, como objetiva Marx, o "corpo social” dado e específico é a condição por onde o ser se efetiva (o abstrato-efetivo), o objeto então inserido nesse "corpo" histórico se torna carcaça de suas próprias mediações concretas e historicamente específicas, agora apropriadas cientificamente (“O último método é manifestamente o método cientificamente exato. O concreto é concreto porque é a síntese de múltiplas determinações") ${ }^{216}$.

Porém isso não significa que todo objeto posto na centralidade da análise científica pela sua centralidade eletiva decorrente da necessária divisão disciplinar do conhecimento seja necessariamente ontológico. A condição ontológica do objeto, conforme se pode extrair do pensamento marxiano, não se põe como o "prêmio de recompensa" pelo reconhecimento de seu caráter universal, abstrato, comum a "todas as épocas da produção" (MARX, 2011; p. 41); o reconhecimento do abstrato universal apenas "poupa-nos de repetições" 217 historicistas.

Tal procedimento não passaria de arbitrariedade cientificista, caso o objeto ontologizável não esteja submetido ao "rigor ontológico" (CHASIN, 2009; p. 58), a sua "dissecação"; ou seja, a busca de sua própria falsa condição gnosiológica, universal e, supostamente, ontológica ou até "natural". Este é o momento em que o objeto experimenta sua autocrítica: onde o ser, a partir do seu ente, é posto contra sua própria existência específica e contra seus determinantes/determinações abstratas e universais, ou como "Daseinform". Como lembra Mészáros, a respeito de Marx, este "desvendou o verdadeiro sentido dessas categorias colocando em relevo a sua base de existência real e as tratando enquanto as mais gerais Daseinform ('formas de existência'), refletidas na filosofia 'como numa câmara escura, numa forma invertida"” (MÉSZÁROS, 2008, p. 95). Isso permitiu ao autor de "O Capital" estabelecer como que "o objetivo verdadeiro da crítica é sempre o determinante fundamental - nesse caso, o modo [não a "coisa" ou o "objeto"] específico do metabolismo social [...]"218. É neste sentido que adverte Marx - na mesma página em que Milton Santos cita-o no "Grundrisse" - sobre a

\footnotetext{
${ }^{214}$ Como assim se estabelece a crítica de Marx contra Hegel: “O momento filosófico [de Hegel] não é a lógica da coisa, mas a coisa da lógica" (MARX, 2013; p. 45).

215 MARX, 1982; p. 14.

216 Id., Ibid.

${ }^{217}$ MARX, 2011; p. 41.

218 Ibid., p. 111.
} 
questão da "diferença essencial”: “As determinações que valem para a produção em geral têm de ser corretamente isoladas de maneira que, além da unidade [universal abstrato comum], não seja esquecida a diferença essencial" (MARX, 2011; p. 41). O objetivo de Marx é revelar a "maliciosa falsificação" 219 dos objetos históricos que se põe como absolutos porque, sem sua especificidade concreta estabelecida, se apresentam no processo de apreensão da consciência e do conhecimento como eterno-presente, logo como "naturais". Neste sentido, elabora Marx tal procedimento usando categorias, aliás bem próximas daquelas que serão, mais tarde, manipuladas pela ontologização da técnica em Milton Santos, como se observa:

\begin{abstract}
Nenhuma produção é possível sem trabalho passado, acumulado, mesmo sendo este trabalho apenas a destreza acumulada e concentrada na mão do selvagem pelo exercício repetido. O capital, entre outras coisas, é também instrumento de produção, também trabalho passado, objetivado. Logo o capital é uma relação natural, universal e eterna; quer dizer, quando deixo de fora justamente o específico, o que faz do "instrumento de produção", do "trabalho acumulado", o capital. Por essa razão, toda a história das relações de produção aparece em Carey, por exemplo, como uma maliciosa falsificação provocada pelos governos (MARX, 2011; p. 41).
\end{abstract}

Do ponto de vista da história da filosofia, tal entendimento da posição marxiana, em que o abstrato se contrapõe e se reconhece negativamente no concreto, representa o passo ontológico que se segue depois da revelação da auto-alienação da filosofia em relação à religião e à teologia: "Portanto, a tarefa histórica, depois de desaparecido o além da verdade, é estabelecer a verdade do aquém" (MARX, 2013; p. 152). Do ponto de vista da história humana concreta, o passo ontológico marxiano, que se dá desde a Crítica ao Direito de Hegel até seus últimos escritos, não seria outro senão o reconhecimento da "revolução radical" para a "emancipação humana universal" (2013; p. 160), ou a "verdadeira história humana" (1982; p. 26).

Em Santos, a síntese de fusão filosófica que irá colocar a "intencionalidade" (junto com a "razão" e a "ação") no posto de substância dos objetos técnicos, e da própria técnica, não tem a mesma fundamentação ontológica marxiana. Aqui a ontologia é entendida a partir de um problema de apropriação consciente do real (como em Marx), mas não para a "dissecação" do objeto posto na análise: o espaço. Pelo contrário, a ontologia se apresenta como instrumento explicativo-positivo para uma forma de engajamento crítico que, ao mesmo tempo, revelam a dimensão do espaço pela técnica, fornece ainda elementos afirmativos de substantivação para

${ }^{219}$ Ibid.,; p. 41. 
"encorpar" a teoria que se pretende geográfica, como sintomaticamente procede Santos com uma de suas referências: "Uma outra noção de intencionalidade, vinda da psicologia e da psicanálise, pode ser apropriada na análise geográfica, com a acepção que, aqui, estamos querendo sugerir: [...] 'A ideia de evento intencional está implícita na ideia de conduta, de ação"” (SANTOS, 2008; p. 92).

A ideia de "evento"220 será a saída encontrada por Santos para relacionar a especificidade com que a "imagem-meta" (intencionalidade, ação, razão) atinge um "objetometa", este por sua vez representado pelos próprios objetos, ou sistemas de objetos, reais e empíricos que, revelada sua especificidade racional, irão constituir a paisagem para depois (como citado) orientar “a evolução da própria sociedade" (2002; p. 244). Santos então remete propriamente à geografia, completando sua síntese de fusão, a objetivação elementar de sua ontologia baseada na relação entre intencionalidade e objeto, que põe a "ação humana como projeção da matéria", como assim admite:

Em sua versão da tese da intencionalidade, T. Hägerstrand (1989) completa e aperfeiçoa as propostas anteriormente avançadas por D. Ley (1977), A. Buttimer (1976), N. Smith (1979), D. Seamon (1982), J. Pickles (1985) e outros. Fundando-se no filósofo sueco Jakob Meloe (1973), refere-se à ação humana como uma projeção da matéria (SANTOS, 2008; p. 93)

Depois de toda amarração amalgamática, chega Santos aos objetivos teóricos que irão corporificar o espaço de sentido teórico-filosófico: o papel condicionante de que o espaço exerce sobre a ação humana, na medida em que é também ele substantivado pela "intencionalidade" inerente aos objetos materiais. O estatuto ontológico do espaço se efetiva, assim, como objeto individualizado carregado de relações próprias que comporão seu corpo teórico (uma essência); na medida em que também o espaço concreto passa a ser esse corpo sintético de objetos, autônomo (mas não independente), carregados de ações e intencionalidades. A técnica, como a categoria de mediação entre homem e natureza, ganha, dessa forma gnosiológica, sua autorreferência filosófica em relação a sua diferença essencial específica da "economia política" historicamente posta, na mesma medida em que o espaço também passa a produzir história, tal como a história produz espaço. Uma autorreferência - de franca influência hegeliana - que põe o objeto fechado em sua própria conceituação (como solução epistemológica), como havia denunciado Mészáros contra "imobilidade” (“a

\footnotetext{
${ }^{220}$ Discussão essa que será analisada de forma mais detalhada no tópico "6.4 - A via positiva-epistêmica"
} 
problemática do sujeito-objeto idêntico possa englobar um movimento, este caminha em direção a um ponto de imobilidade: a resolução do fim teleológico originalmente postulado [em prol da intencionalidade]") $)^{221}$ com que a "dissolução conceitual" haveria absolutizado o empírico, no caso de Hegel: "Em Marx, pelo contrário, o movimento é livre e seu propósito fundamental é subversivo, não reconciliatório"222.

Mészáros irá ainda argumentar que a "concepção marxiana da dialética foi além da de Hegel, precisamente desde o momento inicial, em dois aspectos fundamentais" (MÉSZÁROS, 2008; p. 13). Primeiro, no reconhecimento e na crítica da dialética objetiva hegeliana como “construção conceitual especulativa (através da oposição dualista entre ideia e sujeito e existência empírica degradada e simples fenomenalidade)" que tendia, assim, a se pôr como a própria realização objetiva do real. Segundo, a identificação e a demonstração da inversão ideológica que, por conta da “'dissolução e restauração do mundo empírico’ como construção anistórica, que contradiz as potencialidades profundamente históricas da própria concepção hegeliana", obstruíam a análise dialética no reconhecimento do conteúdo histórico real e concreto, tal como as "alavancas necessárias"223 ao processo revolucionário. Nota-se nos dois aspectos fundamentais identificados e demonstrados por Marx os riscos mistificadores que, por meio de suas respectivas formas de rever a realização da "metafísica no empírico", operam Hegel em suas formulações. É dessa forma que, como em Hegel, no caso de Milton Santos, produto e produtor assim se identificam até se conciliarem, ou "unicizarem" na própria empiria, ou na imanência entre sujeito e objeto, perante suas contradições diluídas como a forma de, inclusive, reclamar o equilíbrio dialético entre tempo e espaço.

Somente pondo a dialética nessas condições (mediação formal e autoprodutiva entre história e espaço) é que, assim, pode estar ela, a técnica, disposta, como "potencial”, para a abstrata e universal "apropriação humana". Naturalmente, necessitando de uma dialética para tais finalidades (liberada do "rigor ontológico") e de uma ontologia vinculada à "solução teórica", não poderia Milton Santos encontrar nos procedimentos ontológicos de "dissecação", a partir da "economia política" marxiana, muito menos na ontologia do trabalho de Lukács, seus referenciais.

Por outro lado, isenta da "dialética da contradição" e liberada para montagem por sistemas de fusão em prol do posicionamento afirmativo do espaço na teoria ontológica que se pretende eminentemente geográfica, é que pode a perspectiva miltoniana do espaço se dispor

${ }^{221}$ MÉSZÁROS, Filosofia, Ideologia e Ciência Social, 2008.

${ }^{222}$ MÉSZÁROS, 2008, p. 114.

${ }^{223}$ Id., Ibid. 
às possibilidades de encontro, ou de "reinterpretação", com a ontologia heideggeriana: "É nessa direção que se pode reinterpretar a ideia de Heidegger (1992, p. 90), segundo o qual 'o onde determina o como do Ser, porque Ser significa presença"” (SANTOS, 2008; p. 93). Por desdobramento, é por onde também se encontram as possibilidades de colocar a técnica como centralidade ontológica, como "meio", como "potência" e como essência, também emancipatória, do homem. Na sequência das citações propriamente de Heidegger, no famoso texto "Questões Sobre a Técnica"224, podem ser aclarados a forma como estabelece tais influências (não muito abertamente admitidas) para composição teórica de Santos, e quão absurdamente elas se equivalem. Dirá Heidegger sobre a centralização ontológica da técnica: “Técnica é um modo de desabrigar [como a forma "destinal" humana da revelação da "verdade"]. A técnica se essencializa no âmbito onde acontece o desabrigar e o desocultamento, onde acontece a ['Ideia']” (2007; p. 381). Dirá Heidegger sobre a técnica como meio: "É correto dizer: também a técnica moderna é um meio para fins [...]. Tudo se reduz ao lidar de modo adequado com a técnica enquanto meio. Pretende-se, como se diz, 'ter espiritualmente a técnica nas mãos'. Pretende-se dominá-la"225 (embora esteja Heidegger nessa passagem apenas admitindo o "conceito instrumental", e a necessidade de ir além, de ir à "essência"). Dirá Heidegger sobre a condição de potência da técnica, na forma do que chama de "subsistência": " $\mathrm{Na}$ armação acontece o descobrimento, segundo o qual o trabalho da técnica moderna desabriga o real enquanto subsistência [que é a essência posta como potência na eminência revelação do ser]"226. Dirá Heidegger sobre a possibilidade da "salvação" da essência do homem na essencialização da técnica: "Assim, a essencialização da técnica abriga em si o que menos poderíamos supor, o possível emergir da salvação"227.

O que não se observa neste conjunto de aproximações não francamente admitidas com Heidegger - a ontologização pela técnica, da técnica como meio, da técnica como "potência" emancipatória - são aquelas inconciliações com a teoria do trabalho lukacsiana abertamente tida como também influência na teoria miltoniana, e no discurso ontológico da renovação crítica em geral. O mais curioso é como que tal inconciliação não fora admitida, ou mesmo percebida, afinal não se trata de meros detalhes a forma como a "presença" heideggeriana é "reinterpretada" por Milton Santos. O ponto central da argumentação que se pretende

\footnotetext{
${ }^{224}$ HEIDEGGER, Martin, “Questões Sobre a Técnica”, In: Scientiæ Zudia, São Paulo, v. 5, n. 3, p. 375-98, 2007. ${ }^{225}$ Ibid., p. 376.

${ }^{226}$ Ibid., p. 385-386.

227 Ibid., p. 394.
} 
emancipatória, da natureza da "disposição da técnica" para a apropriação política, é um ponto central da crítica de lukacsiana contra a ontologia heideggeriana, como coloca o próprio Lukács:

Que seja mencionada apenas, como exemplo significativo, a análise fenomenológica do "utensílio" em Heidegger. Uma gênese social real (o trabalho) fica completamente de fora de suas considerações de como realmente, na vida cotidiana imediata do homem atual, mas apenas neste, o "utensílio" é simplesmente "levado às mãos" [zuhanden] (LUKÁCS, 2010; p. $103)^{228}$

Como comenta Lukács, tal forma de entender a "disponibilidade" - do "levado às mãos" - heideggeriana ("Heidegger afirma: 'apenas porque o utensílio tem esse ser em si, e não simplesmente porque ainda aparece, ele é prático no sentido mais amplo e está disponível") ${ }^{229}$, que por onde se retira "importantes consequências ontológicas que se referem ao 'homem em geral"”, contém nela uma "generalização a-crítica", um ser desse homem em geral posto de forma "simplificada" e "abstrata", que apenas remete à "clarificação geral de situações típicas e fundamentais que aí surgem com seus pressupostos e consequências". Tais "pressupostos" e "consequências" que são, no fundo, a própria diferença essencial de sua "generalidade" (LUKÁCS, 2010; p. 103) invertem o que faz do ser, ser-em-si.

Diante de reveladoras aproximações e inconciliações com tais referenciais (essencialista, no melhor estilo heideggeriano), se torna impossível conceber uma dialética que lhe permita, no processo da dissecação interna do objeto ontológico, a busca de suas contradições mais íntimas, como o capital (categoria histórica) e o trabalho (categoria universal) foram para Marx. Tende, dessa forma, a escapar do horizonte geográfico a própria contradição, enquanto possibilidade analítica dada sua forma supostamente específica de se apropriar do mundo porque os métodos estão invertidos: o primeiro (heideggeriano), do objeto à sua revelação existencial verdadeira na busca de sua essência humana; o segundo (marxiano), de sua posição como real-concreto até seu desvelamento lógico, ou "genético", histórico e específico. Ou como dirá Marx na especificidade da crítica contra Hegel:

A verdadeira crítica, em vez disso, mostra a gênese da santíssima trindade no interior do cérebro humano. Descreve seu ato de nascimento. Com isso, a crítica verdadeiramente filosófica da atual constituição do Estado não indica somente suas contradições existentes; ela esclarece essas contradições, compreende sua gênese, sua necessidade. Ela as apreende em seu significado

\footnotetext{
${ }^{228}$ LUKÁCS, György, Prolegômenos: Para Uma Ontologia do Ser Social, São Paulo, Boitempo, 2010.
}

${ }^{229}$ Ibid., p. 103. 
específico. Mas esse compreender, não consiste, como pensa Hegel, em reconhecer por toda a parte as determinações do Conceito lógico, mas em apreender a lógica específica do objeto específico (MARX, 2013; p. 114).

Por isso, retomando a opção concreticista (formação social em detrimento do modo de produção) da ontologização geográfica voltada para o preenchimento da essência heideggeriana, ao tempo em que fornece elementos de corporificação do seu objeto (espaço) conferindo a ela sua essencialização técnica e material, resguarda em uma forma tendencialmente absolutizada esse mesmo objeto contra as possibilidades de sua autocrítica efetiva e histórica.

Para Marx, as fissuras do tempo histórico inteligíveis pelo empírico e objetiváveis em suas "formações sociais" - como de forma concreticista fora admitida para a ontologia geográfica - só deveriam ter sentido analítico a partir da busca interna de sua mediação lógica e contraditória, de sua "metafísica", em seu específico "modo de produção", que confrontaria o próprio ser contra a seu ente (apesar de manter-se em unidade dialética, jamais em ruptura dicotômica) no sentido de seu desvelamento enquanto objeto concretizado, enquanto "carcaça do tempo": como meros portadores de valor, de trabalho abstrato cristalizado. Sujeito e objeto do trabalho seria igualmente compreendido, na análise marxiana, pelas relações de abstração próprias da forma-valor em sua formação social específica, que é o capital.

Não por outro motivo é que o trabalho em Marx é posto em centralidade da análise, e mesmo da ontologia, como assevera Lukács: ou seja, como resultado do método, não como solução teórica, como interpreta Chasin: "Desde o início, pois, a crítica marxiana da economia política se manifesta como impugnação e recusa, forma e material, de um dado corpus científico" (2009; p. 80). Porque a "substância" da riqueza social e da práxis humana "descoberta" somente pela economia política moderna e colocada de forma positiva, como sujeito mesmo da produção, mas cristalizada na forma-mercadoria (propriedade privada), precisava de ser "desvelada" e explicada. Ainda conforme Chasin: "Reconhecido, mas não desvelado; descoberto, mas não explicado. Por isso mesmo concebido unilateralmente, só pelo seu lado positivo, enquanto "essência subjetiva da riqueza"' (2009; p. 79). Positivação essa que revelava apenas sua condição de objeto da própria economia política que, até mesmo enunciadas suas contradições, como em Ricardo e mais sistematicamente em Proudhon, era preciso desvelar sua carcaça social crítica: "É, portanto, na busca da anatomia da sociedade civil que as categorias da economia política são ontocriticamente elevadas à esfera filosófica 
[por Marx], onde esplendem como malha categorias da produção e reprodução da vida humana" (CHASIN, 2009; p. 75).

Especificamente sobre a questão da forma e do objeto "empiricizados" pela Geografia, o que se teria sobre eles diante dessas mediações do valor senão "a mesma objetividade fantasmagórica, uma simples gelatina de trabalho humano indiferenciado, isto é, do dispêndio de força de trabalho humano, sem consideração pela forma como foi despendida" (MARX, 1983; p.47)? No entanto, tais contradições, como "fissuras do tempo", aparecem na crítica da Geografia, como no caso de Milton Santos, como possibilidades afirmativas da substanciação corpórea propriamente geográfica. Tais "físsuras do tempo", ao invés de serem dissecadas e dissolvidas (não apenas conceitualmente) em suas contradições internas, deveriam ser preenchidas positivamente, sobretudo epistemologicamente, na solução de seus vazios para o encontro do "corpo do tempo", que seria o espaço, agora mediado pela técnica.

Mészáros, ao propor uma teoria da transição tendo como fundamentação a gênese contraditória e totalitária do capital, como já demonstrada por Marx, refuta a resignação da teoria em suas condições "empíricas" do concreto, mesmo aquelas por ele admitidas apenas como evidências da crise estrutural. Ir na "produção em si da mercadoria" para retirar daí o fundamento objetivo da teoria da transição em sua "differentia specifica" 230 tem significado revelador quase sempre evitado pela crítica geográfica ainda condicionada àquelas determinações estruturalistas de não "estender-se muito ao infinito". O que Mészáros propõe, em seu retorno a Marx, é muito mais do que a fundamentação de bases teóricas e epistemológicas para a urdidura de sua teoria, mas tem sobretudo um fundamento prático irreprimível: “O projeto socialista, paradoxalmente, só pode definir-se a si mesmo, em primeiro lugar, como uma disjunção radical entre seus objetivos históricos fundamentais e seus objetivos imediatamente realizáveis” (MÉSZÁROS, 2011; p. 1065). Isso significa que a busca de uma "nova história", como diria Marx, em seu avanço "para além do capital", como insistirá Mészáros, só é possível enquanto se reconhece que a gestação de suas possibilidades se dão nas fissuras contraditórias da própria estrutura do capital. O "socialismo", dessa forma, não se reconhece em Mészáros como uma “especulação sobre o futuro”, embora não deixe de ser em última instância uma questão sobre o futuro, mas se estabelece a partir do posicionamento lógico do presente, entremeado na própria estrutura crítica do capital. Sua história é, por isso, lógica-concreta, não puramente "material” e "empírica".

230 “Mas uma explicação que não dá a 'differentia specifica' não é uma explicação” (MARX, 2013; p. 40). 
No entanto, ainda que se deva avançar sobre o "material e o empírico", o que Mészáros propõe como possibilidade prática e imediata é o reconhecimento de que, sendo o inimigo verdadeiro o capital, não o capitalismo em si, as respostas teóricas e práticas deverão ser igualmente abrangentes e totalizantes, por um universal abstrato equivalente à lógica universalizante do capital. Evita-se com isso, de imediato, as soluções que sugerem "volta ao passado" e o decaimento da teoria nas falsas ilusões, há muito já impossibilitadas, de qualquer retorno "socialdemocrata", de natureza como "ganhos do trabalho", "ampliação de direitos" e "democracia plena", etc. Além da ingenuidade e incompreensão do desenvolvimento histórico, fundamenta Mészáros que tais alternativas nas quais muitas perspectivas teóricas não solidamente críticas se formam, acabam se confundindo com o próprio discurso da "barbaridade" de que "não há alternativa". O que Mészáros insiste ao convocar Marx para composição de sua teoria da transição, é o apelo à dialética na sua mais intensa fundamentação (onto)lógica para se entender a história e suas possibilidades: "a relevância dos princípios orientadores marxianos se afirma pelo fato inevitável de que sem eles o próprio trajeto se torna extremamente problemático porque perde a direção, com as consequências mais desorientadoras e desanimadoras" (2001; p. 876).

E o fundamental, no entanto, seria evitar a condição do tempo "empírico" como determinante da lógica, mesmo que uma lógica transitória como é a do capital. Advertirá Mészáros sobre a necessidade de encarar a condição empírica do tempo, e também do "espaço", já que seria "absolutamente irrelevante saber se a necessária ruptura em direção ao socialismo - não em um país só, nem em uma dúzia de países ou mais [...] - precisará de algumas décadas ou de um tempo muito longo para ser alcançada" (2011; p. 876). Mészáros não fala somente do tempo cronológico ou da empiria dos espaços nacionais, da sua dimensão linear ou cronológica, de sua duração ou extensão. Ao contrário, se referirá ao tempo e ao espaço da concretude (ir)racional que, materializado e empiricizado, revelará um grande acúmulo de trabalho cristalizado em forma de "carcaça", como dirá Marx. Aqui, o tempo histórico e o espaço concreto relevante do "filósofo" é o tempo da lógica interna e contraditória do objeto (capital) e o espaço da simultaneidade necessariamente universal (não apenas mundial ou global); da mediação contraditória entre abstrato e sua expressão concreta, sendo seu substrato material nada mais do que sua "carcaça do tempo" que, assim revelado, se expõe como um acumulo (ir)racional de tempos concretos, individuais; que se tornam tempos indiferentes, o tempo em si, tempo abstrato, tempo do trabalho abstrato, tempo do capital, em detrimento da somatória, ainda que de forma "desigualmente acumulados no espaço", de tempos concretos, ou do "tempo inteiro", como aquele identificado por Milton Santos que, materializado pela técnica, "revelam, 
por contraste, no ser humano, o corpo como uma certeza materialmente sensível diante de um universo difícil de apreender" (2008; p. 314).

Entre o geógrafo e o filósofo não há apenas a impossibilidade de conciliação sobre a substância do tempo, mas um movimento teórico inverso. Não apenas porque o percurso da crítica ontológica do espaço (crítica-denúncia social marxista; ontologia lukacsiana; e epistemologia weberiana) se apresenta invertida em relação à crítica ontológica do trabalho (crítica weberiana; ontologia lukacsiana; e teoria marxista da transição), mas também seus objetivos políticos com a teoria passam a se contraporem.

Se para o filósofo a substância do espaço é a "carcaça [abstrata] do tempo" do capital, para o geógrafo é exatamente essa carcaça a substância positiva e afirmativa do seu próprio "corpo material". A negatividade com que o "filósofo" vê a "carcaça do tempo" não é também gratuita. A já reduzida possibilidade de uma teoria da transição para o "geógrafo" não está apenas condicionada à postura política de cada autor, mas a sua efetividade - diante de tais condições teóricas de interpretação positiva e afirmativa para com a dialética - está também limitada à sua "corporificação" material.

["Espaço, corpo do tempo" e a busca do "instrumental” ontológico estruturador]

Não seria demais lembrar os objetivos da tese (de doutoramento) de Ruy Moreira, sintomaticamente intitulada "Espaço, Corpo do Tempo": "a reconstituição desse fundamento, o seu rasteio e resgate, e, então, a formulação de uma hipótese de evidenciação. Nos últimos anos tem havido um grande esforço de dotar-se a Geografia de uma linha instrumental mais contundente de discurso" (MOREIRA, 1994a; p. 04) ${ }^{231}$. O fundamento seria, como aponta Moreira, o paradigma "do trabalho e da política que referencia a construção geográfica das sociedades em cada tempo"232 que, por sua vez, estaria "escondido" em textos históricos da literatura geográfica. Tal ocultação se daria pela "dobra" por onde se conformam "duas geografias, a real e a da leitura, uma dobra que lhe tem embaçado a visão" ${ }^{233}$, e que, por sua vez, teria se efetivado pela falta de um "discurso estruturador mais lógico e assertivo". Por aí, em busca do discurso estruturado, traça Moreira o caminho para se descobrir como que, na modernidade, o espaço exerceria função de controle em relação ao trabalho: "Reclus percebeu-

\footnotetext{
${ }^{231}$ MOREIRA, Ruy, Espaço, Corpo do Tempo: a Construção Geográfica das Sociedades (tese de doutorado), São Paulo, Universidade de São Paulo, 1994a.

${ }^{232}$ Id., Ibid.

${ }^{233}$ Ibid., p. 03.
} 
o com clareza e não se pode dizer que não seja isto o que vemos implícito nas obras de La Blache, Brunhes, Sorre, George e Claval" (MOREIRA, 1994a; p. 231).

Apesar disso, é na fundamentação e na busca deste "implícito" em autores tão distintos que se revela (primeiro) as mesmas práticas de resgate epistemológico por "síntese de fusão", como em Armando Corrêa, e a consequente formação de uma teoria baseada no "amálgama originário"; (segundo) a manutenção do recurso concreticista-gnosiológico tipicamente lukacsiano para daí se retirar pretensas linhas de continuidade entre história humana e a Geografia; (terceiro) a conformação de um estatuto ontológico supostamente atualizado (pela inserção de categorias mais "novas", como comunicação, informação e sua técnica historicamente específica), contraditoriamente, por meio de uma história humana ainda mais remota, como aliás as referências selecionadas já haviam se fundamentado: "O Espaço é fruto disso. É uma paisagem que muda sucessivamente de face conforme o seu grau orgânico de tecnificação. É uma construção, cuja história começa com o fogo e culmina na moderna tecnologia da informática" (MOREIRA, 1994a; p. 183).

A referência à tese de Moreira não é posta aqui de forma gratuita. Sua estrutura argumentativa e discursiva está presente também no primeiro volume da trilogia $O$ pensamento Geográfico Brasileiro, publicado em 2008, sobretudo quando se pretende buscar nas "matrizes clássicas originárias" o fundamento ontológico da análise geográfica. De Reclus a indissociabilidade universal homem-natureza em seu processo de conscientização ("O homem é natureza quando toma consciência de si própria" ${ }^{234}$; De La Blache a contingência do gênero de vida com que o homem se relaciona com a natureza e sua constituição enquanto civilização; Brunhes a dialética entre ordem e desordem com que as energias (naturais e humanas) se envolvem num contínuo processo de destruição-produção; em Sorre a questão da técnica como elemento de costura do "amálgama” de complexos ecológicos (o ecúmeno); de George o espaço como materialidade do tempo histórico e sua organização (“O espaço é história porque o tempo existe como espaço e isso porque o espaço é a condição de materialidade do tempo histórico" ${ }^{235}$; Tricart a morfogênese das interações vivas e físicas e sua determinação estrutural em escalas de análise; em Hartshorne a significação geográfica a partir de sua captação pela diferenciação.

Com relação à tese reafirma Moreira a "descoberta" da gênese do debate ontológico por meio dos eixos identificados como comuns: sociedade-natureza e sociedade-espaço -

\footnotetext{
${ }^{234}$ Famosa frase de Reclus citada por Moreira (MOREIRA, Ruy, O Pensamento Geográfico Brasileiro: As Matrizes Clássicas Originárias, São Paulo, Contexto, 2014a; p. 168).

${ }^{235}$ Assim interpreta Moreira (2014; p. 173) sobre George.
} 
centrado nos elementos universais: técnica, trabalho e homem ("A técnica, o trabalho e o homem são categorias presentes nos dois eixos") ${ }^{236}$, além da condição de "controle" que o espaço exerce contra o processo de trabalho ("E assim, materializada na estrutura global que, retroativamente, controla, determina e regula como movimento metabólico") ${ }^{237}$.

Segundo Moreira, o posicionamento do trabalho é central, embora esteja ele apenas "dedutivamente" apresentado na exposição dos clássicos referenciados (excetuando, em certa medida, Reclus e George). No entanto, advertirá Moreira que entre os clássicos não havia maturado o sentido processual, "metabólico", do trabalho em sua dialética marxiana, restando, apenas, sua dimensão fetichizada, como "coisa" (excetuando, em certa mediada, Tricart).

Nesse ponto se observa um "desdobramento" importante para a análise que se pretende ontológica. Explica Moreira que, apesar da centralidade do trabalho na percepção originária da ontologia geográfica estar focada na relação sociedade-natureza, quando se tem o deslocamento de sua objetividade para a relação sociedade-espaço, tem-se por decorrência o deslocamento da centralidade categorial do trabalho para a técnica, para depois estarem elas concorrendo no nucleamento da ontologia: "Por isso que a técnica aparece como agente da nova materialidade por excelência, dado que sua presença avulta na aparência mais que a ação do homem e do trabalho" (MOREIRA, 2014a; p. 179). Mas qual o significado do termo "aparece"? O de aparência, ou de efetividade: a técnica aparece, no plano da "aparência", ou ela efetivamente é mais do que a ação do homem e do trabalho? A "aparência" estaria no plano da "materialidade por excelência", ou no do fetiche? "Tudo aparece como produto da técnica. Assim também é o espaço" 238 . Moreira, no entanto, termina o livro sem resolver a questão da incompreensão entre os clássicos (e entre eles e o próprio autor na medida em que os discursos acabam se fundindo e se confundindo em um subtópico sintomaticamente intitulado " $O$ que se aprende com os clássicos").

Moreira também não questiona se o deslocamento do trabalho em prol da técnica significaria um movimento de incompreensão do processo metabólico sociedade-natureza, ou admissão de ser ela, a técnica, a mais assimilável para as pretensões teóricas. Ou, de um outro ponto de vista mais problematizado, quais seriam as possibilidades e os limites de composição de uma dialética - antes centrada no trabalho em seus múltiplos complexos de contradições que vão desde a universalidade do metabolismo homem-natureza até a teoria do valor na explicativa da sociabilidade moderna - para uma dialética que fundamentará a ontologia redescoberta pelo

\footnotetext{
236 Ibid., p. 177.

${ }^{237}$ Ibid., p. 180.

${ }^{238}$ MOREIRA, 2014a, p. 180.
} 
próprio Moreira nas origens clássicas, e dada pela técnica (de Max Sorre a Milton Santos), categoria essa tida antes apenas como "potencializadora"239 daquela.

Mas segue Moreira sua linha argumentativa em um movimento bastante sintomático para se entender a forma peculiar de constituição ontológica pela via da solução epistemológica. Retoma a linha argumentativa na identificação de uma universalidade gnosiológica fundamentada, agora, na técnica ("A relação sociedade-natureza se transforma na relação sociedade-espaço porque a localização já é um dado implícito. A técnica é a mediação"240; recai, inevitavelmente, no remotismo diante da busca do universal da técnica como eterno-presente (“A experiência da 'área anfíbia' vai representar um momento de início de dissociação. O Homem traz para os vales dos grandes rios uma forma já sincrética de meios") ${ }^{241}$; para, assim, dentro dos novos parâmetros de cientificidade, chegar aos tempos da modernidade ("O ato cabal vem com o nascimento da ciência moderna, a redução ao inorgânico que ela impõe o conceito da natureza e o mito do poder de progresso da técnica") ${ }^{242}$. Neste momento, Moreira estreita a interpretação com Marx, na especificidade do debate exposto no Manuscritos EconômicosFilosóficos, no sentido de reestabelecimento da unidade (ou tríade) meio-homem-espaço. Moreira busca relacionar a unidade ontológica com a concretude histórica a partir da "economia política do espaço" para retirar dela a "reciprocidade" entre a relação sociedade-natureza (trabalho) e a relação sociedade-espaço (técnica). Encerra-se, assim, na complementariedade, a possibilidade da contradição entre técnica e trabalho chegando mesmo a se confundirem ("A noção autopoiética do trabalho vem na oposição a este conjunto [“do mito do poder de progresso da técnica"]. Repõe a técnica no plano genético da relação orgânica. E reestabelece o primato do homem" $)^{243}$. Por fim, depois de toda amarração amalgamática, dos clássicos das mais variadas perspectivas geográficas até Marx, conclui Moreira com um chamado a pensar uma epistemologia originária e especificamente geográfica, como assim argumenta: "E nesse terreno fez-se mais estudos de história do pensamento que de epistemologia. Pode-se mesmo dizer que tem sido esse pecado capital que pôs a geografia num estado de prestígio intelectual pobre" (MOREIRA, 2014a; p. 186.).

Os recursos da ontologização de Moreira em muito se equivale aos de Milton Santos. $\mathrm{Na}$ constituição de seu estatuto ontológico, que também se fundamentará na técnica de

\footnotetext{
239 “A transformação do meio pelo trabalho potencializado na técnica é o trânsito da transfiguração da relação sociedade-natureza na relação sociedade-espaço, levando toda a complexidade metabólica da primeira para a escala maior do metabolismo espacial" (MOREIRA, 2014a; p. 179).

${ }^{240}$ MOREIRA, 2014a p. 183.

${ }^{241}$ Id., Ibid.

${ }^{242}$ Id., Ibid.

${ }^{243}$ Ibid., p. 185.
} 
Maximilien Sorre ("o primeiro geógrafo a propor, com detalhe, a consideração do fenômeno técnico, em toda sua amplitude" $)^{244}$ como forma de corporificar materialmente seu objeto, assim procede Santos por meio de uma materialidade fundamentada em uma evidenciação histórica "material", também carregada de certa dose de remoticidade histórica que, por sua vez, considerando como fundidos meio técnico e meio geográfico, este seria "[...] um meio que viveu milênios como meio natural ou pré-técnico, um meio ao qual se chamou de maquínico durante dois a três séculos, e que hoje estamos propondo considerar como meio técnicocientífico-informacional espaço", como diria o próprio Santos (2008; p. 41). Também como Moreira, que propõe à constituição histórica "sete espaços" em sua tese (ou nove, como assim considera no livro Pensar e Ser em Geografia, este publicado em 2007), Santos também propõe uma divisão histórica em "três etapas: o meio natural, o meio técnico, o meio técnico-científicoinformacional" 245 .

Na exposição de Moreira em Pensar e Ser em Geografia (2007), se somam aos “nove espaços" (como representação da sociedade e suas formas de espaço no tempo) a evidenciação ontológica do que se constituirá como as "três 'leis' geográficas": a "desnaturização", a "desterreação" e a "desterritorialização". Aqui, novamente, a identificação da cisão entre “corpo e homem" que, desde a antiguidade até os tempos modernos, constituem a "diferença ontológica" do ser-estar-no-mundo, conforme a referência heideggeriana em Santos ${ }^{246}$, mas também presente em Moreira. A desnaturização como cisão homem-natureza, a desterreação como cisão do campesinato e sua mediação com a terra, e a desterritorialização como a radicalização da cisão homem para com o meio na sua efetividade migrante, "um migrante permanente", como proletário a procura de emprego. O processo que Moreira chama de “desespacialização", efetivado na síntese histórica dessas "leis geográficas", se refere ao "deslocamento" da condição corpórea (humana e dos objetos) empiricamente constituída para sua condição abstrata: "Da desnaturização à desterritorialização o espaço vai sendo deslocado de suas constituintes empíricas (a natureza, a terra e o lugar) para assim ser transformado num dado abstrato" (MOREIRA, 2007; p. 138).

Observa-se nesta passagem, além do recurso gnosiológico que põe o ontológico como eterno-presente evidenciado historicamente, a conciliação entre a busca essencialista heideggeriana com a tradição empirista e concreticista da leitura geográfica. Isso leva Moreira a entender o espaço como unidade sem contradição; a contradição admitida (espaço como

\footnotetext{
${ }^{244}$ SANTOS, 2008; p. 35.

245 SANTOS, 2008, p, 234.

${ }^{246}$ MOREIRA, 2007; p. 136.
} 
externalidade, separada dos entes) remete à negativa do próprio espaço, ou não-espaço, ou a "desespacialização": "A partir daí, todos os entes corpóreos, humanos e não humanos estão no espaço. Não são espaço. O espaço se torna uma externalidade radical” (MOREIRA, 2007; p. 138). O espaço real, regido pelas leis determinantes do universal-abstrato próprio do tempo histórico da modernidade, é um "real desespacial", porque descorporificado, ou “desnaturalizado", não são eles, homem e natureza, entes espaciais, mas contidos no espaço.

Onde haveria a admissão da "diferença essencial" (MARX), ou "a função práticosocial de determinadas formas de consciência, independente do fato de elas, no plano ontológico geral, serem falsas ou verdadeiras" (como, novamente, sobre Marx interpretará Lukács) ${ }^{247}$, em suma, de sua realidade concreta como forma em si do ser, do existente em sua determinação histórica e contraditória, real e concreto, esse espaço passa agora a se equivaler a inautenticidade heideggeriana da qual a tentativa de superação se daria pela busca de sua essência, uma essência geográfica perdida pelo seu não reconhecimento nas suas "constituintes empíricas", um espaço relativo, ôntico, o espaço geográfico.

A inautenticidade do espaço geográfico se assimila com a síntese da tese geral de Moreira: do espaço como universal abstrato exercendo função de controle, domínio, no deslocamento de sua materialidade em relação ao corpo do ser (objetos e humanos). Mas é também, e isso é demonstrado implicitamente desde os clássicos da Geografia, a dominação do trabalho pelo capital na forma do espaço moderno. Esse elemento central da tese de Moreira será uma das influências fundamentais de outra tese importante no debate entre ontologia, espaço e trabalho no pensamento Geográfico mais atual: A Dinâmica Gerográfica do Trabalho no Século $X X I^{248}$, de Antônio Thomaz Junior (tese de livre docência): "Se tomássemos de empréstimo o entendimento de Moreira (2007) [...], então o espaço geográfico 'é parte fundamental do processo de produção e da estrutura de controle da sociedade', ou de suas instituições e relações de classe" (THOMAZ Jr., 2009; p. 45) ${ }^{249}$.

A fundamentação central se baseia na decorrência de que a fragmentação dos sentidos (objetivos e subjetivos) do trabalho encontra na sua fragmentação espacial, a partir de sua territorialização também fragmentária, suporte para a efetivação do deslocamento da identificação da luta estrutural anticapital para as questões de segunda ordem que se põem de forma imediatista no âmbito da burocracia política estatal e sindical.

\footnotetext{
${ }^{247}$ LUKÁCS, 2012; p. 284.

${ }^{248}$ THOMAZ JR, Dinâmica Geográfica do Trabalho no Século XXI: Limites Explicativos, Autocrítica e Desafios Teóricos, São Paulo, Universidade Estadual Paulista (Tese de Livre Docência), 2009.

${ }^{249}$ THOMAZ JR, Dinâmica Geográfica do Trabalho no Século XXI, 2009; V.1.
} 
Para Thomaz Jr. o desenvolvimento de suas pesquisas aponta que a luta no âmbito do trabalho, deslocado dos mecanismos estruturais de sua dominação, se encontra restrito "[...] ao regramento jurídico-político da delimitação dessa ou daquela categoria/corporação em consonância ao território delimitado pelo Estado, se nesse ou naquele município, à unicidade sindical" ${ }^{250}$. Por isso o desenvolvimento das pesquisas que o levam à tentativa de formulação de uma "teoria espacial do trabalho" se fundamentam na assertiva de se buscar, a partir da materialidade do território, sua concretude espacial até o limite da "dissecação". Inversamente, seria o acúmulo da investigação até sua "exaustão" analítica que se "corporifica" (ou se torna "carcaça”) na gama de investigação das expressões espaciais do trabalho, como parece demonstrar Thomaz Jr. (em seu extenso memorial que compõe sua tese de livre docência), que o conduzem à descoberta da teoria: “ $[\mathrm{A}]$ teoria espacial do trabalho não será produto de definições apriorísticas ou axiomas, mas sim da nossa capacidade de apreender os desafios e tensionamentos que estão colocados no interior da dinâmica geográfica do trabalho, da luta de classes" ${ }^{251}$. A realidade prática objetiva e efetiva emanando a própria (necessidade) da teoria.

A descoberta da teoria espacial do trabalho advém, assim, da canalização das múltiplas formas de expressão concreta do trabalho no território por meio das formas de ser admitidas a partir de sua personificação: o trabalhador. A questão que envolve a definição de "classe trabalhadora", ou que passa ela a ser diante da fragmentação, ou "plasticidade" (ou quais sujeitos, além dos clássicos "operário" e "proletariado", que deveriam se incorporar ao seu conjunto?), adquire assim condição de objeto central da investigação geográfica: “A exaustão dos exemplos não pode ofuscar a objetividade de as atenções estarem direcionadas para esse movimento dialético [...], no qual buscamos as evidências da negação/afirmação do trabalho e da classe trabalhadora"252. A importância da análise geográfica, que se somaria à dos sociólogos e de filósofos envolvidos no entendimento da "complexa trama" que envolve o mundo do trabalho na atualidade da crise estrutural do capital, seria assim a de revelar, a partir da simultaneidade (ou "reciprocidade") possível na análise espacial, a forma de interação da multiplicidade de "eventos e ocorrências sociais" que compõem a síntese de uma "unidade de complexos" $" 253$. Aqui, neste ponto da "reciprocidade", a teoria espacial do trabalho encontra sustentação na teoria do espaço de Milton Santos, como revela Thomaz Jr.: "Para Santos (1996),

\footnotetext{
${ }^{250}$ Ibid., p. 40.

251 THOMAZ JR, 2009, p. 64.

${ }^{252}$ Ibid., p. 45.

${ }^{253}$ Ibid., p. 44.
} 
é isso que faz do espaço geográfico uma constante relação de reciprocidade dinâmico-dialética ou um movimento ininterrupto de forma-conteúdo" 254 .

Dessa forma, demarcada a objetivação analítica nas formas de expressão territorial (por isso, concreta) do trabalho, a análise deve voltar-se ao reestabelecimento do seu objetivo de última instância para não ser ela apenas uma exaustão de evidências empíricas $e$ concreticistas que apenas contemplaria àquelas determinações ontológicas abandonadas de Antônio C. R. Moraes, de dever o geógrafo, resolvido o problema de seu estatuto ontológico, voltar-se ao "processo de concreção", como citado acima. Mas é exatamente ao revelar seus objetivos de última instância para com a teoria espacial do trabalho, um objetivo de ordem emancipatória (“[esse] debate nos põe atentos à questão imanente que indicamos, ao abrir este texto, ou seja: quem são os homens e as mulheres capazes, no século XXI, de transformar a sociedade e imprimir outro curso histórico para além do capital?") ${ }^{255}$, é que expõe Thomaz Jr. seu problema ontológico: “É, pois, a partir dos seus espaços de produção e de reprodução que estamos nos propondo analisar as dimensões ontológicas (saltos) que qualificam as relações substantivas novas, que impactam na formação de sujeitos históricos conscientes"256. Dessa forma, em última instância, o projeto emancipatório e o estatuto ontológico se reunificam na objetividade e efetividade histórica (não mais gnosiológica) posta num nível de praticidade admitidamente revolucionária e socialista: "não bastaria somente entendê-la, mas, em essência, insisto, transformá-la e, consequentemente, priorizar as questões que, na sua marcha histórica, nos desafiam à perspectiva societária socialista” ${ }^{257}$.

No entanto, a reunificação ontologia-emancipação no plano da efetividade prática da luta de classes, na especificidade do envolvimento real e teórico com os significados do que seria hoje classe trabalhadora, revela consigo um problema de ordem disciplinar para as pretensões de composição do corpo teórico específico requisitado até então pelo exercício epistemológico até aqui analisado. O corolário imediato das requisições da Geografia como uma "ciência positiva real", voltada para os "homens reais ativos" (nos moldes em que Mészáros lembra Marx no texto sintomaticamente intitulado "Filosofia, Ideologia e Ciência Social"), ou de uma ontologia a serviço da classe trabalhadora (não apenas específica do capitalismo, mas específica de um momento histórico criticamente crucial para o futuro do sistema do capital) significaria, por outro lado, a reposição autocrítica das categorias espaciais

\footnotetext{
254 Id., Ibid.

255 THOMAZ JR., 2009, p. 43.

256 Ibid.,p. 41.

${ }^{257}$ Ibid., p. 33.
} 
e o necessário reconhecimento de seus limites no enquadramento das contradições objetiváveis (“O espaço e o território não protagonizam o movimento contraditório da sociedade, mas revelam os conteúdos, os significados e os papéis que fazem com que o trabalho ocupe centralidade" $)^{258}$. Na sequência, significaria ainda a centralização do trabalho na ciência, dada por uma teoria ontológica, dado seu caráter essencialmente transitório, tipicamente lukacsiano e meszariano ("enquanto a unidade metodológica dos nossos estudos tem, na totalidade social, a referência teórica central para compreendermos a categoria trabalho, considerando as formas (expressões) geográficas, enquanto totalidade viva do trabalho") ${ }^{259}$. Além de significar, por fim, a recusa gnosiológica tipicamente geográfica em prol da processualidade histórica no reconhecimento da ontologia como o pôr da "lógica específica da coisa específica" propriamente marxiana ("Todavia, não é uma determinação gnosiológica que eleva um fato de consciência a uma posição teleológica, 'mas sim a função que exerce na processualidade') ${ }^{260}$.

Isso permite a Thomaz Jr. não apenas resgatar Marx do "cômodo residual" que a maioria das perspectivas teóricas da composição da crítica geográfica o havia "exilado" (em detrimento de uma teoria originariamente espacial), nem somente entremear nos mais atualizados e revigorados debates ontológicos e emancipatórios com que Mészáros, sob influência de Lukács, repõe a dialética do trabalho e as possibilidades de uma "teoria da transição", mas também e sobremodo reapresentar para o debate social crítico as possibilidades de uma perspectiva da leitura geográfica admitidamente comprometida, na teoria e na prática, com as questões práticas que envolvem os desafios da classe trabalhadora em contexto de crise estrutural; perspectiva essa cara a uma Geografia que amadurece ainda centrada, em certa medida, na difícil conciliação de sua crítica social às suas especificidades disciplinares amarradas no compromisso de centralização positiva do espaço.

Todavia, tomando ainda como perspectiva as proposições de Thomaz Jr. e a teoria espacial do trabalho, do ponto de vista da manutenção da autocrítica, como conciliar a perspectiva de uma teoria da transição socialista com as teorias geográficas assimiladas em sua composição, como a de Moreira e a de Santos? A forma como a teoria de Moreira e sua perspicaz formulação acerca do controle e do ordenamento do corpo pelo espaço abstrativado, "dessencializado" de matéria, tal como a importante síntese miltoniana do "sistemas de objetos e sistemas de ações" (que funda a mais estrutural solução epistemológica para o problema de fragmentação da crise da Geografia, mas destituída de "trabalho"), ambas de caráter

\footnotetext{
258 Ibid., p. 34.

${ }^{259}$ Ibid., p. 61.

${ }^{260}$ THOMAZ JR., 2009, p. 111.
} 
gnosiológico e epistemológico, como assimilar tais referências diante de uma perspectiva que se põe metodologicamente "liberada" dos compromissos de positivação disciplinar?

Embora seja possível observar certo nível de tensão, ou disputa, por exemplo, entre teoria geográfica miltoniana centrada na técnica e a teoria espacial do trabalho de Thomaz Jr., da qual a centralidade do trabalho é reafirmada como a forma de também se enxergar o "tensionamento vivo da luta de classes" ("e não somente suas evidências geográficas como produto do desenvolvimento do meio técnico-científico-informacional, no qual a técnica protagoniza o processo social") ${ }^{261}$, o limite da contradição entre projeto emancipatório do trabalho e a positivação do estatuto ontológico do espaço não está posto, ao menos de forma sistemática, como um limite do desenvolvimento da teoria crítica geográfica. No entanto, é perceptível como em Thomaz Jr. afloram, inevitavelmente, essas tensões na forma de abstenção do próprio debate: "exercícios empíricos e desafios intelectuais, todavia não nos move a abrir trincheira no âmbito da epistemologia da Geografia ou dos seus fundamentos e atributos teórico-metodológicos, que apesar de estimulantes não é nosso campo de investigação" ${ }^{262}$; além da constante necessidade de reafirmação e reconhecimento dos limites da institucionalização da própria crítica: “[...] essa nova linha de investigação em Geografia não se trata de filão, mas da possibilidade de que a categoria trabalho possa ser objeto de investigação da realidade social e, consequentemente, um tema vivo na Geografia" ${ }^{263}$.

E embora seja notável que a teoria espacial do trabalho, herdeira ativa do movimento de renovação crítica, possa significar ou resguardar os objetivos mais vanguardistas das intenções originárias e revolucionárias, ela (junto com seu autor) se insere em um contexto em que a perspectiva da crítica geográfica tendencia para seu refúgio institucional, onde ela própria se cristaliza. A crítica à forma amalgamática com que a ontologia geográfica se forja é uma expressão dessa necessidade de conceder ao espaço, o objeto positivado e oficializado, sua devida legitimidade. Não por outro meio, se observa na substantiva experiência empírica da qual emana a teoria espacial do trabalho seu forte enlace institucional, como revela Thomaz Jr. em seu "memorial":

Esses Projetos de Pesquisa não somente nos têm auxiliado a alavancar nossas investigações individuais e do Grupo de Pesquisa, mas também a tornar realidade um conjunto de Projetos de Pesquisa e Planos de Trabalho, em nível de Graduação, nas diferentes modalidades da Iniciação Científica e de PósGraduação (com ou sem Bolsas de Estudos) (THOMAZ JR. 2009; p. 27).

\footnotetext{
${ }^{261}$ Ibid., p. 46.

262 THOMAZ JR., 2009, p. 31.

${ }^{263}$ Ibid., p. 35.
} 
Mesmo que reconhecido o esforço pela manutenção dos laços com a prática militante ("estamos ampliando o universo dos nossos leitores/interlocutores em todas as áreas das ciências humanas e fortalecendo nossa participação, no âmbito dos movimentos sociais, inclusive com o desenvolvimento de pesquisas") ${ }^{264}$, o aprisionamento crítico institucional só pode revelar para a perspectiva de uma teoria emancipatória a necessidade de seu reconhecimento enquanto contradição a ser objetivável. O fato de, por exemplo, a teoria espacial do trabalho poder manobrar com liberdade a crítica-emancipatória em terrenos tido como estranhos à Geografia, a ponto de propor a recentralização da dialética que envolve o trabalho em detrimento da já centralizada "dialética (ou filosofia) da técnica"; reafirmar o marxismo (Marx, Lukács, Mészáros) em detrimento da onda conservadora das proposições heideggeriana, weberiana, durkheimiana; a ontologia histórica em detrimento da ontologia gnosiológica; os sujeitos reais da classe trabalhadora em detrimento dos "pobres da cidade" todas elas colocam, ainda que de forma não admitida, um confronto crítico do trabalho contra o espaço, e vice-versa, onde mais cedo ou mais tarde serão enfrentados com o devido e necessário rigor teórico.

\section{4 - Espaço versus geograficidade}

O desenvolvimento do debate ontológico na geografia, no entanto, vai desvelando novas facetas no que concerne à resolução das problemáticas apresentadas acima. É sintomático, nesse sentido, a correlação argumentativa que pode ser observada entre textos que, mais recentemente, incrementam esse viés discursivo. Por exemplo, é de grande importância a análise apresentada por Élvio Rodrigues Martins, sobretudo no texto intitulado Geografia e Ontologia: O Fundamento Geográfico do Ser, publicado em $2007^{265}$. A importância deste texto está não somente na tentativa de aprofundamento de uma análise que se pretende ontológicafilosófica e voltada para a especificidade do campo da geografia, mas também porque se propõe a oferecer uma "interlocução" com autores até aqui amplamente citados sobre a relação ontologia e trabalho, como Armando Corrêa da Silva, Milton Santos, Antônio Carlos Robert Moraes e Ruy Moreira, embora efetivamente somente com este último é que será observado o que o próprio Martins coloca como "algumas diferenças, que não serão encaradas propriamente

\footnotetext{
${ }^{264}$ Ibid., p. 31.

${ }^{265}$ MARTINS, Élvio Rofrigues, “Geografia e Ontologia: O Fundamento Geográfico do Ser”, GEOUSP - Espaço e Tempo, São Paulo, No 21, 2007.
} 
como discórdia, mas como diferenças que suscitam dúvidas, e nesse sentido deixam em continuidade o debate" (MARTINS, 2007; p. 40). Tais "diferenças" com a perspectiva ontológica de Ruy Moreia é baseada particularmente (diante de sua vasta produção dedicada à temática ontológica no campo da Geografia, como se verificou até aqui) sobre suas interpretações contidas no artigo intitulado "Marxismo e Geografia (A Geograficidade e o Diálogo das Ontologias)", publicado originalmente no $6^{\circ}$ Congresso Brasileiro de Geógrafos em 2004 e reescrito e ampliado para sua publicação em $2004^{266}$.

Objetivamente, as "diferenças" expostas por Martins em relação a Moreira se concentram em dois pontos específicos: primeiro, a "objeção da geograficidade como expressão espacial" (MARTINS, 2007; p. 40). Para o autor, a "geograficidade" constitui, para além da “síntese" existência e essência (MOREIRA, 2004), como a própria "expressão superior" da forma da existência do ser. A geograficidade está, por conseguinte, em plano ontológico maior que o do próprio espaço; este como uma das categorias que compõem a própria complexidade da existência concreta ("O que aqui foi afirmado considerar-se-á constituída por mais que espaço, e sim o complexo constituído de categorias de tempo, espaço, movimento e relação, isso ante a unidade processual presente entre homem e meio [...]. $)^{267}$. Segundo: para Martins, a forma como Moreira põe a diferenciação entre as relações homem-meio e homem-espaço, sobretudo na passagem do primeiro para o segundo, como uma metamorfose denominada geograficidade, "deixa em aberto" o entendimento efetivo da relação entre o ente e o ser (o ôntico e o ontológico). Sobre isso questiona Martins se já não estaria o espaço contido na relação homem-meio e se a própria metamorfose ocorrida a partir da relação elementar homem-meio não seria em si as condições de alteração da própria existência (tanto do homem como do espaço), que seria a própria geograficidade.

A “diferença", ou a "objeção", de Martins se põe no sentido de questionar a forma de estruturação argumentativa, relativamente comum na Geografia, de conceber o ôntico como "ciência" (estudo do ente) e o ser como ontológico, estudo da filosofia; tudo isso contido na já tradicional busca ontológica do espaço (embora "escassa" na literatura comprometida com o tema, como observa o autor), sobretudo do espaço geográfico, o objeto da disciplina. Mas, questiona Martins: "o espaço é tomado como ser, e é isso o que nos permite as considerações de ordem ontológica. Fica em aberto, entretanto, quem é o ente, que tem como seu ser, o espaço" (2007; p. 34). Tais indefinições tem levado, ainda segundo Martins, ao completo "equívoco"

\footnotetext{
${ }^{266}$ MOREIRA, Ruy, "Marxismo e Geografia (A Geograficidade e o Diálogo das Ontologias)”, GEOgraphia, Ano 6, n $\mathrm{n}^{\mathrm{O}} 11,2004$.

${ }^{267}$ MARTINS, 2007; p. 40.
} 
de colocar o espaço como ente e como ser, ao mesmo tempo, o que "não inaugura", sequer, uma ontologia que se pretende de "dimensão" geográfica ("Todavia, mesmo aceitando esse equívoco, em supor o espaço como ser, ou então a indisposição em admiti-lo, essa situação, ao nosso ver, não inaugura a dimensão ontológica a ser verificada na ciência geográfica" ${ }^{268}$.

De fato, a resignação ontológica do espaço como ser a partir de sua contraposição como ente carregado de "uma certeza materialmente sensível", seja a partir da técnica de Milton Santos, ou a opção pelas "formações territoriais concretas" de Antônio C. R. de Moraes, por exemplo, não resolve os problemas contidos na busca "corpórea" do espaço, de sua substantivação material confundida como concreto, herdados da tradição da disciplina. $\mathrm{Ou}$ como assumidamente "objeta" Martins: "matéria e corpo, ou mesmo natureza, são aspectos distintos entre si e que designam diferentes dimensões da realidade, e o espaço tem outra posição dentro deste cenário, e que não se confunde definitivamente com matéria, corpo ou natureza" (2007; p. 36).

De sorte que em Moreira, entre sua concepção de 1997 (contida no livro supracitado, "Pensar e ser em Geografia") acerca da "desespacialização" dos entes pela não identificação, ou seu "deslocamento", em relação a seus "corpos" - como processo que caminha desde “desnaturização" na "antiguidade" até os tempos mais atuais do "Mal-Estar Espacial no Fim do Século XX"269 - e sua formulação mais recente acerca da "geograficidade" como existência da expressão espacial, percebe-se algumas alterações. Mesmo conservando entre seus objetivos o levantamento de um pretenso debate ontológico geográfico existente desde os clássicos ("há um caráter ontológico histórico, aqui e ali velado, no tratamento do eixo natureza-homemespaço nos diferentes estudos da geografia") ${ }^{270}$, observa-se, dentre outros, a clarificação do posicionamento ontológico em dois aspectos. Primeiro, o reconhecimento da diferenciação entre gnosiologia e ontologia ("Mas passa-se também uma concepção de ciência e uma preocupação epistemológica que mexem permanentemente com o geógrafo [...] de encontro do marxismo com a geografia, no sentido de uma acentuada intenção de fazer gnosiologia" $)^{271}$; o que afinal poderia recolocar os objetivos da busca ontológica no referencial geográfico, sobretudo nos clássicos, em outros termos da crítica para além da forma conciliatória. Segundo, no avanço para uma unificação dialética entre ser e ente a partir da mudança do referencial

\footnotetext{
${ }^{268}$ Ibid., p. 34-35.

${ }^{269}$ Título do texto escrito em 1997 para o Seminário Interdisciplinar "O Mal-Estar no Fim do Século", organizado pela Sociedade Brasileira de Psicanálise, como consta em nota. Texto esse que abre a sessão sobre "ontologia" no livro já citado Pensar e Ser em Geografia (Cf. MOREIRA, 2007; p. 141).

${ }^{270}$ MOREIRA, 2004; p. 28.

${ }^{271}$ Id., Ibid.
} 
analítico - ainda que baseado na relação não crítica entre "existência" e "necessidade" admitindo para isso as limitações da "ontologia do espaço" e estabelecendo a "geograficidade" como "síntese" que está mais "além”, de amplitude maior, em prol do próprio real ("A ontologia do ser geográfico é mais abrangente, rica e complexa que a ontologia do espaço. A geograficidade vai ontologicamente além"); o que afinal poderia recolocar a busca pelo "corpo" do espaço para além de sua materialidade empírica e de sua limitação epistemológica, efetivamente como o "momento filosófico" a partir da "lógica da coisa", não como a "coisa da lógica" (MARX) que se pretende especificamente geográfica.

Entre Moreira e Martins é notória a tentativa de avanço no debate ontológico na Geografia, sobretudo nas observações repostas que envolvem a forma existencial do ente em relação a seu ser. Martins, desprendido da necessidade de estabelecimento do ser do espaço, busca apenas o "fundamento geográfico constituinte do ser" 272 na própria geograficidade e a partir do seu ente. Segue assim as recomendações de Heidegger, para quem o "ente deve assumir o papel principal na questão do ser" (2005; p. 42) ${ }^{273}$. Colocar a necessidade de "ser do espaço" como a própria forma de "não-ser" dele mesmo ("quando atribuímos ao espaço a condição de ser, estamos na verdade definindo aquilo que o espaço não é. Ele é na verdade categoria, e como tal elemento constituinte da existência de um ente, e não do próprio ser") ${ }^{274}$, em detrimento da geograficidade constituinte da presença heideggeriana, não significa um "rebaixamento" da importância do objeto, o espaço. Ao contrário, o que aparece como objetivos disciplinares modestos se abre como a possibilidade de transitar com grande liberdade entre a filosofia, ontologia e a Geografia. Por mais que se perceba na análise de Martins a tentativa de conciliar sua fundamentação ontológica do ser às perspectivas não objetivamente ontológicas (quase sempre gnosiológicas) de vários nomes da geografia clássica, o que limita sua interpretação para além daquilo que o próprio autor chama de "primeira geografia"275, a liberdade de trânsito teórica o permite não apenas se libertar dos compromissos positivistas de afirmação do objeto, mas ainda estabelecer o rigor diante da questão ontológica, como advertiria o próprio Heidegger sobre a analítica da presença: "O que lhe compete é liberar o horizonte para a mais originária das interpretações do ser. Uma vez alcançado esse horizonte, a análise preparatória da pre-sença exige uma repetição em bases ontológicas mais elevadas e autênticas" (HEIDEGGER, 2005; p. 45).

\footnotetext{
${ }^{272}$ MARTINS, 2007; p. 34.

${ }^{273}$ HEIDEGGER, Martin, Ser e Tempo (Parte I), Petrópolis, Vozes, 2005.

${ }^{274}$ MARTINS, 2007; p. 35.

${ }^{275}$ Ibid., p. 40.
} 
A questão heideggeriana da presença e do ser-aí (Dasein), por meio do debate existencial, também constitui o núcleo da argumentação de Moreira, e bem verdade desde a década de 1990. Mas especificamente no texto supracitado (Marxismo e Geografia Geograficidade e Diálogo das Ontologias), apresenta um recorte de definição mais elaborado. E ainda que, diferente de Martins, a busca ontológica do espaço esteja colocada em pauta, essa passa a ser considerada a partir do manuseio mais rigoroso da problemática ontológica que envolve a geograficidade; esta precedendo a "indagação" ou a "dimensão" ontológica do espaço, o que, consequentemente, é o que permite a consideração do "espaço como ser": "Se a geograficidade pressupõe a indagação ontológica do espaço, o espaço é em si mesmo essencialmente a dimensão ontológica da geograficidade, só nesse sentido podendo-se falar da ontologia do espaço ou do espaço como ser (SILVA, 1982)" (MOREIRA, 2004; p. 34).

Para Moreira, a geograficidade seria o elemento propriamente geográfico que se equivaleria à "estrutura ontológica de mundo" heideggeriana e que não apenas definiria a "mundanidade como tal" (HEIDEGGER, 2005, p. 91) do homem em "qualquer sociedade"276, mas também permitiria apreender "as formas espaciais concretas de existência, algo que difere nos diferentes recortes de território da superfície terrestre. É o ser em sua totalidade geográfica concreta" 277 . Para tal, ainda segundo Moreira, a geograficidade seria, assim, o "modo de expressão [da] essência metabólica" do homem, ou a "hominização do homem pelo homem através do trabalho"278, algo muito próximo do conceito heideggeriano do "desabrigar" do homem pela técnica ${ }^{279}$, como citado páginas acima. Dessa forma, a busca da "essência metabólica" do homem estaria, como assinalado por Moreira, em sua relação com o trabalho, ainda que a técnica não seja desconsiderada. É nesse ponto que a mundanidade de Heidegger encontra a ontologia do trabalho (de Marx, Lukács e do marxismo em geral), no sentido de se constituir como uma pretensa unidade conciliatória como meio de solução ontológica que, "servindo ao marxismo como à geografia" ${ }^{280}$, permitiria o encontro entre a "existência" heideggeriana e a "necessidade" marxista: "O acento marxista é o enraizamento dessa mundanidade de Heidegger, desse ser-estar-no-mundo de Hegel, no âmbito do metabolismo do trabalho" (MOREIRA, 2004; p. 32).

\footnotetext{
276 MOREIRA, 2004; p. 32.

${ }^{277}$ Ibid., p. 34

278 Id., Ibid.

279 "Vale lembrar que a técnica faz parte da experiência ambiental do homem ao longo da evolução de sua história, numa tradição civilizatória em algum momento quebrada em proveito de um fazer técnico conforme com o discurso e as necessidades de padronização dos produtos que só é típica de uma economia de mercado. Tema a ser desenvolvido num próximo texto" (Moreira, 2004; p. 26).

${ }^{280}$ Ibid., p. 32.
} 
A relação reencontrada entre "necessidade/sobrevivência" (marxiana) e "existência" (heideggeriana) é também formulada por Martins ("o que singularizaria cada homem dentro do universo genérico da espécie? [...] A sua escolha, o seu remeter-se para a vida, a necessidade de superação, que para além da sobrevivência agora será existência”) a partir da questão "destinal" da existência: do movimento de tornar o "subsistente" em "desabrigador" por meio da "armação", em termos heideggerianos ${ }^{281}$. De modo equivalente, a conciliação em Martins, tal como em Moreira, encontra no trabalho, também de "origem" marxista, a condição para a "fusão" entre "sobrevivência" e "existência": "O Trabalho que é o superlativo momento em que se fundem sobrevivência e existência, no qual se processa a relação entre subjetividade/objetividade" (MARTINS, 2007; 45). Tal conciliação deve ainda encontrar seu "fundamento geográfico do ser" no que Martins vai, reconceitualmente, tender a colocar no plano da existência, o "Gênero de Vida". Chega assim Martins na unidade sobrevivênciaexistência do ser-aí a partir de sua geograficidade contida no Gênero de Vida, agora assimilado a seu sistema de fusão:

Diante dessa ampliação do conteúdo da categoria Gênero de Vida, considerando-a agora como a relação entre sobrevivência e existência, chegamos ao aí do ser-aí, ou seja, a sobrevivência e a existência exigem a relação entre o homem e o meio, entre a sociedade e a natureza, para que se realize a escolha, e para que esta se defina no trabalho. Cada homem é um conjunto onto-biológico, destinado a uma escolha, escolha esta amparada pelas determinações da sobrevivência, ou seja, pelo conjunto de relações homem-homem/homem-meio regidas pelas formas do trabalho (2007; p. 46)

Colocar em relevo tal passagem, apesar de relativamente longa, é importante para se perceber alguns problemas (que não é exclusivo a Martins, mas é também sintomático porque revela um "padrão" na forma de se constituir-reproduzir o discurso ontológico-epistemológicocrítico) que podem derivar questões a serem aprofundas no debate ontológico.

Da observação sobre a constituição em si das questões que envolvem a "necessidade" e seu referencial mediado pelo trabalho, sobretudo em Marx, e o significado igual e integralmente constituinte da "existência" em Heidegger, deriva um primeiro problema a ser exposto. Conforme argumenta Martins, o espaço como categoria da existência, "surge como categoria da ordem" 282 que permite a identificação dos entes em sua existência recíproca, um se identificando no e a partir do outro; ou seja, a própria condição da presença que identifica

\footnotetext{
${ }^{281}$ HEIDEGGER, 2007; p. 391-392.

282 MARTINS, 2007; p. 37.
} 
um ente em relação ao outro a partir de um determinado/determinante "mundo" (HEIDEGGER, 2005; p. 95). O espaço, por isso, remete à "co-existência" ("trata-se da categoria que nos remete à ordem das relações das coisas que co-existem") ${ }^{283}$ que por meio dela se torna assim possível identificar o fundamento geográfico do ser a partir de sua "distribuição", que remete à alteridade, e que permite identificar o "aí" do ser-aí, ou o Dasein, esse ser carregado de uma essência própria e diferente do ser de outros entes. A essência diferencial do ser a partir do ente se apresenta, assim, como "uma síntese particular derivada da existência" (MARTINS, 2007; p. 35). A essência diferencial se põe como o próprio objeto da busca do que, mediada pelo rigor ontológico propriamente heideggeriano, se constituirá como ponto de partida do fundamento geográfico do ser.

O trabalho, não de outra forma, seria uma dessas categorias com função ontológica fundamental, na medida em que ele revela/produz o conteúdo do ser do homem, segundo sua essência diferencial determinada/determinante pela sua mundanidade: "Devemos ir além, na direção de ver no Trabalho o ato de autoprodução do homem, [...] passando ser a atividade por meio da qual, e na qual, somente o homem se torna aquilo que ele é como homem, segundo sua essência” (MARTINS, 2007; p. 46). O trabalho, desse modo, se insere na existência heideggeriana como elemento ontológico da "hominização do homem" (para lembrar Moreira). No entanto, aqui se revela efetivamente o problema, pois ele só pode se inserir na "geograficidade" de ampla fundamentação heideggeriana se admitir perder sua fundamentação marxista, pois são antitéticas, como se tentará mostrar.

A contraposição entre o "Dasein" de Heidegger e o "Daseinform" de Marx é fundamental para colocar o debate ontológico em nível da crítica-autocrítica que permita uma concepção de "geograficidade" minimamente dialética. Embora Heidegger e Marx coloquem a questão do ser de forma parecida, no sentido de superação de sua dicotomia com o ente e, assim, buscar seu fundamento ontológico na "atitude prática" (para citar Heidegger), ou no "mundo sensível como atividade sensível" (para citar Marx), as formas de como se derivam deles a ontologia a partir do trabalho estão em sentidos inversos e são até inconciliáveis.

Especificamente com relação ao procedimento ontológico, o destaque da relação homem/trabalho em Marx é o que se objetiva, por meio dela, observar a sociedade real e concreta na forma de movimento. Não por outro motivo a ontologia de Lukács não seria possível, no nível da apreensão dialética, se não estivesse fundamentada no caráter "transitório" do trabalho. Marx, ao eleger o "movimento", ou as "mediações", estabelece como objetivo 
partir do "mundo sensível” e a ele se manter em constante retorno, ainda que seja necessário a investigação teórica fundamentada nas abstrações efetivas e determinantes. Detém assim a um imediato sentido prático para com a investigação: "Igualmente, tanto o material de trabalho quanto o homem enquanto sujeito são tanto resultado quanto ponto de partida do movimento. Portanto, o caráter social é o caráter universal de todo o movimento [...]” (MARX, 2004; p. 106). Adquirido o conteúdo de movimento, não de essência (como nos termos heideggeriano), é o que permite à Marx ver, a partir do trabalho, a "diferença essencial" do conteúdo social, o "Daseinform" ("se as línguas mais desenvolvidas têm leis de determinações em comum com as menos desenvolvidas, a diferença desse universal e esse comum é precisamente o que constitui o seu desenvolvimento") $)^{284}$.

O que seria em Heidegger uma busca ontológica no sentido da essência do ser, da "alteridade" de sua essência diferencial, em Marx não passa de uma forma de apropriação do objeto que se põe a partir de sua gênese específica, do seu desenvolvimento interno, na sua diferencialidade diante do universal comum: é, por isso, uma constituição, um processo, uma "gênese". Não há, neste sentido do termo, uma essência ontológica autêntica em torno do trabalho, mas sim o movimento contraditório que opõe a universalidade (que apenas "poupanos de repetições”) contra sua própria condição específica de ser.

É importante observar ainda que entre Marx e Heidegger, na forma de considerar os entes dispostos na existência, situam-se mecanismos de observação que se diferem. A "alteridade", da qual se referencia Martins para retirar daí seu conceito de "distribuição", como forma de identificação relativa do ente em detrimento de outros entes, o que lhe permite ainda chegar no "lugar do seu ente em seu ser-aí" na dimensão geográfica do "espaço vivido"285, em Marx é aparecido de forma inversa, ou seja, de forma não-identitária, negativa. Nesse sentido, pode ser usado como exemplo a passagem, no "Grundrisse", sobre a metamorfose sofrida pelo dinheiro no processo da circulação em que se refere Marx: "Eu só posso pôr efetivamente o seu ser para mim à medida que o abandono como mero ser para outro" (MARX, 2011; p. 177).

Ainda que seja correto considerar que a forma negativa da existência também seja considerada por Heidegger como atributo positivo da presença ${ }^{286}$ (“Só ouvimos o que não é esse ser-em, pretensamente fundamental. De fato. Mas essa predominância dos caracteres negativos não é mero acaso. Ao contrário, indica a peculiaridade do fenômeno e, portanto, num sentido autêntico, [...] positivo"), as naturezas diferenciadas da negatividade entre ambos assim

\footnotetext{
${ }^{284}$ MARX, 2011; p. 41.

${ }^{285}$ MARTINS, 2007; p. 48.

${ }^{286}$ HEIDEGGER, 2005; p. 97.
} 
podem ser estabelecidas a partir da mesma diferença admitida de significado entre a palavras alteridade (Heidegger) e contradição (Marx).

A importância dessa diferenciação se faz pelo simples fato de que o movimento que permite Marx “desessencializar” o dinheiro e, assim, demonstrar que ele é, no movimento da contradição, seu imediato negativo na sua própria "gênese", pelo simples objetivo de desvelar o discurso das "virtudes da riqueza" da ordem dominante, um objetivo prático e imediato, põe a questão da existência em um nível bem diferente dos apontados por Heidegger; e amplamente utilizados por Martins e Moreira. E isso é fundamental para se entender como ao trabalho é permitido aderir o sentido de essência ontológica. Por exemplo, em Moreira se observa a interpretação do "processo de trabalho" de Marx da seguinte forma: primeiro, onde escreve Marx que, "antes de tudo", a natureza da relação universal homem/natureza é metabólica e que se dá por meio das "forças naturais do seu corpo", interpreta Moreira: "Uma relação e uma troca de forças intra-natureza, e então de formas e conteúdos entre entes naturais, numa explicitação de suas essências" (MOREIRA, 2004; p. 32); segundo, onde Marx escreve: "põe em movimento forças naturais do seu corpo afim de apropriar-se dos recursos da natureza, imprimindo-lhes forma útil a vida humana”, interpreta Moreira: “A seguir, o caráter teleológico. O trabalho é uma interferência do homem orientado no sentido consciente da reprodutibilidade da história natural agora como um processo de história socialmente humanizada [...]"287; terceiro, onde escreve Marx: "desenvolve as potencialidades nela adormecidas e submete ao seu domínio o jogo das forças naturais", assim compreende Moreira: "Por fim, o caráter de salto ontológico. O homem socializa-se, socializando a natureza mesmo que diferenciadamente" ${ }^{288}$.

Acerca da exposição de Marx e a interpretação de Moreira é necessário destacar três pontos que podem fornecer uma explicativa sobre um procedimento, relativamente comum nos debates sobre ontologia, mas um tanto problemático, no que se é interpretado a partir dessa famosa passagem marxiana. Um primeiro ponto diz respeito à forma, intencional ou não (isso, de fato, não dá para ser identificado, mas se tem a abertura para a leitura que se segue), em que "metabolismo", "teleologia" e "ontologia" é interpretado, a partir de Marx, de forma linearmente sequenciada. É assim que se pode entender quando Moreira põe em relevo a expressão "antes de tudo" (originalmente de Marx), mas a partir dela dá a devida sequência linear utilizando os termos: "a seguir" e "por fim". De qualquer forma, caso a sequência linear esteja vinculada ao ordenamento lógico em que se dão as três categorias contidas no "processo de trabalho" (metabolismo, teleologia e ontologia), não seria demais lembrar que assim sendo

\footnotetext{
${ }^{287}$ MOREIRA, 2004, p. 33
}

${ }^{288}$ Id., Ibid. 
significaria a quebra do próprio movimento dialético, afinal não se poderia afirmar com exatidão o que antecederia qual, na medida em que uma só existe porque está inscrita às outras. A linearidade significaria a própria quebra da dialética marxiana. Mas caso a sequência linear esteja se referindo apenas à forma em si da exposição argumentativa de Marx, não excluiria um segundo problema que está contido na vinculação das expressões "antes de tudo" e "forças naturais de seu corpo" propriamente de Marx e ao que Moreira chama de: "formas e conteúdos entre entes naturais, numa explicitação de suas essências". Obviamente, constata-se aqui um salto interpretativo muito além do literal, afinal no abismo existente entre "forças naturais" e "essências" ontológicas há uma ponte que poucos se arriscam a atravessar, exatamente porque ao se propor em fazer o caminho de retorno, "essências ontológicas" que se pretendem "históricas" ou "existenciais" podem se cristalizar como "forças naturais". Como lembrado por Mészáros, "Marx rejeitou categoricamente a ideia de uma 'essência humana'. No entanto, manteve a expressão transformando o seu significado original até torná-la irreconhecível" (MÉSZÁROS, 2006; p. 18). Por isso, não se tratava de "acrescentar novas dimensões" ao conceito, mas como exercício do procedimento dissecativo até que sobrasse apenas sua carcaça: a palavra ${ }^{289}$.

O terceiro e último problema derivado da interpretação de Moreira em relação à famosa passagem de Marx é que o capítulo "V" do primeiro livro de "O Capital", sintomaticamente intitulado "Processo de trabalho e Processo de Valorização", em que está contida a referida passagem, não é tomado em sua integridade. Se, para Marx, é a "diferença essencial" o fundamento do ser, o "processo de valorização" é parte integrante da constituição ontológica que envolve o trabalho. Essa observação é quase sempre negligenciada, em parte porque haveria Lukács (principal intérprete da ontologia marxiana) levado a investigação sobre o trabalho a um quadro muito longínquo e remoto, o que tendeu a absolutização e essencialização do próprio trabalho na sua dimensão universal nas interpretações decorrentes; em parte também porque essa dimensão parecia destoar, e por aí ganhar relevo, daquilo que Marx se permitia “exceder" como forma de sofisticação filosófica e gnosiológica: a exposição do universal e comum fundante de sua teoria. Mas o fato é que "processo de trabalho" e "processo de valorização" compõem um único processo, onde o que importa é a contradição que deriva entre eles, seu desenvolvimento erigido a partir da relação entre "o universal" e o

\footnotetext{
${ }^{289}$ Como continua Mészáros: "Neste caso seu objetivo não foi simplesmente acrescentar novas dimensões a um conceito importante (como 'auto-estranhamento'), mas demonstrar o vazio deste termo filosófico, em seu sentido tradicional. E, não obstante, no curso desta demonstração, ele próprio usou o mesmo termo, na maioria das vezes sem indicações polêmicas, embora com um significado radicalmente diferente" (MÉSZÁROS, István, A Teoria da Alienação em Marx, São Paulo, Boitempo, 2006; p. 19).
} 
“comum", por isso seu desenvolvimento específico, sua diferença essencial. ${ }^{290}$ Então, para o debate ontológico fundamentado nesses termos marxianos, o rigor dialético deve ser garantido como forma inclusive de expor efetivamente a condição existencial do ser.

A partir desse ponto é até interessante observar como se tende a apontar uma contradição interna comum nas proposições fundamentadas na geograficidade a partir da existência heideggeriana. Se, por exemplo, conforme entende Martins, a essência se dá somente a partir de suas determinações de mundo, como determinações de existência ("a essência do ser configurar-se-á a partir de determinações geográficas (e históricas), posto que são determinações da existência") ${ }^{291}$ como admitir uma essência do trabalho somente pela dimensão unilateral da sua universalidade hominizante ("Devemos ir além, na direção de ver no Trabalho o ato de autoprodução do homem [...], passando ser a atividade por meio da qual, e na qual, somente o homem se torna aquilo que ele é como homem, segundo sua essência" ${ }^{292}$ ? Se, como determinação de existência, o trabalho está condicionado em sua estrutura de mundanidade, a sua forma de "valor" ou ao "processo de valorização", não deveria o capital participar de sua essência? É, no entanto, diante deste problema que o processo da alienação (“a questão não está na autenticidade ou inautenticidade da existência [...] O sentido do ser, ou então a sua essencialidade, vê-se obliterado no seu conteúdo por meio de outro processo, a saber, a Alienação") ${ }^{293}$ é chamado como equivalente substituto da inautenticidade heideggeriana, questão diante da qual encerra Martins sua exposição ("E como fica o Sentido de Localização diante disso [do processo da alienação]? Mas esse material - autores e temas fica para uma reflexão futura...”).

Por conseguinte, a alienação que seria o ponto final para a abertura de um novo debate em Martins é, por sua vez, o ponto de início do qual empreende Moreira, a diferenciação das "duas formas de metabolismo" (MOREIRA, 2004; p. 25): uma fundamentada no sentido do valor de uso, logo no sentido da realização do homem através do trabalho, e outra no sentido da realização do valor de troca, logo no sentido da alienação e realização do capital.

\footnotetext{
${ }^{290}$ Assim pode ser observado também em outra famosa passagem de Marx, no capítulo "A Mercadoria" em O Capital: "Como criador de valores de uso, como trabalho útil, é o trabalho, por isso, uma condição de existência do homem, independente de todas as formas de sociedade, eterna necessidade natural de mediação do metabolismo entre homem e a natureza e, portanto, da vida humana" (MARX, 1983; p. 50). Esta passagem, que poderia derivar qualquer outra interpretação essencialista do trabalho, está inscrita em um subtópico chamado "Duplo Caráter do Trabalho representado nas mercadorias". Logo, a existência humana pelo trabalho é apenas parte constituinte do movimento que torna o mesmo trabalho parte de sua desgraça existencial.

${ }^{291}$ MARTINS, 2007; p. 41.

${ }^{292}$ Ibid., p. 46.

${ }^{293}$ Ibid., p. 45.
} 
Segundo Moreira, tais formas de metabolismo que se encontram a partir da relação trabalho-natureza na constituição da "riqueza social", temática de origem marxista, mas que chega "entremeada" numa geografia econômica (sobretudo a partir de Pierre George), seria um dos elementos que permitiriam o "diálogo" entre essas duas ontologias: trabalho e geograficidade. Dessa relação, do trabalho se constituindo na condição da essencialização do homem pelo homem, produzindo e sendo produzido por uma geograficidade (existência) dada, até o momento de, por outro lado, se encontrar alienado, tanto do seu trabalho e de si mesmo como do seu espaço, é o que deveria se constituir como unidade crítica para a Geografia ("Uma trama econômica prende então espacialmente os homens a uma sociedade centrada nas relações de classes e do capital. O resultado é a alienação: alienação espacial dos homens") ${ }^{294}$. Mas aí, reconhece Moreira, o não sucesso em tal projeto de unificação ontológica em detrimento da gnosiologia, que parecia inerente à discursiva geográfica (“o discurso plantou-se no âmbito apenas gnosiológico. O plano ontológico do espaço do homem praticamente ficou de lado. E o projeto de renovar e unificar numa totalidade discursiva a geografia ficou no papel" $)^{295}$, condição essa que limitaria em grande medida a interpretação ontológica.

A "alienação do espaço" pela alienação do trabalho não haveria de se constituir elemento importante e central para a "ontologia geográfica" pelas condições dada de sua constituição interna, como observadas em Moreira, isso é verossímil. Mas também, e inversamente, porque a própria constituição da ontologia geográfica (primeiro centrado na gnosiologia, depois na "essência" heideggeriana) não conseguiria superar, ou definir em uma posição mais clara no plano da dialética, a unidade contraditória naquela mesma relação primária, como apresentada por Moreira: valor de uso versus valor de troca. Inadvertidamente ou não, se reproduzem, tanto antes como agora, mas em diferentes níveis de aprofundamento e até de sofisticação, aquelas mesmas vinculações sistemáticas, tão necessárias à epistemologia, de pôr em um plano as mediações vinculadas ao valor de uso ou o "processo de trabalho" como "a" dimensão da essencialidade e autenticidade (agora heideggeriana) verdadeiramente humana; e, de outro lado, o plano das mediações vinculadas ao valor de troca ou "processo de valorização" como "a outra" dimensão, a da alienação do capital e do "espaço"; da inautêntica dimensão não-humana da existência.

O que não se observa, e isso se expressa como tendência, dada a sutileza da questão, é que a busca ontológica geográfica a partir da busca pela essência do trabalho, como essência da hominização contra a alienação do capital, é, ao mesmo tempo, o processo de essencialização

\footnotetext{
${ }^{294}$ MOREIRA, 2004; p. 28

${ }^{295}$ Ibid., p. 27
} 
da existência (geograficidade) do capital como alienação do trabalho; essencialização essa tão criticada pelo próprio Marx. Isso pelo simples motivo de que, na busca ontológica pela essência não há a mediação dialética no sentido da busca das contradições que envolvem o ser social. Ou seja, em última análise, o processo de "alienação" (ou valorização, ou valor de troca, etc.) compõe decisivamente o procedimento ontológico, pois é a partir dele que se estabelece o movimento da contradição; assim, não vem "depois" da ontologia, ou da "essência do ser", como supostamente se faz crer. Dessa forma, o risco mistificador pode se expressar na tendência de se inverter a mediação que constitui a diferença essencial na própria essência diferencial.

Marx haveria de "abrir" 296 o seu sistema filosófico - inclusive por ter identificado no sistema fechado, autorreferenciado e circular de Hegel, suas vinculações especulativas e mistificadoras, o que o tornava insolúvel (MÉSZÁROS, 2009) -, para além da própria “filosofia pela filosofia", exatamente para que assim pudesse "buscar a ideia na própria realidade". Isso acabou por tornar suas próprias "soluções subordinadas ao dinamismo global da práxis social em seu desenvolvimento próprio" (MÉSZÁROS, 2008; p. 99). A via pela economia política, dessa forma, longe de representar um abandono, significaria a "realização da própria filosofia", o que coloca a "dialética da existência do real" em um nível qualitativamente diferente da que, na sequencia histórica, formularia Heidegger: "Marx levantou o problema da universalidade e de sua realização também sob seu outro aspecto vital: como apropriação. De novo, em lugar de meras transformações e soluções conceituais, nos apresentou a dialética objetiva da existência real" 297 .

Ao passo da busca da essência, o procedimento ontológico de Marx, tanto em relação ao homem, como à natureza, tem assim como princípio e fim a sociedade histórica na forma de seu próprio desenvolvimento. Não há, nesse sentido, "essência ontológica" a ser buscada por meio de "bases ontológicas mais elevadas e autênticas" (HEIDEGGER), na medida do que não poderia haver, nas determinações prático-sociais, a distinção formal de serem elas "falsas ou verdadeiras" (LUKÁCS), como assim pode ser lido no próprio Marx:

A natureza que vem a ser história humana - no ato de surgimento da história humana - é a natureza efetiva do homem, por isso a natureza, assim como vem a ser por intermédio da indústria, ainda que em figura estranha, é a natureza antropológica verdadeira" (MARX, 2004; p. 112).

\footnotetext{
296 “[...] O caráter inacabado de todo o trabalho de Marx [referência a não 'conclusão' da obra marxiana, mas sobretudo nos livros específicos como os 'Manuscritos', 'Grundrisse' e 'O Capital'] é inseparável da inovação histórico-universal de seu empreendimento e da abertura desafiadora do seu sistema” (MÉSZÁROS, 2008; p. 100). ${ }^{297}$ Idem; p. 96.
} 
A distinção inconciliável do procedimento ontológico de Marx em relação a Heidegger levanta um outro problema para a solução ontológica pela via da geograficidade, pois assim sendo (na forma como foi interpretado acima) colocaria a referência heideggeriana em uma situação de muita proximidade com os mecanismos de absolutização herdadas da tradição kantiana. Mas, de fato, é por essas vinculações que se fundamenta Theodor W. Adorno naquela que se constitui como uma das mais expressivas críticas contra a ontologia heideggeriana. É exatamente no primeiro capítulo de sua principal obra, "Dialética Negativa", num capítulo intitulado "A Necessidade da Ontologia", que asseverará Adorno em torno da sequência fenomenológica husserliana (“de se voltar para as coisas”) seguidas por Heidegger: "De maneira implícita, achava-se por trás disso a afirmação de que os projetos da razão poderiam impor sua estrutura à profusão do ente; e isto segundo a retomada das antigas filosofias do absoluto, cuja a primeira retomada foi o idealismo pós-kantiano" (ADORNO, 2009; p. 60) ${ }^{298}$.

A análise de Adorno centra na observação de como a "Necessidade da Ontologia" passa a prosperar diante de uma "ordem heterônoma" como veredicto da sanção da verdade, questionando como a busca pelo reconhecimento do ser parecia se pôr ante sua própria justificação na consciência. A novidade heideggeriana, da "profusão do ente" a partir da presença, aparecia como algo de não kantiano, como assim se lê na passagem de Martins em sua referência ao espaço como categoria da existência: “[...] Espaço é atributo do ato de cognição do mundo. Mas como tal, não é um dado a priori, como queria Kant, e sim algo que emerge como construção social, um atributo cultural, uma forma de ver e compreender o mundo" (MARTINS, 2007; p. 37). No entanto, como interpreta Adorno, a "profusão do ente" como negativa kantiana escondia nela mesma a sua própria referência de absolutização kantiana: "A exigência por uma razão objetiva, por mais legítima que seja, não conseguiria eliminar sozinha a crítica kantiana à prova ontológica da existência de Deus [o absoluto]" (ADORNO, 2009; p. 68).

A remissão metodológica pelo eterno-retorno, da volta ao ser como a forma autêntica, da sempre presente referência à cognição como algo de onde se parte em direção a uma essência ontológica cada vez mais além, conforme se aprofunda na sua própria busca, se põe na constituição de si mesmo como a tendência de ser, contraditoriamente, a busca por resposta "talhadas segundo a [sua própria] necessidade" (“A vontade de não se declarar saciado com a experiência de aprender algo de essencial a partir da filosofia é deformada por meio de respostas

298 ADORNO, Theodor W, Dialética Negativa, Rio de Janeiro, Zahar, 2009. 
que são talhadas segundo a necessidade" ${ }^{299}$. Mas nisso se observa e se confirma um tipo de absolutização - não apenas pelo caráter metódico com que Heidegger apresenta a forma com que a ontologia deveria ou não ser aplicada, como também pelo procedimento de tornar a "questão crítico-cognitiva como pré-ontológica"300 - um tipo de "arcaísmo" voltado para o "princípio" e a “origem", onde nada contém de movimento ou contradição: "A insuficiência da questão preliminar à teoria do conhecimento transforma-se em título de direito para sua simples eliminação; o dogmatismo torna-se para ele [Heidegger] a sabedoria mais elevada. Essa é a origem do arcaísmo heideggeriano" ${ }^{301}$.

Esse ponto central da crítica adorniana à "necessidade da ontologia" (heideggeriana), qual seja: a de "eliminar as mediações ao invés de refletir sobre elas" ${ }^{302}$, é ainda um dos pontos centrais da inconciabilidade entre Heidegger e Marx. E não só: era também a forma remissiva e a-crítica de Heidegger "zerar" o sentido do próprio "primato histórico" em prol de um "primato ontológico" 303 , isso em um contexto em que "a própria dominação da primeira

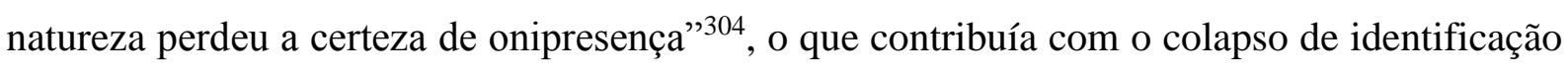
do sujeito da "segunda natureza": este contexto era exatamente a desastrosa primeira metade do século XX, marcada assim pelo "passado de horror”, nas palavras do próprio Adorno. Daí uma inversão irracionalista: "A fidelidade ao ser, um turvo derivado de uma intuição crítica estabelecido em termos de visão de mundo, degrada-se realmente e transforma-se em - como Heidegger certa vez, imprudentemente, a definiu - pertencente ao ser”305.

Não por coincidência, esse último ponto, o do irracionalismo em Heidegger, seria, anos antes da crítica de Adorno, o elemento basilar da crítica de Lukács esboçada em "Destruição da Razão". Embora este tenha sito um livro "controverso" e de difícil aceitação, inclusive por marxistas da importância de Henri Lefebvre e Ernst Bloch, além do próprio Adorno - como observaria Nicolas Tertulian "30 anos depois" 306 , sobretudo porque esse livro força uma linha comum de todo o pensamento alemão de Schelling à Hittler, todos sob o denominador do “irracionalismo". É com muita contundência que observa Lukács, especificamente sobre

\footnotetext{
${ }^{299}$ Ibid., p. 68.

${ }^{300}$ Ibid., p. 67.

${ }^{301}$ Como se encontra em nota de rodapé as observações do tradutor da referida edição, o "Archaismus" (arcaísmo) do qual cita Adorno, está vinculado à ideia de "princípio, origem” (Cf. ADORNO, 2009; p. 67).

302 Ibid., p. 60.

303 "Muito sabiamente, ele teve a cautela de não fazer regredir diante dos olhos de todos a revolução copernicana, isto é, a revolução que conduziu a ideia. Ele distinguiu cuidadosamente a sua versão da ontologia daquela do objetivismo, a sua postura anti-idealista daquela do realismo seja crítico, seja ingênuo" (ADORNO, 2009; p. 64). ${ }^{304}$ Ibid., p. 65

${ }^{305}$ Id., Ibid.

306 TERTULIAN, Nicolas, “A Destruição da Razão: 30 anos depois”, Verinotio, revista on-line - n. 13, Ano VII, abr./2011.
} 
Heidegger, a forma de como por dentro da própria "existência" proclamada havia se perdido o "espírito objetivo" e científico; na medida em que teria se constituído no pensamento heideggeriano a tentativa de "superação" não apenas da metafísica, mas também da teoria do conhecimento $^{307}$. A natureza dessa crítica, revela Tertulian, em muito se reencontrava com a crítica de Ernst Cassirer e Nicolai Hartmam, este último explorado depois pelo próprio Lukács na constituição de sua "Ontologia do Ser Social”. Assim diz Tertulian sobre esse imbróglio com tanta gente envolvida:

Sua meta [Cassirer] era refutar o que lhe parecia ser uma desvalorização em Heidegger do peso do "espírito objetivo" na existência humana: recusando-se a aceitar a sinonímia postulada por Heidegger entre a "impessoalidade" ou a "objetividade" com a "inautenticidade" ou a "degenerescência" (TERTULIAN, 2011; p. 18).

Apesar de Lukács ter reconhecido a importância de Heidegger na refutação da ideologia burguesa da "segurança", um "leitmotiv da ideologia da extrema-direita"308, categoria fundada pelo humanismo clássico alemão, especificamente pela pena de Wilhelm Von Humboldt (irmão do conhecido geógrafo Alexander Von Humboldt ${ }^{309}$, Lukács iria mesmo se alinhar à crítica de Husserl, para quem “não hesitava de repelir [contra Heidegger] 'um Dasein humano individual abstrato qualquer (HUSSERL, 1976; p. 475)"’310. Se observa aqui o alinhamento crítico, congregado por Lukács, de um autor importante: Husserl, declaradamente, era uma das principais influências de Heidegger, como pode ser comprovado em seu depoimento "Meu Caminho para a Fenomenologia": "A obra de Husserl marcara-me de tal modo que, nos anos subsequentes, sempre a li, sem compreender suficientemente o que me fascinava" (HEIDEGGER, 495) $)^{311}$.

Lukács não apenas tinha denunciado a forma de como a "coisa real" em Heidegger tendia a se isolar em sua essência distante e infinitesimal, ao mesmo tempo em que se apresentava próxima da realidade pela pretensa objetividade da presença, por onde se

\footnotetext{
307 "[Heidegger] moldou uma forma muito original de superação da Metafísica. O filósofo convenceu-se de que, até ao seu tempo, toda história da ontologia não passara de uma teologia e que, com os neo-kantianos, caíra numa teoria do conhecimento" (STEIN, Ernildo, "Nota do tradutor", In: HEIDEGGER, Conferências e Escritos Filosófico, São Paulo, Abril Cultural, 1983; p. 201).

${ }^{308}$ Ibid., p. 19.

309 "Encontra-se efetivamente num curso de Heidegger um ataque polêmico explícito contra 'o entendimento burguês' (bürgerlicher Verstand), considerado o acompanhamento necessário da existência inautêntica, a qual Heidegger opunha a meditação enraizada no Dasein autêntico" (TERTULIAN, 2011; p. 19)

${ }^{310}$ Id., Ibid.

${ }^{311}$ HEIDEGGER, Martin, "Meu Caminho para a Fenomenologia", In: Conferências e escritos Filosóficos, São Paulo, Abril Cultural; 1983, p. 295.
} 
reemergiria do mergulho ontológico agora "disposto" na existência (como mencionado a respeito da questão dos "instrumentos"); uma existência desprovida de trabalho, como prontamente não deixaria de observar Lukács. Mas a objeção do filósofo húngaro também se fundamentou na observação de que passava a significar e ganhar terreno uma ontologia nãocrítica. Isso certamente o impulsionou para esse campo de debate que se apresentava como fundamental àquele contexto. A constatação de que, a partir de Marx, a única ontologia crítica possível era a do "ser social" - na medida em que "o caráter social é o caráter universal de todo movimento" (MARX), e este mediado pela única categoria do ser social de caráter transitório, logo o que dá sentido a "todo movimento", o trabalho - representava, por isso mesmo, não simplesmente um posicionamento político, mas sobretudo a demarcação de uma teoria que situava Lukács em polo filosófico radicalmente oposto ao de Heidegger.

Ainda que, no plano da fenomenologia, apesar da discordância, Husserl e Heidegger podem ser conciliados dentro de uma perspectiva específica; entre Lukács, Adorno e Marx (ou o marxismo em geral) e o autor de "Ser e Tempo" essa possibilidade só se tornaria possível se fosse admitido que assim se faz somente por meio de um sistema pretenso de fusão amalgamática, como aquelas aqui já debatidas. Embora seja necessário também admitir que a interpretação geográfica tenha muito mais o que aprofundar nas especificidades das ontologias lukacsiana e heideggeriana, tal como a resistência adorniana no plano da metafísica e sua consequente rejeição às ontologias, o fato que pode ser aqui adiantado é que entre elas há muito mais contraposições a serem assimiladas, como forma de melhor situar o debate ontológico, do que propriamente possibilidades de fusão. Como observado, se a "existência" heideggeriana, ao tempo em que representa a saída ontológica pela geograficidade, como expressão do próprio rigor ontológico, como foram urdidas as perspectivas de Moreira e Martins, por exemplo, deve ser considerado que este é também, como corolário, seu ponto mais problemático para a "solução" teórica, sobretudo quando se admite o trabalho como categoria base para o pensamento socialmente crítico na Geografia.

\section{5 - As possibilidades da crítica na ontologia do espaço}

Se, como indicado acima, a presente fase de maturação em que encontram a tese de Moreira (tal qual suas atualizações de 2007 e 2008) e a concepção final de Santos tendem ao rompimento com a centralidade das categorias críticas que compõem a gênese de uma "teoria da transição", todas elas herdadas da ontologia do ser social fundamentada no trabalho, isso não se daria apenas pelo deslocamento de Lukács dentre seus referenciais e a consequente 
aproximação com Heidegger, nem também pela urgência em constituir devidamente o estatuto ontológico para o espaço, mas sobretudo pela natureza da teoria que deveria admitir em seu "corpo" um nível de conciliação entre a diversidade filosófica e a tradição disciplinar. A consequência, inevitavelmente, é a tendência em recair numa bifurcação onde, ou se abandona o rigor dialético-contraditório, ou se assimila a contradição como um elemento não objetivável em prol de um corpo ontológico constituído em sua própria essência empírica e material. Para se perceber isso (o deslocamento da crítica social em prol de uma teoria ontológica “essencialmente geográfica”), não basta só mencionar o movimento de internalização dos geógrafos na própria geografia, o que no fundo seria sua própria e pretensa "autorreferenciação" - como evidenciado pela tentativa de estabelecimento de uma linha de continuidade "crítica" que revelaria a "dominação" do trabalho pelo capital desde os "clássicos", como tentado por Moreira, ou pelo "abandono" de categorias propriamente críticas como classe trabalhadora, por Santos -, mas também deve-se tentar elucidar os objetivos teóricos-políticos contidos em suas propostas.

Nesse sentido, a importância em comparar essas duas propostas de interpretação da ontologia espaço (Moreira e Santos), e entre elas, a obra de maturidade de Mészáros, é reveladora. Não apenas porque elas se sucedem um ano depois da outra (Moreira em 1994, Mészáros em 1995 e Santos em 1996, o que significa que elas falam no/do mesmo contexto histórico), mas também pelos motivos de como que elas chegam a resultados extremamente opostos diante desse contexto: a geografia desagua na necessidade de reconhecimento de sua efetividade epistemológica por um estatuto ontológico que concedesse ao espaço sua condição de "corpo do tempo"; e Mészáros na identificação de uma crise estrutural e a necessidade de uma teoria da transição socialista para além da "carcaça do tempo", que é o capital. A diferença do posicionamento político individual entre as propostas dos geógrafos e a do filósofo não seria suficientemente explicativa, já que em todas elas há admissão de pretenderem ser teorias “emancipatórias". Por isso que tais diferenças, de efetividade política, não se explicam somente pela sua contextualidade histórica marcada por uma inflexão política no seio da crítica geográfica, pelo arrefecimento no engajamento político dos geógrafos e sua consequente institucionalização observada desde os anos 1990. Tal explicação deve ser obtida também em seu interior teórico, de sua constituição íntima, sobretudo a partir de como a dialética e a contradição são por elas admitidas para, assim, compreender suas possibilidades e limites práticos.

Por essa via, tomando como referência o que sobrou e o que se superou da influência ontológica lukacsiana, é igualmente revelador o que se pode encontrar. E também muito 
curioso. Pela vertente das propostas fundamentadas na busca da ontologia do espaço (em que já havia "abandonado" efetivamente Lukács como referencial) ${ }^{312}$, se observa a manutenção e conservação dos pontos identificados pelo "filósofos" como condições limitantes para a efetividade de uma crítica radical. Esses pontos seriam limites jamais superados pelo próprio Lukács, como apontado por Chasin e Mészáros, e se referem exatamente à "remoticidade" e à "concreticidade" com que sua ontologia e sua história, respectivamente, estariam fundamentadas. Tanto em Moreira como em Santos, a concepção "concreticista" de história para a fundamentação ontológica (do movimento metodológico para tornar o "em-si" em "paranós") é igualmente mantida, tendo em vista uma perspectiva mais geral. Milton Santos irá até mesmo citar o filósofo húngaro (embora sem o referenciar) no interior da argumentação do seu conceito de totalidade, diante da necessidade de identificação do "processo que precede" a efetividade do movimento do abstrato para o concreto; ou melhor, diante do estágio anterior das manifestações universais em suas particularidades empiricizadas e "corporificadas" no espaço: “A coisa acabada nos dá a cristalização do movimento, mas não a própria vida [...]. Também Lukács chama a atenção para esse momento de passagem, essa atualidade cuja percepção exige que o todo seja surpreendido em seu movimento” (SANTOS; 2008, p. 121).

Pela vertente da ontologia do trabalho contido na teoria da transição, da qual Lukács é o ponto de partida fundamental, mas para sua própria superação (porém não negação), a reinserção da dialética em sua universalidade total, a reintrodução da lógica numa teoria prática, a fundamentação do "para-nós" no "em-si" - movimento este metodológico de abstração desde sempre renegado pela renovação da crítica geográfica diante dos "riscos de metafisicalização" (ou de "estender-se muito ao infinito") -, possibilitaram à crítica da teoria da transição a reafirmação de categorias históricas inseridas em um discurso ontológico: socialismo, trabalho, classe trabalhadora, capital, etc. Isso pressupôs um posicionamento crítico da condição histórica-concreticista das formulações de Lukács e a conformação dessas mesmas categorias "com claro caráter de transição" em uma estruturação ontológica que seria a um só tempo crítica e autocrítica ${ }^{313}$. Para isso, aponta Mészáros a necessidade de uma franca influência em Marx:

Na visão de Marx isto se torna possível apenas como resultado do impacto corretivo e cumulativo da autocrítica radical exercida pelo sujeito social da

\footnotetext{
312 Tanto em Milton Santos (2008) como em Ruy Moreira (1994), Lukács não consta entre suas referências.

313 'Lukács levanta a questão da 'autocrítica' do proletariado. Significativamente, contudo, em agudo contraste com Marx - que a define como incessante reexame radical e reestruturação prática das formas sociais objetivas e instituições criadas pela revolução socialista -, ele a confina estreitamente no nível da consciência, equiparando 'a luta do proletariado contra si próprio' à luta 'contra os efeitos devastadores e degradantes do sistema capitalista sobre sua consciência de classe’ (p. 80; ed. port., p. 96)”. (Mészáros, 2011; p. 400).
} 
emancipação, o trabalho, que não deve estar apenas nominalmente (como vimos até agora, sob a autoridade das "personificações do capital" póscapitalistas), mas genuína e efetivamente encarregado do processo sociometabólico (MÉSZÁROS, 2011; p. 599).

A crítica-autocrítica se propõe, assim, como uma ontologia condicionada na forma de dissecação interna e dialética do objeto; do ser em si definido por suas mediações contraditórias e por meio de abstratos determinantes, e não como epistemologia crítica a ser aplicada perante as formas de existência fenomênica do objeto que, assim, só poderia se apresentar como exterioridade, conforme se expressa a crítica geográfica. Por isso, quando Mészáros aponta, diante da perspectiva de superação da concreticidade e remoticidade com que a história tende a se fundir nas ontologias epistemológicas das ciências conformadas em disciplinas - do qual o modelo lukacsiano é usualmente o mais apropriado para aquelas com objetivos críticossociais, porque se apresenta como "histórico-materialista" - a necessidade de se conformar uma "ontologia unicamente humana do trabalho" 314 , apenas pode admitir como totalidade o movimento da contradição como princípio interno de sua objetivação.

Rechaçada a absolutização e a imediaticidade do recurso "essencialista" - quando não heideggeriana, é corriqueiramente baseado na "evidência" da eterna presença do suposto objeto ontológico na história universal - a posição ontológica do trabalho só pode se efetivar, assim, pela necessidade de ser suficientemente crítica perante as contradições que historicamente se põe como corolário emergido de si próprio (Trabalho contra Capital); suficientemente negativa perante qualquer possibilidade de entende-los confundidos, ou "unicizados", como imanência (Trabalho como Capital); e suficientemente afirmativo para se pôr como o radical antagônico interno e emancipatório (Trabalho para além do Capital). Tudo isso a um só tempo, como simultaneidade dialética, que pertence à história, mas a ela também se contradiz como determinação (absoluta), indeterminação (contraditória) e possibilidade (histórica).

["Mediações de Primeira Ordem" versus "Mediações de Segunda Ordem”]

Diante das impossibilidades de proposição de uma teoria da transição, as formulações geográficas-ontológicas, de natureza (aberta ou implicitamente) lukacsiana, não haveria de avançar muito na radicalidade de sua crítica. Seja porque não são autocríticas, seja porque a concreticidade lukacsiana admitida representa apenas uma saída teórica providencial, tal

${ }^{314}$ MÉSZÁROS, 2011, p. 212. 
influência não vai muito além do que a convocação de um abstrato longínquo correspondente apenas a um passado remoto para a constatação do espaço e da técnica nas formas de sociedade na história. Como aliás advertiria o próprio Mészáros: "não pode haver certa nostalgia romântica em relação a alguma 'condição original' ou 'estado natural' idealizado. Nenhuma delas poderia ser considerada primária, num sentido cronológico” (2011; p. 214).

O recurso à ontologia, remota e "dúbia" 315 , de se buscar na "essência" humana do trabalho e da técnica, como aquelas contidas no processo de trabalho dotado de "consciênciade-qualidade", mediado por uma técnica destituída de "norma" e "controle" e qualitativamente orientado para um fim (valor de uso), só haveria de encontrar referência no trabalho e na técnica daquele remoto "produtor do machado de pedra" dotado de consciência e liberdade onde a produção mantinha seu valor de uso "liberado" das determinações quantitativas para a troca (valor de troca) $)^{316}$.

Mesmo Milton Santos que, no auge de sua maturidade teórica teria o cuidado de limitar a discussão ontológica do espaço diante de um quadro mais teórico e menos historiográfico, como observado na primeira parte de "A Natureza do Espaço", haveria de buscar nos recursos remotos e absolutizantes da relação homem-meio os argumentos legitimadores para o seu conceito de "meio técnico-científico-informacional", este como a forma historicamente específica e atual da "eterna" mediação, pela técnica, do homem com a natureza. Essas argumentações estão presentes na terceira parte da mesma obra, parte essa sintomaticamente intitulada "Por uma Geografia do Presente". Assim argumenta Santos: "Quando tudo era meio natural, o homem escolhia da natureza aquelas suas partes ou aspectos considerados fundamentais ao exercício da vida [...]" (SANTOS, 2008; p. 238), para assim fundamentar sua conformação, junto com o trabalho, de estar ela, a técnica, entremeada com as "dádivas da natureza" ("As técnicas e o trabalho se casavam com as dádivas da natureza, com a qual se relacionavam sem outra mediação") ${ }^{317}$; até, por fim, chegar em suas formas mais desenvolvidas, em uma sequência acumulativa de técnicas (“O terceiro período começa praticamente após a segunda guerra mundial, e sua afirmação, incluindo os países de terceiro mundo, vai realmente

\footnotetext{
315 "Na ausência de qualquer crítica substantiva aos fundamentos socioeconômicos existentes e suas formações estatais, é compreensível que Lukács tivesse necessidade desses dúbios fundamentos ontológicos" (MÉSZÁROS, 2011; p. 506).

316 “Assim, o discurso ontológico de Lukács sobre o 'bom trabalho' como 'categoria fundamental da vida dos trabalhadores', desde o ancestral primitivo que afiava com consciência-da-qualidade o machado de pedra até a 'subjetividade adequadamente livre dos seres humanos livres na sociedade comunista', simplesmente evita a questão das mediações materiais, em vez de empreender a crítica radical vitalmente necessária das formas estabelecidas de mediação socioeconômica e política" (MÉSZÁROS, 2011; p. 507).

317 (SANTOS, 2008; p. 238)
} 
dar-se nos anos 70") ${ }^{318}$; e por onde se apresentaria algo qualitativamente novo: "Estamos diante da produção de algo novo, a que estamos chamando de meio técnico científico informacional" 319

Tal recurso compreensivelmente assimilado, dada a urgência com que a "solução epistemológica" deveria equacionar diante dos mesmos problemas de fragmentação disciplinar denunciados por Armando Corrêa da Silva ainda na década de 1970, se generaliza como a forma em si de ter que conceber uma história do espaço para sua ontologia. Observa-se em Milton Santos "maduro" a permanência daqueles recursos estruturalistas, sobretudo althusserianistas dos tempos de "Por Uma Geografia Nova", naquela forma bem descrita por Ruy Fausto: "Hoje o althusserianismo é considerado superado. Mas de certo modo, ele nunca foi refutado. E aqueles que não 'historicizaram' (e da maneira mais selvagem), 'althusserizam' sem querer” (1983; p. 21).

Identificados os limites do recurso concreticista e remoticista com que a história é introjetada na ontologia (que assim passa a ser um mero recurso metodológico de legitimidade teórica, não uma epistemologia efetivamente crítica), porque remeteria a uma contradição entre a identificação do objeto ontológico na história universal a partir da evidência do concreto eternamente presente, mas que se põe como um abstrato longínquo diante de sua "diferença essencial", a ontologia possível e criticamente efetivável só encontraria lastro, segundo Mészáros, na identificação das "mediações de primeira ordem" que operam no interior das próprias “mediações de segunda ordem” erigidas pelo sistema metabólico do capital.

"Marx jamais discutiu detalhadamente as formas históricas intermediárias e correspondentes de intercâmbio metabólico que ligam a relação-capital à ordem social por ele antevista [o comunismo]”, assim observa Mészáros (2011; p. 204) buscando como justificativa para tal "incapacidade" de Marx as "restrições socioeconômicas de sua época". Mas se fundamenta no mesmo Marx para identificar dois polos de análise que permitiriam uma teoria da transição. Por um lado: "a avaliação realista das realizações históricas e a imensa força prática do sistema do capital”, e, por outro "a identificação dos antagonismos estruturais que tendiam a prejudicá-lo como sistema viável de reprodução sociometabólica ou 'processo de vida social", 320 .

O que busca Mészáros em Marx é a fundamentação de que estariam contidos na base da própria produção do capital os elementos constitutivos de sua superação, como nas palavras de

\footnotetext{
${ }^{318}$ Id., Ibid.

${ }^{319}$ Id., Ibid.

${ }^{320}$ MÉSZÁROS, 2011; p. 204.
} 
Marx, citadas por Mészáros: "Por outro lado, nas forças produtivas do trabalho que ela desenvolve em oposição ao trabalhador, nas condições de produção e nas relações de comunicação, ela cria as condições para um novo modo de produção" ${ }^{\text {"21 }}$. O que em nada tem a ver com a "disponibilidade" essencialista e potencializadora da técnica heideggeriana/miltoniana, apesar de ser interessante notar a presença daquelas categorias identificadas pelo geógrafo, sobretudo quanto a análise da comunicação e seu papel na atualidade. Entretanto, na sequência, observa-se também aquelas outras categorias, de certa forma "abandonadas" (modo de produção e até a formação social ${ }^{322}$ ) pela "maturidade" da epistemologia ontológica do espaço. Como diz Marx na sequência da citação selecionada por Mészáros “[...] ela cria as condições para um novo modo de produção, relegando a forma antagônica do modo de produção capitalista e lançando a base material para um processo de vida social com nova formação e, daí, uma nova formação social” (MÉSZÁROS, 2001; p. 204).

É, no entanto, por vias deste modo de produção contraditório e historicamente específico, as "mediações de segunda ondem" do capital, que se pode conformar as possibilidades de, assim externalizadas como prática emancipatória, uma formação social fundamentada em um sistema "sociometabólico de primeira ordem" inteiramente novo. A identificação das mediações de primeira ordem são, assim, expressões das mesmas mediações de segunda ordem, só que invertidas e condicionadas a sistemas de mediações novos e radicalmente diferentes do que, do ponto de vista qualitativo e histórico, só pode representar algo absolutamente novo ${ }^{323}$ : uma nova "diferença essencial”. A condição de efetivação como realidade da experiência inteira e radicalmente nova teria como princípio o controle social (e não a partir do Estado), segundo Mészáros, “da atividade produtora biológica, mais ou menos espontânea e imprescindível" entre população e disponibilidade de recursos; do processo de trabalho e o intercâmbio da "comunidade com a natureza" na garantia de "satisfação" humana de produtos, meios e instrumentos do próprio trabalho; adequação das relações de troca às necessidade humanas historicamente produzidas; a "alocação racional dos recursos humanos e materiais disponíveis, combatendo a tirania da escassez" diante do avanço do desenvolvimento

\footnotetext{
321 Id., Ibid.

322 Em Milton Santos, a Formação Social, diferente de suas objetivações como "teoria e como método" dos idos de 1977, em A Natureza doo Espaço, ela (F. S.) se apresenta com um conceito mais próximo ao de escala nacional como delimitação objetivável da análise concreta geográfica: “A formação social nacional funciona, pois, como uma mediação entre o Mundo e a Região, o Lugar. Ela é, também, mediadora, entre o Mundo e o Território (SANTOS, 2008; p. 236-237).

323 "De agora em diante, qualquer que seja o futuro do socialismo, este terá que ser estabelecido em fundamentos radicalmente novos, para além das tragédias e dos malogros do tipo soviético de desenvolvimento que se paralisou desde muito cedo, logo após a conquista do poder da Rússia por Lenin e seus seguidores” (MÉSZÁROS, 2011 ; p. 349).
} 
produtivo; e "a promulgação e administração das normas e regulamentos do conjunto da sociedade, aliadas às outras funções e determinações da mediação" (MÉSZÁROS, 2011; p. 213).

Sobre tais formas de controle social deve ser considerado a linha tênue entre seus significados de ordem primária e aquelas já efetivadas pelo metabolismo do capital. Tais riscos, contudo, devem ser assumidos como problema da própria autocrítica da prática emancipatória como última instância objetiva, em detrimento das possibilidades de serem confundidas e identificadas com seu imanente negativo, afinal essa é a estratégia do próprio capital: ter suas especificidades históricas confundidas como essencialidade humana por "um círculo viciosos onde aparentemente não há fuga" ("Pois elas se interpõem, como 'mediações', em última análise destrutiva da 'mediação primária', entre os seres humanos e as condições vitais para a sua reprodução, a natureza") $)^{324}$.

O próprio Marx já havia desvelado essa estratégia da "consciência burguesa" de inverter, para se pôr como "natural", o controle social efetivo do capital em liberdade individual de mercado e a divisão hierárquica e regulatória do trabalho em divisão e diversidade social, tal como haveria também insinuado a necessidade de "controle social da produção" no contexto de sua própria denúncia.

Como assim assinala Marx em famosa passagem:

A mesma consciência burguesa, que festeja a divisão manufatureira do trabalho, a anexação do trabalhador por toda a vida a uma operação parcial e a subordinação incondicional dos trabalhadores parciais ao capital como uma organização do trabalho que aumenta a força produtiva, denuncia com igual alarido qualquer controle e regulação social consciente do processo social de produção como uma infração dos invioláveis direitos de propriedade, da liberdade e da 'genialidade' autodeterminante do capitalista individual (MARX, 1983; p. 280).

Assim, dentro de tais limites, as possibilidades de composição de uma ontologia não mais voltada para a conformação epistemológica, mas também não deixando de ser diante dos enfrentamentos teóricos e práticos de última instância para a crítica-autocrítica emancipatória em seu método dialético francamente desenvolvido, são postas sem a necessidade dos limitados recursos concreticista e remoticista.

${ }^{324}$ MÉSZÁROS, 2011, p. 179. 
3.6 - Das "linhas de fuga" aos "refúgios" de uma crítica não efetiva

Os limites efetivos da crítica geográfica diante da necessidade admitida de "transformar o mundo" não se explicam apenas pelo posicionamento político, inerentes ou adquiridos, dos geógrafos que mais contribuíram para o movimento da renovação. É por demais sabido, por exemplo, que Milton Santos, o geógrafo que mais influenciou e continua a influenciar gerações inteiras de outros geógrafos brasileiros, nunca haveria de se envolver com uma militância política, como assim abertamente assumia o próprio Santos diante das questões sobre os compromissos militantes, e especificamente em relação à questão racial: "Eu não sou militante de nada, seja da política, seja do racialismo" (2000; p. 86). Condição de intelectual, aliás, muito próxima daquela em que Lukács haveria de estar vinculado em sua plena maturidade, posicionamento "injustificado", até mesmo pelo seu mais importante assistentecolaborador, como lembra o próprio Mészáros: “ele pôde afirmar [também em entrevista] que: 'não desejo me intrometer nas questões políticas diárias. Não me considero um político. ... apenas levanto a questão do ponto de vista do sucesso ideológico da democracia'”,325.

As limitações da crítica também não poderiam ser explicadas somente pelo deslocamento político das perspectivas "revolucionárias" para admissão de objetivos "mais modestos" para com a crítica, como aqueles assimilados por Silva, Moraes e Moreira; ou mesmo o abandono total com a perspectiva da transformação, como é o caso de Wanderley Messias da Costa, que, junto com Moraes, escreveu na década de 1980 o instigante e inspirador "Geografia Crítica: A Valorização do Espaço", como analisado no capítulo 1.2 ("A Valorização do Espaço"). Quase duas décadas depois, em um artigo publicado em $2002^{326}$, irá Costa se debruçar sobre os problemas da "legitimidade geográfica" apontando que, diante da "crise da Geografia", o seu afastamento e isolamento em relação às disciplinas do "núcleo duro" da pesquisa técnica ("hard science") seria "provavelmente" seu elemento mais grave ${ }^{327}$.

A evidenciação de que a maturação da crítica geográfica levou a sua anticrítica, ou ao seu conformismo intelectual como queiram tantos outros, tem ainda um problema mais sério dentro de sua composição teórica. A comparação entre o destino da crítica geográfica conformada em uma ontologia do espaço e uma crítica da transição atuando em uma ontologia do trabalho não foi, assim, posta na presente construção argumentativa de forma gratuita. Serve

\footnotetext{
${ }^{325}$ Mészáros, 2011; p. 504.

${ }^{326}$ COSTA, Wnaderley Messias da, "Ciência, Tecnologia e a Crise da Geografia", São Paulo, GEOUSP - Espaço e Tempo, $n^{\circ} 12,2002$.

${ }^{327}$ Esse ponto do deslocamento da crítica dos autores de A Valorização do Espaço foi analisado no tópico "1.2 - 'A Valorização do Espaço"”
} 
para demonstrar dois pontos que evidencia a falsa fatalidade histórica da crítica geográfica: (primeiro) que o recurso ontológico e o seu desenvolvimento não necessariamente deve se conformar em um efetividade epistemológica e tendencialmente a-crítica; (segundo) que a garantia de maturidade de uma crítica científica, como as teorias do espaço, só pode ser efetivamente social no momento em que admite seus problemas metodológicos que envolvem o manuseio da dialética (um debate em prol da "realização filosófica") para identificação das contradições históricas-sociais no sentido de sua superação, e não apenas na explicação em si.

Por outro lado, isso não significa que a posição afirmativa de uma teoria da transição, como a de Mészáros, não deva admitir suas contradições históricas. Daí o papel da autocrítica que, do ponto de vista das finalidades socialmente transitórias da teoria, deve se estabelecer na mesma intensidade que a afirmação da crítica positiva; ao passo que, dado os compromissos de soluções epistemológicas para crises disciplinares, deve-se considerar as limitações de seu desenvolvimento como forma de se evitar as próprias fissuras ou paradoxos internos na busca pela unidade epistemológica. Como observado, no caso da Geografia, o caminho que leva à crítica epistemológica está tendencialmente na contramão da crítica efetivamente histórica e social. O fato é que, ainda conforme Mészáros e diante do mesmo quadro de universalidade crítica (inclusive materializada) observado pela Geografia, tais desafios não podem ser deslocados para o futuro, ou mesmo para além dos compromissos da crítica científica.

Mas, fundamentando no próprio Mészáros, poderiam argumentar os geógrafos resignados na pretensa universalidade de sua crítica parcial sobre "os princípios gerais" de sua crítica: "uma teoria [que deve] ser claramente [diferenciada] de suas aplicações às condições e circunstâncias específicas, mesmo que estas últimas necessariamente entrem novamente na constituição dinâmica dos próprios princípios fundamentais” (MÉSZÁROS, 2011; p. 517). Contudo, confrontando os objetivos dos "princípios gerais" para os resultados de suas análises, perceberá o geógrafo que, novamente, os recursos da dialética, tal como da ontologia, estão resignados naquele "cômodo residual" (CHASIN) para onde são "refugiadas" aquelas outras categorias e conceitos que levariam a crítica geográfica "estender-se ao infinito", não sobrando nada delas do que sua função formal de legitimidade e institucionalidade para suas "soluções epistêmicas".

Não basta só lembrar o escorregadio terreno que Moreira, em sua tese, e perante a tentativa de salvaguardar a análise do "espaço pós-industrial" de Claval, avança no sentido da afirmação que prega a dissolução da diferença entre cidade e campo: "a dissolução das diferenças entre a cidade e o campo é substituída pela diferenciação que já vinha se desenvolvendo entre as cidades metropolitana e o espaço no seu todo" (MOREIRA; 1994; p. 
181). Essas são as mesmas prerrogativas de "unicidade espacial" presente em Milton Santos, em que praticamente as contradições campo versus cidade, por exemplo, desaparecem em favor de um espaço urbano universalizado pela técnica.

É interessante contrapor, nesse terreno escorregadio, a interpretação de Ariovaldo U. de Oliveira, que, ao buscar contradições, e não conciliações, apresenta um outro campo, totalmente desfigurado das pretensões de unicização positiva com o urbano universal e tecnificado, um campo com relações de "produção não-capitalista de capital”, com "a expansão das relações de produção e de trabalho camponesas", com "o crescimento contraditório do trabalho familiar e do trabalho assalariado", "o crescimento dos latifúndios e das unidades camponesas", a expansão paralela do "caráter rentista da terra e o uso do solo", etc. Assim, observa Oliveira que a unidade dialética campo-cidade é uma via de mão dupla, pois ao tempo em que ela "solda a união contraditória" entre agricultura e indústria tende também a refirmar seus opostos contraditos e conflitivos: "Mas não só os assalariados do campo que lutam na cidade por melhores salários, são também os camponeses que lutam na cidade [...] de modo a manter as condições para continuarem camponeses" (OLIVEIRA, 2007; p. 104) ${ }^{328}$.

As formulações mais maduras e sustentadas por uma ontologia do espaço, mediado pela técnica, não somente haveriam de encontrar insustentabilidade em relações que não sejam altamente tecnificadas, como a "agricultura científica globalizada" levantada por Milton Santos, como se houvesse esgotado as contradições do campo pela tecnificação da agricultura que se imporia de forma irresistivelmente verticalizadas ("Na agricultura, e em função do mercado global, a prática é científica [...] E na cidade não. Acho que na cidade há surpresas... e a surpresa é a mãe da novidade") ${ }^{329}$. Mas também é notório como que se torna vacilante e não claro quanto a identificação dos seus sujeitos históricos. Ainda no exemplo de Milton Santos, é conhecido como a centralização do espaço ontologizado pela técnica haveria de encontrar como sujeitos históricos, urbanizados, os "pobres da cidade": uma abstração que não teria mais como correspondente a própria produção do valor-capital em seu processo de mediação contraditória com o trabalho abstrato, mas na especificidade empírica e materializada do espaço. Em Ruy Moreira, que na tentativa de resguardar a crítica do espaço pós-industrial de Capel no mesmo processo teórico em que se objetiva a identificar o "operariado", assim

\footnotetext{
${ }^{328}$ OLIVEIRA, Ariovaldo Umbelino de, "A Geografia Agrária e as Transformações Territoriais Recentes no Campo Brasileiro", In: Novos Caminhos da Geografia Brasileira / Ana Fani Alessandri Carlos (org.), São Paulo: Contexto, 2007; p. 55.

${ }^{329}$ Milton Santos chega a falar sobre uma cidade do campo, porém essa ainda presidida pela técnica globalizada: "A Cidade do campo preside à parcela técnica porque tem os agrônomos, as vendas das sementes, etc. Mas ao mesmo tempo é solicitada a produzir a relação do chamado campo com o mundo, já que o mercado é global" (2000; p. 56).
} 
argumenta a favor da leitura espacial: "a relação com o modo de vida urbano é para essa classe social paisagisticamente tão transparente, que não há como não perceber-se que o seu próprio perfil está indissociado da sua inserção na interface entre a fábrica e a cidade". Continua assim Moreira seu argumento de que, ao contrário da "teimosia da esquerda marxista", insistente em ver o proletariado "pelo prisma puro da produção fabril [...], a cidade tem dito mais sobre o que esta classe tem sido do que a própria fábrica” (MOREIRA, 1994a; p. 231).

Não somente Ruy Moreira, mas também Milton Santos, não haveriam de retirar outras conclusões diante de tais fundamentações acerca do espaço. No caso de Moreira, a identificação do "proletariado" no "espaço pós-industrial" não teria como admitir nenhuma contradição nos termos, pois inviabilizaria a pretensa "fusão de síntese" epistemológica entre Capel e a crítica do trabalho. Por isso sua busca deve se restringir a sua formalidade concreticista "paisagisticamente transparente" contida na cidade onde o operariado se reproduz. Isso também permite Moreira inserir em sua crítica, ou em sua busca ontológica pelo trabalho na "construção geográfica das sociedades", até mesmo autores como André Gorz, esses que se inserem no rol das teses do fim do trabalho, como sintomaticamente é intitulado uma de suas principais obras, "Adeus Ao Proletariado: Para Além do Socialismo" "330. São por tais referenciais que Moreira fundamentará, a título de demonstração, sua busca pela dimensão do cotidiano do trabalho: “[...] agora por uma simplificação ao contrário, a do lado da concepção, que tudo indica tender a eliminar o puro ato de execução separado do ato de concepção como cotidiano do trabalho (Gorz, 1982; Lojkine, 1990)" (1994; p. 232).

A forma "amalgamática" com que a ontologia do espaço é forjada não haveria de conceder lugar ao papel da contradição. Esse cotidiano "paisagisticamente transparente" só poderia revelar, com sentido até mesmo apologético à ordem estabelecida, aquela mesma harmonia fantasiosa e ideológica identificada advertidamente por Mészáros: "No entanto, é bastante revelador que os apologistas do modo estabelecido de reprodução sociometabólico continuem a fantasiar sobre a nossa alegada 'sociedade pós-industrial'" (MÉSZÁROS, 2011; p. 179). O sentido apologético do discurso baseado em tais fundamentos espaciais e perdido em suas próprias pretensões de crítica se daria, exatamente, no momento em que estaria ele "descartando perversamente as condições absolutas da sobrevivência humana como anacronismo histórico" 331

${ }^{330}$ C.f. GORZ, André, Adeus Ao Proletariado: Para Além do Socialismo, Rio de Janeir, ForenseUniversitária, 1987.

${ }^{331}$ MÉSZÁROS, 2011; p. 179. 
Não somente o "camponês", como requerido por Ariovaldo U. De Oliveira, mas o próprio "trabalhador" em sua composição lógica e concreta, não haveriam de existir enquanto categoria contraditória do movimento da globalização ou tecnificação identificada pela solução epistemológica do espaço ontológico. Não poderia, por isso, de ter como objetivação a contradição (e consequentemente a própria dialética efetiva) no interior de tal análise espacial porque, seja na "síntese de fusão" de Moreira, seja na "solução epistemológica" de Santos, isso significaria a própria contradição dos termos da teoria, uma contradição em si diante dos objetivos afirmativos e positivos da epistemologia.

Isso tende a revelar como que a própria posição política dos geógrafos se explica, sobretudo, por suas condições teóricas. Elas são, por isso, inseparáveis. O que resta? Em última instância, uma crítica cindida em duas linhas de fuga: por um lado, a tendência, sobretudo aquela identificada como "teimosa esquerda marxista", que continua a considerar como objetivo primeiro da crítica geográfica a transformação social, por uma composição teórica voltada para a concreticidade dos homens reais ativos, viés esse muitas vezes tido como "nãogeográfico"; por outro lado, aquela tendência que, receosa em "não estender-se muito ao infinito", traçou o caminho de uma militância epistêmica, muitas vezes tidas efetivamente como “não-críticas". E, seguindo o caminho oposto das leituras sobre o processo histórico da renovação crítica, entre essas duas tendências não será buscada quaisquer conciliações entre si, mas seus conflitos, como forma de entender as contradições internas do discurso crítico que tende se institucionalizar como refúgio e resguardo legitimador de si próprio.

O objetivo que se anuncia, como evidenciado, é o de que, diante das inversões objetivas com que a constituição de uma via ontológica para a crítica se converteu em busca para a legitimidade epistêmica concedida pelo estatuto ontológico do objeto, que agora se tornaria propriamente geográfico, e diante da "teimosia" do geógrafo em não realizar o processo da inversão dialética diante da tradição de sua forma específica de se apropriar do mundo (evidenciado pela conservação das leituras concreticista e, por vezes, remoticista), observa-se um dado importamte: que a busca metodológica operada pelo movimento da renovação crítica, foi, em última análise, uma busca epistemológica.

Epistemologia e método não estavam somente confundidos, mas efetivamente invertidos: quando se fala de método, fala-se de metodologia; quando se fala de epistemologia, fala-se estruturação conceitual para a aplicação da metodologia. Não de outra forma, em quase todos os textos de cunho "epistêmico" para com o espaço se observa certa dose do tom manualístico, isso quase sempre confundido como uma necessidade de liberação da própria crítica geográfica, quando não se reconhecia que era seu próprio aprisionamento disciplinar. A 
forma de como a dialética se inseriu apenas de modo enunciativo, se reproduzindo para efetivar conciliações entre teorias que deveriam estar admitidamente em contradições, para que, assim, pudessem forjar relações entre forma e conteúdo, espaço e tempo, trabalho e técnica, como complementários e recíprocos (jamais como contrapostos), é suficientemente evidente para a prerrogativa de que o método não fora, de fato, o que condicionara a orientação da crítica. Sua discussão, por isso, não saiu do terreno da epistemologia. E essa é uma herança do ideal estruturalista não admitida e, por isso também, não superada.

É então justificável que, diante do eterno discurso de crise epistemológica, não fosse o caminho da própria epistemologia o majoritariamente preferido para a solução dos problemas disciplinares. A questão da "tradição do enfoque geográfico" jamais haveria de ser questionada, pelo receio da própria dissolução disciplinar. Não basta somente, a título de exemplo, lembrar dos esforços de Moreira e Silva na composição de suas "sínteses de fusão", mas também em Milton Santos, quando, recorrentemente, ao iniciar vários textos propositivos para a composição da crítica, inicia pela concordância com alguma Geografia do "passado"332. Tal estratégia, muito mais do que reconhecimento e respeito de contribuições de "geógrafos do passado", as vezes inconciliáveis com as pretensões de crítica para com a atualidade, se revela também, e contraditoriamente, como instrumento de continuidade (para os objetivos de legitimidade, "como herdeiro da disciplina") e de descontinuidade (para os objetivos de se estabelecer enquanto algo inteiramente diferente, como "descoberta do novo").

Isso irá, por sua vez, estabelecer uma linha de continuidade bastante prejudicial e limitante para o desenvolvimento da própria teoria, que se pretende nova em relação a um "passado" a-crítico, e até reacionário. Mas o que não foi reconhecido é que, para além da necessidade da "solução epistemológica", tal debate seria uma discussão especificamente de método, sobretudo em torno da dialética. Debate este que, por sua vez, estaria para além dos próprios limites disciplinar, é certo, mas que à disciplina retornaria como solidez teórica. Contudo, refugia-se a geografia nela própria, como a própria "solução epistemológica". Os meios dela, em compasso com as demais ciências, oferecer um ensaio sobre o processo fetichizante que também atinge o fazer ciência, e propor efetivamente um processo transitório e emancipatório, se expressam assim em possibilidades reduzidas.

\footnotetext{
332 Em relação à referência com outros geógrafos, é mais notável no Por Uma Geografia Nova. Até a maturidade e especificamente em A Natureza do Espaço, a presença de filósofos se faz mais perceptível.
} 
[O refúgio perante o debate dialético]

Em Mészáros, por exemplo, as condições teóricas que possibilitam a efetivação de uma teoria da transição não estão somente vinculadas à intensa avaliação autocrítica do socialismo, sobretudo a partir dos limites estruturais da experiência soviética, análise essa que ocupa quase a metade de sua principal obra, "Para Além do Capital". Mészáros, como assistente de Lukács, acompanhou efetivamente a trajetória e a "tragédia” da crítica lukacsiana, tal como suas limitações que ganhariam corpo diante da crítica adorniana. Adorno que, segundo Ruy Fausto, haveria de manejar a dialética como nenhum outro desde Hegel e Marx ${ }^{333}$, vai estabelecer com Lukács, talvez, o principal debate sobre a natureza da crítica, e sobre os caminhos da história, sobremaneira a partir da segunda metade do século XX. A querela em questão teve início no debate sobre a arte, mas avançaria sobre a estética, sobre a ética, até chegar nos fundamentos em si da dialética ${ }^{334}$.

Mészáros irá até mesmo dedicar um capítulo inteiro, em outra obra de grande importância, "O poder Da Ideologia”, aos teóricos da Escola de Frankfurt, da qual Adorno será um dos mais objetivados em sua crítica. Para Mészáros, que se debruça sobretudo no período de "retorno" dos teóricos à Frankfurt no período pós-Segunda Guerra, e diante do contexto de influência exercida pelo texto mais importante de Adorno ("Dialética Negativa", citado anteriormente), as concepções frankfurtianas haveriam absolutizado a crítica em seu apelo negativo, assim como o processo de reificação, se abstendo do debate político sem, no entanto, oferecer nada em seu lugar, atuando como mero discurso "evasivo": "Adorno presenteava constantemente o leitor com lampejos verbais e uma espécie de 'malabarismo conceitual' que davam a ilusão de uma solução depois de insistir [...] que era impossível encontrar uma solução" (MÉSZÁROS, 2004; p. 159) ${ }^{335}$.

No entanto, é difícil não reconhecer que, diante das "precauções" dialéticas da crítica do trabalho apresentadas por Mészáros, ou até diante do reconhecimento dos limites da ontologia do mestre Lukács (ainda que cercado de grandes "justificações”), o movimento de reposição do debate metafísico em torno da dialética, movimento proposto pelos frankfurtianos,

\footnotetext{
333 "Os pensadores de frankfurt, Adorno sobretudo, "manejaram" a dialética como não se fizera desde Hegel e Marx” (FAUSTO, 1983; p. 20)

334 “A famosa querela deflagrou-se por definitivo com o artigo de Adorno "A reconciliação extorquida"1 de 1958 , a respeito do ensaio de Lukács Realismo crítico hoje publicado no ano anterior, que por sua vez recebeu réplica lukacsiana no Prefácio de 1962 à Teoria do romance, e estendeu-se até a redação da Dialética negativa, onde Adorno responde ao estudo de Lukács "Heidegger redivivus" de 1949" (SOUZA, Leandro Candido de, "Avessos da dialética: Adorno, Lukács e o realismo no século XX”, In: Verinótio: revista on-line de educação e ciências Humanas: n. 12, Ano VI, out./2010 - Publicação semestral - ISSN 1981-061X.; p. 02).

${ }^{335}$ MÉSZÁROS, István, O Poder da Ideologia, São Paulo, Boitempo, 2004.
} 
haveria de influenciar, ainda que criticamente, o acabamento e os cuidados da proposição meszariana em torno de uma teoria da transição. A forma de como a dialética se insere na proposição de Mészáros, pelo menos em relação à Lukács, apresenta fortes traços herdados desse debate. Mas isso não significaria que uma tendência negativa eventualmente seria assumida pelo autor; ao contrário. Mészáros será desde sempre um forte defensor da ofensiva prática socialista: “A atual 'crise do marxismo' se deve principalmente ao fato de que muitos dos seus representantes continuam a adotar uma postura defensiva, numa época em que [...] deveríamos nos engajar numa ofensiva socialista em sintonia com as condições objetivas" (2011; p. 787). Mas, por isso mesmo, como sinais de acúmulo de uma crítica histórica, tal influência irá se expressar nos cuidados de expor as pretensões teóricas de uma dialética histórica, sempre em constante retorno com as "leis internas de desenvolvimento". Dirá Mészáros: "é necessário explicar como é possível que, sob certas condições, uma dada 'natureza' (a natureza do capital) se desdobre e se realize [...] seguindo suas próprias leis internas de desenvolvimento". Isso significaria que "é preciso entender a dialética objetiva da contingência e da necessidade, assim como do histórico e do trans-histórico no contexto do modo de funcionamento do sistema do capital” (2011; p. 184).

Por outro lado, se a crítica ontológica geográfica não haveria de avançar em suas possibilidades afirmativas em torno de uma teoria da transição (por tantos outros motivos que poderiam se somar aos já apresentados), não foi porque ela haveria de ter se enveredada por um viés negativo de absolutização do fetiche do real. Ao menos de forma consciente. É certo que haveria em Milton Santos, por exemplo, forte influência da teoria weberiana ${ }^{336}$ no seu conceito de racionalidade (conceito este central em sua substanciação da técnica), sobretudo intermediado por Habermas, talvez o maior herdeiro dos postulados frankfurtianos. Mas é certo também a forte influência de um específico "marxismo", ainda que althusseriano, na composição de sua epistemologia. Mas Santos não seria o único "amalgamático". As "vias de fuga" que se apresentam como "soluções epistemológicas", desde Silva, passando por Moraes até Moreira, têm as evidências de como a Geografia em geral havia se ausentado desse debate central acerca da dialética e da ontologia. Mais interessante é como isso passa a ser admitido, sem nenhum constrangimento, diante da justificativa de que estariam os geógrafos preocupados com a formulação de sua própria "metadisciplina", como insistirá Milton Santos, desde sempre e até seus últimos escritos:

\footnotetext{
${ }^{336}$ A Influência de Weber na Escola de Frakfurt é significativa, sobretudo na delimitação da crítica na história e sua condição "moderna". Tal relação ficou, assim, conhecida como "marxismo weberiano".
} 
O desafio está em separar da realidade total um campo particular, susceptível de mostrar-se autónomo e que, ao mesmo tempo, permaneça integrado nessa realidade total. E aqui enfrentamos um outro problema importante, e que é o seguinte: a definição de um objeto para uma disciplina e, por conseguinte, a própria delimitação e pertinência dessa disciplina passam pela metadisciplina e não o revés (SANTOS, 2008; p. 20).

Mas a crítica ontológica geográfica também não poderia encontrar terreno de sustentação na crítica avassaladora propriamente frankfurtiana, sobretudo a de Adorno. Pois, se assim o fizesse encontraria uma crítica contra seus objetivos disciplinares e científicos ainda mais avassaladoras do que aquelas urdidas pela crítica ontológica do trabalho urdida pela teoria da transição de Mészáros. Por exemplo, Adorno expõe a mais profunda denúncia contra os movimentos de ontologização, em especial aquelas que, como da Geografia, teria claros motivos com sua legitimação disciplinar. Assim dirá Adorno, numa crítica que dificilmente os epistemólogos da "Geografia Crítica” não a identificarão contra si mesmos:

A tendência crítica continuou vigente, não contra os conceitos dogmáticos, mas antes como esforço por não estabelecer nem construir mais os absoluta [elementos absolutos] desprovidos agora de sua unidade sistemática e separados uns dos outros, mas por acolhê-los receptivamente, em uma postura formadora a partir do ideal positivista de ciência, e descrevê-los (ADORNO, 2009; p. 60).

Como a crítica ontológica geográfica escaparia da cilada autocrítica por essas duas formas antagônicas, mas criticamente complementárias (Mészáros e Adorno), de conceber a crítica ontológica do espaço sem admitir suas contradições internas? Ou seja, como não admitir o "ideal positivista de ciência" de uma crítica ontológica que, por onde quer que vá, encontrará "território" infértil para sua gênese? Diante dessas questões é necessário admitir que o máximo que a autocrítica geográfica chegou foi nas acusações de "ecletismo" e "estruturalismo" 337 , até porque elas próprias não estavam fundamentadas no debate da crítica dialética e ontológica que haveria de se voltar contra elas próprias.

Sobre as denúncias de "ecletismo", trata-se de uma falsa crítica. Seu caráter vago e não argumentativo serviu muito mais para reafirmar a condição precária da dialética inserida na "estruturação epistêmica" da crítica geográfica do que, necessariamente, contribuir com a identificação dos seus limites. E ainda que a crítica geográfica, em específico essas baseadas

\footnotetext{
${ }^{337}$ Tal assunto será tratado de forma mais ampla no tópico: "6.4 - A via positiva-epistêmica”.
} 
no recurso ontológico para as "soluções epistemológicas" (que eram em si soluções disciplinares, apesar do avanço na análise sobre o real), nunca conseguissem de fato superar plenamente sua herança estruturalista, incapacidade essa que não se dava, no entanto, como opção, mas como resignação. Não apenas porque a crítica anti-estruturalista foi posta apenas de modo formal e enunciativa, mas porque essencialmente os planos de "busca do objeto" estavam na contramão de uma crítica efetiva e para aquém dos compromissos emancipatórios.

Resta notar que, na crítica geográfica, o sentido concreticista de entender o espaço pela qual a ontologia se fundamentaria assim o foi pela perspectiva de encontrar nele suas mediações mais concretas e objetivas. No entanto, acabou por tornar em abstrato as mediações limitadamente concretas e empíricas provindas do mesmo vazio abstrato que tantas vezes orientou a "linha de fuga" da crítica geográfica; aquelas mesmas que "optaram" pela concretização com receio de não se estender muito ao infinito" das abstrações "internas" e "metafísicas" da "produção".

Por isso que a "escolha" por uma via de constituição de uma ontologia do espaço pela formação social em Silva, mas também em Moraes, como visto, não haveria de ser gratuita. Muito mais do que uma "adaptação" dos novos termos da crítica social à especificidade disciplinar da Geografia foi ainda um deslocamento da "lógica" contraditória do espaço, esta vista como debate da "metafísica", por isso não-geográfica, ao "cômodo residual" da filosofia. A urdidura epistemológica positiva encontrava assim sua primeira "linha de fuga" no refúgio de suas contradições para "territórios" externos a ela.

E, sobre o sentido da epistemologia e a metodologia tenderem a se confundir, não em uma unidade idealista, mas em assumir o papel invertido do outro, se tornaria impossível sua constatação caso se admita a ausência efetiva de uma autocrítica. Ou seja, que a busca epistemológica, dada sua condição inadvertidamente propositiva e positiva, substanciou suas teorias afirmativas muito mais por contribuições metodológicas, no sentido mesmo da estruturação conceitual-instrumental aplicável, do que necessariamente a uma estrutura epistemológica que possibilitasse formulações teóricas críticas emancipatórias, substanciada por uma dialética da contradição, acerca do espaço. Isso se observa não somente pelo tom "manualístico" contido nas principais obras propositivas ("o espaço deve ser entendido..."; "a geografia deve buscar...", “a categoria seguida deve ser...”), nem apenas pela forma conciliatória com que as influências e categorias seriam incorporadas, mas sobretudo porque não foi concedido a ela a oportunidade de centralizar a contradição como recurso de método, que contrapusesse as mesmas categorias afirmadas contra as demais e em relação aos autores. 
A Geografia, diante da busca do estatuto ontológico para o espaço, mesmo em seu movimento de renovação crítica, sobre tais base dialéticas tenderia a não conseguir extirpar em definitivo sua condição de "ciência de síntese"; e o geógrafo de se livrar de sua tradição "amalgamática" que, em comparação à interpretação que se faziam de Marx, descreveria Chasin: aparece como "amálgama tríplice”, ou seja, como aquele que conseguiu "sistematizar", de forma "somatória", a economia política inglesa, a política socialista francesa e a filosofia dialética alemã. Em relação à crítica do geógrafo, ainda que não seja mais suficiente buscar suas vinculações no exterior de sua originalidade (Geografia ativa, França, ou geografia Radical, Estados Unidos, principais substratos irradiantes da crítica), seu amálgama se faz perceptível pela ausência daquela inversão das coisas, de suas próprias influências, de pôr a Geografia de "cabeça para baixo", como ao seu tempo Marx admitiu fazer em relação as suas principais influências da filosofia e da economia política, para descobrir algo inteiramente novo, do ponto de vista das possibilidades, sobretudo de sua crítica social radical. 
PARTE II - O TRABALHO NAS FISSURAS DA CRÍTICA GEOGRÁFICA: ENTRE POSTOS E PRESSUPOSTOS 
[A crítica geográfica entre postos e pressupostos]

Rui Fausto, ao comentar sobre a "morte" da dialética a partir do que se passou a considerar como "morte do marxismo", elabora duas reflexões sobre os termos: primeiro que a dialética está para além das formas de existência do marxismo e que sua própria condição dogmática, via da qual haveria o marxismo se afundando, significaria o momento da ausência em si da dialética na própria análise marxista ${ }^{338}$; que a existência da dialética está assegurada enquanto houverem contradições a serem desveladas. Em relação aos acusadores e seus erros interpretativos, destaca Fausto: "O manejo rigoroso da distinção entre pressuposição (discurso implícito) e posição (discurso explícito) lhes escapa" (1983; p. 19).

Sobre as observações de Fausto acerca da crítica vazia que se faz contra a dialética e contra o marxismo, e como ela se relacionaria com o movimento da renovação crítica geográfica iniciada na década de 1970, é sintomático como as interpretações sobre a sua história tenham deixado "escapar” a relação entre as "pressuposições” teóricas e as "posições” políticas dos fundamentos da crítica pretendida. Um projeto de autonomia e independência disciplinar se conformando em paralelo ao arrefecimento da crítica social. Tudo isso diante de uma radicalização crítica das condições da crise do capital no final do século XX e início do século XXI.

Estaria a crítica geográfica tendendo contra o movimento histórico de radicalização, totalização e incontrolabilidade das contradições estruturais da sociedade do capital em prol do seu projeto disciplinar? Haveria uma contradição interna entre teoria e prática na efetivação da crítica Geográfica? Observa-se que tal questão não fora levantada de forma objetiva. A pressuposição é que a necessidade de se forjar uma "unidade" para sua legitimação histórica e teórica veio antes mesmo da necessidade em se estabelecer sua própria autocrítica, especialmente aquela voltada para a reflexão sobre a natureza de sua própria crítica social e histórica pretendida.

A ausência da autocrítica pode ser observada a partir dos indícios no que concerne, sobremodo, à falta do debate interno sobre as questões que envolvem a natureza da dialética a ser incorporada nas propostas de crítica. Em parte porque o debate sobre a dialética foi, de fato,

\footnotetext{
338 "Sabemos que a dialética vai mais longe que o marxismo, que não haverá novos marxismos, mas que pode haver novas dialéticas". Ainda que requeira certa cautela com relação a impossibilidade de novos marxismos, pois o futuro é um terreno incerto e não se sabe o que pode vir ser chamado de "marxismo", em última instância a crítica comum que se faz ao marxismo, ou ao "fim do marxismo", é fundamentalmente ideológica, pois requer um rigor de critério do qual os "críticos" em sua ampla maioria parece não estarem dispostos a fazer: "Que o marxismo tenha envelhecido e que ele seja ao mesmo tempo desconhecido, isso quer dizer que se foi além dele, mas que ao mesmo tempo estamos aquém dele" (FAUSTO, Marx: Lógica e Política, 1983; p. 18).
} 
quase inexistente, se fundamentando muito mais em pressupostos apriorísticos desta ou daquela referência para compor uma "estrutura epistêmica"; em parte também porque o debate sobre a natureza e o rigor da dialética, da sua lógica interna regida pela contradição, como fundamento para uma teoria crítica geográfica, nunca fora admitida como central no processo da renovação da Geografia. Mas por que um movimento de renovação crítica não haveria de debater profundamente as noções de dialética como forma de composição de sua crítica social? Estaria ela, a necessidade do debate da dialética na crítica social, conflitando ou mesmo contradizendo com a necessidade de formulação de uma dialética própria para a crítica epistemológica? Tal questão também não fora levantada de forma objetiva. Ao contrário, observa-se que a relação entre a crítica social e a crítica epistemológica deveria se apresentar de forma "harmônica", conciliatória, na construção das principais propostas que emergiram do movimento de ebulição crítica da década de 1970. Mas onde se ocultariam os conflitos e como foi tratada a contradição nessa dialética sem crises?

A observação sobre a ausência da dimensão da contradição nas "dialéticas" incorporadas, tanto nas formulações internas das teorias como nas formas em que o processo da renovação crítica foi interpretado, é igualmente importante: significaria a tendência da efetivação de uma crítica teórica e uma crítica histórica sem contradição. Um problema de gênese então se desdobraria: uma crítica teórica ou histórica sem a dimensão da contradição é uma contradição em seus próprios termos. Estaria dessa forma na contramão da própria crítica, como advertiria Ruy Fausto: “assumimos a contradição para não nos contradizer” (1983; p. 33). E o que sobraria, uma crítica não crítica?

Desde Armando Corrêa da Silva ${ }^{339}$ em seu pioneiro e importante artigo, "A Renovação Geográfica no Brasil - 1976/1983”, Antônio Carlos Robert de Moraes em seu famoso "Geografia: Pequena História Crítica", até Ruy Moreira em sua atualizada trilogia " $O$ pensamento Geográfico Brasileiro", nenhum destes importantes textos, muito lidos pela comunidade acadêmica (sobretudo pelos iniciantes estudantes de graduação), tiveram de fato se atentado para uma autocrítica sobre a natureza da dialética (mediada pelo rigor da contradição), diante do exercício epistemológico que fundamentou as mais influentes e diversificadas perspectivas teóricas desde a renovação crítica.

Ruy Moreira, em contexto mais recente (2014) e em posse do distanciamento histórico que o permite elaborar "o essencial do painel necessário ao acompanhamento do trajeto analítico da renovação das ideias" ${ }^{340}$ no movimento de reformulação da Geografia no Brasil,

\footnotetext{
${ }^{339}$ SILVA, A Renovação Geográfica no Brasil, 1984.

${ }^{340}$ MOREIRA, O Pensamento Geográfico Brasileiro (v. 2), 2014; p. 10.
} 
aproxima das possibilidades de analisar os fundamentos da dialética inserida na crítica geográfica pretendida. Ao se propor debruçar sobre "os eixos da crítica" reconhece como elemento comum dentre os geógrafos envolvidos no movimento da renovação três características: um "forte acento social", o "espaço como foco", e o "marxismo da maioria" (MOREIRA, 2014b; p. 77) $)^{341}$.

Baseado neste tripé, que concerne a questão da dialética, Moreira analisa as perspectivas e influências de David Harvey e Neil Smith e seu fundamento sobre o valor. Aponta desses geógrafos suas contribuições no sentido de aproximar a economia política com o propósito de "dialetizar a relação" entre os conceitos de espaço e natureza: "como produtos simultâneos e entrelaçados em suas ações recíprocas" ${ }^{342}$. Desta forma, identifica Moreira a "simultaneidade" e "reciprocidade" como mediações dialéticas entre espaço e natureza. No entanto, estão elas admitindo apenas o caráter de complementariedade da relação: uma produzindo a outra. Mas onde estaria a contradição? Seria possível admitir somente o sentido positivo em que a natureza produz espaço, e vice-versa, ou a "dialetização da relação" deveria admitir ainda seu caráter negativo, em que espaço e natureza estariam também em contradição?

Moreira continua a análise em busca do caráter contraditório da natureza "desigual e combinada do desenvolvimento geográfico" proposto por Smith. Assim interpreta Moreira: “[...] em vez de uma combinação de desenvolvimento espaciais e desiguais, [vincula] aos efeitos da relação espaço e natureza enquanto relações de correspondência e às contradições de diferenciação e equalização que daí emanam"343. Nota-se aí que a contradição parece estar muito mais ligada à natureza da expressão fenomênica, como ela se positiva no espaço, do que a natureza da mediação interna e dialética entre as categorias que as constitui.

Avançando sobre essas suspeitas, pode-se levantar pistas a partir das considerações de Moreira acerca os objetivos da teoria de Smith: “oferecer um conceito novo e geográfico válido para uma teoria capaz de levantar tanto a análise geográfica quanto a marxista a descobrir 'padrões e processos espaciais gerais' que originam e regem desigualdades" 344 . Aqui parecem fortalecidas as suspeitas do entendimento das contradições como formas de expressão das "desigualdades", ou como as desigualdades se especializam, não como manipulação dialética no interior da teoria. Seria este um problema em Smith, ou na sua interpretação feita por

\footnotetext{
341 O Pensamento Geográfico Brasileiro: As Matrizes Da Renovação (v. 2), São Paulo, Contexto, $2014 \mathrm{~b}$. ${ }^{342}$ MOREIRA, 2014b, p. 79.

${ }^{343}$ Id., Ibid.

${ }^{344}$ Id., Ibid.
} 
Moreira? Ou nos dois (tanto nas questões internas da teoria, quanto nas questões externas de interpretação das teorias)?

Moreira, ainda no mesmo capítulo, continua a análise da derivação do debate dialético levantado por Quaini quando este se propõe, inspirado em Marx, intervir sobre a "confusão conceitual" que faz da leitura geográfica uma "representação caótica do todo": "Isso faz do método (um processo de ida do abstrato ao concreto, isto é, do real-empírico ao real-concreto

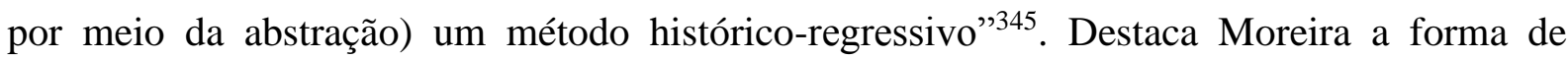
procedimento metodológico com que Quaini propõe ler paisagem (como a categoria "posta na geografia moderna como no centro da própria reflexão"346) da mesma forma que o trabalho é posto por Marx, ou seja, “de suas determinações mais simples [...] caminhando em suas múltiplas determinações até chegar a totalidade" ${ }^{347}$. Entretanto, ressalta Moreira que os compromissos com tal "método" não garantiriam em si o aprofundamento necessário quanto às “determinações do homem e natureza, um diante o outro" "348. Tais limitações, aliás, estariam, segundo Moreira, presentes desde o debate entre as perspectivas da Geografia de Kant a Hegel, em que pese sua absolutização enquanto "externalidade" empírica. Os perigos estariam na forma de entendimento de uma Geografia que, ou se absolutiza enquanto externalidade apriorística kantiana, ou se relativiza na "dissolução [hegeliana] da natureza enquanto realempírico"349. O desafio seria, para Moreira, conceber uma Geografia que nem seria uma realidade a priori absoluta, nem uma ciência passível de dissolução na ideia, mas um pensamento que possibilitasse contribuir para o "salto do reino da necessidade para o reino da liberdade", como nos termos proposto por Marx. Aparecem aqui, a um só tempo, as preocupações de Moreira com o caráter libertário e emancipatório da ciência geográfica e com o caráter disciplinar e rigoroso, igualmente importante.

É nesse momento que se dá a fusão entre as perspectivas de Moreira e a de Milton Santos, quanto à necessidade de estabelecimento do objeto disciplinar para resolver o problema do vazio simplório e empírico com que as perspectivas tentadas até então haveriam se estabelecido: "A desatenção habitual do geógrafo com a epistemologia da Geografia, entretanto, tem reforçado o empirismo do método existente e dado o tom singular da 'representação caótica' na Geografia” ${ }^{350}$. Santos e Moreira parecem concordar com a solução

\footnotetext{
${ }^{345}$ MOREIRA, 2014b, p. 79-80.

${ }^{346}$ Ibid., p. 80.

347 Id., Ibid.

348 Id., Ibid.

${ }^{349}$ Ibid., p. 81.

${ }^{350}$ Ibid., p. 80.
} 
epistemológica para conceder legitimidade crítica da leitura geográfica perante as ciências sociais. Como destacaria Santos em seu texto seminal "Por uma Geografia Nova" sobre o "grave erro epistemológico": "Os progressos tentados consistem muito mais em substituir significados buscados geralmente em disciplinas afins, do que mesmo a partir das realidades ou aspectos da realidade que caberia examinar" (2002; p. 19) $)^{351}$. Mas, e as observações sobre como operacionalizar, ou "dialetizar a relação", entre as categorias e conceitos que deveriam compor o quadro epistemológico?

A saída epistemológica teria como garantia a fusão entre uma pretensão de crítica social e uma dialética fundamentada e grande medida naquela nos termos propostos por Marx. No entanto, o debate epistemológico fora tomado de forma imediato por meio que não se buscou uma autocrítica sobre sua necessidade. Por exemplo, o próprio Marx, tido como referência para o livro de Moreira ${ }^{352}$, no âmbito de suas formulações parecia não concordar muito com a proposição epistemológica para a elaboração da crítica científica. Tal evidência pode ser revelada quando se observa que o autor de "O Capital" dispõe em se colocar abertamente disposto a apenas manipular as categorias da então economia política. Já em seu primeiro escrito de síntese (MÉSZÁROS, 2006) ${ }^{353}$, Manuscritos Econômicos-Filosóficos, assim indica o procedimento:

Partimos dos pressupostos da economia nacional [a própria economia política]. Aceitamos sua linguagem e suas leis. Supusemos a propriedade privada, a separação de trabalho, capital e terra, igualmente do salário, lucro de capital e renda da terra, da mesma forma que a divisão do trabalho, a concorrência, o conceito de valor de troca etc. A partir da própria economia nacional, com suas próprias palavras, constatamos que o trabalhador baixa à condição de mercadoria e à de mais miserável mercadoria, que a miséria do trabalhador põe-se em relação inversa à potência e à grandeza da sua produção, que o resultado necessário da concorrência é a acumulação de capital em poucas mãos, portanto a mais tremenda restauração do monopólio, que no fim a diferença entre o capitalista e o rentista fundiário desaparece, assim como entre o agricultor e o trabalhador em manufatura, e que, no final das contas, toda a sociedade tem de decompor-se nas duas classes dos proprietários e dos trabalhadores sem propriedade (MARX, ; p. 79) ${ }^{354}$.

Sobre o posicionamento de Marx acerca da sua forma específica em manipular a teoria na garantia do rigor dialético, Lukács chega mesmo a afirmar que, diante da busca pelo

\footnotetext{
${ }^{351}$ SANTOS, Por Uma Geografia Nova, 2002.

352 "Vem com Marx a Possibilidade que o livro quer demonstrar" (Idem; p. 81).

${ }^{353}$ MÉSZÁROS, A teoria da alienação em Marx, 2006.

${ }^{354}$ MARX, Manuscritos econômico-filosóficos, 2004.
} 
reconhecimento da ontologia na obra marxiana, a identificação da "processualidade" e da "contraditoriedade" dialética "implícita" ao seu "método", essas as condições por si mesmas seriam suficientemente capazes de caracterizá-la qualitativamente como "o novo tipo representado na história da filosofia e da ciência [...]. Ele jamais pretendeu expressamente criar um método filosófico próprio ou, menos ainda, um sistema filosófico" (2012; p. 290) ${ }^{355}$. Chasin vai mais além afirmando que, em relação ao método, se este for compreendido como "uma arrumação operativa, a priori, da subjetividade, consubstanciada por um conjunto normativo de procedimentos, ditos científicos, com os quais o investigador deve levar a cabo seu trabalho, então não há método em Marx" (2009; p. 89) ${ }^{356}$. Ainda que se queira fundamentar em Marx a necessidade da solução epistemológica como forma da solução da análise do geógrafo para o mundo em crise, tal relação não pode ser dada sem a consideração desses problemas críticos na interpretação da obra marxiana. Daí porque não se torna tão simples conciliar Marx e a necessidade da epistemologia geográfica; daí também (diante da possível inconciliação) o não encontro da "Geografia" na teoria desse autor e o consequente afastamento da crítica geográfica em relação a crítica marxiana quase sempre sob a acusação de ser esta insuficiente em relação aos propósitos daquela.

$\mathrm{O}$ que se diferenciaria em Marx entre o rigor científico de uma crítica dialética (fundamentado na busca pelas contradições mais internas e ocultas do capital na sua forma alienada e centrada do trabalho, como aquela desenvolvida posteriormente em "O Capital") e a necessidade do rigor epistemológico para a garantia da dialética como crítica científica? É certo que, como destaca Moreira, "Marx vai partir desse pressuposto de Hegel, mas para fazerlhe uma 'inversão dialética"” (MOREIRA; p. 81). É certo ainda que a natureza da "inversão dialética" proposta por Marx estava no sentido de tornar a própria dialética o fundamento de uma leitura do "ser real-concreto", como é certo também que isso deveria significar para Marx a adoção de um caminho pela ciência, mas não somente porque a ciência daria melhores condições de "inverter" para o plano material da consciência uma dialética que estava antes desenvolvida somente no interior de uma metafísica mistificadora na forma hegeliana, mas também porque deveria ser uma crítica interna aos seus próprios termos e moldes: o uso da ciência contra ela própria, como assim significaria o subtítulo de sua principal obra: "Crítica da Economia Política".

Diferente daquela esboçada por Marx, para o movimento da renovação da Geografia os objetivos com a crítica deveriam ter um aprisionamento disciplinar como forma de garantir sua

\footnotetext{
355 LUKÁCS, Por Uma Ontologia do Ser Social, 2012.

${ }^{356}$ CHASIN, Estatuto Ontológico e Resolução Metodológica, 2009.
} 
própria legitimação, mas agora fundamentado no seu objeto. Ainda ecoava a incômoda acusação de não ser ela, a Geografia, "verdadeira ciência"357. Isso tem forte significação, já que não se pode ignorar que o deslocamento das questões sobre "o que era a Geografia" para as questões sobre o "objeto da Geografia” (como irá insistir Milton Santos ainda em sua obra seminal) não representaria de fato uma ruptura radical com os compromissos "narcisistas" dos geógrafos para com a Geografia. Agora, fundamentado na busca pelo espaço, mas não tanto diferente como antes, a preocupação sobre questões como "autonomia disciplinar", "independência" e "reconhecimento científico", "legitimidade", etc. ${ }^{358}$, deveriam ser reafirmados, o que tendia a estabelecer os limites da crítica em sua "geograficidade", ou em sua "espaciologia", ainda e novamente sob a justificativa de não poder ela se "estender muito ao infinito".

A questão, de fato, nem estaria nos problemas em que ela, a crítica, poderia se perder nos caminhos da metafísica ou do empirismo, como alerta Moreira. Isso se trata de um falso problema na medida em que, a exemplo de Marx, a mediação dialética entre o empírico e o metafisico pode ser resolvido no interior da própria dialética, não necessariamente em um corpo “disciplinar carregado de coerência interna e externa" (SANTOS, 2008; p. 21) ${ }^{359}$. A questão mesma estaria ligada aos objetivos implícitos com a elaboração da "estrutura epistêmica". Retomando o problema do rigor com que a dialética deveria ser tratada, o exercício teórico envolvido na estruturação epistemológica estaria disposto a levar a crítica ao seu mais profundo retorno dialético a partir do reconhecimento das contradições?

Por exemplo, analisando a forma com que Ruy Moreira interpreta as formulações e perspectivas (postas em livros principais) de geógrafos tão distintos como David Harvey, Neil Smith, Milton Santos, Máximo Quaini, Jean Tricart, Yan Fu-Tuan e Yves Lacoste para uma "teoria geral", assim diz:

Podemos, assim, ver esses sete geógrafos por esse prisma. Mas seus livros se diferenciam e se identificam mais por um intento comum de busca de uma teoria geral, por onde se intercruzam as matrizes do pensamento geral de onde vêm e por onde aqui os analisaremos: Harvey e Smith pela economia política do espaço, Milton Santos pela formação social, Quaini pelo metabolismo

\footnotetext{
357 "Há aproximadamente três anos, um debate sobre a reforma do ensino secundário francês relançou uma antiga discussão em torno do papel e da importância da manutenção da geografia no currículo do ensino básico [...]. Em resposta, os geógrafos sublinharam os progressos relativos aos diversos domínios incriminados pelos críticos [...]" (GOMES, Paulo Cesar da Costa, Geografia e Modernidade, Rio de Janeiro, Bertrand Brasil; 1996).

358 "A Geografia realizada até o presente ganhou o estatuto, que deve e necessita ser reconhecido como amplamente alcançado, de uma disciplina científica, que deveria denominar-se Geografia Descritiva ou Geografia Empírica" (SILVA, De quem é o Pedaço? 1986; p. 38).

${ }^{359}$ SANTOS, A Natureza do Espaço. 2008.
} 
territorial da renda da terra como um processo de relação homem-meio, Tricart pelo metabolismo espacial dos ecossistemas, Tuan pela estrutura simbólica do espaço e Lacoste pela escala estrutural diferencial do espaço (MOREIRA, 2014b; p. 85).

A forma como Moreira explicitamente relaciona, ainda de forma amalgamática, perspectivas teóricas distintas e até conflitantes na perspectiva de uma "teoria geral" diz muito sobre os caminhos com que a dialética é entendida e inserida na empreitada epistemológica. Diz muito também sobre seus objetivos para com a crítica. Importa nesse exemplo não só o esforço em conciliar perspectivas conflitantes e até mesmo antagônicas, como as de Harvey e a de Tuan, mas a natureza com que o conciliamento se estabelece. Um primeiro ponto a ser observado é que os conflitos e antagonismos desaparecem como possível elemento de unidade, mesmo que em uma unidade contraditória. A "diferença” tende a se posicionar onde poderiam estar "contradições". Um segundo ponto diz respeito aos objetivos implícitos, na medida em que o exercício epistemológico parece estar vinculado à necessidade de garantir uma unidade harmônica como fundamento de uma "teoria geral" para que assim todos pudessem ser “incluídos". Por isso, uma estruturação epistemológica nitidamente voltada aos seus objetivos de conformação e unidade disciplinar. Um terceiro ponto é que a "amplitude" e a "generalidade" teórica requeridas parecem estar garantidas na unidade do diferente e do diverso, não na natureza da relação interna com que categorias e conceitos geográficos poderiam dialeticamente e contraditoriamente se relacionar em busca de sua totalidade. A totalidade aparece, assim, como "somatória" de conceitos, categorias, interpretações, etc., não como a mediação complementária e contraditória entre elas (“a comparação das teorias destes sete livros traz-nos a sensação, pois, de um embutimento de abrangências que, ao mesmo tempo, as diferencia e as articula num ordenamento sistemático do pensamento cada vez mais amplo e geral" $)^{360}$.

O que resta dos propósitos críticos quando se observa a ausência da autocrítica na própria forma de ser da crítica, sobretudo no que diz respeito a se buscar e/ou reconhecer contradições internas em sua própria perspectiva de "teoria geral"? Dado o reconhecimento dos objetivos implícitos postos por uma "dialética conciliatória", a tendência é que não poderia haver no interior da perspectiva da "teoria geral" uma outra forma de natureza crítica que não fosse uma crítica "oficial", dada por uma "Geografia Crítica" (assim mesmo, com letras 
maiúsculas), agora como antes, institucional, que passariam a estabelecer como procedimento crítico o meio de pôr as coisas como elas se afirmam, não como elas se negam.

Entendido desta forma, os problemas institucionais, sempre considerados como um limite da crítica, ganha uma nova dimensão interpretativa, pois passa a ser tratada como um problema inerente à própria forma em que se efetiva exercício teórico, e não como um problema meramente "externo", dada ao campo político dos geógrafos. Se é verdade que o grande avanço da crítica geográfica se deu em decorrência da busca pela unidade crítica e científica, o próprio exercício crítico deve revelar os limites do seu desenvolvimento no interior do mesmo exercício epistemológico que se objetiva como teoria geográfica crítica. E não deve haver nenhum absurdo em colocar o exercício crítico contra o exercício epistemológico, ou de confrontar perspectivas teóricas distintas, não apenas na busca de sua unidade harmônica, mas de seus conflitos. Afinal, não foi isso que Milton Santos insinuaria e insistiria contra Marx um certo "comportamento" anticrítico?: "Marx mostrou-se severo com os adversários, mas quanto aos amigos se eximiu de denunciar esse lapso, reconhecido em Lassalle. Terão os marxistas, marxólogos ou marxizantes que reproduzir, dogmaticamente, o comportamento do fundador?" (SANTOS; 1996; p. 133). ${ }^{361}$

Todavia, considerando a possibilidade de inconciliação entre a crítica marxiana e a crítica epistemológica que se pretende especificamente geográfica, é necessário continuar a destacar seus elementos, pois tal forma de procedimento teórico adotado hegemonicamente como solução epistemológica se distancia daquela urdida por Marx, tida como referência não somente para Moreira, mas em grande medida para o movimento da renovação em si. São por demais conhecidas as influências da dialética de Hegel na sua forma de manipular as categorias da economia política contra elas próprias em busca de se desvendar, como diria o próprio Marx, "a lei econômica do movimento da sociedade moderna" (1983; p. 13). Marx, apesar de reconhecer as influências de Hegel, reconhece também os problemas de mistificação de tal influência em seu exercício autocrítico: "meu método dialético não só se difere do hegeliano, mas é também a sua antítese direta" (1983; p. 20). Entre "diferente" e "antítese" há uma mudança qualitativa de significado: não há em Marx simplesmente mais uma proposta de ver o mundo (como entenderia Moreira sobre Harvey e Tuan), diferente das outras a partir de uma "instância" da realidade, mas sim a busca de uma totalidade concedida pelo movimento da contradição que põe as categorias da sociedade moderna não somente em relação de complementariedade somatória, como também, ao mesmo tempo, em uma unidade

\footnotetext{
${ }^{361}$ SANTOS, Novos Rumos da Geografia Brasileira, 1996.
} 
contraditória, concreta e historicamente expressa. Por isso o reconhecimento de ser sua dialética a "antítese" (a "inversão" negativa e identitária) daquele.

E o que a formação de uma crítica fundamentada em uma dialética sem contradição e uma historiografia conciliatória destituída de conflitos têm a ver com a categoria trabalho? Os compromissos epistemológicos significaram a necessidade de estabelecer relações hierárquicas entre as categorias. Era assumidamente preciso colocar o espaço, como lembra Moreira, no "foco" do debate. E, antes dele, uma "estrutura epistêmica" como forma de o conceber cientificamente; ou a própria mediação do "filosófico" para o "científico".

Considerando-se a modernidade como uma leitura em si da contradição, uma forma de pensar em si da crítica, como entende Lefebvre, "como um esboço mais ou menos adiantado de crítica e de autocrítica, numa tentativa de conhecimento" (1969; p. 04) ${ }^{362}$, é notório como o trabalho exerceu condição central para a crítica da sociedade moderna desde os fisiocratas, passando por Adam Smith, David Ricardo, pelos "filósofos modernos" e literários românticos e realistas, até chegar em Marx, que, em conjunto com a "metafísica invertida" de Hegel, elabora a mais completa crítica moderna.

Mesmo em Lefebvre, a quem a renovação da crítica geográfica deve uma de suas mais significativas influências filosóficas no trato sobre a produção do espaço, o trabalho aparece como categoria central para o entendimento da "produção": "A categoria Trabalho, na visão de Lefebvre, estabelece, em princípio, uma forma de analisar e entender a sociedade, o Estado, o capital, o poder, a produção e as relações espaço/sociedade" (GODOY, 2008; p. 126) ${ }^{363}$.

Contudo, é certo também que a leitura que se faz de "O Capital", por exemplo, é constantemente marcada por certa dificuldade em entender o nível da crítica marxiana, pois, como observa Fausto, "ou se trata de filosofia, ou se trata de economia, mas não as duas coisas ao mesmo tempo" (1983; p. 20). Mas tal dificuldade de compreensão - ainda que por vezes ideologicamente reafirmada como forma de supor contradições nos termos em si da análise de Marx - expressa a complexidade contraditória da sociedade moderna regida pelas leis do capital. Depois de Marx, tem-se uma sequência do movimento crítico que, por vias de afirmação positiva ou negativa, por vias dogmáticas ou "libertárias", apresenta o trabalho no centro da crítica da teoria social. Exemplo marcante disso é o desenvolvimento da crítica no século XX feita por Lukács e Adorno, como visto anteiormente: o primeiro na elaboração mais fundante de uma ética filosófica emancipatória a partir da centralidade ontológica e crítica do trabalho,

\footnotetext{
${ }^{362}$ LEFEBVRE, Introdução à modernidade, 1969.

${ }^{363}$ GODOY, Paulo Roberto Teixeira de, “A Produção do Espaço: Uma Reaproximação Conceitual da Perspectiva Lefebvriana”, São Paulo: GEOUSP - Espaço e Tempo, № 23, 2008.
} 
e o segundo no mais profundo retorno às bases metafísicas da dialética no sentido de retirar o exercício crítico dos seus aprisionamentos concretos e fetichizantes, como assim representaria o trabalho.

No entanto, seja como afirmação positiva da centralidade, seja como negatividade própria da modernidade, o trabalho se põe como categoria moderna central porque, desde Marx, passou a significar não somente o elo entre as "leis da sociedade moderna" e as formas "metafísicas" para sua compreensão, mas a perspectiva para se pensar ou experimentar a própria superação do capital. E é notório como o trabalho foi central para o movimento de renovação crítica geográfica. Desde o que significou a perspectiva de uma "Geografia do Trabalho" em Pierre George, até sua assimilação nas formas de entendimento da mediação homem-natureza em Armando Corrêa da Silva, ou a proposta da leitura sobre a "Valorização do Espaço"364 de Costa e Moraes, por exemplo, o trabalho foi elemento chave para o estabelecimento do elo entre a crítica geográfica e a crítica social. Tal relação contribuiu para o debate sobre as formas de elaboração de uma teoria crítica geográfica, além do reconhecimento da necessidade de se inserir a dialética a essa empreitada. O trabalho, por isso, não só permitiria o relacionamento com a crítica social (mesmo em relação àquelas contidas no acúmulo das experiências emancipatórias do século XX, por mais contraditórias que tenham se mostrado), mas também permitiria a aproximação com a teoria crítica geral porque representa ainda o elo categorial com o poderoso instrumentário contido na teoria do valor e no entendimento da dialética em si.

Para o movimento de renovação da geografia, que assimilaria a necessidade de sua estruturação epistemológica como exercício anterior ao do debate sobre a dialética para a formação da noção da sua crítica, o caminho para a centralização do espaço representaria, contraditoriamente, um certo distanciamento com a tradição da crítica social. A estruturação epistemológica deveria conter o objeto de estudo (espaço) e toda sua rede conceitual e categorial auxiliar própria da tradição geográfica. Tendendo, assim, com o passar do tempo, mais para um tipo de renovação "revisionista" do que propriamente "revolucionária" 365 , perante as formas de engajamento político do geógrafo. Por outro lado, isso significaria, necessariamente, o deslocamento de categorias da crítica social que não correspondessem diretamente à dimensão espacial pretendida. O trabalho passaria a ser uma daquelas categorias "expulsas do sistema

\footnotetext{
${ }^{364}$ COSTA; MORAES, Geografia Crítica: A Valorização do Espaço, 1984.

${ }^{365}$ Para Milton Santos, "teoria revolucionária" estaria mais relacionada a sua forma de se apresentar como "novo", do que propriamente vinculada à uma crítica radical sobre o real. "Desse modo, toda verdadeira teoria é sinônimo de teoria revolucionária" (2002; p. 195).
} 
central" (SANTOS; 2008; p. 21), se refugiando como categoria auxiliar nos confins metafísicos da relação homem-meio, na busca pela fundamentação de uma ontologia do espaço. ${ }^{366}$

A predominância da necessidade estruturalista de determinação da ciência pela definição do seu objeto e pela estruturação epistemológica, ou o "despertar [epistemológico] tardio" da crítica geográfica, como caracterizaria Dosse (2007; p. 387), representaria uma escolha política de crítica, dada as circunstâncias do debate nas ciências sociais na década de 1970. O distanciamento com os debates sobre a dialética já bem desenvolvidos pela Escola de Frankfurt desde a década de 1950, a necessidade da crítica contundente contra o "marxismo oficial” como aquela já levantada por Lefebvre (1969), a reposição de uma teoria crítica afirmativa e emancipatória como aquela iniciada por Lukács e continuada por Mészáros, se efetivaria para o movimento da renovação crítica na mesma intensidade em que o trabalho foi sendo deslocado de sua centralidade crítica. Tais influências serviriam apenas como "auxílios" para a confecção de uma dialética conciliatória que deveria fundamentar uma crítica cristalizada e assegurada pela estrutura epistemológica em si. Ou seja, uma forma de crítica que seria garantida pelas "regras de consistência, adequação e pertinência" (SANTOS, 2008; p. 21).

[A busca da autocrítica dialética]

É no sentido da busca do "rigor" no traquejo da dialética que a crítica geográfica em seu "movimento de renovação" será submetida nesta última parte do estudo. Isso pressupõe colocar em dúvida se a assimilação apriorística da necessidade de estruturação epistemológica e sua ordenação categorial "eminentemente geográfica" se compõe como única forma de efetivar uma teoria crítica para a Geografia. Para isso, torna-se necessária uma análise sobre a lógica interna da dialética que subsidiou a fundamentação de uma pretensa teoria crítica geográfica baseada no deslocamento de categorias da crítica social em prol da reafirmação de sua tradição categorial.

O objetivo é demonstrar como que se procedeu a retirada do trabalho do rol das categorias centrais para a composição da crítica geográfica; categoria essa presente nas mais completas vias da crítica histórica e social do século XX. Pressupõe-se assim mostrar que o desenvolvimento da crítica geográfica tendeu a se processar por meios de um exercício teórico que, ao mesmo tempo em que se buscava uma estruturação epistemológica dotada de coerência interna e externa, ia se esvaindo a substância da crítica social contida na origem do movimento

\footnotetext{
366 O "refugio" do trabalho na busca ontológica do espaço será debatido com mais profundidade no tópico "3.5 Das Linhas de Fuga aos Refúgios de uma Crítica Não Efetiva”.
} 
crítico: a saber, a dialética. Tal processo se deu pelas contradições não assumidas e até ocultadas entre afirmações e negações de categorias que estão na gênese da crítica social moderna em termos dialéticos, dentre elas o trabalho.

O deslocamento paulatino da crítica geográfica em direção à sua internalização epistemológica representou um movimento contrário ao próprio desenvolvimento da sua crítica social no momento em que se ausentam e se fetichizam em torno de si um compromisso de autonomia e independência disciplinar, por mais que não fosse admitido. No caso específico do deslocamento do trabalho perante a necessidade de centralização do espaço (ou da técnica), é notório como foi sendo conformada a tendência de sua negação absoluta sem o reconhecimento consequente de que tal movimento traria prejuízos à própria crítica. Como observado durante toda primeira parte do presente texto, isso se daria no momento em que tenderiam a serem abandonados desde os debates relacionados à economia política e a questão das classes até as questões de fundo "metafísico" em torno da dialética e da história. Tem-se então uma perspectiva de crítica baseada em dois segmentos a-críticos: uma ontologização remota, baseada em uma historiografia empírica da relação homem-meio, por isso destituída de "lógica" e "metafísica" (dialética); e uma proposta de crítica não objetivável e historicamente não identificável, no momento em que se abandona o debate central (afirmativo ou negativo) em torno da teoria do valor, do trabalho e das classes sociais.

Se o trabalho representou a possibilidade de mediação entre a crítica social e a pretendida crítica geográfica nos momentos iniciais do movimento de renovação, seu deslocamento para posição secundária e "auxiliar" não se deu sem prejuízos para a própria crítica efetivada posteriormente, até a sua total contradição. A demonstração de como a crítica geográfica tendeu a se tornar seu próprio fim (como os discursos pós-modernos passaram assim a assumir diante da suposta "fragmentação" e "fim" da modernidade), dado que sua formação se fundamentou numa dialética "frouxa" e conciliatória voltada eminentemente para a garantia da unidade categorial em sua estrutura epistêmica, será tentada, não a partir do seu simples resgate histórico com tradicionalmente se faz, mas a partir da "história da crítica" e as formas de relacionamento com a crítica geográfica.

É claro que, perante a diversidade das perspectivas assumidas e propostas no interior do movimento de renovação, uma outra diversidade de noções sobre a crítica se constituiu, mas é preciso buscar a unidade desse diverso para entender os próprios limites das críticas concretas. É preciso, assim, buscar sua abstração para colocá-la contra suas formas concretas efetivadas e observar as contradições que exalam dos seus conflitos para, assim, entender suas oposições e antíteses. Evita-se, dessa forma, o abismo inócuo da fragmentação quando se admite apenas a 
"diversidade" como existente. Isso significa buscar a natureza contraditória da crítica pretendida, analisar suas cisões e conflitos, e a confrontar com ela própria dentro de sua natureza dialética tão requerida. Ou seja, da crítica geográfica contra a teoria crítica histórica e social. Ou, no limite: crítica versus crítica.

Partir de tais pressuposições acerca das contradições inerentes ao movimento de renovação da Geografia (como posições não assumidas) para se chegar à natureza das próprias posições assumidas (como forma de revelar o contraditório), é por onde se orienta a presente análise a partir de então, na sequência lógica dos três capítulos que se seguem: as posições (exposição do explicito), os conflitos não admitidos e as pressuposições (exposição do implícito). 


\section{CAPÍTULO 4 - A EXPOSIÇÃO DO EXPLÍCITO: AS PRETENSÕES DA CRÍTICA E O PAPEL DA CONTRADIÇÃO}

A respeito de Pierre George, de quem haveria originado e depois abandonado o projeto de uma Geografia do Trabalho, descreve Ruy Moreira sobre os limites de sua perspectiva: “Cedo esta dialética de 'riqueza versus pobreza' mostrar-se-á uma dialética pobre. Apenas se prepara o salto para fora dos quadros da 'geografia oficial"' (1994b; p. 52). Segundo Moreira, tais limitações se dariam pelo laço "institucional, na forma acadêmica de cunho liberal" 1 ainda estabelecido com a geografia tradicional francesa ${ }^{2}$. Se estaria em George o embrião de uma crítica que se pretende amadurecer pelo exercício epistemológico e assim promover o "salto" sobre suas condições "institucionais" e para além do caráter denunciativo e "liberal", as formas de inserção da contradição deveriam ser revistas a partir de três condições. Primeiro, as contradições sociais, não mais por vias do "denuncismo" vago, mas por objetivação analítica consistente e rigorosa. Segundo, as contradições internas da Geografia por vias de uma autocrítica à Geografia Tradicional e à tecnicista. Terceiro, a contradição deveria também ser a substância da dialética, metodológica, que operaria na relação entre categorias e conceitos para o fundamento da crítica, sem, no entanto, deixar se perder na sua dimensão meramente conceitual como o legado hegeliano havia ensinado.

Relembrando Ruy Moreira, a necessidade de "inserir a contradição" orientou a disputa pelo "espaço novo" no movimento de renovação. Permanece, entretanto, decorridos cerca de 40 anos, a necessidade de se entender as vias pelas quais o contraditório foi inserido. Ou seja: se o "salto epistemológico" se efetivou de fato por uma crítica dialética madura, socialmente referenciada, fundamentado na busca das contradições sociais por meio do reconhecimento das contradições mais íntimas e estruturais da realidade concreta.

Não obstante, é necessário admitir que as pretensões de crítica mais embrionárias tiveram no estruturalismo seu fundamento primeiro. Como lembra François Dosse: "Mais que o estruturalismo, que estava neste momento agonizante, é o sistemismo que conhece então uma certa voga entre os geógrafos, sobretudo após a publicação na França da Teoria Geral dos

\footnotetext{
${ }^{1}$ MOREIRA, 1994b, p. 52.

2 "A disciplina geográfica continua a se definir, nos anos 60 , como uma ciência das relações entre a natureza e a cultura, entre os elementos da geomorfologia e da climatologia, etc. [...] Marcados pela Geografia tradicional e prisioneiros de seu empirismo, esses geógrafos não lograrão abalar sua disciplina nem abri-la para um questionamento epistemológico sobre seus fundamentos ou para diálogos teóricos interdisciplinares" (DOSSE, François, História do Estruturalismo: O canto do cisne, Bauru; Edusc, 2007, v.2. p.383 - 385).
} 
Sistemas" (2007; p. 389). O "sistemismo", do qual fala Dosse, se refere à vinculação mecânica, por isso não dialética, ao movimento da crítica estruturalista. Ainda assim, por meio de uma vinculação "precária" e destituída de uma dialética desenvolvida e voltada para as contradições do real, já representava um grande avanço frente a ruptura que se pretendia em relação à tradição geográfica francesa. Como testemunha Jacques Lévy, em entrevista à Dosse, a respeito de um seminário de cunho introdutório em relação ao estruturalismo: "esse seminário intitulava-se 'Estruturas, sistemas e processos' e puseram-lhe o apelido de 'Estruturas e troços', para significar que se tratava de coisas abstratas e incontroláveis"3.

"Estrutura, processo, forma e função são categorias da mesma sociedade global" (2011; p. 187) ${ }^{4}$, escreveria Milton Santos na segunda metade da década de 1970, em um texto intitulado "A Totalidade do Diabo". Importa também a respeito do presente texto seu subtítulo: "Como as Formas Geográficas Difundem o Capital e Mudam as Estruturas Sociais”. Aqui o termo "estrutura", posta desde o título até a fundamentação categorial da epistemologia pretendida, não será acidental em relação ao estruturalismo e o acompanhará até suas ultimas formulações, apesar dos protestos contrários do próprio autor. Se, no entanto, é correto afirmar que a herança estruturalista foi percebida e rechaçada, inclusive pelo próprio Milton Santos, por outro lado não havia nada de efetivamente proposto em seu lugar. $\mathrm{O}$ “ideal estruturalista" persistirá ao longo da renovação da crítica geográfica a partir das "necessidades de estruturação epistemológica", "sistematização categorial", "definição do objeto da geografia", etc. No entanto, àquelas noções já levantadas nos seminários estruturalistas franceses da década de 1970, nota-se ainda, como no exemplo de Milton Santos, a inserção da categoria "processo", que teria como objetivo embutir e fortalecer o movimento no interior das relações entre as categorias. Tira-se daí uma protoforma de dialética.

Apesar disso, para além dos aprisionamentos do ideal estruturalista de ciência, " $A$ Totalidade do Diabo" é um texto importante, pois se observa um enlace de Santos com o profundo engajamento analítico e denunciativo dos projetos de modernização do capital que, como aponta o autor em diferentes exemplos empíricos, vai projetando a separação excludente da "economia pobre rural [em relação a] economia pobre urbana", ao mesmo tempo em que o "circuito inferior da economia" torna-se cada vez mais dependente e explorado pelo "circuito superior da economia”. Mas ainda aqui, apesar de sua aproximação explícita com a teoria do valor de Marx, a dialética envolvida no processo de separação e segregação das pessoas em

\footnotetext{
${ }^{3}$ DOSSE, 2007, p. 389.

${ }^{4}$ SANTOS, Economia Espacial: Críticas e Alternativas, 2011 a.

${ }^{5}$ Ibid., p. 197.
} 
relação às formas espaciais (postas como circuitos espaciais superior e inferior) estão separadas, não por contradição, mas por "muros", "barreiras", que caracterizam o processo excludente da população pobre ("tais consequências são inevitáveis quando se ergue uma barreira e separamse os dois lados de um único modo de produção concreto, como no caso de Dar-se-Salan") ${ }^{6}$. A contradição possível diante de tal forma de conceber a dialética não avança muito no sentido de método, mas como o meio de reconhecimento da forma de sua expressão fenomênica aparecendo, assim, como externalidade na forma de "pobreza", "exclusão", etc.

A ausência da contradição como motor dessa dialética tende a ser compensada pela profundidade com que o autor se propõe a entender o conteúdo das formas geográficas: "muitos geógrafos simplesmente ignoraram os mistérios das formas; eles são empiristas que, atraídos pela falsa objetividade do mundo sensível, interpretaram a coisa através da própria coisa, espaço apenas pelo espaço"7 . Santos então se aproxima da relação entre forma e processo, mas só para novamente se distanciar de qualquer possibilidade de inserir a contradição como movimento preponderante em sua dialética. Como as demais categorias (estrutura, forma e função) processo seria mais uma "instância" do todo devendo ele "cooperar" até mesmo autonegativamante perante as demais categorias ("um processo termina quando uma fração de estrutura chega a ser objetivada numa forma particular, com uma função particular" ${ }^{\text {}}$ ). Sua concepção não contém somente um ideal estruturalista, mas também e por isso mesmo deve ela admitir necessariamente sua "geografização".

Como formulará Santos:

\begin{abstract}
A noção de processo permeia todas essas categorias. O processo, entretanto, nada mais é do que um vetor evanescente cuja a vida é efêmera; é um breve momento, a fração de tempo necessária à realização da estrutura, que deve ser geografizada, ou melhor, especializada, através de uma função, isto é, através de uma atividade mais ou menos duradoura e pela sua indispensável união a uma forma. A forma geralmente sobrevive à sua função específica (2011; p. 199)
\end{abstract}

Tal passagem é sintomática, inclusive para se entender a sequência do destino histórico da crítica de Milton Santos e sua forma de conceber as categorias centrais para a formulação de sua crítica geográfica, como totalidade, dialética e contradição. Primeiro, em relação à totalidade, entre as categorias que representariam instâncias da análise espacial, Santos supõe

\footnotetext{
${ }^{6}$ SANTOS, 2011b, p. 197.

${ }^{7}$ Ibid., p. 198.

${ }^{8}$ Ibid., p. 199.
} 
uma "solidariedade" entre elas como garantia de sua "indissociabilidade", como assim interpretará Moraes: "permite propor uma solidariedade da análise entre 'estrutura, processo, forma e função', enunciado que terá um importante papel na argumentação posterior de Milton Santos, sendo um dos pilares de sua teoria do espaço e da geografia" (2013; p. 40) ${ }^{9}$. Segundo, em relação à dialética, a natureza conciliatória e autoprodutiva da relação que une as categorias não poderia ser diferente, nem se movimentar pelas contradições, pela própria forma complementária com que elas deveriam conjugar os propósitos de sua positivação no espaço. Assim como o processo que deve se "encerrar" na medida em que a forma e a função se fundem, por uma dialética também conciliatória que se expressa fenomenicamente como empiria, o conteúdo da forma (sua função) deve ainda garantir sua relação epistemológica com a estrutura técnica. Estão, assim, consolidadas as garantias de uma totalidade "geografizada". Terceiro, sobre a contradição, destaca Santos que "toda forma tem uma função que tanto pode cooperar com a estrutura como contradizê-la". Santos admite aqui a possibilidade de existência de uma forma e um conteúdo mediado pela contradição, mas não desenvolve seus argumentos, citalizando-a à causalidade.

Em detrimento do desenvolvimento da dialética e da natureza contraditória contida na relação entre as categorias, prefere Milton Santos esclarecer a natureza da relação pretendida diante das categorias seletivas (estrutura, forma, processo, função): "as relações entre as categorias são muitas vezes vistas como uma ordem rígida, inalterável, como uma verticalidade, à maneira estruturalista" ${ }^{\prime 10}$. Ao antecipar a crítica anti-estruturalista afirmando que sobre sua proposta não estaria ela composta por um sistema hierárquico entre as categorias, não observa Santos que a sobredeterminação epistemológica proposta já é a conformação em si, vertical, hierárquica e sistemática das categorias que permitiriam "geografizar" melhor, em detrimento daquelas por ele mesmo utilizada de forma "auxiliar" em sua análise: “valor", "mercadoria”, "sobrevalor", “capital”, "trabalho". É nesse momento que se observa o sentido limitado do desenvolvimento da crítica. Milton Santos fala sobre valor de uso e valor de troca na composição da lógica interna da mercadoria, admite sua relação eminentemente contraditória, como proposta por Marx, mas esbarra perante a necessidade epistêmica de não levar os “compromissos metafísicos" muito além das possibilidades de positivação espacial do processo.

Em Marx, citado como referência e para quem a dialética não deveria se limitar às “formas de positivação espacial”, garantindo que a contradição devesse fluir como objetivo

\footnotetext{
${ }^{9}$ MORAES, Antônio Carlos Robert, Território na Geografia de Milton Santos, São Paulo, Annablume, 2013.

${ }^{10}$ Ibid., p. 200.
} 
último da crítica, o processo (de produção, por exemplo) jamais poderia se encerrar na forma (mercadoria). O processo deve continuar em sua totalidade, não porque haveria de ser aprioristicamente infinito, mas porque ela só se completa no momento de sua autocontradição, que seria o consumo (ou exercício da função da forma), como assim entende Marx: "a produção é imediatamente consumo e o consumo é imediatamente produção. Cada um é imediatamente seu contrário. Mas tem lugar simultaneamente um movimento mediador entre ambos [a contradição]" (2011; p. 46). Enquanto que para Milton Santos a totalidade se encerra na "cooperação" e "indissociabilidade" das categorias explicativas do real, em Marx ela deve atingir o momento último da autonegação diante do objeto afirmado, como aliás é a única “cooperação" possível diante das condições contraditórias da produção social.

Ainda a título de exemplo, assim depõe Marx sobre a relação entre "processo de trabalho" e "processo de valorização", admitindo seu caráter complementário e contraditório: "Como a própria mercadoria é unidade de valor de uso e valor, seu processo de produção tem de ser a unidade do processo de trabalho e processo de transformação de valor" (1983; p. 155). Entre ambos observa Marx o mesmo movimento contraditório que ocorre no interior da mercadoria em que uso e troca se medeiam num processo de alienação: "Na verdade, o vendedor da força de trabalho, como o vendedor de qualquer outra mercadoria, realiza seu valor de troca e aliena seu valor de uso"11. Para Marx isso significa a própria mudança da natureza do trabalho em seu polo antagônico, no momento em que, a partir da contradição inerente ao processo, tem-se uma forma de inversão da condição qualitativa do processo de trabalho em sua mera condição quantitativa, como tempo de trabalho, no processo de valorização: "O mesmo processo de trabalho apresenta-se no processo de formação de valor somente em seu aspecto quantitativo" 12 . O trabalho passa assim a se destituir de sua condição universal e autônoma de "atividade orientada a um fim"13 para ser, na especificidade histórica do capital, o mero tempo de duração da atividade em si - "representa tantas horas, dias, etc."14.

O entendimento de Marx sobre a relação entre processo de trabalho versus processo de valorização diz muito sobre a natureza da dialética envolvida na análise sobre a categoria "processo". A todo momento o que se pretende buscar é o movimento contraditório, a mediação entre as categorias. Ainda que sua expressão fenomênica no plano real seja o objetivo último da crítica marxiana, no sentido de sua desmistificação (“embora as botas, por exemplo,

\footnotetext{
${ }^{11}$ MARX, 1983, p. 160.

12 Ibid., p. 161.

${ }^{13}$ Ibid., p. 153.

${ }^{14}$ Id., Ibid.
} 
constituam de certo modo a base do progresso social e nosso capitalista seja um decidido progressista, não fabrica botas por causa delas mesmas") ${ }^{15}$, suas formas de positivação real perpassam também pelo crivo e pelo rigor da contradição dialética ("Nosso amigo, até pouco capitalisticamente arrogante, assume subitamente a atitude modesta de seu próprio trabalhador. Não trabalhou ele mesmo? Não executou o trabalho de vigilância? [Mas ele mesmo] Não daria um centavo por ela"16). A admissão da existência das categorias historicamente postas para Marx é somente a sua própria condição para coloca-las contra elas mesmas, "valor contra valor" 17 .

A tomada de exemplo da relação e da manipulação dialética entre processo de trabalho e processo de valorização em Marx não foi posta aqui gratuitamente. Em relação a Milton Santos, que em concordância com S. T. Meliulin busca "a determinação essencial interna ao objeto" (SANTOS; 2011; p. 200) para encontrar uma legalidade geográfica na análise que se pretende espacial, em Marx a substância do objeto (sobretudo em sua forma capitalista) deveria encontrar no trabalho sua essência mais fundamental. Aqui se bifurcam as perspectivas miltoniana e marxiana. Baseado na necessidade de "distinguir epistemologicamente entre o modo de produção e a formação socioeconômica", Santos opta pela formação social porque lhe “confere significação real-concreta dentro do sistema", como apontado no tópico "3.2 Estatuto ontológico versus "teoria da transição"”. O objetivo de Santos é demonstrar como que as formas, que admitem seus conteúdos racionais e objetivos, participam da produção do real chegando mesmo a "comprometer o futuro" ("todas as formas são dotadas de uma estrutura técnica que compromete o futuro. Isso se torna ainda mais intenso no presente período tecnológico") ${ }^{18}$. Segundo Moraes, é possível notar em tal posicionamento de Santos que "certa herança morfológica continua a acompanhar a abordagem específica da sua geografia” (2013; p. 40). Para Marx, no entanto, não se trata de se buscar pelas vias da concreção morfológica do real, a partir da formação social, o entendimento da condição de "determinante universal histórico" do capital, mas, pelo contrário, de mostrar seu "monstruoso" poder incontrolável e igualmente contraditório inerente ao movimento de abstração universalizante do processo contraditório de valorização, inclusive a tudo que se pretende pretensamente específico na história moderna, seja perante as formas, funções e estruturas: “[...] ao incorporar força de trabalho viva à sua objetividade morta, transforma valor, trabalho passado, objetivado, morto

\footnotetext{
${ }^{15}$ MARX, 1983, p. 155.

${ }^{16}$ Ibid., p. 159.

${ }^{17}$ Id., Ibid.

${ }^{18}$ Id., Ibid.
} 
em capital, em valor que se valoriza a si mesmo, um monstro animado que começa a 'trabalhar' como se tivesse amor no corpo" (MARX, 1983; p. 161).

A relação entre o pensamento de Marx e de Milton Santos se faz assim também por discordâncias. Isso se observa, não somente porque o conteúdo que deveria "animar" as formas, funções e estruturas geográficas está destituído da substância fundante e estruturalmente contraditória do trabalho moderno, mas porque também suas maneiras com que os autores entendem a dialética é bastante desigual. A diferença é nítida quanto aos objetivos de Marx, que, ao entender a totalidade como movimento das contradições, expressa uma crítica fundante e radical da sociedade moderna, e Santos, que ao entender uma totalidade fundada por uma dialética conciliatória e complementária perante as categorias "cooperadas" do real, expressa uma crítica fundante para a análise espacial e para o exercício epistemológico geográfico: "Será, sem dúvida, uma teoria menor embutida no bojo de uma teoria maior que é a teoria social" $(\text { SANTOS, } 1984 ; \text { p. } 13)^{19}$.

Mas também, entre Marx e Santos não há somente naturezas de críticas diferentes, procedimentos diferentes de entendimento do real, mas perspectivas inconciliáveis. Tal afirmação pode ser assegurada quando se observa o caminho histórico traçado pelo desenvolvimento e maturação da principal influência para renovação da crítica geográfica. Entre o texto referenciado, "A Totalidade do Diabo", tido como um dos mais "marxistas" de Milton Santos, até sua obra de maturidade, "A Natureza do Espaço", é notório como os objetivos da crítica vão se voltando para uma rigorosa "estruturação epistemológica" eminentemente geográfica à medida que se afastam dos seus compromissos políticosemancipatórios. Como assim dirá Santos, em sua última grande obra, sobre a necessidade da coerência interna da teoria, devendo ser ela "obtida através da separação de categorias analíticas que, por um lado, deem conta da respectiva superfície do real, própria da fração do saber e, por outro lado, permitam a produção de instrumentos de análise, retirados do processo histórico" (SANTOS, 2008; p. 21).

Em relação a Marx, Santos não somente foi se distanciando até onde mais "não poder alcançá-lo"20, mas também, em relação ao método (dialético), isso desde as formulações embrionárias das críticas mais radicais onde já estavam estabelecidas a relação de incompatibilidade, apesar dos intentos do geógrafo com a aproximação da dialética marxiana:

\footnotetext{
${ }^{19}$ SANTOS, Milton, "Para que a Geografia Mude Sem Ficar a Mesma Coisa”, In: Boletim Paulista de Geografia. ( No 59, outubro de 1982), São Paulo: AGB, 1984.

${ }^{20}$ Assim diria Milton Santos em entrevista no ano de 2000: "Marx me ensinou muito, mas hoje está lá em cima da minha estante onde eu não posso mais alcançá-lo” (SANTOS, Território e sociedade, 2000).
} 
“Agora, o método que se utilizou, esse me será sempre útil. Só que eu é que tenho de reencontrar os materiais, que não são os mesmos de Marx, mas os que me permitem produzir ideias do que existe no chamado mundo real" (SANTOS, 2000; p. 45).

A forma de conceber as categorias forjadas no interior dos debates estruturalistas que se constituíram como um dos pilares da obra de Milton Santos foi também fundamental para a proposta de estruturação epistêmica de Armando Corrêa da Silva. Nele também estão reproduzidas as desconfianças em torno de uma "fundamentação metafísica" (a única possibilidade de superação em si do ideal estruturalista), dado que o debate sobre o método deveria estar em uma filosofia propriamente geográfica. Não de outra forma proporia Milton Santos uma "Filosofia das Técnicas" que, no seu interior, deveria guiar a constituição de um método propriamente geográfico (“[...] sejamos guiados, em nosso método, pelo fenômeno técnico visto filosoficamente, isto é, como um todo" ${ }^{21}$ ). Em Silva, desde sua obra seminal (e aqui já citada, “O Espaço Fora do Lugar”), encontram-se também as pretensões de um filosofar especificamente geográfico, como forma de se evitar os riscos do abismo metafísico: "evitouse desde logo a crítica de que a preocupação substancial com o espaço geográfico fosse encarada como uma indagação de ordem metafísica no conhecido aspecto 'negativo' do termo” (1988; p. 09) $)^{22}$.

Para Silva, assim como em Milton Santos, o espaço geográfico deveria estabelecer como fundamento epistemológico a "formação do espaço geográfico, de sua estrutura, de suas características, de seus processos e funções, de suas transformações e do significado desses elementos constitutivos do todo para a consciência" (SILVA, 1988; p. 09). Tais "elementos constitutivos" deveriam compor, por meio de uma dialética, também conciliatória, sua indissociabilidade. Em Silva é possível supor o caminho da "epistemologização" como a saída para a composição desde uma filosofia própria do espaço até a crítica de natureza eminentemente geográfica.

No entanto, a título de demonstração, é possível observar que, além de Marx, outras influências para o movimento da renovação crítica geográfica procuraram mostrar a possibilidade de propor uma análise fundamentada em uma "dialética das contradições" sem necessariamente recair no ideal estruturalista de ciência. É exatamente em um capítulo intitulado "Sociologia das Classes Sociais"23 que Henri Lefebvre observa aquelas categorias postas mais tarde pelos "simpósios estruturalistas franceses", mas a partir da leitura do próprio

\footnotetext{
${ }^{21}$ SANTOS, 2008; p. 23.

${ }^{22}$ SILVA, O Espaço Fora do Lugar, 1998.

${ }^{23}$ LEFEBVRE, Sociologia de Marx, 1966.
} 
Marx: "Precedentemente, havíamos atribuído à sociologia marxista, em nome do próprio pensamento de Marx, o estudo das interações entre formas e conteúdos, entre estruturas e movimentos, entre funções e processos genéticos” (1966; p. 73). Para tal análise, resgata Lefebvre as observações de Marx sobre seu procedimento de abstração, que estaria fundamentado num processo de redução, em que a qualidade estaria reduzida à quantidade, a matéria à forma, o uso à troca, etc., na especificidade histórica do capital. Para Lefebvre, a análise do aspecto duplo da dialética é que reside a dificuldade: pois ela é combinativa e contraditória. Estariam desta forma qualidade e quantidade unidas pela contradição, da mesma maneira que a forma e conteúdo. Diferente de Milton Santos em que as contradições podem ser admitidas na relação, para Lefebvre elas são o próprio conteúdo da relação. A partir daí, desenvolve Lefebvre seu conceito de forma em relação ao conceito de forma-mercadoria de Marx; "a dupla forma ou a forma desdobrada (relativa, equivalente) opõe dois elementos complementares relacionando-os um ao outro, isto é, que se excluem na polarização" ${ }^{24}$.

Esse meio de conceber a dialética tem suas consequências mais fundamentais para o entendimento do que seria a materialidade da forma. Ao contrário do que considera Milton Santos, a forma material admitida como componente da relação forma-conteúdo, como "instância" da realidade empírica, está para Lefebvre como ininteligibilidade. Isso porque a relação da forma (material) com o seu conteúdo deve estar mediada pelas relações de produção (no sentido amplo do termo) sobredeterminadas em abstrações amplas, "metafísicas" e genéricas (e isso não tem nada a ver com o que ficou pejorativamente conhecido como "metanarrativas"). A materialidade específica da forma não significa nada se não tiver ela sobredeterminada pela especificidade de sua produção, que lhe confere um conteúdo abstrato. Ou seja, o conteúdo da forma não seria a sua função concretamente assimilada ("racionalização do uso"), mas sua natureza abstrata historicamente específica. Como esta forma se apresenta perante o tempo histórico do capital, deve admitir ela sua natureza enquanto valor (abstrato), como assim destaca Lefebvre: "Estas relações formais substituem a realidade sensível, material do objeto. Esta substituição a metamorfoseia em mercadoria: em coisa abstrata" ${ }^{25}$.

Em Lefebvre o conteúdo da forma deve, além de admitir sua autocontradição "nãomaterial”, também admitir como sua substância a condição contraditória do trabalho: aqui o espaço encontra as possibilidades de se relacionar não somente à economia política, o valor e o trabalho, mas sobretudo com a dialética em seu mais profundo manejo filosófico: “A forma,

\footnotetext{
${ }^{24}$ LEFEBVRE, 1986, p. 69.

${ }^{25}$ Id., Ibid.
} 
com sua estrutura polar, não pode ser concebida sem o movimento dialético do trabalho social" 26 .

Os motivos de colocar em relevância exatamente esse texto de Henri Lefebvre sobre a "Sociologia das Classes Sociais", cumpre destacar, não foi acidental nem gratuito. Primeiro por conta do autor. Lefebvre é uma das principais influências para o movimento da renovação crítica brasileira, inclusive para Milton Santos e Armando Corrêa da Silva. Como filósofo, foi um dos pioneiros a centralizar o espaço na leitura sobre a realidade pós-Segunda Guerra Mundial, momento em que a "Globalização" começa a demonstrar seus "primeiros lineamentos", como observa Milton Santos (2000; p. 27). No entanto, passou "despercebido" textos de aprofundamento teórico e metodológico, como o supracitado, que relacionam categorias incorporadas à crítica geográfica e outras já desenvolvidas em áreas afins, como na economia política e na sociologia. É, dessa forma, reveladora a opção dos geógrafos por textos "fundamentalmente espaciais" (se é que seria possível conceber isso a partir de Lefebvre), sobretudo dos geógrafos envolvidos por uma pretensão epistemológica de elaborar sua própria teoria espacial (filosófica e científica) eminente e especificamente geográfica. Segundo, por conta da elucidação do método: Lefebvre demonstra, ainda que a partir dessa rápida apresentação, a possibilidade da dialética se incorporar aos temas espaciais sem que, necessariamente, isso deva significar um "abismo metafísico", nem uma positivação das expressões fenomênicas no espaço em seu ideal estruturalista ou positivista de ciência. Terceiro: a assimilação dialética no tratado das categorias espaciais. Assim como Milton Santos e Armando Corrêa da Silva, trata Lefebvre das mesmas categorias: forma, processo, função, estrutura, mas, inversamente, condicionam-nas dentro de um rigor dialético pondo as contradições como princípio objetivado. A contradição não é desta forma incompatível com uma teorização espacial. A necessidade, quase imperiosa, de "estruturação categorial", "sistematização epistemológica", se mostram na verdade como opções políticas de fazer ciência na medida em que ela não é a única forma coerente e rigorosa para a análise espacial, demonstrando, assim, que o rigor no tratado dialético para a crítica necessária não deve ser confundido com a necessidade epistemológica para a garantia dialética da crítica.

Um outro motivo mais especial deve ser destacado. Refere-se à questão de categorias da crítica social que, quando não foram expulsas do projeto de "estruturação epistemológica" propriamente geográfica, foram postas em segundo plano e relegadas a apriorismos. Dentre elas, as classes sociais e, novamente, o trabalho.

\footnotetext{
${ }^{26}$ Id., Ibid.
} 
Conforme Milton Santos, em um texto publicado na primeira metade da década de 1980 e sintomaticamente intitulado "Para Que a Geografia Mude Sem Ficar a Mesma Coisa", trata o autor sobre "as seduções e o risco do enfoque marxista". Santos reitera a importância das contribuições marxistas quanto à inserção das noções de meios de produção e formação social para o entendimento das relações entre o abstrato e o concreto e adverte sobre os perigos das "tautologias" decorrentes de uma inserção não reflexiva e mecânica de temas como "lutas de classes" e "acumulação de capital". Para o autor, no entanto, evitar o "dogmatismo" significaria tratar os temas "segundo um ângulo espacial e à maneira sistêmica" (SANTOS, 1984; p. 14). Santos se fundamenta em Lukács, citando o autor marxista em nota de rodapé, onde o mesmo haveria advertido que o que diferenciaria o enfoque marxista do burguês não seria a fundamentação econômica para a história da sociedade, mas o "ponto de vista da totalidade" 27. Santos convoca a "totalidade" marxista para fundamentar a necessidade de sua totalidade epistemológica especificamente geográfica sem, no entanto, anotar a incompatibilidade derivada da forma de conceber e tratar a dialética. Neste momento específico de maturação do seu "sistema", considera Santos a importância e relevância das classes sociais e do trabalho ${ }^{28}$.

\section{1 -As "unicidades" e a tendência de mistificação}

Observa-se, contudo, que no desenvolvimento de sua obra as referidas categorias vão se distanciando da constituição da própria crítica social e emancipatória, se colocando no rol daquelas "categorias já dadas". Os argumentos são de que a crítica deveria se fundamentar na necessidade de superação de categorias que não teriam mais validade histórica e que, em decorrência disso, haveria certa "fixidez" em sua introdução, tendendo, assim, ao dogmatismo. Por exemplo, em sua obra de maturidade, "A Natureza do Espaço", a argumentação de que a estruturação categorial do espaço fundamentada na relação entre sistema de objetos e sistema de ações deve se pôr no lugar da relação proposta por Marx entre forças produtivas e relações de produção para a análise espacial porque, no tempo histórico atual, relações e forças de

\footnotetext{
${ }^{27}$ SANTOS, 1984, p. 14.

${ }^{28}$ Sobre a Geografia Colonial, critica Milton Santos a ausência nela da noção da divisão de classes inerente à sociedade capitalista: “O que preocupa essa Geografia é o homem médio e não o homem verdadeiro, e a sociedade como criadora de espaços é a sociedade "global” e não a sociedade como ela é, dividida em classes". Mais adiante, mas ainda na mesma página e na mesma linha de crítica contra a Geografia colonial, destaca Santos: "Felizmente, há os que se rebelam contra tal maneira de interpretar a face da terra a sua transformação pelo trabalho dos homens" (1984; p. 06).
} 
produção se encontram "confundidas" mediante a própria condição da técnica ("[...] nas condições históricas atuais essas duas categorias históricas se encontram confundidas" ${ }^{29}$ )

Inviabilizadas pela suposta unicidade identitária, a contradição capital x trabalho e suas personificações na contradição de classes emergida das relações de produção, tal como a questão do desenvolvimento da produtividade do trabalho em sua relação com o capital a partir da condição histórica atual das forças produtivas, não haveria mais sentido de serem elas consideradas sob a dimensão do espaço, como já suporia o próprio Santos em outro texto do início da década de 1980 e intitulado “Alguns Problemas Atuais da Contribuição Marxista”:

Noções como modo de produção, forças produtivas, relações de produção, luta
de classes etc., que com insistência aparecem no linguajar dos marxistas
restam, apenas, sonoridades ineficazes, se não reexaminadas, a partir do
concreto, dentro de um método onde as categorias filosóficas acima
enunciadas se combinam (SANTOS, 1996; p. 135).

Haveria diante de tal postulado a afirmação implícita de inviabilidade e propensão ao dogmatismo nas leituras que considerariam o trabalho e a "luta de classes" como categorias centrais. Decorre de tal suposição a possibilidade de sua argumentação estar fundamentada em um recurso mistificador. Isso pode ser observado a partir de três problemas que podem emergir diante do enunciado. Todas essas três questões envolvem a observação de como a contradição é inserida na análise crítica da proposta miltoniana, e nas demais dela derivada.

[1 $1^{\circ}$ problema: A Geografia preferida quando "confundidas" força produtivas e relações de produção]

A necessidade de reconhecimento do espaço, de sua condição concreta e material, como se devesse encontrar nas "forças produtivas" sua equivalência com o "sistema de objetos", tal como "relações de produção" em "sistema de ações", não é de todo correto. Por um lado, deve ser considerado que há, na intimidade dos conceitos marxianos de "forças produtivas" e "relações de produção", uma relação dialética-contraditória entre determinadas formas específicas de ações e de objetos. A identificação de "forças" com "objetos" e "relações" com "ações", assim, divorciadas e sem o devido reagrupamento mediado pela contradição interna (por mais que sua justificação esteja fundamentada na tentativa de torná-las inteligíveis) tende

\footnotetext{
${ }^{29}$ SANTOS, 2008; p. 64.
} 
a uma mistificação. Isso não apenas porque há um certo nível de arbitrariedade na desconsideração da totalidade dialética interna do conceito, mas também porque tende a relativizar essa mesma dialética no sentido de "torturá-la até que ela confesse" uma suposta unidade ininteligível entre "relações de produção" e "forças produtivas".

A contradição nos termos dessa interpretação está no fato de que tal "relativização" pode levar inclusive à consideração de que estão também "confundidos" os sistemas de objetos $e$ os sistemas de ações, pretensamente postos como "mais atuais". Por outro lado, a suposta impossibilidade de ler o espaço pelo marxismo a partir dessas específicas categorias "confundidas" (forças produtivas e relações de produção) sinaliza ainda um outro nível de arbitrariedade. Ao contrário de Lefebvre, por exemplo, que parte da "metafisicalidade" da mercadoria para analisar a forma, função, processo e estrutura (demonstrando assim a possibilidade múltipla de conceber o espaço pela dialética, pelo trabalho e pelo valor), como visto acima, a escolha de categorias "mais físicas" para a crítica anti-marxista insinua que há uma "certa Geografia" selecionada no seio do marxismo (e sobretudo em Marx) que deverá ser identificada e colocada como objeto da crítica dos geógrafos.

Observa-se uma tendência de que, quase sempre, a "Geografia" que se identifica em Marx, e no marxismo em geral, estão relacionadas às passagens mais elementares e descritivas acerca da empiria das "relações de trabalho", "meios de produção" e da "expansão do capital pelo mundo", sobretudo. Todas elas deslocadas das partes mais "abstratas", em que a "dialética interna" do capitalismo era posta à prova nas formulações de Marx. Isso supõe uma certa preleção em encontrar em Marx as mesmas "geografias" que não servem mais aos geógrafos: a da localização, a da distribuição, da distribuição dos sistemas produtivos, etc. A arbitrariedade nessa forma de crítica está no fato de que a "geografia” identificada já é a "geografia” negada.

Como visto, enquanto que em Lefebvre se observa a possibilidade de encontrar uma leitura "espacial” na obra de Marx desde o primeiro capítulo de O Capital ("A Mercadoria"), e sobretudo no processo de produção; em David Harvey, por exemplo (para não sair do plano do marxismo), se nota que, em relação à questão de Marx não ter solucionado totalmente o problema deixado por Hegel sobre o "ajuste espacial", como deslocamento das contradições internas do capitalismo para o espaço, assim se deve a uma "falha" por não ter Marx atentado para o problema geográfico.

Para isso Harvey observa que somente a partir do capítulo final do primeiro volume de "O Capital”, além do terceiro livro, é que se torna possível retirar qualquer perspectiva para a solução do problema (“O Capítulo sobre a colonização, talvez, seja o suficiente para o primeiro volume de $O$ Capital, em que Marx se concentra exclusivamente sobre a questão da 
produção") ${ }^{30}$. A teoria do "ajuste espacial" é uma das principais contribuições de Harvey para a análise geográfica da expansão imperialista do capital, mas ainda se encontram os mesmos sintomas de uma certa fixação no concreto como físico, como realidades concretas específicas (posta em contraposição ao abstrato universal onde funda a dialética que permite entender as contradições do capital), que demarcará toda uma perspectiva da crítica geográfica (“[...] o exame atento de suas obras revela que ele [Marx] reconheceu que a acumulação de capital ocorria num contexto geográfico, criando tipos específicos de estruturas geográficas") ${ }^{31}$.

A ausência de uma visão espacial desde a "mercadoria" e a "produção" (como destacada por Lefebvre) pelo movimento de renovação da crítica geográfica, pode assim ser observado, por exemplo, na decorrência das preocupações de Ariovaldo Umbelino de Oliveira. É exatamente na perspectiva de contrapor ao movimento de "atropelo" com que grande parcela de geógrafos tratavam a dialética, e que por isso não haveriam eles identificado em Marx as condições de uma leitura para o espaço, que recomenda Oliveira para a necessidade de ir além do Livro 1 de "O Capital": "Uma leitura atenta ao Livro 2 e mesmo do Livro 3 [processo de circulação e processo global] poderá, certamente, fazer com que esses geógrafos mudem de ideia" $(1996 ; \text { p. } 67)^{32}$.

Embora, no caso de Harvey, o debate específico do "ajuste espacial” deva mesmo seus objetivos estarem assumidamente limitados aos momentos em que Marx extrapolou a “dialética interna' do capitalismo em crise” (HARVEY, 2005a; p. 114), a forma como a espacialização física das contradições do capital em estruturas histórica e geograficamente específicas demarca uma característica comum das críticas que emergiram do movimento de renovação geográfica. Isso representa não apenas uma limitação, mas uma evidência de que jamais tentou ela contemplar à sua teoria, sobretudo "sua" dialética, as formulações mais profundas acerca da contradição genéticas que move a "dialética interna" do capital.

[2 $2^{\circ}$ Problema: Questão da fisicalidade]

As concepções sobre o "concreto", nos termos da proposta miltoniana até aqui analisada, por exemplo, estão relacionadas a uma leitura sobre o real que, na especificidade que deveria representar a Geografia diante as ciências sociais, estaria condicionada pela reafirmação

\footnotetext{
${ }^{30}$ HARVEY, David, A Produção Capitalista do Espaço, São Paulo, Annablume, 2005a; p. 114.

${ }^{31}$ HARVEY, 2005a, p. 43

${ }^{32}$ OLIVEIRA, Ariovaldo Umbelino, "Espaço e Tempo: Compreensão Materialista Dialética”, In: Novos Rumos

da Geografia Brasileira, São Paulo, UCITEC, 1996.
} 
das condições físicas, concretas e específicas da realidade. Tal necessidade se consagrou desde a proposta embrionária contida em "Por Uma Geografia Nova", como já debatido ao longo do "Capítulo 2 - A necessidade epistemológica: crítica da crise à crise da geografia". Dizia Milton Santos sobre a mediação possível do tempo para entender o "espaço objetivo": "a noção de tempo empírico é a única capaz de ser compatibilizada com a noção de um espaço objetivo" (2002; p. 22). Bem mais adiante, em "A Natureza do Espaço", assim consagrava as determinações empíricas do contexto atual: "Pela primeira vez na história, estamos convivendo com uma universalidade empírica" (SANTOS, 2008; p. 115). Diferente de Milton Santos, que "liderava" 33 uma via epistemológica, também entre aqueles que reafirmavam a centralidade da via militante-política da crítica geográfica, ainda como exemplo Ariovaldo U. de Oliveira, pode-se observar a tentativa de "resolver" a dialética contida na fisicalidade do materialismo histórico a ser incorporado à Geografia sem que se chegasse a uma total negatividade dela ("Como o materialismo dialético tem como ponto de partida a materialidade do mundo, mister se faz que tratemos rapidamente do que é matéria") $)^{34}$. Assim estaria a dialética e as abstrações universais tendendo a se voltar determinadamente às suas expressões concretas, ou formas de "concreção" e fisicalidade no/do espaço. Ou como diria Santos: "que seja a totalidade o instrumento de conhecimento do real-individual-concreto, isto é, da coisa individual, que a dialética seja o meio de se chegar a construção da gênese e, desse modo, apontar para o futuro [...]" (1996; p. 135).

Ficaria óbvio para o movimento de renovação a necessidade de conservar positivamente o físico como uma "instância da realidade", ou uma "parte" na totalidade do espaço, que deveria apresentar como conteúdo uma substância social ("A dialética no espaço supõe que sejam separadas [...] as categorias de paisagem e espaço propriamente dito, à maneira da oposição complementar entre natura naturata e natura naturans") ${ }^{35}$. A fisicalidade como materialidade contida na paisagem (o "fixo"), apesar de estar em "oposição" ao novo conceito de espaço, deveria ser reafirmada como parte de sua herança científica, também como elemento importante da constituição espacial ("fixos e fluxos, interagindo, expressam a realidade geográfica e é deste modo que conjuntamente aparecem como um objeto possível para a Geografia") ${ }^{36}$.

\footnotetext{
${ }^{33}$ Diria Milton Santos no momento de seu retorno ao Brasil na década de 1970, ao encontrar uma propensão ao questionamento e à perspectiva de renovação: "Isso me permitiu, quando cheguei ao Brasil, assumir uma liderança nesse movimento" (SANTOS, 2013; p. 160)

${ }^{34}$ OLIVEIRA, 1996; p. 91.

${ }^{35}$ Ibid.,p. 136.

${ }^{36}$ SANTOS, 2008; p. 62.
} 
Tal dimensão onde se expressam as finalidades das formas físicas e fixadas, por sua vez, poderiam ser observadas a partir do território, ou de sua configuração, em mediação com as "relações sociais" (“a configuração territorial não é o espaço já que sua realidade vem de sua materialidade, enquanto o espaço reúne a materialidade e a vida que a anima") ${ }^{37}$. Ao conceito de objetos deveria ser incorporada a sua capacidade de influenciar o próprio movimento social, pois carregam em sua gênese material a finalidade da ação histórica objetivada. Tal historicidade objetivada e empiricamente concebida é a forma pela qual passaria a análise geográfica a fundamentar sua crítica, já que deveria ela "[...] indicar claramente a separação sistemática de categorias de análise aplicáveis empiricamente" (SANTOS; 1996; p. 137) ${ }^{38}$.

À Geografia caberia a análise sobre as derivações concretas e específicas da produção do real. Não de outra forma, como já observado, sugeriria Milton Santos abarcar além de uma história empírica a noção de "Formação Social" em detrimento da noção de "Modos de Produção", pois esta última estaria mais vinculada às questões abstratas e "metafísicas". Ainda que sob os protestos de Ariovaldo U. Oliveira - que considerava a falta de um aprofundamento maior por parte dos geógrafos sobre as questões dialéticas que envolveriam a noção marxista sobre a "matéria" (inserida relação espaço-tempo) para fundamentar a opção pela categoria formação social $^{39}$-, considerará Santos a difusão de sua sugestão em proceder a crítica por meio da categoria "formação sócio-espacial": "Nosso apelo não ficou sem eco. Além de inúmeros trabalhos empíricos que, sob essa inspiração, foram escritos, expandem-se também, e nessa direção, uma literatura teórica. Destacamos, dentre outros, [...] Ruy Moreira (1979) e Richard Peet 1979" (1996; p. 135)

O movimento da dialética admitida pela proposta miltoniana, e depois estendida hegemonicamente para a renovação como um todo (excetuando poucas contrapropostas de bem menor impacto), era por isso fundamentada na composição de uma "dialética interna complementária e conciliatória" onde moveriam as categorias explicativas sobre o espaço (o

\footnotetext{
${ }^{37}$ Id., Ibid.

38 "Novas ideias são, de um lado, concreções abstratas das novas realidades, isto é, das realidades e das aparências empíricas emergentes, isto é, um retrato da atualidade e, de outro lado, para que tenham conteúdo científico, e eficácia política, devem, obrigatoriamente, ser acompanhadas dos instrumentos de trabalho elaborados no mesmo movimento revelador, isto é, devem indicar claramente a separação sistemática de categorias de análise aplicáveis empiricamente" (SANTOS, 1996; p. 137).

39 "Muito se tem escrito a esse respeito [sobre a compreensão materialista dialética], porém o surgir de textos críticos sobre o objeto da geografia científica, a formação social, coloca-nos novamente em uma situação delicada frente a realidade lato sensu de um lado e o segmento social representado pelos intelectuais, de outro" (OLIVEIRA, 1996; p. 66-67).

${ }^{40}$ Soma-se a esses geógrafos Ana Fani Alessandri Carlos e Sandra Lencioni, em um texto intitulado "A Categoria 'Formação Econômica da Sociedade' na Análise Geográfica”, publicado em Caderno de Texto (Borrador 1): Teoria e Método da Geografia, São Paulo, AGB, março de 1982. Além do exemplo mais expressivo, que seria o destino histórico da proposta de Antônio Carlos Robert de Moraes e sua perspectiva da "Geografia Histórica".
} 
exercício de abstração) para sua consequente externalização sobre o real (o exercício empírico). Na verdade, isso esteve sempre implícito: desde a opção por "formação social" em detrimento de "meios de produção", "globalização" em detrimento de "imperialismo", "técnica" em detrimento de "trabalho", "desigualdade", "diferença", "exclusão" em detrimento de “contradição". A contradição apareceria, no máximo, perante o momento da "externalização". Como o exemplo fundamental, nota-se o sucesso que logrou o conceito de "desenvolvimento desigual e combinado", elaborado por Trotsky e amplamente desenvolvida por Edward Soja. Como assim assinalaria Milton Santos, ainda na década de 1980, sobre as questões que envolveriam "o papel do Estado" e suas "ações concretas, inclusive sobre o território", para o desenvolvimento da crítica geográfica: “A própria explicação do desenvolvimento desigual no espaço encontra na dialética entre essas instituições e seus aparelhos uma de suas explicações" (1984; p. 14).

Isso não apenas explica o porquê de a "dialética interna" (desde os aspectos contraditórios da produção em si) de Marx ter sido negligenciada, ajudando a entender também como a crítica filosófica só se direcionou, sem conseguir sua superação de fato, aos pressupostos de uma Geografia kantiana, inclusive em relação a Hegel, este interpretado de forma destituída do que haveria de mais fundamental em sua dialética: a mediação entre os imanentes negativos. Em relação a Marx, no âmbito da necessidade de apresentar "o novo", isso significava o distanciamento e até a tentativa da destituição da legitimidade de sua crítica sobre o valor. O mesmo Milton Santos irá sugerir, em um contexto mais adiantado de sua reflexão teórica, a incapacidade explicativa do "valor" diante de um mundo real-concreto "universalmente empiricizado" e mediado pela "unicidade da técnica": "não há objetividade quando a questão é o valor" (2000, p. 37).

A incompatibilidade entre a dialética marxiana e a "dialética pretensa e eminentemente geográfica" não se daria, como tentou ser justificada, pela inserção em si do espaço na crítica, mas pelas formas de inserção da contradição (ou da não-contradição) em sua "dialética espacial". Pois precisava ser ela explicativa, positiva, na reafirmação do "real-concretoindividual", em oposição aos riscos de uma "metafisicologia" remota. O prejuízo mais importante de conceber o "concreto-objetivo" de tal maneira foi, contraditoriamente, a perda da capacidade de identificação objetiva dos sujeitos concretos. Destituída das noções de "modo de produção", "de valor" e da contradição imanente "capital-trabalho", estariam também as classes e seus conflitos, sobretudo a classe trabalhadora e o trabalhador como sujeito histórico, ausentados e incompatíveis com o "novo" discurso geográfico. Ainda que isso se expresse como tendência, e ainda que esta tendência seja majoritária, é necessário considerar a importância e 
a relevância de perspectivas de uma geografia combativa, emancipatória e fundada na identificação objetiva do trabalhador como sujeito histórico, sobretudo em linhas de análise voltada para uma Geografia agrária e uma Geografia urbana.

Consideradas as exceções, é interessante e curioso como que o "novo" discurso da crítica geográfica, voltado para o concreto e empírico real-objetivo, irá preencher esse vazio prático e político. Primeiro se expressa uma tendência de tornar o próprio espaço, e até mesmo os "objetos", o sujeito do "processo social". Em Milton Santos, pode ser derivado tal interpretação: “A significação geográfica e o valor geográfico dos objetos vem do papel que, pelo fato de eles estarem em contiguidade, formando uma extensão contínua, e sistematicamente interligados, eles desempenham no processo social” (SANTOS, 2008; p. $78)^{41}$. E depois, conforme ainda expressa Milton Santos, a centralização da técnica permitiu destituir os sujeitos próprios da contradição interna capital versus trabalho em prol de uma "atualização" da crítica para pôr em seu lugar categorias ainda mais remotas de formações sociais até mesmo anteriores à especificidade histórica do capital: "pobres", "povos pobres", “atores hegemônicos" (SANTOS, 2011b) ${ }^{42}$, etc. A condição empírica da substância do "objeto geográfico", que supõe até mesmo a aproximação dela com a concepção positivista durkheimiana de objeto, está dessa forma destituída de qualquer contradição em sua "dialética". Não seria demais lembrar, como apresentado anteriormente, que a conciliação entre Marx e Durkheim tentada por Milton Santos acerca da "substância" cristalizada no "objeto" se mostra imprópria exatamente por não considerar o caráter contraditório do trabalho cristalizado no objeto em si.

A mistificação em tal comparação só se torna possível quando desconsiderado a contradição interna entre valor de uso e valor de troca no interior do trabalho cristalizado no objeto. Em Marx, "trabalho morto" jamais poderia significar qualquer tipo de inércia interna em sua dialética. O "morto" só está morto em potencial já que ele sempre está em constante reavivamento perante as forças produtivas, seja a partir do consumo produtivo, seja a partir do consumo individual. Isso significa que, apesar de "morto", se movem em seu interior forças "metafísicas" que estão permanentemente se contrapondo a sua condição puramente física,

\footnotetext{
${ }^{41}$ É necessário, no entanto, advertir que tal leitura de Milton Santos não se apresenta explicitamente, mas também não está explicitamente ausente. Por isso se expressa como tendência. Sobretudo porque vincula sua leitura a uma tradição morfológica da sociologia de Durkheim: "Foi uma pena [a Geografia ter se distanciado da proposta de "Morfologia Social"], pois a ideia de Durkheim para quem o meio era formado de coisas e pessoas, poderia haver aproximado a geografia de uma definição do seu objeto epistemologicamente operacional" (SANTOS, 2008; p. 75).

${ }^{42}$ SANTOS, Milton, Por Uma Outra Globalizaçãa: do Pensamento Único à Consciência Universal, Rio de Janeiro, Record, 2011b.
} 
dado seu sentido histórico de existência, de existir enquanto valor no movimento da autovalorização. Como desse modo resumiria Marx sobre a relação do valor com seu invólucro mistificador físico: "Em direta oposição à palpável e rude objetividade dos corpos das mercadorias, não se encerra nenhum átomo de matéria natural na objetividade do seu valor" (MARX, 1983; p. 53-54).

A objetividade material, composta mesma de materialidade física que caracterizaria a paisagem, ou a dimensão do "objeto", representou uma "rugosidade" nos termos históricos para a própria renovação da crítica geográfica. Mesmo que inserida em uma "dialética própria", ela jamais poderia estar em contradição, ou "oposição", imediata e fulminante contra a "ação" ou a "utilização" que conferiria em nossos dias seu conteúdo. Milton Santos tinha a devida consciência (desde final da década de 1970 e início da de 1980) sobre a necessidade de situar a “dialética geográfica" dentro de seu ideal estruturalista de ciência, afinal era preciso explicar e colocar as coisas como elas se afirmam, não como elas se negam: "não basta opor forma e conteúdo, temos que levar em conta o tempo que passa e as funções que mudam” (1996; p. 136)

Lefebvre havia percebido os riscos de tentar qualquer tipo de restauração da objetividade com qualquer tipo de forma que não fosse mediada pela contradição. Ainda derivando de Lefebvre, a verdadeira objetividade diante de processos contraditórios, como é o processo da reprodução sociometabólica do capital, só pode encontrar em suas abstrações suas próprias vias de explicação. E é pelo desenvolvimento desta abstração universal e lógica que se expressam o movimento inverso, rumo às suas contradições efetivadas no plano real e concreto. Daí o fato de reaparecer, constantemente, a questão da "luta de classes" como aquela relegada a um apriorismo de sociologismos e não-geográfico. Isso nada mais é do que a desconsideração das determinações abstratas e lógicas do próprio conflito capital versus trabalho na composição do valor. O que as tornam inteligíveis, ao contrário do que esboça Milton Santos, é a própria objetividade contraditória do valor, este entendido como determinação abstrata das diferentes formas de produção sob o julgo do capital: "O surgimento das classes e seu conflito permanente se constroem, pois, teoricamente a partir das formas, funções e estruturas, cujos conceitos permitem representar a história tornando-a inteligível” (LEFEBVRE, 1966; p. 72).

[3º Problema: A contradição não observada na "diluição" entre relações de produção e forças produtivas]

A forma de conceber "confundida" a mediação entre "relações de produção" e "forças produtivas" não apenas é possível somente com a retirada da contradição da relação, como 
também tende a recair numa mistificação idealista quando não apontadas suas determinações. A questão da "unicidade da técnica" que conformaria o pressuposto teórico de uma "universalidade empírica" e eminentemente geográfica capaz de se tornar o novo viés explicativo perante a superação das contradições entre "relações" e "forças" produtivas nos termos acima postos por Milton Santos, deve ser analisada com mais rigor. Se o período técnico atual se caracterizaria pela ativação do último nível de abstração da técnica, no momento em que tende a desaparecer qualquer relação "hegemônica" entre elas ${ }^{43}$, é preciso, no entanto, confrontar essa mesma condição técnica com sua empiria no território. Aqui, para se buscar os "riscos mistificadores", será preciso colocar em prática os planos da "empiricização do mundo" contra sua própria empiria. Isso significaria levantar a questão invertendo o sentido: até que ponto as "técnicas hegemônicas atuais" não significariam a condição para uma "destecnificação" do mundo? Isso mudaria tudo: da assimilação ("hoje, as técnicas não hegemônicas são hegemonizadas") para a contradição (técnica e a negação destrutiva da técnica). A presente questão poderia ser sustentada por três fenômenos: "desindustrialização" 44 , destruição produtiva e desemprego estrutural, todas elas em escala universalizante, igualmente mundial e irreversível.

Milton Santos afirma que no estágio crítico atual da reprodutibilidade sócio-produtiva "a competitividade toma lugar da competição" (2011; p. 46). Seu objetivo é demarcar o fim de qualquer perspectiva civilizatória, ou "solidária", da concorrência. Trata-se de um recurso linguístico de demarcação crítica, pois, o objetivo da concorrência capitalista nunca deixou de se expressar de forma universalmente destrutiva quando lhe faltam alternativas expansivas. Mesmo nos períodos de franca expansão capitalista, como aquele observado entre o fim da segunda-Guerra Mundial e a década de 1970, subsidiado pelo discurso da "Revolução Verde", a dimensão destrutiva do "auxílio ao desenvolvimento" para os países do "Terceiro Mundo" poderia ser observada pela transferência de tecnologia suja e obsoleta que, como aponta Mészáros, "só removem as práticas produtivas mais odiosas, juntamente com suas consequências altamente poluentes, dos 'países capitalistas avançados', depositando-as frequentemente [...] na soleira dos países dependentes” (MÉSZÁROS, 2004; p. 138).

\footnotetext{
43 "Esse é um fenômeno novo na história das técnicas e na história dos territórios. Antes havia técnicas hegemônicas e não hegemônicas; hoje, as técnicas não hegemônicas são hegemonizadas" (SANTOS, 2011 b; p. 14)

${ }^{44} \mathrm{O}$ que não significa a emergência de uma sociedade "pós-industrial", mas apenas um limite estrutural e contraditório inerente ao próprio desenvolvimento da técnica, ou da produtividade do capital. A "desindustrialização" aqui posta se refere ao processo de ativação do limite dessa contradição onde a própria lógica da produção moderna se submete à lógica determinante da produção do valor.
} 
As duas guerras mundiais, todavia, também não seriam suficientemente elucidativas quanto às dimensões atuais potencialmente destrutivas, pois a forma como a crise atual se expressa, de forma "rastejante" e sem alternativas (MESZÁROS, 2011), apresenta seu caráter autodestrutível não imediatamente identificável. A liberação de capitais da "esfera produtiva" para a "esfera financeira" é uma de suas evidências centrais.

Como observa Mészáros, o período de desenvolvimento pós-Segunda Guerra Mundial foi de intenso dinamismo da "atividade econômica em todo mundo" (2011; P. 1072). A aparente forma ilimitada de auto-expansão do capital encontra seus limites em sua própria superprodução que atinge a década de 1970 e expõe os limites acumulativos. A esta altura o deslocamento para o enfrentamento da concorrência destrutiva intercapitalista a nível global não haveriam mais de encontrar nos grandes monopólios produtivos vias de valorização segura. A necessidade da financeirização da economia, que irá encontrar terreno fértil com o fim do tratado de Breton Woods em $1971^{45}$, representaria uma saída viável, mas também contraditória. Isso porque, por um lado, ao tempo que significava a abertura de uma via de médio prazo para o processo de valorização, reforçava por outro lado o processo restrições técnica-produtivas fundamentado na tecnologia molecular digital e na flexibilização toyotista. Isso foi notavelmente em favor dos EUA, que passariam a controlar o mercado de dinheiro devido ao dólar ter se tornado a moeda internacional. Mas isso apenas a curtíssimo prazo, porque o "controle" seria apenas formal, por ter a sede de emissão dos papéis-moedas.

Pouco tempo depois, já no início da década de 1980 e sobretudo em toda década de 1990, ficou perceptivo o caráter incontrolável e autônomo, igualmente destrutivo, daquilo que François Chesnais chamará de "hipertrofia da esfera financeira". Seus impactos para o comércio produtivo são desastrosos: "Entre 1980 e 1992, o crescimento dos ativos financeiros acumulados foi mais de duas vezes e meia mais rápido do que a formação do capital fixo" (CHENAIS, 1996; p. 244). Isso irá repercutir num total desmantelamento do setor produtivo direto, sobretudo nos países do "eixo norte" que passariam a controlar o mercado de ações. Isso tem consequências muito sérias para o que poderia ser chamado de fundamento moderno da técnica e da produção material: a destruição da própria indústria, como lembra Mészáros ao citar tal processo contraditório entre produção e financeirização no centro da produção capitalista:

\footnotetext{
45 “A derrubada do sistema monetário internacional que havia sido estabelecido ao fím da Segunda Guerra Mundial está no âmago de toda falta de regulação ulterior. A morte desse sistema em 1971, levou, por etapas, não somente o desaparecimento de qualquer ancoragem internacional das moedas, como também à transformação do mercado de câmbio em um espaço onde moedas e ativos financeiros estão indissoluvelmente imbricados" (CHESNAIS, 1996; p. 248).
} 
Assim, a tendência de destruir certas indústrias e de transferir boa parte dos recursos financeiros assim gerados para os EUA de forma alguma é acidental. (Embora, evidentemente, seja bastante grotesco que a Grã-Bretanha, por exemplo, que lidera o mundo capitalista em tal processo de "desindustrialização", figure também hoje como um dos principais países credores.) (MÉSZÁROS, 2011; p. 1085).

Financeirização, mudança do padrão tecnológico e flexibilização fazem parte do pacote da chamada reestruturação produtiva do capital perante a crise estrutural que se montava no final da década de 1980. Seu caráter limitado (frente suas possibilidades de solução da crise) e destrutivo estava imbricado com as formas técnicas admitidas pela nova necessidade produtiva, como destaca Ricardo Antunes: "As novas técnicas de gerenciamento da força de trabalho, somadas à liberação comercial e às novas formas de domínio tecno-científico, acentuaram o caráter centralizador, discriminador e destrutivo deste processo" (2002; p. 32) ${ }^{46}$ Completava-se a este quadro o neoliberalismo e o discurso da globalização como expressões políticas do processo.

O conjunto dessas modificações tornou ainda mais agudo o processo de monopolização de uma economia concorrencial cada vez mais mundializada. Mesmo nos países "centrais" da economia capitalista, os efeitos destrutivos das próprias condições produtivas neste contexto não foram menos perceptíveis. Ainda segundo Antunes, "na década de [19]80, por exemplo, ela afetou especialmente nos EUA, que então perdiam a batalha da competitividade tecnológica para o Japão. [Entretanto, a partir dos anos 1990], passou a também a atingir o Japão e os países

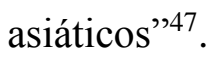

Para Mészáros, todos esses fenômenos estão interligados pela própria natureza contraditória do capital de ser ele "uma forma incontrolável de controle sociometabólico" (2011, p. 96). Isso permite entender como que o próprio desenvolvimento técnico, inclusive para a "fundação" de um período inteiramente novo do "Meio Técnico-CientíficoInformacional", só pode ser assimilável quando se torna possível admitir a existência do seu corolário mais antagônico: a "destecnificação" e a retomada de relações de produção e de trabalho mais arcaicas no seio mesmo da produção avançada. A título de exemplo, descreve Antunes (citando Stephenson) $)^{48}$, sobre o processo de reestruturação técnica da inserção da

\footnotetext{
${ }^{46}$ ANTUNES, Os Sentidos do Trabalho, 2002.

47 Id., Ibid.

48 (STEPHENSON, Carol, (1996), "The Diferent Experience of Trade Unionism in Two Japanese Transplants", In ACKERS, P. et al, op. cit.).
} 
Nissan no competitivo mercado automobilístico Inglês, a partir das formas de produção de uma de suas fornecedoras, Ikeda Hoover (fornecedora da parte de acabamento dos carros), que utilizava a colocação de máquinas de costura no chão mesmo da fábrica: "tratando-se de empresas diferentes, é um equívoco imaginar que o funcionamento da Nissan seja integralmente transplantado para a Ikeda Hoover" (2002; p 81). Aqui, o processo de "unicidade das técnicas" ainda pode ser vislumbrado, mas é necessário considerar que o sentido com que as mutações técnicas inseridas na fábrica central (Nissan) estão em posição diametralmente oposta de sua subsidiária (Ikeda).

Contudo, o sentido contraditório pode ganhar níveis de radicalidade em outros exemplos expressivos quando se observa, por exemplo, no Brasil, o aumento exponencial das relações de trabalho fundamentados na superexploração ou na servidão moderna (trabalho análogo à escravidão), além do trabalho infantil ${ }^{49}$. Tais relações "primitivas" de produção estão vinculadas sobretudo à zona da expansão da moderna produção de soja, do cerrado para a floresta amazônica brasileira, quando considerado sua cadeia produtiva (desmatamento, pasto, criação bovina e, finalmente, a soja). O processo, acumulativo dessa forma, assimila sua própria contradição (trabalho escravo mais produção tecnificada), como haveria denunciado a Organização Repórter Brasil:

Exemplos de trabalho escravo em plantações do grão remetem, por exemplo, aos fazendeiros Fernando Ribas Taques e Leandro Mussi. Em 2007, enquanto estavam na "lista suja", ambos venderam soja à Bunge, a maior empresa do agronegócio no Brasil (2011; p. 12) $)^{50}$.

Mais revelador ainda é o que aponta o Atlas do Trabalho Escravo no Brasil ${ }^{51}$ ao mostrar com nitidez o movimento espacial das atividades modernas agroindustriais "acompanhando" o movimento territorial da soja do Cerrado em direção à Amazônia, ainda vinculadas enquanto

\footnotetext{
49 "De todas as crianças no mundo, mais de 200 milhões são trabalhadoras infantis. Mais de 100 milhões estão nas piores formas de trabalho um milhão nunca irão à escola. Das crianças trabalhadoras no mundo, algumas têm só 5 anos e a maioria tem menos de 15. Muitas estão em atividade perigosa manipulando ferramentas ou operando máquinas perigosas; trabalhando em fazendas e plantações; minas ou pedreiras ou em canteiros de obras; respirando gazes tóxicos e expostos à produtos químicos nocivos além de outros perigos. Milhões estão presas às suas piores formas: escravidão, servidão por dívida, servidão, trabalho forçado, conflito armado e prostituição" (ORGANIZAÇÃO INTERNACIONAL DO TRABALHO (OIT). O trabalho infantil. Disponível em: <http://www.oitbrasil.org.br/>. Acesso em: 05 maio 2007).

50 ORGANIZAÇÃO REPORTER BRASIL. Cadeias Produtivas e Escravidão. Disponível em: <http://reporterbrasil.org.br/wp-content/uploads/2015/02/7.-caderno_cadeias_produtivas_baixa.pdf >. Acesso em: 10 maio 2015.

51 THÉRY, Hervé, Atlas do Trabalho Escravo no Brasil / Hervé Théry, Neli Aparecida de Mello, Julio Hato, Eduardo Paulon Girardi, São Paulo, Amigos da Terra, 2009.
} 
cadeia produtiva. É possível, através da comparação entre os mapas dispostos no Atlas, perceber tal movimento. Por exemplo, quando se compara as áreas de desmatamento e o sentido produtivo da soja rumo à Amazônia, como pode ser observado na Figura 1: Brasil: desmatamento versus produção de soja (2009).

\section{Figura 1:}

\section{Brasil: desmatamento versus produção de soja (2009)}

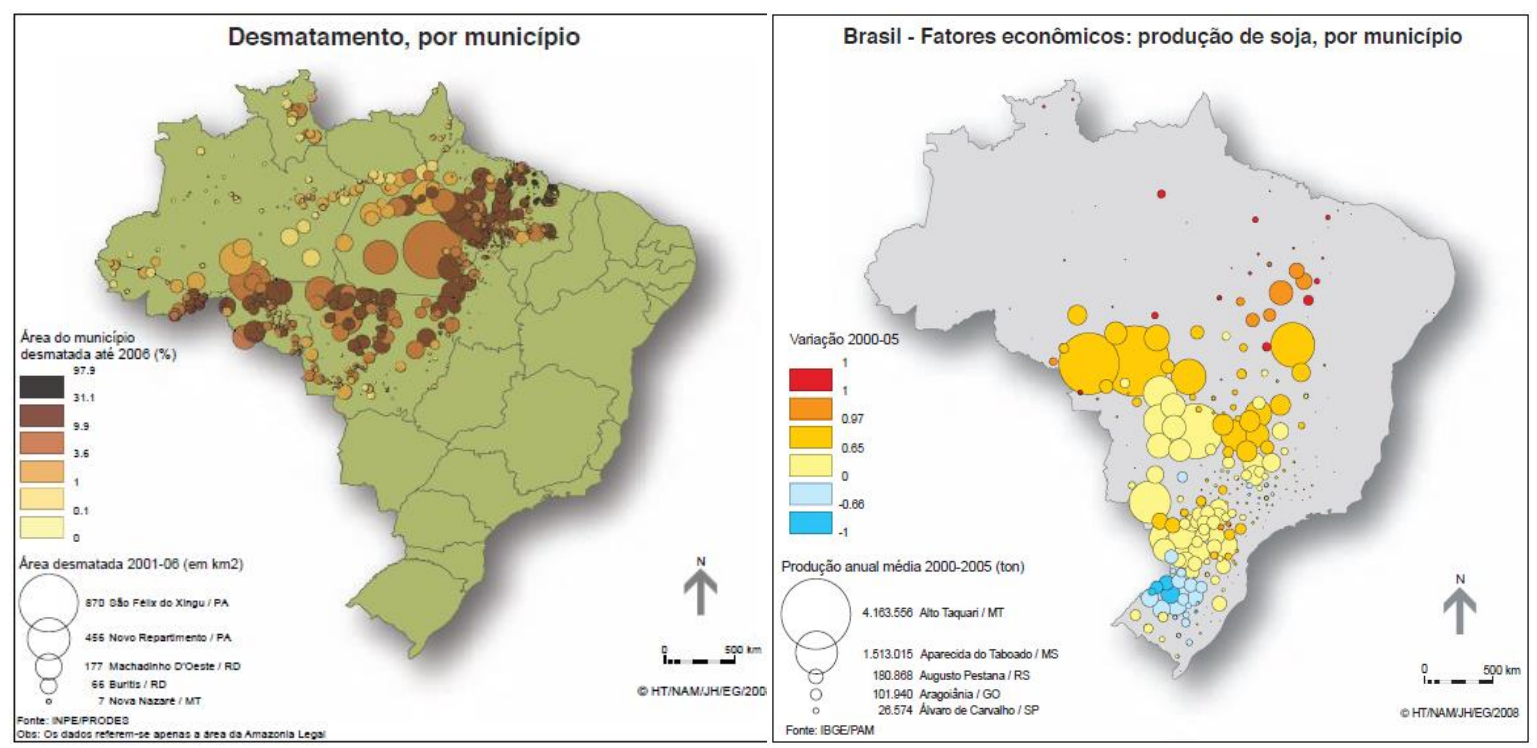

(ATLAS DO TRABALHO ESCRAVO NO BRASIL, 2009; p. 47; 46)

Quando se estabelece a relação entre as atividades agropastoris, atividades essas que vêm na sequência lógica do desmatamento, e os casos comprovados de utilização do trabalho escravo (dados referentes à libertação de trabalhadores em regime análogo a escravidão) é bastante reveladora a nitidez com que todo o circuito de modernização da produção está integrado com suas formas destrutivas, tanto da "natureza" como das relações de trabalho. A região de contato, ou a "zona de fronteira" entre elas, se caracteriza pela forte presença do trabalho escravo, revelando, como destaca C. H. da Silva, sua "fronteira de acumulação" 52 ; que se move pelo território, mediado pelo processo produção destrutiva e reconfigurando politicamente o mesmo território, como mostra sua pesquisa sobre os projetos de divisão

\footnotetext{
${ }^{52}$ SILVA, Carlos Henrique da Silva, O Pará aos pedaços: projetos de criação dos estados do Carajás e Tapajós no contexto da fronteira de acumulação, São Paulo; Dissertação (Mestrado) - FFLCH USP, 2014.
} 
territorial do estado do Pará. Assim também pode ser observado na figura abaixo onde etsá relacionado o trabalho escravo com as atividades agropastoris:

Figura 2:

Brasil: Atividade agropastoril versus trabalho escravo (2009)

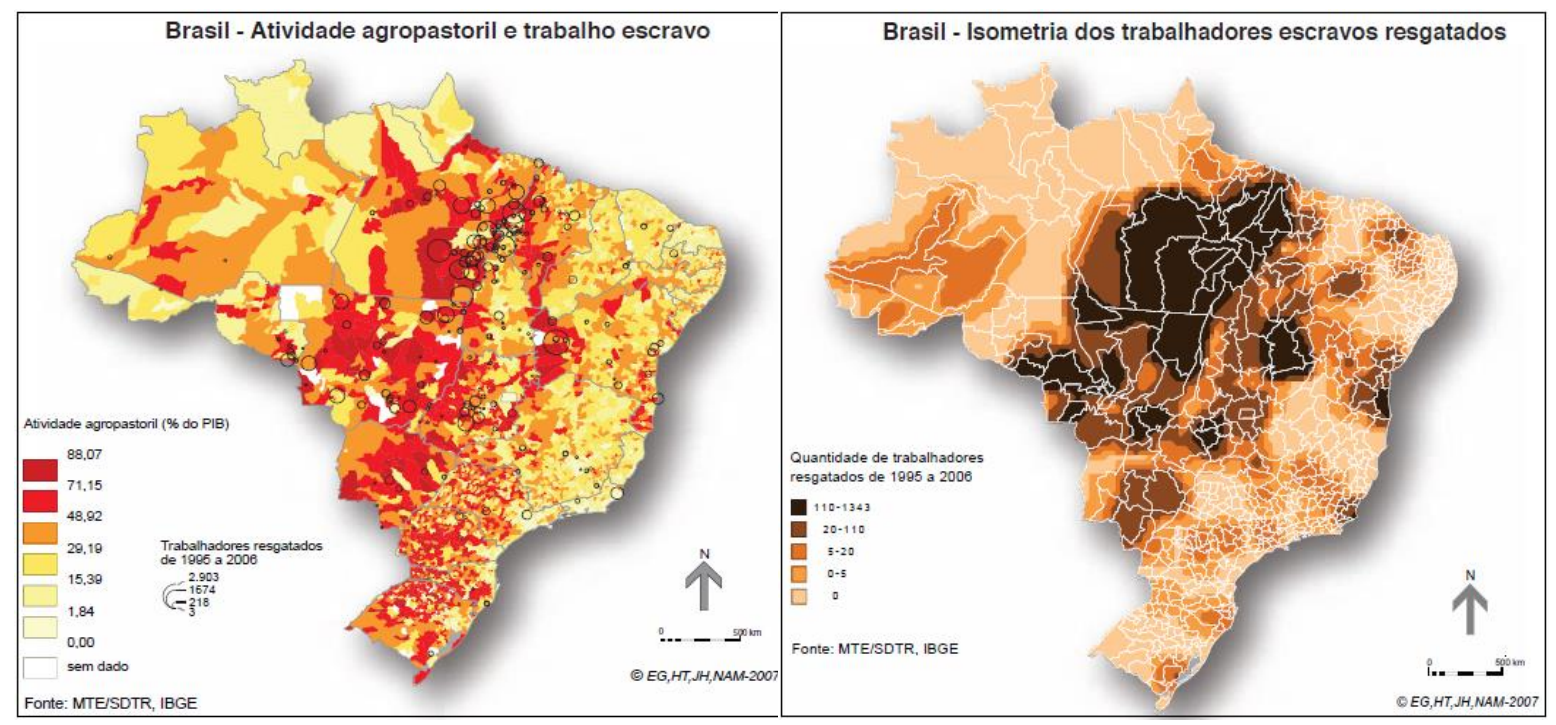

(ATLAS DO TRABALHO ESCRAVO NO BRASIL, 2009; p. 38; 24)

Não se trata somente da constatação óbvia de entender o trabalho, na mais radical exploração de sua dimensão viva ou "destecnificada", como instrumento "prévio" da modernização do campo, como no exemplo acima, nem que por isso esteja ele desvinculado da técnica moderna ou científica, tampouco que sejam essas relações de trabalho resíduos ou "rugosidades" (no sentido anacrônico do termo) a serem superadas, como consta na tabela abaixo (Trabalho escravo no Brasil: 1995 a 2013), que aponta uma tendência, no novo século, de aumento no uso deste tipo de exploração do trabalho, nem se trata também de uma especificidade do "rural", como espaço do atraso, pois é preciso salientar o crescimento do trabalho escravo no espaço urbano. Como já havia revelado a Comissão Pastoral da Terra (CPT), 2013 foi o ano em que o trabalho escravo nas cidades (51\% de trabalhadores libertados) ultrapassou as ocorrências em relação ao espaço agrário (49\%), sobretudo nos setores de construção civil (38\% dos trabalhadores libertados) e confecção $(5 \%)^{53}$. Tal crescimento

\footnotetext{
${ }^{53}$ Comissão Pastoral da Terra, Síntese Estatística em 31/12/2013 (atualização 23/06/14) - Campanha da CPT contra o Trabalho Escravo. Disponível em <SÍNTESE ESTATISTICA em 31/12/2013 (atualização 23/06/14) CAMPANHA DA CPT CONTRA O TRABALHO ESCRAVO>. Acesso em: maio de 2015.
} 
parecia seguir, de forma pendular, o mercado requerente pela realização dos grandes eventos esportistas. Mas dados disponibilizados pelo Ministério do Trabalho e Emprego para 2014 revelam a manutenção da tendência ao mostrar que, dentre os cinco maiores setores de uso do trabalho escravo (construção civil, agricultura, pecuária, extração vegetal e carvão), do total de 892 libertações de trabalhadores nesses setores, 48\% delas (437) foram feitas apenas na construção civil $^{54}$ (em 2013 esse valor relativo era de 41\%, o que evidencia, até o momento, uma tendência de deslocamento e concentração do trabalho escravo para a cidade).

Tabela 1:

Trabalho escravo no Brasil: 1995 a 2013

\begin{tabular}{|c|c|c|c|cc|}
\hline Ano & $\begin{array}{c}\text { N. }{ }^{\circ} \\
\text { Operaçoses }\end{array}$ & $\begin{array}{c}\text { N. }{ }^{\circ} \text { de } \\
\text { inspecionados }\end{array}$ & $\begin{array}{c}\text { Trabalhadores } \\
\text { Resgatados }\end{array}$ & $\begin{array}{c}\text { Pagamento de } \\
\text { Indenização }\end{array}$ & $\begin{array}{c}\text { Als } \\
\text { Lavrados }\end{array}$ \\
\hline 2013 & 179 & 300 & 2.063 & $8.236 .288,02$ & 4.297 \\
\hline 2012 & 141 & 255 & 2.750 & $9.676 .387,36$ & 3.753 \\
\hline 2011 & 170 & 341 & 2.485 & $6.159 .707,42$ & 4.493 \\
\hline 2010 & 142 & 310 & 2.628 & $8.786 .424,89$ & 3.976 \\
\hline 2009 & 156 & 350 & 3.769 & $5.908 .897,07$ & 4.535 \\
\hline 2008 & 158 & 301 & 5.016 & $9.011 .762,84$ & 4.892 \\
\hline 2007 & 116 & 206 & 5.999 & $9.914 .276,59$ & 3.139 \\
\hline 2006 & 109 & 209 & 3.417 & $6.299 .650,53$ & 2.772 \\
\hline 2005 & 85 & 189 & 4.348 & $7.820 .211,26$ & 2.286 \\
\hline 2004 & 72 & 276 & 2.887 & $4.905 .613,13$ & 2.465 \\
\hline 2003 & 67 & 188 & 5.223 & $6.085 .918,49$ & 1.433 \\
\hline 2002 & 30 & 85 & 2.285 & $2.084 .406,41$ & 621 \\
\hline 2001 & 29 & 149 & 1.305 & $957.936,46$ & 796 \\
\hline 2000 & 25 & 88 & 516 & $472.849,69$ & 522 \\
\hline 1999 & 19 & 56 & 725 & ND & 411 \\
\hline 1998 & 17 & 47 & 159 & ND & 282 \\
\hline 1997 & 20 & 95 & 394 & ND & 796 \\
\hline 1996 & 26 & 219 & 425 & ND & 1.751 \\
\hline 1995 & 11 & 77 & 84 & ND & 906 \\
\hline TOTAL & 1.572 & 3.741 & 46.478 & 86.320 .330 & 44.126 \\
\hline & & & & & \\
\hline
\end{tabular}

(Ministério do Trabalho e Emprego, 2013) $)^{55}$

Entendido como "cadeia”, como sugere o estudo da Organização Repórter Brasil (e não haveria de ser diferente, considerando a totalidade como relação contraditória), a integração do trabalho (escravo) à técnica "unicizada", moderna e científica, só pode se estabelecer de forma

\footnotetext{
${ }^{54}$ Ministério do Trabalho e Emprego. "MTE divulga análise do trabalho escravo em 2014". Disponível em <http://portal.mte.gov.br/imprensa/mte-divulga-analise-do-trabalho-escravo-em-2014.htm〉. Acesso em: 17 maio 2015.

${ }^{55}$ Ministério do Trabalho e Emprego; Divisão de Fiscalização para a Erradicação do Trabalho Escravo, "Quadro Geral das Operações de Fiscalização para a Erradicação do Trabalho Escravo" (Atualizado em 22/05/2013). Disponível 
contraditória, no sentido mais antagônico que possa significar. Isso porque o uso do trabalho escravo representa a última fronteira da radical separação contraditória entre as formas mais modernas de envolvimento da técnica na produção e sua total negação, em prol da superexploração do trabalho vivo. Ao mesmo tempo em que está ela integrada às formas de acumulação, está também afirmando o plano de sua negação, no sentido de sua re-substituição pelo trabalho. Como aponta José de Souza Martins: "um momento em que, é preciso que se diga, a escravidão por dívida representa de exploração do trabalho que contribuiu para intensificar o processo de acumulação não capitalista do capital no país.” (2002, p. 152) ${ }^{56}$. Isso porque, inserida no processo de realização do valor, tais relações só podem ser assimiladas pela contradição radical.

Ao ponto que se reafirmam o nível da competitividade e superprodutividade capitalista até o limite de ativação de suas últimas fronteiras destrutíveis, se constituem por outro lado um processo de desvalorização do próprio capital, tanto em seu componente variável como em seu componente constante. Esta pode ser, aliás, a contradição mais profunda e não assimilada da técnica em sua dimensão mais avançada, pois conserva em si a natureza da contradição do valor em sua forma mais radical; no momento em que não deixa ela de representar instrumento de intensificação da mais-valia relativa, promove, por outro lado, sua própria negatividade quando se fundamenta em relações de trabalho vinculadas à radical extração da mais-valia absoluta (o trabalho escravo). Por estes meios de uso "mais primitivos" das relações de trabalho, pode o capital compensar a taxa decrescente de exploração do trabalho ocorrida nos centros avançados de envolvimento científico-tecnológico. Estas relações não são somente diferentes ou desiguais, onde a mais primitivas tendem a caminhar no sentido das mais "hegemônicas", mas são elas necessariamente desiguais como forma de compensação do tempo médio de exploração do trabalho, tempo este em franco descenso na composição orgânica ${ }^{57}$ do capital social total.

Isso significa considerar que o desenvolvimento das "forças produtivas", além de produzir um desenvolvimento das "relações de produção", pode produzir também a "destruição" dessas mesmas relações de produção desenvolvidas. Mészáros chega mesmo a identificar em Marx (em sua carta endereçada à Lawrence e Wishart, no ano de 1845) o momento em que, no desenvolvimento "unilateral das forças produtivas", este mesmo desenvolvimento se converte em "forças destrutivas". Assim observa Marx sobre a etapa do

\footnotetext{
${ }^{56}$ MARTINS, José de Souza, “A vida entre parênteses: migrações internas no mundo contemporâneo", In: A sociedade vista do Abismo, Petrópolis, Vozes, 2002.

${ }^{57}$ Sobre o desenvolvimento da composição orgânica do capital social total e sua tentativa de equalização da taxa de exploração, foi analisado de forma mais detalhada no capítulo "1.3 - Valor-Trabalho, Contradição e Crise: inversões nos limites da solução teórica".
} 
desenvolvimento em que "essas forças produtivas, sob o regime da propriedade privada, obtêm apenas um desenvolvimento unilateral, convertem-se na maioria em forças destrutivas e uma grande quantidade dessas forças não consegue alcançar a menor utilização na propriedade privada" (MARX, 2007, p. 60). ${ }^{58}$

Para Mészáros, o que estava apresentado apenas como potencialidade diante as contradições internas e estruturais do capital no tempo de Marx, se impõe na atualidade de forma "onipresente" e incorrigivelmente destrutiva ${ }^{59}$ ("Hoje, o funcionamento "normal" e a contínua expansão do sistema do capital são inseparáveis do exercício irrestrito das 'forças produtivas-destrutivas unilateralmente desenvolvidas' que dominam a nossa vida") ${ }^{60}$.

Nessas condições, a relação entre forças produtivas e meios de produção não apenas "podem" estar em contradição, mas, diante da ativação dos limites últimos da desvalorização do capital, "devem" estar em contradição. Como assinalado, se no período de expansão capitalista pós-Segunda Guerra Mundial até antes da década de 1970 a via desenvolvimentista do capitalismo ainda conseguia promover, em relação ao "Terceiro Mundo", algum tipo de transferência tecnológica, no período atual qualquer forma de "cooperação" é impossível, dado os próprios limites da produtividade técnica. Ou seja: se no período de exportação da tecnologia suja da "Revolução Verde" haveria a possibilidade de algum tipo de "unicidade da técnica", mesmo considerando seu caráter desigual e combinado que permitisse o alcance "confundido" entre "forças" e "relações" de produção, essa mesma possibilidade deixou de ser inteligível porque a contradição entre elas se radicalizaram: elas se negam no seu próprio processo de afirmação.

Para além da desindustrialização, a condição destrutiva se expressa ainda por vias da destruição programada dos meios e resultados da produção, tal como o fenômeno do desemprego, que são igualmente expressões desse mesmo processo. A força de trabalho, posta como mercadoria, tal como as mesmas mercadorias oriundas do processo produtivo (para o consumo individual ou consumo produtivo), haveriam de encontrar na superpopulação dos desempregados atuais sua expressão como resultado desvalorizado da superprodutividade capitalista. Aí se encontra uma contradição fundamental no momento em que explodem as crises de superprodução.

\footnotetext{
${ }^{58}$ MARX, K.; Engels, F, Ideologia Alemã, São Paulo, Boitempo. 2007.

${ }^{59}$ Os elementos mais específicos da condição destrutiva da crise estrutural serão melhor analisados na introdução e no tópico "2.1 - O meio 'técnico-científico-informacional': entre o 'colapso da modernização' e a 'crise estrutural"”.

${ }^{60}$ MÉSZÁROS, 2011, p. 58-59.
} 
Harvey havia suposto os desdobramentos geográficos, a partir do "Ajuste Espacial”, que explicariam como o deslocamento físico-espacial de capital ou de trabalho poderiam retardar os efeitos destrutivos da crise. Para tanto teve de considerar a efetivação da "lei geral da acumulação capitalista" que tende a separar contraditoriamente, em polos de excedentes distintos, capital e trabalho (HARVEY, 2001). Essa separação se expressará, no plano do real, como a massa de força de trabalho desempregada e a massa de meios de produção, inconciliavelmente divorciadas.

Mas, ainda sim, essas duas condições que se interagem na efetivação da "força produtiva" e das "relações de produção" precisam ser "consumidas" numa dialética produtiva, conforme se intensificam as exigências do tempo médio mínimo para a valorização. No reencontro crítico forçoso, como visto, a força de trabalho é consumida pelas formas concretas que devem garantir, por um lado, uma extração de altas taxas de mais-valia relativa (por isso tendem se encontram com as "técnicas hegemônicas"), e, por outro lado, uma extração de alta taxas de mais-valia absoluta (aí tendem a se encontram por meio de relações de superexploração do trabalho com baixo, ou quase nula, mediação técnica, necessariamente), como forma de equalizar, e mesmo "frear" (HARVEY, 2001; p. 195), o caminho em direção à crise. Como também visto, essas formas contraditórias do desenvolvimento podem (e devem) se encontrar sobrepostas no tempo e no espaço, num mesmo contexto ou ponto produtivo, o que exigiria da teoria do "ajuste espacial” um condicionamento mais lógico (do ponto de vista de sua "dialética interna") e menos extensível no espaço.

Já o excedente dos meios de produção e dos meios de subsistência devem ter seu consumo mediado pela tendência da "taxa de utilização decrescente no capitalismo" (MÉSZÁROS, 2011, 634) ${ }^{61}$, em que a sobreposição da necessidade do valor de troca tende a se realizar em velocidade ainda maior que a realização do valor de uso ${ }^{62}$. Isso, ainda segundo Mészáros, se daria nos tempos atuais a partir de duas frentes: além da velocidade programada da destrutibilidade dos resultados da produção (meios de produção e materiais para subsistência), também a constituição de um setor estratégico especificamente adaptado para receber o deslocamento de capitais especializados, bastante produtivos, e muito restritivos: “o

\footnotetext{
${ }^{61}$ A análise da produção destrutiva sobre a taxa de utilização decrescente no capitalismo foi objeto de análise do tópico "2.2 - Técnica: a autossustentação, a autorreferenciação e o sistema filosófico fechado".

62 Destaca Mészáros que tal regra só pode se expressar em forma de tendência, na medida em que seria "extremamente problemático afirmar que, ultrapassando certo ponto na história do capitalismo avançado, este processo - intrínseco ao avanço produtivo em geral - seja completamente revertido da mais intrigante forma: em que a 'sociedade dos descartáveis' encontre equilíbrio entre produção e consumo, necessário para a sua contínua produção, somente se ela puder 'consumir' artificialmente e em grande velocidade (isto é, descartar perpetuamente) imensas quantidades de mercadorias que anteriormente pertenciam às categorias de bens relativamente duráveis" (2011; p. 640).
} 
complexo industrial militar"63. Em ambos mecanismos destrutivos estão inclusos a "técnica" e todos seus "sistemas de objetos".

O caráter destrutível explicitamente posto como parâmetro de realização do valor é uma determinação do tempo de sua própria "utilização" efetiva, ou uso. Por isso ela está incorporada na substância dos "objetos" como atributo especificamente histórico da natureza do trabalho cristalizado nela. Milton Santos expõe a necessidade de reflexão sobre a política no uso da técnica, e mesmo considerando que não se trata de pura "neutralidade" sobre ela é, por outro lado, necessário reconhecer que uma estabelece diante a outra uma relação apenas de exterioridade, ainda que mediadas por uma relação de indissociabilidade por onde se pretende forjar uma dialética, mas apenas uma dialética formal, como garantia da complementariedade. É, no entanto, necessário ir mesmo na substância contraditória mais elementar; desde o que constitui sua "forma" até sua "utilização". Pois, se é correto afirmar, como destaca Santos, que "não há inocência no uso atual das técnicas dominantes"64, o que haveria de "inocente" em sua substância se fosse a ela admitida o caráter contraditório e destrutivo do valor nos tempos de crise estrutural? Quais possibilidades emancipatórias e analíticas lhes restariam se a contradição estivesse inerente à natureza da técnica atual?

Mészáros expõe os riscos mistificadores com que o deslocamento da contradição - da “dialética interna" para a sua expressão fenomênica empírica, como exterioridade - pode subverter a busca pelo "novo", inclusive no que concerne aos claros objetivos da crítica geográfica; seja pela afirmação da "unicidade" da técnica, seja pela "identidade confundida" entre relações e forças produtivas. Sem as contradições de sua natureza interna devidamente objetivadas, que são as próprias contradições do trabalho em sua franca oposição dialética com o valor, pode a teoria sobre a técnica cair no "mito da unidade orgânica" que, ainda segundo Mészáros:

\footnotetext{
Vem dominando o discurso ideológico desde que o relacionamento social teve de se conformar aos imperativos materiais de garantia da continuidade da produção no interior da estrutura potencialmente explosiva da divisão social e hierárquica do trabalho, que repetidamente mudou suas formas do curso da história, mas não sua substância exploradora (2011; p. 1032)
}

\footnotetext{
${ }^{63}$ Como será també debatido no tópico "6.2 - A via teórica-afirmativa".

64 “Elas são 'neutras', na medida em que o resultado depende das intenções dos atores, aos quais as técnicas apenas fornecem possibilidades. Mas na medida em que são de uso exclusivo de atores hegemônicos, tornam-se tão hegemônicas quanto elas (SANTOS, 2000; p. 31-32).
} 
Em relação ao caso específico de Milton Santos, a "divisão social hierárquica do trabalho" assinalada por Mészáros, tal como sua estrutura atual "potencialmente destrutiva", tende a se converter em termos mais brandos, como o da "fragmentação" e da "diversificação" dos tempos próprios da "Globalização" ("Com a marcha do capitalismo, amplia-se a tendência a que, sobre a diversificação da natureza, operada pelas formas naturais, se realiza uma outra diversificação, também na escala global, mediante forças sociais" ${ }^{65}$, da mesma forma que a "substância" exploradora, que passa a ser destituída do valor, se converte na "razão técnica", agora movida pela informação ("Hoje, o motor da divisão do trabalho, tornada claramente internacional, é a informação" $)^{66}$.

Os riscos de mistificação na interpretação de Milton Santos, como visto, tencionam-se não apenas na medida em que se observa sua aproximação com o recurso mistificador da concepção materialista explicitamente fundamentada no positivismo durkheiminiano, como também se aproxima das mistificações tecnicista weberianas ao substituir a substância do objeto, do trabalho, para a "racionalidade" contida na "informação", este como o motor da técnica. Assim demonstra proceder Santos quando, após se referenciar nos postulados weberianos contidos em Habermas, assinala que:

Aqui, nossa afirmação é que a marcha do processo de racionalização, após
haver (sucessivamente) atingido a economia, a cultura, a política, as relações
interpessoais e os próprios comportamentos individuais, agora, neste fim de
século XX, estaria instalando-se no próprio meio de vida dos homens, isso é,
no meio geográfico (SANTOS, 2008; p. 289-290).

As influências de Max Weber em Milton Santos, embora já estivessem presentes desde textos mais embrionários da sua crítica ${ }^{67}$, é providencial para o momento de maturidade do geógrafo. A função da "racionalidade da técnica" para composição de sua teoria permite engrenar uma série de fundamentos que deveriam se apresentar como o "novo"

\footnotetext{
${ }^{65}$ SANTOS, 2008; p. 131.

66 Id., Ibid.

${ }^{67}$ É interessante a aproximação de estabelece Milton Santos entre o estruturalismo e weberianismo ainda em textos produzidos na segunda metade da década de 1970, como identifica Moraes sobre tais aproximações no texto "Sociedade e espaço: a formação social como teoria e como método": "Apesar de transitar por uma grande variedades de autores, Milton Santos revela uma sintonia fina com a interpretação de Althusser ao aproximar o conceito de modo de produção de um tipo ideal weberiano, isto fica evidente ao falar dos modos de produção "puros", que não existem "em nenhum lugar", e que "só tornam-se concretos sobre uma base territorial historicamente determinada" (MORAES, 2013; p. 33).
} 
desencantamento do mundo ${ }^{68}$, agora "globalizado", um desencantamento especificamente geográfico e condizente com os propósitos de constituição e legitimidade de sua "filosofia própria". Primeiro com relação à afirmação das relações “confundidas” e, por isso, superadas, da "velha" forma de produção que, antes fundamentada no valor, tenderia agora a adquirir um coeficiente comparativo entre categorias mais abrangentes (em detrimento da suposta verticalidade entre capital e trabalho). Isso tornaria viável a horizontalidade empiricamente objetivada e desejada, ou a "racionalização por baixo"69: "racionalização" técnica como denominador comum entre a "economia", "cultura", "política", "relações interpessoais", "comportamentos individuais". O espaço, como "campo de ação instrumental" "70, encontra na técnica racionalizada e informacional sua via de efetivação, como elemento condicionador das demais "instâncias" da realidade. E, depois, com relação à destituição da legitimidade analítica da substância do trabalho (e sua evidente contradição com o valor) para algo "mais geográfico", a técnica, que assim passa a ser " “tornada uma espécie de princípio para toda a atividade, toda coisa', [sendo] em si mesma, 'um princípio racionalizante"”, como assinalará Santos (2008; p. 298) em concordância com os postulados de Marc Humbert.

As possibilidades de encontro da "racionalidade" weberiana com a "técnica" miltoniana não seria apenas providencial, mas necessária no momento em que carregaria para si um legado da crítica sistematicamente já elaborada. Como assinalará Weber no início do século XX: “A forma peculiar do moderno capitalismo ocidental foi, à primeira vista, fortemente influenciada pelo desenvolvimento das possibilidades técnicas" (1967; p. 09) ${ }^{71}$. Caberia à Geografia atualizar sua leitura dentro do novo contexto "informacional", observando suas metamorfoses especificamente contextuais de "empiricização" (sobretudo no território) de um mundo globalizado e, ao mesmo tempo, fragmentado pelas mesmas "possibilidades técnicas" por Weber já levantadas. Como dessa maneira procederá Santos: “É somente neste fim de século, com as novas técnicas de transmissão e coleta da informação que estamos propriamente autorizados a falar de fluidez do território em sentido amplo" (2008; p. 292)

Mas, do ponto de vista da crítica, o encontro entre Max Weber e Milton Santos não se dá sem os mesmos riscos de mistificações, como aqueles presentes no sociólogo alemão já no início do século XX. Weber já havia assim tentado para, primeiro, deslocar o processo de

\footnotetext{
${ }^{68}$ Weber haveria de ter se tornado, sobretudo para a tradição da filosofia alemã, o teórico do desencantamento do mundo. MATOS, Olgária C. F, Escola de Frankfurt: Luzes e Sombras do Iluminismo, São Paulo: Moderna, 1993.

${ }^{69}$ SANTOS, 2008; p. 292.

${ }^{70}$ Chega, agora, a vez de ser o espaço considerado como "racional", desde que vejamos como ele realmente é um campo de ação instrumental. (SANTOS, 2008; p. 292).

${ }^{71}$ WEBER, Max, A Ética Protestante e o Espírito do Capitalismo, São Paulo, Livraria Pioneira Editora, 1967.
} 
espoliação do trabalho da gênese do princípio capitalista para pôr em seu lugar uma espécie de "cultura" do ganho individual e, segundo, promover uma relação idealista (não contraditória) entre suas categorias modernas para composição do "espírito capitalista". Como resultado desaparecem as "diferenças" (para não dizer "contradições"), tal como as condições estruturais do conflito capital versus trabalho, por exemplo, personificada nos sujeitos de sua história classista, já que tanto o "fabricante" como o "trabalhador" estariam envolvidos pela mesma lógica da "racionalidade" totalizante: "O fabricante que permanentemente se opuser a estas normas será economicamente eliminado, tão inevitavelmente como o trabalhador que não puder ou não quiser adaptar-se a elas será lançado à rua sem trabalho” (WEBER, 1967; p. 34).

Aqui não há somente uma outra forma de ler a "luta de classes", mas uma tentativa de absolutização do "espírito" e da "razão" capitalista a toda forma de "sujeito", sujeitos estes que se "confundem" (para utilizar a expressão de Milton Santos) no processo da modernidade perante a busca por "mais dinheiro". A mistificação está explicitamente posta numa forma (absoluta) de "ideia", ou "espírito", que precede até mesmo de sua efetividade histórica ("[...] na terra natal de Benjamim Franklin (Massachusets) o espírito do capitalismo [ou seja, como 'ética' pela busca do dinheiro] estava presente antes do "desenvolvimento capitalista") 72 . A "cultura" capitalista ganha sua própria universalidade humana ${ }^{73}$, apesar de Weber considerar sua forma moderna, o "ethos", instrumentalmente racionalizada como especificidade histórica.

Em Weber se observa a busca por um abstrato universal determinante a partir da retirada da "contradição" como mediação entre as categorias modernas para fundar, nos mesmos termos hegelianos, a "ideia" e o "espirito" como síntese de uma "unicidade" forjada do princípio capitalista. Marx já havia se atentado para esse recurso mistificador quando, ao analisar a dialética entre produção e consumo, acusava os economistas de idealismo por não se atentarem para as mediações contraditórias, enquanto estes viam somente a identidade (imediata ou negativa) entre elas: em síntese, diria Marx: "Esta identidade de produção e consumo vem a ser a mesma coisa que a proposição de Espinoza: determinatio est negatio [...]. Mas ainda mantêm-se exteriores entre si. [Por isso] tem lugar um movimento mediador entre ambos" (2011; p. 45-46). O que Marx observa é que a identidade da relação dialética não deveria se encerrar no reconhecimento da identidade em si, mas na mediação que é sempre regida pela contradição. Sobre os economistas que não observaram a necessidade da

\footnotetext{
72 WEBER, 1967, p. 34.

73 “'Capitalismo’ houve na China, na Índia, na Babilônia, na Antiguidade Clássica, na Idade Média. Mas em todos eles faltavam estes casos faltava como veremos, este ethos particular” (WEBER, 1967; p. 32).
} 
contradição, assim observa: "Com isso, nada mais simples para um hegeliano do que pôr a produção e o consumo como idênticos" (MARX, 2011; p. 48).

São sobre esses riscos idealistas e mistificadores - não puramente por analogia, mas pela forma de manipulação da dialética especificamente - que a solução de Milton Santos para afirmação da "unicidade" da técnica racionalizada pela informação, agora a partir da relação entre sistema de objetos e sistema de ações (já que atualmente as relações de produção e os meios de produção haviam se "confundidos"), apresentam também seus riscos mistificadores. Primeiro porque os objetivos em apresentar um "universal" efetivo e afirmativo (como denominador comum), como aqueles de Weber, também são percebidos em Santos. Não por outros motivos buscará em J. Ellul o conceito de “universal técnico", em J. Ladrière e S. Breton a "manifestação de um universal concreto" e exclusivamente em S. Breton a "universalidade racional" (SANTOS, 2008; p. 1997-198). Percebe-se aqui trajetória equivalente àquela de Weber: a categoria universal (técnica), sua universalização efetiva (universal concreto), sua forma historicamente específica (universalidade racional).

Observa-se ainda, no que se refere à concepção da dialética, uma outra diferente daquela fundamentada na complementariedade e conciliação, como observado até então. Aliás, é curioso como a dialética é alternadamente manipulada por Milton Santos nesse específico aspecto: primeiro ela se apresenta "idealista" ao afirmar a "unicidade" e uma identidade "confundida" entre forças produtivas e relações de produção; depois ela se apresenta conciliatória e complementativa ao relacionar sistemas de objetos e sistema de ações: no primeiro ela se dá de forma negativa, no segundo de forma positiva. Diante da alternância entre esses procedimentos perante a dialética, não apenas se observa a ausência da contradição, mas por isso mesmo se observa certo nível de arbitrariedade do que deve se pôr ou não como validade histórica. E isso, consequentemente, dever ter repercussões na "aplicabilidade" de sua própria teoria.

Se é verdade que Milton Santos desenvolve os principais mecanismos explicativos para o entendimento da condição técnica da "sociedade globalizada", sobretudo acerca daquelas formas empíricas de mediação mais avançada da imbricação técnica-ciência-informação ("produção científica", "agricultura científica"), não é de todo gratuito as acusações sobre suas teorias de não serem elas tão "aplicáveis" (para usar o termo do próprio Santos) quanto as explicações do seu corolário imediato: relações produtivas com baixo nível de desenvolvimento do capital orgânico, que se efetiva no encontro entre as mais "avançadas técnicas" primitivamente destrutivas e as formas de trabalho mais precarizadas (da terceirização à escravidão). Santos chega mesmo a considerar a possibilidade de alguma forma de "antagonia" 
entre elas, dado o caráter "invasor" da técnica hegemônica, mas só para reafirmar depois o caráter "conciliatório e completar" de sua dialética: "Essa força invasora, combinada ao seu caráter sistêmico, é responsável por dois traços econômicos aparentemente antagônicos, mas realmente complementares" (SANTOS, 2008; p. 195).

As possibilidades analíticas pela contradição aparecem no plano da "aparência". Não apenas porque as vias de entendimento sobre as categorias que envolvem relações de produção e forças produtivas mais "primitivas" (valor e trabalho) foi se distanciando do núcleo central da teoria de Santos em seu processo de maturação intelectual na mesma intensidade com que também, por exemplo, se deslocava o conceito de "circuito inferior". Mas, porque as formas de inserção da contradição não se efetivam em sua plenitude, elas poderiam representar a própria negação do objeto afirmado: a técnica. Para os objetivos epistemológicos nesses termos, a contradição significaria um paradoxo. Daí se apresentam suas "limitações", por exemplo, para explicar como as relações de produção "mais primitivas" se desenvolvem necessariamente no seu corolário, lado-a-lado, numa assimilação negativa, com as mais avançadas técnicas científicas e informacionais.

Sem as observações de tais contradições, a suposição de "unicidade" confundida", tende a recair naqueles mesmos pressupostos mistificadores hegelianos e weberianos. O que se tem é que tanto em Milton Santos como na Geografia que majoritariamente dele se deriva como movimento crítico, a mediação que compõe a dialética tende a ser afirmativa e não rigorosa, porque elas oscilam entre uma dialética complementária e conciliatória, quando os objetivos e "aplicação" empírica da teoria são objetivados, e uma dialética idealista, quando os objetivos epistemológicos com a determinação das "unicidades" e das "uniões ininteligíveis" se sobrepõem para a invalidação de categorias concorrentes no seio da crítica geográfica. Dessa forma, o que pode sobrar para a crítica? Ou se cai num relativismo vazio, ou numa positivação forçada das categorias que se pretendem eminentemente geográfica.

\footnotetext{
74 “Com a emergência do período técnico-científico, no imediato pós-guerra, o respectivo sistema técnico se torna comum a todas as civilizações, todas as culturas, todos os sistemas políticos, todos os continentes e lugares" (SANTOS, 2008; p. 192).
} 
4.2 - O papel (ausente) da autocrítica

No famoso texto A Geografia Está em Crise. Viva a Geografia! $!^{75}$, publicado na ebulição de 1978, Carlos Walter Porto Gonçalves alerta que, diante dos sinais da crise capitalista, seria necessária uma resposta positiva e afirmativamente teórica dos geógrafos em torno da proposição de uma "Geografia da Crise", para que assim não fossem "levados de roldão pela crise da Geografia" (1978; p. 06). As preocupações de Gonçalves não se diferenciariam muito daquelas levantadas, também em 1978, por Milton Santos sobre a necessidade de superar a postura "narcísea" dos geógrafos para com a geografia, e aquelas outras apontadas posteriormente por Antônio C. R. Moraes e Wanderley M. da Costa acerca dos riscos da "autofagia da crise". Ou como ainda observaria Armando Corrêa da Silva: "ignorando a crise da Geografia, os geógrafos deixavam-se levar pela crise, apesar dos protestos de alguns" (1984; p. 76)

À primeira vista, o título do texto de Gonçalves parecia sinalizar para um sedutor convite do repensar a Geografia a partir das possibilidades do desenvolvimento crítico substanciado pela própria crise interna da ciência. O pressuposto é de que estaria em sua própria crise os fundamentos de sua crítica, os quais, consequentemente, criariam as possibilidades de repensar os objetivos da Geografia, não a partir de sua luta afirmativa e disciplinar, posta pela "necessidade epistemológica", que tendeu a positivar a crítica em uma cristalização de estrutura conceitual e categorial pretensamente geográfica, mas a partir de sua continua autorreflexão e autocrítica. A autocrítica perecia ser, assim, o motor da própria crítica social.

Isso pareceria óbvio também para Ariovaldo U. de Oliveira, para quem, como também já citado, o movimento de renovação haveria abraçado com tanta intensidade a necessidade de apresentar a "descoberta do novo" $" 76$, pela busca do objeto, que poderia ele cair no deslocamento da necessidade da própria autocrítica. Isso levaria aos mesmos riscos positivistas, tão objetivamente denunciado pela renovação crítica.

A autocrítica apareceu como a necessidade primeira. Mas como entender a história de forma autocrítica? Gonçalves parece concordar que a leitura historicista, etapista e evolucionista, que colocaria a "visão homem-terra" ou "ecológica", a "visão regional" ou "estudo da área" e a "visão espacial" (assim, em sequência linear) "pouco ou quase nada esclarece sobre o problema do desenvolvimento e da natureza das crises do pensamento

\footnotetext{
${ }^{75}$ GONÇALVES, Boletim Paulista de Geografia, 1978.

${ }^{76}$ Alusão à famosa frase de Milton Santos posta em Por uma Geografia Nova: "o novo não inventa, descobrese" (2002; p. 18)
} 
geográfico" (1978; p. 08). A autocrítica aparecia, desse modo, como uma necessidade lógica e cotidiana, e não ao "passado". Deveria estar ela, a formulação científica de crítica, inserida em sua condição histórica ("no caso da sociedade de classes, é de onde emanam os antagonismos através dos quais a história se move" ${ }^{77}$. Observa-se, portanto, na proposta de leitura crítica da história geográfica a necessidade de se relacionar à autocrítica (uma crítica interna e permanente) uma crítica histórica dos "antagonismos" de classes. Mas até que ponto a autocrítica seria motivada pela busca das suas próprias contradições internas do seu exercício de reflexão na mesma intensidade com que deveria ser buscada as contradições históricas (“externas") presentes nos "antagonismos" de classes? Este problema, no entanto, não chegaria a ser observado por Gonçalves que, como outros já apresentados, não conseguiria ir além da solução epistemológica; paradoxalmente posta como a própria solução da mesma crise que, pelo sedutor título, parecia nutrir a Geografia de estímulo:

Avançamos a concepção de que tais crises de hegemonia não constituem somente crises teóricas e metodológicas de uma determinada visão da Geografia, mas sim crises que estariam subjacentes a essas questões; para que uma abordagem epistemológica se faz necessária (GONÇALVES, 1978; p. 11)

Como visto, o "rigor" científico no tratado da dialética não apareceu como necessidade tão imediata como aquele requerido perante o estabelecimento das categorias e conceitos para a nova estruturação epistemológica que fundamentaria o espaço. A "necessidade" do objeto se antecipou ao seu tratado dialético como, para que assim fosse, justificava Santos: "Desgraçadamente, porém, de todas as disciplinas sociais, a Geografia foi a que mais se atrasou na definição do seu objeto e passou, mesmo, a negligenciar completamente este problema" (2002; p. 144). Isso não apenas apareceu como necessidade imediata e lógica, para encerrar os longos debates sobre a metodologia que se fazia internamente na disciplina desde os primeiros sinais de esgotamento da chamada geografia tradicional ${ }^{78}$, mas também como resposta a sua própria crise: a necessidade afirmativa do objeto como garantia em si de cientificidade da própria crítica. Embora a definição correta do método dialético (ou do "método marxista") tenha mesmo aparecido como o "ponto de partida" (COSTA \& MORAES, 1984), não o foi de outra forma senão a partir de sua própria submissão perante a necessidade de positivação do objeto.

\footnotetext{
77 GONÇALVES, 1978; p. 09.

${ }^{78}$ Em discordância, citará Milton Santos o geógrafo americano Hartshorne: "Um dos geógrafos mais influentes do Estados Unidos pelo vigor de sua vocação como teórico, Hartshorne (1939, p. 374), asseverou que 'a geografia deveria ser definida antes pelo seu método próprio e particular de aproximação ou de enfoque do que em termos de seu objeto" (2002; p. 144).
} 
A contradição, como motor da dialética, não apenas tenderia a ser exilado do exercício teórico geográfico como elemento de "filosofismo metodológico", mas também para a composição de sua própria autocrítica. E isso se observa a partir da forma com que sua própria histórica é interpretada. Seja como "salto epistemológico" (MOREIRA, 1994b), seja como "geografia nova" (SANTOS, 2002), seja como “crítica e radical” (MORAES, 2007), é sempre tentado a exaltar os elementos de descontinuidade, ou de "ruptura", com que as perspectivas do "passado" se basearam: "essa postura crítica e radical, frente à Geografia existente (seja a tradicional ou a pragmática), a qual será levada ao nível de ruptura do pensamento anterior" (MORAES, 2007; p. 119).

Concebida dessa forma, a "necessidade epistemológica" de definição do espaço já sairia "na frente" diante da necessidade do seu debate dialético e autocrítico, pois sua autojustificação já seria garantida como a própria necessidade histórica (e "natural") de desenvolvimento teórico. Isso não só permitiu o deslocamento dos debates sobre a dialética do interior da renovação sob a justificativa se ser ele assunto da "metafísica", o que acabou, por sua vez, viabilizando uma dialética onde fosse possível assimilar autores como Durkheim e Weber, como visto acima, como também permitiu também o deslocamento das contradições internas inerentes ao exercício epistemológico que, inclusive, deveria identificar os limites do embrião estruturalista inerente ao projeto da renovação.

Os limites da crítica pretendida pelo movimento da renovação não puderam assim serem identificados porque em sua própria interpretação não havia se expressar a contradição, diante dos esforços em se criar uma pretensa unidade crítica mediados por uma dialética conciliatória de perspectivas, por vezes, conflitantes e contraditas. A unidade presumida passa a ser mediada pela não contradição. A "via epistemológica" ganhava assim sua legitimidade como determinação histórica ao mesmo tempo em que seus conflitos eram apagados de sua história. Milton Santos (1982) chegou até mesmo a considerar os possíveis elementos de continuidade que poderiam representar limitações para a renovação crítica ("fenomenologia positivista e humanismo individualista", "neoculturalismo, neodarwinismo, sociobilogia", "seduções e riscos do enfoque marxista"), mas jamais poderia identificar o estado da natureza conciliatória de sua dialética pelo próprio ideal estruturalista contido em sua proposta.

A autocrítica, assim, se tornaria inviável pelos próprios mecanismos mistificadores com que a crítica pretendida é concebia historicamente. Rosa Luxemburgo, por exemplo, já havia esbarrado nos limites da "legitimação histórica" do discurso científico dentro do próprio marxismo. Declarava ela acerca dos "epígonos" que fizeram "campanha oficial” contra suas 
"Contribuições ao Estudo do Imperialismo"79, especificamente em "Anticrítica": "a melhor maneira de garantir seu vigor é dedicar-se a autocrítica e atentar para a História" (1984; p. $180)^{80}$.

Em relação à Geografia, se é notório que a autocrítica que se fez, isso desde Moreira (1994), Moraes (2007) e Santos (2002) - para citar os mais influentes na renovação crítica - foi dirigida com toda força contra o empirismo da geografia francesa, o imediatismo da geografia regional e o tecnicismo da geografia quantitativista pela importância e efervescência da denúncia no seu contexto de crise, o saldo dessa autocrítica no entanto não continuou vigorado no seu debate horizontal, entre as propostas que estavam sub judice da Geografia Crítica.

Pela própria necessidade de afirmação política e ideológica, a crítica teórica reconheceu muito mais suas possibilidades (isso explica o esforço de Ruy Moreira, por exemplo, em buscar as "convergências" e conciliações entre as perspectivas) do que seus limites, diante das bases epistemológicas e metodológicas com que a dialética (o método escolhido) deveria se enquadrar perante a tradição geográfica requerida. A necessidade de entender as mediações (a dialética necessária) entre as categorias já concebidas (da Geografia: espaço, paisagem, lugar, território, região, etc.; da dialética: contradição, totalidade, mediação, etc.) estaria subjugada à necessidade de sua formalização em um "sistema coerente" necessário para a definição do objeto (o espaço). Ficaria claro mais tarde que a renovação da crítica traçou por linhas não equitativas a intensidade entre os esforços de ressignificar os conceitos tradicionais de suas próprias categorias em detrimento de sua articulação dialética e contraditória. O que, paradoxalmente, cairia naqueles mesmos equívocos apontados por Durkheim e concordados por Santos: "o erro de trabalhar mais ou menos exclusivamente com os conceitos do que com as coisas" (SANTOS, 2002; p. 143).

Disso tudo resulta, ainda que seja o "espaço social" a realidade em a ser objetivada pela crítica geográfica, a natureza dessa crítica não conseguiria superar totalmente o ideal positivista para com a ciência; a de conceber as disciplinas como "parcela" do todo social. Onde muito além conseguiu chegar se estancou nas soluções estruturalistas sobre a interdisciplinaridade. Por exemplo, diria Santos contra Émile Durkheim, sobre a impossibilidade do estabelecimento dos "domínios muito precisos" para cada ciência: "mas se não é capaz de reconhecer o domínio de uma ciência, pode cair naquilo que [o mesmo] Durkheim falava em relação à sociologia, o perigo de ver sua esfera de ação estender-se muito ao infinito" (2002; p. 146). Entre os “domínios muito precisos" e o "infinito", proporia Santos sobre a coerência sistêmica da

\footnotetext{
${ }^{79}$ Subtítulo de sua principal obra: A Acumulação de Capital.

${ }^{80}$ LUXEMBURG, Rosa, Anticrítica, São Paulo, Abril Cultural, 1984.
} 
disciplina geográfica que "também seja formulado a partir do conhecimento prévio da parcela da realidade social considerada como uma totalidade menor. Essa parcela ou aspecto da vida social assim considerado vem a ser o objeto de cada disciplina particular" ${ }^{\prime 1}$. E entre o "particular" científico e a "totalidade" social, a solução interdisciplinar: "o que se quer conhecer, por intermédio das ciências particulares, são os diversos aspectos da realidade que compete estudar globalmente" $" 82$.

Nesse ponto é que se observa uma nova tendência de inversão mistificadora na mediação entre ao exercício epistemológico e o exercício da crítica social (que agora tendem a se dicotomizar e até mesmo se contradizerem). Isso não apenas porque sua autocrítica se tornara impossível (dado os compromissos afirmativos da crítica), mas porque se justifica neste processo a ausência de uma dialética fundamentada na contradição (e suas últimas consequências). Posta como "o salto", como mais "desenvolvida", a crítica epistemológica da Geografia Nova, e seu caráter exclusivamente afirmativo, não haveria de promover sua própria "anticrítica". Pois isso significaria um retorno ao debate metodológico "infinito" que, por sua vez, passou a ser identificado supostamente com o debate "narcísio" já em vias de superação.

Para isso as questões sobre as contradições internas precisariam ser abordadas, pois se é correto que a autocrítica da chamada Geografia Crítica em muito se debruçou às outras geografias do passado será, no entanto, suficiente a crítica de sua própria história? Mas quão "madura" deveria ser a história que permitisse sua avaliação como "história pronta", encerrada na forma de objeto efetivo para sua autocrítica? Como estabelecer tal objeto em sua própria validade histórica, sobretudo quando se entende a história como um processo de rupturas, é certo, mas ainda carregadas de continuidades prementes?

Ruy Moreira, em "E Assim se Passaram Dez Anos", texto originalmente escrito para o Encontro Nacional de Geógrafos de $1988^{83}$, relembra os autores e as obras seminais, aponta um "roteiro de rupturas" e faz um "balanço" para aquele momento: “A progressão no conceito novo do espaço, que constituiu-se no vetor da geografia renovada, na medida que foi proclamado seu objeto, foi por força disso limitada" (2000; p. 27). No entanto, para Moreira, a limitação estaria em questões ainda não assimiladas, ou não "conciliadas", como "temas que ficaram de fora" pelo movimento: “A requalificação da linguagem" e o "reentranhamento da natureza". O referido texto vinha na sequência dos esforços de Aramando Corrêa da Silva em acompanhar a

\footnotetext{
${ }^{81}$ SANTOS, 2002, p. 147.

82 Ibid., p. 144.

83 "A década, todavia, passou em branco no encontro da AGB. E o destino deste texto foi a gaveta." (MOREIRA, Ruy, "E Assim se Passaram Dez Anos", GEOgraphia - Ano. II - No 3 - 2000, p. 27).
} 
maturação da crítica geográfica. Tais esforços estão materializados em texto de grande empenho teórico e empírico, e aqui já citado: “A Renovação Geográfica no Brasil - 1976/1983 (As Geografias Crítica e Radical em Uma Perspectiva Teórica)", em que se conclui que haveria três questões a serem resolvidas: "A Questão das Categorias”, "A Questão do Sujeito", “A Questão Política” (1984). Diante de tais lacunas, Milton Santos, em entrevista realizada no ano de 2000 (tamm já citado), adverte que o movimento da renovação crítica "não chega a ser [história], é muito recente" ${ }^{\sharp 4}$, ainda que já tivesse decretado os limites de sua efetivação em entrevista anterior, no ano de 1993: "no meu modo de ver, essa busca teórica foi, de alguma maneira, atrofiada" (SANTOS, 1996; p. 171) ${ }^{85}$. Entretanto, mais recententemente, ao prefaciar um dos famosos livros símbolos do movimento da renovação crítica, "Geografia: Pequena História Crítica", de A. C. R. Moraes, Manoel Fernandes Sousa Neto (2007) sugere, a partir do livro-símbolo, uma certa história conformada: "deixando de ser um livro sobre a história da disciplina para ser parte dessa história" (2007; p. 15$)^{86}$.

De qualquer modo, o vai-e-vem da história como objeto, conformado ou não para sua análise crítica, pode remeter a uma falsa polêmica, pois se trataria de debruçar sobre as questões da maturidade do tempo para sua conformação histórica, sem ainda necessariamente objetivar a identificação das contradições e limites, seja na sua epistemologia, seja na sua história, seja na natureza de sua crítica. Isso implicaria em afastar da análise as possiblidades de interpretálas a partir de sua linearidade, como Gonçalves havia recomendado, embora não efetivado. Dessa forma, tratar-se-ia de colocar o movimento da renovação crítica contra ele próprio, contra a própria crítica, buscar suas contradições para experimentar seu movimento, entender a natureza de sua crítica e seus limites. Afinal, seria o acúmulo de sua autocrítica que a concederia efetividade histórica, como síntese contraditória, e não meramente acumulativa; ou por meio da exaltação de seus feitos teóricos positivos transcorridos e "somados" no tempo, por mais críticos e bem intencionados que pretendiam ser.

Eliseu Savério Spósito ${ }^{87}$, por exemplo, havia identificado que em todas as leituras que se debruçaram sobre a temática da Geografia Crítica $^{88}$ seria possível observar o caráter

\footnotetext{
${ }^{84}$ SANTOS, Milton, "Entrevista”, In: SCARIM. Paulo César, Coetâneos da Crítica: Contribuição ao Estudo do Movimento de Renovação da Geografia Brasileira (Caderno de Anexos), São Paulo, Universidade de São Paulo (Dissertação de Mestrado), 2000.

${ }^{85}$ Tal entrevista, originalmente concedida à Revista Margem e publicada no ano de 1993, pode ser encontrada no livro já citado: SANTOS, Técnica, Espaço, Tempo, 2013.

${ }^{86}$ SOUSA NETO. Manoel Fernandes. “Uma Pequena História da Crítica no Brasil (apresentação)”, In: MORAES, Antônio Carlos Robert, Geografia: Pequena História Crítica, São Paulo, Annablume, 2007.

87 SPOSITO, Eliseu Savério, "Pequenas Argumentações para uma Temática Complexa.", In: Elementos de Epistemologia da Geografia Contemporânea, Curitiba, UFPR, 2002.

88 "Vários textos já publicados abordam essa temática por vários ângulos (ANDRADE, 1987; CAPEL, 1981; CLAVAL, 1993; CORRÊA, 1989; DI MÉO, 1991; GREGORY, 1996; LENCIONI, 1999; MENDONZA et al.,
} 
historicista com que a crítica se vinculava ao "passado", baseando em enquadramentos e em uma linha histórica sequenciada ("o dimensionamento temporal dos acontecimentos, principalmente do passado para o presente, procurando se enquadrar, sempre, a discussão do pensamento geográfico em uma linha de tempo estabelecido pelo autor") ${ }^{89}$. No entanto, esclarece Spósito, não se trata de "erro" de interpretação da história, na medida em que os autores por ele citados se mantiveram "atentos aos fatos e as ideias que representaram", relegando, assim, para outros autores (estes por sua vez não identificados) o caráter enfadonho com que a história é interpretada. Como os demais, Spósito reconhece a condição a-crítica do historicismo dominante inclusive no movimento de renovação crítica, mas não identifica a ausência da contradição nem da autocrítica. Em contrapartida, e diferente dos demais, põe no lugar da história linear uma história das ideias: desde a "discussão da linguagem", passando pela teoria do conhecimento até chegar na "leitura dos paradigmas e emprego do método".

As possibilidades afirmativas de uma crítica propositiva não aparecem, assim, por meio do acúmulo de sua anticrítica, tanto em relação ao seu objeto de estudo, o espaço (a forma de entender a realidade), como dela própria (a forma de se auto-entender). Isso significa, inclusive, que a possibilidade de melhor compreender as "outras" geografias do passado, já criticadas e postas como "superadas", também se encontra limitada. A história, concebida por esses meios, possibilita entender a totalidade dos elementos de continuidade, ou herdados a-criticamente, que a crítica geográfica, sintetizada pelo movimento de renovação, ainda preserva em seu interior. Sem isso não se torna possível a identificação dos limites da própria crítica pretendida. Por isso observa Lefebvre que, perante a necessidade de se buscar na história o fundamento da crítica, deve se dar partir do procedimento "regressivo-progressivo" 90 . Na verdade, Lefebvre incorporou aos seus objetivos específicos o que havia identificado em Marx sobre a necessidade de se buscar, a partir da autocrítica, o método de interpretação histórica.

Especificamente em Marx essa era a própria forma de se buscar na história a referência para crítica: “A religião cristã só foi capaz de contribuir para a compreensão objetiva das mitologias anteriores quando sua autocrítica estava, por assim dizer, [potencialmente], pronta" (2011; p. 59). Sobre a economia política, afirmaria em seguida que "a Economia burguesa só chegou a compreensão da sociedade feudal, antiga e oriental quando começou a autocrítica da sociedade burguesa" ${ }^{91}$. E especificamente sobre a economia burguesa, Marx observa que

1982; MONTEIRO, 1980; MORAES, 1981, 1986 e 1990, MOREIRA, 1982; PEREIRA, 1989; QUAINI, 1979 e 1983; SANTOS, 1978; entre outros" (SPOSITO, 2002; p. 63)

${ }^{89}$ Id., Ibid.

${ }^{90}$ LEFEBVRE, Henri, Lógica formal/Lógica dialética, $3^{\mathrm{a}}$ ed, Rio de Janeiro, Civilização brasileira, 1983.

${ }^{91}$ MARX, 2011, p. 59. 
somente em Adam Smith, por exemplo, é que aparece a forma desenvolvida e moderna do conceito de trabalho abstrato, ou seja, independente de suas formas concretas ou passadas. Essa foi, para Marx, uma transição do pensamento possível somente a partir do momento em que a própria Economia burguesa tornou-se alvo da própria crítica econômica, e não somente a partir do acúmulo do seu conhecimento. Apesar disso, ressaltaria Marx a extrema dificuldade com que isso se dá: "o fato que o próprio Adam Smith ainda recair ocasionalmente no sistema fisiocrata mostra como foi difícil e extraordinária essa transição" ${ }^{92}$.

Com relação à analogia entre religião e economia política, o que se pode extrair para a análise histórica da crítica geográfica pretendida pela renovação? Se, como observa Marx em analogia com a história da religião, as mitificações passadas só se tornariam potencialmente perceptíveis a partir dos esclarecimentos de suas próprias mistificações atuais, o que se deve buscar quando se objetiva a crítica social da geografia seriam seus próprios elementos mistificadores. Não somente em relação ao "passado" (que assim posto nem seria tão passado assim), mas em relação a natureza em si da crítica.

Ainda que o recurso à analogia possa também significar um recurso mistificador (sobretudo entre ciência e religião) quando não se aclara seus últimos objetivos, o que deve ser exaltado é o rigor ao método pretendido para se chegar na crítica: a dialética. A ausência da autocrítica, pela ausência da contradição, com que a história da Geografia Crítica passa a ser lida, implica na ausência de três considerações fundamentais que se põem, assim, como limitantes ao desenvolvimento da crítica social pretendida: $\left(1^{\circ}\right)$ que há na história a condição da contradição: “determinatio est negatio" 93 (como citava Marx nos momentos de concordância com o procedimento dialético hegeliano). Somente a partir dela, da contradição, como foco objetivo da análise é que se torna possível superar a visão linear que preambula as "conquistas" do movimento da renovação crítica. Isso pressupõe a autocrítica da crítica pretendida como forma de ser da própria crítica, e não puramente seu avanço, ou "salto", epistêmico. Novamente, como diria Fausto, “assumir a contradição para não nos contradizer" (1983; p. 33); (2º que o avanço epistêmico, ou as conquistas teóricas, no momento em que ela não reflete uma crítica social, em detrimento de sua autoafirmação científica, pressupõe que a dialética necessária à práxis foi quebrada e, como tal, a proposição da crítica epistêmica tende "a revelar perfis problemáticos - de fato até as contradições - de soluções muito estreitamente vinculados àquele grupo social” (MÉSZÁROS, 2008; p. 42), ou, no caso, o grupo social dos geógrafos. Sobre isso

\footnotetext{
92 Ibid., p. 57.

93 "Essa identidade [negativa e contraditória] de produção e consumo vem a ser a mesma coisa que a proposição de Spinosa: determinatio est negativo" (A determinabilidade é a negação) (2011; p. 45).
} 
há de se reconhecer que a preocupação com o "status" da disciplina não ocorrera somente em paralelo à crítica social, mas também e em grande medida concorreu contra ela. Diria Armando C. da Silva sobre a importância para o movimento da renovação: “[...] os geógrafos descontentes com o status oficial de sua disciplina haviam apenas esboçado um movimento de elaboração teórica. Mas é a partir de 1979 que começam a surgir as primeiras promessas dessa elaboração" (1984; p. 78); (3) que a possibilidade de conformação dos "perfis problemáticos" no movimento de renovação crítica-geográfica poderia se dar pela incapacidade de manter, na esteira da reformulação epistêmica, laços sólidos com a crítica social geral (da filosofia e das ciências sociais), sobretudo acerca das formas de introdução da dialética e da contradição na manipulação de suas categorias e conceitos.

[Arrefecimento da crítica na maturação teórica]

Diante disso, é preciso pôr em questão se a suposta autonomia epistêmica pretendida, ao mesmo tempo em que objetivava conceder independência teórica à Geografia, contraditoriamente passou a significar seu próprio isolamento discursivo perante a crítica social. Ou a que pé chegou aquela bifurcação em duas tendências que, já no início da década de 1980, identificava Silva: “o daqueles que consideravam importante a participação política como assalariado do conhecimento e o daqueles que desenvolvem sua práxis através da teoria" (1984; p. 78).

Por exemplo, sobre a natureza da crítica contida em "Por Uma Geografia Nova", livro embrião da renovação brasileira, assim destaca Ruy Moreira, depois de considerar o conteúdo "ético-finalista" contra uma Geografia secularizada, crítica essa contida na primeira parte da obra:

Toda a segunda metade de Por Uma Geografia Nova, a partir do capítulo X, é rica massa crítica. Idem os capítulos sobre a espacialidade diferencial, de $A$ Geografia Serve Antes de Mais Nada para fazer a Guerra. E, mais ainda, toda a reflexão analítica sobre a alienação do trabalho, do Marxismo e Geografia [de Máximo Quaini] (MOREIRA, 2000; p. 37).

O que Moreira observa na parte conclusiva da obra embrionária de Milton Santos seriam as vinculações do autor a um conjunto de categorias intimamente ligadas a uma crítica social universal fundamentada, basicamente, na perspectiva da crítica do trabalho, como aquela já levantada por Quaini. Ou como diria o próprio Santos acerca dos objetivos de sua crítica: “É 
chegado o tempo em que uma nova geografia pode ser criada, porque o homem começa, um pouco em toda parte, a reconhecer no espaço trabalhado por ele uma causa de tantos os males que o afligem no mundo atual" (2002; p. 262.)

Sobre "A Natureza do Espaço", livro de maturidade de Milton Santos, consideraria também Moreira (1999) ${ }^{94}$ : a questão da totalidade como resultado de uma dialética de “interações” autoprodutiva (“A totalidade tão buscada pelo geógrafo é não mais então que uma dialética de diversidade-unidade [...], numa dialética de trocas de posição constantes sobre a qual a ação humana intervém e cujo resultado é o lugar" $)^{95}$ e, em decorrência dela, as possibilidades que se abrem para o "feliz resgate" da teoria clássica lablachiana sem, supostamente, deixar de ser referência para a nova "relação homem-meio" (“ [...] território e técnica integralizando-se num meio técnico (expressão que sugere um feliz resgate do gênero de vida de La Blache, numa ótica ao mesmo tempo clássica e nova da relação homem-meio) $)^{96}$, além da necessária solução epistêmica ("Condição epistêmica, Milton Santos reolha por conseguinte a técnica, ao tempo que geograficamente a reinventa [...]. Técnica e território vivendo uma relação recíproca de constituição") ${ }^{97}$.

De novidade, ainda conforme o entendimento de Moreira, é a própria natureza da solução epistêmica já que o livro de Santos se fundamenta na centralização da técnica, e na fundamentação do seu estatuto ontológico, a partir de sua mediação com o território para a corporificação de uma teoria social (“A novidade corre por conta do papel crescente que a técnica, mas, sobretudo, o território, na sua relação ontológica com o espaço e interativa com a técnica, vão adquirir na trajetória da teoria do espaço enquanto uma teoria social [...]") ${ }^{98}$. Do ponto de vista político, observa Moreira que, sendo a proposta de Santos uma teoria espacial e fundamentada em uma teoria da "ação" do/no lugar - uma teoria propriamente geográfica -, objetivar-se-ia ela contra o próprio objeto no sentido de revelar sua "intencionalidade" como síntese da própria relação sujeito-objeto, que seria a essência mesma do objeto analisado (“A ação é quem lhe dá [ao objeto] essa ligação e sentido, dado o seu caráter de intencionalidade, uma essencialidade portada pela técnica na forma da divisão do trabalho e que liga ação e objeto numa relação de sujeito-objeto")"99. Daí que ao "afirma-se então como uma teoria do lugar"100 conseguiria ela, numa tacada só, resolver o problema da legitimidade epistêmica-disciplinar

\footnotetext{
${ }^{94}$ MOREIRA, Geographia, 1999.

${ }^{95}$ Ibid., p. 152.

${ }^{96}$ Id., Ibid.

${ }^{97}$ Id., Ibid.

${ }^{98}$ Ibid., p. 151.

${ }^{99}$ MOREIRA, 1999, 152.

${ }^{100}$ Ibid., p. 153.
} 
("rejuvenescer o imenso repertório vocabular perdido na dissolução das identidades") ${ }^{101}$ e reestabelecer o sentido da unidade sociedade-natureza como "discurso teórico da ação geográfica"102.

O potencial da "idéia-força" de Milton Santos, no sentido de oferecer uma solução a tão requisitada unidade geográfica, não haveria de ser a única que fez a interpretação de Moreira sobrepor suas virtudes em detrimento de qualquer possibilidade de reconhecimento dos seus problemas ou limites. O não reconhecimento na natureza conciliatória da dialética e a consequente assimilação a-crítica de relações amalgamáticas entre Durkheim, Weber e Marx, por exemplo, que resultam na própria teoria da ação do/no lugar; ou, do ponto de vista da ontologia, a relação entre autores inconciliáveis, como Lukács e Heidegger, para a composição de uma unidade teórica em prol de um estatuto ontológico; ou a posição do nível concorrencial com que a técnica se põe em relação ao trabalho como centralidade analítica em prol da "geograficidade" da leitura (mudança essa não percebida como descontinuidade em relação ao livro de 1978); e seus desdobramentos para o significado que a crítica assume ao admitir como referência teóricos que, como Habermas, compartilham sobre as teses do "fim do trabalho"; nem tão pouco os ressignificados sobre a natureza que a crítica geográfica passa a assimilar diante de tais questões até aqui levantadas... Estes não seriam apenas problemas “despercebidos" por Moreira diante da oportunidade de levantar um debate crítico sobre o livro de Santos, mas revelam também como que a solução epistêmica da crítica geográfica tendeu a ser admitida, implicitamente, como a solução da própria autocrítica, encerrando-a na sua própositividade.

Ainda sobre os limites de desenvolvimento da autocrítica, o ponto central "despercebido" é o deslocamento do trabalho de sua centralidade crítica-emancipatória nas ciências sociais e no período "embrionário" do movimento de renovação geográfica. Ou, como colocaria o próprio Milton Santos, num sentido inverso daqueles objetivos universalmente traçados em torno do trabalho, agora a partir de uma universalidade da técnica cheio de possibilidades existentes no lugar e, por sua vez, mediado pelo território: "É o lugar que oferece ao movimento do mundo a possibilidade de sua realização mais eficaz. Para se tornar espaço, o Mundo depende das virtudes do lugar. Nesse sentido pode-se dizer que, localmente, o espaço territorial age como norma" (SANTOS, 2008; p. 338). Em tal passagem, por exemplo, observase não apenas o redirecionamento para uma análise mais "tecnicamente" geográfica ("território", "lugar", "espaço", no esforço de inserção e legitimação da Geografia na 
centralidade da crítica social), mas a tendência de autonomização das forças que movem essas mesmas categorias eminentemente geográficas. Do ponto de vista geral, entre a obra embrionária e a de maturidade de Santos, tem-se ainda que o deslocamento do trabalho tendeu a significar o próprio deslocamento de sua substância contraditória - que se concretiza nas lutas de classes entre sujeitos a elas pertencentes, a partir do motor alienante do valor-capital (tal como sua condição destrutiva atual) - para uma forma de absolutização weberiana da racionalidade técnica e todas suas consequências mistificadoras da "racionalização da sociedade" que, desde a revolução industrial, avança de forma totalizadora até a efetividade do que passou a se chamar de "racionalização do espaço geográfico"103.

Exemplo significativo também pode ser apresentado em relação a Antônio Carlos Robert Moraes, outro autor importante da renovação da crítica geográfica que, conjuntamente a Wanderley Messias da Costa Ribeiro, em conhecida (e já citada) obra propositiva no início da década de 1980, assim justifica a opção por uma "Geografia Marxista" diante os objetivos de "transformar o mundo": "Para o marxismo, só a perspectiva de transformar o mundo fornece a possibilidade de compreendê-lo, só a visão crítica permite apreender a essência dos processos sociais, só a inserção no movimento propicia seu entendimento" (1983; p. 35). Em contrapartida, afirmaria em um momento mais avançado de sua maturidade teórica (2005), diante da proposição da "Geografia Histórica”, assumindo uma postura menos combativamente emancipatória e se direcionando para objetivos menos revolucionários ("cidadania plena, direitos assegurados, emprego, renda mínima, políticas sociais universalizadas e de qualidade [etc.], enfim, um horizonte de reivindicação que integram um projeto democrático de país"), assim assumiria: "Para tanto, temos que abandonar o ideal de buscar de imediato uma utopia celeste (o céu na Terra) e superar a desesperança do inferno do presente. É o que anima o caminho na trilha do purgatório..." (MORAES, 2011; p. 143) ${ }^{104}$.

Também no caso de Wanderley M. da Costa, coautor de "A Valorização do Espaço", apresentaria em texto mais atual, sintomaticamente intitulado Ciência, Tecnologia e a Crise da Geografia (2002) (105 $^{10 x}$ (to também já citado), o argumento de que um profundo problema de legitimação atual da Geografia estaria em sua forma problemática de se integrar aos setores mais avançados da ciência, "sobretudo da chamada "hard science""106. Neste texto específico,

\footnotetext{
103 "Já vimos como o movimento da racionalização da sociedade que marcou o século das luzes e o início da revolução industrial foi, pouco a pouco, ocupando todos os recantos da vida social e alcança, agora, um novo patamar, com o que podemos chamar de racionalização do espaço geográfico" (SANTOS, 2008; p. 331).

${ }^{104}$ MORAES, Geografia Histórica do Brasil, 2011.

${ }^{105}$ COSTA, GEOUSP, 2002.

106 Ibid., p. 01.
} 
Costa procede desenvolvendo uma interpretação de como se encontra o estágio atual de participação dos geógrafos nas questões de estratégia territorial do "projeto nacional", observando a perda da sua condição de "vanguarda e [do] domínio do próprio processo de inovação tecnológica". Observa Costa que essa seria "provavelmente a mais grave das evidências da crise atualmente vivenciada pela geografia"107. O autor, após identificar o projeto nacional com o "desenvolvimento e a justiça social do país"108, expressa em tom de lamentação os motivos que promoveu o distanciamento do geógrafo (e sua crítica emergida no movimento da renovação) do que consideraria como a "mais simbólica das instituições nacionais dos geógrafos brasileiros"109: o Instituto Brasileiro de Geografia e Estatística ("cometeu um dos seus mais graves equívocos políticos, ao deflagrar uma guerra que levou à longa agonia desse campo do saber no IBGE") ${ }^{110}$. Para Costa, à Geografia caberia o resgate de seus laços com o compromisso do nacional, via "conhecimento aplicado ao planejamento das políticas territoriais" "111, que visasse garantir o desenvolvimento "genuinamente" brasileiro, a partir de "parcerias com as empresas nacionais do setor [de tecnologias]" "112, para que assim pudesse contribuir com a "luta" e a "inserção das comunidades locais" em "redes nacionais e internacionais" ${ }^{\prime 13}$. Sobre o desenvolvimento da crítica, destaca Costa a necessidade do “inadiável engajamento" da Geografia às determinações técnicas atuais, de forma objetiva e prática, para que assim não caia, "sob o pretexto da crítica genérica"114, no seu próprio isolamento (“discursando sobre a revolução técnico-científica mas sem dominá-la, produzi-la e liderá-la, a geografia poderá ter reduzida rapidamente a sua importância como campo científico dotado de relativa autonomia e legitimidade") ${ }^{115}$.

Aqui se observa não somente a efetivação daqueles riscos mistificadores tensionados pela dialética conciliatória que envolve a teorização sobre a técnica presente em Milton Santos. O “mito da unidade orgânica”, denunciada por Mészáros (como mostrado acima), se apresenta em Costa não apenas pela "conformação dos imperativos" técnicos-científicos, mas por supor qualquer relação não contraditória entre "projeto nacional" dirigido pelo Estado, "planejamento territorial", "lutas" e "inserção de comunidades locais" em redes "nacionais, regionais e internacionais". Objetivar tal relação, em uma pretensa "conciliação", sem centralizar os

\footnotetext{
${ }^{107}$ Ibid., p. 03.

108 Ibid., p. 04.

${ }^{109}$ Id., Ibid.

${ }^{110}$ Id., Ibid

${ }^{111}$ Id., Ibid.

${ }^{112}$ Ibid., p. 07.

${ }^{113}$ Id., Ibid

${ }^{114}$ Id., Ibid

${ }^{115}$ Id., Ibid
} 
conflitos que necessariamente devem emergir diante de tal suposição, demonstra não apenas ingenuidade, mas uma perda de referência nos termos em si de uma crítica social em prol da defesa da Geografia e sua inserção no quadro geral das "hard sciences”. Posição essa cada vez mais fundada em justificações sociais não menos genéricas e mistificadoras como, paradoxalmente, aquelas mesmas denunciadas pelo próprio Costa: “é urgente um novo impulso criador destinado a iniciar a reconstrução e a reconquista do nosso específico aparato técnico, desta feita sob novas bases epistemológicas e um claro compromisso com o desenvolvimento e a justiça social do país" (2002; p. 04).

Se pode ser observado que entre esses exemplos, quantitativamente pouco expressivos, mas qualitativamente muito significativos para a conformação da crítica geográfica, o deslocamento total do trabalho e um arrefecimento da crítica social presente pode não ser fruto de mera coincidência. Mesmo em Milton Santos, que nem de longe pode ser identificado com a forma ingênua de assimilação entre técnica e política apresentada por Costa - ainda que sua dialética conciliatória sobre a técnica não permita a amarração crítica suficiente que impossibilite seu uso para tais fins não-críticos -, é possível observar um mecanismo mistificador, fruto da ausência da contradição, na sua sofisticada relação dialética entre técnica e trabalho. Entre essas categorias, a dialética conciliatória permite, e mesmo serve, para ocultar o caráter de "concorrência", ou conflito, entre elas, ao mesmo tempo que tende a afirmar, em prol do espaço, sua centralidade como solução epistêmica. É, por isso, providencial.

Entendido dessa forma, pode-se avançar a análise no sentido de buscar revelar dois problemas importantes que limitam a autocrítica. Primeiro: as amarrações científicasinstitucionais com que a crítica afirmaria haveria de ter uma equivalente fundamentação teórico-metodológico: a solução epistemológica e a dialética conciliatória. Segundo: como desdobramento do primeiro, o destino político que tende a crítica geográfica (mais "branda" conforme se "amadurece") não está somente determinada pela posição política dos geógrafos, mas tem ela também sua determinação teórica, ou na própria forma de como se dá o exercício epistemológico. Do ponto de vista do rigor da crítica, tem-se que a "frouxidão" com que as categorias passam a se mediar, de forma conciliatória, é uma importante condição que permite as mais variadas guinadas político-teórica (do revolucionário ao conservador), sem que para isso se abra mão do "sacro nome da dialética", ou da própria crítica. O resultado é a tendência da mais absoluta relativização do que seria crítica, dialética, emancipação, etc.

Nota-se nos exemplos citados que aquela crítica não admitidamente negada e fundamentada no trabalho - aquela baseada nos princípios abandonados de que "só a perspectiva de transformar o mundo fornece a possibilidade de compreendê-lo" - passa a 
representar um estágio primário diante da crítica do espaço, mais "desenvolvida" e "amadurecida" ao longo do tempo. Uma história da crítica se monta, então, a partir do que seria sua condição pré-crítica, como aquela vinculada à militância e ao engajamento políticotransformador, e a crítica efetiva, como aquela promovida pelo desenvolvimento e amadurecimento teórico-epistemológico.

Levantar tal questão poria em relevo não apenas o uso de mais um recurso mistificador que legitimasse por meio da história linear as virtudes do "salto epistemológico" (MOREIRA, 2007; p. 32), mas ainda uma tendência própria do movimento da renovação crítica: o caráter inconciliável com que a necessidade imperiosa da centralização de outras categorias "ainda fora de cena" (no caso, as “categorias espaciais") se relacionará com as categorias sociais que, diante das necessidades disciplinares assumidas, vão perdendo significado e influência dentro da própria crítica geográfica. Em desdobramento, assim também é quanto à tendência de orientação do foco discursivo da crítica que, em detrimento da reestruturação categorial e da necessidade de centralização ontológica do objeto geográfico, se desloca dos temas específicos da modernidade (“capital", “capitalismo", “classes", "valor", "Estado") para temas supostamente mais universais, típicos do humanismo pós-moderno, que variam desde questões sobre a "linguagem", a "ação", os "povos", até as questões culturalistas, como aquelas insinuadas por Costa.

Por isso que, retomando a questão anteriormente apresentada acerca da conformação histórica ou não da "Geografia Nova", se trata ela de uma falsa polêmica. A análise do movimento de renovação deve se voltar para a natureza da crítica pretendida e efetivada, e não apenas pela sequência histórica com que suas críticas "amadurecem". Afinal, elas podem significar nada mais que uma reorientação política do seu autor. Na medida em que se refere ao mesmo tempo a um processo de efetivação epistemológica, na forma da Geografia Crítica ou "Marxista", e de efetivação de uma crítica histórica-social, deve também se tratar de uma autocrítica contínua, na busca pelas suas próprias contradições, como a inicialmente tentada por Armando Corrêa da Silva. Ou seja, pelo que há de contraditório entre a efetivação epistemológica, uma positividade, e sua desconstrução (auto)crítica, uma negatividade contestatória.

O desenvolvimento da crítica a partir de sua contradição, entre a positividade epistêmica e a negatividade contestatória pode, portanto, ser não somente o caminho para o entendimento da urdidura da crítica geográfica tentada, mas a forma em si de como ela se efetivou. Ou seja, sendo fruto de um movimento contraditório, seria ela propriamente a síntese de uma contradição: a crítica sendo ao mesmo tempo sua anticrítica. O que se busca, por meio da 
autocrítica é seu "dissecamento" entre o que haveria de contradição no seu interior: crítica epistêmica versus crítica social. Isso representaria um caminho que apontaria como a crítica significou não somente uma positivação epistêmica em conceitos, categorias e teorias, mas o distanciamento até o ponto da sua própria negação enquanto crítica social.

Posto tal pressuposto, como ensina o legado hegeliano, considerando ser correto afirmar

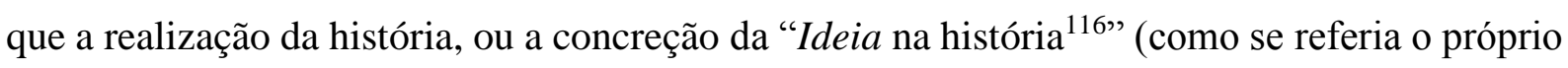
Hegel) só se efetiva inteligivelmente pela contradição, é possível (e necessário) estender sua lógica para a análise da história do pensamento geográfico em seu momento de disputa crítica (entre trabalho e espaço) para que, inclusive, se avance no desvendamento da dimensão nãocrítica da crítica pretendida. Ainda que, reconhecendo os limites do idealismo em Hegel e tendo como necessidade a sua "inversão" materialista, como proposta por Marx ${ }^{117}$, seja preciso reconhecer na história seu movimento dialético, não a partir do conceito em si e seu imanente negativo, tampouco de uma "pureza" dialética e idealista garantida pela pura afirmação da complementariedade, ou conciliação, entre teoria e prática (uma epistemologia crítica gerando, suficientemente e por si mesma, uma leitura crítica da realidade), mas a partir das contradições que se concretizaram entre o discurso e a prática, entre a epistemologia e a práxis emancipatória, em suma: entre o positivo epistemológico e o negativo contestatório. Para isso é preciso admitir os conflitos, como a forma real-concreta de expressão da contradição.

No caso da presente análise, pressupõe-se que entre a frente epistemológica e a frente social-política se estabeleceu um "hiato", em que se encontra certa intensidade de conflito, e até antagonismo, por mais frustrado que isso possa ser às pretensões de unidade (ou convergência) entre teoria e prática da "militância geográfica" herdada do período da efervescência de sua crítica. Isso pressupõe uma tendência do movimento de renovação, até certo ponto majoritária, que a necessidade do rigor crítico foi identificada positivamente com a necessidade de um rigor epistêmico, como se o segundo fosse necessariamente a garantia em si do primeiro.

\footnotetext{
${ }^{116}$ HEGEL, Georg W. F, A Razão na História: Uma Introdução Geral à Filosofia da História, São Paulo; Centauro, 2012.

${ }^{117}$ Marx se assumia “discípulo" de Hegel, dentro do contexto em que o "grande pensador" havia sido considerado um "cachorro morto" pela mesma intelectualidade de se beneficiara dos seus postulados, vinculados ao pensamento da nova classe reacionária: a burguesia. Sendo um hegeliano "invertido", admitia "a mistificação que a dialética sofre nas mãos de Hegel não impede, de modo algum, que ele tenha sido o primeiro a expor as suas formas gerais de movimento de maneira ampla e consciente. É necessário invertê-la, para descobrir o cerne racional dentro do invólucro místico" (MARX, 1983; p. 20 (v.1, t. 1)).
} 


\section{3 - A suficiência do "salto epistemológico"}

A questão de a Geografia ter se tornado "viúva do espaço", como denunciado por Milton Santos (2002; p. 118), relevou a necessidade de ter ela que se voltar para o conteúdo social do próprio espaço como o objeto de estudo. A disputa pelo objeto, o espaço, em detrimento de suas discussões "narcíseas" "118, passa a ser posta como a necessidade primeira da reorientação crítica, como assim concorda, por exemplo, Costa e Moraes, sobre o salto metodológico que representou o caminho entre o que era "temário" e o que se tornou "objeto" (1984; p.23) da análise geográfica. Em Moreira (2007; p. 32), para quem a crítica tenderia a passar de uma "denúncia ético-finalista" para "avançar" aos seus "fundamentos" também está contido o entendimento linear entre a necessidade de superação da dimensão negativa contestatória para se avançar na dimensão positiva epistêmica. É a efetivação do plano de garantia de que a sistematização das categorias inerentes ao espaço fossem a garantia em si da própria crítica social: "a coerência científica, que deve ser o objetivo final da reflexão, não pode ser obtido de outra forma" (SANTOS, 2002, p. 24).

Essa forma de considerar o alcance da estruturação interna e epistemológica como "avanço", ou "salto epistemológico", revela uma forma específica de entender a construção da crítica: uma militância epistemológica que parecia ser suficiente para a crítica geográfica, em detrimento de uma militância política supostamente imatura em termos teóricos. Daí que a fase da "denuncia ético-finalista", tal como seu significado militante-social e político, tende assim a ser posto como o "prelúdio", ou momento imaturo, da crítica geográfica: a negatividade contestatória amadurecendo e se efetivando posterior e necessariamente na positividade epistemológica.

O que tal consideração pode revelar ainda é que nela está pressuposta uma determinada forma, não somente de fazer, mas também de se ler o referido processo histórico, não mais pela dialética tão requerida, mas pela linearidade. A crítica pretendida como positivação epistêmica aparece, dessa forma, como a condição "madura", "superior", da condição contestatória negativa. Os perigos de tal empreitada teórica e interpretativa estão, logicamente, nos riscos de se desaguar em uma perda de perspectiva com a necessidade de condicionar a crítica (geográfica) às necessidades emancipatórias humanas reais identificáveis e historicamente objetiváveis em detrimento de um novo "teorismo academicista".

${ }^{118}$ SANTOS, 2002, p. 18. 
Milton Santos, por exemplo, tenta se resguardar de tal cilada positivista a partir da afirmação de um conteúdo político na empreita epistêmica: "quando alguém se dispõe a mostrar tais preconceitos, a tarefa científica se torna também uma tarefa política" ${ }^{119}$, além de considerar também o exercício da renovação científica como aquele que: "sempre equivaleu à tarefa da renovação das formas de pensar da sociedade e isso, em nossos dias, é talvez ainda mais válido do que no tempo de Galileu" (2002, p.24).

Ainda que não caiba neste momento o desenvolvimento da análise de como resolver o problema deixado pelo autor entre o desafio diante dos "preconceitos" arraigados na ciência e a forma de superá-los por dentro dela própria (sobretudo a partir da autoafirmação de um campo em específico) - já que os "preconceitos" científicos nunca serão puramente científicos, mas também condizente à disputa ideológica entre as classes antagônicas em determinada sociedade - vale ressaltar somente que os compromissos "não preconceituosos" do avanço científico devem ser inclusive mais fortes que os preconceitos da forma em si de fazer ciência, e do fazer sociedade, que nesse sentido, enquanto resguardada a necessidade de sua legitimação cientifica no rol da divisão hierárquica do trabalho (e do trabalho intelectual), é também expressão e reflexo afirmativo da sociedade dividida em suas classes antagônicas. Na ausência de um avanço prático da teoria que se pretende política - ao menos em sua autoafirmação -, de uma posição afirmativa e historicamente identificável no que concerne sua viabilidade concreta, o risco inerente a tal esforço epistêmico está na sua própria tendência mistificadora de tornar crítico aquilo que é meramente propositivo, como constatado em W. M. da Costa. Isso significa que o exercício epistemológico como tal está vinculado e inserido na própria condição histórica em que é proposta, seja no que tange a condição "pré-histórica" ${ }^{120}$ própria da sociedade de classes, seja na sua limitada condição disciplinar.

Sem tais considerações resta apenas uma história também linear, a partir do "discurso dos vencedores", como irá denunciar Vesentini (2009; p. 133) ${ }^{121}$. Mas, como observa Ariovaldo Umbelino de Oliveira, para quem já se mostravam claros os riscos com que os geógrafos cada

\footnotetext{
${ }^{119}$ A citação no seu interim: "Sabemos a que riscos nos expomos. Bertrand Russel dizia (1965, p.93) que 'qualquer doutrina dotada de alguma coerência é, seguramente, pelo menos em parte, penosa e contrária aos preconceitos correntes'. Quando alguém se dispõe a mostrar tais preconceitos, a tarefa científica se torna também uma tarefa política, porque os erros, às vezes deliberado, numa ciência comprometida, beneficia certos grupos de interesse" (SANTOS, 2002; p. 24)

${ }^{120}$ Ao afirmar que a sociedade burguesa é a mais desenvolvida dentre a sociedade classistas, Marx demonstra que, no entanto, é a partir dela que a "verdadeira história" humana criam suas bases materiais de existência. Tal raciocínio não está somente na deliberada crítica ao pensamento hegeliano sobre "fim da história", mas aponta também a monstruosa tarefa de superação de suas contradições e antagonismos, dentre eles a necessária vinculação de uma teoria que fundamente tal tarefa histórica: "Daí que com essa formação social se encerra a pré-história humana da sociedade humana" (MARX, 1982; p. 26)

${ }^{121}$ VESENTINI, Ensaios de geografia crítica, 2009.
} 
vez mais se enveredavam na empreitada pela definição do objeto para a conformação do "estatuto científico": "como bem lembra Caio Prado Jr., procurar resolver a questão do estatuto científico de uma disciplina pela pura e simples busca do objeto do conhecimento é, no mínimo, uma postura positivista". Por mais crítico e social que fosse a reorientação conceitual em torno do espaço, tratava-se, pois, de avaliar se tal empresa "coloca-nos novamente em uma situação delicada frente a realidade lato sensu de um lado e o segmento social representado pelos intelectuais, de outro" (OLIVEIRA; 1996; p. 66).

Ainda de acordo Ariovaldo U. de Oliveira, ao seu tempo já estavam sendo montadas as bases de um conflito pela crítica que, por sua vez, colocava em debate aquilo que se apresentava ainda como perspectiva: a importância da militância crítica-social na militância epistemológica. $\mathrm{Na}$ importância em se ater a tal unidade, já pressupunha certa cisão no seio da crítica. Tal cisão, por sua vez, era percebida por dois fatores de interpretação da teoria crítica:

O primeiro está ligado basicamente a uma busca, por dentro da própria geografia de uma concepção de espaço acrítica, que faz com que se vagueie desde o materialismo vulgar ao idealismo, sem que esta questão seja importante ou mesmo fundamental. $\mathrm{O}$ segundo está ligado a posturas alienadas numa busca pela dialética e mesmo, justiça se faça, pelo materialismo histórico, numa busca, a nosso ver, aparentemente cega pelo mesmo estatuto científico da geografia, que, certamente, levaria a situar-se na mesma posição que Caio Prado Jr. critica no marxismo de Althusser (OLIVEIRA, 1996; p. 67).

A pressuposição do conflito entre a empreitada epistêmica e a empreitada crítico-social advém não só dos posicionamentos ideológicos dos geógrafos envolvidos na renovação crítica sobre a questão da práxis, nem também se alarga ao ponto do debate sobre a teoria do conhecimento e as contradições com que as ciências modernas encaram a divisão do trabalho do conhecimento científico no capitalismo, como procede o próprio Ariovaldo U. de Oliveira $^{122}$. Embora tais problemas imanentes estejam estruturalmente contidos na forma moderna de fazer ciência, no caso específico do movimento de renovação crítica da Geografia sua concretude pode ser observada a partir do distanciamento paulatino de uma ideologia emancipatória, ou de uma teoria da superação capitalista, que foi cada vez mais sendo lapidada em prol do projeto disciplinar "dotado de condições de coerência e operacionalidade"

\footnotetext{
${ }^{122}$ Em seu texto já referenciado, Oliveira dedica um dos cinco capítulos para a discussão sobre "A questão da Divisão do Trabalho Acadêmico" fazendo um recorte estrutural da forma possível do fazer ciência sob a égide da divisão hierárquica do trabalho, tal como sua consonância classista, operada no capitalismo (OLIVEIRA, 1996; p. 68).
} 
(SANTOS, 2008; p. 21). Uma certa racionalidade metodológica tende a imperar, reforçando o suposto caráter autossuficiente do viés epistemológico em detrimento do viés crítico-social: “A segunda geração [de geógrafos críticos], por sua vez [...], preocupa-se muito mais com o método, com novos enfoques para analisar o "espaço", com o prestígio científico ou social" (VESENTINI, 2009; p. 132). 


\section{CAPÍtUlO 5 - A ORIGEM E A GÊNESE CONTRADITÓRIA DA CRÍTICA: DISPUTAS E CONFLITOS}

A construção teórica que fundamentou a crítica da Geografia foi "atrofiada". Assim observa Milton Santos, que, desde seu retorno ao Brasil na década de 1970, passaria a assumir a "liderança deste movimento". Tal afirmação decorrente de entrevista concedida pelo geógrafo, originalmente publicada na Revista Margem no ano de 1993, se refere às perspectivas de rebento da chamada Geografia Crítica ("No meu modo de ver, essa busca teórica foi, de alguma forma, atrofiada") ${ }^{1}$. Ainda segundo Santos, seu envolvimento em tal movimento (no Brasil) se deu por influência, em um primeiro momento, "através de um número do Boletim Paulista de Geografia da segunda metade da década de [19]70, quando geógrafos sem posto de comando utilizaram-se da revista para lançar o movimento". E em um segundo momento a partir de "um artigo de crítica da geografia quantitativa de Manoel Correia de Andrade" (1996, p. 170$)^{2}$.

Armando Corrêa da Silva também reconhece as raízes institucionais do movimento de renovação, especificamente a partir do Departamento de Geografia da Universidade de São Paulo: "Ele juntou esforços da sua área de Geografia Humana, aos da Associação dos Geógrafos Brasileiros, então seção regional de São Paulo, através do boletim Paulista de Geografia" (1984, p. 73). Orlando Valverde, por sua vez, destaca a horizontalidade com que o debate acerca da renovação se espalha pelas instituições nacionais, desde o interior de São Paulo até o Rio de Janeiro e Recife, todas elas "reatando" os "laços" de criticidade com a escola francesa de Geografia a partir, sobretudo, das "ideias de Jean Tricart, Michel Rochefort, Ives Lacoste [que] voltam a influenciar os jovens geógrafos" (1984; p. 17).

Por outra linha, destaca Antunes e Souza Neto o papel "predominante" da atuação dos estudantes (movimento estudantil) no processo da renovação, inclusive sendo fundamental para a "consolidação" da orientação epistemológica do que seria a "Geografia Crítica": "A compreensão desse processo faz-se plena a partir do entendimento das medidas e das maneiras pelas quais o Movimento Estudantil em Geografia foi responsável para consolidação do campo epistemológico da Geografia Crítica no Brasil” (2008; p. 88) ${ }^{3}$.

\footnotetext{
${ }^{1}$ SANTOS, Técnica, Espaço, Tempo, 2013; p. 161.

${ }^{2}$ Ibid., p. 160.

${ }^{3}$ ANTUNES, Charles da França; SOUSA NETO, Manoel Fernandes, “Os Estudantes, a Associação dos Geógrafos Brasileiros (AGB) e o Movimento de Renovação", In: Boletim Paulista de Geografia: 1978 + 30: AGB em Movimento, Volume especial, No 88, julho de 2008.
} 
Indo até mais longe, José W. Vesentini (2009), em caráter de “depoimento", ressalta que o movimento de renovação crítica da Geografia se deu, sobretudo, pela base social e política, para além das instituições universitárias: “a geografia crítica no Brasil - como também na França, segundo o depoimento de Yves Lacoste - não se iniciou nem se desenvolveu inicialmente nos estudos ou teses universitários". Continua argumentando o caráter não institucional da origem da crítica: "[...] tampouco no IBGE e muito menos nas análises ambientais ou nas de planejamento”. Para tanto, destaca a forma com que os professores do ensino básico - dentre eles os de Geografia - se envolviam nos contextos políticos no Brasil e na França, esta a mais importante referência europeia de onde originalmente emanavam as principais pautas políticas e epistemológicas. Tais pautas, ainda segundo Vesentini, decorriam dos movimentos contestatórios (como o maio de 1968, as lutas étnico-raciais e o movimento feminista, por exemplo) e das questões sobre imperialismo (como guerra do Vietnã e o subdesenvolvimento), ainda na década de 1960. No Brasil, alia-se a essa ebulição política internacional as questões nacionais acerca das lutas democráticas (contra a Ditadura Militar) e contestatórias (movimentos sociais urbanos e agrários) fazendo com que a década de 1970 oferecesse o terreno mais fértil para o desenvolvimento da crítica: "Ela se desenvolveu, a partir em especial nos anos 1970, nas escolas de nível fundamental (de $5^{\mathrm{a}}$ à $8^{\mathrm{a}}$ séries) e principalmente no ensino médio, o antigo colegial ou $2^{\circ}$ grau" (VESENTINI, 2009; p. 129).

Ainda que a escola de ensino médio não deixasse de ser instituição de reprodução do discurso geográfico oficial, tal como a universidade expressava natureza comum ${ }^{4}$, o fato de considerar (e, ainda segundo Vesentini, podia-se mesmo afirmar) que a crítica geográfica chega à academia pelo “"encontro’ ou diálogo desses professores de nível médio (ou de alguns cursinhos pré-vestibulares)" com alguns docentes, sobretudo da Universidade de São Paulo, dispostos a orientar teses e dissertações desses "professores militantes", revela que, do ponto de vista do discurso, haveria de supor certo nível de criticidade sendo emanado das tensões sociais para o plano acadêmico.

Tal movimento de criticidade, por sua vez em via de incorporação ao debate nas universidades, foi analisado por vários autores que se dispuseram à leitura acerca da origem da crítica geográfica. Como destaca Ruy Moreira, "Nos vários cantos do país movimentos de crítica e renovação, espontâneos, difusos e, portanto, sem hegemonia nacional vinham

\footnotetext{
4 “A geocrítica no Brasil, portanto, se iniciou como um esforço, por parte de alguns docentes, em superar (o que não significa abandonar totalmente) a sua tradição, a sua formação universitária, aquilo que as universidades diziam que "deveria ser ensinado"” (Ibid., 119).
} 
acontecendo" (2007; p. 24) ; Antônio C. R. Moraes reforça, a respeito da Geografia Crítica, de não se tratar de um movimento "monolítico, mas, ao contrário, de um agrupamento de perspectivas diferenciadas" (2002; p. 126) ${ }^{6}$; Luis Lopes Diniz Filho, acerca das questões que envolvem o termo "crítica" à unidade de um movimento tão difuso, acrescenta que "entre o final dos anos 70 e início dos 80 seria apenas 'uma certa criticidade', isto é, um espírito crítico na análise da produção geográfica realizada até então e dos problemas da sociedade capitalista $(2003 ; \text { p. } 308)^{7}$.

As observações sobre o caráter fragmentário com as "críticas" que emanam das contradições do movimento real da sociedade capitalista feita por geógrafos "sem posto de comando" é comumente avaliada como um momento prévio da crítica; decomposto em críticas parceladas e fragmentárias, e em via de sistematização pela Geografia acadêmica. A própria forma com que a principal obra de influência para o movimento ("A Geografia, isto serve, em primeiro lugar, para fazer a guerra", de Yves Lacoste $)^{8}$ passa a ter seu caráter de "ensaiopanfleto" - caráter esse assumido pelo próprio autor frente aos objetivos da crítica em torno de uma postura militante e teórica - reduzido à mera forma denunciativa e puramente ideológica ${ }^{9}$ evidencia a tensões pela preferência por uma determinada forma de crítica geograficamente sistematizada. Soam daí aspirações e pretensões de "cientificizar" o discurso geográfico, com uma proposta de estruturação "interna" e autônoma, um sistema epistemológico próprio, com o propósito de "superação da crítica ideológica", por uma "Geografia nova".

Como observa o próprio Milton Santos, sobre o caráter "fragmentário" e "parcial" com que a Geografia havia inserido a lógica de um tempo em que "a significação das coisas experimentam uma mudança praticamente revolucionária": "desde a fundação do que historicamente se chama Geografia Científica, no fim do século XIX, jamais nos foi possível construir um conjunto de proposições baseadas num sistema comum e entrelaçado por uma lógica interna" (2002; p. 18).

A necessidade de construção de uma estrutura epistemológica própria e autônoma se confunde com a necessidade de desenvolvimento da própria crítica em si às contradições da

\footnotetext{
${ }^{5}$ MOREIRA, Pensar e Ser em Geografia, 2007.

${ }^{6}$ MORAES, Antônio Carlos Robert, Geografia, pequena história crítica, São Paulo; HUCITEC, 2002.

${ }^{7}$ DINIZ FILHO, Luis Lopes, “A Geografia Crítica Brasileira: Reflexões sobre um Debate Recente”, Geografia (Rio Claro), Rio Claro (SP), v. 28, n.3, p. 307-322, 2003.

${ }^{8}$ LACOSTE, Geografia: isso serve, em primeiro lugar, para fazer a guerra, 1988.

9 “[Milton Santos] publicou, em 1978, a obra "Por uma geografia nova. Da crítica da geografia a uma geografia crítica", que, no fundo, pretendeu emular com o mencionado livro-manifesto de Yves Lacoste e também propugnar uma 'nova geografia', só que 'científica' e 'não ideológica' (com uma forte clivagem entre ciência e ideologia, inspirada em Althusser, que Lacoste considera sem importância) e que enfatizasse o espaço enquanto 'totalidade' (VESENTINI, 2009; p. 143).
} 
modernização capitalista. Perpassa por esse caminho uma série de debate metodológico acerca da trajetória e sistematização da crítica, que haveria agora de ser circunscrita nos limites categoriais (metodológicos) de um sistema epistemológico propriamente geográfico (COSTA e MORAES, 1984; MORAES, 1984; SANTOS, 1978; MOREIRA, 1979). Um "conteúdo normativo" é pretendido como forma de orientar o movimento que identifica a crítica, ou as críticas, à necessidade de conformação de uma "Geografia Crítica"; um movimento que, do ponto de vista da origem do discurso se apresenta como necessário e lógico, como supõe o subtítulo da obra "seminal" de Milton Santos (Por uma Geografia Nova): "Da crítica da Geografia à Geografia Crítica". Sobre isso, destaca Moreira acerca de sua importância: "Um livro com o qual Milton Santos traz para o movimento aquilo que lhe faltava: a base substantiva e sistemática das ideias" (2007; p. 27). Nesse mesmo sentido de "sistematização", destaca Moraes \& Costa sobre a sistematização da "crítica interna": "Se a década de setenta foi marcada pelo fogo cerrado à Geografia tradicional, os anos oitenta demandam novas proposta substantivas". Sobre a possibilidade de "perda" do horizonte histórico da crítica, a necessidade de estruturar epistemologicamente a crítica se justificava perante a possibilidade de sua "autofagia" perante a crise. Daí a necessidade de "buscar novos caminhos", "formular novas vias para o trabalho do geógrafo, incorporando, além da crítica teórica, uma moderna tecnologia de pesquisa e novos objetivos sociais. Enfim, cabe ao presente construir uma nova Geografia" (1984; p. 20).

As "fragmentadas" e "parceladas" críticas de natureza geográfica, tidas como "genéricas", tende assim a desembocar na sistematização, em uma unidade, que promovesse a pretendida transição para um sistema epistemológico geográfico a fim de assegurar a pretendida autonomia e legitimidade. Tal movimento histórico é posto como movimento lógico e necessário no percurso da crítica para seu "estágio superior", ou "científico" "10, daí a irrefutabilidade acerca da necessidade de "cientifização" para o então movimento denunciativo e fragmentado da crítica social e teórica: "O movimento de renovação da ciência não pode, todavia, viver só da crítica às formulações tradicionais. Nenhuma ciência substantiva-se apenas pela negação" (COSTA; MORAES, 1984; p. 19). A necessidade de superação da geografia regional, de tradição francesa e seu caráter monográfico nas análises espaciais, mas sobretudo

\footnotetext{
10 “O conhecimento científico é um produto histórico, um resultado do desenvolvimento das relações entre a sociedade e a realidade em que estão inseridas. Essa forma de conhecimento expressa um estágio superior de apreensão, representação e sistematização da realidade. As ciências - suas definiçõos, classificações etc. - são construções humanas sujeitas, portanto, as determinações da época e da sociedade” (SANTOS, 1984; p. 15)
} 
a necessidade de denúncia do caráter ideológico e mistificador da Geografia quantitativa compõe a dimensão interna da crítica, ou das críticas geográficas.

\section{1 - Fissuras na síntese}

[Primeiro Movimento: a produção de uma crítica]

O projeto de uma Geografia Crítica passa a ser identificado com seu próprio projeto de constituição científica em detrimento do "criticismo vulgar" designado às formas "desarticuladas" da crítica por parte dos geógrafos "sem comando". Tratar-se-ia, assim, de “desideologizar" a crítica em prol de uma ciência crítica" ${ }^{11}$ A crítica genérica, "libertária", tomada por parte de geógrafos engajados politicamente em torno de um projeto de sociedade alternativo à capitalista, por isso também um projeto ideológico, tende cada vez mais a se destituir em prol de um projeto de constituição de um campo científico (discursivamente também engajado em um projeto político) denominado "Geografia Crítica".

Tinha-se como objetivo não só estreitar as referências como o movimento crítico social, mas, para além disso, cindir dela uma crítica geográfica do rol das "críticas genéricas". Tal movimento se fez subsidiado, como no caso de Milton Santos, pela concepção do espaço como "instância social": à análise geográfica se concede seu significado de totalidade de uma outra totalidade social mais genérica (2002; p. 22). À síntese da crítica geográfica se conforma, em paralelo, a fissura de uma crítica abstrata e metafísica desenvolvida, por exemplo, não só pelo movimento estruturalista ${ }^{12}$, nem apenas pela crítica do marxismo ocidental, mas também pela chamada "Teoria Crítica" da já conhecida Escola de Frankfurt, dentre outras correntes críticas de cunho mais "genérico" ou "metafísico".

Acerca das análises sobre a gênese dessa "transição", destacam os esforços em encontrar a referida unidade na diversidade da crítica como forma de garantir a nitidez da separação entre estes dois momentos: "o criticismo vulgar" e a "crítica científica":

\footnotetext{
11 A respeito da perspectiva da crítica "não ideológica" proposta por Milton Santos esboçada em "Por Uma Geografia Nova", observa Vesentini: "um ecletismo (não confundir com pluralismo), isto é, mistura ou sobreposição sem coerência, sem trabalhar a interligação das perspectivas, da análise sistêmica via ecossistemas com a concepção kantiana do 'espaço como acumulação desigual de tempos', com a ideia hegelo-marxista de totalidade (entendida pelo viés althusseriano, que afinal de contas é stalinista), com certo cientificismo (separação rígida entre ciência e ideologia, na pretensão de 'fundar' uma geografia científica ou uma espaciologia) e com visível flerte com determinadas ideias terceiro-mundistas panfletárias" (2007; p. 143-144).

12 É nítido neste movimento as influências do estruturalismo althusseriano, da qual as relações de interdisciplinaridade irão se forjar: "A visão estruturalista de espaço como instância trazida à Geografia por Milton Santos oferece o elemento essencial à crítica da abordagem neopositivista, embora nela, o sujeito da história, contraditoriamente, seja sublimado" (MOREIRA, 2007; p. 28).
} 


\begin{abstract}
Afirmou-se até que a proposta dos geógrafos que há cerca de vinte anos empreenderam uma renovação profunda da Geografia brasileira nunca foi a de estabelecer uma nova vertente de análise geográfica designada pelo termo "crítica", pois o que havia de comum nos trabalhos produzidos entre o final dos anos 70 e início dos 80 seria apenas "uma certa criticidade", isto é, um espírito crítico na análise da produção geográfica realizada até então e dos problemas da sociedade capitalista (DINIZ FILLHO, 2003; p. 308).
\end{abstract}

É dessa forma que passa a ser, por exemplo, analisado o significado do $3^{\circ}$ Encontro Nacional de Geógrafos, organizado pela Associação Nacional de Geógrafos (AGB) e realizado na cidade de Fortaleza, em 1978. O Encontro passa a ser o símbolo do momento da "renovação", ou mesmo da "origem". Moraes chega mesmo a argumentar: "O Encontro da AGB de 1978 é um marco. Tem gente até que minimiza isso, mas eu arriscaria dizer que quem minimiza com marco é porque não esteve lá" (MORAES, 200; p.154) ${ }^{13}$. Não de outra forma, tal encontro compor-se-ia como signo da "convergência" de "um estado de ebulição" crítico que, por sua vez, se encontrava fragmentado "nos vários cantos do país" (MOREIRA, 2007; p. 24-25). A Geografia Crítica passa, assim, a ser identificada a partir desse marco inicial histórico, como o momento da síntese, de "convergência", dos movimentos contestatórios da crítica de geógrafos militantes para um projeto epistemológico crítico propriamente Geográfico.

Em contrapartida, para Vesentini trata-se de um "mito" identificar o Encontro da Associação dos Geógrafos Brasileiros de Fortaleza, em 1978, como a “origem” da Geografia crítica. Tal pressuposto, ainda segundo Vesentini, teria como objetivo conceder ao movimento da crítica sua história institucional e retirar dos professores secundaristas o mérito da ousadia de, em plena ditadura, constituir um "movimento de geografias críticas" (2009; p. 127-128). A importância desta atuação dos geógrafos militantes na esfera da educação e do ensino de Geografia foi também percebida por Moreira "no ambiente carioca", sobretudo a partir da influência dos textos de Lacoste e George: "Basta uma consulta aos livros didáticos e apostilhas dos cursinhos da época [...] para atestar se o fato de que, menosprezada pela academia, a Geografia georgeo-lacostiana é a que chega à sociedade mais ampla" (2007; p. 25). Em Vesentini, o "encontro" entre a militância política e o debate acadêmico tinha como objetivo "gramscianamente 'tomar a universidade', local a partir do qual teriam uma maior influência cultural e, consequentemente, política." (2009; p. 132). E que, apesar de "altos e baixos, trabalhos de excelente nível e outros nem tanto", tratava-se de buscar a sustentação teórica e o

\footnotetext{
${ }^{13}$ MORAES, Antônio Carlos Robert, “Entrevista”, In: SCARIN, Coetâneos da Crítica (caderno de anexos), 2000.
} 
rigor científico para a crítica social, mesmo que para os trabalhos de "excelente nível” houvesse tantos outros "dogmáticos e até panfletários"14.

Tanto para Vesentini como para Moreira, a história da crítica geográfica se dá por movimentos que se descrevem como "gerações" ou "fases", respectivamente ${ }^{15}$. Tal recurso historiográfico, ao mesmo tempo em que cria uma história para a "Geografia Crítica", torna-o síntese legítima ao lhe conceder o caráter de unidade e desenvolvimento. Isso tende também a ocultar o caráter contraditório com que a unidade, o desenvolvimento e a própria síntese da crítica se deram. Tal relação pode ser observada a partir da forma como o movimento de "criticidade" vai sendo assimilado ao movimento da "crítica": o primeiro tornando o prelúdio do segundo, como se faz a entender em Moraes (2007) ${ }^{16}$ e Diniz Filho (2003), por exemplo.

As contradiçãos que podem se estabelecer entre o criticismo e a efetividade disciplinar da crítica se encontra muitas vezes ocultada sob a forma de "paradoxos", ou "ambiguidades". Por exemplo, em Vesentini a diferença entre as "gerações" é posta como "relativa", dada as “ambiguidades ou aporias" (2009; p. 133) no interior da própria crítica geográfica; já para Moreira a relação entre as "fases" se dá no sentido do "redescobrimento da geografia" para uma "opacificação", dada a "oficialidade (uma 'Geografia Crítica'), [que] muda o ritmo e o sentido de rumo e assim confunde sua primazia e se consome nesta mudança" (2007; p. 36). Pressupõe aí a possibilidade de que no interior do debate histórico, posto como sucessões de fases ou gerações, exista um movimento de legitimação de uma crítica posta como "científica", em detrimento de outra posta como "ideológica", que assim concede status de oficialidade à Geografia Crítica.

A relação entre politizar criticamente o debate acadêmico e institucionalizar a crítica que se fazia panfletária começa a se evidenciar na forma de uma disputa sobre a origem da crítica. A forma como a crítica é historicizada no movimento de renovação da Geografia não fornece muitos elementos que revelem sua gênese contraditória. Pelo contrário, passa a ser conformado o discurso de continuidade que apregoa às fases, ou gerações, certa linearidade da crítica na história, mesmo quando imersas em limitações analíticas, ambiguidades e paradoxos.

\footnotetext{
${ }^{14}$ VESENTINI, 2009, p.32.

15 Para Vesentini, os primeiros professores secundaristas que chegam aos cursos de pós-graduação compõem “a geração que produziu trabalhos pioneiros de pesquisas e/ou reflexões críticas acadêmicas nos anos 1970 (principalmente no final dessa década) e nos anos 1980. Depois dela, veio a segunda geração, aquela dos anos 1990 e desta primeira década do século XXI, a qual, em grande parte, é constituída por ex-alunos ou orientandos dessa primeira geração (com a qual convive). (2009; p. 132)". E para Moreira: "Duas fazes distinguem-se no momento da renovação. A primeira situa-se no período imediatamente anterior e posterior ao $3^{\circ}$ ENG, reunindo os anos de virada das décadas de 1970 e 1980 [...]. A segunda situa-se a partir da segunda metade da década de 1980 (2007; p. 36)

${ }^{16}$ MORAES, Antônio C. R, Geografia: Pequena História Crítica, São Paulo, Annablume, 2007.
} 
Em parte, isso se deve à tentativa de resgatar uma suposta unidade que concedesse à Geografia Crítica legitimidade histórica, como parece ser o caso de Moreira, por exemplo. Apesar disso, o meio de formular uma leitura linear da história da crítica pode ser também o fundamento discursivo que concede o caráter de verdade a uma determinada forma de uma crítica que se pretende efetivamente científica, em detrimento de outra crítica que se estabeleceria como "précientífica". Esta, por sua vez, "dogmática e ideológica", como fora considerada a crítica marxista por Diniz Filho (2002).

O debate que aparentemente pode ser extraído da leitura história acerca das origens da crítica - se política, se acadêmica -, tende, contudo, a levar a uma falsa polêmica. Isso porque não se trata de "resolver" somente o problema de como a crítica foi inserida e conduzida na história do movimento de renovação, suas "fases", "gerações", "momentos", etc. Mas, sobretudo, trata-se de entender a própria história como síntese contraditória. Isso significa pôr a crítica efetivada pelo movimento da renovação geográfica como objeto de crítica efetiva; significa debruçar-se sobre si buscando suas contradições no sentido de desvelar suas próprias formas de apropriação científica e ideológica, num movimento autocrítico que, aliás, não fora realizado.

O próprio Ruy Moreira, ao colocar a tríade Lacoste, Milton e Quaini na condição de tripé da Geografia Crítica não resolve o problema por ele mesmo levantado: que entre os presentes autores não haveria somente um legado marcado por uma "pluralidade convergente" (2007; p. 31) da crítica (libertária, epistemológica, emancipatória) que sustentasse o movimento, mas propostas conflitantes que colocariam a crítica geográfica em disputa epistemológica e teórica. Se, por um lado, como escreve o próprio Moreira sobre a geografia brasileira, "os protagonistas da ebulição de imediato se reconhecem no livro de Milton Santos" que assimilaram e identificaram de imediato à proposta de uma "Geografia Nova", por ser considerada "indiscutivelmente" uma referência "sistematizada" da crítica pretendida (2007; p. 28), por outro, não havia ainda sido esclarecido o "mistério", levantado pelo próprio Moreira, que envolve a forma como os textos de Lacoste ("A Geografia", mas também "A Geografia Serve Antes de Mais Nada Para Fazer a Guerra"), estes bem anteriores aos de Milton Santos ${ }^{17}$, acabaram sendo desconstituídos do rol de referências da crítica epistemológica por serem assim reduzidos ideologicamente à condição panfletária, "como um puro texto de agitação": "Parece inacreditável que não tenhamos entendido quanto ao que era, um verdadeiro programa de ruptura conceitual" (MOREIRA, 2007; p. 26). Não apenas neste exemplo de Moreira em

\footnotetext{
${ }^{17}$ Sobretudo aqueles que compõem a coletânea Economia Espacial (2011a)
} 
referência ao famoso texto de Lacoste, mas genericamente se pode sustentar a afirmativa de que, entre a agitação panfletária e a constituição "efetiva" da crítica (porque supostamente cientifica e epistemológica), os limites entre um e outro não se apresentariam claros restando certa dose de arbitrariedade para se definir a crítica efetiva e aquilo que passa ser a pré-crítica.

[Segundo movimento: a produção de uma "outra crítica"]

O projeto de constituição da Geografia Crítica, movido pela necessidade de conformação de um sistema epistemológico, tendeu a ser cada vez mais identificado com a negação da própria crítica em si, aquela abstrata e genérica, considerada em sua totalidade como movimento metodológico de busca da contradição, da sua condição filosófica; ou seja, da crítica como estabelecimento da condição contraditória como o pressuposto analítico do ser. Tal movimento está imerso em um movimento maior: o "amadurecimento" da crítica - por vias do necessário rigor científico na constituição dos esforços teóricos - sendo identificado e confundido com a necessidade em si da "disciplinarização" da crítica em torno de uma ciência geográfica crítica. A necessidade de busca e estabelecimento do rigor e critério perante o método científico, como forma legítima de análise, tende a ser assimilada como a própria necessidade da constituição de uma disciplina científica com seu método próprio. Assim, do ponto de vista do discurso, o projeto da "crítica cientifica" se desenvolve a partir da "produção" de "uma outra crítica", posta como "criticista" e "vulgar", que passa a ser seu oposto negativo e "ultrapassado" ${ }^{18}$, conforme se efetivam as pretensões de unidade da "nova" ciência geográfica, ou "Geografia Crítica", que necessariamente passa a se desenvolver em torno do seu objeto, o espaço.

Isso pressupõe que, para além do caráter de continuidade com que se lê o movimento da crítica, e seu devir "Geografia Crítica", há também que considerar o movimento da contradição, que inevitavelmente tende a se estabelecer entre o "criticismo" e o "despacho científico da crítica". Tal relação se mostra imanente ao movimento, segundo a análise dialética da história do processo de renovação da Geografia.

Posto dessa forma, a origem da crítica (ou seu desenvolvimento histórico) tende a revelar a natureza de sua gênese (ou seu desenvolvimento contraditório), que, como toda síntese

\footnotetext{
${ }^{18}$ Necessidade esta que, quando não reconhecida sua importância, é "trocada por um discurso pretensamente crítico, mas estéril, por ser incapaz de dar uma interpretação deográfica para as estratégias atuais do capital" (TOLEDO JUNIOR, Rubens de, "Por uma Geografia Nova, 30 anos: uma abordagem geográfica para uma teoria social crítica", In: Encontro com o Pensamento de Milton Santos: o Homem e sua Obra, Salvador; EDUFBA; 2009; p. 252).
} 
histórica, é composta pelo movimento dialético; movimento de onde, do ponto de vista da análise, emanam cisões no seio da unidade considerada, no caso, da crítica geográfica. Tal movimento, agora sob a luz da contradição, dado o caráter conflitante com que os elementos cindidos se relacionam, está, entretanto, ocultado. Ao desenvolver a leitura histórica do movimento sobre o prisma da continuidade lógica, o "criticismo" passou, em primeiro lugar, a ser o rótulo das críticas não "bem-vindas”, e, em segundo lugar, a significar o momento prévio da "crítica", como assim tendeu a ser considerado toda a riqueza do debate da economia política como "economicista", toda riqueza do debate sociológico como "sociologismo", a riqueza do debate marxista como "dogmatismo". Dessa forma se compõe os elementos discursivos que vão estabelecendo à crítica (social, genérica e abstrata) seu adjetivo de "criticismo" tomando, ela mesma, os contornos de sua condição "pré-histórica" da Geografia Crítica, ou ao menos em relação à crítica que seria eminentemente geográfica, como supõe o próprio Moreira:

Descontextualizados de um mapeamento pré-indicativo desses temas fluidos quanto ao centro de referências que balizam e articulam seus discursos num nexo estrutural, esses textos mais lembram navios à busca de um rumo que baterias de fogo concentrado sobre alvos perfeitamente definidos (2007; p. 24).

Como naus desorientadas e o receio do naufrágio total da crítica, a tomada de rumo à "convergência" não parece, no entanto, explicar o movimento contraditório por trás da "unificação da crítica" geográfica, já que havia outras perspectivas críticas não dispostas a se sistematizarem em torno de uma "unidade" epistemológica, sem ter que, para tanto, abandonar o rigor científico necessário às suas análises. O movimento da “convergência crítica” passa, por outro lado, a ser considerado como estando ele mesmo na contramão do desenvolvimento da crítica social, pois tenderia a seguir os mesmos passos institucionais e discursivos que preconizam o movimento em torno da legitimidade científica posto sob o prisma de um "ideal positivista de ciência" (ADORNO; 2009; p. 60) ${ }^{19}$. Além disso, significaria reproduzir e incorporar a própria forma de ser das "Geografias criticadas": a Geografia Tradicional e a Nova Geografia. Apesar de todas as ressalvas sobre o critério dialético a ser incorporado, a estruturação da crítica no corpo disciplinar poderia, contraditoriamente, também ser entendida como um meio de sua própria positivação no seio de uma Geografia que se pretendia

\footnotetext{
${ }^{19}$ ADORNO, Dialética Negativa, 2009.
} 
"autônoma" e "independente". Passa a ser a partir de tais prerrogativas que se compõe certa recusa por parte de Vesentini à proposta miltoniana:

[Milton] Santos, por sua vez, não soube muito bem a quem se dirigir e com um viés positivista propôs uma "nova ciência" - inclusive sugeriu o termo espaciologia - que enfocasse o espaço enquanto sujeito (sic) e como totalidade (ou melhor, como formação sócio-espacial, inspirada na leitura althusseriana de formação sócio-econômica; Althusser afirma que essa formação tem instâncias - a econômica, a política e a ideológica - e Santos nela acrescenta a "instância espacial"). (VESENTINI, 2007; p. 144).

A necessidade de mudança de foco das preocupações geográficas, de suas discussões "narcíseas" da disciplina para a definição do seu objeto de análise (o espaço), intensifica as ressalvas por parte de geógrafos não dispostos a positivar a crítica. A proposta miltoniana, para seguir o exemplo, compõe-se em um projeto de estruturação teórico-epistemológico por uma Geografia nova, ou a "Geografia Crítica", que, apesar do cuidado em torno de se constituir pela via dialética - ou de tentar resolver os problemas das dicotomias científicas positivistas pregando uma "totalidade da totalidade", para além das "especializações disciplinares", "um estudo de uma instância do real" (SANTOS, 2002) -, se apresenta como determinação de via única, ou seja, sem contradição, por uma dialética conciliatória. Tal forma de se pôr como proposta vem sempre apregoado da "necessidade" de um projeto metodológico disciplinar como pré-condição da própria crítica geográfica. Neste processo, se identificam e se confundem a necessidade do rigor científico da crítica com a sua determinação científica disciplinar. E é sintomático os descaminhos com que a crítica disciplinar, sobretudo a partir da proposta miltoniana, passa a promover a pretensão de ter "resolvido" os problemas que envolvem a crítica geográfica no conjunto das ciências sociais, como assim é interpretada sua obra “seminal” (Por uma Geografia Nova) por Toledo Júnior, por exemplo, que ao falar sobre os fundamentos do seu pensamento assevera que o mesmo "[Santos] consegue resolver o problema da inserção da Geografia no conjunto das ciências sociais, quando define seu objeto e a coloca no mesmo nível que as demais ciências sociais" (TOLEDO JÚNIOR, 2009; p. 250).

Se, para autores como Milton Santos, que toma para si a responsabilidade de, inclusive por auto-intitulação, se apresentar como "líder" do movimento de renovação crítica e propor uma "Geografia nova", pondo o "novo" como não inventado, mas descoberto, no plano da ciência, assim o faz no sentido de "elaboração de um conjunto de princípios de base, capaz de servir como guia para a formulação teórica, para o trabalho empírico e também para a ação" (2002; p. 19), conservando assim, seu caráter manualístico. O objetivo é, de forma nítida, 
relacionar as críticas postas de forma (ainda) parcial e fragmentadas no escopo da análise geográfica e compor um sistema científico epistemológico e teórico: uma Geografia crítica. Como observa a proposta central em, "Por Uma Geografia Nova": "[...] Propor, finalmente, uma linha de estudo baseada nas realidades atuais e que seja, ao mesmo tempo, uma teoria e uma epistemologia" (2002; p. 33). Compõe-se assim o projeto de estruturação teóricoepistemológico por uma Geografia nova, ou a "Geografia Crítica" bastante vinculado aos moldes estruturalistas, por sua vez legitimado e reconhecido como necessidade de cientificização necessária da crítica geográfica.

Adesão ao projeto logo se torna "a" via a ser seguida por aqueles que se identificavam com a "necessidade epistemológica" e tornaram suas críticas assimiláveis à necessidade da crítica social na leitura geográfica. E por mais que não tenha sido a única via, esta logrou mais sucesso, seja pela influência e autoridade teórica do seu autor, seja pelo mérito de antecipação do debate em um período ainda de consolidação da geografia brasileira, seja pelo momento oportuno da publicação de "Por Uma Geografia Nova" - no caso, o emblemático Encontro Nacional da Associação dos Geógrafos Brasileiros em Fortaleza em 1978. Passa então grande parte dos geógrafos, muitos deles "ainda militantes", a ter que se enquadrar ou propor uma estrutura epistemológica que desse conta das formulações de conceitos novos, através de categorias novas, para formulação de teorias novas.

Porém, a presumida "resolução" dos problemas que envolvem a análise (crítica) geográfica, a partir da estruturação epistemológica - por mais considerável que merecidamente pudesse ser a genialidade de seus autores -, incute assumir a possibilidade de que, a partir do uso de seus "novos conceitos", na inter-relação de suas "novas categorias", pudessem por si mesmo garantir o posicionamento crítico nas análises feitas pelos mais variados pesquisadores sobre as diferentes realidades pesquisadas. Aqui, da crítica que se realiza no movimento político-emancipatório no interior e para além da ciência, também se observa, inversamente, o movimento da ciência tendendo a se forjar como a própria crítica em si. Considerar tal possibilidade significaria atentar para o fato que, se a crítica social abstrata e genérica dos geógrafos é o prelúdio da crítica científica geográfica, uma crítica "verdadeira" ou "superior" só se realizaria a partir de uma "Geografia Crítica". Um movimento contraditório se observa a partir daí: da crítica social que emana uma necessidade epistemológica geográfica, agora, à epistemologia geográfica, a crítica social tende a se enquadrar como requisito de sua oficialidade acadêmica e institucional. Dessa forma, para os geógrafos, a "garantia" da crítica estaria relacionada não mais às negativas contestatórias em torno das contradições da sociedade moderna, negativas essas efetivadas cientificamente ou não, mas sim ao que a ciência 
(geográfica) pudesse formular teoricamente a partir de sua própria estrutura epistemológica, em torno de tais questões. O movimento rumo a "autonomia" epistemológica, em prol de uma crítica cientificamente efetivada, é então tido como necessidade imanente, tal qual assim também foi considerado o propósito de "cientificização" por uma autonomia da razão em relação ao "desencantamento da natureza" promovida pela New Geography.

Se, como afirma Ana Fani A. Carlos, a partir do movimento de renovação crítica, caberia “à Geografia [...], no processo de divisão intelectual do trabalho, a análise do espaço através do materialismo dialético, que pensa o espaço enquanto produção/produto da ação da sociedade" (2007; p. 14), sua proposta de "metageografia", por exemplo, teria como objetivo se debruçar sobre os processos de produção/reprodução do "espaço real", orquestrada pelo processo de mundialização, processo este que estabelece como pressuposição a relação entre produção e apropriação do espaço. A dimensão da "construção do mundo objetivo enquanto prática espacial" seria aquela observada pela Geografia, cabendo a ela o levantamento das contradições que animam a relação entre a "existência humana como processo de reprodução da vida" e o processo de apropriação dessas mesmas condições de existência ${ }^{20}$.

O desenvolvimento da referida proposta, no entanto, além de não seguir o caminho clássico da busca ontológica, da qual o espaço foi inserido como forma de ser do objeto da análise Geográfica, observado em Armando Correia da Silva e depois em Milton Santos, por exemplo, também não segue o "compromisso" da estruturação epistemológica como condição do desenvolvimento científico da crítica:

Assim o caminho aqui apontado sinaliza a necessidade de ultrapassar a dimensão ontológica do espaço, embora tão pouco se trate de elaborar uma nova epistemologia para a geografia, mas de voltar o conhecimento para a produção/reprodução do espaço enquanto nível da realidade, num movimento que articula passado, presente e futuro (CARLOS, 2007; p. 12).

O título do artigo de Ana Fani A. Carlos (“Da 'Geografia Crítica' à Crítica da Geografia"), somado às "ressalvas" de Ariovaldo Umbelino de Oliveira, torna-se claro o suficiente para revelar uma contraposição, ou certa "disputa" pela crítica, sua origem e sua gênese. Para Carlos, trata-se de reafirmar o compromisso da crítica como forma de revelar os processos de produção e apropriação das riquezas geradas "em lugares e classes concentradas no espaço e na sociedade" ${ }^{21}$ como forma de construção de um projeto de sociedade tendo a

\footnotetext{
${ }^{20}$ CARLOS, 2007; p. 14.

${ }^{21}$ Id., lbd.
} 
Geografia como instrumento, não somente no "plano da razão tal qual pretendem alguns autores, mas integrando-a ao plano do (que se pode chamar de) irracional e deste modo envolvendo a articulação dos conceitos ao vivido e nesta dimensão incorporando o virtual"22. À geografia caberia o instrumentário para a militância da crítica social.

Para Milton Santos, que aponta em seu livro "Por uma Geografia Nova" o projeto “ambicioso" sobre "O Espaço Humano", contendo nela inicialmente "uma revisão crítica" para estabelecer o objetivo "de apontar aqueles problemas que [...] impedem a construção de uma geografia orientada para uma problemática social mais ampla e mais construtiva” (2002; p. 21), a crítica seria o motor e a via das observações científicas geográficas da qual, e a partir dela, pudesse assim pensar em um projeto de sociedade por devir. À Geografia caberia sua própria militância epistemológica, como ciência que promovesse a busca pelo espaço do homem.

As diferenças entre a crítica fomentada por via de uma epistemologia militante e por via de uma militância epistemológica se apresentam bastante sensíveis. Mas é a partir de sua análise, de seus choques conflitantes, que há de se desvendar suas contradições, no momento em que se reconhece a crítica cindida, redefinindo sua trajetória entre a busca de uma perspectiva humana nos limiares do emancipatório e do contemplativo.

A dificuldade em estabelecer as relações contraditórias entre as vias pressupostas de desenvolvimento da crítica se dão porque seus conflitos não são abertamente assumidos. Elas não somente se apresentam a partir de uma leitura que presume a complementariedade de uma na produção da outra, numa "dialética sem crises”, como é o caso da análise em Ruy Moreira (1994) e em Antônio C. R. Moraes (2007), como também aparecem ocultadas, escondidas, nas sublinhas dos textos sobre a história do movimento, como prerrogativa de garantia de uma certa "unidade" da crítica no movimento de renovação.

\section{2 - Os fundamentos da crítica herdada}

A necessidade de se reconhecer os fundamentos da crítica herdada (ou da outra crítica negada, a "abstrata" e "genérica") como forma de situar a própria pretensão da crítica geográfica se torna, nos termos da presente abordagem, muito importante. Isso porque, em determinado momento de positivação do epistemologismo, a negação da crítica "abstrata", "genérica", "universal", postas como criticismo, passa a significar um procedimento tão

\footnotetext{
${ }^{22}$ CARLOS, 2007; p. 14.
} 
importante quanto o próprio estabelecimento da crítica que se pretendia especificamente geográfica.

Neste sentido, é preciso reconhecer, em um primeiro momento, as influências do caráter dogmático com que o marxismo soviético tratou a teoria social, afinal foi ela a primeira "forma de crítica" a ser usada pelo movimento de renovação. O reconhecimento posterior do seu caráter puramente ideológico, o desencantamento com a experiência soviética e o reconhecimento dos limites da natureza de sua crítica (mais positivistas do que realmente dialéticas) abriu espaço para um outro problema. Por um lado, a avaliação não criteriosa da "experiência soviética", do "marxismo oficial", da "dialética dogmática" tendeu, ainda que para os mais ideologicamente "desatentos", a relacionar tal forma especifica de "crítica" a tudo que representasse qualquer tentativa de construção de uma teoria socialmente revolucionária, fazendo com que o "socialismo", o "marxismo" e a própria dialética fossem excluídas de forma apriorística do debate crítico. Por outro lado, em detrimento de tal descrença, passou a ser estimulada a tendência ao abandono das categorias, que passaram a ser apresentadas como "anacrônicas" e "insuficientes" para o novo contexto que se apresentava para além dos "tempos soviéticos": trabalho, classes sociais, estrutura/superestrutura, etc.

Em um segundo momento, a crítica ao marxismo soviético tendeu, ideologicamente, a se totalizar como como crítica ao marxismo em si. Não cabe, por ora, se alongar ao baixo nível da crítica feita ao marxismo, como aquelas lembradas por Ruy Fausto ("no que se refere ao marxismo, insistimos sobre o baixo nível da crítica: se lê ou se retém sobretudo os prefácios de Marx, esquecendo que se é sempre desaconselhável fixar-se nos prefácios [...]") ${ }^{23}$. Mas sobre estes dois momentos apresentados é importante notar que, ao tempo em que iam se impondo ideologicamente as limitações da experiência e da crítica soviética, na medida em que também ia se maturando a crise capitalista na década de 1970 até sua forma acabada e contínua de "crise estrutural do capital" (MÉSZÁROS, 2011), ao invés de reforçar os compromissos em torno de uma crítica emancipatória e politicamente engajada, a reorientação significou muito mais uma "liberação" dos campos científicos, tanto do rigor metodológico com a própria crítica que se pretendia científica como dos intelectuais e seus compromissos sociais/revolucionários, como assim observaria Douglas Santos:

Tal como em todos os âmbitos da discussão acadêmica, também na geografia a crise do pensamento stalinista permitiu que as diversas correntes de pensamento pudessem se expressar sem que tivessem de fazer citações ou

${ }^{23}$ FAUSTO, 1983; p. 19. 
grandes digressões com as obras mais clássicas do marxismo e, mesmo assim, sem deixar de lado suas preocupações com as reivindicações e/ou necessidades dos movimentos populares (lembremos que tais leituras também se espalharam no interior dos próprios movimentos populares), no limite do entendimento que cada corrente de pensamento se dispõe a construir (2008; $\mathrm{p}$. $38)^{24}$.

Na renovação da Geografia isso se deu de forma ampla e reconhecidamente legitima de se efetivar a crítica social por meio da crítica científica. Ainda é bastante latente a reafirmação da necessidade de construção do conhecimento geográfico fundamentado em um método propriamente geográfico: em Milton Santos ela aparece como a dialética entre os "sistemas de objetos e os sistemas de ações" ${ }^{25}$, em David Harvey $(2005)^{26}$ e Edward Soja (1993) ${ }^{27}$ o "Materialismo Histórico-Geográfico" como a derivação espacial do materialismo histórico e dialético.

Tal "operacionalidade" epistemológica tem, por sua vez, desdobramentos que apontam tentativas de conformar um projeto epistêmico-disciplinar que tende a caminhar cada vez mais em direção contrária aos próprios objetivos de construção/contribuição para um conhecimento metanarrativo da superação no metabolismo do capital. A efeito de exemplos, não basta somente lembrar os motivos do início abandonado da crítica de Pierre George e Lacoste, sob a justificativa de não ver em Marx a Geografia por eles pretendida, argumentos também comprados por David Harvey (embora para este último a teoria marxiana ainda seja central em sua análise): "Concluo que a visão política e a teoria de Marx ficaram abaladas pela falta de laboração, em seu pensamento, de uma dimensão sistemática e especificamente geográfica" (2005; p. 143).

A pressuposição é que uma totalização da crítica, a partir da totalização da crítica geográfica disciplinar, agora dotados de seu objeto, de seu método, de sua epistemologia com categorias e conceitos eminentemente geográficos, tenha se tornado, contraditoriamente, como desconfiava Ariovaldo U. Oliveira, o próprio limite da crítica social. Partir de tal pressuposto não seria efetivamente inócuo e sua explicitação estaria na análise sobre a forma de como a

\footnotetext{
${ }^{24}$ SANTOS, Douglas, "Entrevista", In: Boletim Paulista de Geografia: 1978 + 30: AGB em Movimento, Volume especial, $\mathrm{N}^{\circ} 88$, julho de 2008.

${ }^{25}$ SANTOS, 2008, p. 21.

26 “A geografia histórica do capitalismo deve ser o objeto de nossa teorização, enquanto o método de inquirição deve ser o materialismo histórico geográfico" (HARVEY, 2005a; p. 144).

${ }^{27}$ Soja, ao analisar a crítica de Harvey em Lefebvre, onde aquele considera "exagerada" a centralidade do espaço na teoria deste, retoma o debate desde 1979 para se debruçar na "tentativa de resgatar a afirmação inicial da dialética sócio-espacial e da necessidade de um materialismo histórico-geográfico (SOJA, Edward, Geografias Pós-Modernas: a reafirmação do espaço na teoria social, Rio de Janeiro, Jorge Zahar, 1993; p. 100).
} 
renovação da crítica geográfica foi "escanteando" categorias da crítica social carregadas de acúmulo histórico e "revolucionário" como, por exemplo, o trabalho.

\section{3 - Influências universais}

A relação entre a militância epistemológica e a militância política, agora entendidos como movimentos contraditos e conflitantes, como movimentos cindidos da crítica social, seria a efetivação concreta (na Geografia) de uma disputa pela crítica que se estabeleceu no seio das ciências sociais e da filosofia na década de 1940/50. Embora tal disputa não chegasse a ser abordada, reconhecida ou mesmo percebida pelos geógrafos dispostos à elaboração da crítica nas décadas de 1970 e 1980, dado o "atraso" com que a Geografia se insere na "desnaturalização da análise humana" (DOSSE, 2007) ${ }^{28}$, está ela inevitavelmente inserida em tal movimento genérico. Isso porque a forma como a crítica social e teórica passam a ser abordadas - pelo estruturalismo, pela Teoria Crítica da Escola de Frankfurt, pelo dogmatismo soviético ainda muito atuante, pela autocrítica ao "Marxismo Oficial" e pela "releitura" da teoria marxiana (ou seja, fundamentada no próprio Marx) - se apresentam poderosas demais, como influências universais do seu tempo (e ainda hoje), para serem desconsideradas do rol de influências, ainda que indiretas, da renovação geográfica.

Se, ainda conforme Dosse (2007; p. 30), a Geografia é a "convidada de última hora"29 do movimento crítico que passa a orientar a crítica das ciências sociais desde a virada da primeira para a segunda metade do século XX, tal atraso não a isenta das influências universais que se encontrarão já amadurecidas da filosofia à antropologia e sociologia nas décadas de 1970 e 1980. Mesmo que o estruturalismo e a ortodoxia do "Marxismo Oficial" fossem, em um primeiro momento, como se pode observar em Moreira (1994) ${ }^{30}$ e Moraes (2007), as influências mais diretas para a renovação crítica da Geografia brasileira, outras influências se destacarão no seu desenvolvimento. Isso é notório quanto ao trato sobre a categoria trabalho, a título de exemplo, na renovação da Geografia desde o início abandonado de uma Geografia do Trabalho em Pierre George, ou mesmo o abandono do projeto da "Geografia Marxista" de Costa \& Moraes, até a efetuação das chamadas “expulsões do sistema central” de categorias tidas como

\footnotetext{
28 "A disciplina geográfica continua a se definir, nos anos 60, como uma ciência das relações entre a natureza e a cultura, entre os elementos da geomorfologia e da climatologia, etc. [...] Marcados pela Geografia tradicional e prisioneiros de seu empirismo, esses geógrafos não lograrão abalar sua disciplina nem abri-la para um questionamento epistemológico sobre seus fundamentos ou para diálogos teóricos interdisciplinares" (DOSSE, François, História do Estruturalismo: O canto do cisne, Bauru; Edusc, 2007, v.2. p.383 - 385).

${ }^{29}$ DOSSE, História do Estruturalismo: O canto do cisne, 2007, v.2.

${ }^{30}$ MOREIRA, O Que é Geografia, 1994b.
} 
"dadas", processada pela epistemologia miltoniana iniciada em "Por Uma Geografia Nova" e conformada (pela centralização da técnica) em "A Natureza do Espaço"31.

Em todos esses exemplos, opera-se a mesma descentralização do trabalho como aquela operada pelo estruturalismo e orientada pela Teoria Crítica da Escola de Frankfurt, estes como movimentos teóricos mais universais. Do estruturalismo se herda a necessidade de "superar" as categorias dogmatizadas do marxismo soviético para a confecção dos sistemas epistemológicos das ciências envolvidas com a renovação crítica; da Teoria Crítica se herda a necessidade de repor a dialética e o pensamento humano para além das determinações fetichizantes do sistema do capital, como o trabalho e o proletariado passaram assim a serem entendidos. Entre elas convoca-se a necessidade de uma ciência que não só vai além das formas de determinação concretas no tempo e no espaço das relações capitalistas, mas que retorne à modernidade como objeto da crítica.

Como observa Mészáros (2004), o movimento de descentralização do trabalho significou não somente um definhamento conceitual no interior das ciências (como na Geografia), ou na mera relocação categorial no interior dos sistemas epistemológicos, mas propriamente a negação em si de um projeto afirmativo de sociedade (ou a centralidade de sua negação, como no exemplo frankfurtiano) em detrimento de questões tidas como mais científicas e apropriadas ao tempo que se apresentava como atual: a modernidade, a globalização, etc. "Capitalismo", “capital", "classes”, "Estado" passam a ser dispostas como “categorias dadas", na forma mais elegante para sua reclusão à filosofia vulgar esquerdista, concluindo assim o projeto de suplantação da totalidade das perspectivas objetivamente identificáveis da superação delas próprias. Por outro lado, do ponto de vista das ciências renovadas, como a Geografia, tal procedimento aparece como sintoma de amadurecimento epistemológico.

A importância do trabalho, como categoria de análise da sociedade moderna, desenvolvida pela teoria crítica-social desde Marx até os herdeiros mais atuais, tanto da teoria afirmativa emancipatória de Lukács (como, por exemplo, em István Mészáros), como da "dialética negativa" da Teoria Crítica frankfurtiana (a exemplo de Robert Kurz), é central para se entender os destinos que a crítica social tomou em cada corrente divergente. Ela se torna também central para compreensão das formas de inserção da Geografia no rol das ciências sociais críticas, tal como para o entendimento da consequente "disputa interna", ou "cisão" da crítica, entre uma militância epistemológica e uma militância política na Geografia. Isso porque

\footnotetext{
31 "O que se torna residual é considerado como um "dado" e, desse modo, expulso do sistema central" (SANTOS,
} 2008; p. 21). 
o conceito de trabalho que chega à ciência geográfica, como sustentação do conceito de espaço social, ou de "técnica" (SANTOS, 2002), ou mesmo da "valorização do espaço" (COSTA \& MORAES, 1984), carregam a genética do seu tempo histórico, tal como suas variações, que vão desde a exclusividade da dimensão física do trabalho (trabalho cristalizado), inicialmente desenvolvida por Pierre George e suas influências nos "sistemas de objetos", de Milton Santos, e no "capital fixo fixado", de A. C. R. de Moraes, até sua dimensão ontológica desenvolvida por Lukács e trabalhada por Armando Corrêa e Ruy Moreira.

Mészáros (2004) entende que só é possível analisar a trajetória da crítica científica (e também da crítica geográfica) se se tomar como parâmetro a sequência do movimento teórico universal, que se dá a partir do "remodelamento" das categorias tidas também como universais, categorias essas da qual o trabalho está, na sociedade moderna, em posição nuclear. Tal "remodelamento" conceitual irá, por sua vez, conformar tendências muito distintas; desde o "Pós-Estruturalismo" até Teoria Crítica da Escola de Frankfurt; desde o revigoramento do pragmatismo neoliberal até o revigoramento do marxismo combativo. Embora não nitidamente delimitadas, tais influências chegam ao processo de renovação geográfica e, por sua vez, se estabelecem como orientação universal que vai repercutir no destino do movimento, tanto na sua natureza teórica como na atuação política dos "geógrafos críticos".

Esse contexto é exatamente o mesmo em que se engajam no plano teórico e prático as principais teses de reafirmação e negação do trabalho como categoria central para a explicação do estágio hodierno da modernidade. Tal relação não é casual e estabelecerá profundas marcas entre as frentes epistemológica e política da Geografia, um conflito que irá configurar "avanços longos" na filosofia do conhecimento, como, por exemplo, aquele feito por Paulo César da Costa Gomes em "Geografia e Modernidade" (2003) $)^{32}$, ou em Milton Santos, ao compor uma "metadisciplina", a partir da "delimitação disciplinar", pela "construção de seu objeto de estudo", o espaço (2008; p. 20) ${ }^{33}$. Isso tem certa dose de contraposição aos objetivos mais ligados à efetivação de um projeto de sociedade como aqueles apontados por Ana Fani A. Carlos em sua "metageografia".

Na dimensão do trabalho, a suposição do conflito pode, por exemplo, ser observada na “disputa" entre a necessidade epistemológica e disciplinar, quase que consensualmente assumida, em se estabelecer o objeto da Geografia, o espaço, e a forma problemática de retirar

\footnotetext{
${ }^{32}$ Para Gomes, o conflito a ser objetivado é aquele acerca da compreensão da modernidade, a partir da ciência, entre o racionalismo e o romantismo, como forma de entender os desígnios do pensamento geográfico (GOMES, 2003).

${ }^{33}$ SANTOS, Milton, “As Técnicas, O Tempo e O Espaço Geográfico”, In: A Natureza do Espaço: Tecnica e Tempo, Razão e Emoção, São Paulo; EDUSP, 2008.
} 
do trabalho a centralidade posta pela crítica combativa, como nas ciências sociais como um todo. Tal conflito entre a afirmação e a negação das categorias críticas universais, como o trabalho, na estruturação epistemológica do espaço e do fazer crítico das ciências não se deu somente na Geografia, mas necessário é admitir que aqui ele, o conflito, ainda não fora posto como objeto de análise crítico e, sobretudo, autocrítico, podendo trazer, assim, importantes elementos para a compreensão da natureza da crítica geográfica, seus limites e suas contradições. 


\section{CAPÍTULO 6 - A EXPOSIÇÃO DO IMPLÍCITO: O TRABALHO ENTRE AS VIAS DA CRÍTICA SOCIAL E DA CRÍTICA GEOGRÁFICA}

O movimento que demarcou os embates teóricos nas décadas de 1970 e 1980 teve forte influência da perspectiva de crítica desenvolvida por geógrafos franceses que buscaram, desde a década de 1950, no epicentro de suas formulações teóricas, aproximações com a teoria social a partir de categorias que possibilitassem a devida mediação com a teoria social crítica.

Como se verá, o trabalho, enquanto categoria da análise da crítica social, exerceria papel central nesse processo pela sua capacidade de trazer ao debate científico-geográfico um rol de temáticas que envolvem desde a mediação homem-meio às leis econômicas que regem a sociedade moderna (MARX, 1983). Mas também o trabalho garantiria à renovação geográfica o posicionamento crítico frente a tradição naturalista e tecnicista da leitura geográfica feita até então e frente aos processos de crise capitalista que se montaram no período pós-Segunda Guerra Mundial.

A inserção do trabalho na crítica geográfica se daria em diferentes gradientes de intensidade que podem se visualizados em quatro vieses mais genéricos: $\left(1^{\circ}\right)$ o viés "denunciativo" (até seu extremo dogmático), aquele de herança do "marxismo oficial", apresentou variantes desde o "gramiscismo" mais ingênuo (VESENTINI, 2009; p. 131) até o leninismo mais pragmático; $\left(2^{\circ}\right)$ o viés da "afirmação combativa-emancipatória" (até seu extremo revolucionário), aquele mais atento aos caminhos que a crítica remodelou à necessidade da emancipação humana, sobretudo a partir dos problemas decorrentes do "fim do socialismo real". Se manteve marxista, apesar das ondas modistas do tipo "pós-marxismo", "pós-industrialismo", "pós-modernismo", e se deteve à reflexão criteriosa e crítica de Marx e do marxismo. Abarcou variantes mais tímidas desde o lukacsianismo até algum tipo de lefebvreanismo; $\left(3^{\circ}\right)$ o viés da "negatividade" (até seu extremo mais lógico-contemplativo) de forte influência dos debates filosóficos mais recentes acerca da dialética, tem forte influência da Escola de Frankfurt, e variam desde uma retomada da teoria crítica adorniana por um filosofismo de "malabarismo conceitual" até tendências mais fragmentárias pós-modernas de cunho pragmático, culturalista e empiricista ${ }^{34} ;\left(4^{\circ}\right)$ e o viés da "positividade" (até seu extremo epistêmico-contemplativo), detido à necessidade epistêmica de solução dos problemas práticos,

\footnotetext{
34 “[...] A época se caracteriza ao mesmo tempo, pelo menos em certos meios, por uma formidável pressão positivista e tecnocrática. Ex- 'dialéticos' só juram pelo empirismo e pela empiria. Neste sentido os pensadores de Frankfurt são os mais atuais do que nunca” (FAUSTO, 1983; p.19)
} 
sendo, por isso, de bastante influência althusseriana, que varia desde o "escolasticismo" (LEFEBVRE; 1968; p. 78) mais acadêmico e cientificista até o tradicionalismo positivista mais estruturalista.

Estes quatro caminhos compõem, em síntese, o próprio destino histórico da crítica social no século XX que na Geografia é vista como uma crítica de herança marxista e, em menor influência, anarquista, dado os vínculos positivos e/ou negativos com as questões sobre a dialética e a crítica social. Temática essa presente em perspectivas tão distintas e até conflitantes como as de Reclus, Stalin, Lukács, Adorno (este mais exclusivamente sobre a dialética e a Teoria Crítica), Althusser, e até mesmo o um nome importante do estruturalismo, Lévi-Strauss, que, desse modo, também assumiria sua aproximação com o marxismo: "Marx fascinou-me de imediato. Não demorei muito a mergulhar na leitura de 'O Capital'” (DOSSE, 1993; p.31).

No centro do debate estão as categorias que vão balizar a compreensão sobre a modernidade (sujeito, objeto, razão, contradição, crítica), sobre o capitalismo (propriedade, sujeito, classes, mercado, imperialismo) e sobre o sociometabolismo do capital, este fundamentado no tripé: capital, trabalho e Estado (MÉSZÁROS, 2011). No entanto, conforme irão se desenvolver, no movimento em torno da dialética, cada uma dessas vias se forjará em campos individualizados do pensamento e, até, antagônicos entre si. Tornam-se assim irredutíveis a sua forma originária, fazendo com que o "marxismo" (e "anarquismo"), ainda que se mantenha como elemento embrionário comum entre elas, não seja suficientemente explicativo para o entendimento dos desígnios da crítica ao longo do século XX, como propôs Costa \& Moraes ao supor uma "Geografia Marxista", sem se aterem às escalas de disputas antagônicas de sua crítica.

Notadamente, proposta como "Geografia Marxista", a renovação crítica da Geografia representaria a unidade de críticas tão diversas que dentre elas algumas poderiam até ser a anticrítica da outra. Para além disso, é necessário considerar que nem toda crítica proposta pela Geografia em seu processo de renovação se assumia marxista, apesar de sua proximidade, tal como é possível considerar, como nos exemplos mais dogmáticos e ideológicos, que nem todo autointitulado "marxismo" fora de fato crítico. Diz Moreira sobre tal questão: "Mas é preciso dizer que se um inédito processo de refundição marxista ocorre por dentro da renovação da Geografia, a renovação, todavia, não se confunde com o marxismo e os geógrafos de formação marxista" (2007; p. 29) ${ }^{35}$. Ademais, no plano da crítica social e eminentemente marxista, é exemplar ainda o inconciliável debate entre Lukács e Adorno sobre a ontologia e a práxis. Daí

${ }^{35}$ MOREIRA, Pensar e Ser em Geografia, 2007. 
porque o marxismo, embora seja o ponto de partida da análise, não representa em si "unidade" sólida e imutável (não contraditória) sobre o embate entre as críticas pretendidas. Muitas delas, sob o rótulo de marxista, foram até concebidas como antimarxistas por seus opositores. Tal generalização pode provocar graves equívocos como, por exemplo, aquela em que ao se referir à via dogmática como "certa má herança marxista" (DINIZ FILHO, 2002) acaba tendendo a englobar e totalizar como dogmático toda forma de marxismo (ou o marxismo em si), inclusive àqueles que buscavam exatamente a destituição crítica do "marxismo oficial", como as urdidas pelos próprios Lukács e Adorno.

De fato, as "vias da crítica" ao longo do século do capital se tornaram tão inconciliáveis e traçaram caminhos teóricos tão distintos que inviabilizou o resgate de qualquer unidade entre elas sem o risco do ecletismo. Por isso, para a compreensão da categoria trabalho e sua relação com a crítica geográfica, se justifica a opção de assim proceder a análise por uma história da crítica (tomada como gênese) e sua relação com o trabalho, ou vice-versa, e não por uma "história do marxismo" do século XX.

\section{1 - A via dogmática-positiva}

Acerca das composições primárias da crítica geográfica, é notória a forma denunciativa e mecânica com que a "dialética" foi importada "do socialismo real" para o "ocidente". Milton Santos (2002, p. 41) adverte sobre os "perigos da analogia" com as ciências naturais ("Inicialmente não se pode transpor, e sobretudo de forma mecânica, o que se passa no mundo físico") que, por sua vez, levou a Geografia a uma leitura mecânica da sociedade quando se buscava o status cientifico no momento de sua sistematização no início do século XX. Na elaboração da crítica social na segunda metade do mesmo século se percebeu o mesmo problema de mecanização da análise, mas em movimento inverso: as leis da específica sociedade moderna capitalista como fundamento explicativo de leis naturais. Como lembra Moraes \& Costa (1984; p. 40), a "Geografia Física, [de] Cailleux e Tricard [que] propõe a Geomorfologia climática como a 'visão proletária' dos processos naturais" carrega para a análise física da natureza uma suposta crítica social, como se a analogia entre a estratificação das classes sociais capitalistas pudesse oferecer condições explicativas para a dinâmica estratificada das camadas dos solos. É interessante notar que tais condições se deram como posiocionasmentos críticos inadvertidos, porque não autocríticos, e em um momento onde apenas se poderia ensaiar uma dialética efetiva na Geografia, sobretudo a partir de um autor tão importante para a renovação da crítica brasileira como Tricart. Os objetivos tricartianos 
eram, no entanto, reestabelecer os traços então perdidos de um discurso que visasse a totalidade: "a totalidade inclui, assim, o homem, sem que Tricart esteja a fazer sociologia, e as camadas de rochas, sem estar a fazer Geologia, para pegarmos dois exemplos que a visão fragmentária vê como extremos" (MOREIRA, 2014b; p. 83)

Este seria um traço comum do "marxismo oficial" soviético. A forma "forçosa" com que categorias sociais tendiam e se inserir nos movimentos mecânicos da natureza, ou da "Geografia Física", por exemplo, não só reforçava a mecanicidade de um certo tipo de entendimento de natureza destituída de movimento histórico, mas também forçava o entendimento e um movimento histórico mecanizado e instrumentalizado por "categorias aplicáveis" a toda forma de conhecimento em que nada de dialético lhes restava. O trabalho, como uma dessas categorias sociais e mecanicamente instituídas, passa a representar a tábua rasa da salvação comunista sem que fosse, por um lado, salvaguardado o mínimo de rigor com a dialética, e por outro, fossem sequer interpeladas as mediações mais básicas do metabolismo social do capital em seu movimento contraditório, presente também na "experiência socialista". Como destaca Mészáros acerca das condições em que a dialética e a prática socialista estavam envolvidas:

\footnotetext{
Naturalmente, ela [a experiência soviética] também não oferecia espaço para o método dialético, que teria que visualizar não apenas possibilidade, mas também a necessidade de mudanças qualitativas em termos das quais as transformações revolucionárias poderiam ser racionalmente previstas e preparadas, ao contrário do "determinismo econômico" gradualista e mecânico-quantitativo da segunda internacional (2011; p. 54).
}

Do ponto de vista do trabalho, isso significa que, no plano histórico, não só se mantiveram inalteradas as condições alienantes da natureza do valor da riqueza social (a partir da extração das taxas de sobretrabalho) como dela passou a se sustentar a partir do discurso ideológico "proletário" (soviético e/ou socialdemocrata) em defesa forçosa das condições insustentáveis que se seguiam, como "dependentes do objeto que negavam"37 (MÉSZÁROS, 2011; p. 29). Significava ainda que, como fonte alienada da riqueza, o trabalho, tal como as demais categorias com potencial crítico-contraditório, passa assim a assumir a identidade

\footnotetext{
${ }^{36}$ MOREIRA, O Pensamento Geográfico Brasileiro (v. 2), 2014; p. 83.

37 “Os partidos políticos do movimento operário não puderam elaborar uma alternativa viável porque se concentraram em sua função de negação, exclusivamente na dimensão política do adversário, tornando-se, desta forma, completamente dependentes do objeto que negavam" (MÉSZÁROS, 2011; p. 29).
} 
positiva de sua própria negação no momento em que se torna parte de um "sistema fetichista" "38 na dada forma de sociabilidade.

A "sociedade do trabalho" prometida, sem as devidas mediações com a crítica dialética, torna-se seu próprio corolário na forma das mediações mesmas do capital. Para a Geografia, essa via dogmática ainda tem relativa importância, pois ainda permanece presente e atuante sob o julgo da necessidade de uma prática revolucionária imediatista. Todavia, estaria ela carregada de inconsistência no rigor teórico que envolve o exercício dialético e que, consequentemente, lhe impossibilitaria uma prática efetivamente emancipatória. Sem o aprofundamento em tal exercício, no que diz respeito ao rigor dialético de pensar e experimentar o mundo a partir do reconhecimento da contradição, a tendência é o esvaziamento e até o abandono, tanto em relação à ação prática política-emancipatória sobre a realidade concreta, como em relação à prática teórica. As perspectivas teóricas dentro de tais condições em que se apresentam por meios de uma dialética precária, quando não se tornam mais uma perspectiva "liberal", se arriscam entre o imediatismo revolucionário e a ingenuidade perante os desafios do real, na medida que não são reconhecidas a grandiosidade de tais desafios: "Inevitavelmente, o desafio histórico de instituir-se uma alternativa viável à ordem dada também exige uma grande reavaliação do quadro estratégico do socialismo e das condições de sua realização, diante dos fatos e decepções do século XX” (MÉSZÁROS, 2011; p. 41).

É sobre tal aspecto que se desenvolve, por exemplo, a Geografia do Trabalho de Pierre George. Este não só concebeu o trabalho a partir de sua dimensão mais pragmática (como relação de assalariamento), mas também universalizou esta mesma dimensão como "princípio" para o desenvolvimento econômico dos então "países subdesenvolvidos". Adota, dessa forma, o posicionamento do capital no momento em que se distancia da análise das contradições do processo de universalização do trabalho abstrato, como um mal necessário da modernização. Em prol da afirmação de um "olhar geográfico", aponta a necessidade de se observar os níveis de exploração e superexploração do trabalho - esta última posta como "anomalia" da modernização -, a questão da diferença de suas relações nos "lugares", suas condições institucionais (legislativas) e suas condições em relação à técnica específica de cada contexto: em resumo, uma observação empírica sobre as formas de uso da força de trabalho e suas desigualdades no mundo. Tal forma de inserir o discurso crítico por meio da inserção de uma

\footnotetext{
38 "A identidade de classe encontrou sua razão numa ontologia errônea do trabalho, que não foi compreendido como elemento e parte integrante do sistema fetichista da mercadoria, mas sim de forma quase bíblica (isto é, 'protestante'), como essência eterna da humanidade que apenas externamente foi violentamente modificada pelos sujeitos ‘exploradores', os capitalistas” (KURZ, O Colapso da Modernização, 1992; p.48).
} 
categoria de "tradição marxista" não só reduziu a condição do trabalho de categoria analítica para tema de pesquisa geográfica, salvaguardada pela empiria típica da Geografia Regional, como destituiu de todas as possibilidades do movimento dialético a ela inerente.

Na experiência de Pierre George está contido um traço que demarca a maioria dos desentendimentos entre as formas de inserção da crítica em relação às preocupações com o rigor necessário ao movimento dialético. Tais desentendimentos estão, sobretudo, na forma de conciliar uma leitura crítica para o movimento de renovação da Geografia brasileira e as tentativas de "adaptação" das categorias de viés crítico, como o trabalho, à especificidade do olhar geográfico, ou da dimensão espacial, tensionado pelo movimento de reorientação epistemológica. Tais heranças continuam a serem reproduzidas ${ }^{39}$, e com certa intensidade, em textos esporádicos em anais de eventos e revistas científicas e em alguns trabalhos de conclusão de curso nos diferentes níveis acadêmicos. Isso levou Milton Santos à avaliação de que "uma boa parcela do que hoje aparece como Geografia marxista é ideológica: trabalha com uma história que não existe mais, daí certa fixidez nos conceitos" $\left(1996\right.$, p. 172) ${ }^{40}$. Mas também tal herança continua como via de influência expressa em diferentes níveis de intensidade (do pontual ao estrutural) em textos embrionários de profunda influência para o movimento de renovação, sobretudo aqueles espelhados em exercer "função didática" para a extensão do debate sobre a proposta crítica.

Manoel Fernandes de Sousa Neto, por exemplo, ao prefaciar um dos mais importantes livros do contexto da renovação crítica, "Geografia: pequena História Crítica", assim observa sua influência:

Seria possível imaginar, feito um levantamento dos currículos universitários dessa ciência geográfica no auge da sua estampa ou grife crítica no brasil, que pequena história crítica foi o mais adotado, lido e referenciado manual acadêmico de tantos quantos aprendizes tenham entrado para a corporação geográfica de ofício durante o período (SOUSA NETO, 2007; p. 12)

Importa nessa passagem não só a influência "de tanto quantos aprendizes" tenham sido influenciados pelo referido texto, mas também o significado de um livro tido como "manual acadêmico" poder exercer tamanha influência. Depois de propor suposições para a questão

\footnotetext{
${ }^{39}$ A relação da Geografia com o marxismo "dogmatizado" e "mecanizado" tem suas raízes desde a fundação da própria disciplina e se perdura até tempos mais modernos. Diria Milton Santos: "Ao seguir cegamente Marx, os fundadores da geografia científica utilizaram uma metodologia congelada, pecaram por dogmatismo e sobretudo consagraram um erro de interpretação que desgraçadamente perdura até hoje" (2002, p. 52).

${ }^{40}$ SANTOS. Novos Rumos da Geografia Brasileira, 1996.
} 
sobre "o que fez do Geografia: pequena história crítica de tanto sucesso editorial, uma espécie de 'best seller?'” (praticidade, qualidade da síntese teórica, mercado editorial, etc.), continua Sousa Neto acerca de um problema que se deriva: "porque este livro de mais de vinte anos continua a ser uma das obras mais vendidas da área de geografia no Brasil? E porque é preciso levantar este problema?" ${ }^{41}$. Apesar de todas as transformações ocorridas desde o momento de sua escrita, apesar de todas as atualizações do debate e das técnicas da leitura geográfica, a "pequena história crítica", como observa Sousa Neto, revela um problema "da comunidade científica que continua a consumi-lo" ${ }^{\prime 2}$.

Considerando sua "história linear e evolutiva", sua "visão ocidental de ciência" e as suas "simplificações que acabou por engendrar, produzindo um certo Ratzel, um certo Vidal de La Blache, uma certa escola americana de geografia [...]"43, ou seja, questões caras ao desenvolvimento de uma leitura dialética para a própria crítica histórica, a influência da "pequena história crítica" revela, dessa forma, "nosso 'calcanhar de Aquiles', nossas fraquezas teóricas", tendência essa ainda atual que se reproduz por vias denunciativas e dogmáticas (ainda que não estruturalmente postas) e que fazem com que o referido manual "deixa de ser um clássico apenas, para ser um clássico incômodo" 44 .

A importância de se observar a "via denunciativa”, contudo, está não somente na forma simplista em que a dialética foi tratada, sua forma apriorística, com que as categorias "revolucionárias" deveriam ser inseridas nas perspectivas teóricas, mas importou também a intenção combativa-emancipatória em volta dela, compondo propriamente uma via militante, muito importante e necessária, em torno de um projeto socialista. Tal perspectiva combativaemancipatória, por sua vez, tendeu a não se desenvolver por sustentação teórica efetiva e foi paulatinamente abandonada. Isso pode ser observado, por exemplo, desde a proposta de "Geografia do Trabalho", de P. George, até a proposta de uma "Geografia Marxista" e seu estudo sobre a "Valorização do Espaço", de Costa e Moraes.

\section{2 - A via teórica-afirmativa}

Se o legado combativo-emancipatório da via militante com que a crítica genérica e universal se reproduziu importou mais do que a própria dialética na conformação da teoria crítica, tornou-se necessário reconstituir a dialética para além do pragmatismo apriorístico e,

\footnotetext{
${ }^{41}$ SOUSA NET, 2007, p. 13.

${ }^{42}$ Ibid., p. 14.

${ }^{43}$ Id., Ibid.

${ }^{44}$ Ibid., p. 15.
} 
por vezes, positivista, e ao mesmo tempo propor um viés teoricamente afirmativo e não menos combativo-emancipatório. Destacam-se, entre outros, os esforços de Lukács e, posteriormente e mais intensamente, Mészáros ${ }^{45}$ :

Deve-se reconhecer que a história não pode terminar no ponto da total negatividade, pois nenhuma força social consegue apresentar suas reivindicações como uma alternativa hegemônica sem também indicar, pelo menos em esboços gerais, a dimensão positiva/afirmativa de sua negação radical" (2008; p. 41)

Tal perspectiva não só se dedicará ao reestabelecimento da dialética na teoria objetiva sobre as contradições estruturais do sistema metabólico do capital, mas também se dedicará ao desenvolvimento de uma perspectiva emancipatória fundamentada no trabalho, na classe trabalhadora e na perspectiva socialista. Como lembra Ricardo Antunes ${ }^{46}$, o projeto de escrita de “o capital dos nosso dias" (2011, p. 15) idealizado por Lukács e elaborado por Mészáros, deveria oferecer não somente uma leitura sobre as contradições que se radicalizaram no último quartel do século XX e início do XXI a um extremo inimaginável até pelo próprio MarX - as duas guerras mundiais seriam mais que suficientes para demonstrar isso, além do risco do extermínio humano pela via nuclear -, mas também oferecer as condições de elaboração da mediação para uma teoria da transição socialista:

Apesar de termos de estar alertas para os imensos perigos que surgem no horizonte, não basta negá-los para enfrentá-los com todos os meios ao nosso alcance, é também necessário definir uma alternativa positiva, corporificada num movimento socialista radicalmente reconstituído (MÉSZÁROS, 2011; p. 21).

O revigoramento da dialética combativa e afirmativa tentada por Mészáros, nos moldes da herança lukacsiana, se tornou, certamente, uma das mais importantes correntes de análise da teoria crítica no Brasil. A retomada da crítica social que tem como referência a centralidade (ontológica) do trabalho ${ }^{47}$ se tornou um movimento avançado, de relativa maturidade,

\footnotetext{
${ }^{45}$ MÉSZÁROS, Filosofia, Ideologia e Ciência Social, 2008.

${ }^{46}$ ANTUNES, Ricardo, “Apresentação (à edição brasileira)”, In: MÉSZÁROS, Para além do Capital, 2011.

${ }^{47}$ Ainda que, para Sergio Lessa, seja importante observar que, dentre a variedade de análises feitas por autores brasileiros no campo do marxismo que trabalham na perspectiva das teses sobre a centralidade do trabalho, algumas delas "deram adeus ao proletariado": "De modo pioneiro, Demerval Saviani publicou em 1991 Pedagogia histórico-crítico (Saviani, 2000), seguido em 1994 pelo artigo 'O trabalho como princípio educativo frente às novas tecnologias' (Saviani, 1994). Em 1998 veio a público Trabalho na Contemporaneidade, de Marilda Iamamoto, seguido logo depois por Os sentidos do trabalho de Ricardo Antunes. Iamamoto e Savini são
} 
sobretudo na educação, filosofia e sociologia, mas também no Serviço Social e na psicologia. Destacam-se nessa tendência autores como: José Chasin, José Paulo Netto, Leandro Konder, Ricardo Antunes, Sergio Lessa, Ivo Tonet, Giovani Alves, Eleutério Prado, Mário Duayer, Demerval Saviani, Ester Vaisman, dentre outros. Do ponto de vista da Geografia, se destaca o Grupo de Pesquisa sobre Estado, Capital, Trabalho e Políticas de Re-Ordenamentos Territoriais (GPECT), coordenado por Alexandrina Luz Conceição, e o Centro de Estudos sobre Geografia do Trabalho, sob coordenação de Antônio Thomaz Junior, que têm como objetivo congregar e desenvolver estudos em Geografia tendo como referência a investigação das contradições que envolvem a relação capital versus trabalho na apropriação/produção do espaço.

Vale ressaltar que se, por um lado, as influências diretas de Mészáros se tornaram as mais atuais e centrais diretrizes da crítica combativa, por outro é também importante resgatar as influências diretas de Lukács para a elaboração embrionária das propostas de Armando Corrêa da Silva e, posteriormente, mas não menos influente, das contribuições de Ruy Moreira, Antônio C. R. de Moraes, dentre outros. A especificidade do olhar geográfico para Armando C. da Silva é, pois, o retorno a uma totalidade que envolve a natureza em si da Geografia: a natureza da relação metabólica sociedade-natureza. É por isso, desde o princípio, a busca da ontologia do espaço, proposição da qual Silva seria pioneiro, a partir das influências diretas do filósofo húngaro (como visto no capítulo "3 - A Solução Ontológica e os Limites para a Centralidade do Espaço"). Da condição metabólica do trabalho, no sentido ontológico lukacsiano, caminha Silva em suas incursões na dinâmica do trabalho no sentido de encontrar os pressupostos para a ontologia do espaço. Como analisa Ruy Moreira a respeito do mestre Armando Corrêa, este derivando a história centrada no processo de trabalho marxiano " [...] no qual o homem transforma-se a si mesmo no mesmo momento em que transforma a natureza, num processo de autoconstrução em que a natureza faz o homem e o homem faz a natureza

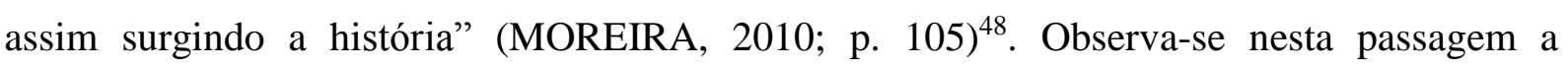
aproximação com a tese de Lukács sobre o trabalho como protoforma da práxis social:

Somente o trabalho tem, como sua essência ontológica, um claro caráter de transição: ele é, essencialmente, uma inter-relação entre o homem (sociedade) e a natureza, tanto inorgânica (ferramenta, matéria-prima, objeto do trabalho etc.) como orgânica, inter-relação que pode figurar em pontos determinados da cadeia a que nos referimos, mas, antes de tudo, assinala a transição, no

pesquisadores muito importantes em suas respectivas áreas e, tal como ocorre com Antunes, são referências para um amplo setor da esquerda e dos movimentos sociais" (LESSA, Sérgio, Trabalho e Proletariado no Capitalismo Contemporâneo, São Paulo, Cortez, 2007; p. 80).

${ }^{48}$ MOREIRA, Ruy, O Pensamento Geográfico Brasileiro: As Matrizes Brasileiras (v. 3), São Paulo, Contexto, 2010 . 
homem que trabalha, do ser meramente biológico ao ser social (LUKÁCS, 2013; p. 44) ${ }^{49}$.

Tal referência se estende, por conseguinte, às formulações do próprio Ruy Moreira, herdeiro direto do legado de Armando C. da Silva ("A hominização do homem pelo trabalho de transformação da natureza é decorrência de ser ele sujeito e o objeto de sua própria história") ${ }^{50}$ e também às de Horieste Gomes ("É pela ação do seu trabalho social realizado sobre o mundo da natureza e da sociedade que o ser humano vem formando a sua consciência, aperfeiçoando-a continuamente") ${ }^{51}$, por exemplo. Tal via continua a ter forte influência em formas mais atuais de se pensar uma Geografia como um instrumentário teórico politicamente combativo e afirmativo, no entanto, apesar de sua abrangência e diversidade conceitual acerca das questões internas que envolvem a dialética do trabalho, podem ser apontados duas questões, ou lacunas limitantes (de um rol mais amplo de outras lacunas e questões mais específicas) que desafiam a constituição efetiva de uma via teórica-afirmativa, fundada no caráter "transitório e ontológico do trabalho", tanto em termos de uma crítica geográfica, como de uma crítica social. Isso porque, ao mesmo tempo em que uma proposta ontológica possibilita estabelecer centralidade conceitual à determinada categoria de análise (seja o espaço, seja o trabalho), pode ela mesma se "absolutizar" na forma de essencialismo dogmático e fetichizante que, contraditoriamente, significaria o próprio fim da crítica social.

Primeira Questão (Os problemas da mediação entre a elaboração ontológica e a realidade concreta histórica):

O amplo projeto teórico de Lukács tinha como objetivo reestabelecer, dentro de uma proposta dialética, a estruturação do pensamento crítico a partir da identificação do estatuto ontológico de uma teoria crítica para o "ser social". O aprofundamento em uma análise abstrata no sentido de atestar a validade do pensamento marxiano a partir de longínquos recuos históricos (por exemplo: "pensamos a caça no período paleolítico. As dimensões, a força e a periculosidade dos animais a serem caçados tornam necessária a cooperação de um grupo de homens" ${ }^{52}$, apareceu, para os mais desatentos, como a sequência de uma teoria essencialista

\footnotetext{
${ }^{49}$ LUKÁCS, Para uma Ontologia do Ser Social, 2013.

${ }^{50}$ MOREIRA, R, O Que é Geografia, 1994b; p. 80.

${ }^{51}$ GOMES, H, Reflexões sobre Teoria Crítica em Geografia, 1991; p. 102.

${ }^{52}$ LUKÁCS, 2013, p. 83.
} 
de herança engelsiana, como aquela presente em Anti-Dühring ${ }^{53}$, ou a "Dialética da Natureza", que mais contribuiu para a efetivação de um dogmatismo do tipo soviético do que para a própria natureza da dialética histórica ${ }^{54}$. Este parece não ser, no entanto, o objetivo de Lukács, pois se tratava mais de se buscar "uma abstração sui generis", da qual os saltos ontológicos mediados pelos "momentos predominantes" estabelecem a forma em si do ser: a tentativa de se buscar uma ontologia que fosse ao mesmo tempo uma perspectiva de superação da ordem do capital. O trabalho seria essa categoria que, ao mesmo tempo em que representasse a universalidade do metabolismo homem e natureza, representaria também a possibilidade da transição, pois, novamente, como citado acima: "somente o trabalho tem, como sua essência ontológica, um claro caráter de transição” (LUKÁCS, 2013; p. 44). Esse caráter transitório, logo histórico, do trabalho é o fundamento ontológico dele mesmo contra sua absolutização anti-histórica. No entanto, seria então pelo "método intelectivo", não puramente empírico ou historicista, que se torna possível a "dissolução" dialética do objeto, o que implica o recurso das abstrações como forma de apropriar conscientemente do $\operatorname{ser}^{55}$.

As preocupações de Lukács acerca da história eram centrais, mesmo em sua ontologia, que deveria ser lida como um fundamento da história em transição a partir do trabalho. A acusação, no entanto, de ter sido um "acomodado oportunista" ligado às questões metafísicas sem se importar com a realidade concreta se explica ainda pelas condições contextuais. Tratase de entender o momento histórico em que se inseria a obra e o autor para desvendar a suposta recusa ao projeto histórico. Como lembra Mészáros, o texto de Lukács sobre a “Democratização", escrito em 1956, carregado de uma leitura sobre o momento histórico da Hungria pós-revolução socialista e integração ao Estado Soviético foi mesmo censurado pelo próprio Partido Comunista húngaro por ter sido considerado "politicamente perigoso". Isso levou o filósofo a um período tido como "internalização" que lhe afastarou, inclusive, das

\footnotetext{
${ }^{53}$ Assim admite o próprio Lukács acerca das influências de Engels: "É mérito de Engels ter colocado o trabalho no centro da Humanização do homem. Ele investiga as condições biológicas do novo papel que o trabalho com o salto do animal ao homem" (2013, p. 45).

54 “Estas formulações de Engels não conheceram grandes desdobramentos, sua repercussão praticamente se limitou a alguns autores (como Plekânov e Kautsky) da geração seguinte. Severas críticas já foram levantadas, por eminentes pensadores marxistas, a tais formulações de seus desdobramentos. Elas apontam as concessões ao positivismo e aos darwinismo aí contidas. As tentativas de Lisenko no período stalinista mostraram-se ainda mais prejudiciais à pesquisa científica" (COSTA \& MORAES, 1984; p. 55)

55 “É exatamente a penetrante irreversibilidade do caráter histórico do ser social que nos impede de reconstruir, por meio de experiências, o hic et nunc [agora ou nunca] social deste estágio de transição. [...] O máximo que se pode alcançar é um conhecimento pós festum, aplicado ao método marxiano, segundo o qual a anatomia do homem fornece a chave para a anatomia do macaco e para o qual um estágio mais primitivo pode ser reconstruído intelectualmente - a partir do estágio superior, de sua direção de desenvolvimento, das tendências de seu desenvolvimento. [...] O salto, no entanto, permanece sendo um salto e, em última análise, só pode ser esclarecido conceitualmente através do experimento ideal que nos referimos" (LUKÁCS, 2013; p. 42-43).
} 
atividades políticas perante o partido. Como depõe Mészáros: “O problema foi a internalização por Lukács, dos limites fundamentais dos acontecimentos pós revolucionários, e não uma acomodação pessoal oportunista à linha partidária" (2011; p. 502). Tal “internalização”, que traduzia uma "reclusão forçada" 56 , começou a ser aclarada quando se tornavam insustentáveis a lógica da reprodução stalinista na Hungria duas décadas depois, período em que os arquivos dos textos censurados, dentre eles o "Presente e Futuro da Democratização", de Lukács, começaram a ser publicados pelo próprio Partido Comunista húngaro.

O que importa nesse resgate histórico (em aclarar o que tendia a ser obscuro em Lukács) é que não somente demonstra como se deram os conflitos pela crítica (histórica versus dogmática), mas também os limites históricos para o desenvolvimento de uma dialética histórica que completasse a dialética ontológica, na especificidade de Lukács. A necessidade da elaboração de uma obra de análise histórica idealizada por Lukács (“o Capital dos nossos dias") reflete a admissão de seus próprios limites. Sobre tais admissões, inclusive sobre o caráter "panfletário" do texto censurado sobre a democratização, autocriticado pelo próprio Lukács, analisa Mészáros:

Na verdade, este ensaio é muito mais problemático do que indicam as reservas de seu autor, pois ele tenta oferecer soluções para agudos problemas políticos e socioeconômicos no plano metodológico abstrato e num discurso ontológico remoto, sem indicar as necessárias mediações materiais e institucionais que pudessem superar, pelo trabalho crítico estratégico, as dificuldades e contradições identificadas do presente (2011; p. 501)

Os limites que se apresentam em relacionar o estatuto ontológico de uma teoria crítica e os desafios para afirmação de um salto ontológico histórico, na direção do que Marx chamou de "verdadeira história humana", representou um problema muito mais sério do que o próprio Lukács considerou. "A proposição constantemente repetida de que 'apenas a ética pode superar o dualismo entre o particularismo dos indivíduos e seu caráter genérico’ etc., funciona em todo lugar como mero postulado em relação aos problemas discutidos" (MÉSZÁROS, 2011; p. 501). Tais limitações, que são decorrentes da dialética mal resolvida entre o abstrato ôntico e o concreto histórico, impõe questões não menos sérias sobre o tratado teórico e prático de uma via que se pretende combativa, emancipatória e afirmativa.

\footnotetext{
${ }^{56}$ Citará Mészáros (2011; p. 502) uma carta do próprio Lukács: "Espero que os desdobramentos da Hungria não levem a uma situação tal que medidas administrativas contra verdadeiros marxistas húngaros forcem-me novamente a reclusão intelectual da ultima década” (In: Társadalmi Szelme, abril de 1990, p. 89).
} 
Para o movimento de renovação da Geografia, problema dessa ordem se desdobrou de profundas maneiras. Ao passo que, no plano das ciências sociais no Brasil, vão se aclarando as influências de um revigoramento teórico de afirmação para a transição socialista baseada na centralidade ontológica e histórica do trabalho (referenciada diretamente em Lukács e Mészáros), no plano do desenvolvimento da crítica geográfica tais influências foram se distanciando do horizonte da renovação epistemológica. A tarefa de inserir o espaço dentro da perspectiva ontológica em prol da atualização de uma teoria socialista parecia caminhar para um "retorno" à Geografia denunciativa e dogmática, dada a suposta remoticidade do discurso ontológico. O que estava no plano da aparência (os perigos de um retorno dogmático) fora mais tarde confirmada como tendência histórica que não só continuou a confundir os objetivos teóricos da superação capitalista como "puramente ideológicos" “autossuficiência epistêmica" para os objetivos de transformação social.

O desenvolvimento de uma frente epistemológica que concedesse ao espaço o estatuto e a legitimidade ontológica equivalente àquela elaborada por Lukács foi paulatinamente se dando em um distanciamento das questões práticas e políticas. Em Ruy Moreira, por exemplo, é notório como a denúncia "ético-finalista" contida em seu texto embrionário, "O que é Geografia", que é subsidiada por uma precária relação ontológica (mesmo se considerando o caráter didático do texto) entre trabalho e espaço:

Nas 'sociedades naturais', assim chamadas porque a terra é o meio universal de trabalho, há uma unicidade orgânica entre homem e natureza. O ritmo do trabalho e da vida dos homens repete o ritmo da natureza. A organização espacial só mostrará sociedades diferenciadas quando se estiver perante diferentes modos de produção.

Os objetivos originais de propor, no entanto, "uma teoria do espaço que seja uma teoria social”, preocupada com "a prática da transformação social” (MOREIRA, 2007; p. 62) ${ }^{58}$, desaguam em preocupações “mais epistemológicas” que passam a variar desde as relações entre

\footnotetext{
${ }^{57}$ É notório como que as advertências de Milton Santos em direção a "uma boa parcela do que hoje aparece como geografia marxista" foi lida como o "enfoque marxista" em si na Geografia. Não importa somente o recurso linguístico que transforma "uma boa parcela" em todo o "enfoque marxista", mas importa também os objetivos ideológicos em afirmar que, pressupondo acriticamente uma unidade na diversidade do marxismo, em última instância todos eles são dogmáticos: "O problema da 'atrofia teórica' conjugaram-se o 'enfoque marxista', isto é, a fixação no marxismo que serviu de base, em grande parte, dessa geografia renovada" (SILVA, O Pensamento Geográfico Brasileiro na Travessia do Século XX para o XXI, 2010).

${ }^{58}$ Objetivos "éticos-finalistas" postos em texto germinal, escrito originalmente em 1978, de bastante influência e importância para o movimento de renovação crítica da Geografia brasileira: "A Geografia serve para desvendar mascaras sociais".
} 
a "epistemologia e a ontologia" até as preocupações com o "papel da engenharia genética" em uma sociedade cada vez mais tencionada para o "bioespaço, uma espécie de mix do gênero de vida e do meio técnico-científico. Um meio técnico-científico e biogeoreferenciado, como poderíamos chamar" (MOREIRA, 2007; p. 180).

Mais que isso, também no plano específico do debate ontológico, observa-se uma tendência cada vez mais vinculada às "soluções internas" acerca da urdidura de uma estrutura lógica propriamente geográfica e eminentemente espacial. Não por acaso, ainda que a precariedade dialética na ontologia do trabalho - como pano de fundo de uma leitura geográfica demonstrada acima no exemplo de Ruy Moreira - apresentasse uma séria limitação teórica, ao menos os compromissos em torno de uma crítica social voltada para a transformação social estavam reafirmados. O que a necessidade de desenvolvimento epistemológico promoveu para além de um mergulho na reestruturação teórica que objetivasse a solução dos graves problemas "políticos e socioeconômicos" de um sistema em crise estrutural - foi um aprofundamento ainda maior acerca das "questões internas" da ontologia espacial. Por isso a transição da referência ontológica lukacsiana para uma ontologia heideggeriana se tornou, por exemplo, uma das fortes tendências para a necessária positivação do espaço (e, por sua vez, para a legitimação disciplinar) partir da conservação do "ideal positivista de ciência", nos termos adornianos. Somente a partir daí, da "internalização" do espaço em sua própria dimensão eminentemente ontológica e necessariamente geográfica, é que se pode não só se desvincular dos compromissos políticos-emancipatórios, mas torná-los mesmos inconciliáveis em relação ao projeto de sutura epistemológica, pois de que outra forma (ainda para usar as expressões de Adorno publicadas em 1969) “As ontologias na Alemanha, sobretudo a ontologia heideggeriana, [continuariam] exercendo influência, sem que os rastros do passado político provoquem qualquer horror"?

A importância de Heidegger como referência para a busca da ontologia do espaço não cai somente nas questões políticas que envolvem sua filosofia com seu contexto histórico ${ }^{59}$, mas porque sua proposta ontológica se situa na tentativa do "ser" para além das determinações da modernidade, se envolvendo em uma couraça que a blinda das “deturpações” políticas internas

\footnotetext{
59 “Ninguém ignora que esse filósofo apoiou Hitler e o nazismo. Parece-me ademais inacreditável que alguém que tenha lido e compreendido a obra maior de Heidegger, 'Ser e Tempo', de 1927, seja capaz de negar a impressionante afinidade entre o teor de certas pretensões desse livro e grande parte da ideologia nazista, que ele estranhamente antecipa. Basta lembrar que ambos rejeitam a modernidade filosófica, o iluminismo, o individualismo, o humanismo e o universalismo, enquanto exaltam o que consideram a autenticidade do indivíduo que se sacrifica em prol do destino particular da comunidade e do Estado a que pertence. A partir da ascensão de Hitler ao poder na Alemanha, em 1933, Heidegger explicitamente articula seu pensamento com as concepções nazistas" (CICERO, Antônio, "Heidegger e o Nazismo", In: Folha de São Paulo: Caderno Ilusrada, São Paulo, 20 de fevereiro de 2010.
} 
e externas. A possibilidade do eterno retorno à questão fundante do ser (“deve-se colocar a questão do sentido do ser" ${ }^{\prime 60}$ ), conjugado com uma exposição clara do método e da busca ôntica, além de suas "aproximações geográficas" a partir de suas formulações sobre a "ideia de mundanidade" e do "ser-no-mundo", oferece uma possibilidade para o desenvolvimento epistemológico geográfico. Por exemplo, Ruy Moreira irá se fundamentar no filósofo para efeito de entendimento da "diferença ontológica" da "forma espacial real e concreta de ser-estar do homem-no-mundo atual como um homem alienado do espaço e por isso de si mesmo": "a desnaturalização, a desterreação e a desterritorialização" (2007; p. 134), uma relação criativa e instigante entre a ontologia heideggeriana e a alienação do trabalho marxiana, apesar de ainda aí se conservarem os traços comuns de uma "ontologização remota" desprovida de mediações de superação de sua alienação com o espaço (como amplamente analisado no "Capítulo 3 - A solução ontológica e os limites para a centralidade do espaço").

O caminho que passa a tender o desenvolvimento da crítica geográfica, de uma frente militante-política, para cada vez mais se conformar em uma frente epistemológica reflete, ademais, mais do que um suposto amadurecimento teórico, mas também uma inversão objetiva na mediação entre teoria e prática. Isso porque sua efetivação enquanto teoria social crítica se encontra no movimento inverso em relação à tendência da crítica lukacsiana, fundamentada no trabalho, que tendeu a se reproduzir, por sua vez, por um caminho cada vez mais afirmativo e combativamente emancipatório, voltado para as formas de ser no momento histórico em que as contradições mais esgarçam seus potenciais destrutivos na forma da crise estrutural do capital $^{61}$.

A busca pela epistemologia espacial diante do problema mal resolvido desde Lukács, entre a ontologia e a dialética histórica, ou a necessidade de afirmação de estatuto ontológico (abstração) e a necessidade de afirmação de uma leitura histórica crítica (concreção), se tornou, para os geógrafos, um problema de grandeza ainda maior do que para os filósofos. Se Mészáros tenta a solução para tal lacuna propondo uma ontologia "mais lógica" entre as contradições das mediações de primeira ordem e as mediações de segunda ordem $^{62}$ como forma de se distanciar da tendência de "absolutização da ontologia", propondo uma teoria da transição histórica, para a Geografia tratava-se, pois, não só de manter a estrutura lógica entre ontologia e as formas históricas de existência (entre o ser e o ente), mas ainda de inserir o espaço em detrimento do

\footnotetext{
${ }^{60}$ HEIDEGGER, Ser e Tempo (parte I), 2005; p. 31.

${ }^{61}$ As questões sobre a crise estrutural do capital serão tratadas no tópico "2.1 - O meio "técnico-científicoinformacional': entre o ‘colapso da modernização' e a 'crise estrutural'”.

${ }^{62}$ A relação entre as mediações de primeira e segunda ordem serão tratadas no tópico "3.5 - Das Linhas de Fuga aos Refúgios de uma Crítica Não Efetiva"
} 
trabalho. O exemplo de Ruy Moreia atesta não somente que tal empreitada não poderia se dar sem sérios prejuízos para a crítica social, como também aponta que a efetivação de uma teoria ontológica do espaço é em si a negação de uma teoria ontológica do trabalho. Tal contradição, posta em tal negatividade não admitida, antes mesmo do caminho traçado por Ruy Moreira, foi observado em Armando Corrêa da Silva, pioneiro no debate sobre a ontologia do espaço no movimento de renovação.

Para Silva (1986; p. 38), pensar sobre as questões mais atuais acerca do papel da geografia, ou "o que ela deve fazer", está em, primeiro, reconhecer sua dimensão qualitativa que mais exerceu contribuição à sua efetivação enquanto disciplina científica: "A Geografia Descritiva ou Geografia Empírica” (1986; p. 38). E, em segundo, reconhecer que há questões teóricas, a exemplo do espaço absoluto e espaço relativo, que a Geografia desenvolvida até então não resolve, daí a necessidade de uma Geografia teórica. Ainda segundo Silva, a proposta apresentada por David Harvey acerca do "espaço relacional", ainda que resolva a dicotomia até então vigente entre o espaço relativo e o espaço absoluto, se mostra como uma solução parcial:

No entanto, essa solução apresentada [por Harvey] representa um problema, ou seja, o espaço não se põe como ser. A solução no que diz respeito ao movimento do espaço é remetida à prática humana, que valida a questão da ação política e do debate crítico, mas não resolve o problema teórico (1986; p. 39).

O problema teórico do qual fala Silva é exatamente a necessidade de composição do estatuto ontológico do espaço. É notório o distanciamento da "necessidade" ontológica em Harvey, mais preocupado com as formas expressivas da existência do/no espaço. De fato, onde Lukács interpreta a "atividade orientada a um fim" em Marx (1983; p. 150), posta na famosa passagem sobre distinção da natureza do trabalho entre o "pior arquiteto da melhor abelha"63, como a enunciação da "categoria ontológica central do trabalho" que "através dele realiza-se, no âmbito do ser material, um pôr teleológico enquanto surgimento de uma nova objetividade" (LUKÁCS, 2013; p. 47), para Harvey o caráter universal do trabalho, enquanto metabolismo insuperável da mediação homem (sociedade) x meio (natureza), compõe a dialética produto $x$

\footnotetext{
63 "Pressupomos o trabalho numa forma em que pertence exclusivamente ao homem. Uma aranha executa operações semelhantes às do tecelão, e a abelha envergonha mais de um arquiteto humano com a construção dos favos de suas colmeias. Mas o que distingue, de antemão, o pior arquiteto da melhor abelha é que ele construiu o favo em sua cabeça, antes de construí-lo em cera. No fim do processo de trabalho obtém-se um resultado que já no início deste existiu na imaginação do trabalhador, e portanto idealmente" (MARX; 1983; p. 150).
} 
produção da própria história, em que determinadas condições dadas são somente as condições de sua própria transformação, mas não de natureza ontológica.

Tal leitura fica evidente quanto a sua interpretação sobre Marx. Na passagem sobre o "processo de trabalho" em "O Capital", a interpretação de Harvey sinaliza uma "mudança de orientação" da escrita do autor: “[...] este capítulo é incomum em certo aspecto. Na maior parte do texto, Marx deixa claro que está lidando apenas com categorias conceituais formuladas no modo de produção capitalista e adequadas unicamente a este modo de produção" (HARVEY, 2013; p. 113) ${ }^{64}$. Para Harvey, tal mudança em direção a uma universalidade assumida do trabalho não representa a composição de uma centralidade ontológica para o pensamento crítico, como objetiva Lukács, mas a transformação em si das condições históricas em que o próprio processo de trabalho está "aprisionado" no capitalismo, como assim se faz entender ao afirmar:

Em seus primeiros escritos, Marx deu grande ênfase à ideia de um "ser genérico" especificamente humano, (apoiando-se talvez na antropologia kantiana e nas formulações antropológicas tardias de Feuerbach). Essa ideia é relegada a um segundo plano nas formulações d'O Capital, mas vez ou outra tem uma influência furtiva, como neste caso (HARVEY, 2013; p. 114)

Dessa forma, o que para Armando Correa da Silva se apresenta como um problema não resolvido a respeito da proposta do espaço relacional proposto por Harvey, é na verdade a própria solução para uma teoria histórica do espaço a partir de sua negação ontológica. A não vinculação à determinação teórica de uma teoria ontológica do espaço em Harvey aparece, desse modo, como uma tentativa de se evitar desde a absolutização apriorística kantiana até a absolutização materialista feurbachiana para, por fim, propor um "materialismo histórico e geográfico" (HARVEY, 2005a; p. 144). Para Silva (1986; p. 39), o “problema teórico” está para além "da prática humana, que valida a questão da ação política e do debate crítico" e deve ser resolvido segundo os termos "racionalistas" da contradição que se põe entre o "espaço relacional" (totalidade) e o problema das "estruturas" (e seus atributos próprios ou ideológicos).

Se em Harvey a negação do recurso ontológico caminha em direção a um reconhecimento da mesma dificuldade presente em Lukács e acusada por Mészáros - qual seja, o problema das mediações entre a ontologia e a condição prática-histórica -, para Silva este é exatamente o problema a ser resolvido. Importa situar que o referido debate apresentado acima está em um texto intitulado “O Espaço como Ser: Uma Auto-Avaliação Crítica”. Importa mais

\footnotetext{
${ }^{64}$ HARVEY, David, Para Entender O Capital: Livro I, São Paulo, Boitempo; 2013.
} 
ainda situar a natureza do que representou "uma auto-avaliação crítica" na obra de um dos autores mais influentes da renovação crítica brasileira, no que concerne o destino da relação entre a ontologia do trabalho e a ontologia do espaço para a composição de uma crítica social.

Assim como Ruy Moreira, Armando Corrêa da Silva traça um caminhar por vias "mais epistemológicas" ("No entanto, o espaço se põe como ser, mas por uma via epistemológica" ${ }^{65}$ ). Sobre a questão levantada acerca da estrutura (se ideológico ou atributo do objeto), opta por um caminho de complementariedade entre Harvey e Lacoste: "só a prática humana resolve em Harvey, e só a prática intelectual resolve em Lacoste"66, mas somente para depois negá-la ao considerar a solução de Milton Santos como a mais apropriada (“aqui, a estrutura não é nem um componente ideológico, nem um atributo do objeto") ${ }^{67}$. Do ponto de vista do método abordado por Silva para o problema de pôr o espaço como ser a partir da questão sobre a natureza da estrutura, pondera que tanto a interpretação de Harvey como a de Lacoste são relativas "ao lugar de observação: os Estados Unidos e a Europa"68 e justifica a concordância com Santos por este ver a questão a partir de uma "totalidade interna" e condizente com a realidade do Terceiro Mundo.

A aproximação com a proposta miltoniana é também uma aproximação com a proposta estruturalista para uma solução epistemológica (“O 'estruturalismo sistêmico' torna irrelevante a questão de se a estrutura é uma ideologia ou se é um atributo do objeto") ${ }^{69}$, não somente porque nutre concordâncias com a postura reconhecidamente estruturalista de Lacoste ("Lacoste trabalha com uma modalidade de estruturalismo que se qualifica como "estrutura da espacialidade diferencial"”), mas também por encontrar "em Althusser, as noções de estrutura e sobredeterminação, mas separando o positivista do filósofo dialético"70.

A forma como procede Armando Corrêa da Silva em efetivar separação da dimensão "positivista" em relação à "filosofia dialética" estruturalista em Althusser, e ao mesmo tempo proceder por vias epistemológicas a partir de "estruturas internas" da "totalização de totalizações", é um complicador a mais para além de tantas outras complicações presentes em suas influências mais diretas (no plano da composição do espaço como ser) em sua proposta amalgamática: de Leibniz a teoria das mônodas, de Kant a elucidação do problema da dicotomia entre "razão pura" e "razão prática", de Hegel o procedimento crítico-dialético entre tese

\footnotetext{
${ }^{65}$ SiILVA, 1986; p. 41.

${ }^{66}$ Id., Ibid.

${ }^{67}$ Id. Ibid.

${ }^{68}$ Ibid., p. 41.

${ }^{69}$ Ibid., p. 43.

${ }^{70}$ Ibid., p. 44.
} 
(território)-antítese (região)-síntese (área), de Marx a dialética materialista e o materialismo histórico, de Windelband as noções de ideográfico e nomotético para a ciência, de Wittggenstein a filosofia analítica para entender a epistemologia, da fenomenologia a teoria da percepção e a teoria geral, do existencialismo o entendimento existencial do sujeito e do objeto $^{71}$.

Sobre essa aparente "colcha de retalho" teórica, Armando Corrêa da Silva faz uma autodefesa prévia - embora tal necessidade apareça com a própria autodenúncia - de que a formatação de sua proposta de ontologia do espaço não representa nem elitismo, nem ecletismo, pois se trata de uma teoria do conhecimento necessária a partir da união de diferentes influências que, pelo rigor teórico, não deve se significar "nem mistura nem arbitrariedade"72. No caso específico da ontologia do espaço, retorna Silva para a argumentação sobre a necessidade de se debruçar em uma "teoria do valor em Geografia" que resgate o "princípio" de um "modo de produção natural", também de um "trabalho natural", como forma de assegurar a compreensão das "relações no e do espaço" em detrimento da noção de "ocupação do espaço". Tal procedimento deve conceder à Geografia sua legitimidade social para além "de ser apenas uma ciência auxiliar e externa a outras ciências" "73. Aqui, novamente, se reforçam os compromissos com a legitimidade cientifica.

Notadamente, a tentativa de estruturação de uma ontologia espacial (ainda que tomada aqui a partir de um ponto em específico do debate), com a profundeza filosófica peculiar de Armando Corrêa da Silva, fornece algumas pistas para se pensar nos caminhos inversos em que a crítica epistemológica e a crítica social caminharam na renovação geográfica. Apontar pelo seu desfecho substanciado na reafirmação de categorias como "modo de produção natural", ou "trabalho natural", pode assim ser desvelada a efetivação de duas tendências contraditórias. Tais contradições precisam ser colocadas em relevo, não só por apresentar mais um demonstrativo acerca dos caminhos contraditos entre a crítica do trabalho e crítica geográfica, mas também por tender a indicar lacunas na formulação do pensamento crítico-geográfico: primeiro que o desenvolvimento da empreita epistemológica significou refugiar (ou mesmo exilar) o trabalho nele próprio, ou seja, em sua dimensão mais longínqua e profunda no plano da abstração, nos confins da metafísica, chegando ao ponto mesmo de negá-lo da práxis emancipatória no plano real-concreto; e segundo que o reconhecimento apontado por Mészáros acerca dos perigos da ontologia de Lukács, ou do seu "discurso ontológico remoto", está aqui

\footnotetext{
${ }^{71}$ SILVA, 1946, p. 44.

${ }^{72}$ Id., Ibid.

${ }^{73}$ Ibid., p. 46.
} 
novamente reiterado, mas não por uma "internalização politicamente forçada" (como fora o caso do filósofo húngaro), mas sim por uma "internalização disciplinar forçada", ou seja, pela ausência de uma avaliação (auto)crítica sobre a necessidade epistemológica ${ }^{74}$ posta como necessidade em si, por isso apriorística.

Segunda Questão (Os problemas da natureza da diciplinarização epistemológica)

Os desafios de se elaborar uma crítica universalmente afirmativa e emancipatória a partir de uma sistematização disciplinar fundamentada na ontologia (seja do trabalho, seja do espaço) está relacionado a uma contradição. Se, por um lado, ao passo que a ontologização da categoria central (espaço) - que contempla a necessidade epistêmica da ciência (geográfica) -, tende a recair nas determinações absolutas e essencialistas de uma "ontologia remota" frente aos desafios reais de superação das contradições socioeconômicas historicamente postas, por outro lado, e de modo inverso, a tentativa de constituição de uma perspectiva teórica afirmativa e emancipatória fundamentada na liberação ontológica do trabalho frente as determinações alienantes do capital deve se pôr como a própria perspectiva da transformação social no seio da ciência. Isso significaria considerar os compromissos disciplinares e epistemológicos de forma (auto)crítica, de uma Geografia que tenta se estabelecer como legítima, autônoma e independente frente a divisão do trabalho intelectual.

Tal contradição tendeu a ser resolvida de modo mais ingênuo na proposição de uma universalização da crítica geográfica como a universalização da crítica social-histórica em si: libertando o espaço, liberta-se o homem de sua alienação, sem que se atentasse para os perigos alienantes de se conceder a condição de sujeito ao espaço em detrimento do homem, sem que se atentasse também para as mediações objetivas de como "libertar" o espaço se é ele também condição da alienação humana. Tais questões não estão resolvidas nas perspectivas teóricas de boa parte dos geógrafos comprometidos na elaboração de uma ontologia do espaço, desde a

\footnotetext{
${ }^{74} \mathrm{O}$ procedimento ontológico em que se expressou tal necessidade epistêmica acrítica estabelece como forte corrente, de cunho apriorístico (kantiano), pode levar a certas confusões, como aquela que tende a se desenvolver por meio de uma leitura essencialista da própria totalidade, esta agora posta como categoria ontológica de positivação do espaço, e não mais como movimento revelador de contradições (negativos) da dialética histórica: "Podemos assim, caminhar em direção ao entendimento do espaço como ser, agora, abarcando a categoria totalidade. Deste modo, a Totalidade é o ser como potência, a essência universal dos entes, desde seu especulado "momento primevo". Então temos o ser enquanto essência, aquilo pelo qual uma coisa é o que ela é (uno e potência), e o ser enquanto existência, o que confere à essência o ato de existir (múltiplo e ato). Troquemos então o ser por espaço, teremos então que qualquer ente presente em nosso universo é espacial, resumindo: o espaço é a totalidade, como essência universal dos entes!" (GUIMARÃES, Humberto Goulart, "Ensaio Sobre o Espaço como Modalidade Ontológica do Ser: Nos Caminhos de Armando Corrêa da Silva", In: Revista Discente Expressões Geográficas, $n^{\circ}$ 05, ano V, p. 31 - 48. Florianópolis, maio de 2009; p. 36).
} 
"busca do lugar" Armando Corrêa ${ }^{75}$ até a "libertação da técnica""76 em Milton Santos. Por outro lado, não menos ingênuas são aquelas propostas que tendem a negação absoluta da ciência em prol de um certo tipo de holismo humanístico. Contraditoriamente, se substanciam de uma certa "fenomenologia do lugar", herdada de uma perspectiva crítica, para absolutizar o próprio espaço como fração totalizada no lugar - muitas delas inspiradas inclusive nos conceitos mal interpretados de Milton Santos e Armando Corrêa da Silva sobre a "subtotalidade" reproduzindo, assim, a fragmentação e negação de uma metanarrativa da história em detrimento da supervalorização perceptiva do sujeito observador: o cientista.

Diante de tais questões, como situar uma Geografia do trabalho, ou geografias do trabalho? Se "uma" Geografia do trabalho estaria disposta a reproduzir o caráter epistêmicodisciplinar, a partir de uma ontologia do trabalho, ficaria ela condicionada à própria negação da "condição transitória" de sua categoria basilar? Ou se a suposição de "geografias" do trabalho estiver ligada às condições objetivas da realidade do mundo do trabalho poderia ela se perder no eterno-retorno a uma empiria do seu próprio objeto de pesquisa? É claro que esses dois extremos existem como tendências da reprodução de uma leitura mal compreendida da relação entre ontologia e história, mas, como possibilidades, se portam como reais e se expressam não eventualmente em pesquisas que variam desde o empirismo vulgar até a "ontologização remota".

Tais limites foram assimilados pelo "manifesto" "Por Uma Geografia do Trabalho"77, de Antônio Thomaz Junior, ao estabelecer as bases de sua construção que deve superar os "preconceitos" acerca de uma proposta que, para além de se constituir mais uma subdivisão disciplinar, propõe a se estabelecer a centralidade do trabalho como objetivação para análise geográfica:

A Geografia do trabalho se põe em cena, assim como as demais disciplinas ou ramos do conhecimento científico, para responder as perguntas em relação à realidade, sabendo-se, pois, que a temática do trabalho, assim como a sociedade de maneira geral não é exclusiva ou restrita a nenhuma delas. Inicialmente focado na dimensão do território, recorte de domínio do espaço, é possível reconhecermos por dentro da dinâmica da sociedade as diversas faces e interfaces do mundo do trabalho. Em outros termos, intentamos, num só movimento, a partir da ordenação territorial do fenômeno, movimentar-nos

\footnotetext{
75 "Trata-se de construir o conhecimento geográfico a partir de uma visão não fragmentada do mundo, trabalho que vem sendo realizado agora, a partir do momento em que os geógrafos percebem que as ideias também têm lugar em Geografia" (SILVA; p. 128).

76 As contradições sobre a "libertação da técnica", sendo ela mesma produto da divisão hierárquica do trabalho e condição da alienação do trabalho (alienação) foi ponto de debate no tópico "2.2 - Técnica: a autossustentação, a autorreferenciação e o sistema filosófico fechado".

${ }^{77}$ THOMAZ Jr., Revista Pegada Eletrônica (Geografia), 2002.
} 
tanto do ponto de vista da escala territorial (e as generalizações daí decorrentes), quanto da escala categorial, isto é, do que entendemos ser o “jogo" das determinações (THOMAZ JR. 2002; p. 17).

Os "preconceitos" "78, aos quais se refere Thomaz Jr., estão inseridos no próprio limite apriorístico do que "é ou não geográfico"79, tanto com relação às limitações "essenciais" de seu objeto (a busca da espaciologia), como em relação a sua tradição temática: "o que tem a ver Geografia com o trabalho" ${ }^{80}$. Neste último caso, há de considerar que a proposição da Geografia do Trabalho deve partir de duas condições analíticas: entender o trabalho como a mediação fundante da relação homem (sociedade) e meio (natureza), logo como categoria também fundante do espaço geográfico; e entender as formas concretas com que o trabalho se expressa no território, sobretudo entendendo a dimensão espacial como a forma especificamente histórica de regulação do trabalho pelo capital em suas diferentes escalas: “a gestão do capital sobre o território pode ser vista como sendo sua própria autogestão territorial, que tem como limite a abrangência da estrutura empresarial [...]" ${ }^{\prime 1}$. Tal forma de entender a dimensão espacial tem como referência a interpretação presente em Milton Santos, mas sobretudo em Ruy Moreira ${ }^{82}$, para quem, do chão da fábrica até os arranjos espaciais, "quanto mais [se lê] sobre o espaço, mais [se fortalece] na cabeça a ideia de que, para o capital, o espaço é uma forma de regulação" (MOREIRA, 2001; p. 51$)^{83}$.

No entanto, diferente de Milton Santos e Ruy Moeira, a perspectiva da Geografia do Trabalho de Thomaz Jr. estabelece seu estatuto ontológico no trabalho, não no espaço. Dessa forma, as categorias geográficas se situam como mediadoras no processo de análise: "as categorias de base da Geografia (paisagem, território e espaço) farão as mediações necessárias, atendendo os desafios postos pelo sujeito, no esforço contínuo de teorização para a concreção de uma Geografia do Trabalho" (THOMAZ JR. 2001, p. 01).

Para Thomaz Jr. a proposição de uma ontologia do trabalho posta como centralidade e de uma epistemologia geográfica, por sua vez, situada como "instrumentário" para análise científica é abertamente assumida, no momento em que se reafirma: "não somos candidatos a, pura e simplesmente, protagonizar uma nova nomenclatura interna à Geografia, com recorte

\footnotetext{
78 THOMAZ JR., 2002, p. 02.

${ }^{79}$ Id., Ibid.

${ }^{80}$ Id., Ibid.

${ }^{81}$ Ibid., p. 10.

${ }^{82}$ MOREIRA, II Jornada sobre o Trabalho, 2001.

83 “Estes arranjos geográficos vão desde aqueles dos impérios até aquele do chão da fábrica e quanto mais eu leio sobre o espaço, mais me fortalece na cabeça a ideia de que, para o capital, o espaço é uma forma de regulação. Assim, a finalidade é o controle corporal do trabalhador" (MOREIRA, 2001; p. 51).
} 
temático para a questão do trabalho" ${ }^{\text {}}$. Tal posicionamento indica a existência de certo nível de conflito e disputa pela crítica, no momento em que admite se isentar do "jogo de vaidades" 85 existente em uma "disputa acadêmica pela crítica" não abertamente admitida; uma crítica que se hegemoniza por vias cada vez mais isentas de seu conteúdo emancipatório, sobretudo do trabalho ("assunto distante da Geografia do dia-a-dia") ${ }^{86}$. Para isso se propõe a execução de um nível de interdisciplinaridade que vai desde as formulações conceituais mais básicas até a concretude e realização do debate. Isso pode ser percebido pela assimilação da noção "atualizada" de classe trabalhadora da sociologia brasileira ("classe-que-vive-do-trabalho") ${ }^{87}$, ou pela formulação do conceito ontológico "metabolismo societário do trabalho" (THOMAZ JR. 2001; p. 05), que nitidamente se aproxima ao conceito de envergadura histórica do “sociometabolismo do capital" de Mészáros (2011) nos debates assumidos com a sociologia.

A natureza de tal interdisciplinaridade é inversa à da natureza da interdisciplinaridade proposta pela frente epistemológica liderada por Milton Santos, para quem a estrutura disciplinar deve evitar o "grave erro epistemológico" (2002; p. 18) e buscar na sua própria estruturação interna rigor e autonomia a partir do seu objeto, como suporte efetivo para contribuição da análise da totalidade social. Ruy Moreira, para quem tal necessidade é a forma viável da contribuição geográfica, acerca do debate sobre a forma de se ler a dimensão geográfica da relação capital $x$ trabalho, propõe:

Qual seria o eixo que nos permitiria juntar tudo em um discurso minimamente integrado? A relação capital x trabalho. Por onde, no meu entendimento, a relação metabólica, homem x meio, no discurso da geografia do trabalho, entraria a relação capital $\mathrm{x}$ trabalho? Numa certa estratégia de transferência que o capital vem utilizando a muito tempo: dos custos do trabalho no âmbito direto da relação capital $\mathrm{x}$ trabalho, para a relação capital $\mathrm{x}$ recurso (MOREIRA; 2001; p. 43).

Aqui novamente se percebe a recusa da contradição: e se a dimensão do trabalho e do espaço, antes da sua necessidade de se complementar ou unir, estivessem em contradição? Para

\footnotetext{
84 THOMAZ JR. 2002, p. 05.

85 Id., Ibid.

${ }^{86}$ Ibid., p. 12.

87 A tentativa de "ampliação" da noção de classe trabalhadora para além do operariado fabril tradicional que abordasse a "polissemia do trabalho" (desempregados, camponeses, subempregados, sem-terra, etc.) foi tentada por Ricardo Antunes, sobretudo em seu texto "Os Sentidos do Trabalho". No entanto não logrou muita representatividade e recebeu várias críticas, não somente da sociologia, mas de todo um rol de teóricos debruçados na temática. Primeiro porque fora acusada de redundância a-política (e qual a classe que não vive do trabalho?); segundo porque sugeria, como assevera Sérgio Lessa, "o adeus ao proletariado" (LESSA, Trabalho e Proletariado no Capitalismo Contemporâneo, 2007; p. 80).
} 
isso, a "transferência" categórica da qual Moreira se refere vem sendo orquestrada pelo capital desde sua gênese, no sentido de manter a relação de dominação com o trabalho na medida em que ia se compondo e fortalecendo a luta de classe, as organizações do trabalho, os ganhos trabalhistas e o consequente "aumento dos custos do trabalho". Continua a argumentar que tal transferência se deu a partir de "deslocamentos" de contradições ao longo da história e se deu originariamente pelo processo de "desterritorialização" do campesinato, na fase embrionária da grande indústria: "A força de trabalho vai ficando cada vez mais cara para o capital, por enquanto ele vai podendo resolver através de uma desterritorialização crescente do campesinato" (MOREIRA, 2001; p. 44), no sentido de sua proletarização. A constante e crescente oferta de trabalho tende a rebaixar os custos de sua reprodução, consequentemente, os custos do capital (variável) e dos salários. Contudo, à medida que se efetiva internamente (da nação) o plano da "descamponesação" ${ }^{88}$, os limites do controle do capital se arrefecem, dada a própria necessidade de expansão constante do capital na forma de novos investimentos. Para Moreira, a limitação dessa condição espacial interna de controle do trabalho é a condição da sua própria expansão para outros países, onde tais contradições não se desenvolveram. Esse novo "deslocamento" é o princípio da fase imperialista, que teve sua gênese no final do século XIX e encontrou, consequentemente, seus limites no processo da globalização, que, através do neoliberalismo, supôs uma universalização contraditória do capital até seu esgotamento mais atual.

Ruy Moreira então adverte que o "deslocamento" atual se dá por vias de um recrudescimento do processo de exploração do "meio ambiente" 89 , mais especificamente pela busca de recursos energéticos por meio de guerras, o que explica, como fez David Harvey, a condição militar do "Novo Imperialismo" $"$

Para mim, o discurso da biodiversidade talvez seja a nova forma da estratégia do capital, de deslocar os custos de sua relação com o trabalho para a relação com a natureza, então a relação do capital com a natureza faria parte da sua relação com o capital. É onde eu quero chegar (MOREIRA, 2001; p. 49).

Mesmo sem explicitar se tal "deslocamento" da relação do capital com o trabalho para o meio-ambiente seja um discurso (ideológico) que visa encobrir as próprias relações de

\footnotetext{
${ }^{88}$ MOREIRA, 2001, p. 45.

89 “Eu não trabalho com meio-ambiente, eu tenho uma visão muito crítica da questão, acho que a questão ambiental é importante, mas acho que pela linha que estou discutindo, ou pelo menos por aí que prefiro discutir, não é um assunto desimportante, o que estou discutindo é uma questão ambiental, é uma leitura de relação" (MOREIRA, 2001; p. 49).

${ }^{90}$ HARVEY, David, “Tudo Por Causa do Petróleo”, In: O Novo Imperialismo, São Pauo, Loyola, 2005 b.
} 
trabalho no que há de mais recente no processo de apropriação da mesma natureza, ou se de fato sugere um direcionamento da análise geográfica do trabalho para as formas em si de apropriação dos recursos naturais - ou até mesmo algum tipo de relação entre as duas perspectivas: ideológica e efetiva -, a análise de Ruy Moreira tende a oferecer uma riqueza interpretativa para a "função" do espaço no controle do trabalho pelo capital, além de buscar resolver o problema da especificidade da leitura geográfica no âmbito da relação capital $\mathrm{x}$ trabalho: "para quem trabalha com Geografia a relação do capital com a natureza é uma das dimensões, faz parte da relação necessária com o trabalho" "91.

O "deslocamento" do trabalho em detrimento do espaço (ou do meio-ambiente, natureza, recursos, etc.) resolve, dessa forma, o que por um lado parece estar no centro da preocupação disciplinar, a posição que teria uma geografia do trabalho na unidade geográfica (“[...] no sentido de questionar-nos se o tema do trabalho poderia ser desenvolvido, discutido pela geografia, se existiria algo em torno de uma geografia do trabalho, com letra minúscula, não como uma corrente nova na Geografia ${ }^{92}$ "). Por outro lado, a centralização do espaço "pela razão pura e simples de que o mundo hoje se organiza em termos espaciais" 93 em detrimento da centralidade do trabalho no debate atual sobre as formas de reprodução do controle sociometabólico do capital deixa outras contradições expostas e não resolvidas (no sentido de sua elucidação).

Ainda conforme a análise referenciada, acerca de se haveria ou não a eminência de uma crise estrutural, afirma Ruy Moreira: “A democracia é uma conquista tão sine qua non quanto a conquista do salário. Neste sentido eu não diria que o capitalismo está em crise permanente e prolongada $^{94 "}$. Sem precisar entrar numa discussão mais prolongada sobre a natureza da “assimilação da democracia nos tempos de paz", que faz dela própria muito mais exceção do que uma regra política para o século XX (desconsiderando ainda as barbáries "autocráticas" que dominaram plenamente a lógica do capitalismo dos séculos anteriores), basta citar o próprio Moreira para se ter uma noção de como a democracia se fragiliza perante a crise. Em um momento anterior no seu texto, ao apontar a guerra (do Afeganistão e do Iraque) como resultado do novo "deslocamento" categorial do trabalho para o "meio-ambiente", e a respeito do receio de alguns movimentos anti-globalização acerca de que a guerra contra o terror significasse perda de direitos civis nos Estados Unidos e na Europa, admite: "nada impede que amanhã o

\footnotetext{
${ }^{91}$ MOREIRA, 2001, p. 50.

92 Ibid., p. 42.

${ }^{93}$ Ibid., p. 59.

${ }^{94}$ Ibid., p. 60.
} 
movimento anti-globalização seja reprimido em nome da repressão ao terrorismo ${ }^{95}$ ". E, um pouco mais adiante, apresenta a contradição fundamental antes negada: "O problema é que nos dias de hoje a democracia capitalista está cada vez mais difícil de ser garantida pelos interesses capitalistas" 96 .

Para Ruy Moreira, a necessidade de manutenção do imperialismo e sua expressão fenomênica através da guerra e ocupação do território como forma de reprodução atual do próprio capital não mais teria sentido histórico, haja vista que "para uma economia fortemente transnacionalizada é onde o capitalismo está em todos os lugares, e isso já é desnecessário. A territorialidade hoje para o capital é a da mais livre territorialidade possível" ${ }^{\text {"97 }}$. Como, no entanto, "resolver" a contradição de um mundo em que o "espaço virou a realidade de nosso tempo", ao mesmo tempo em que, supostamente, formas primitivas de acumulação (guerra por território) se apresentem como a via mais avançada da reprodução do capital? A não solução do problema por parte do geógrafo (e o próprio Ruy Moreira não oferece pistas para a elucidação da contradição por ele mesmo levantada) pode estar exatamente na incapacidade de o exercício interdisciplinar (nos presentes moldes da solução epistemológica) reconhecer a contradição entre espaço e trabalho.

Para tal problema em específico acerca da interdisciplinaridade, o que Rui Moreira não observa, dado os compromissos com a disciplina do espaço, é que, tal como o capital tendeu a "deslocar" suas contradições espacialmente, houve também um "deslocamento" do sentido e dos objetivos territoriais do novo imperialismo. O limite está em entender duas questões: como relacionar o "deslocamento" das contradições capital x trabalho para a contradição capital x meio-ambiente desconsiderando o deslocamento a natureza militar-imperialista do território em si mesmo (como busca de um novo "arranjo territorial") para uma forma de território pressuposto para a valorização? E como nessa dinâmica não entender a constituição do complexo militar-industrial como polo dinamizador da economia?

São vastos os textos (não na Geografia) em que são apontados os objetivos últimos dos territórios em disputa militar. No caso específico da finalidade da guerra como forma renovada da lógica imperialista, destaca Mészáros: “o instrumento disposto e capaz de romper o nó górdio e de combinar a máxima expansão possível com a taxa de utilização mínima apresentou-se ao capital na figura do complexo militar-industrial" (2011; p. 685). Isso se apresentou como estratégia, não somente nas duas guerras mundiais, mas como importante setor (direta e

\footnotetext{
${ }^{95}$ MOREIRA, 2001, p. 58.

${ }^{96}$ Ibid., p. 60.

${ }^{97}$ Ibid., p. 61.
} 
indiretamente) "para o estabelecimento e/ou modernização de ramos industriais inteiros, nos quais se fundam os 'milagres' do desenvolvimento econômico japonês e alemão do Pós[Segunda] Guerra"98, por exemplo. O complexo militar-industrial do qual se refere Mészáros como setor capaz de combinar "máxima expansão possível com a taxa de utilização mínima", dada a natureza sigilosa e estratégica (assegurada pelo sacro nome da "segurança nacional"), não se dá somente por mobilizar grande quantidade de capital estatal e sob condições suspeitas (de diferentes naturezas, tanto em termos de sua quantidade, como da qualidade - "quem investe?"), mas também de mobilizar grandes subsetores (de alta tecnologia à indústria de base) onde o processo de exploração do trabalho atinge talvez sua condição última de controle e exploração, considerando sua forma "sigilosa" de existência. Paralelo a isso, a natureza em si da mercadoria produzia: feita para destruir outras mercadorias na sua autodestruição imediata, em que o tempo de efetivação do valor de uso (“a taxa de utilização mínima”) se dá absolutamente, pondo em prática a radical diminuição da vida útil das próprias mercadorias produzidas ao ponto de seu autoconsumo ${ }^{99}$, processo este que se intensifica conforme novas guerras são estimuladas, e novos territórios passam a ser "ocupados".

A ausência de um polo de dinamização da economia não mais identificada por Ruy Moreira, a partir do exemplo brasileiro ${ }^{100}$, pode encontrar na própria natureza monopolista da indústria militar (salvaguardado pela tutela sigilosa da "segurança nacional") os motivos de sua "ocultação econômica", ao mesmo tempo que se torna "incompreensível” para o geógrafo, dada as condições em que o "espaço virou a realidade do tempo", conceber tal dinâmica territorialista-imperialista, que passa a sustentar de forma eficiente e efetiva setores importantes da produção da mais-valia sob a falsa perspectiva do território. Para isso é preciso pôr em prática o exercício de "desgeograficizar a Geografia"101, no sentido de inclusive permitir à análise geográfica condições de ampliar sua forma de ler e ver o mundo para além de seus próprios horizontes. Isso se expressa no exercício da autocrítica de colocar em questão, ainda conforme o exemplo dos efeitos últimos e avançados que representam o complexo militarindustrial para a manutenção da expansão da acumulação em crise, um novo rol de

\footnotetext{
${ }^{98}$ MOREIRA, 2001, p. 686.

99 “A grande inovação do complexo militar-industrial para o desenvolvimento capitalista é obliterar afetivamente na prática a distinção literalmente vital entre consumo e destruição" (MÉSZÁROS, 2011; p. 687).

100 "Aquele modelo centrado na indústria automobilística, e isso enquanto a indústria automobilística na sua expansão no Brasil significava um polo dinâmico, tão dinâmico que era capaz de passar margens de dinamismo para todos os outros segmentos da economia brasileira, inclusive a agricultura. Nós sabemos que com o tempo, este dinamismo da indústria vai diminuindo no próprio ramos da indústria automobilística e a e a indústria vai perdendo a capacidade como um todo de extrair do setor automobilístico dinamismo" (MOREIRA, 2001; p. 47). ${ }^{101}$ Como assim se refere como Manoel Fernandes Souza Neto (anotações em aula na Faculdade de Filosofia Letras e Ciências Humanas da universidade de São Paulo em Maio de 2014).
} 
“contradições não resolvidas" acerca do papel da centralidade da técnica no processo de empiricização do tempo no espaço, da qual destaca Milton Santos, e em acordo com Ruy Moreira.

A empiricização do tempo pela técnica pode ter seu corolário imediato nos novos sentidos de abstração do valor. A forma como a mercadoria tende a superar cada vez mais as últimas distinções entre "consumo e destruição", a exemplo da produção do complexo militarindustrial, não somente põe em evidência os novos valores que devem admitir o conceito de território - no sentido de não tender mais estar no seu "uso" ou "conquista" sua lógica de existência, mas no eterno-retorno de sua produção mediante o seu constante processo de destruição -, mas também na evidência de um tipo de técnica cada vez menos universalizada, autodestrutiva e desumana, dada as necessidades em se manter à frente na corrida concorrencial intercapitalista cada vez mais monopolista, em nome da "segurança nacional".

Não se trata somente de considerar o caráter universal que a técnica logrou centralidade na denominada "era do espaço", mas sobretudo de seu caráter essencial e necessariamente não universalizante. Ainda a título de exemplo do complexo militar-industrial, vale destacar o real significado do que se denominou como "Iniciativa de Defesa Estratégica (SDI)", como módulo garantidor das "vantagens industriais do sigilo militar" para os Estados Unidos, em uma demonstração clara do exercício imperialista frente a produção de conhecimento e tecnologia da União Europeia. Em um documento, já em meados da década de 1980, do Comitê de Coordenação para o Controle das Exportações Multilaterais Europeia, era alertado:

A Comissão Europeia está alertando aos governos do Mercado Comum de que
a participação europeia no programa norte-americano "Guerra nas Estrelas"
poderia prejudicar a integridade dos programas de pesquisas pan-europeus,
como o Esprit e projetos domésticos, como o Alvey. A comissão enviou uma
carta confidencial aos dez governos-membros, antes da reunião da cúpula do
Mercado Comum em Milão, advertindo que a participação na iniciativa de
defesa espacial pode ser muito prejudicial à indústria de alta tecnologia. A
carta alerta que a participação europeia na pesquisa do projeto "Guerra nas
Estrelas" dispensaria esforços de pesquisas europeus. Além de ameaçar o
Alvey e o Eprit, poderia diminuir seriamente a pesquisa global europeia,
reforçando as limitações que já estão sendo unilateralmente impostas pelos
Estados Unidos a pesquisa de alta tecnologia na Europa (in: MÉSZÁROS,
2011; p. 1083) ${ }^{102}$

102 Segundo Mészáros, isso levou não somente aos protestos de muitos cientistas do Reino Unido, como ao pedido de demissão do então diretor do projeto de pesquisa Alvey, Richard Ennals (Imperial College) (2011; p. 1083). 
Conjugado a isso, destaca ainda Mészáros o tema da "extraterritorialidade" nos debates parlamentares britânicos no verão de 1985: "Uma vez que afetava negativamente vários setores do capital britânico, podia ser assumido por todas os matizes de opinião do espectro parlamentar"103. Essa nova faceta da dimensão do território não diz respeito ao amplo exercício de ocupação territorial, como veio a ocorrer posteriormente no Oriente Médio, por vias militares como formas de efetivar a demanda da indústria de guerra, mas na forma de interferência na dinâmica produtiva territorial do trabalho dentro da própria Europa: “[...] O procurador geral britânico, Sir Michaels Havers (conservador), descreveu as tentativas de controle dos EUA como uma 'intromissão injustificada à jurisdição do Reino Unido contrária ao direito internacional" "104.

A natureza da relação dos EUA com a Europa, e em específico com a Inglaterra, levou ao entendimento de que se tratava de uma "interferência monstruosa" à soberania inglesa, o que, por sua vez, fez com que o Partido Trabalhista britânico (na sugestão de um de seus parlamentares, Michel Meacher) considerasse que "o tema da soberania fosse um ponto-chave na eleição geral de $1987^{\prime 105}$. Isso porque as consequências desse ordenamento produtivo "extraterritorial" estavam se propagando não somente no campo do controle estratégico da técnica, mas também no controle da massa de trabalho ocupada dentro da própria Europa. Como escreve Mészáros ao lembrar as alegações de outro parlamentar britânico, Paddy Ashdow: “500 mil empregos já tinham sido perdidos na Europa em decorrência disso"106

O que se tem, a partir deste exemplo de como a expansão do capital vai reconfigurando a forma de entendimento do território e da técnica, é uma evidência de que a lógica do valor está cada vez mais (e há de se questionar: quando não esteve?) assimilada também na lógica do espaço. Isso significa que, assimilado à natureza contraditória autodestrutiva do capital, seria necessário admitir que tanto o território como a técnica não exercem somente a "função" de controlar o trabalho (do "chão da fábrica aos arranjos", ou por meios dos "deslocamentos" de suas contradições), mas que se tornaram a forma em si de ser do próprio capital. Ou seja, há algo de mais radical em considerar o espaço, a partir de suas expressões na técnica e no território, somente como meio de controle do trabalho, mas também como dimensão negativa do próprio trabalho; como capital. Isso não somente por vias de que, como demonstra Mészáros (o controle do mercado "poderia diminuir seriamente a pesquisa global europeia"), o próprio

\footnotetext{
103 Ibid., p. 1082.

104 Id., Ibid.

105 Id., Ibid.

106 Id., Ibid.
} 
desenvolvimento da técnica se torna a negação de si própria, no momento em que as condições para seu incremento estão subjugadas a sua existência no mercado como mercadoria. Milton Santos, por exemplo, parece não ter atentado para a natureza contraditoriamente destrutiva com que o "envelhecimento" (da técnica e da produção em si) é programaticamente acelerado: “O que conduz a esse envelhecimento rápido do patrimônio técnico que nos cerca é a doutrina e a prática da competitividade" (SANTOS, 2008; p. 222). A questão é que a "competitividade" determina as formas de ser em si da técnica se tornando ela mesma a condição destrutiva de si mesma.

O que muda no momento de radicalização do processo em direção à "obliteração de qualquer distinção entre produção e destruição" é que o significado de "envelhecimento antecipado" provocado pela concorrência atual tende a abnegar qualquer perspectiva futura de desenvolvimento da própria técnica. Significa considerar que não há nenhum resquício do projeto iluminista, progressista ou desenvolvimentista dos tempos heroicos das revoluções (burguesas) industriais. Nem ao menos se torna mais possível a racionalizar o caráter destrutivo da própria técnica produzida sob tais condições em que a acumulação de níveis cada vez mais intensos da competitividade transformou ela própria em algo qualitativamente diferente: na própria “destruição". Como reitera Robert Kurz perante a mudança qualitativa dos significados da concorrência: "Realmente eliminada foi apenas a função da concorrência de aumentar a força produtiva, mas não a rivalidade abstrata entre as instâncias sociais e os indivíduos" (1993; p. $119)^{107}$.

A mudança na natureza da própria técnica, entendo-a agora como assimilada integralmente à lógica do capital (e como tal carregando para si todas as contradições a ele inerente), deve apontar para a necessidade de uma outra reflexão autocrítica: de que, para além do questionamento de seu estatuto ontológico, os desafios de "liberar" a técnica das condições políticas da "globalização", como propõe Milton Santos ${ }^{108}$ ("não vem da técnica essa necessidade frenética da competitividade, mas da política" ${ }^{109}$, se desdobram em problemas muito mais sérios que os limites da Geografia poderiam supor, reinserindo-a assim necessariamente na disputa da "economia política". Pois, assimilada como capital, passa ela a se compor como processo e cristalização da contradição inerente ao trabalho abstrato: uso $\mathrm{x}$ troca.

\footnotetext{
${ }^{107}$ KURZ, O Colapso da Modernização, 1992.

${ }^{108}$ Tal argumentação está contida no tópico "2.2 - Técnica: a autossustentação, a autorreferenciação e o sistema filosófico fechado".

${ }^{109}$ SANTOS, 2008, p. 222.
} 
De forma semelhante tende o território a se constituir: como meio de valorização do capital. Sob a gênese das mesmas condições de que a máquina destruidora de guerra (não tão recente nem tão limitada às superpotências como se supõe ${ }^{110}$ ) opera a reconfiguração, ou o arranjo espacial, no sentido da negação de sua materialidade. Ou seja, a objetivação do território assimilada a forma de ser do capital (que variam por meios desde a ocupação efetiva do Oriente Médio até os mecanismos da "extraterritorialidade" imperialistas contra a Europa) indicam que a própria natureza autodestrutiva do valor (a simultaneidade tendida entre produção e destruição) condiciona o território a sua eterna e constante forma de se produzir diante o processo destrutivo. Não se trata somente de se territorializar, se constituir como território, configurar um sistema de objetos, para assim extrair as taxas de mais-valia objetiváveis sob condições mais constantes, pacíficas e seguras possíveis, mas de acelerar esse processo na constante destruição (algo muito mais radical e qualitativamente diferente do que a “desterritorialização”) desse mesmo território construído. É, por exemplo, evidente as alianças entre o capital militar de guerra e o capital de incorporadoras, do ramo da construção civil, no processo de "reestruturação" de países atingidos por guerras civis e militares em todo continente africano e do oriente. Elas indicam muito mais que a configuração de um território, um processo de territorialização constante, mas um processo de abstração, uma valorização sem fim (por quanto for possível a reprodução da acumulação). O território se contrapõe de forma cada vez mais radical frente a sua própria materialidade, a ponto mesmo de sua própria negação. Tal contradição, longe de ser puramente de ordem metafísica, só indica a similaridade que o território estabelece com a natureza contraditória do capital. Este que, na sua forma de valor, se contradiz (também cada vez mais radicalmente) com suas formas concretas de existência (trabalho concreto, trabalho vivo, valores de uso, etc.); na mesma medida que também as reafirmam sob condições cada vez mais precárias da existência material humana (desemprego, guerra, destruição, etc.).

A contribuição do trabalho para a análise geográfica se dá, como visto, por ser o único meio de estabelecer o elo com a teoria do valor. Tal necessidade é, por sua vez, apontada como fundamental, tanto por Thomaz Júnior como por Ruy Moreira: “A mais-valia segue sendo, creio eu, ainda hoje, a única fonte de valor, é produzindo a mais valia que se produz o valor, e só o trabalho produz a mais-valia, o valor a mais" (MOREIRA, 2001; p. 15). A busca das

\footnotetext{
110 “[...] Mesmo no caso de países em que a participação direta do complexo militar-industrial local na economia nacional é relativamente pequena (se comparando a dos estados Unidos e à de alguns outros países), a contínua expansão produtiva das economias nacionais em questão não pode ser separada da importância global da produção militarista no que se refere à sua aparente e incurável dependência da economia norte-americana e do preponderante complexo militar-industrial no seu interior" (MÉSZÁROS, 2011; p. 687).
} 
contradições que se estabelecem entre as formas concretas de existência do espaço com seu "universal determinante" (o valor) é um exercício dialético. Uma dialética que está sempre colocando em opostos (negativos e afirmativos, num só tempo) as categorias que pretendem expressar a realidade (como território e territorialização, democracia e capitalismo, trabalho e capital: contraditos, mas também essencialmente afirmativos em relação ao outro, dentro da lógica do valor).

A teoria do valor e sua mediação através do trabalho é, por isso, também um exercício crítico: tanto com relação à crítica social como a autocrítica geográfica. Essa "qualidade metodológica" ausente ainda, de certa forma, na proposição de uma Geografia do Trabalho'111 expressa uma necessidade constante de retornar à gênese do debate dialético presente desde Marx (e antes mesmo em Hegel) para se evitar os equívocos entre os limites puramente metafísicos de uma “ontologia remota” ou, por outro lado, de uma empiricização a-crítica.

Quando Marx acusa a dialética hegelina de mistificadora, "porque parecia tornar ela sublime o existente" (1983; p. 20), assim o faz no sentido de quebrar suas determinações idealistas e trazer as contribuições possíveis desse instrumento de análise para a realidade concreta. Para tanto, Marx efetiva a famosa “inversão", e o faz de forma tão radical que se pode considerar como a aplicação da dialética contra ela própria: "é necessário invertê-la, para descobrir o cerne racional dentro do invólucro místico" ${ }^{" 12}$. Mesmo considerando Hegel o primeiro "a expor as suas formas gerais de movimento de maneira ampla e consciente"113, ressalta Marx a necessidade de entende-la, a partir das categorias postas historicamente (no caso de Marx, as categorias da economia Política), como movimento em processo de contradições. Daí porque nenhum movimento dialético pode estar garantido a priori por nenhum sistema epistemológico em si de qualquer ramo científico. O que Marx faz, a exemplo de seu tempo, é pôr as categorias da Economia Política em conflito contra elas próprias.

O que o exemplo de Marx ensina para os limites disciplinar de constituição da Geografia do Trabalho (ou de uma "geografia do trabalho", nos termos de Ruy Moreira) é que o rigor

\footnotetext{
${ }^{111}$ Tomando como referência as pesquisas (dissertações e teses) vinculadas ao Centro Estudos sobre Geografia do Trabalho disposta em sua página (até 20013) observa-se certo direcionamento das temáticas aos "estudos de caso". Embora não seja integralmente verdadeiro, mas apenas indicativo, é sintomático a desproporcionalidade com que a "escolha empírica" das relações de trabalho é objetivada nas pesquisas. Isso, de forma preliminar, pode significar a conformação de uma tendência que aponta mais para uma via de objetivação do "trabalho concreto", ou das formas de mediação fenomênica da exploração do trabalho no espaço, ao passo que se apresenta nula a opção por temáticas centralmente voltadas para discussões mais "abstratas", que envolvem a Geografia, suas categorias e temáticas, frente questões como trabalho abstrato, dialética, totalidade, contradição, etc. (embora seja igualmente importante considerar que tais questões estão tentadas no bojo interno das presentes pesquisas).

${ }^{112}$ MARX, 1983, p. 20.

${ }^{113}$ Id., Ibid.
} 
analítico com o corpo categorial não terá sentido se o mesmo rigor não se aplicar contra ela própria, como assim se faz entender em Marx:

[...] No entendimento positivo do existente, ela inclui ao mesmo tempo o entendimento de sua negação, da sua desaparição inevitável; porque apreende cada forma existente no fluxo do movimento, portanto também seu lado transitório, porque não se deixa impressionar por nada e é, em sua essência, crítica e revolucionária. (MARX, 1983; p. 21).

Tais observações reforçam a necessidade de uma leitura com rigor analítico no sentido de se buscar a crítica revolucionária contida na dialética. Rigor esse que não se confunde com a rigorosidade com que de um determinado sistema categorial disciplinar deve se constituir, pois, considerado em si mesmo, tende a se tornar insuficiente. Isso significa que, mesmo estando a proposição de uma Geografia do Trabalho essencialmente sobredeterminada pelas mediações disciplinares de uma Geografia auto-afirmativa, nunca seria insuficiente relembrar Ruy Fausto, que, em relação aos compromissos dialéticos frente os desafios da ciência, a admissão da contradição é uma forma de não se contradizer (1983; p. 33).

\section{3 - A via da negatividade}

A condição ontológica "claramente transitória do trabalho" que se desenvolve sob as influências tanto de Lukács como de Mészáros são as mais elementares influências para a proposição da Geografia do Trabalho: do primeiro a herança ontológica de uma perspectiva emancipatória do ser social; do segundo as mediações concretas do tempo histórico para a efetivação de uma teoria que possibilite a "passagem do reino da necessidade para o reino da liberdade”. Para as pretensões geográficas, tais influências contribuem para uma teorização mais bem elaborada acerca das questões ontológicas (do espaço ou do trabalho) no momento em que funda o ser social na relação elementar do debate geográfico: relação homem x meio. Mas também representa, como temática para pesquisas, importante objeto a ser explorado no momento em que as relações de trabalho ganham importante notoriedade frente as últimas formas de controle do capital (seja incorporada como técnica, seja pelo território) no estágio da reestruturação produtiva ${ }^{114}$. Entre os riscos de uma "ontologia remota" e uma "empiria pragmática", se constitui um debate sobre a dialética ainda não tentada nem por aqueles que propõem uma Geografia do Trabalho, como Thomaz Junior, nem por aqueles que propõe uma

\footnotetext{
${ }^{114}$ Como visto no capítulo " 2 - A Necessidade Epistemológica: crítica da crise à crise da Geografia”.
} 
geografia do trabalho, como Ruy Moreira. E é sobre a necessidade de retomada desse debate, e seu consequente aprofundamento metafísico, que vai se estabelecer um viés crítico em torno da negatividade inerente ao rigor da dialética do trabalho. Tal influência chega à Geografia de forma pontual, imerso em algumas formulações teóricas, mas também tem se efetivado mais recentemente em grupos de estudo e pesquisa, por exemplo, na Universidade de São Paulo ${ }^{115}$.

A necessidade de estender a crítica por dentro da própria tradição marxista, sobretudo na exaltação do caráter combativo-emancipatório em torno do trabalho, é o ponto central de ruptura inconciliável com que o viés da "negatividade" se constituiu como nova via para o desenvolvimento da teoria social crítica e independente da "ortodoxia marxista", sobretudo a partir da segunda metade do século XX. A gênese desta perspectiva se encontra nas formulações de autores, dentre outros, como Adorno, Horkheimer, Marcuse e, posteriormente, Habermas, organizados em torno do que ficou conhecido como Escola de Frankfurt ${ }^{116}$. A perspectiva da crítica social (ou da "Teoria Crítica") tendia a ganhar novos contornos numa tentativa de resgate de seus debates filosóficos mais profundos através da releitura dos clássicos como Hegel e Weber, mas, sobretudo, Marx. O objetivo era superar os aprisionamentos práticosemancipatórios em que a dialética se vinculou (sobretudo pelo marxismo "mal orientado" soviético e lukacsiano) para a sua mais completa liberação metafísica. Tal liberação estava relacionada ao reconhecimento de que a dialética havia se tornado prisioneira das próprias necessidades práticas de emancipação humana; ou seja, à necessidade de sua positivação, por meio de uma crítica afirmativa, que deveria se efetivar no plano real/concreto (e científico) como perspectiva/projeto de sociedade, seja na forma do socialismo real soviético, seja a partir de um projeto de ruptura e transição socialista (como aquela tentada por Mészáros posteriormente): "o fato de a ciência como força produtiva e meio de produção cooperar para o processo de vida da sociedade não justifica, de forma alguma, uma teoria pragmática do conhecimento" (HORKHEIMER, 1990; p. 07) ${ }^{117}$

Tratava-se de uma completa renovação no plano da dialética no sentido de superação das ontologias (postas como "essencialistas") e das categorias "irreversivelmente fetichizadas" pelo próprio capital: trabalho, classes sociais, capitalismo, etc. Buscava-se, conforme iam sendo

\footnotetext{
${ }^{115}$ É o caso, por exemplo, dos grupos de estudos que se organizam na Universidade de São Paulo em torno de alguns professores que pesquisam nessa área: Heinz Dieter Heidemann, Anselmo Alfredo e Carlos de Almeida Toledo.

${ }^{116}$ Vale ressaltar que a proposição de uma via da negatividade está mais vinculada à reorientação da teoria crítica do Instituto Para Pesquisa Social a partir do período pós-Segunda Guerra Mundial, depois, portanto, do retorno dos teóricos (até então refugiados nos EUA) e a consequente refundação da Escola em Frankfurt, Alemanha. Este período sacramenta, também, a reorientação efetiva do foco da análise: "a hegemonia era não mais da economia, mas da filosofia" (MATOS, 1993; p. 12).

${ }^{117}$ HORKHEIMER, Max, Teoria Crítica: Uma Documentação, São Paulo, Perspectiva; EDUSP, 1990.
} 
negado os compromissos "epistêmicos" e ontológicos da análise teórica, situar a dialética na modernidade e perante o processo de modernização, que tendiam cada vez mais a extrapolarem suas próprias contradições em crises cada vez mais agudas. Paulo César da Costa Gomes identifica essa influência no discurso da renovação geográfica: "para os radicais, no entanto, a ideia principal era a de crise. Crise do capitalismo, crise política, crise da ciência política, do positivismo. Como vimos anteriormente, a ideias de crise tornou-se uma imagem-força da modernidade [...]" (1996; p. 279).

Ainda conforme Gomes, que aliás pode ser identificado por essa via da negatividade, estabelece em seu texto "Geografia e Modernidade" alguns pressupostos comuns à Escola de Frankfurt. Primeiro a questão da crítica ao modelo cientifico moderno, ou seja, "a constatação de uma ciência insuficiente, limitada, pretenciosa e frágil é objeto de um verdadeiro consenso e os argumentos avançados são aceitos sem muitos protestos ou controvérsias" (1996; p. 11 12). Tal concepção em muito se equivale aos argumentos de Horkheimer para quem, desde a segunda metade do século XIX, a definição moderna de ciência, "como uma meta parcial de emancipação burguesa [...] já havia perdido seu sentido progressista e, ao contrário, provocou ser um instrumento de limitação do processo científico" (1990; p. 08-09). As similitudes argumentativas em torno de uma crítica à ciência vão mais adiante. É notório também como Gomes se utiliza do recurso da mistificação para fundamentar sua crítica à análise marxista ("a concepção do progresso social na teoria marxista reforça a ideia de mito da modernidade"118) de forma parecida com a que Adorno e Horkheimer (1985) ${ }^{119}$ denunciam o caráter mistificador da razão iluminista, posto através da relação entre o esclarecimento e mito em "Dialética do Esclarecimento" $" 120$.

Há ainda a questão do entendimento histórico da modernidade. No que concerne ao entendimento dos tempos "mais atuais" de Paulo César da Costa Gomes em relação às formulações da Escola de Frankfurt em meados do século XX, compartilha Gomes os pressupostos negativos de uma concepção metanarrativa da história. Se utiliza de tal prerrogativa (negativa) para identificar o marxismo como discurso da "ordem geral", iluminista, do qual, mediante a eminência da "crise da modernidade", se assevera: "a pretensa revolução

\footnotetext{
118 Ibid., p. 283.

${ }^{119}$ ADORNO, Theodor W. \& HORKHEIMER, Max, Dialética do Esclarecimento, Rio de Janeiro, Jorge Zahar, 1985.

${ }^{120}$ É igualmente interessante observar como o recurso da analogia do mito passa a ser utilizada como instrumento de relativização da própria razão científica: "Por conseguinte, queremos lembrar aqui da geografia mítica e heroica, tão menosprezada e agora colocada junto às demais, até com a própria científica" (OLIVEIRA, Lívia, "Ainda Sobre Percepção, Cognição e Representação em Geografia", In: Elementos de Epistemologia da Geografia Contemporânea, Curitiba, Ed. Da UFPR, 2002; p. 194).
} 
do saber geográfico pela teoria e a prática marxista mostra claramente sinais de esgotamento" (1996; p. 303).

O “esgotamento do marxismo" seria evidenciado pela necessidade de tomada de direção no sentido de uma "teoria crítica humanística", descarregada dos compromissos de estabelecimento das "leis universais" de funcionamento da sociedade moderna. Como ressalta Gomes, tais alterações no âmbito interno da Geografia se efetivaram em uma redescoberta positiva da importância da análise geográfica a partir, por exemplo, da nova relevância concedida ao "conceito de formação socioeconômica graças ao conceito de desenvolvimento desigual" (1996; p. 301). E, talvez, o mais sintomático dentro de todas as importantes alterações humanísticas surgidas: "os grupos sociais concretos ressurgiram nas análises para substituir as abstrações muito gerais, centradas, nos primeiros tempos, nas classes sociais"121. Esta corrente, que seria uma "redescoberta da flexibilidade de toda ação social e, por conseguinte, a importância de uma análise que leve em conta o valor e o antropocentrismo da vida social"122, se configuraria numa forma de aproximação do materialismo histórico com o humanismo, este último, ainda segundo Gomes, "[desembaraçado] do idealismo e do subjetivismo, que caracterizaram as primeiras análises" 123 . No entanto, é ao se referenciar em Sayer que Gomes abandona o plano das evidências e das pistas e revela, de fato, sua relação de influência mais íntima com as perspectivas da Teoria Crítica frankfurtiana: "Segundo Sayer, por exemplo, as possibilidades de diálogo entre este dois pontos [materialismo histórico e humanismo] já eram concebidas há muito tempo pela teoria crítica (Habermas, Guidens)"124.

Habermas é reconhecidamente um dos mais importantes herdeiros das proposições frankfurtianas, sobretudo aquela fundamentada na reorientação acerca da centralidade do trabalho para a centralidade da "racionalidade comunicativa" ${ }^{125}$. Habermas tende a operar a transição conceitual ausente no debate da modernidade entre a "ação orientada a um fim" (pressuposto marxiano do fundamento ontológico em Lukács) para o "agir comunicativo" (pressuposto weberiano da racionalização tipicamente moderna): “[...] essa crítica [da ação de Weber, instalada em seus próprios textos] levou-me a uma alternativa que exige uma mudança

\footnotetext{
${ }^{121}$ GOMES, 1996, p. 301.

122 Id., Ibid.

123 Id., Ibid.

124 Ibid., p. 302.

125 Harbermas, de fato, tinha como objetivo dar sequência às formulações frankfurtianas, sobretudo aquelas desenvolvidas por Adorno, como fica evidente nos objetivos do seu conceito "racionalidade comunicativa": "As ideias de liberdade e de conciliação, que Adorno delineia nos limites de uma dialética negativa por não ter conseguido fugir do fascínio exercido por Hegel, necessitam de uma explicação. E esta pode ser tecida com o auxílio de um conceito 'racionalidade comunicativa' que emerge simultaneamente nas reflexões adornianas" (HABERMAS, Jürgen, Teoria do Agir Comunicativo, 2: Sobre a Crítica da Razão Funcionalista, São Paulo, WMF Martins Fontes, 2012; p. 04).
} 
de paradigma, do agir teleológico ao agir comunicativo" (2012; p. 585) ${ }^{126}$. O âmbito da negatividade teleológica - ou seja, da teleologia presente nas teorias de superação do capitalismo da via afirmativa-emancipatória -, representa aspecto constante em decorrência da desilusão e ceticismo com a crítica teórica politicamente engajada num projeto revolucionário. Nos dizeres de Ricardo Antunes: "Habermas propugna, em sua análise sobre a sociedade contemporânea, que a centralidade do trabalho foi substituída pela centralidade da esfera comunicacional ou da intersubjetividade" (ANTUNES, 2002; p.146).

Dois aspectos são importantes sobre a forma como tal perspectiva vai influenciar as ciências sociais, e também a Geografia: primeiro para a composição de um discurso crítico voltado para as formas de desvelamento do processo de fetichização em si, que se universaliza no contexto do "Colapso da Modernização" e, por isso, se direcionada a uma análise mais voltada para a Economia Política, sem, no entanto, abandonar os compromissos metafísicos frankfurtianos. Como assevera Robert Kurz: “é possível que a era das trevas da crise do sistema produtor de mercadorias, com suas formas em percurso e acontecimentos catastróficos, abranja boa parte do século XXI" (1992; p. 223). No entanto, a evidência do colapso deve apontar para uma mudança de perspectiva da crítica, sobretudo do marxismo:

Uma vez que a crise consiste precisamente na eliminação tendencial do trabalho produtivo e, com isso, na supressão negativa do trabalho abstrato pelo capital e dentro do capital, ela já não pode ser criticada ou até superada a partir de um ponto de vista ontológico do "trabalho", da "classe trabalhadora", ou da "luta das classes trabalhadoras". Nessa crise, e em virtude dela, revela-se todo o marxismo da história como parte integrante do mundo burguês da mercadoria moderna, sendo por isso atingido ele próprio pela crise (KURZ, 1992; p. 227)

A perspectiva negativa em frente ao marxismo até então constituído como teoria crítica, dada suas "vinculações" de aprisionamento com os próprios limites do capital, é, por outro lado, um segundo aspecto da influência. Esta, por sua vez, vai se direcionar aos compromissos em reestabelecer a fenomenologia na análise social que irão variar desde a tendência de atomização das experiências dos "grupos sociais" até os debates mais pragmáticos sobre o papel da percepção e cognição no trabalho científico (também do geógrafo). Entre elas a constituição de uma perspectiva de negação das categorias como totalidade, capitalismo, trabalho, classes etc.

\footnotetext{
${ }^{126}$ HABERMAS, Jürgen, Teoria do Agir Comunicativo, 1: Racionalidade da Ação e Racionalização Social, São Paulo, WMF Martins Fontes, 2012; p. 04.
} 
em prol de procedimentos vinculados às questões que envolvem a legitimidade da crítica pósmoderna.

Estas duas derivações, no entanto, embora compartilhem influências comuns em torno da negatividade em relação à compreensão da história contida nas teorias metanarrativas, se opõem quanto a concepção da própria crítica. A título de exemplo, na Geografia, se, por um lado, como se posiciona Paulo C. da C. Gomes, incorporar as questões levantadas por Habermas sobre a crítica pós-moderna (esta identificada como crítica em si da razão alienante da modernidade $)^{127}$ para fundamentar um pensamento geográfico humanista e supostamente não dogmático (em detrimento do dogma das classes sociais tipicamente marxista), por outro lado, a rejeição da pós-modernidade, e toda relativização e fragmentação posta em torno da verdade científica e das "categorias totalizantes", deve ser também colocada como outro momento do fetiche a ser desvelado. Esta é, por exemplo, a natureza da crítica de Anselmo Alfredo, para quem o resgate da teoria do valor, como parte central de uma teoria do espaço, ou "crítica à economia política do espaço", deve ser encarado como exercício de reafirmação do seu caráter e rigor dialético, não para a positivação da teoria geográfica, mas para a própria negatividade com que as categorias históricas devam ser confrontadas perante sua própria "simultaneidade negativa", ou seja, na centralidade da negativa do trabalho. Em concordância com Kurz, afirma Alfredo:

Tem-se um momento em que a desigualdade das relações sociais baseadas na descentralização do trabalho passa a constituir o capital pelo seu aspecto negativo, de modo que a mesma se põe afirmando o capital e o capitalismo em sua determinação crítica. Kurz (2004) expressa isso como simultaneidade negativa, onde toda forma de simultaneidade e, portanto, de espaço, se expressa, neste momento do capitalismo, como potência negativa e, portanto, crítica da reprodução social da modernização. $\left(2013 ;\right.$ p. 61) ${ }^{128}$

Enquanto que, para Gomes, a questão do trabalho, tal como a questão das classes sociais, perde centralidade porque representa uma totalidade anacrônica diante de uma realidade fragmentária, pós-moderna, para Alfredo a descentralização de tais categorias que tendem a

\footnotetext{
127 "No final do século XVIII, no começo do XIX, assim como na virada do século seguinte, a veemência contestadora destes movimentos alimentou perspectivas similares às sustentadas no atual discurso pós-moderno, justificando a pergunta [posta por Habermas]: 'Não seria o pós-moderno exatamente um slogan que permite incorporar sub-reciprocamente a herança das relações que a modernidade cultural recebeu contra ela desde meados do século XX?"” (GOMES, 1996; p. 26).

${ }^{128}$ ALFREDO, Anselmo, Crítica à Economia Política do Desenvolvimento do Espaço, São Paulo, Annablume; Fapesp, 2013.
} 
exercer condição metanarrativa e política, se dá por meio da necessidade de enquadrá-las, perante o rigor dialético, como formas de concreção do próprio processo de fetichização abstrato do capital que, ao se efetivar perante essas categorias históricas no estágio atual do “colapso", se põe muito mais para afirmar, do que negar, as condições da própria crise.

[Milton Santos, razão weberiana e a inconciliabilidade ontológica]

Para além dessas formas mais efetivas com que se concretiza a via da negatividade, sob forte influência da Teoria Crítica da Escola de Frankfurt, é também importante considerar outras formas, não tão assumidas, que vão se constituindo no interior das formulações teóricageográficas. Tais influências aparentemente pontuais vão, consequentemente, redefinindo a postura teórica e política da crítica geográfica. O exemplo mais significativo são as influências dessa via nas formulações teóricas em Milton Santos, sobretudo na relação exercida entre a "teoria do agir comunicativo" de Habermas na sua formulação conceitual do "sistema de ações". Tais influências contribuem para o entendimento da transição entre uma descentralização do trabalho em detrimento de uma centralização do espaço, e consequentemente suas implicações políticas, no "deslocamento" da natureza da prática emancipatória do sujeito do trabalho (classe trabalhadora) para o sujeito do espaço (os pobres).

Tal relação em Milton Santos se apresenta no momento da explicativa da inversão em que as ações, orientadas a um fim em si, por isso racionalmente conscientes, se invertem em ações mediadas por uma razão orientada ao estranhamento da própria ação pela técnica orientada por um fim alienado, pois ato e finalidade passa a não ser identificada ao sujeito da ação. Ou seja, a "alienação local" ou "alienação regional", quando considerados a "esquizofrenia" e o "distanciamento" do "processo criador de eventos" (2008; p. 80). Isso significa, para Santos, uma limitação das ações, porque as escolhas também são limitadas. O ponto central na concordância com Habermas, e também com Weber, está ao mostrar que, no plano da "racionalidade" weberiana, como norma/conduta do agir-comunicativo, a ação se condiciona às possibilidades mesmas da racionalidade técnica. Estabelece, dessa forma e em concordância com Habermas, oposição e estranhamento entre a "atividade instrumental" e a "atividade comunicacional": a primeira mediada pelo trabalho humano no processo de apropriação/transformação da natureza; a segunda como processo de intermediação entre os homens. O objetivo de Santos é demonstrar como, apesar de que, em última análise, "a ação é 
o próprio homem"129, o funcionamento do sistema de ações está "racionalizado" pelo sistema de objetos que o medeia. A questão que se coloca é: qual o nível de sobredeterminação em que um sistema de objetos racionalizado pode condicionar um sistema de ações? E a que tipo de racionalidade o sistema de ações tem que se objetivar num sistema de objetos? Santos assimila essas questões para demonstrar que se o espaço deve ser entendido enquanto síntese do sistema de objetos e ações relacionadas, deve ele mesmo "participar", na mesma intensidade, "da condição social e física" do mundo ("admitir a existência do 'espaço' não é ser 'geodeterminista', como na crítica de Werlen") ${ }^{130}$. Na relação de concomitância entre ação e o objeto da ação, tal como os objetos de sua mediação, mudando-se a coisa, muda-se a si mesmo. Santos objetiva inferir sobre a capacidade do espaço como elemento produtor da realidade. Nesse momento se observa uma aproximação com a abordagem de Marx sobre o caráter humano-universal (ou ontológico, para Lukács) do trabalho. Como assumirá Milton Santos:

Trata-se, aliás, de uma das ideias bases de Marx e Engels. Quando, através do trabalho, o homem exerce ação sobre a natureza, isto é, sobre o meio, ele muda a si mesmo, sua natureza íntima, ao mesmo tempo em que modifica a natureza externa $^{131}$. (2008; p. 78)

A relação com o trabalho estabelece a possibilidade de pôr o espaço em condições ontológicas, ou sua condição universal-comum em diferentes formações sociais. Mas aí, ao restabelecer a relação com o "agir comunicativo" de Habermas e com a "racionalização" de Weber, teorias que explicam processos de fetichização específico da modernidade, pode-se revelar uma contradição em tal sistema teórico, que se pretende também ontológico, sobretudo com referência em Marx.

A condição histórica de existência de uma "razão", da qual deriva a racionalidade weberiana, que medeia a existência de um sistema de objetos para um tipo de ação não mais orientada a um fim, ou uma ação alienada, se constitui como a forma de ser da "razão" em si, admitida por Weber, mas também por Habermas, no tempo histórico específico da modernidade. Ou seja, não se trata de uma "razão" ontológica que ao tempo se tornou alienada, pois esta seria impossível, dado que seria a própria "não-razão". A impossibilidade de existência de uma "não-razão" se dá ao fato que ela mesma seria a própria "razão", ainda que imersa numa perspectiva contraditória, por isso, "irracional", do qual se refere Marx dado a

\footnotetext{
${ }^{129}$ SANTOS, 2008, p. 82.

${ }^{130}$ Ibid., p. 86.

${ }^{131}$ Ibid., p. 78.
} 
natureza "desumana" do capital. Mas esse "irracional” é a "razão" em si de existência das mercadorias sob o julgo das relações do mercado específicos da modernidade. Ou seja, o irracional de Marx é a própria racionalidade de Weber. A questão é que entre Marx e Weber não há somente uma forma diferente de entender a "razão", mas formas opostas, conflitantes e inconciliáveis.

Se não for possível admitir a impossibilidade de que um sistema de ação alienado mediado por uma "não-razão", assim sendo não teria razão da própria existência de um tipo de sistema técnico que assim condicionasse a ação alienada. Ou seja, a "razão" não pode ser a mediação entre um sistema de objeto e um sistema de ação para um espaço que se pretende ontológico. Falta um elemento de mediação que garanta historicidade à condição irracional da razão, elemento este que admita uma contradição. Tal problema interno da teoria miltoniana resulta da condição não ontológica da teoria da "razão instrumental" de Horkheimer (1990), esta como oposição à razão crítica que põe a técnica estritamente como a razão em si da fetichização. Tal como a racionalidade weberiana, estão elas, assim, situadas no plano das mediações do tempo histórico do fetiche da mercadoria e do capitalismo, jamais no plano da ontologia, como pretende Santos.

Se, como admite Milton Santos, do ponto de vista ontológico, como observado em tempos "não-modernos", "os objetos revelavam propósitos de cada sociedade e eram os seus meios próprios à realização de seus próprios fins" 132 , a condição mediadora da "razão" estava identificada na própria razão orientada ao fim mesmo da ação sobre a técnica. Nestas condições "não alienadas" não haveria nem sentido a existência de um sistema de objetos e um sistema de ações, nem uma "razão" para mediá-las, pois elas estariam constituídas em uma unidade não só indivisível, mas “indissecável” analiticamente. Se, como admite Santos, estiverem corretas as premissas de Habermas e de Weber, a composição de uma teoria do espaço fundamentada na relação/contradição entre sistema de objetos e sistema de ações só poderia ser efetivada diante das condições especificamente históricas e contraditórias postas pela modernidade; o que seria a própria negação de sua proposta ontológica. O próprio Milton Santos demonstra a natureza especificamente histórica (não ontológica) da racionalidade weberiana ao usar uma elucidação do próprio Habermas. Em nota de rodapé, cita: "Marx Weber introduziu o conceito de 'racionalidade' para caracterizar a forma capitalista da atividade econômica, a forma burguesa das trocas ao nível do direito privado e a forma burocrática da dominação [...] (J. Habermas, 1968, p. 3)" (SANTOS, 2008; p. 289).

${ }^{132}$ SANTOS, 2008, p. 81. 
Se envolver no debate da contradição entre ontologia do espaço e o caráter moderno da razão instrumental não é, claramente, o objetivo de Milton Santos, embora isso se torne um problema não resolvido na inerência de sua proposição teórica. Habermas e Weber são utilizados para dar suporte à elaboração de uma teoria espacial, e não estabelecer sua essência em si. São por isso influências pontuais onde um dado específico (como no caso da razão, ou racionalidade) é tomado como elemento somatório para a composição de um corpo teórico mais abrangente. Daí que, como justifica o próprio Milton Santos: "quando as realidades do mundo se complicam e novas disciplinas científicas se estabelecem para tentar explicar os contornos até então existentes da história, recusar a utilização de tais ensinamentos é estupidez pura e simples" (SANTOS; 1996; p. 133).

Milton Santos no entanto, sem "resolver" esse problema entre ontologia e modernidade, segue sua linha argumentativa incorporando ao "sistema de ações" seu conteúdo alienado e prédeterminado pela técnica, também expressa por Horkheimer em conformidade com sua "crítica à razão instrumental”: "É assim que a ação exprime a 'razão formalizada' expressa por Horkheimer, reclamando uma linguagem matemática, linguagem do cálculo, fria, que deseja impor-se com a exclusão da emotividade e da surpresa" (SANTOS; 2008; p. 223). A relação com a "racionalidade" de Weber também prossegue na continuidade argumentativa de Santos pela defesa da tese de que o espaço haveria de ter incorporado à condição racional weberiana: “Chega, agora, a vez de ser o espaço considerado 'racional', desde que o vejamos como ele realmente é - um campo de ação instrumental. "133

Weber seguirá o percurso argumentativo da "racionalização do espaço" em Milton Santos como, aliás, seguiu na "teoria do agir comunicativo" de Habermas. Não somente isso. A própria Teoria Crítica frankfurtiana, até a composição de uma via da negatividade como tendência para a crítica que chega à Geografia, teve em Weber referência central, sobretudo na “justificativa teórica" para o abandono de uma leitura fundamentada no trabalho, nas classes sociais e na forma de entender a superação capitalista. Tendência essa operada no seio da crítica geográfica, como se verá.

[Desdobramentos ideológicos da negatividade weberiana]

Apesar de Hegel ter sido o filósofo que pôs a dialética em mais alto nível metafísico, apesar de Marx ter posto a dialética em seu mais alto nível material-concreto, a visão do

${ }^{133}$ SANTOS, 2008, p. 292. 
capitalismo em si como negatividade pôs Weber como influência central nessa perspectiva de análise. "Tanto para Weber como para os românticos, o advento do capitalismo e a universalização do valor de troca, do mercado, do dinheiro como fetiche são vistos como miséria" (MATOS, 1993; p. 17). Por isso Weber configura como o intelectual do desencantamento do mundo "utilitário" capitalista, em detrimento, por sua vez, de Marx, dadas suas supostas "vinculações positivas" para com a conquista da "verdadeira história humana" (comunismo). A obra de Marx haveria de ser, como concorda Paulo Cesar da Costa Gomes, “considerada por muitos como o último grande sistema filosófico do iluminismo" (1996; p. 280).

A via da negatividade representa a tentativa mais atual desses objetivos postos desde o romantismo (passando por Weber) de desencantamento do mundo que seria a denúncia negativa do projeto iluminista não realizado, nem pela modernidade, nem pela modernização. Por isso, suas categorias fundantes deveriam passar pelo processo "desmistificador" do qual à dialética não haveria de impor qualquer tipo de fronteira na composição da crítica. Daí que as categorias fundantes do marxismo deveriam também passar pelo crivo do rigor da "dialética negativa" como forma de aclarar o mundo para além das ideologias que se portavam como a crítica em si da sociedade do capital. Em resposta às "Teses sobre Feuerbach”, em que Marx conclama a tarefa de transformação do mundo e, diante disso, os descaminhos com que a dialética se torna ideologia do "marxismo oficial" soviético, retruca Adorno expondo, ao mesmo tempo, os objetivos históricos da "teoria crítica" em sua famosa passagem: "posto que a filosofia não conseguiu transformar o mundo, cabe continuar a interpretá-lo”.

Se, como denuncia Adorno a respeito da perspectiva de "absolutização" do ser a partir da imposição da "necessidade ontológica" que vai caracterizar o pensamento alemão ainda no período pós-Segunda Guerra, o que fez os percursos teóricos "esquecerem" os rastros do passado de "horror", sobretudo aqueles de base heideggeriana, qual seria, entretanto, as vinculações políticas que fizeram com que Max Weber, “que possuía uma concepção de democracia extremamente conservadora e inclinada ao bonapartismo, [ter] se tornado, no decorrer dos desenvolvimento político-ideológicos do século $\mathrm{XX}$, o pensador referenciado [...]"134, não apenas pelas perspectivas da "democracia liberal e "do mundo livre" capitalista,

\footnotetext{
${ }^{134}$ Um outro exemplo a ser notado. Antes mesmo de Adorno estabelecer como denominador comum aqueles que detinham o "monopólio do capital" e o "monopólio do trabalho", o que colocam os nazistas e os esquerdistas (como Lukács, por exemplo) em franca linha de equidade, tomando para si a postura de verdadeiro antifascista, para Mészáros isso deveria soar meio "dubio", pois, como o mesmo revela, "Hannah Arendt, uma refugiada da Alemanha de Hitler, condenou Adorno explicitamente pelo que considerava ser sua 'mentalidade quase colaboracionaista' durante a década de 1930" (2004; p. 180).
} 
mas também pelo próprio movimento da Teoria Crítica frankfurtiana? Além disso, se a "metafísica" não poderia se separar da política, como no caso da crítica a Heidegger e suas imbricadas relações com o nazismo, como salvar Weber e sua "negatividade" diante de suas relações com o mesmo "passado de horror"? Pois é sabido os conselhos de Weber sobre as "vantagens da democracia" ao então chefe do estado-maior alemão, Ludendorf, um dos primeiros apoiadores de Hitler:

Estas foram as palavras de Weber registradas não por algum crítico hostil, mas por sua viúva Marianne Weber: "Em uma democracia o povo elege como líder um homem em quem confia. Então, o eleito diz: 'Agora, calem e obedeçam!'. Nem o povo nem os partidos podem contradizê-lo. [...] Depois disso, cabe ao povo julgar - se o líder falhou, à forca com ele'. E Lukács acrescentou com razão: 'não surpreendente que Ludendorf respondesse: 'Esta democracia me soa bem!'. Assim a ideia de Weber de democracia caía em um cesarismo bonapartista" (MÉSZÁROS, 2004; p. 148).

Contraditoriamente, o caráter negativo próprio do romantismo alemão incorporado à erudição teórica de Weber concedeu, diante do grande saldo destrutivo da Segunda Guerra, a perspectiva mais "avançada" do caráter "antiideológico" em que as composições teóricas puderam se estruturar. $\mathrm{O}$ desencantamento do mundo weberiano parecia se encaixar com o contexto desencantado de um mundo recém-saído de disputas profundas do qual as "grandes" ideologias, dentre elas o "socialismo", passaram e ser identificadas.

Mas o caráter adaptativamente virtuoso da negativa weberiana tinha o fundo ideológico não assumido pelos seus seguidores. A formulação da crítica weberiana fundamentada na "racionalidade" e na "burocracia tecnológica" carregava em si um nível de estruturação condizente com a própria incapacidade de se pensar a superação do objeto negado, não por limitação mesma da razão condicionada e fetichizada no capitalismo, mas propriamente pela absolutização de sua própria negação. Isso significa a tomada em direção a uma "negação universal abstrata", por vias de um deslocamento ideológico não admitido da crítica propriamente weberiana. A sofisticação da "negatividade" weberiana, transcrita nas autolimitações teóricas dos vários significados de postulados não tão sofisticados, como os do tipo "nós só sabemos que não sabemos e que não podemos saber" ${ }^{135}$, escondia um outro posicionamento ideológico antissocialista e antimarxista de natureza derrotista, também não tão sofisticado (do tipo "não proporemos porque estamos submissos às condições de existência da

${ }^{135}$ MÉSZÁROS, 2004, p. 213. 
época") e se desaguaram em tantos outros postulados supostamente críticos e não menos vagos, do tipo "não saberemos para onde vamos, mas é preciso continuar negando o real".

Tida como não ideológica, a postura ideológica de Weber se escondia nos mais íntimos e sutis meios de mistificar a insuperabilidade da razão capitalista-moderna - ao menos pelos sujeitos por ela "racionados" - na sua própria teorização de desmistificação do mundo. Não somente porque havia Weber se tornado o "homem para todas as estações do capitalismo do século XX"136, tampouco pela facilidade com que sua teoria caminha da "esquerda" à "direita", mas a ideologia negativa weberiana poderia encontrar nos mais ocultos meandros dos "tipos ideais" - com a qual a análise científica poderia estruturar seu objeto analítico sem os “desmandos dos juízos de valor" para uma "perfeição puramente lógica" - sua forma de existir sem se revelar. E, a partir daí, deslocar com notória perspicácia as contradições históricas no âmbito do trabalho na gênese do capital para o princípio norteador, racional, da "cultura" do investimento privado própria da "ética protestante".

A expansão da influência weberiana, dado o potencial não-ideológico da ideologia interna em exercer sua condição teórica amplamente adaptativa para se fazer apologia e/ou crítica ao capitalismo, foi assim observada por Mészáros:

Paradoxalmente, tal concepção convinha não apenas aos abertos defensores do sistema social estabelecido, mas também a abordagens como a "teoria crítica" da Escola de Frankfurt e a conceituação similares do mundo contemporâneo na França e em outros locais. Estas últimas, levando em conta exclusivamente a opulência temporária de umas poucas "sociedades industriais avançadas", desenvolveram suas concepções de protesto e oposição em um vácuo social, tendo como base pressupostos derrotistas (equivalente às conclusões práticas pessimistas), como a suposta integração estrutural da classe trabalhadora ao mundo do "capitalismo organizado" (2004; p. 148).

Esta passagem trazida por Mészáros levanta pontos importantes para se pensar a via da negatividade em suas principais pressuposições. A primeira é aquela vinculada à negativa de qualquer forma de superação das mesmas contradições negadas. Tal tomada de postura encontra suas mais íntimas justificativas na própria negação de se pensar a contradição entre o posto e o devir, pois o esforço do pensamento em si (logo, de afirmação crítica) já estaria imerso aprioristicamente na reificação total da modernidade. Isso tende a ser tomado como pressuposto, um "a priori", na medida em que se considera a história como produto, e o sujeito

${ }^{136}$ Ibid., p. 211. 
pensante como produto dessa história, determinada unilateralmente no âmbito da reificação universal. Como assinala Mészáros sobre a análise de Adorno no âmbito da crítica estética da música, especificamente contra o jazz: "Na estrutura aforística de declarações e declamações de Adorno, é suficiente apenas afirmar os preconceitos ideológicos do autor e suas negações genéricas da 'sociedade em si'",137

[Arbitrariedades na equalização positiva para a crítica negativa]

As negações genéricas da sociedade em si revelariam o caráter não objetivável (ou como fora acusada de ser: uma negatividade circular e vazia) da via da negatividade. Isso tende a se reproduzir por vias de posturas teóricas, não somente elitista, mas fundamentado em certa arbitrariedade na forma de supor o que seria ou não "o fetichizado". Isso representaria a própria necessidade de também pôr em evidência a "negatividade do negativo" que, não necessariamente, pressupõe como resultado uma positivação aos moldes positivistas; ela não necessariamente deixa de ser crítica. Ou seja, isso significa que a "ação negativa" deverá estar também sob a tutela criteriosa de seu próprio método e, enquanto perspectiva teórica, deve admitir sua própria ideologia (como os weberianos ideologicamente não admitiriam) haja vista que, por mais "negativa" que se apresente, haverá sempre seu "imanente negativo" a ser objetivado. Não se trata de relativização, pois desconsiderar o caráter ideológico de qualquer teoria é se negar à dialética; afinal, dizer-se não ideológico, por mais anti-ideológico que se possa considerar, é ao menos um ato positivista. Daí que a forma de se caracterizar distintas perspectivas teóricas como "a-criticas", pondo como denominador comum e definidor o caráter afirmativo (ou mesmo ontológico) dessas teorias de diferentes naturezas, é uma avaliação que está no mesmo plano de "ideal positivista" que as influências adornianas mais recentes, por exemplo, coloca, numa tacada só, sob o adjetivo de "absolutistas", perspectivas tão opostas e inconciliáveis como aquelas tentadas por Heidegger e Lukács.

A não observação de tal arbitrariedade, no interior da definição do critério da criticidade, pode levar aos exageros do tipo pós-moderno, a-crítico, que sobre a rotulação de "crítica" chega mesmo a considerar, por exemplo, algum tipo de natureza comum entre a perspectiva científica de Marx e Comte, como assim procede Paulo C. da C. Gomes:

Exatamente como em A. Comte, a ciência para Marx se torna o único meio positivo de instituir a verdade e deve servir àqueles que querem agir na

${ }^{137}$ MÉSZÁROS, 2004, p. 156. 
sociedade. A denominação "socialismo científico", reivindicada pelo próprio Marx, exprime, aliás, a diferença fundamental entre suas concepções racional, lógica e metódica, e as outras utopias socialistas, que são apenas fruto da imaginação (1996; p. 284)

A absurda analogia se expressa não só pela força do sentido contido no termo "exatamente como", mas a tentativa de equalização de perspectivas de teóricas tão distintas, o que chega a ser grotesca pelo simples motivo de que não se poderia admitir qualquer ponto comum entre tais perspectivas que não seja a da própria negação de uma com a outra ${ }^{138}$. No entanto, e contraditoriamente, a importância de tal passagem revela um procedimento ideológico de pura relativização, pela equalização positiva para a crítica negativa de tudo que tende a ser proposto e afirmativo como "emancipatório". Primeiro porque o caráter negativamente crítico da posição de Marx em relação à mistificação do que passou a ser chamado de socialismo utópico não significa, necessariamente, uma positivação cega da ciência, o que o incomparável a qualquer referência do positivismo de Comte; segundo porque é interessante notar como que o "caráter negativamente crítico" marxiano se inverte, arbitrariamente, em positivação a-crítica relativo até mesmo ao positivismo clássico.

Por outros meios, mas em nível incomparavelmente mais elaborado de lucidez crítica e de profundidade teórica, e por isso também mais "sofisticada", a equalização positiva para a crítica negativa pode ser percebida também em Robert Kurz. Ainda sobre do autor de " $O$ Capital", assim escreve: "Marx nunca deixou de ver o lado positivo, progressista, emancipatório da concorrência, chamando de 'missão civilizatória do capital'” (KURZ, 1992; p. 80). Tomando tal passagem isoladamente, mas não gratuitamente dado que ela expõe várias outras derivações críticas do autor, como se verá, percebe-se aí a tendência de se tomar como parâmetro o "lado positivo" como forma de supor qualquer impossibilidade da afirmativa "emancipatória" marxiana. Certamente Marx nunca deixou de ver o "lado positivo" do desenvolvimento das forças produtivas do trabalho sob o capital, mas de forma alguma viu exclusivamente esse "lado". Não é difícil identificar em várias passagens na obra de Marx (e também Engels) o "lado negativo" das condições de "ferro e sangue" com que o projeto

\footnotetext{
${ }^{138}$ Sobre o "inútil" positivismo de Comte, escreve Marx para Engels: "Estou estudando Comte, pois os ingleses e franceses estão fazendo muito barulho com este tipo. O que admira nele é o toque enciclopédico, a síntese. Mas, comparado com Hegel, Comte é minúsculo (embora Comte, como matemático e físico profissional, seja superior em questão de detalhes, Hegel é infinitamente superior em conjunto). E esse desprezível e inútil positivismo apareceu em 1832!" (MARX, Karl \& ENGELS, Friedrich, Cartas Filosóficas e o Manifesto do Partido Comunista, São Paulo, Moraes, 1987; p. 34).
} 
civilizatório do capital ${ }^{139}$ engendrou o desenvolvimento de suas forças produtivas mediado pela concorrência capitalista; desde o momento em que, como escreveria Marx, "estabeleceu uma única e implacável liberdade: a liberdade de comércio. Em uma palavra, substituiu a exploração encoberta pelas ilusões religiosas e políticas pela exploração aberta, cínica, direta e brutal" (MARX \& ENGELS; 1987; p. 105). Kurz, no entanto, embora chegasse mesmo a se referenciar em Schumpeter para insinuar concordâncias com o que este chamava de "descrição quase entusiasmada dos resultados que trouxe ao capitalismo" 140 , retoma e reconhece a vitalidade da crítica de Marx acerca de sua importância para a análise do capital. Entretanto, tal retomada é novamente composta de sentidos negativos outros, quase não identificáveis à leitura do próprio Marx: "Na verdade, a crítica da economia política de Marx somente tem em conta a ambiguidade da dinâmica capitalista" ${ }^{141}$. Se, no entanto, onde Kurz chama de "ambiguidade" fosse visto como "contradição", como situaria Marx a respeito de sua própria forma de conceber o capitalismo ${ }^{142}$, a "crítica da economia política" deste seria interpretada por aquele como algo bem além do que a mera simplificação contida nos termos: "somente tem em conta [...]".

A desconstituição do "lado" negativo e contraditório inerente à teoria de Marx tem o objetivo de substanciar, a partir das próprias formulações marxianas, aquilo que Kurz vai chamar de "emancipação negativa". Ou seja, dado o desenvolvimento da concorrência capitalista e o consequente desenvolvimento das forças produtivas que elevariam o nível das contradições internas entre o trabalho concreto e o abstrato, como analisadas por Marx, deveria significar, como assevera Kurz, o próprio ponto de uma "abolição do trabalho". Neste momento é que reside uma bifurcação entre Marx e Kurz. Pois o que, para o primeiro, a radicalização das leis do desenvolvimento contraditório capitalista só pode ser analiticamente apontada como "tendências" (e Marx vai dedicar um capítulo inteiro de sua principal obra para a análise das “causas contrariantes", ou contratendências) $)^{143}$, para Kurz trata-se de uma objetivação da “crise absoluta" que assim determina o próprio fim do trabalho:

\footnotetext{
139 “Obriga todas as nações, sob pena de extinção, a adotarem o modeo burguês de produção; força-as a ingressarem no que ela chama de civilização, isto é, a se tornarem burguesas. Em uma palavra, cria um mundo a sua imagem e semelhança" (MARX \& ENGELS, 1987; p. 107)

140 "Quase admirado, observa Josef Schumpeter que Marx, apesar de sua crítica fundamental do capital, apesar de pronunciar sua sentença de morte, deu no fundo uma 'descrição quase entusiasmada dos resultados que trouxe ao capitalismo’ (Schumpeter, 1980 [1942], pp. 23ss)” (KURZ, 1992; p. 80).

${ }^{141}$ Id., Ibid.

142 “O movimento, repleto de contradições, da sociedade capitalista faz-se sentir ao burguês prático de modo mais contundente nos vaivéns do ciclo periódico que a indústria moderna percorre em seu ponto culminante - a crise geral" (MARX, 1983; p. 21)

${ }^{143}$ MARX, K, "Causas Contrariantes", (Cap. XIV). 1983; p. 177.
} 
Em outras palavras: a abolição do trabalho, no invólucro do sistema produtor de mercadorias, não nasce como pura alegria e felicidade, mas somente em forma negativa, como crise, e finalmente como crise absoluta da reprodução realizada dessa forma, situação que já se anunciou por uma sequência histórica de crises de ascensão relativas da sociedade de trabalho moderna (KURZ, 1993; p. 81).

Mas quais são os elementos que permitem decretar a efetivação desse ponto de ruptura absoluto para afirmação de não ser mais o trabalho o fundamento da produção do valor no estágio atual da modernidade em seu "colapso"? Quais os elementos que comporiam a exaustão definitiva do rol das "causas contrariantes" que dispõe o capital para prolongar, ainda que criticamente, suas formas de extração de sobretrabalho? Em suma, como se estabelece a "mediação de ruptura" para uma nova forma de existência do valor?

Para Kurz os elementos de absolutização do fim do trabalho já estariam postos sob duas condições: de uma condição da realidade empírica alcançada no período pós-Segunda Guerra em que o desenvolvimento dos meios de produção atingiu o nível de supressão do valor a partir do trabalho abstrato (e consequentemente do trabalho concreto) tornando, assim, a monetarização e a estatização da crise uma evidência histórica fundamental que demonstraria o caráter negativo (superado) do trabalho nos tempos atuais do "colapso"; e da condição sobre a concepção de história do qual, tradicionalmente centrada no trabalho, não possibilitou ao "movimento operário marxista" vislumbrar os limites de uma sociabilidade não fundada no próprio objeto que negam: o trabalho.

A respeito da condição empírica, é notória a aproximação entre a avaliação de Kurz e de tendências da própria (auto)crítica marxista, como a exemplo de Mészáros, com relação aos limites da crise: como estágio de "ativação dos limites absolutos do capital". Nesse ínterim, tratam sob o mesmo aspecto das impossibilidades de reprodução do capitalismo, na forma de reprodução prolongada do capital, consideram a natureza da experiência socialista como uma outra forma de existência histórica do capital, e destacam o caráter destrutivo do capital como princípio fundante da reprodução em crise.

Para Kurz, o colapso do "capitalismo de caserna" se dá, não por coincidência, no momento de colapso da economia capitalista global e da sociedade de trabalho em geral ("Na verdade, a moderna sociedade de trabalho como um todo está no fim e, com isso, também o estão suas categorias básicas da forma-mercadoria e da forma-dinheiro" ${ }^{144}$, este sendo não só mera evidência do colapso geral do sistema produtor de mercadorias, mas sua própria condição.

${ }^{144}$ KURZ, 1993, p. 30. 
Todavia, as vias de mediações objetivas e diretas para explicar, por exemplo, como que um terço dos pobres do mundo - aqueles que "caíram fora" do sistema, mas que continuam a trabalhar ainda mais do que antesm - representam em si a negação de si mesmo, e não mais expressão das condições de "causas contrariantes" (como ponderava Marx) que reafirmam o trabalho ainda regido pelo capital na sua criticidade acumulativa. De uma outra perspectiva contrariante: quais os níveis de mediações objetivas e históricas que permitem afirmar o salto, daquilo que estava posto como tendência, para sua absolutização? Kurz, de fato, irá se fundamentar em abstrações genéricas (generalidade idêntica à admitida pelo poder de abstração do capital na atualidade) de fetichismos dos "pobres do mundo", "os que caíram fora", os "perturbadores da paz", como o que restou da classe trabalhadora. A diferença entre afirmar a presença de um futuro bárbaro não mais capitalista (Kurtz) e afirmar um capitalismo cada vez mais bárbaro e sem futuro (Mészáros) parece sutil, mas compõe toda uma diferença para inclusive melhor situar historicamente as possibilidades da transição para essa suposta sociedade terrivelmente nova da qual se refere Kurz, ou as possibilidades para o projeto emancipatório dos quais se refere Mészáros. Aqui, novamente, toda a concreção que aparece como empiria e que fundamentaria a evidência de uma sociedade cada vez mais do trabalho, dada a condição em que todos os bilhões de "não vencedores" se envolvem forçosamente na condição precária do trabalho, é tida apenas como mais um fetichismo, arbitrariamente posto na arbitrária equivalência positiva para a crítica negativa.

A mediação do que se apresenta como tendência histórica até a afirmação absoluta de uma outra história parece ser o ponto chave para o entendimento da crítica da negatividade; e ao mesmo tempo seu ponto de fragilidade, pois, não aclaradas as mediações de como se dá tal "passagem", podem assim cair num "abstratismo (ou negativismo) remoto" e mistificador. E aí, exatamente nesse ponto, é que se observa o recurso às formulações weberianas e seu entrelaçamento diante das perspectivas de insuperabilidade capitalista, contraditoriamente.

A respeito da condição sobre a concepção da história, este é o ponto chave de ruptura da avaliação kurziana em relação ao marxismo (até àqueles "mais críticos e radicais", como em Mészáros). Para Kurz, a própria avaliação do "socialismo real" e do "colapso" estão intimamente ligadas à do projeto da modernização, como equivalentes. Seria, de outra forma, anacrônico ler e experimentar a história para além da modernidade, daí que inviabilizaria qualquer perspectiva de uma "teoria da transição socialista". Pois, tanto os "revolucionários soviéticos" como os "marxistas críticos" já estariam todos eles "modernizados", portanto incapazes de superar seu tempo histórico a partir das próprias categorias (reais e/ou analíticas) modernas dispostas diante de si. A crítica kurziana resgata aqui a crítica adorniana sobre a 
condição ilógica (ou não dialética) da ontologia, ou sobre sua impossibilidade operacional no plano da consciência lógica ou no plano real, dado que seria em si uma trans-historicidade nos mesmos termos da anacronia denunciadas pelo próprio Marx: "uma robinsonada". ${ }^{145}$ Segue, portanto, a interpretação de Kurz (inclusive sua interpretação do "velho Marx") em direção ao resgate de uma "fenomenologia do espírito" do objeto especificamente histórico da modernidade: o capital. Mas este não enquanto expressão da ideia, de um "espírito do tempo", como nos termos hegelianos, mas como uma abstração determinante do tempo presente, um "tipo ideal", propriamente weberiano. Pois, somente por aí, seria possível entender o sentido de como o trabalho, gênese da sociedade do capital, se torna ele mesmo o fetiche de sua própria superação, desde Marx até o marxismo mais crítico e atual. Como assinala o próprio Kurz:

Mas essa inversão no contexto do sentido subjetivo, forma pela qual Max Weber descreve uma inversão, que evidentemente não é claramente percebida por ele, no processo de reprodução da sociedade, pôde brotar historicamente apenas no clima religioso-ideológico do protestantismo; as novas virtudes (burguesas) nele criadas, porém, não precisam limitar-se necessariamente a esse específico lugar histórico e às vestimentas ideais ali encontradas (KURZ; 1993; p. 22-23).

Aqui, novamente, o recurso da equalização positiva para a crítica negativa não só do movimento marxista soviético, mas de toda forma de ser do "socialismo operário", independente da natureza de sua autocrítica: "o socialismo operário nunca esteve muito distante desta criação fetichista da motivação do antigo protestantismo" ${ }^{146}$.

A absolutização negativa weberiana se estabelece, dessa forma, como a condição de colocar em caminho de colisão a história e as perspectivas revolucionárias-emancipatórias da crítica marxiana e marxista. Enquanto que, para autores como Mészáros, a proposição de uma teoria da transição socialista, ainda que considerando toda a circunstância de estabelece-la dentro da dialética entre a autocrítica e a afirmação política, seria um exercício necessário para o não abandono da história enquanto categoria da própria dialética, para Kurz trata-se de uma outra forma de fetichização que inevitavelmente levaria a um tipo de positivação a-crítica.

\footnotetext{
${ }^{145}$ E novamente neste ponto se percebe a utilização de uma equivalência positiva para a crítica negativa no momento em que tende a colocar a ontologia de Lukács, por exemplo, como mera proposição positivista, transhistórica. Isso porque teria Lukács partido do pressuposto marxiano de ser o trabalho o único elemento ontológico de transição histórica. Outro ponto importante de incompreensão: a ontologia de Lukács teria suposto uma universalização na forma de ser do valor de uso humano, desconsiderando sua existência para além de seu par dialético: o valor de troca. Lukács, no entanto, se defende perante suposta ingenuidade: "não nos devemos escandalizar a utilização da expressão 'valor de uso', considerando-a um termo muito econômico, uma vez que se está falando de gênese" (LUKÁCS, 2013; p. 44).

${ }^{146}$ Id., Ibid.
} 
[A negatividade e o problema da "emancipação geográfica"]

São essas mesmas bases de influências weberianas que chegam à Geografia: inicialmente, a tentativa de "atualização" da crítica geográfica contra o marxismo vulgar sem, no entanto, abrir mão de sua perspectiva emancipatória. A Geografia Crítica, tenderia, dessa forma, ser a união entre essas duas frentes que, do ponto de vista da perspectiva sobre a história lógica da crítica, são inconciliáveis. Inevitavelmente, a tradição do enfoque geográfico de tê-la como ciência de síntese preponderou no sentido de tentar conciliar o trabalho de atualização de seu sistema epistêmico e seu compromisso político emancipatório. O resultado, como não poderia ser diferente, foi um tipo de reivencionismo categorial pretensamente fundamentado em categorias "puramente geográficas". Estas deveriam explicar a realidade dentro de sua própria condição científica (espacial), mas ao mesmo tempo passaram a propor uma perspectiva emancipatória cada vez mais vaga e destituída de sujeitos historicamente identificáveis, nos termos frouxos da "emancipação do espaço", "emancipação do território", "emancipação das nações pobres". Isso porque a perspectiva da negatividade que deveria se estabelecer perante tudo que assim fosse considerado tradicional (como as categorias marxistas), não se atentou para o caráter inconciliável presente em um tipo de referência negativa, que põe categorias da modernidade limitadas à própria modernidade e, ao mesmo tempo, supor, perante essas mesmas categorias (específicas da modernidade, como racionalidade e alienação técnica), uma ontologia do espaço: ou seja, uma ontologia assumidamente trans-historicista ${ }^{147}$ com um corpo categorial assumidamente limitado à modernidade. Mais complicado ainda é supor desse movimento uma filosofia do espaço, ou das técnicas, de onde deveriam surgir, inclusive, os sujeitos de superação da alienação do próprio espaço. Um exemplo disso é o deslocamento nesse sentido da centralidade do sujeito histórico "trabalhador" para o sujeito histórico "pobre" em Milton Santos.

De outra forma, o deslocamento ou a descentralização dessas categorias (como o trabalho e classe trabalhadora), por não serem "espaciais" e não mais corresponderem ao estágio atual do "colapso" ou da "globalização", tendeu a significar a mudança no sentido de se buscar uma "horizontalidade" ao discurso crítico da geografia. Trata-se de se aproximar da leitura

\footnotetext{
${ }^{147}$ É notório por exemplo, a proposição de Milton Santos em elaborar uma história da técnica no meio de sua tentativa de ontologização do espaço: "meio natural", "meio técnico" e "meio técnico-científico-informacional". Ou também a perspectiva de Ruy Moreira em supor uma história da alienação do espaço como garantia de sua condição ontológica crítica: "desnaturização", "desterreação" e a "desterritorialização".
} 
geográfica uma condição real mais atual, mais empírica: “é desta forma que, na convivência com a necessidade e com o outro, se elabora uma política, a política dos de baixos, constituída a partir das suas visões de mundo e dos lugares" (SANTOS, 2011b; p. 132) ${ }^{148}$. A contradição está, exatamente, na contrapartida de que o mesmo processo de fetichização das categorias da modernidade (razão e alienação técnica) em sua forma-capital, da qual a Geografia passa a assumir o discurso, se supõe como via de superação dos processos de alienação do espaço a partir de sua liberação política. A ausência das mediações entre o reconhecimento da fetichização absoluta (tida como intransponíveis pela crítica da negatividade) e a necessidade de sua superação (tida como remotas pela crítica positiva-emancipatória, caso não se recentralize categorias internas da teoria do valor) põe a perspectiva do movimento da crítica geográfica uma condição contraditória não resolvida, nem sequer assumida.

\section{4 - A via positiva-epistêmica}

Dentre as propostas teóricas para a renovação crítica da Geografia; dentre todas elas que admitiram a necessidade imanente da crítica geográfica se estruturar em um corpo epistemológico propriamente geográfico ${ }^{149}$, concordando com a postura de ser o espaço geográfico uma "instância da realidade", ou uma "subtotalidade" interdisciplinar; e dentre tantos estes que não assumiram que suas propostas se alinhavam ao ideal estruturalista de ciência, excetua-se Armando Corrêa da Silva. A admitia a aproximação com Althusser revelou sua concepção estruturalista para a ciência como forma possível de se atingir intelectivamente a "fenomenologia", ou a "estrutura interna" do espaço. Armando Corrêa da Silva não só reconhece tais influências em suas teorias, mas as reconhecem também como parte importante das formulações de Milton Santos, para quem "lida com 'totalidade e estrutura interna'. O todo aparece como sistema dinâmico, ou em funcionamento" (SILVA, 1986; p. 42). Ainda assim, para A. C. da Silva, a proposta de Milton Santos é viável porque permite operacionalizar um sistema de fusão ao relacionar, por exemplo, a perspectiva teórica de Lacoste e a de Harvey ${ }^{150}$ : "Milton aqui amplia a discussão de Harvey e Lacoste, quando sugere a noção de 'estruturalismo

\footnotetext{
148 SANTOS, Por Uma Outra Globalização, 2011 b.

149 Antônio Carlos Robert de Moraes, em obra mais recente, Geografia Histórica do Brasil, irá também depor contra a necessidade epistemológica: "Mostrar a especificidade desta abordagem, indicando os fundamentos teórico-metodológicos que a sustentam, é o objetivo do presente livro que renega de início a ideia de ser a Geografia uma ciência 'excepcional', epistemologicamente diferente de todos os demais campos do conhecimento científico” (2009; p. 09).

${ }^{150}$ De Lacoste a perspectiva em torno da estruturação racional (mental) dos “conjuntos espaciais"; de David Harvey, as “"estruturas distintas', que podem ser 'diferenciadas uma das outras"” (Idem; p. 40).
} 
sistêmico'. O 'estruturalismo sistêmico' torna irrelevante a questão de se a estrutura é uma ideologia ou se é um atributo do objeto" (SILVA, 1986, 43).

O que Silva não expõe é a questão de até que ponto a positivação epistêmica, em torno de um projeto disciplinar, não configuraria uma via de "ideal positivista" que fez tantos outros geógrafos negarem suas vinculações estruturalistas para resguardar a própria legitimidade científica. O "ideal positivista", representaria, desta forma, não o positivismo em si, mas a forma apriorística de se fazer ciência dentro de sua limitação disciplinar por tantas vezes criticada, e até negada na convergência da renovação. Neste sentido, uma outra questão se desdobra: dado os limites da via disciplinar, como estabelecer uma crítica (estrutural, na medida em que impor ou supor limites a ela seria uma contradição nos termos em si) se antes de tudo teria ela que se estabelecer na forma de anticrítica perante seu próprio corpo disciplinar sem, necessariamente, redundar numa proposição não científica em prol de um filosofismo vulgar? Ou seja, quais os limites entre a positivação e a negação de uma crítica científica? Um limite que além de conjuntural, é também estrutural, diante dos evidentes imperativos da divisão social do trabalho.

É certo que um tipo de autocrítica fora estabelecido desde Milton Santos em sua obra "Por uma Geografia Nova": "De fato, a geografia oficial, foi 'desde os seus começos' mais uma ideologia que uma filosofia, e isso não se deu apenas na Alemanha, mas um pouco pelo mundo inteiro" (2002; p. 29). Também em Antônio C. R. Moraes: "Há uma crise de fato da Geografia Tradicional, e esta enseja a busca de novos caminhos, de nova linguagem, de novas propostas, enfim, de uma liberdade maior de reflexão e criação” (2007; p. 103). Rui Moreira: “A 'Nova Geografia' [ou 'New Geography'] entra em crise, com ela revelando o que meritoriamente conseguia esconder: no plano mais imediato a própria crise da 'geografia oficial'; no plano mais geral a crise do capitalismo" (1994; p. 48). Mas isso revela uma autocritica dentro do corpo disciplinar (e em caráter histórico) que, ao mesmo tempo em que precisava ser questionado e negado para assim tornar possível a concepção do "novo" (ou da "Geografia Nova"), era ao mesmo tempo a forma de se conservar este "passado" criticado como garantia de seu próprio "presente"; para sua legitimidade, como herdeiros, ainda que "críticos", de uma história efetivada: a história da disciplina que agora pretendia-se "Geografia Crítica".

[O "ecletismo" como falsa avaliação autocrítica]

No entanto, uma autocrítica atualizada, como parte da reflexão do próprio fazer-se crítico na ciência, como parte de um debate sobre a natureza da crítica, de sua relação com a 
dialética ou com o real, com o fenômeno ou a fenomenologia, essa pareceu um tanto ausente. Rui Moreira reconhece o caráter "refratário" (2007; p. 37) do "matiz institucional” com que a perspectiva da crítica teve que caminhar. A explicativa, ou justificativa, tende recair na "efervescência", da "ebulição", do momento. Daí que a reorientação, como dizia o próprio Moreira, "caminha para um maior ecletismo, onde, sobre a base funcionalista clássica, misturam-se elementos tirados daqui e dali” (1994; p. 50).

A "Geografia Crítica" teria assim sua origem epistemológica admitidamente amalgamática. Daí porque foi importante designar a essa "fase" primeira como o prelúdio da própria crítica que se efetivaria depois, ocultando assim sua gênese contraditória (como observado no tópico "4.2 -O Papel (ausente) da autocrítica"). Uma evidência disso é como que recorrentemente a adjetivação de "ecletismo" tem sido usada para "analisar" as propostas que ainda atualmente são as mais influentes: "Em que pese o ecletismo epistemológico deste autor [Milton Santos], não há como negar que sua visão crítica da sociedade capitalista sempre teve afinada com teorias e ideologias marxistas" (DINIZ FILHO, 2002; p. 82) ${ }^{151}$. Desta forma, posta como "eclética", a crítica à Crítica geográfica foi se ocultando, e até se ausentando gradativamente da necessidade de seu aprofundamento, pois parecia ela resolvida pela adjetivação genérica de "eclética". E a reflexão de como poderia ser possível, por exemplo, conjugar a dialética, num corpo teórico geográfico que se pretendia único e crítico, perspectivas tão distintas e conflitantes - como a ontológica lukacsiana e a negatividade de adorniana, ou o "processo de trabalho" marxiano e a ontologia heideggeriana - tendia a se esvair. De fato, a denúncia de "ecletismo", tanto em relação a Milton Santos como em relação a Armando Corrêa da Silva, por exemplo, nunca tiveram como perspectiva a análise crítica das possíveis contradições inerentes às suas respectivas propostas teóricas situando, assim, muito mais como “justificação" da necessidade da solução epistemológica impostas para a ciência pela própria forma com que "as realidades se complicam" (SANTOS, 1996; p. 133)

Desta forma, a identificação do projeto disciplinar da renovação geográfica, como admitida por Ruy Moreira, além do caráter "eclético", se deu por caminhos "cheio de sinuosidades" (2007; p. 31), onde a aparente identificação de uma crítica social à uma estruturação epistemológica foi concebida sem muita reflexão autocrítica. Esta encontrou, consequentemente, nessas vias de positivação, sua influência mais direta. Ocorria aqui aquilo que Ruy Fausto considerou àquele momento em que os limites do althusserianismo eram identificados criticamente, mas que nunca haveriam de ter sido refutados efetivamente entre

${ }^{151}$ DINIZ FILHO, Elementos da Geografia Contemporânea, 2002. 
aqueles que, ou continuam a "historicizar", ou "althusserizar", "frequentemente sem querer" (1983; p. 21).

Tratava-se também, conforme iam se intensificando as influências do estruturalismo, de uma renovação no plano da composição das ciências sociais, ou da forma de se inserir na nova divisão do trabalho científico. Tal processo iniciado na antropologia e só mais tarde na Geografia, se fundamentou na "desnaturalização" a análise científica e humanização do discurso em prol de uma crítica social. Tal perspectiva que tenta uma "horizontalização", "ampliação", da análise nas ciências sociais, e especificamente na Geografia, passa a sobrepor como foco o exercício epistemológico em si em detrimento, sobretudo, do "marxismo vulgar". Como destaca Henri Lefebvre sobre tais influências:

Tem-se a impressão de saltar do "vazio teórico" para uma plenitude representada pelo Dr. Lacan, por Lévi-Straus e alguns outros. O estruturalismo nada teria de ideologia? Trataria ele a ciência, constituída talvez sob a influência de Marx, mas sem ligação com o marxismo teórico e prático? (1968; p. 81-82) ${ }^{152}$

Tal passagem de Lefebvre em muito se identifica ao caminho percorrido pela renovação da Geografia. Primeiro, como visto, se produz um "vazio teórico" por meio de uma crítica ao "passado" para introduzir uma "nova" necessidade de natureza eminentemente epistêmica: "sempre, e ainda hoje, se discute muito mais sobre a geografia do que sobre o espaço, que é o objeto da ciência geográfica" (SANTOS, 2002; p. 18). Depois trata-se de se buscar um exercício de superação das leituras "ideológicas” para se propor uma adequação científica: "A relação entre ciência e ideologia é, notadamente nestes campos, bastante tensa e não cristalina - como propõe os adeptos do criticismo vulgar" (COSTA \& MORAES, 1984; p. 16). Em seguida a “consequente necessidade" de se estruturar no enquadramento da divisão do trabalho científico: “A questão da divisão das ciências e da classificação de seus campos é, entretanto, importante para o controle lógico do trabalho científico, numa era de intensa especialização das pesquisas"153. Passando por sua "justificação de ciências particulares autônomas" tipicamente estruturalista: “[...] Mas, a autonomia não é independência. O movimento particular que cada ciência cria com seu próprio sistema próprio de pensar uma parte, um aspecto da coisa tem que estar subordinada ao universo geral dado pela realidade total" (SANTOS, 2012; p. 19). Para, por fim, propor uma "teoria e uma epistemologia [...] que forneça ao mesmo tempo, a 
explicação da realidade 'espacial' e os instrumentos para sua análise"154, como já citado anteriormente. Ou, de forma resumida, como sintetiza Ruy Moreira o "roteiro da ruptura":

Começa-se com a crítica do discurso existente, seu sentido ideológico, seu envolvimento institucional e político, seu estatuto epistemológico. Desconfiase de um imbricado ontológico. Pergunta-se sobre o sentido de sua real utilidade. Projeta-se sua viabilidade prática. E culmina-se na mudança substancial do conceito de espaço (MOREIRA, 2007; p. 31)

Assim, passo a passo, sequenciado e linear, passa a ser hegemonicamente concebido os caminhos para a estruturação da crítica geográfica num corpo disciplinar eminentemente geográfico. Se, por sua vez, não se efetivou de forma harmônica a unidade da crítica, como na sequência do seu texto concorda Moreira ${ }^{155}$, certamente porque houve "incoerências" incontornáveis no seio do processo que, necessariamente, haveria de ser conflituoso ${ }^{156}$. Em parte, isso se dará pela "teimosia" com que o "marxismo" continuaria a existir como perspectiva para a geografia; e em parte porque se supôs erroneamente que "antigas ideologias" haveriam de ter sido superadas pela simples forma de excluí-las do quadro geral do sistema epistemológico que, necessariamente, haveria de resguardar a especificidade da Geografia com seu devido rigor analítico.

[O entendimento do "marxismo" excluído]

Pode-se argumentar que as prerrogativas de Milton Santos, por exemplo, foram interpeladas de forma desatenta e ideologicamente tentada para um cientificismo puro e pretensamente Geográfico. Isso pode ser observado quando Santos, preocupado com o rigor científico da Geografia, ao afirmar que "não basta jogar com as categorias marxistas de forma dogmática como se os fatos, ontem ou hoje, se pudessem dar de uma vez por todas" (1996; p. 133), não foi considerado o fato que buscava ele uma crítica à "uma" forma específica de se fazer ciência, a dogmática, e não a "toda" forma de marxismo. Isso, na sequência do movimento da renovação crítica, não foi bem atentado e pode ser observado, por exemplo, em afirmações como essa: "O problema da 'atrofia teórica' [da qual Santos qualifica o desenrolar da Geografia

\footnotetext{
154 SANTOS, 2012; p. 23-24.

155 "Mas, ao fim, avança-se desigualmente no tema do projeto unitário, reclamado por Lacoste, do desencantamento do fetiche do espaço, requerido por Milton Santos, e do desvelamento da alienação classista dos ordenamentos espaciais da sociedade moderna, propugnado por Quaini" (Ibdem).

156 Temas esses do tópico "5.1 - Fissuras Na Síntese”.
} 
crítica] conjugaram-se o 'enfoque marxista', isto é, a fixação no marxismo que serviu de base, em grande parte, dessa Geografia renovada (SILVA, 2010; p. 22). A autora elabora tal conclusão diante da afirmativa de Santos em que diz: "uma boa parcela do que hoje aparece como geografia marxista é ideológica [...]"157. Não importaria tanto a ausência do questionamento sobre os motivos ideológicos que levou Santos a utilizar a palavra "ideológica" depois de "marxismo", dado que seria impossível uma um tipo de marxismo "não ideológico" (ou qualquer outra perspectiva teórica que não contenha sua própria ideologia, crítica ou não ${ }^{158}$ ). Também não importaria tanto se debruçar sobre os motivos que levaram a autora a usar a expressão "grande parte", quando se leu "uma boa parcela", expressão essa inserida na forma de aposto numa frase de cunho conclusivo. Mas, a ausência dessas duas observações, somadas, torna ao menos evidente certa tendência de vincular toda forma de dogmatismo ao marxismo, como se não houvesse uma forma de ideologia dogmática no processo de "epistemologização como desideologização da geografia", tipicamente estruturalista.

Também em Luiz Lopes Diniz Filho, a quem intitula um texto como "certa má herança marxista" e, em um dos pontos da conclusão, escreve que "[...] a aceitação do marxismo foi posta pelos geógrafos críticos dos anos 70 e 80 como uma questão de ordem ética, estabelecendo assim um raciocínio extremamente maniqueísta [...]” (2002; p. 103), como se acusar o planejamento do Estado no período em questão e seu engajamento político-econômico em prol das classes dominantes fosse algo exclusivo de marxistas. Aqui também é indispensável, tão flagrante que seja, a falta de cuidado e critério abandonado ao longo do texto a respeito de como que "certa má herança" tornou o próprio marxismo em sua totalidade em "todo maniqueísta". O referido texto caminha vinculando paulatinamente o "marxismo ortodoxo" a "todo marxismo" e o faz, inclusive, retirando a "qualidade" de marxista autores de "porte" reconhecidamente marxistas, como David Harvey ("Isso fica nítido na forma como um autor no porte de Harvey - que jamais poderia ser reduzido a um exemplar de marxismo estreito [...] ${ }^{\gg 159}$ ), mas assim é posto somente para situá-lo como um híbrido entre o marxismo e o pósmodernismo: "Neste sentido, pode-se afirmar que a combinação de teorias marxistas e 'pósmodernas' a que assistiu a geografia nos anos 80 e 90 constitui uma tentativa renovada de concretizar uma das maiores promessas da geografia crítica radical” 160 .

\footnotetext{
${ }^{157}$ SILVA, 2010, p. 22.

158 Como concorda Mészáros, o conceito de ideologia fundamentado na exclusividade da falsa consciência é apenas um conceito que não admite sua totalidade dialética. A ideologia, ainda conforme Mészáros, está entremeado em sua condição estrutural e positiva do real. As ideologias críticas, como o marxismo, são por isso efetivas (Cf. MÉSZÁROS, O Poder da Ideologia, 2004).

${ }^{159}$ DINIZ FILHO, 2002, p. 97.

${ }^{160}$ Id., Ibid.
} 
O texto de Diniz filho é sintomático para situar como que se opera uma certa "desmarxiização da geografia", para assim tornar "válida a preocupação em dotar a geografia de independência epistemológica"161. Mas é também notório como se observa as inversões teóricas (e seus respectivos prejuízos para a crítica) que se constituem por enquadramento ideológico a garantia de tais objetivos epistêmicos. Dentre a outras inversões ideológicas apresentadas no desenvolvimento do referido texto, podem ser destacados duas, a saber: a economia política como economicismo e a luta de classes como sociologismo.

Sobre a "articulação, na teoria marxista, [entre] economia e política". Assim se situa Diniz Filho, primeiro, na questão do reducionismo da teoria econômica à uma indeterminabilidade histórica: “Tal articulação entra em crise, entre outros motivos porque a teoria da revolução construída pelo marxismo tinha como um de seus pressupostos fundamentais uma análise crítica da economia capitalista" ${ }^{162}$. Segundo, a questão não muito bem situada sobre a gravidade estrutural da crise atual capitalista: "[o marxismo] procurava demonstrar a inevitabilidade de uma crise fatal do capitalismo, no qual este modo de produção iria sucumbir sob o peso das próprias contradições" ${ }^{163}$. Como parece não reconhecer o saldo desastroso com que o capital se reproduz na atualidade da crise, conclui: "Justamente as visões apocalípticas do capitalismo é que caíram em descrédito nas últimas décadas"164. É, de fato, difícil reconhecer o aprofundamento "fatal" das contradições do capitalismo quando não se reconhece as instâncias mais intimas de suas contradições estruturais. Daí porque grande parte dos geógrafos preocupado com a "geograficização" não pôde entender a economia política se não fosse por vias de um economicismo vulgar e imediato. Inversamente, aí também se explica porque as categorias da economia política passam, assim, a serem tratadas como "economicistas" e, desta forma, necessariamente dispensadas pela Geografia.

Sobre a questão da "luta de classes" e seu rebaixamento sociologista, assim se propõe a analisar Diniz Filho a teoria de Marx: "as teses de Marx sobre a luta de classes foram profundamente marcadas pelos movimentos revolucionários de 1848 ”. É óbvia a participação da análise de Marx sobre os eventos de 1948 (inclusive materializado textualmente em "A Lutas de Classes em França de 1848 a 1850”), mas nem de longe a leitura sobre a questão das classes sociais pode ser restrita exclusivamente a este escrito contextual de Marx sem a observação de que as classes, são elas, sobretudo, "personificações" de categorias econômicas. Um leitor

\footnotetext{
161 Id., Ibid.

162 Ibid.p. 93.

163 Id., Ibid.

164 Id., Ibid.
} 
principiante lembraria do famoso prefácio da primeira edição de "O Capital" onde, com um tom de advertência contra a possibilidade da interpretação esvaziada, interpela Marx:

Para evitar possíveis erros de entendimento, ainda uma palavra. Não pinto, de modo algum, as figuras do capitalista e do proprietário com cores róseas. Mas aqui só se trata de pessoas à medida que são personificações de categorias econômicas, portadoras de determinadas relações de classe e interesse. (1983; p. 13)

Sem as devidas observações, no entanto, continua Diniz Filho sua intepretação das “teses" de Marx sobre a questão de como que a "oposição entre as classes sociais [...] não se ampliou com a evolução do capitalismo": “a) o regime republicano logrou construir uma ideologia capaz de pôr novamente em xeque a noção de classe social"165 (só não explica Diniz como que uma ideologia "republicana" pode ter a força de resolver a contradição entre trabalho e capital, que substanciam materialmente as classes a elas inerentes); “b) [...] o desenvolvimento do capitalismo não produziu um proletariado numericamente majoritário em relação à demais classes, mas sim um declínio relativo e até absoluto"166 (Diniz só se esquece que o proletariado não corresponde a diversidade ou totalidade da classes trabalhadora, e sua redução relativa e até absoluta consta sim como tendência do desenvolvimento capitalista, ligada a também redução do capital variável, sobretudo no capitulo em que Marx dedica às "Leis da Acumulação Capitalista"). c) "apenas em circunstancias históricas excepcionais constituem-se classes sociais no sentido marxista do termo, de modo que a análise sociológica marxista torna-se intrinsecamente problemática"167 [...]" (Diniz só não se atenta para o fato de que não existe estado não excepcional que permitam as condições de existência histórica do capital e que, assim, a história do capitalismo é uma excepcionalidade na história universal humana onde o ilógico, o irracional e o contraditório é a forma determinante do próprio ser histórico. Entender de outra forma é supor uma certa história natural).

Se estivesse atendo às formulações de Marx, talvez Diniz Filho entenderia que a relação entre a economia política e a classes já está dada sob a forma de gênese, e que, por exemplo, a redução relativa do proletariado só se dá em decorrência também de uma redução relativa do capital variável, aquele exatamente envolvido na dimensão da produção do mais-valor. Sem essa leitura, não tem, nosso geógrafo, condições de entender a gravidade da crise, por vias que se tornam inteligíveis. Também não pode entender que essa relação é irreversível e estrutural

\footnotetext{
${ }^{165}$ DINIZ FILHO, 2002, p. 133.

${ }^{166}$ Id., Ibid.

${ }^{167}$ Id., Ibid.
} 
e, como tal, dada as condições estremas de dessa contradição, faz o geografo olhar para o espaço e não ver mais o trabalho, mas sim uma realidade que o permite proclamar, como conclui Diniz, o colapso “[do] conceito de 'sujeito político revolucionário’ e, por conseguinte, [do] projeto de revolução"168.

Baseada em todas essas pressuposições sobre a crítica pretensamente pós-marxista, propõe ainda Diniz Filho, como contribuição para o desenvolvimento epistemológico, numa tentativa de "combinar" os "valores humanistas da geografia cultural contemporânea" com a contribuição da análise do "funcionamento do mercado", tipicamente marxista: "A primeira vista, essa relação só poderia ser negativa (como geralmente tem sido no Brasil), pois a fenomenologia humanista é pródiga em crítica ao pressuposto do ‘homem econômico' [...]"169. As questões que se abrem, e permanecem abertas, são: estaria Diniz Filho, ao propor "uma complementaridade entre as perspectivas analíticas"170 tão distintas, opostas e conflitantes, forjando mais uma suposição pós-moderna, ou estaria ele fundamentado na prerrogativa miltoniana, acerca da estruturação epistêmica, onde as possibilidades para tal relação se tornaria justificável dado que "a realidade do mundo se complica" novamente? Ou, de forma mais estrutural: quais são as amarras feitas pelas propostas de sistematização epistêmica que limitariam o desenvolvimento da banalização e relativização da crítica social própria do movimento fragmentário pós-moderno?

[A necessidade de positivação do objeto em detrimento rigor teórico e metodológico]

Apesar de deixar claro a "insatisfação" com que a Geografia vem sendo tratada nos "tempos atuais" (“como estivesse demasiado prisioneira de uma moda, a geografia sucumbiu às fragilidades do enfoque da pós-modernidade, cuja a versão mais popular é uma abordagem frequentemente adjetivável e metafórica") ${ }^{171}$ a condição da crítica da Geografia em Milton Santos tende a se tornar cada vez mais vinculada a urdidura de um sistema epistemológico efetivo, como o "corpus" da disciplina e subordinado ao objeto ("Na realidade, o corpus de uma disciplina é subordinado ao objeto, e não ao contrário") ${ }^{172}$ em detrimento a suas amarras e rigor metodológico e teórico. É notório, aliás, a forma de tratamento para com a crítica social que se desenvolve na obra de Santos desde os textos que irão compor a coletânea "Economia

\footnotetext{
${ }^{168}$ DINIZ FILHO, 2002, p. 94.

${ }^{169}$ Ibid.p. 105.

${ }^{170}$ Id., Ibid.

${ }^{171}$ SANTOS, 2008; p. 19.

172 Id., Ibid..
} 
Espacial" - sobretudo no texto "A totalidade do Diabo: Como as formas Geográficas Difundem o Capital e Mudam as Estruturas Sociais", onde aparece um momento de ruptura com a influência francesa da Geografia Ativa e apresenta uma "perspectiva essencialmente crítica [...], fazendo deste livro uma das obras mais radicais do autor, na qual ele revê teorias e conceitos assimilados e utilizados em trabalhos anteriores" (MORAES, 2013; p. 36) ${ }^{173}$-; passando pela "militância epistemológica", mas ainda carregada de "militância crítica-social", que caracteriza o "Por Uma Geografia Nova" (um "acerto de contas com a tradição com o campo disciplinar"174); até, por fim, chegar em sua obra de maturidade, "A Natureza do Espaço", um livro que, como destaca o próprio autor, caminha para o "desejo explícito [da] produção de um sistema de ideias que seja, ao mesmo tempo, um ponto de partida para a apresentação de um sistema descritivo e de um sistema interpretativo da Geografia" (SANTOS, 2008; p. 18).

O "desejo" que ora se apresenta "explícito" não poderia ser outro senão a identificação de uma crítica social como "saldo" da crítica epistêmica, relação esta tornada cada vez mais imbricada, conforme os saldos da crise social iriam arrefecendo as ebulições sociais no período seguinte do final da década de 1980. O risco de sua "autofagia" (COSTA \& MORAES, 1984; p. 20), ou o risco de ser ela consumida pelo próprio tempo, tenderam para sua cristalização na forma específica de uma epistemologia crítica geográfica, cada vez mais em prol da própria legitimidade da Geografia. Têm-se neste momento a identificação, ou a confusão, entre o estabelecimento do que seria uma crítica dialética com o necessário rigor científico ou estabelecimento da necessidade da ciência para o rigor da crítica dialética. Tal mudança de perspectiva, longe de ser sutil, foi o elemento embrionário adotado e indiscutido, sobretudo na forma mais influente da proposição de Milton Santos que não acidentalmente assim subintitula sua obra seminal: "da crítica da geografia a uma Geografia Crítica".

[O não rigor dialético e a consequente relativização da crítica]

O debate sobre a crítica que se tem ante tal necessidade e que aprece de forma apriorística é, assim, aceita como a forma em si da crítica: ou seja, sua necessidade de existência epistêmica. A crítica é posta como a forma específica de uma dada estrutura epistemológica cabendo agora a análise de suas múltiplas formas, como objeto mesmo de investigação. Eliseu Savério Spósito (em texto já referenciado - "Pequenas Argumentações para uma Temática

\footnotetext{
${ }^{173}$ MORAES, Território na Geografia de Milton Santos, 2013.

174 Ibid.p. 43.
} 
Complexa, 2002), por exemplo, ao propor a recusa de um recuo historicista sobre os significados da crítica na Geografia ${ }^{175}$ estabelece um diálogo com a filosofia para situar a crítica geográfica em uma suposta diversidade: começa pelo seus sentidos etimológicos; passando pelos elementos da linguagem por ela adquiridas, seguido os métodos de orientação do qual a dialética aparece como par determinante até sua efetivação enquanto paradigma. A "crítica" vai, desta forma, se deslocando de seu conteúdo contestatório-histórico-emancipatório que fluía dos movimentos sociais para seu aprisionamento epistêmico, ou o que passava a significar frente a proposta da epistemologia da "Geografia Nova". Tende, assim a se decompor enquanto "frente ética" para se substantivar como "adjetivação" de uma proposta determinada: Geografia Crítica, Geografia Ativa, Geografia Radical. Desta forma, sem as preocupações sobre os sentidos da dialética necessária ao debate da natureza da crítica, se chega até mesmo a concebêla como um apriorismo dispensável (no sentido kantiano dos termos) dado que já haveria ela cumprido seu papel na Geografia, como assim procede tendências de reflexões pós-modernas. Como concordará José Willian Vesentini:

Sem dúvida que existe certa verdade na afirmação que há diferentes vertentes autodenominadas críticas na geografia (como na ciência social e na filosofia em geral) e que talvez o melhor seja deixar de lado esse adjetivo, pois, afinal de contas, já não teria ele cumprido o seu papel? (2009; p. 121).

A forma de como que a crítica passa a se tornar "adjetivo" dispensável só é possível quando um processo de mistificação da própria dialética se efetiva ("Não é mais possível levar a sério a concepção de dialética como portadora do segredo da história, ou como o 'método científico' por excelência") ${ }^{176}$ na forma de reducionismos que retiram sua condição de instrumento para a reflexão das contradições e desvelamento dos fetiches (aparência versus essência), onde tudo passa a ser permitido, inclusive decretar em alto relevo "Não existem ideias ou teorias críticas em sii" ${ }^{177}$ e as vinculam como imediatismos políticos e históricos, do tipo: "Elas só o são em função do papel que desempenham no seu contexto, razão pela qual podem ser críticas numa época, num momento e num lugar determinados - por exemplo, o marxismo na Europa Ocidental do século XIX"178.

\footnotetext{
${ }^{175}$ Ver também o tópico: 7.1.1 - O papel (ausente) da autocrítica.

176 VESENTINI, 2009, p. 115.

177 VESENTINI, 2009, p. 121.

${ }^{178}$ Id., Ibid.
} 
De certo que entre Milton Santos e Vesentini há uma profunda diferença diante de suas perspectivas teóricas, mas um ponto comum entre ambos pode ser notado exatamente no peso que eles dão à composição da ciência como possibilitadora de incorporação da crítica. No entanto, diferente de Santos, Vesentini vai muito além ao afirmar suas crenças na ciência em si, como projeto iluminista:

[...] Temos que levar em conta que a geografia é ou pretende ser uma ciência. $\mathrm{O}$ que Kant almejava com a sua crítica como prolongamento do iluminismo era exatamente libertar a humanidade das amarras dos dogmatismos e dos autoritarismos, da escuridão enfim (VESENTINI, 2009; p. 26).

O retorno a Kant não é causal e indica pontos comuns dentre aquelas perspectivas que se encaixam no compromisso da necessidade de se estabelecer uma via positiva-epistêmica para a crítica geográfica. A passagem onde Vesentini situa a natureza da crítica de Marx e Hegel como "equivocadas" e "insuficientes", porque, segundo sua interpretação, havia uma tentativa de "teleologizar a história e a pretensão de identificar um agente portador do futuro e do segredo da história (a razão ou o proletariado)" "179, uma simplificação vulgar que o permite estabelecer uma relação, não menos vulgar, dos supracitados com Kant ("não perder de vista o que há de comum entre eles e Kant") ${ }^{180}$, se tornou comum aos geógrafos que, portados de uma pretensa epistemologia própria, amalgamática, que se pretende "metadisciplina", tenderam a abandonar aqueles mesmos desafios lançados pela Teoria Critica da Escola de Frankfurt; quais seriam o de reestabelecer à crítica suas bases dialéticas no seu mais puro rigor e liberdade metafísica ${ }^{181}$. Algo necessário e válido para a própria ciência, como assevera Horkheimer em seus escritos sobre "Teoria Crítica" acerca da crítica vinda da metafísica e dirigida a atividade científica: "Isso não significa, de modo algum, que seus próprios representantes não estivessem interessados na verdade pura" (1990; p. 10). Quanto aos riscos contidos na possibilidade de assim poder levar o exercício teórico a se constituir como uma metafísica remota, não objetivável e excessivamente abstrata, isso é um problema a ser resolvido internamente no próprio exercício dialético.

Como demonstra Marx, o uso da dialética de Hegel na sua mais profunda abstração metafísica jamais poderia representar a justificativa em si para seu abandono, tratando-a como

\footnotetext{
${ }^{179}$ Ibid.p. 115.

180 Id., Ibid.

${ }^{181}$ Como assevera Rui Fausto, “Os pensadores de Frankfurt, Adorno sobretudo, 'manejaram' a dialética como não se fizera desde Hegel e Marx” (1983; p. 20).
} 
"cachorro morto"; como assim fizeram os antigos hegelianos e a "ex-revolucionária" burguesia em relação ao grande filósofo, como assim fazem os “atuais” geógrafos em relação a dialética. Os objetivos de constituir uma leitura científica sobre a realidade posta como concreta a partir da dialética metafísica hegeliana - e por isso mesmo, uma dialética agora "invertida", de ponta cabeça, não idealista - não impediram Marx de reconhecer a dialética como o "método"182 fundamental para a análise crítica da sociedade moderna.

No entanto, no que interessa a crítica em si, ainda que estivesse em Kant o fundamento da crítica moderna, ao situar no plano da consciência aquilo que se apresentava enquanto "razão", posto fora-de-si, apriori, e que assim passasse ele a abrir a possibilidade do questionado científico perante o "absoluto" a partir de sua expressão fenomênica (mesmo que restrita ao plano do espírito) é somente em Hegel que este absoluto, determinado fora-de-si, se "disseca" internamente em suas contradições, se quebrando em teses e antíteses, ao mesmo tempo que se historicista na forma de síntese, enquanto ser-em-si na sua própria fenomenologia. Enquanto que "Kant afasta o princípio da contradição do terreno da ciência" (MATOS, 1993; p. 21), Hegel a toma como o próprio pressuposto da crítica dialética, considerando que as "coisas e os seres históricos e sociais", ao contrário da razão absoluta kantiana, "se constituem por sua negação interna" ${ }^{\prime 183}$.

O uso da abstração kantiana, posto na forma absoluta da razão do ser, encontra em Hegel sua forma de operacionalizar o próprio entendimento do devir, na medida em que ela, a abstração, se põe na história como potência do espirito. Ou seja, tudo é passível de ser inserido na sua própria determinação negativa, na sua própria contradição. Para Marx, isso representa a própria descoberta da negatividade do positivo-real que põe as categorias históricas em franca contradição consigo mesmas, como as categorias que envolvem o capital, desde os seus primeiros escritos até sua última obra sobre a economia política ("em sua configuração racional, é um incômodo e um horror para a burguesia e para seus porta-vozes doutrinários, porque, no entendimento positivo do existente, ela [a dialética] inclui ao mesmo tempo o entendimento de sua negação" ${ }^{184}$. Mais do que a operacionalização entre positividade-negatividade imanente do ser, é a descoberta dessa mesma expressão contraditória para com a história. Afinal, qual o significado dado por Marx à era do capital como "pré-história humana", senão a contradição

\footnotetext{
${ }^{182}$ Se refere Marx à leitura do seu "método" de pesquisa posta em O Capital, resenhada pelo Correio Europeu, de Petesburgo: "Ao descrever de modo tão acertado e, tanto quanto entra em consideração a minha aplicação pessoal do mesmo, demodo tão benévolo aquilo que o autor chama de 'meu verdadeiro método', o que descreveu ele senão o método dialético" (MARX, 1983; p. 20).

${ }^{183}$ MATOS, 1993, p. 21.

${ }^{184}$ MARX, 1983; p. 21.
} 
dialética de ser ela mesma uma não-história, uma história negada? Ou seja, Marx encontra na dialética a condição transitória da história que põe o tempo do capital, não como a realização da história mesma - como fora mistificada no próprio Hegel, contraditoriamente - mas também como sua própria negação (“[...] porque apreende cada forma existente no fluxo do movimento, portanto também com seu lado transitório; porque não se deixa impressionar por nada e é, em sua essência, crítica e revolucionária"). Isso explica porque Hegel passou a desinteressar a então burguesia dominante europeia; afinal haveria ele criado seus próprios demônios.

[A não-contradição como fundamento da "dialética geográfica"]

Para a renovação da Geografia isso tem uma importância fundamental. A via da positivação-epistemológica, de maior influência dentre todas outras, teria que afirmar uma forma de crítica que evitasse sua própria autocrítica, sob o risco de se admitir uma contradição nos termos em si. O discurso da necessidade da estruturação epistemológica fundamentado nas justificativas de conquista da "autonomia", "legitimação", "independência" da disciplina, conjugada com o "manual" estruturalista para as ciências sociais, logo ganha caráter hegemônico porque assim poderia dar a Geografia a possibilidade de sua crítica explicar as coisas como elas se afirmam, não como elas se negam. Seria difícil para Milton Santos, por exemplo, que buscou por mais de vinte anos estruturar um sistema de ideias efetivo, dotado de coerência interna obtida através da "separação de categorias analíticas que, por um lado, deem conta da respectiva superfície do real, própria a tal fração do saber, e por outro lado, permitam a produção de instrumentos de análise, retirados do processo histórico" (SANTOS, 2008; p. 21), um sistema propriamente geográfico sobre o seu objeto, o espaço, que por fim encontra na técnica seu elemento fundante, ter que por fim admitir, como necessidade do rigor inerente a dialética a negatividade epistêmica em seus próprios termos.

O exemplo de Milton Santos é sintomático, mas pode ser estendido para o movimento da frente epistemológica como um todo. Para além da técnica, basta lembrar como que o "sistema de objetos e sistema de ações", o sistema categorial "forma-função-processoestrutura", fora difundido e utilizado como prerrogativa da própria condição da crítica quando que, na verdade, a "dialética" que as relacionavam serviriam muito mais para introduzir os elementos de "complementariedade", a própria "conciliação", do que propriamente o da “contradição", ou "negatividade". Como exemplo específico pode ser observado a questão de 
como Milton Santos trata a dialética em um capítulo sintomaticamente intitulado como "Espaço e a Noção de Totalidade" em sua principal obra, "A Natureza do Espaço".

Com sua forma didática peculiar, inicia Milton Santos advertindo que o debate da totalidade deve ser feito a partir de "sua própria província do saber, isto é, de um aspecto da realidade global" (2008; p. 114), no caso, a Geografia. Estabelecido os "limites" de manobra para com a dialética, prossegue Santos mostrando que, na especificidade da Geografia, a totalidade deve estar inserida no estágio atual da "universalidade empírica"185 e que, assim, dentro de uma epistemologia eminentemente geográfica, a totalidade poderia ser observada na relação “totalidade-mundo e os lugares" (universal para o particular) ${ }^{186}$. Avança Santos para a relação com que a totalidade expressa com suas partes: "as partes que formam a totalidade não bastam para explica-las. Ao contrário, é a Totalidade que explica as partes"187. Santos se utiliza de Wittgenstein para introduzir a noção de "movimento" (sem contradição) a uma totalidade que se propõe "integrada" e que, concordando com Karpik, remete a noção de totalidade real a ser compreendida como o "Planeta, isto é, a natureza e a comunidade humana" ${ }^{188}$. De Kosik, Santos introduz a noção de que a totalidade do universo, sendo um todo estruturado, deveria ele ter "leis internas" e que, assim, se põe como "totalidade concreta"189. Ao chegar no tópico "A Cisão da Totalidade", Santos supõe um movimento inverso feito até então ao observar que a "totalidade está sempre se desfazendo"190. Isso remete a decomposição do todo, mas novamente uma decomposição limitada as suas "partes" pelo processo de "cissiparidade, subdivisão, esfacelamento"191. De Sartre estabelece Milton Santos a distinção entre "totalidade e totalização". Aqui, pela primeira vez, assume a noção de contradição, mas uma contradição feuerbachiana, com pobreza de abstrações, e, consequentemente, por ele mesmo rechaçada. Sobre a relação entre sociedade e meio, escreve Milton Santos: "Cada qual, ao seu tempo, dá origem e explica a outra"; aqui, novamente, a reafirmação da relação dialética entre as categorias nos limites da complementaridade apenas.

Seguindo as orientações de Sartre ${ }^{192}$ se aproxima Milton Santos da noção de Hegel de "potência", colocando o espaço na condição possibilitadora da sociedade global "se realizar

\footnotetext{
185 SANTOS, 2008, p. 115.

186 Id., Ibid.

${ }^{187}$ Id., Ibid.

188 Ibid.p. 117.

189 Id., Ibid.

190 Id., Ibid.

${ }^{191}$ Ibid.p. 118.

192 "Sartre, que deve certamente alguma coisa à fenomenologia do Espírito de Hegel, escreve uma Crítica da Razão Dialética da qual a lógica de $O$ Capital não conhece Hegel” (FAUSTO, 1983; p. 20).
} 
como fenômeno" 193 . Em uma nova oportunidade de inserir a contradição na leitura, em prol da legitimidade do espaço, subverte Milton Santos à uma dialética complementativa: “A sociedade em geral, não são mais do que um real abstrato, o real concreto sendo uma ação, relação de produção específicas, cuja historicidade, isto é, cuja realização concreta somente pode dar-se no espaço" 194 . É notório o esforço para salvaguardar a unidade somatória, conciliativa do espaço, afinal o que seria dele se o "real abstrato" da sociedade em geral fosse o polo oposto, estivesse em contradição, fosse a identidade negativa, do "real concreto"? Assim continua Milton Santos a odisseia em busca da contradição negada. No tópico "A precedência do processo" Milton Santos encontra Hegel (mas novamente mediado por Sartre) e até mesmo Lukács, de quem se inspira para afirmar que "a melhor maneira de surpreender este movimento é observar a cisão da totalidade" ${ }^{195}$. Mas, novamente, assim o faz só para não reconhecer o caráter contraditório da "cisão" na atualidade ("Atualidade é unidade do universal e do particular: este aparece como se fosse separado, existindo por si, mas é sustentado e contido no todo") ${ }^{196}$.

Milton Santos, ainda no texto supracitado, chega novamente a usar a palavra "contraditório", mas só para concordar com J. J. Goblot acerca da adjetivação do "erro stalinista". Sobre a relação entre real-abstrato e real-concreto, relação de onde emerge toda a contradição interna do fetiche em Marx, por exemplo, fica Santos limitado a um jogo de sequência de metamorfoses lineares e "evolutiva": "Só se torna existência, só se realiza completamente, através das formas sociais, incluindo as geográficas. E a cada momento de sua evolução, a totalidade sofre uma nova metamorfose. Volta a ser real abstrato" ${ }^{197}$. Sobre indivíduo e totalidade, novamente a ausência da contradição: “cada indivíduo é apenas um modo da totalidade, uma maneira de ser: ele produz o Todo e só tem existência em relação ao todo", ou seja, um se afirmando no outro.

Na sequência da leitura do texto referenciado, enfim chega Milton Santos em Hegel de fato, sem mediações sartreanas. Considera o caráter contraditório na composição do espírito e sua objetivação na forma da ideia. Mas o faz só para pôr a totalidade como "objeto", nos mesmos termos mistificadores do conceito da Ideia hegeliana. Segue, então, Santos sobre a relação entre totalidade e potência, ou "latência", na forma "perfeita" admitida pelas categorias: "a totalidade como latência é dada pelas suas possibilidades reais mas históricas e

\footnotetext{
${ }^{193}$ SANTOS, 2008, p. 119.

${ }^{194}$ Id., Ibid.p. 120.

195 Id., Ibid.p. 121.

196 Id., Ibid.p. 121.

${ }^{197}$ Id., Ibid.p. 122.
} 
geograficamente irrealizadas"198; o particular volta a se estabelecer como positivação do universal no lugar ("Levando o universal ao particular, cria uma particularidade"); reforça o caráter da "combinação" na relação entre o existente e o "latente" (“[...] essas combinações irão, por sua vez, condicionar as novas qualidades possíveis"199); e vê "diacronia" onde poderiam haver "contradições" no desenvolvimento desigual e combinado ("Trata-se de uma evolução diacrônica, consagrando mudanças não só homólogas do valor relativo de cada variável" $\left.{ }^{, 200}\right)$.

Talvez, por força de demonstração, a citação mais importante do capítulo supracitado, onde seja possível considerar, de fato, a ausência do caráter contraditório na dialética miltoniana, seja:

Não se pode, deste modo, considerar uma dialética que hierarquize estrutura
(essência, totalidade nua) processo, função e forma segundo um movimento
linear, ou de uma maneira unívoca pois, de um lado, a estrutura necessita da
forma para tornar-se existência e, de outro lado, a forma-conteúdo tem um
papel ativo no movimento do todo social.
Toda forma-conteúdo pela presença da ação, a forma torna-se capaz de
influenciar, de volta, o desenvolvimento da totalidade, participando assim, de
pleno direito, da dialética social (2008; p. 126)

Não é primeira passagem em que Santos tende a se distanciar da influência estruturalista por considerar suficiente a argumentação de que sua "estrutura" não se trata de verticalização entre as categorias unidas no seu sistema. No entanto a identificação do ideal estruturalista da proposta miltoniana não se encontra gratuitamente na "estrutura" de sua epistemologia, mas na relação entre as categorias, o que não fora ainda observado. Estão elas foltadas a si mesmas, de forma conciliatoriamente circular, por isso autorreferenciadas (como se observou no tópico "2.2- Técnica: a autossustentação, a autorreferenciação e o sistema filosófico fechado") O problema da dialética social de Milton Santos é que não há conflito em suas relações constituintes e o social não aparece. A não existência de "hierarquia" entre categorias não garante que elas estejam mediadas por uma dialética da contradição. $\mathrm{O}$ autor fala em "estrutura necessitando da forma" para existir, como se devesse existir positivamente, e não contraditoriamente. As principais categorias da análise geográfica miltoniana, relacionadas de forma sintética na citação acima estão envolvidas em uma harmonia complementária, sem

\footnotetext{
${ }^{198}$ SANTOS, 2008; p. 124.

199 Id., Ibid.

${ }^{200}$ Ibid.p. 125.
} 
negações, sem contradições - como aliás contraditório é a sociedade -, porque isso significaria seu próprio fim. Santos fala em ação gerando uma forma, em uma forma gerando uma ação, para o "desenvolvimento" de uma totalidade, mas quando a totalidade pode ser questionada, posta de forma crítica, e por meio de uma crise, por meio de uma ação contra uma forma, de uma forma contra uma ação, para a negação total do que poderia se constituir como totalidade? Isso seria propor um embaralhamento da estrutura epistemológica que a Geografia parece não dispor a fazer, o que evidencia os limites de sua crítica. Daí porque Milton Santos pode assim afirmar que sua visão "renovada" da "dialética concreta abre novos caminhos para o entendimento do espaço, já que, desse modo, estaremos atribuindo um novo estatuto aos objetos geográficos, às paisagens, às configurações geográficas, à materialidade”. Não seria um total absurdo, diante de tal afirmação, inferir a tese de que tal dialética está a serviço e uma epistemologia cada vez mais distante de uma crítica social.

Concebendo assim a dialética e retomando a questão da técnica, não poderia jamais estar ela, como categoria central, em contradição consigo mesma; ou seja, em uma autonegação sem que seja uma contradição nos termos. O caminho que Milton Santos encontra para resolver os problemas em decorrência da necessidade de inserir a dialética para com a técnica, mas conservar sua positividade categorial, foi o de deslocar a contradição para o campo da política, ou "uso político da técnica", destacando que não seria a técnica em si a portadora da "razão alienante do seu uso", mas seu uso político. A técnica, assim, tende a resguardar sua universalidade lógica na "eternidade ontológica". Por isso que o recurso ontológico para com a técnica (e em consequência para o espaço) não se deu por vias de uma "metafísica" hegeliana, onde o objeto expresso como síntese deveria buscar na negação imanente a sua razão contraditória de ser, mas em uma "história da técnica", onde a partir de suas "periodizações" haveria de se provar que ela sempre esteve presente, como categoria universal independente das formações sociais, na mediação necessária entre o homem e a natureza.

Esta busca por uma ontologia - quase que marxiana, caso se substitua "técnica" por "trabalho", mas sem suas devidas mediações dialéticas - tenderia a recair numa ontologia ainda mais remota como a que de Lukács fora acusada de ser. Isso se Milton Santos, com toda sua lucidez, não se tivesse dado a ela uma leitura empírica de um tempo presente (como assim o faz deliberadamente no capítulo "O Tempo (os Eventos) e o Espaço"), mesmo que para isso fosse preciso sacrificar o potencial crítico de uma dialética agora posta "em termos".

[O mito da tecnicidade (epistemológica) da dialética] 
Entre os moldes da "estruturação epistêmica" da qual se propôs a Geografia cristalizar a crítica em um sistema coerente de ideias e procedimentos e o desenvolvimento autônomo e dialético da crítica por meio (ou não) de categorias geográficas, há uma contradição inconciliável. Como destaca Fausto: "a ideia de que a dialética possa prescindir uma certa tecnicidade é um mito" (1983; p. 14). E essa contradição não foi posta como problema no seio da constituição da crítica geográfica. Como visto, o Hegel lido pela Geografia não é o mesmo utilizado por Marx para o manuseio de sua dialética. Inversamente, o que se foi apoderado de Marx pelo movimento de renovação da crítica geográfica foi um outro, destituído da dialética hegeliana o que, facilmente, tendeu recair num economicismo vulgar, como o de Pierre George. Se a via metafísica da dialética, como aquela operada por Hegel e Adorno, precisa, para os objetivos científicos da Geografia, encontrar uma via de efetivação, seria necessário o estabelecimento da autocrítica, na mesma intensidade que em se busca a crítica efetiva.

Como destaca Ruy Fausto, "o fato de o grande texto da dialética clássica depois de Hegel ter sido uma crítica da economia política, crítica bastante técnica porque ela é ao mesmo tempo 'a apresentação do sistema (da economia burguesa) e pela a apresentação a sua crítica"” (1983; p. 20), isso fornece alguns indícios para o desvendamento da forma com que a dialética se introduz na crítica científica sem limitar seu potencial de desenvolvimento.

Desta forma, é sintomático como que Marx, ao estrear sua primeira obra de síntese no campo da economia política (MÉSZÁROS, 2006), "Os Manuscritos Econômicos-Filosóficos", já se põe advertido diante a necessidade de sua crítica ter que se fundamentar num sistema conceitual inteiramente novo, como apresentado no início da segunda parte do presente estudo: "Parte II - O trabalho nas fissuras da crítica geográfica: entre postos e pressupostos". A abstenção ao compromisso epistêmico não aparece de forma acidental ou ingênua, é ela propriamente assumida como condicional para a legitimidade da própria crítica ("Partimos dos pressupostos da economia nacional [ou a própria economia política]. Aceitamos sua linguagem e suas leis").

A formulação da crítica de Marx, que aparece como uma crítica "externa", se dispõe a colocar em vias de colisão as categorias da economia política contra elas próprias. Esse caráter "externo" pode ser estendido a postura do próprio autor, quando assim se observa um distanciamento sintomático frente a própria ciência que lhe serve. Marx chega mesmo a afirmar que a economia política já haveria até "terminada" antes mesmo de sua crítica mais profunda, como aquela posta em "O Capital", como assim diz nos "Grundrisse": "A história da economia 
política moderna termina, com Ricardo e Sismondi” (2011; p. 127) ${ }^{201}$. E elucida que os motivos para tal afirmação estão exatamente nos "caminhos científicos" que se decompõe na "literatura político-econômica posterior [que] se perde seja em compêndios ecléticos, sincréticos [...]"202 etc.

Ao pôr o capital como objeto de análise, procede Marx em sua obra de maturidade a sua mais inteira decomposição negativa, "desfetichizando" a mercadoria em sua lógica abstrata e reconhecendo em seu interior o conflito entre valor de uso e valor de troca, mas diferente de feito até então pelos economistas, essas estão em contradição na sua própria complementaridade. Desta contradição sintetiza uma teoria do valor, reencontra sua "substância" no trabalho, mas só para novamente a decompor em sua forma concreta e abstrata, também mediada por uma dialética da contradição. Dominado pelo capital (este já cindido e contraditoriamente unido entre variável e constante) descobre Marx uma tendência de redução relativa do trabalho empregado na geração do valor, tendência essa determinada pelas próprias leis positivas da concorrência capitalista. Dessa nova contradição formula uma lei que expressa também uma contradição: que o processo de valorização é também um processo de desvalorização do próprio capital. Isso permite formular, em termos lógicos, os limites do próprio capital determinado pela contradição fundante de que seu crescimento é, ao mesmo tempo, sua retração; que a expansão é também e imediatamente sua recessão, mesmo que não seja na sua expressão fenomênica no plano real; que a acumulação é ao mesmo tempo crise, e quanto mais intensas forem a acumulação mais estruturais serão as crises. E o quê, em última instância, descobre Marx ao mostrar que o capital é a negação de si próprio? A mais profunda crítica social e histórica da modernidade, permitida somente porque se atreveu colocar seu objeto de análise contra si mesmo.

O que se tona possível fazer com a dialética e com a crítica depois disso é igualmente importante. Por exemplo, os esforços de Lênin em introduzir para a história a superação de tais contradições; os esforços de Lukács em supor as bases para uma teoria da superação da "préhistória" a partir da ontologia do trabalho; e por outro lado, a crítica metafísica de Adorno na tentativa de estabelecer o mais absoluto vigor crítico da dialética; além dos esforços mais atuais de Mészáros em elaborar uma teoria crítica da transição socialista, etc.

De todos esses exemplos de operacionalidade da dialética, o que fica para o geógrafo? Estaria ele disposto a, se preciso, negar suas categorias, coloca-las em franca rota de colisão contra elas próprias, como os físicos fazem com suas mais elementares partículas em 
aceleradores experimentais somente para descobrir leis que podem explicar os princípios do universo? Estaria o geógrafo em condições de tais experimentos, negar o espaço contra suas expressões no território, as "técnicas" contra os "objetos" e esses, por sua vez, contra as "ações"? Conceber uma sociedade em franco conflito com seu espaço, um "território" que nega o "lugar", de forma que um não seja mais apenas "expressão" do outro, a não ser enquanto contradição? Tudo isso só para encontrar alguma "substância social" que permita pensar numa nova sociedade? Estaria disposto o geógrafo a sacrificar sua própria geografia, a se "desgeograficizar", colocando o trabalho, o estado, o capital contra sua estrutura epistemológica?

Claro que estas questões são de pura "ficção científica", ainda que geográfica, e por menos sério que sejam não deixa de indagar sobre a natureza de sua crítica e seus objetivos finais. Por isso que o debate sobre a crítica de Kant, levantada por Vesentini, pode aqui se mostrar reveladora, pois ela pode indicar evidências sobre a natureza científica da crítica da renovação geográfica.

[As vinculações kantianas]

Tomando como parâmetro que ela, a crítica geográfica positiva-epistêmica, não tem fundamento na dialética marxiana, porque o projeto epistemológico tende a sobrepor, para na sequência contradizer, a um projeto de crítica social; também não pode ela se fundamentar por uma crítica hegeliana porque suas categorias se auto-afirmam, quando deveriam se autonegarem. Assim, ela é, em certa medida de tendência, kantiana porque sua estruturação epistêmica, por mais relacional e interdisciplinar que tente ser, pressupõe uma "subtotalidade" própria, pretensamente independente de uma "totalidade" que se apresenta abstrata, inalcançável (Kant chamaria de razão absoluta), se não for vias de sua própria estruturação interna, racional, teórica e epistemológica, como disciplina científica.

É sintomática as admissões sobre tal tendência quando, em certa medida, por exemplo, procede Armando Corrêa da Silva acerca da complexidade de problemas por ele mesmo levantado sobre as "razões de ordem ecológica", que sintetizam o meio natural e o meio cultural, provocando situações de "equilíbrio" cada vez mais incertos, etc. E é exatamente ao colocar a dificuldade, ou mesmo "impossibilidade", diante de suas questões, que procede Silva o recurso de estabelecimento dos apriorismos: "Neste caso, um certo a priori é inevitável. O seu tratamento ao nível de axiomas ou de postulados pode evitar uma preocupação de tipo metafísico como a indicada" (1988; p. 11). Observa-se um procedimento kantiano quando se 
nega a desenvolver uma abstração, retira-a as possibilidades da abordagem científica e a coloca no plano da metafísica a partir de um tipo absolutização a priori. Ainda no mesmo capitulo, intitulado "Espaço Geográfico Como Totalidade" (que não por coincidência tem um título muito parecido com àquele de Milton Santos analisado acima), reforça Silva o procedimento da "fuga" da Geografia diante das questões "metafísica" ao, referindo-se em Hartshorne sobre a "superfície da terra", afirma: "evitou-se desde logo a crítica de que a preocupação substancial com o espaço geográfico fosse encarada como uma indagação de ordem metafísica no conhecido aspecto negativo do termo (Anuchin, 1961; Santos, 1971; Harvey, 1975)"203. Além da passagem da negação da metafísica, é importante também notar que, dentre os autores citados, estão Milton Santos e David Harvey.

No caso especial de Milton Santos, dado sua representatividade para a renovação da Geografia brasileira, é também importante observar que, na "estruturação epistemológica" proposta, ao mesmo tempo em que se identifica uma dialética "frouxa", sem o rigor e os desafios "metafísicos" da contradição - o que, em tese, o relaciona às possibilidades de estabelecer as mediações quais queiram entre as categorias, desde que geográficas, inclusive aquelas propostas por Diniz Filho apresentadas anteriormente -, por outro lado, apresenta Santos uma profunda rigorosidade enquanto a delimitação dessas mesmas categorias e conceitos que, em relação a coerência interna, seriam: "paisagem, a configuração territorial, a divisão territorial do trabalho, o espaço produzido ou produtivo, as rugosidades e as formasconteúdo" (SANTOS, 2008; p. 22).

Tais "categorias internas" derivariam, por sua vez, à questões dos "recortes espaciais", das quais inseriam o problema da região, do lugar, das redes e das escalas; a "tecnoesfera e a psicoesfera"; um conceito espaço derivado das redes e da globalização e um conteúdo geográfico fundamentado no cotidiano. Tais categorias e conceitos internos supõe, segundo Santos, processos básicos externos: "a técnica, a ação, os objetos, a norma e os eventos, a universalidade e a particularidade, a totalidade e a totalização, a temporalização e a temporalidade, a idealização e a objetivação, os símbolos e a ideologia" ${ }^{204}$. Esses processos, destituídos do "contraditório" e aliado a sua estrutura categorial e conceitual interna, representam o "saldo" das considerações prévias daquilo que deveria ficar ou ser "expulso": "o que se torna residual é considerado como ‘dado' e, desse modo, expulso do sistema central”.

Mas o que seria considerado “dado", passível de “expulsão", senão um “a priori”? Além do que, tais decisões remetem sempre a uma dimensão política fundamentada na concepção de

\footnotetext{
203 SILVA, 1998, p. 09.

${ }^{204}$ Ibid., p. 30.
} 
ciência do cientista. Mas, para Milton Santos, que se propõe a sugerir uma estrutura epistemológica com tais categorias e conceitos pré-definidos, ainda que sugestivamente, deveriam os limites da análise geográfica (tal como sua crítica) estarem assim asseguradas em torno do seu objeto envolvido por tal estruturação. Como assim sinaliza o autor, a seguridade da crítica não estaria condicionada à manipulação dialética na relação entre as categorias, mas no seu uso a priori. Além das tendências pontuais de natureza kantiana, aqui novamente se reapresentarem aquelas condições tipicamente estruturalistas (que são, na verdade, expressões de autorreferenciamento) em que a crítica dialética com o necessário rigor científico se submete ao estabelecimento da necessidade da ciência para o rigor da crítica dialética.

Assim se elucida o porquê daquelas acusações dirigidas aos principais nomes do movimento de renovação acerca do seu envolvimento com o estruturalismo. No entanto, as acusações estão corretas e ao mesmo tempo equivocadas. Estão equivocadas porque o enquadramento do movimento de renovação crítica não se deu por vias de um positivismo simplista que tendeu caracterizar o estruturalismo que dominou os campos científicos. Por exemplo, não se pode reduzir a grandiosa obra de Milton Santos, ou mesmo a de Armando Corrêa da Silva, a uma crítica nestes termos. Mas ao mesmo tempo é correta a denúncia porque, para os objetivos que tenderam a se sobrepor à crítica social, pela via positiva-epistêmica, não encontrariam eles outra forma mais consistente de promover sua efetivação, a não ser por vias que se propõe a fragmentação pós-moderna.

E aí que se encontra um outro problema. Pois se a pós-modernidade se pretende ao extermínio das categorias modernas das quais se inserem a "crítica" e a "dialética", por outro lado, ela se faz por meio de uma fenomenologia mistificadora tentada a ser hegeliana. No entanto, a dialética hegeliana não mais pode ser usada para fins de mistificação da verdade idealizada. Por mais que se tente universalizar fragmentos da realidade supostamente pósmoderna, sua forma metodológica não mais pode ser caracterizar como crítica, muito menos como dialética. Daí porque encontra Vesentini justificativa "plausível” em pôr fim a dialética (e em consequência a crítica) vinculando ela ao tempo específico da modernidade; daí também o porquê do conforto em se livrar da modernidade sob o "invólucro" mistificador da pósmodernidade. Tal mistificação do que supõe como "fenomenologia" do humanismo, não pode desta forma, encontrar em Hegel seu fundamento filosófico. Em parte, porque este processo mistificador já teria sido desmistificado por Marx e assim já estabelecido vinculação, de forma que qualquer tentativa de a reintroduzir seria facilmente identificada, como aliás já é; em parte também porque, novamente, seria um contrassenso, nos termos já apresentados, se dispor a operacionalizar a dialética nos critérios de autonegação de suas próprias categorias forjadas. 
Daí porque a pós-modernidade, não de outra maneira, não poderia senão representar o fim da própria crítica. 


\section{CONCLUSÃO}

O que a história da crítica no movimento de renovação composta nestes quatro momentos, como analisado no capítulo anterior, importa para a relação do trabalho com a crítica geográfica?

Primeiro, o destino histórico do trabalho na crítica social coincide, em um primeiro olhar, ao destino histórico da crítica na Geografia: de seu momento denunciativo-dogmático, passando por sua fase de maturação crítica propositiva-afirmativa ou negativa, para a sua "sistematização epistemológica" desenvolvida em torno de uma crítica ampla e até "plural” que desse conta não somente dos "anacrônicos" desdobramentos da relação capital-trabalho, mas do espaço humano, sobretudo no âmbito da globalização ou mundialização.

Segundo, é necessário reconhecer que essas diferentes vias de desenvolvimento da crítica continuam a se reproduzir em "unidades", ou "correntes teóricas", relativamente independentes e concorrentes, tanto nas ciências sociais em geral, como na Geografia (algumas por resistências, outras por perspectiva de sociedade, outras pela unidade epistemológica e científica, e até mesmo aquelas por modismo). Tal reconhecimento interfere na forma de analisar o desenvolvimento histórico da crítica social e geográfica, pois se torna inconcebível entende-las a partir de uma linearidade, como se uma fosse o prelúdio da outra (como supõe as leituras sobre a "unidade" da Geografia Crítica a partir de seu mero resgate histórico). Por exemplo, a "via denunciativa" originária de parte dos geógrafos franceses não pode ser simplesmente entendida como o momento prematuro da Geografia Crítica desenvolvida no Brasil, ainda que tenha sido sua principal influência. Tal como a via dogmática do "marxismo soviético" não pode ser simplesmente considerada como o embrião da leitura desenvolvida pela teoria crítica da chamada Escola de Frankfurt, ainda que não tenha deixado de ser. São muito mais influências negativas, no sentido de que a maturação de uma não se dá exatamente na positivação do desenvolvimento da outra.

Terceiro, o "salto" que representa uma estruturação epistemológica, sua composição em unidade teórica, revela uma escolha política. Por exemplo, os interesses políticos da "teoria do agir comunicativo" desenvolvida por Habermas (e parcialmente assimilada por Milton Santos) a partir da descentralidade do trabalho assume uma posição política diametralmente oposta à “teoria da transição" em Mészáros e sua reafirmação da centralidade do trabalho admitida por Thomaz Jr.

Está em foco não somente perspectivas teóricas de ciência social da qual a Geografia está inserida a partir da natureza de sua crítica, mas perspectivas de sociedade. 
A relação dessas perspectivas com a categoria trabalho continua não se dando ao mero acaso: o movimento teórico e político de destituição do trabalho na teoria social tende a ser o mesmo movimento de destituição de uma crítica geográfica combativa e emancipatória cada vez mais efetivada pela própria Geografia Crítica. É claro que os limites entre elas não estão expostos de forma pura ou explícita. Por exemplo, no caso de Milton Santos, que apresentou a proposta mais lúcida e consistente para a fundamentação da crítica geográfica, no capítulo sobre "As Unicidades: A Produção da Inteligência Planetária" de seu livro tido como o mais importante, "A Natureza do Espaço", conclui com um tópico dedicado à crítica da mais-valia e seu papel como "motor unitário, das ações mais características da economia" (2008; p. 212). Isso não deveria causar estranheza para quem se refere ao caráter globalizado e fragmentado da produção capitalista mundial se, ao longo de todo o capítulo, não estivesse o autor tendendo a fundamentar o deslocamento do valor (agora concebido como "dinheiro") em detrimento da informação, que passa a ser a substância da técnica, como fundamento central dos "motores" sociais atuais ("as informações que constituem a base das ações são seletivas [...]. Essa é uma lei implacável, num mundo sequioso de produtividade onde o lucro é uma resposta ao exercício da produtividade") $)^{205}$. Isso representa que, embora o trabalho tende a desaparecer da centralidade analítica da própria mais-valia, está ele reafirmado por vias mais ocultas dentro mesmo da própria crítica do valor pretendida para a Geografia, mas agora como negação.

A presença negativa do trabalho (e não confundir com o ponto de vista do trabalho dotado criticamente) não seria plenamente admitida. Seja porque a crítica geográfica jamais teria se voltado contra o que se formula na própria Geografia, seja porque a autocrítica, muito mais do que instrumento que pudesse identificar as fissuras teóricas, foi tomada como possibilidade de fragmentação da unidade disciplinar, a identificação de tal problema pode revelar as condições políticas e teóricas postas na formulação da crítica. Uma delas é a forte evidência de que a necessidade de renovação esteve antecipada a própria necessidade da crítica: se desenvolve muito mais sobre a necessidade de uma estruturação epistemológica do que o debate sobre a crítica social

A tomada afirmativa com que as perspectivas teóricas envolvidas na suposta necessidade imanente da positivação de sua crítica - sem uma autocrítica acerca dos perigos de seus desdobramentos a-críticos - diz muito sobre seus objetivos reais de última instância. Por exemplo, entender o "salto epistemológico" como um salto qualitativamente "mais avançado" em relação à frente militante e aos seus compromissos políticos por uma leitura que se pretende

${ }^{205}$ SANTOS, 2008, p. 203. 
unitária e legitimadora da Geografia Crítica não deixa de representar uma postura ideológica que cada vez mais afasta dos próprios compromissos epistemológicos os necessários objetivos emancipatórios. Daí que no seio do movimento epistemológico deve haver, e ser admitida (na mesma intensidade com que se propõe afirmativamente), a dimensão de sua própria negação. Contradição essa que, quando não admitida, tende a tornar a própria crítica autocontraditória, ou uma contradição nos termos em si. Assim se faz necessário não exclusivamente por força do rigor da dialética e do sentido da negatividade conceitual (como faz a dialética autorreferenciada de Hegel em que tudo deve haver um par imanente negativo, contudo apenas conceitual), mas também por conceber a necessidade de uma postura teórica afirmativa e concretamente identificável à necessidade de mudança radical da realidade.

[Renovação x Revolução]

O "salto" que representou a Geografia Crítica se deu por meio de um movimento contraditório na formatação de sua crítica. Enquanto que "internamente" a estruturação epistemológica encontrava força na motivação política da denúncia do quadro de crise do capitalismo, seu amadurecimento epistemológico passou a se estabelecer conforme iam se esvanecendo suas forças de militância-combativa, tendendo a sua cristalização institucional como estratégia de reprodução. A primeira dificuldade de desenvolvimento da unidade entre a crítica social e a crítica epistemológica na renovação geográfica brasileira se deu por meio do "desencontro" entre os tempos da própria crise: ou seja, ela se mostrava universal e se apresentava de forma significativamente importante nos países de capitalismo avançado, onde seus sinais eram logo assimilados de forma denunciativa (maio de 1968, movimentos étnicosraciais e revoltas contra a Guerra do Vietnã nos EUA), ao passo que internamente, na "periferia", ainda que houvesse importantes convulsões sociais (redemocratização, lutas pela reforma agrária, etc.), precisava ela de um lastro institucional de referência que assim subsidiasse a assimilação das questões "internas" e "externas". Assim, os limites da "ruptura" esbarravam no quadro da institucionalidade científica da própria Geografia. De imediato, a necessidade de transformar a Geografia em uma ciência social tende a sobrepor a própria necessidade de transformação social.

O desenvolvimento de uma análise fundamentada em uma crítica social totalmente renovada e a perspectiva de manutenção de uma unidade e uma continuidade em relação à tradição Geográfica significava uma tensão entre forças que tendiam a oposição. Por isso uma renovação tensionada entre a ruptura e a continuidade. 
Com relação à "crítica interna", o movimento foi em direção à inserção de categorias como totalidade, contradição e dialética. Tais categorias significavam formas de rupturas com a Geografia tradicional e tecnicista. Do ponto de vista epistemológico, a crítica se constituiu pela conceituação do "espaço social", mas também pela inserção do trabalho como categoria de mediação com a crítica social, que supõe uma práxis transformadora, do ponto de vista do trabalho. Como visto, é notória a aproximação de autores como Armando Corrêa, Ruy Moreira e Thomaz Jr. com as teses lukacsianas sobre o trabalho e sua dimensão ontológica. A relação com o trabalho se expressa também em Milton Santos (sobretudo nas tentativas "embrionárias" contidas em "Por uma Geografia Nova") e em sua principal influência francesa, Pierre George, este que teria se disposto a desenvolver uma geografia do trabalho.

A dimensão institucional, que pressupõe uma "continuidade", se deu pela perspectiva de que nessa autocrítica de ruptura haveria de ter como necessidade a manutenção da unidade da "leitura" geográfica como forma da autopreservação científica. Era preciso manter sua legitimação no conjunto das disciplinas científicas e sociais. É igualmente notória a tentativa de manutenção dessa "unidade geográfica" a partir do resgate de alguns postulados de autores como Vidal de La Blache, na perspectiva de supor uma "continuidade" para a análise geográfica: "a Sociabilidade é um conceito que faz lembrar o gênero de vida, de Paul Vidal de La Blache, e de meio técnico, de Milton Santos [...]” (MOREIRA, 2007; p. 175). Tal continuidade é mantida por "componentes" que se relacionam em três conceitos: "[...] e se aproxima deles particularmente por intermédio de três componentes essenciais que esses três conceitos têm em comum: o meio, a cultura técnica e a regulação institucional" "206. A "sociabilidade" da qual se refere Moreira, como elemento comum entre conceitos e teorias tão distantes tempo-espacialmente (La Blache à Santos), tem por referência exatamente a perspectiva ontológica do trabalho para a análise do "todo societário formado pela interação das esferas da vida humana pelo metabolismo do trabalho"207. A "sociabilidade" é, por sua vez, o desenvolvimento das mediações que o trabalho humano desenvolve com outras categorias também humanas, como o espaço. Tal conceito de trabalho havia sido originariamente desenvolvido por Lukács: "Lukács chega a este conceito no mesmo momento, mas numa direção oposta, em que a intelectualidade, plural em suas origens ideológicas, chega ao conceito de meio ambiente e ao movimento político que engendra com base nesta" ${ }^{208}$.

\footnotetext{
${ }^{206}$ MOREIRA, 2007; p. 175.

${ }^{207}$ Id., Ibid.

208 Id., Ibid.
} 
O trabalho está envolvido nessa histórica tensão contraditória de rupturas e manutenção de tradições. Um "elemento externo" garantindo a reestruturação dos "elementos internos" que se pretendem críticos. À guisa de exemplo, é dessa forma que o trabalho, em seu processo de inserção na crítica geográfica, teve sua dialética "quebrada" para que sua dimensão concreta pudesse ser arbitrariamente apropriada em prol da tradição concreticista da Geografia, tradição essa que não seria sequer questionada. Por isso que os movimentos de continuidade e descontinuidade são, na verdade, um movimento só: a transformação significou também um reforço conservador. Na dialética desse movimento há limites bastante tênues em relação aos significados assumidos pela crítica: até onde são socialmente revolucionárias, até onde são epistemologicamente renovadoras, até onde são disciplinarmente apenas conservadoras?

No que concerne o trabalho, tal relação da crítica geográfica com seus significados teóricos e políticos são sintomáticos. Pois o trabalho, como elemento de mediação com a teoria e a transformação social, não havia (no pensamento geográfico) resolvido seus problemas em torno da composição de uma totalidade, ora servindo como tema de linhas de pesquisa denunciativas (conceito trabalho abstrato, mais-valia, assalariamento, etc.), ora servindo como categoria auxiliar para a "justificação ontológica" do espaço social (conceito de trabalho concreto, atividade finalística, teleologia, etc.). No âmbito das referidas influências francesas, a totalização do trabalho abstrato pode ser observada nas pesquisas temáticas sobre o trabalho em Renée Rchefort ${ }^{209}$, além da obra de Pierre George; já o refúgio do trabalho em sua condição concreta nas ontologias geográficas pode ser observado (no âmbito da Geografia que se pretendeu no Brasil) em Armando Corrêa, Milton Santos, Ruy Moreira e Antônio Carlos R. Moraes (como visto no capítulo 3: “A Solução Ontológica e os Desafios para a Centralidade do Espaço"), cada qual em seu respectivo contexto e em sua especificidade teórica.

Entre a objetivação epistemológica e a afirmação da práxis, o quanto há, na crítica e no trabalho, de revolucionária ou renovadora? O limite não é fixo e se move conforme a força com que a crítica se insere, ou seja, quão profundos serão seus impactos sociais e teóricos. Isso vai ser expresso na própria multiplicidade de "correntes", com tendências distintas e até antagônicas dentro da própria Geografia Crítica. Por exemplo, não dificilmente se distingue tendências de postura transformadora e emancipatória que se organiza teoricamente em torno do campesinato, no caso da Geografia agrária no Brasil, em detrimento de outras tendências de cunho reformista, integralista, que se organiza teoricamente em torno do "desenvolvimento

${ }^{209}$ ROCHEFORT, Renée, Le Travail en Sicile: Étude de Géographie Sociale, Presses Universitaires de France, Paris, 1961. 
agrário", ou mesmo aquelas de cunho mais positivistas que se desenvolvem em torno de uma Geografia da agricultura ${ }^{210}$.

A Geografia Crítica aparece, por isso, como síntese de dois movimentos que mais se contradizem do que se completam: dos movimentos de tendências de rupturas revolucionárias no plano da concretude histórica (revoluções socialistas, maio de 1968, ditaduras militares na América Latina, etc.) e teórica (leninismo, gramscismo ${ }^{211}$, etc.), e no plano da "renovação". Nestes descaminhos da crítica, se monta aí a ideia da "convergência"212, como foi considerado, por exemplo, o simbólico Encontro Nacional de Geógrafos Brasileiros (ENG), em 1978. Por isso que o movimento ficou conhecido como Movimento de Renovação Crítica.

Tal Movimento de Renovação Crítica revela em si a própria forma da natureza da crítica: muito mais "geográfica" do que social; isso, claro, expresso na forma de tendência. Como aparece em Moreira, o grande saldo da síntese da crítica está na conformação da "crítica epistemológica", entendido como totalidade que comportaria em si a própria totalidade da crítica social, em uma pretensa unidade sem contradição. O problema da "unidade sem contradição" na sistematização da Geografia Crítica não está no fato que ser a ela negada uma unidade ao ser afirmado seu caráter contraditório, mas na forma desta unidade se expressar em "diversidades", "sinuosidades" 213 e tantos outros termos que tendem a ocultar o conflito político em torno de uma crítica social expressas também na Geografia.

Se, por um lado, a efetivação da "crítica epistemológica" aparece como o resultado do “desenvolvimento", do "aprimoramento" linear da leitura crítica da Geografia sobre um mundo que se apresenta crítico no período pós-Segunda Guerra Mundial, por outro, a necessidade da estruturação da crítica em um sistema epistemológico propriamente geográfico aparece, por seu turno, como a necessidade em si da crítica que, agora, se pretende eminentemente geográfica. A crítica tende a perder seu conteúdo político e sua garantia passa a ser assegurada pelo uso em si das categorias da Geografia Crítica como se, por exemplo, falar de ontologia do espaço, ou de meio técnico-científico-informacional, fosse em si a garantia dela. Tal necessidade se

\footnotetext{
${ }^{210} \mathrm{O}$ debate é intenso. Dentre os que dele participam se destacam Ariovaldo Umbelino de Oliveira na Geografia agrária, a partir de uma perspectiva emancipatória; Sérgio Schneider, sociólogo, mas com grande influência nos estudos sobre desenvolvimento agrário na Geografia; e José Alexandre Felizola Diniz a partir da Geografia da agricultura.

${ }^{211}$ Para Vesentini, a "geocrítica" se insere nas instituições universitárias a partir de professores secundaristas sob forte influência de Gramsci e que tendiam a fazer o movimento político dentro desses espaços.

212 "Essa ebulição e a convergência de consciências e ideias que então aconteceu em 1978 deixaram vários registros, mas esse é um tema que até agora não mereceu um estudo mais sistemático" (MOREIRA, 2007; p. 25). 213 "Que progressão foi essa? Naturalmente, não foi a de uma linha reta. Mas a de um movimento cheio de sinuosidades" (MOREIRA, 2007; p. 31).
} 
fundamenta no próprio discurso de superação de dicotomias (ciência e sociedade) $)^{214}$ e de perspectivas teóricas postas aprioristicamente como dogmáticas ${ }^{215}$. Aqui se expressa aquilo que Moraes chama de "soberba geográfica" (2009; p. 09) ${ }^{216}$.

\section{[Abandonos e rupturas]}

Sobre a crítica pretendida pela geografia francesa (principal influência da renovação da crítica geográfica no Brasil), destaca Moreira: “sente-se a intenção de se introduzir a contradição como motor da dinâmica global. Mas é impressionante a vagueza como a contradição está posta: de um lado 'freios', de outro, aceleradores” (1994; p. 51). Tal avaliação é direcionada especificamente às perspectivas da crítica elaborada por Pierre George e seu conceito de "situação" como um conjunto de forças que num dado momento expressa o movimento crítico entre transformação e manutenção das condições do meio.

A perspectiva crítica de Pierre George é sintomática para se entender o movimento da crítica pretendida pela renovação da Geografia no Brasil. É a partir de sua perspectiva, na proposta de uma geografia do trabalho que se lançam as bases críticas para a análise geográfica fundada em uma totalidade e fluida na forma de uma organização em sistemas econômicos, não mais restrito às dinâmicas naturais, como reconhece o próprio Moreira: “é com Pierre George que a organização geográfica do espaço mundial perde, pela primeira vez, seus alicerces clássicos: a divisão natural em continentes. Os novos alicerces são os sistemas econômicos" (1994; p. 51 $)^{217}$. No entanto, ao tempo do avanço crítico o imperativo das "limitações epistemológicas".

O caminho de Pierre George e sua aproximação com o marxismo é expressivo ao seu contexto de crise e da crítica pela sua própria vinculação ao Partido Comunista Francês. O que havia de "pobre", ainda segundo Moreira, em sua dialética de "riqueza versus pobreza"218

\footnotetext{
214 Como observa Santos: “Acreditamos que uma teoria que não gera, ao mesmo tempo, a sua própria epistemologia, é inútil porque não é operacional, do mesmo modo que uma epistemologia que não seja baseada numa teoria é maléfica, porque oferece instrumentos de análise que desconhecem ou deformam a realidade" (SANTOS, Milton, Por uma Geografia Nova, São Paulo, ED. USP, 2002; p. 24).

${ }^{215}$ É o caso do que tende a se tornar o marxismo em si, mesmo considerando suas múltiplas e até antagônicas formas, por exemplo, em DINIZ FILHO, Elementos de Epistemologia da Geografia Contemporânea, 2002). ${ }^{216}$ Como já referenciado no tópico "2.2: A técnica: a autossustentação, a autorreferenciação e o sistema filosófico fechado".

${ }^{217}$ Milton Santos também reconhecerá os créditos de Pierre George "Merece o crédito de haver estabelecido a importância das estruturas socioeconômicas na explicação geográfica. Suas primeiras publicações sobre população (1951- 1959), Geografia social (1946) e seu tratado sobre as cidades (1952) demonstram seu esforço em abarcar a dinâmica dos sistemas socioeconômicos com as estruturas da produção" (SANTOS, Milton, "Geografia, marxismo e subdesenvolvimento", GEOUSP - Espaço e Tempo, São Paulo, v. 19, n. 1, p. 166 - 172, 2015; p. 166).

218 "Cedo esta dialética de 'riqueza versus pobreza' mostrar-se-á uma dialética pobre” (MOREIRA, 1994b; p. 52).
} 
significa muito mais uma tendência combativa da crítica, politicamente engajada, do que seu objetivo epistemológico final. Percebia-se nela forte inclinação inicial à tendência de buscar nas contradições estruturais do capitalismo, muito embora seus objetivos epistemológicos estivessem resguardados como necessidade apriorística. Mas, tão revelador quando sua "pobreza" dialética, foi seu rompimento com o próprio marxismo. $\mathrm{O}$ abandono da perspectiva de um amadurecimento da crítica sob a luz das categorias que envolvem o capital (a partir do trabalho imerso na teoria do valor) pela não identificação da Geografia no marxismo (e na própria teoria de Marx) significou muito mais um retrocesso crítico do que um "zelo" epistemológico $^{219}$.

O movimento de avanço e retrocesso da "crítica marxista" em Pierre George não foi casual, nem historicamente isolado no seio de uma Geografia que pretendia firmar seu discurso crítico. Foi mais do que isso. Havia na composição interna da proposição teórica de George profunda limitação no entendimento de método que ao menos indicava a impossibilidade, diante de tais condições, de prosseguimento com a proposição de sua geografia do trabalho fundamentada numa concepção crítica e dialética. A interpretação de Ariovaldo Umbelino de Oliveira é esclarecedora em sua análise específica sobre o livro "Geografia Econômica" do geógrafo francês: “queremos esclarecer que o 'econômico' a ser discutido [em George] é a infraestrutura ou base, ou seja, estrutura econômica da sociedade" (OLIVEIRA, 1982; p. 23) ${ }^{220}$.

A concepção econômica, instrumental e linear, que mais atende "ao respeito ético à divisão do trabalho acadêmico" 221 do que propriamente a uma crítica social, deve ser estendido, ainda no caso de George, a sua concepção de geografia do trabalho. Em um outro importante livro do autor intitulado "Populações Ativas", dirá George sobre os objetivos do que seria sua geografia do trabalho:

Desse modo vemos se desenhar progressivamente os objetos de uma geografia do trabalho:

- a distinção de sistemas técnicos, econômicos e sociais que comportam formas particulares de articulação das diferentes atividades, de divisão da "força de trabalho" conforme formas e lugares de trabalho.

- a avaliação das taxas de utilização da força de trabalho e de suas estruturas e técnicas;

\footnotetext{
219 "Essa ruptura concorrerá para o nítido refreamento do processo [de renovação crítica], uma vez que impediu a confrontação da base funcionalista da geografia com o marxismo" (MOREIRA, 1994b; p. 50).

${ }^{220}$ OLIVEIRA, Ariovaldo Umbelino, "O 'Econômico' na Obra Geografia Econômica de Pierre George: Elementos para uma Discussão", In: MOREIRA, Ruy (org.), Geografia: Teoria e Crítica - Os Saberes Posto em Questão, Rio de Janeiro, Vozes, 1982.

${ }^{221}$ Id., Ibid., p. 25.
} 
- o local do trabalho no tempo e espaço vivido, a gênese de um direito do trabalho e dos quadros institucionais no plano nacional e internacional (1979: p. 13$)^{222}$.

A concepção econômica de George se sobrepõe à concepção de trabalho. O trabalho é considerado a partir da dimensão imediata de uma das partes do processo produtivo, se põe ao lado dos sistemas e estruturas "técnicas", está ao lado do capital e se encontra na produção. O trabalho se torna "atividade" mediante a relação de troca, ao contrato de compra e venda de sua força. É condição concreta e material, vivido no cotidiano, e sua forma assalariada é sua determinação histórica. É sintomática a importância dada por George a distribuição nos lugares, sua forma de emprego nos países de diferentes estruturas produtivas, como se comporta frente aos ambientes de trabalho, e a estatística sobre sua população, que se faz justificada dada a importância de se localizar estruturas produtivas deficientes que "desperdiçam" trabalho e potencial de riqueza, que em consequência geram pobreza e miséria em um mundo moderno que se apresenta desigual.

Thomaz Jr. também irá se somar à natureza de tal crítica: “até onde se sabe, Pierre George foi um dos pioneiros a representar em nome de uma pretensa Geografia do trabalho um princípio analítico, no entanto, muito mais voltado às atividades de trabalho, ou, no limite, uma Geografia do emprego"223 (2002; p. 03). Diante de tal condição identificada pela própria crítica dos geógrafos, os limites da geografia do trabalho de George se dilui em suas próprias insuficiências internas a ponto de se tornar uma contradição nos termos, ou de ter se constituído muito mais como uma geografia do capital. Na ruptura da perspectiva de George com o marxismo havia muito mais inconciliabilidade metodológica do que somente política: "tudo indica que sua obra traz em si uma contradição fundamental, isto é, confundir o materialismo histórico com o método histórico da economia" (OLIVEIRA, 1982; p. 24).

$\mathrm{O}$ abandono de George foi uma ruptura condicional que demonstra a importância do fundamental entrelaçamento entre o método rigorosamente apreendido e suas vinculações políticas de última instância. Mas se é correto que a autocrítica geográfica direcionada ao caso de George conseguiu importante avanço na demonstração dos limites internos de sua geografia do trabalho, ou "econômica", há na identificação da natureza dessa crítica algo de mais fundamental e que, de certa forma, não fora ainda identificada.

\footnotetext{
${ }^{222}$ GEORGE, Pierre, Populações Ativas, São Paulo; DIFEL, 1979

${ }^{223}$ THOMAZ, "Por Uma Geografia do trabalho", Revista Pegada Eletrônica (Geografia), 2002.
} 
A inversão metodológica de George, fruto da interpretação confundida do "materialismo histórico" em "método histórico da economia", que permitiu também sua inversão da geografia do trabalho para a geografia do capital, teve no interior de suas formulações um problema de ordem estrutural. Política e método não estavam apenas incorporados formalmente na perspectiva de George, mas estavam em franca contradição. Na dimensão política, é correto o entendimento que George adotou o ponto de vista do trabalho, mas na dimensão metodológica o ponto de vista do trabalho fora tomado pela unilateralidade positiva. A adoção do ponto de vista do trabalho tomado positivamente é um problema da crítica de George que se universaliza como mais uma questão da natureza da crítica geográfica.

Oliveira identifica corretamente que a ausência da contradição no "econômico" em George se dá pelo não vislumbramento da questão que envolve as classes: “[...] não temos, em momento algum de sua obra, a própria essência dessa posição: o conceito de 'classes sociais', assim como não temos a própria essência da história: as lutas de classes" (OLIVEIRA, 1982; p. 24). Pode-se ainda ser somado à presente observação crítica a forma como o próprio George anota a questão da alienação: "O trabalho industrial, sentido como algo de estranho para aquele que exerce, é definido pelos sociólogos como trabalho alienado [..]. E a recusa ao emprego não é - ao contrário - a forma extrema de alienação?"224 . A questão da classe se ausenta porque não parece ser geográfico, este tomado como fundamentalmente empírico e que, assim considerado, deve promover a conservação de sua suposta totalidade da dimensão complementária com a "natureza", também positivamente considerada: "confundir o trabalho com a modificação da natureza para fins de produção apenas oferece uma definição parcial do trabalho"225.

Ao se buscar um nível de abstração que envolve a dialética do trabalho, é possível observar que os motivos de sua quebra, em George, se deram em prol da conservação da leitura geográfica: a tomada positiva, empírica e concreticista de uma relação que é fundamentalmente contraditória. O ponto de vista do trabalho é tomado positivamente porque assim pode ser ele observado em sua unilateral concreção empírica, que se supõe como eminentemente geográfica. Em outro nível de abordagem, é inevitável lembrar como essa questão continua a ser tratada nas perspectivas do movimento de renovação crítica das geografias do trabalho aqui abordadas.

Como demonstrado especificamente no tópico "1.2 - "A Valorização do Espaço", é salutar observar como o critério que leva W. M. da Costa e A. C. R. Moraes (1984) a "pulverizar" o valor continua sendo aquele de ordem empírica e concreticista do trabalho

${ }^{224}$ GEORGE, 1979; p. 12.

${ }^{225}$ Id., Ibid., p. 11. 
tomado positivamente, seja a partir da impossibilidade de "aferição" da mais-valia na mercadoria, de "difícil identificação empírica"226, seja pela observação também empírica da mudança na estrutura de classe que se dá pela "pequena proporção do proletariado (industrial e agrícola)" no que se tornou a complexidade dos assalariados no "capitalismo avançado" 227.

Os critérios empíricos e concretos dotando positivamente o real estabeleceriam ainda o ponto de referência da leitura geográfica de Ruy Moreira na sua tentativa e conciliação entre o "proletariado" e o polêmico conceito de sociedade "pós-industrial". Como visto no tópico "3.5 - Das Linhas de Fuga aos Refúgios de uma Crítica Não Efetiva”, a tomada positiva do trabalho se dá pela condição "paisagisticamente transparente" de apontar o momento em que a cidade diz mais sobre o proletário do que a própria fábrica. Supõe-se entre trabalho e espaço uma zona de conflito entre o geógrafo e a "teimosia marxista", do qual o espaço passa a dizer mais. Aqui a categoria proletariado é tomada em sua dimensão concreta, do operário, e assim estendido para todo e qualquer "marxismo" (MOREIRA, 1994a; p. 231).

Também em Milton Santos, para quem a "empiricização da universalidade” demarca o contexto das "técnicas unicizadas", que haviam ainda unicizado as relações produtivas e meios de produção, a questão da classe passaria a referenciar-se no seu posicionamento diante da técnica. Na empiricização apresentada por Santos o lugar passa a admitir a expressão do espaço global: "cada lugar é, a sua maneira, o mundo" (SANTOS, 2008; p. 314). Isso se dá pela estruturação técnica no território. Nesta perspectiva, os conflitos se dão a partir do posicionamento desigual diante dessa estrutura técnica-global e pela sua apropriação política. As categorias que mediam tal dinâmica passam a ser "objetos", "as ações", "a técnica" e "o tempo". Nestes termos geográficos a questão da classe social recai num relativismo diante de sua diversidade concreta ("classes inferiores", "classes superiores", "classes mais abastadas") ao tempo em que o "proletário" desaparece em favor do que Santos denominará de "os pobres da cidade". Isso à luz de uma substituição muito nítida do referencial marxista pelo weberiano, em especial àquele mais diretamente vinculado à perspectiva de Habermas da esfera comunicacional da teoria do agir comunicativo: "Por serem 'diferentes', os pobres abrem um debate novo, inédito, às vezes silencioso, às vezes ruidoso, com as populações e as coisas já presentes [...]. É na esfera comunicacional que eles, diferentemente das classes ditas superiores, são fortemente ativos" (SANTOS, 2008; p. 326). Tal debate foi feito no tópico "8.3 - A via da negatividade".

\footnotetext{
${ }^{226}$ COSTA; MORAES, Geografia Crítica: A Valorização do Espaço, 1984; p. 158.
}

${ }^{227}$ Id., Ibid., p. 156. 
Se a dimensão concreta do trabalho tomada positivamente por grande parte das perspectivas da geografia do trabalho significou em muitos termos a tomada da teoria pelo ponto de vista do trabalho, tal posicionamento já indica em si uma postura crítica frente a ordem estabelecida. Mas é necessário admitir que esta é apenas uma dimensão que envolve a dialética da realização e desrealização do trabalho. A não observação da totalidade que envolve a dialética do trabalho pode gerar aqueles mesmos problemas de inconciliabilidade metodológica e política observados em George. A tendência que se tem - e em grande medida se observa quando se nota um processo de deslocamento do trabalho em sua própria inserção crítica - é de não apenas o deslocamento do trabalho como categoria da análise geográfica, mas o rompimento com o referencial e com o poder da crítica envolvida em sua dialética.

Entender o "abandono" de P. George, tanto em relação a sua geografia do trabalho, como em relação ao marxismo, é importante porque revela alguns traços gerais sobre os limites da "conciliação" entre a perspectiva geográfica (tomada em sua generalidade positivaepistêmica) e a dialética marxiana. Quando Milton Santos admite um Marx cada vez mais distante e perdido na sua "estante de livros", não é exatamente o que ele autodeclara: "um marxista sem as categorias de Marx", mas um reconhecimento não admitido de uma inconciliabilidade. Também não é correta a justificativa de que o "distanciamento" de Santos em relação a Marx se dá pela necessidade de atualização da análise histórica, haja vista que tal distanciamento se dá em contrapartida com a aproximação de outros autores não tão atuais como Comte, Durkheim, Weber, etc.

O que se tem em ambos os casos - e se pode agora, a título de conclusão, generalizar para a crítica oriunda do movimento de renovação como um todo - é que por trás da "ruptura" com o marxismo há um franco movimento de "abandonos": com o trabalho e seu ponto de vista (mesmo positivamente tomado), com a crítica (tendendo apenas ao criticismo científico), com a dialética (esta tornada instrumento de legitimação teórico-epistemológica), e, por fim, com os objetivos humanos-emancipatórios de última instância.

[O problema da classe: o proletariado]

De todas as categorias rompidas com a crítica geográfica, a mais notável é, sem dúvida, o proletário. Identificado como "anacrônico", dada a nova sociedade empiricamente apreendida pela leitura do geógrafo, o proletário passa a representar a "ortodoxia marxista" a ser negada. Mesmo em Thomaz Jr., para quem se propõe uma autocrítica geográfica e marxista, o discurso de superação da ortodoxia tem dado sentido à busca da nova complexidade que a 
classe trabalhadora passa a adquirir nos tempos de sua (des)realização diante da crise estrutural do capital: “ [...] estamos colocando em questão a asfixia em que se encontra a ortodoxia marxiana, que blinda a oxigenação da teoria para preservar a formulação original, negando a própria dialética e as limitações ideológicas e políticas que devem e podem ser repensadas e reformuladas" (THOMAZ, 2011; p.24) 228 .

A "plasticidade do trabalho", ainda segundo Thomaz Jr., do qual compõe um mesmo movimento da precarização que envolve os sujeitos do mundo do trabalho, do campo, da cidade, assalariados, desempregados, informais, autônomos, camponeses, etc., corresponde ao "fluxo" que redimensiona o trabalho, conforme se dá a "externalização" na atualidade do processo de fragmentação da própria classe ("estamos tentando entender os fluxos e as ligações entre as diferentes formas de externalizações do trabalho como expressão de sua plasticidade" ${ }^{229}$. O objetivo é se fundamentar na dimensão "viva" do trabalho, no sentido de ir além dos "diversos

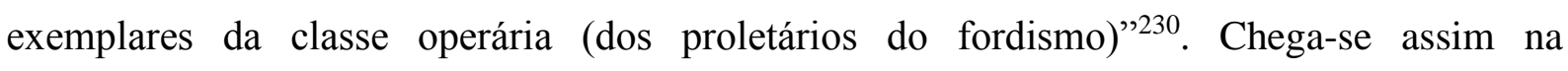
multiplicidade pulsante do trabalho constantemente refeita, conforme se intensifica a dinâmica dos fluxos que determinam sua materialidade. Thomaz Jr. assim procede para se chegar nas "múltiplas determinações da totalidade social do trabalho"231.

O conceito da "plasticidade do trabalho" e suas "múltiplas determinações" no âmbito de sua materialidade "viva" tem dado conta de explicar o processo fragmentário produtivo no âmbito da condição da classe. Ainda segundo Thomaz Jr., assim se faz importante tendo em vista os objetivos de última instância humanos-emancipatórios. Mas, se assim o for, as considerações sobre o processo empírico-geográfico da desrealização do trabalho devem admitir também sua dimensão categorial. Ou seja, se é correto, como aponta o autor, entender o processo "pelo viés da dialética existente entre negatividade/positividade do trabalho", sua tomada pelo ponto de vista de sua "externalidade", que demonstra sua condição diante do capital, deve estar contemplada pela contradição interna de sua autonegação, por mais que aparente ser isso uma contradição nos termos.

A "externalidade" com que a condição viva do trabalho é apropriada permite revelar sua condição geográfica, mas oculta sua condição histórica. Não seria gratuita, nem em Thomaz Jr. nem em Moreira, a forma de se referir ao operariado industrial como "proletários fordistas",

\footnotetext{
${ }^{228}$ THOMAZ JR, Antônio, "Um Olhar Autocrítico Do Trabalho E Da Classe Trabalhadora No Brasil No Século XXI", Revista Eletrônica da Associação dos Geógrafos Brasileiros, Seção Três Lagoas/MS, nº 13, Ano 8, Maio 2011.

${ }^{229}$ Ibid., p. 12.

${ }^{230}$ Ibid.p. 19.

${ }^{231}$ Ibid.p. 21.
} 
como se o proletariado estivesse confundido nas determinações em que se dão o encontro entre relações de produção e as forças produtivas especificamente no que ficou conhecido como capitalismo concorrencial (dos tempos de Marx) e, posteriormente, como fordismo-taylorismo. Isso reflete, primeiro, que a condição abstrata do proletário como categoria antitética correspondente as mesmas determinações universais do valor, da qual ela é antítese, está diluída na própria concreção. Segundo, não observar a dimensão do proletariado, para além de sua "expressão" específica do tipo chão da fábrica, a partir de seu viés ontológico (de sua gênese interna enquanto ser da classe trabalhadora), é negar a própria dialética constantemente vislumbrada.

Quando Thomaz Jr., no seu exercício autocrítico, se dispõe a avançar sobre a “ortodoxia marxiana", que se encontra "asfixiada" diante da necessidade de manutenção das "formulações originais", assim está exposto o sentido de "repensar" e de "reformular" a teoria por meio de uma forma apropriada de acompanhar o movimento vivo do trabalho pela condição de sua classe. Mas então seria necessário remeter essa "oxigenação" da teoria contra as mesmas considerações "originais" de Marx, sobretudo porque pretende ser ela autocrítica, dialética e histórica. Nesses termos, é importante situar o próprio Marx nesse debate, quando o mesmo se refere à relação entre a condição categorial e histórica do proletariado: "Não se trata deste ou daquele proletário, ou até mesmo do que o proletariado inteiro pode imaginar de quando em vez como sua meta. Trata-se do que o proletário é e do que ele será obrigado a fazer historicamente de acordo com seu ser" (MARX; ENGELS, 2011; p. 49) ${ }^{232}$.

A passagem citada acima é sintomática, principalmente porque foi motivo de grandes equívocos, de "um certo Marx" etapista, linear e determinista, como o interpretado por J. W. Vesentini para justificar o fim da dialética e da própria crítica (como abordado no tópico "8.4 - A via positiva-epistêmica"). Todavia a (auto)crítica geográfica não iria também buscar a fundamentação dialética dessa passagem de Marx, da qual, na sequência do mesmo parágrafo, ainda pode ser lido: "Sua meta e sua ação histórica [do proletário] se acham clara e irrevogavelmente predeterminadas por sua própria situação de vida e por toda a organização da sociedade burguesa atual". Seria muito mais incômodo sequer buscar o sentido do rigor dialético dessa passagem que tem como trechos, supostamente antidialéticos, as determinações “irrevogavelmente predeterminadas" do proletariado, tal como seria muito cômodo cristalizar a referida passagem no contexto do autor, condição aparentemente admitida pelo próprio Marx quando o mesmo se refere ao seu contexto da "sociedade burguesa atual". A qualidade de

\footnotetext{
${ }^{232}$ MARX, Karl; EGELS, Friedrich, A Sagrada Família, São Paulo, Boitempo, 2011.
} 
"ortodoxia" é, dessa forma, o meio encontrado em supor a necessidade de "repensar" e de "reformular", como exercício autocrítico, daquilo que já estava abandonado, sem que estivesse esgotado todas as potencialidades de sua dialética não observada.

A forma com que se dá a ruptura ou o abandono do proletariado (confundido com expressões historicamente superadas do operariado) se torna ainda mais reveladora quando observada a partir de perspectivas teóricas que, ao admitirem estabelecer a relação entre "autocrítica" e o rigor dialético, pretendem-se ainda ontológicas, como a de Thomaz Jr. Tomando com mais atenção o entendimento de Marx, em especial o que está colocado em relevo pelo próprio autor na passagem citada acima, pode-se retomar a relação entre o concreto e o abstrato em sua análise histórica sobre a categoria "proletário": "Não se trata deste ou daquele proletário, ou até mesmo do que o proletariado inteiro pode imaginar de quando em vez como sua meta". Notadamente, o foco de Marx não se refere a sua forma concreta, deste ou daquele proletário, no tempo ou no espaço, nem o que sua coletividade organizada ou não "imagina" sobre sua prática, mas sua condição em si, abstrata, universal: "trata-se do que o proletário é e do que ele será obrigado a fazer historicamente de acordo com seu ser". Os destaques são do próprio Marx e parecem chamar atenção para uma advertência fundamental, a condição ontológica do proletariado: o que ele " $e$ "' e sua condição histórica em sua forma de "ser".

Marx chama atenção para a necessidade de colocar claramente em evidência a condição categorial do proletariado como forma, inclusive, de se pensar sua prática revolucionária: sua forma de "ser". Mészáros, autor amplamente referenciado pelo próprio Thomaz Jr., irá contribuir com o desenvolvimento de tal análise ao mostrar que, posto nesses termos, já estariam excluídas quaisquer possibilidades de reducionismos concreticista, mecânicos ou supostamente "históricos", pois “o 'ser' de qualquer classe é a síntese abrangente de todos os fatores atuantes na sociedade, enquanto os proponentes de um determinismo econômico [...] isolam apenas um fator, e, grosseiramente, o sobrepõe a todos os outros" (MÉSZÁROS, 2008; p. 56$)^{233}$.

Essa interpretação é fundamental, pois garante a dialética que envolve o que determina e o que é determinado na forma de ser e na forma de existência concreta do proletariado, além de garantir sua totalidade analítica. Isso repõe o debate sobre a ontologia do "ser social" em sua condição realmente "viva", não como algo apenas "dado", de referenciação para o posicionamento teórico desvinculado de uma prática real, ou apenas posto de forma enunciativa

${ }^{233}$ MÉSZÁROS, Filosofia, Ideologia e Ciência Social, 2008. 
pela afirmação do "destino histórico" qualquer. Por sinal, esta é a forma de como, por exemplo, Lukács é abordado, apenas como referencial e sem uma análise crítica sobre o seu pensamento, como assim se observa em quase todas as perspectivas aqui analisadas que se dispuseram a um debate ontológico (conforme debatido no capítulo "3 - A Solução Ontológica e os Limites para a Centralidade do Espaço”).

A "externalidade" da qual a crítica geográfica parece estar irremediavelmente vinculada representa apenas uma dimensão da dialética que deve subsidiar uma análise no sentido da retomada a contradição pelo ponto de vista do trabalho e pelos conflitos de classes. Na medida em que ela somente permite se apropriar de uma dimensão da história, aquela acumulativa no tempo, se torna unilateralizante. Para superar tal condição a análise necessita também se internalizar pela dimensão categorial e abstrata, de tomar "a coisa em si" pelo seu dissecamento, se assim for considerada a necessidade de um enfoque ontológico que não esteja condicionado à remoticidade do eterno-presente (como debatido no tópico "3.3 - Corpo versus Carcaça: entre a substantivação e a dissecação"). Mas ela, a "externalidade", parece estar também inadvertidamente unilateralizada como a condição em si do "geográfico".

Mészáros fala sobre uma abertura que se deva dar pelo reconhecimento da complexidade ontológica que envolve o proletário, segundo os referenciais marxianos ("as afirmações de Marx sobre o significado ontológico da economia só fazem sentido se formos capazes de apreender sua ideia de "interações complexas", nos mais variados campos da atividade humana") ${ }^{234}$. O proletariado, como categoria, pode ser ontologicamente "isolado" como objeto para efeito de análise, mas apenas relativamente. É necessário considerar sua condição histórica, por isso especificamente moderna, e o que representa ela imersa em suas determinações.

É notório que Marx - mesmo em um texto relativamente destituído de importância filosófica por aqueles nutrem o discurso da "ortodoxia marxiana", texto este que passou a ser considerado puramente panfletário e "dogmático", como o "Manifesto Comunista" - , ao apontar o destino histórico revolucionário do proletariado, tenha se atentado para tal rigor analítico da sociedade especificamente moderna: “[...] a sociedade burguesa moderna, surgida das ruínas da sociedade feudal, não aboliu os antagonismos de classes [...]. No entanto, a nossa época, a época da burguesia, possui uma característica distintiva: simplificou os antagonismos de classes" (MARX; 1987; p. 103) ${ }^{235}$. Uma distinção qualitativa que se dá exatamente em seu caráter de universalidade pela própria afirmação da "sociedade global": "A sociedade global

\footnotetext{
${ }^{234}$ MÉSZÁROS, 2008; p. 57.

${ }^{235}$ MARX, Cartas Filosóficas e o Manifesto Comunista de 1948, 1987.
} 
divide-se cada vez mais em dois campos hostis, em duas classes diretamente opostas entre si: a burguesia e o proletariado"236. O proletariado é apresentado como o correspondente negativo, como o "produto mais autêntico"237 dessa sociedade: "o proletariado não tem propriedade; suas relações com a mulher e os filhos nada têm em comum com as relações familiares burguesas; [os capitais nacionais] despojaram-no de todos os traços de caráter nacional" ${ }^{238}$. E a sua constituição se dá como contradição e avanço do próprio trabalho abstrato: “Os vários interesses e condições de existência dos proletários se igualam cada vez mais, à medida que a máquina aniquila todas as distinções de trabalho e reduz, quase por toda parte, os salários a um mesmo baixo nível”239.

Nem é preciso demonstrar novamente como a diminuição das condições de reprodução material do proletariado haveria de se dar empiricamente na história, como suficientemente já fizera T. Pikety (e exposta no início do capítulo " 1 - Da crítica ao capitalismo à valorização do espaço: em busca da solução teórica"), mas interessa aqui também sua composição lógica, sua gênese como abstração universal, especificamente moderna e diretamente correspondente à força de expansão e domínio do capital em sua composição global: como categoria que remete ao sujeito histórico desprovido materialmente, sem nação, sem riqueza, que se auto-identifica pelo trabalho em si, não pela sua atividade qualitativa, mas quantitativa, como tempo médio de trabalho. Condição esta que, por conseguinte, corresponde à natureza da produção do próprio proletário, de apenas se reproduzir, de forma igualmente quantitativa, exatamente no interior do sistema qualitativamente mais avançado de produção da riqueza humana. O proletário assim se produz apenas pela sua capacidade de se reproduzir em prole ${ }^{240}$, como "espécie" ([...] o custo de produção de um operário se reduz, quase completamente, aos meios de subsistência de que ele necessita para viver e para perpetuar a espécie") ${ }^{241}$.

A gênese do proletariado resguarda assim sua mediação com as condições históricomateriais, mas corresponde às mesmas condições de universalidade e abstração determinante dessa mesma materialidade. A forma de ser do proletariado é resguardado em sua própria condição histórica: dialeticamente insuperável enquanto não superada for a materialidade da forma do seu ser social. É a contradição viva entre os limites da mesma materialidade que o condiciona, mas que também contém a possibilidade se sua superação ("tanto em relação à

\footnotetext{
${ }^{236}$ Id., Ibid.

${ }^{237}$ Ibid.p. 113.

${ }^{238}$ MARX, 1987; p. 109.

239 Ibid., p. 112.

${ }^{240}$ Créditos às observações do professor Vladimir Safatle, em curso sobre a dialética de Hegel, Marx e Adorno, ministrado em maio de 2015 na Faculdade de Filosofia da Universidade de São Paulo.

${ }^{241}$ MARX, 1987; p. 110.
} 
gênese histórica das formas mais complexas de intercâmbio humano como diante do fato de que as condições materiais constituem a precondição de vida humana estruturalmente necessária em todas as formas concebíveis de história") ${ }^{242}$.

O proletariado representa a universalidade da realização humana, porque como sujeito abstrato efetivo (abstraído de todas as condições possíveis de sua individualidade específica) é tanto produto como condição do metabolismo do capital: sua produção se dá de modo incontrolável, totalitário e expansionista ${ }^{243}$, como um movimento quase autônomo, mas também contraditório. Essa é a condição verdadeiramente universal do proletariado porque a sua realização não se dá apenas pela destituição da burguesia, tampouco pela destituição do poder político nela concentrado, mas na destituição de todas as classes, sobretudo a partir de sua própria destituição. O proletariado é a única classe que se realiza na sua autotranscedência, por isso é a única autorrealizável pela sua própria desrealização, ou nas palavras de Mészáros citando o filósofo alemão: “de acordo com Marx, a ação política direta é apenas o primeiro passo do caminho em direção a uma 'auto-realização autotranscendente' da 'classe para si'”244.

O proletariado se constitui como a única classe que reúne em sua totalidade contraditória as condições de ser classe em si e classe para si. A sua autonegação como condição de sua autorrealização a põe em um nível transcendental incompatível com qualquer outra classe: se medeia consigo mesma, de forma negativa, para sua realização. "É por isso que a burguesia, diferente do proletariado, não pode ser descrita como uma classe em si e para si. Ela não pode 'mediar-se consigo própria através de sua negatividade', pois ela se coloca em relação antagônica ao proletariado, sendo este sua negação" (MÉSZÁROS, 2008; p. 78).

Do ponto de vista prático, em relação ao que se tem debatido até aqui no presente texto, abordar a questão da contradição moderna a partir do proletariado é também um exercício autocrítico. Como foi observado, o ponto de vista do trabalho que pareceria ser suficiente para a garantia de um posicionamento crítico da teoria é, na verdade, um primeiro passo. A sequência se dá no rigor dialético e categorial, afinal, partir do ponto de vista do trabalho, mas tomá-lo positivamente em prol da suposta "natureza própria" da Geografia, significa blindar a

\footnotetext{
${ }^{242}$ MÉSZÁROS, 2008; p. 57.

${ }^{243}$ Referência à caracterização feita por Mészáros sobre o que o mesmo considera do "sociometabolismo do capital": "Não se pode imaginar um sistema de controle mais inexoravelmente absorvente - e neste importante sentido, 'totalitário' - do que o sistema do capital globalmente dominante, que sujeita cegamente aos mesmos imperativos a questão da saúde e a do comércio, a educação e a agricultura, a arte e a indústria manufatureira, que implacavelmente sobrepõe a tudo seus próprios critérios de viabilidade, desde as menores unidades de seu 'microcosmo' até as mais gigantescas empresas transnacionais, desde as mais íntimas relações pessoais aos mais complexos processos de tomada de decisão dos vastos monopólios industriais, sempre a favor dos fortes contra os fracos" (MÉSZÁROS, Para Além do Capital, 2011; p. 96).

${ }^{244}$ MÉSZÁROS, 2008; p. 77 (As passagens de Marx são do livro Crítica da Filosofia do Direito de Hegel, MARX, 2013).
} 
teoria em sua internalidade a-crítica. A afirmação negativa do proletariado é, em última análise, a garantia da crítica se abrindo para as possibilidades do real, que é contraditório. Mészáros insiste na necessidade de tomada teórica do ponto de vista do trabalho dotado criticamente, para que assim não seja possível recair naquelas mesmas "contradições nos termos" em que Marx identificava nos socialistas em seu tempo: "Se os escritores socialistas atribuem ao proletariado esse papel histórico-mundial, isso não acontece, de nenhuma maneira, conforme a Crítica crítica pretexta dizer que acontece, ou seja, pelo fato de eles terem os proletários na condição de Deuses" (MARX, 2011; p. 49).

Pelo contrário. Como outras categorias (mercadoria, valor, trabalho abstrato) que se dão de forma relativamente autônomas, mas em movimento contraditório, o proletariado posto em sua forma de ser é mais do que sua forma sociológica de existir. Por isso a importância da ontologia, que é diferente da epistemologia. Pois o ser e o existir do proletariado estão também em contradição, de forma que sua negação no existir não é nada mais que sua confirmação como ser: "Sua existência enquanto 'classe em si' é, portanto, uma pseudopositividade: 'uma mera aparência de existência', uma 'positividade' feita de negação"245.

A questão da auto-extinção do proletariado, longe de ser uma contradição nos termos, foi muito mais um problema de difícil solução para teorias que mesmo se pretendendo ontológicas, jamais sairia do plano da epistemologia. Geradora de embaraços, seguiu-se abandonada porque representava um limite interno das teorias (como as geográficas) que pretendiam sua auto-afirmação positiva não admitindo, assim, efetivamente a contradição. Passagens de Marx como essa posta abaixo seriam consideradas apenas de forma enunciativa, no máximo para repensar estratégias políticas, não como objeto de reflexão para a constituição da própria teoria:

O proletariado na condição de proletariado, de outra parte, é obrigado a suprassumir a si mesmo e com isso a sua antítese condicionante, aquela que o transforma em proletariado: a propriedade privada. Este é o lado negativo da antítese, sua inquietude em si, a propriedade privada que dissolve e se dissolve (MARX, 2011; p. 48).

A não admissão da contradição entre ser e existir do proletariado levou a considerações sobre seu fim. Mas nada mais confuso. É impressionante, por exemplo, a energia gasta no campo da sociologia para se buscar uma empiria que se posicione contrariamente a empiria das

${ }^{245}$ MÉSZÁROS, 2008; p. 78. 
teses sobre o fim do trabalho. É claro que a empiria é fundamental, mas a própria empiria da negação do trabalho é, dialeticamente, a mesma empiria de sua afirmação, quando a análise está fundamentada em tais referenciais ontológicos sobre o proletário. No plano da exposição dialética, seria negação dela própria assumir qualquer posicionamento que não fosse do reconhecimento do proletariado categoricamente constituído, caso seja considerada válida as categorias da modernidade.

Por exemplo, aquela tese da descentralidade do trabalho esboçada por Claus Offe: "É exatamente esse amplo poder macro - sociologicamente determinante do fato social do trabalho (assalariado) e das contradições da racionalidade empresarial e social que o comanda, que agora se torna sociologicamente questionável" (OFFE, 1989; p. 16) 246 $^{246}$ ou aquela de André Gorz: “[...] 'economia do conhecimento' significa transtornos importantes para o sistema econômico. Ela indica que o conhecimento se transformou a principal força produtiva, e que, consequentemente, os produtos da atividade social não são mais, principalmente, produtos do

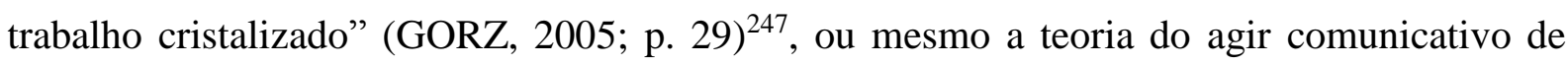
Habermas, tal como a radicalização do fetiche do trabalho em Kurz (como observado no tópico “6.3 - A via da negatividade”), a todas elas há essa dimensão não observada, categorial, do proletariado. À todas elas uma resposta demonstrativa, quase sempre empírica, por exemplo em Ricardo Antunes $(2002 ; 2003)^{248}$, Giovanni Alves $(200)^{249}$ e Beverly J. Silva (2005) ${ }^{250}$. Tal como nas perspectivas da crítica geográfica até aqui analisadas ${ }^{251}$, observa-se também no debate travado na sociologia as mesmas condições em que o pensamento dialético se põe em relação à empiria do trabalho: não como negatividade, contradição, mas como positivação.

Do ponto de vista da crítica geográfica, a ruptura com o proletário, dada sua suposta condição não mais empiricamente observável, além de significar a inversão em que o concreto

\footnotetext{
246 OFFE, Claus, “Trabalho como categoria sociológica fundamental?”, In: Trabalho e sociedade: problemas estruturais e perspectivas para o futuro da "sociedade do trabalho, Rio de Janeiro, Tempo Brasileiro, v.1, 1989.

${ }^{247}$ GORZ, André, O Imaterial: Conhecimento Valor e Capital, São Paulo, Annablume, 2005.

248 ANTUNES, Os Sentidos do Trabalho, 2002; ANTUNES, Ricardo. Adeus trabalho?: ensaio sobre a metamorfose ecentralidade do mundo do trabalho, São Paulo, Cortez Ed. Unicamp, 2003.

249 ALVES, Giovanni, O novo e precário mundo do trabalho: reestruturação produtiva e crise do sindicalismo, São Paulo, Boitempo Editorial, 2000.

${ }^{250}$ SILVER, Beverly J, Forças do trabalho: movimentos trabalhistas e globalização desde 1870, São Paulo, Boitempo, 2005.

${ }^{251}$ É necessário ponderar a perspectiva de Thomaz Jr., porque ela entra na fileira das teses de reafirmação da centralidade do trabalho, mas pela via de superação do proletariado. A imprecisão do posicionamento de classe, de retirar o proletário sem nada de efetiva e dialeticamente de concreto pôr em seu lugar, é sintomática. Por exemplo, é notório que Thomaz Jr. tenha se orientado pelo conceito de "classe que vive do trabalho", formulada originalmente por Ricardo Antunes, categoria essa depois abandonada pelo próprio Antunes, dado os limites de sua formulação, como aqueles demonstrados em LESSA, Trabalho e proletariado no Capitalismo Contemporâneo, 2007.
} 
tende a se apresentar como a própria abstração, por isso confundidos, é também uma inversão na lógica da crítica que se pretende emancipatória, pois representa o abandono à objetividade dialética na relação entre "afirmação/negação" do trabalho. Seja no plano concreto da mediação entre relações de produção e forças produtivas, em que o processo da reestruturação produtiva tem avançado sobre o trabalho, diminuindo ainda mais a já "pequena proporção do proletariado (industrial e agrícola) no conjunto dos assalariados de uma sociedade capitalista avançada", seja no plano político em que sua capacidade organizativa tenha se apresentado desmobilizada em sindicatos cada vez mais recuados, seja no plano histórico em que o "ethos" do trabalho teria perdido seu referencial aglutinador e se tornado aparentemente uma contradição nos termos, seja diante do referencial teórico que se monta em torno de tais condições na afirmativa de novas centralidades sociais e ontológicas, perspectivas essas de cunho derrotista e não objetivamente engajada no projeto emancipatório, todas essas dimensões do que ficou conhecido como "teses da descentralidade do trabalho" apresentam como elemento comum a mesma ruptura com a dialética do trabalho. E a leitura sobre o proletariado é sua maior fragilidade autocrítica. Nesse sentido, tem elas muito em comum com a forma "eminentemente geográfica" de se pensar: como expressão, como externalidade, unilateralmente "concreta". São elas, por isso, regidas por um pensamento "pré-marxiano", pois, não se observa o proletariado também como categoria carregada de contradições internas, por isso dissecável, por isso também objetivável em sua complexidade ontológica que se abre para um real (e também para um teórico) que está constantemente a negá-la.

Assim, é muito significativo que Milton Santos, por exemplo, perceba uma "materialização da universalidade" e não veja o proletário, mas os "pobres da cidade". Também é muito significativo que Thomaz Jr., diante da "plasticidade do trabalho", tenha conseguido ampliar a leitura sobre as classes, no campo e na cidade, e visto trabalhadores se "unindo" na radicalidade da desrealização do trabalho pelo profundo processo de fragmentação e exploração, mas não tenha se atentado para aquelas condições já postas por Marx, das quais "as camadas inferiores da classe média - os pequenos industriais, pequenos comerciantes e pessoas que possuem rendas, artesão e camponeses - caem, pouco a pouco, no proletariado" (MARX, 1987; p. 111).

A ruptura com o proletariado, e consequentemente com a dialética do trabalho, do interior das perspectivas teóricas significa ainda a retirada da cena política a "classe social combativa-emancipatória" (MÉSZÁROS, 2004; p. 161) ${ }^{252}$, composta historicamente em torno

${ }^{252}$ MÉSZÁROS, O Poder da Ideologia, 2004. 
do trabalho, sem que fosse apresentado um substituto substancial e historicamente “identificável”. Na Geografia, tal como nas demais ciências sociais efetivadas em correntes não-combativas quanto ao projeto emancipatório, a "mente autônoma" substitui o intelectual engajado, tal como a classe é substituída por "povos", e o trabalhador pelo "pobre"253, como possibilidades possíveis da "horizontalidade" em detrimento das "verticalidades" (SANTOS, 2011b). O horizonte teórico, no entanto, se abre para toadas genéricas que sugerem alternativas anticapitalistas não efetivamente objetiváveis. Pode-se afirmar que a crítica geográfica se encontra em tal condição, mas que por meio de suas próprias fissuras pode-se abrir e se voltar para os homens reais ativos, por eles e para eles.

253 "Trata-se de uma política de novo tipo, que nada tem a ver com a política institucional. Esta última se funda na ideologia do crescimento, da globalização etc. e é conduzida por partidos e empresas. A política dos pobres é baseada no cotidiano vivido por todos, pobres e não pobres, e é alimentada pela simples necessidade de continuar existindo" (SANTOS, 2011b, p. 133). 


\section{REFERÊNCIAS}

ADORNO, Theodor W. Dialética Negativa. Rio de Janeiro: Zahar, 2009.

ADORNO, Theodor W. \& HORKHEIMER, Max. Dialética do Esclarecimento. Rio de Janeiro: Jorge Zahar, 1985.

ALFREDO, Anselmo. Crítica à Economia Política do Desenvolvimento do Espaço. São Paulo: Annablume: Fapesp, 2013.

ALVES, Giovanni. O novo e precário mundo do trabalho: reestruturação produtiva e crise do sindicalismo. São Paulo: Boitempo Editorial, 2000.

ALVES, José Manoel P. Resenha: Geografia Crítica: a valorização do espaço. (Antônio Carlos Robert Moraes; Wanderley Messias da Costa, São Paulo, Hucitec, 1984). São Cristóvão: Geonordeste, ano 2, n. 1, 1985.

ANDRADE, Manuel Correia de, O pensamento Geográfico e a realidade Brasileira. São Paulo;

: Boletim Paulista de Geografia, n 54, 1977.

ANTUNES, Charles da França; SOUSA NETO, Manoel Fernandes. "Os Estudantes, a Associação dos Geógrafos Brasileiros (AGB) e o Movimento de Renovação". In: Boletim Paulista de Geografia: 1978 + 30: AGB em Movimento, Volume especial, No 88, julho de 2008.

ANTUNES, Ricardo. Os Sentidos do Trabalho: Ensaios Sobre Afirmação e Negação do Trabalho (6 $\left.6^{\text {ed. }}\right)$. São Paulo: Boitempo, 2002.

Adeus trabalho?: ensaio sobre a metamorfose ecentralidade do mundo do trabalho. São Paulo: Cortez Ed. Unicamp, 2003.

BRITO, Igor Arantes; HOLLAND, Márcio, "Resenha: A crise de 2008 e a economia da depressão" (Paul Krugman, Rio de Janeiro, Campus, 2009). Rio de Janeiro, Campus: Revista de Economia Política, 2010.

CARLOS, Ana Fani Alessandri. A Geografia Brasileira, Hoje: algumas reflexões. São Paulo: Terra Livre, ano 18, v.1, n. 18, 2002. 
Carta Maior (Economia). "A Austeridade Falhou: uma carta aberta de Thomas Piketty a Ângela Merkel”, São Paulo, 09 de julho de 2015. Disponível em: $<$ http://cartamaior.com.br/?/Editoria/Economia/A-austeridade-falhou-uma-carta-aberta-deThomas-Piketty-a-Angela-Merkel/7/33945>. Acesso em: 20 jul. 2015.

CHASIN, José. Marx: Estatuto ontológico e Resolução Metodológica. São Paulo: Boitempo, 2009.

"Marx: A Determinação Ontonegativa da Politicidade", In: Espaço de Interlocução em Ciências humanas, Verinotio - Revista On-Line de Filosofia e Ciências Humanas. N. 15, ano VIII, ago. 2012.

CHESNAIS, François. A Mundialização do Capital. São Paulo: Xamã, 1996.

CONCEIÇÂO, Alexandrina Luz. Às margens do Beberibe e do Capibaribe: a crítica de Tobias Barreto nos meandros da geografia (tese de doutorado). São Paulo: Universidade de São Paulo, 2001.

CORRÊA. Roberto Lobato. "Geografia Brasileira: Crise e Renovação". In: MOREIRA, Ruy (org.) Geografia: Teoria e Crítica - Os Saberes Posto em Questão. Rio de Janeiro: Vozes, 1982.

COSTA, Wnaderley Messias da. "Ciência, Tecnologia e a Crise da Geografia". São Paulo: GEOUSP - Espaço e Tempo, nº 12, 2002.

COSTA, W. M. da.; MORAES, A. C. R. "A Geografia e o Processo de Valorização do Espaço". In: Novos Rumos da Geografia Brasileira. São Paulo: UCITEC, 1996.

Dicionário Editora. Dicionário Alemão-Português. Porto Editora: Porto, Porto Editora, 2000.

DINIZ FILHO, Luís Lopes. "Certa Má Herança Marxista: Elementos para Repensar a Geografia Crítica". In: KOSEL, Salete \& MENDONÇA, Francisco (org.) Elementos da Geografia Contemporânea. Curitiba: Ed. UFPR, 2002.

. "A Geografia Crítica Brasileira: Reflexões sobre um Debate Recente": Geografia (Rio Claro). Rio Claro (SP), v. 28, n.3, p. 307-322, 2003.

DOSSE, François. História do Estruturalismo: O canto do cisne. Bauru: Edusc, 2007. 
Comissão Pastoral da Terra, Síntese Estatística em 31/12/2013 (atualização 23/06/14) Campanha da CPT contra o Trabalho Escravo. Disponível em <SÍNTESE ESTATISTICA em 31/12/2013 (atualização 23/06/14) - CAMPANHA DA CPT CONTRA O TRABALHO ESCRAVO>. Acesso em: maio de 2015.

Conselho Nacional de Pesquisa. Diretório dos Grupos de Pesquisa no Brasil (grupos por área). Disponível em: <http://lattes.cnpq.br/web/dgp/por-area>. Acessado em: 10 jul. 2015.

Conselheiros entregam Plano de Habitação de São Paulo ao Prefeito Gilberto Kassab”. 29 de setembro de 2010. Disponível em <http://www.prefeitura.sp.gov.br/cidade/secretarias/habitacao/noticias/?p=21864>. Acessado em: 22 jun. 2015.

CONSTANTINO, Rodrigo. "A esquerda Ainda não Entendeu o Conceito de Escassez", Veja: Blogs e Colunas. Disponível em: <http://veja.abril.com.br/blog/rodrigoconstantino/tags/thomas-piketty/>. Acesso em: 03 jun. 2015.

COSTA, W. M. da; MORAES, A. C. R. Geografia Crítica: A Valorização do Espaço. São Paulo: HUCITEC, 1984.

FAUSTO, Ruy. Marx: Lógica e Política. São Paulo: Brasiliense, 1983.

FEUERBACH, Ludwig. Princípios da Filosofia do Futuro. Covilha: Luso Sofia Press, 2008.

GEORGE, Pierre. Populações Ativas. São Paulo: DIFEL, 1979.

GODOY, Paulo Roberto Teixeira de. “A Produção do Espaço: Uma Reaproximação Conceitual da Perspectiva Lefebvriana”. São Paulo: GEOUSP - Espaço e Tempo, № 23, 2008.

GOMES, H. Reflexões sobre Teoria Crítica em Geografia. Goiânia: Cegraf - UFG, 1991.

GOMES, Paulo Cesar da Costa. Geografia e Modernidade. Rio de Janeiro: Bertrand Brasil, 1996.

GONÇALVES, Carlos Walter Porto. “A Geografia Está em Crise. Viva a Geografia!”. In: Boletim Paulista de Geografia ( $n^{\circ}$ 55). São Paulo: AGB, 1978. 
GORZ, André. Adeus Ao Proletariado: Para Além do Socialismo. Rio de Janeiro: Forense Universitária, 1987.

O Imaterial: Conhecimento Valor e Capital. São Paulo: Annablume, 2005.

GUIMARÃES, Humberto Goulart. "Ensaio Sobre o Espaço como Modalidade Ontológica do Ser: Nos Caminhos de Armando Corrêa da Silva". In: Revista Discente Expressões Geográficas, nº 05, ano V, p. 31 - 48: Florianópolis, maio de 2009.

HABERMAS, Jürgen. Teoria do Agir Comunicativo. São Paulo: WMF Martins Fontes, 2012.

HARVEY, David. Condição pós-moderna: uma pesquisa sobre a origem da mudança cultural. São Paulo: Edições Loyola, 1993.

A Produção Capitalista do Espaço. São Paulo: Annablume, 2005a.

. ‘Tudo Por Causa do Petróleo”. In: O Novo Imperialismo. São Pauo: Loyola, 2005b.

Para Entender O Capital: Livro I. São Paulo: Boitempo, 2013.

. "Reflexões sobre "o Capital”, de Thomas Piketty", São Paulo, Blog da Boitempo, 2014. Disponível em: <http://blogdaboitempo.com.br/2014/05/24/harvey-reflexoes-sobre-ocapital-de-thomas-piketty/>. Acessado em: 01 maio 2015.

HEGEL, Georg W. F. A Razão na História: Uma Introdução Geral à Filosofia da História. São Paulo: Centauro, 2012.

HEIDEGGER, Martin. "Meu Caminho para a Fenomenologia". In: Conferências e escritos Filosóficos. São Paulo: Abril Cultural, 1983.

. Ser e Tempo (Parte I). Petrópolis: Vozes, 2005.

. “Questões Sobre a Técnica”. In: Scientiæ Zudia. São Paulo, v. 5, n. 3, p. 375-98, 2007.

HORKHEIMER, Max. Teoria Crítica: Uma Documentação. São Paulo: Perspectiva; EDUSP, 1990. 
Instituto Brasileiro de Geografia e Estatística. Total de Domicílios em São Paulo: Senso IBGE, 2010.

Disponível

em:

<http://www.ibge.gov.br/home/estatistica/populacao/censo2010/tabelas_pdf/total_domicilios_ sao_paulo.pdf $>$. Acessado em: 22 jun. 2015.

KONICZ, Thomasz. "Mais uma Vez se Põe a Questão: quando estoura a grande bolha de Liquidez em que está preso o sistema financeiro mundial?" 2015. Disponível em: <http://obeco.no.sapo.pt/tomasz_konicz5.htm>. Acesso em: 18 jul. 2015.

KURZ, Robert. O Colapso da Modernização: Da Derrocada do Socialismo de Caserna à Crise da Economia Mundial. Rio de Janeiro: Paz e Terra, 1992.

"O Consumo do Futuro", 2011. Disponível em: <http://obeco.planetaclix.pt/rkurz380.htm>. Acessado em: 19 jul. 2015.

KRUGMAN, Paul (org.). A Crise de 2008 e a Economia da Depressão. Rio de Janeiro: Campus, 2009.

LACOSTE, Yves. A Geografia - Isso Serve, em Primeiro Lugar, para fazer a Guerra. Campinas: Papirus, 1988.

LEAL, Victor Andrade Silva. Trabalho versus Técnica na Produção Histórica do Capitalismo. (monografia de graduação). Vitória da Conquista: Universidade Estadual do Sudoeste da Bahia, 2014.

LEFEBVRE, Henri. Sociologia de Marx. Rio de Janeiro: Editora Forense, 1968.

Introdução à modernidade. São Paulo: Paz e Terra, 1969.

Lógica formal/Lógica dialética. $3^{\text {a }}$ ed, Rio de Janeiro: Civilização brasileira, 1983.

LESSA, Sérgio. Trabalho e Proletariado no Capitalismo Contemporâneo. São Paulo: Cortez, 2007.

LUKÁCS, Gyögy. Prolegômenos: Para Uma Ontologia do Ser Social. São Paulo: Boitempo, 2010. 
Para uma Ontologia do Ser Social, 2. São Paulo: Boitempo, 2013.

LUXEMBURG, Rosa. Anticrítica. São Paulo: Abril Cultural, 1984.

MATOS, Olgária C. F. Escola de Frankfurt: Luzes e Sombras do Iluminismo. São Paulo: Moderna, 1993.

MARTINS, Élvio Rodrigues. “Geografia e Ontologia: O Fundamento Geográfico do Ser”. São Paulo: GEOUSP - Espaço e Tempo, Nº 21, 2007.

MARTINS, José de Souza. "A vida entre parênteses: migrações internas no mundo contemporâneo”. In: A sociedade vista do Abismo. Petrópolis: Vozes, 2002.

MARX, Karl. Para a Crítica da Economia Política. São Paulo: Abril Cultural, 1982.

O Capital: Crítica da Economia Política. São Paulo: Abril Cultural, 1983 (v.1, t. 1).

. Manuscritos Econômico-Filosóficos. São Paulo: Boitempo, 2004.

Grundrisse: Manuscritos Econômicos de 1857 - 1858. São Paulo: Boitempo; Rio de Janeiro: Ed. UFRJ, 2011.

. Crítica da Filosofia do Direito de Hegel. São Paulo: Boitempo, 2013.

MARX, Karl; EGELS, Friedrich. Cartas Filosóficas e o Manifesto do Partido Comunista. São Paulo: Moraes, 1987.

Ideologia Alemã. São Paulo: Boitempo, 2007.

A Sagrada Família. São Paulo: Boitempo, 2011.

MÉSZÁROS, István. Século XXI: socialismo ou barbárie? São Paulo: Boitempo, 2003.

O Poder da Ideologia. São Paulo: Boitempo, 2004. 
. A Teoria da Alienação em Marx. São Paulo: Boitempo, 2006.

Filosofia, Ideologia e Ciência Social. São Paulo: Boitempo, 2008.

Para além do Capital: rumo a uma teoria da transição. São Paulo: Boitempo, 2011.

Ministério do Trabalho e Emprego; Divisão de Fiscalização para a Erradicação do Trabalho Escravo, "Quadro Geral das Operações de Fiscalização para a Erradicação do Trabalho Escravo" (Atualizado em 22/05/2013). Disponível em <http://portal.mte.gov.br/data/files/8A7C816A45B26698014625BF23BA0208/Quadro\%20res umo\%20opera\%C3\%A7\%C3\%B5es\%20T.E.\%201995\%20-\%202013.\%20Internet.pdf>. Acesso em: 05 maio 2015.

MORAES, Antônio Carlos Robert. "Em Busca da Ontologia do Espaço”. In: MOREIRA, Ruy (org.) Geografia: Teoria e Crítica - Os Saberes Posto em Questão. Rio de Janeiro: Vozes, 1982.

Geografia, pequena história crítica. São Paulo: HUCITEC, 2002.

Geografia Histórica do Brasil: cinco ensaios, uma proposta e uma crítica. São Paulo: Annablume, 2009.

Geografia Histórica do Brasil: capitalismo, território e periferia. São Paulo: Annablume, 2011.

Território na Geografia de Milton Santos. São Paulo: Annablume, 2013.

MOREIRA, Ruy. Espaço, Corpo do Tempo: a Construção Geográfica das Sociedades (tese de doutorado). São Paulo: Universidade de São Paulo, 1994a.

O Que é Geografia. São Paulo: Brasiliense, 1994b.

. "Resenha: A Natureza do Espaço. Técnica e Tempo, Razão e Emoção" (Milton Santos.

Editora HUCITEC: São Paulo, 1996). Rio de Janeiro: Geographia, Ano 1, nº 1, 1999. 
“E Assim se Passaram Dez Anos”. In: GEOgraphia - Ano. II - No 3 - 2000.

. "Trabalho e Movimentos Sociais no Brasil: um diálogo possível no âmbito da luta emancipatória?". In: II Jornada sobre o Trabalho. Caderno de Textos - Centro de Estudos de Geografia do Trabalho (CEGeT). Presidente Prudente: CEGeT, 2001.

"Marxismo e Geografia (A Geograficidade e o Diálogo das Ontologias)". In: GEOgraphia, Ano 6, nº 11, 2004.

Pensar e Ser em Geografia: ensaios de história, epistemologia e ontologia do espaço geográfico. São Paulo: Contexto, 2007.

O Pensamento Geográfico Brasileiro: As Matrizes Brasileiras (v. 3). São Paulo: Contexto, 2010.

O Pensamento Geográfico Brasileiro: As Matrizes Clássicas Originárias (v. 1), São Paulo, Contexto, 2014a.

O Pensamento Geográfico Brasileiro: As Matrizes Da Renovação (v. 2), São Paulo, Contexto, 2014b.

OLIVEIRA, Ariovaldo Umbelino de. "A Geografia Agrária e as Transformações Territoriais Recentes no Campo Brasileiro”. In: Novos Caminhos da Geografia Brasileira / Ana Fani Alessandri Carlos (org.). São Paulo: Contexto, 2007.

"Espaço e Tempo: Compreensão Materialista Dialética", In: Novos Rumos da Geografia Brasileira, São Paulo, UCITEC, 1996.

O "Econômico" na Obra Geografia Econômica de Pierre George: Elementos para uma Discussão. In: MOREIRA, Ruy (org.). Geografia: Teoria e Crítica - Os Saberes Posto em Questão. Rio de Janeiro: Vozes, 1982.

OLIVEIRA, Lívia. "Ainda Sobre Percepção, Cognição e Representação em Geografia”, In: Elementos de Epistemologia da Geografia Contemporânea. Curitiba: Ed. Da UFPR, 2002.

OFFE, Claus. Trabalho como categoria sociológica fundamental? - in: Trabalho e sociedade: problemas estruturais e perspectivas para o futuro da "sociedade do trabalho". Rio de Janeiro: Tempo Brasileiro, v.1, 1989. 
ORGANIZAÇÃO INTERNACIONAL DO TRABALHO (OIT). O trabalho infantil. Disponível em: <http://www.oitbrasil.org.br/>. Acesso em: 06 maio 2007.

ORGANIZAÇÃO REPORTER BRASIL. Cadeias Produtivas e Escravidão. Disponível em: $<$ http://reporterbrasil.org.br/wp-content/uploads/2015/02/7.-

caderno_cadeias_produtivas_baixa.pdf >. Acesso em: 02 maio 2015.

PAULO NETO, José. “Apresentação”, In: LUKÁCS, Gyögy. Para uma Ontologia do Ser Social, 1. São Paulo: Boitempo, 2012.

PEDROSA, Breno Viotto. "A Geografia Crítica Brasileira e o Debate sobre a Ontologia do Espaço: uma Aproximação”. Revista Geografares. n¹1, p.139-168, Junho, 2012. ISSN 2175 -370 .

PIKETTY, Thomaz. O capital no Século XXI. Rio de Janeiro: Intrínseca, 2014.

PRADO JR, Caio. O Estruturalismo de Levi-Strauss; O Marxismo de Louis Althusser. São Paulo: Brasiliense, 1971.

ROCHEFORT, Renée. Le Travail en Sicile: Étude de Géographie Sociale. Presses Universitaires de France: Paris, 1961.

SANTOS, Douglas, "Entrevista". In: Boletim Paulista de Geografia: 1978 + 30: AGB em Movimento. Volume especial, No 88, julho de 2008.

SANTOS, Lucas Maia dos. A constituição do meio técnico-científico em Goiás: relações de trabalho e luta de classes no setor sucro-energético (tese de doutorado). Goiania: Universidade Federal de Goiás, 2014; p 27

SANTOS, Milton. "Espaço e Sociedade: e formação da sociedade como teoria e como método", In: Boletim Paulista de Geografia. № 54, São Paulo: AGB; 1977.

"Para que a Geografia Mude Sem Ficar a Mesma Coisa". In: Boletim Paulista de Geografia. (Nº 59, outubro de 1982). São Paulo: AGB, 1984.

. "Alguns Problemas Atuais da Contribuição Marxista". In: Novos Rumos da Geografia Brasileira. São Paul: Hucitec, 1996. 
"Modo de Produção Técnico Científico e a Diferenciação Espacial". Revista TERRITÓRIO, ano IV, nº 6, jan./jun. 1999.

Território e sociedade: entrevista com Milton Santos. (Entrevistadores: Odete Seabra, Mônica de Carvalho e José Corrêa Leite). São Paulo: Perseu Abramo, 2000.

Por uma Geografia Nova. São Paulo: ED. USP, 2002.

A Natureza do Espaço. São Paulo: Ed. USP, 2008.

Economia Espacial: críticas e alternativas. São Paulo: EDUSP, 2011a.

Por Uma Outra Globalização: do Pensamento Único à Consciência Universal. Rio de Janeiro: Record, 2011b.

Técnica, Espaço, Tempo: Globalização e Meio Técnico-Científico-Informacional. São Paulo: Ed. USP, 2013.

Espaço e Método. São Paulo: ED. USP, 2014.

Geografia, marxismo e subdesenvolvimento. GEOUSP - Espaço e Tempo, São Paulo, v. 19, n. 1, p. $166-172,2015$.

SCARIM, Paulo César. Coetâneos da Crítica: Contribuição ao Estudo do Movimento de Renovação da Geografia Brasileira. São Paulo: Universidade de São Paulo (Dissertação de Mestrado), 2000.

SILVA, Ana Cristina da. O Pensamento Geográfico Brasileiro na Travessia do Século XX para o XXI: O Território na Trama das Significações Imaginárias (tese de doutorado). Presidente Prudente: Universidade Estadual Paulista, 2010.

SILVA. Armando Corrêa da. De Quem é o Pedaço?: Espaço e Cultura. São Paulo: Hucitec, 1986.

. “A Renovação Geográfica no Brasil - 1976/1983 (As Geografias Crítica e Radical em Uma Perspectiva Teórica)”. São Paulo: Boletim Paulista de Geografia, n 60, 1984. 
Geografia e Lugar Social. São Paulo: Contexto, 1991.

$\frac{}{1993 .}$. "A Geografia e a Teoria do Valor". In: Informa AGB. São Paulo: n. 48, junho der . "Contribuição à Crítica da Crise da Geografia”. In: Novos Rumos da Geografia Brasileira. São Paulo: UCITEC, 1996.

O Espaço Fora do Lugar. São Paulo: Hucitec, 1998.

SILVA, Carlos Henrique da Silva. O Pará aos pedaços: projetos de criação dos estados do Carajás e Tapajós no contexto da fronteira de acumulação. São Paulo (Dissertação de Mestrado) - FFLCH USP, 2014.

SILVER, Beverly J. Forças do trabalho: movimentos trabalhistas e globalização desde 1870. São Paulo: Boitempo, 2005.

SOJA, Edward. Geografias Pós-Modernas: a reafirmação do espaço na teoria social. Rio de Janeiro: Jorge Zahar, 1993.

SOUZA, Leandro Candido de, "Avessos da dialética: Adorno, Lukács e o realismo no século XX”. In: Verinótio: revista on-line de educação e ciências Humanas: n. 12, Ano VI, out./2010 - Publicação semestral - ISSN 1981-061X.

SOUSA NETO, Manoel Fernandes. "Uma Pequena História da Crítica no Brasil (apresentação)", In: MORAES, Antônio Carlos Robert. Geografia: Pequena História Crítica. São Paulo: Annablume, 2007.

SPOSITO, Eliseu Savério. “Pequenas Argumentações para uma Temática Complexa.”. In: Elementos de Epistemologia da Geografia Contemporânea. Curitiba: UFPR, 2002.

STEIN, Ernildo. "Nota do tradutor". In: HEIDEGGER, M. Conferências e Escritos Filosófico. São Paulo: Abril Cultural, 1983.

TERTULIAN, Nicolas. “A Destruição da Razão: 30 anos depois”. In: Verinotio, revista online - n. 13, Ano VII, abr./2011. 
THÉRY, Hervé. Atlas do Trabalho Escravo no Brasil / Hervé Théry, Neli Aparecida de Mello, Júlio Hato, Eduardo Paulon Girardi. São Paulo: Amigos da Terra, 2009.

THOMAZ JR, Thomaz. Dinâmica Geográfica do Trabalho no Século XXI: Limites Explicativos, Autocrítica e Desafios Teóricos. São Paulo: Universidade Estadual Paulista (Tese de Livre Docência), 2009.

"Geografia e trabalho no século XXI: os limites para a compreensão da classe trabalhadora no Brasil”. OKARA: Geografia em debate, v.1, n.2, p. 79-97, 2007.

"Por Uma Geografia do trabalho". In: Revista Pegada Eletrônica (Geografia), Vol. 3 (edição especial). Presidente Prudente: CEGET, 2002.

. Um Olhar Autocrítico Do Trabalho E Da Classe Trabalhadora No Brasil No Século XXI. Revista Eletrônica da Associação dos Geógrafos Brasileiros - Seção Três Lagoas/MS $-\mathrm{n}^{\mathrm{o}} 13$ - Ano 8, maio 2011.

TOLEDO JUNIOR, Rubens de. "Por uma Geografia Nova, 30 anos: uma abordagem geográfica para uma teoria social crítica". In: Encontro com o Pensamento de Milton Santos: o Homem e sua Obra. Salvador: EDUFBA, 2009.

VAISMAN, Ester. ALVES, Antônio José Lopes. "Apresentação". In CHASIN, Marx: Estatuto ontológico e Resolução Metodológica. São Paulo: Boitempo, 2009.

VESENTINI, José William. Ensaios de geografia crítica: história, epistemologia e (geo)política. São Paulo: Plêiade, 2009.

VIANA, Myrna T. Rego. "Editorial”. In: Boletim Paulista de Gerografia. São Paulo: N`51, junho de 1976.

WEBER, Max. A Ética Protestante e o Espírito do Capitalismo. São Paulo: Livraria Pioneira Editora, 1967. 